\author{
UNIVERSIDADE DE SÃO PAULO \\ INSTITUTO DE ENERGIA E AMBIENTE \\ PROGRAMA DE PÓS-GRADUAÇÃO EM CIÊNCIA AMBIENTAL
}

ANA CAROLINA CORBERI FAMÁ AYOUB E SILVA

DANO POR DERRAMAMENTO DE ÓLEO NO MAR:

RESPONSABILIDADE E REPARAÇÃO 

ANA CAROLINA CORBERI FAMÁ AYOUB E SILVA

\title{
DANO POR DERRAMAMENTO DE ÓLEO NO MAR: RESPONSABILIDADE E REPARAÇÃO
}

\author{
Tese apresentada ao Programa de Pós- \\ Graduação em Ciência Ambiental do Instituto \\ de Energia e Ambiente da Universidade de São \\ Paulo para a obtenção do título de Doutora em \\ Ciência Ambiental.
}

Orientadora: Profa. Dra. Patrícia Faga Iglecias Lemos

Versão Original 
AUTORIZO A REPRODUÇÃO E DIVULGAÇÃO TOTAL OU PARCIAL DESTE TRABALHO, POR QUALQUER MEIO CONVENCIONAL OU ELETRÔNICO, PARA FINS DE ESTUDO E PESQUISA, DESDE QUE CITADA A FONTE.

FICHA CATALOGRÁFICA

Silva, Ana Carolina Corberi Famá Ayoub e.

Dano por derramamento de óleo no mar: responsabilidade e reparação.

/ Ana Carolina Corberi Famá Ayoub e Silva; orientadora: Patrícia Faga Iglecias Lemos. - São Paulo, 2019.

407 f.: il; $30 \mathrm{~cm}$.

Tese (Doutorado em Ciência Ambiental) - Programa de PósGraduação em Ciência Ambiental - Instituto de Energia e Ambiente da Universidade de São Paulo.

Elaborado por Maria Penha da Silva Oliveira CRB-8/6961 
Nome: SILVA, Ana Carolina Corberi Famá Ayoub e

Título: Dano por derramamento de óleo no mar: responsabilidade e reparação

Tese apresentada ao Programa de PósGraduação em Ciência Ambiental do Instituto de Energia e Ambiente da Universidade de São Paulo para a obtenção do título de Doutora em Ciência Ambiental.

Aprovada em:

Banca Examinadora

Prof. Dr. Instituição:

Julgamento: Assinatura:

Prof. Dr. Instituição:

Julgamento: Assinatura:

Prof. Dr. Instituição:

Julgamento: Assinatura:

Prof. Dr. Instituição:

Julgamento: Assinatura:

Prof. Dr. Instituição:

Julgamento: Assinatura:

Prof. Dr. Instituição:

Presidente Assinatura: 

À minha amada avó Maria Luiza, por nunca soltar a minha mão, in memoriam.

Aos meus pais e irmão, exemplos de união e generosidade.

Ao Marcus Vinícius, meu marido, maior inspiração de amor à natureza e positividade. 



\section{AGRADECIMENTOS}

O processo de elaboração desta tese não se limitou aos aprendizados acerca dos derramamentos de óleo no mar. Muito pelo contrário! Foi um aprendizado pessoal sobre resiliência, e pelo gosto pelo desafio. Graças a ele conheci profissionais incríveis, e retomei amizades com pesquisadores admiráveis. Por meio dele pude recarregar a paixão pela minha primeira profissão, estando mais certa ainda de que o Direito Ambiental precisa muito da Biologia, e de que eu mesma preciso muito da Biologia. Foram cinco anos de incertezas e de buscas intermináveis por informações e respostas, mas graças a algumas pessoas especiais tudo isso foi possível. Em primeiro lugar, gostaria de agradecer à Deus, pois ao recorrer a ele tive sempre a certeza de que conseguiria atingir meus objetivos. Em seguida, à minha orientadora, Professora Patrícia Faga Iglecias Lemos, por todas as oportunidades desde o início da minha vida acadêmica no Direito, por confiar no meu trabalho e sempre me incentivar. Gratidão à minha coorientadora, Professora Sonia Maria Flores Gianesella, por me acolher com tamanho carinho e entusiasmo pelo meu trabalho, e ao Professor Evandro Mateus Moretto por, tanto em suas brilhantes aulas, quanto durante a minha qualificação, ampliar os meus horizontes acerca da interdisciplinariedade. Muito obrigada minha mestra de ensinamentos que não estão nos livros, Professora Íris Regina Fernandes Poffo, por tamanha paciência em me ouvir e transmitir tanto conhecimento. Ao Valter Polido, sou grata por sempre me atender com tanta atenção. Agradeço aos meus pais e irmão, guias da minha vida, por todo o apoio e acolhimento, ao meu marido Marcus Vinícius, por compartilhar todo o seu conhecimento passional pela biologia, sendo meu maior incentivador, à minha madrinha, Professora Helena Aparecida Ayoub Silva, a quem venero por tamanha dedicação aos seus alunos e espero um dia seguir seus passos, à minha avó Jacyra e tia Helena, por tantas orações e pela compreensão por minha ausência. Agradeço ainda aos amigos cujo apoio foi essencial para a construção deste trabalho: Vicente Gomes, Ravi Campos, João Roberto Rodrigues, André Castilho, Marcelo Daniel Rechulski e Flavio Prol. Por fïm, mas não menos importante, um agradecimento especial à Camila Figueiredo, e à Juliana Andrade, por tamanho empenho e paciência comigo. Gratidão imensa pela dedicação de todos. 

Silva, Ana Carolina Corberi Famá Ayoub e. Dano por derramamento de óleo no mar: responsabilidade e reparação. 407 f. Tese (Doutorado em Ciência Ambiental) - Programa de Pós-Graduação em Ciência Ambiental - Instituto de Energia e Ambiente da Universidade de São Paulo, São Paulo, 2019.

\section{RESUMO}

No Brasil, os derramamentos de óleo no mar são geralmente associados aos raros, porém significativos, acidentes envolvendo plataformas offshore, ou navios petroleiros. Entretanto, o cenário real é, em grande parte, composto por derramamentos constantes, de baixos volumes, ocasionados por pequenas ou médias embarcações, ou ainda, sem que haja a identificação das fontes geradoras, originando as chamadas "manchas órfãs". Nesse sentido, a busca pela satisfatória reparação dos ambientes e indivíduos afetados pelo óleo deve considerar, primeiramente, os tipos de derramamentos que afetam à costa brasileira. Em seguida, os danos decorrentes merecem ser amplamente identificados, considerando suas complexidades, em conjunto com os diversos bens afetados direta, ou indiretamente, a exemplo de ecossistemas, qualidade de vida e bens materiais e imateriais no geral. Para que isso ocorra, não se pode mais deixar de considerar o caráter interdisciplinar inerente a esses incidentes, devendo ser avaliados por meio de uma intersecção de abordagens. É nesse sentido que o Direito, mais precisamente no âmbito da responsabilidade civil ambiental, deve se adaptar, ao impor as formas de reparação aos danos decorrentes de derramamentos de óleo no mar. A mera atribuição de indenização, como forma de reparação, parece não atender às reais necessidades tanto dos ambientes, quanto dos próprios indivíduos afetados. Assim, acredita-se ser possível que a aplicação da legislação e de conceitos jurídicos seja realizada levando-se em conta contribuições de outras ciências e, assim, objetivando-se uma maior compatibilidade entre a justiça humana e a justiça ecológica.

Palavras-chave: Derramamento de Óleo - Dano Ambiental - Mar - Responsabilidade Civil Ambiental - Reparação de Danos 

Silva, Ana Carolina Corberi Famá Ayoub e. Oil spill damages at sea: liability and response. 407 f. Thesis (Environmental Science Doctorate) - Post Graduation Program in Environmental Science - Energy and Environment Institute from University of São Paulo, São Paulo, 2019.

\begin{abstract}
In Brazil, the oil spills at sea are usually associate with rare, but significant accidents involving offshore platforms, or oil tankers. However, the real scenario is largely related to constant spills of low volumes of oil, occasioned from small or median vessels, or even, without identification of the sources, forming the "orphans spots". In this sense, the search for a satisfactory response to the environments and individuals affected by the oil must consider, at first, the kind of oil spills that affects the Brazilian coast. After that, all the damages should be thoroughly identified, including material and moral, considering their complexity, the diversity of the ecosystems directly affected, and the quality of life impaired. In order to make that possible, it is important to consider the interdisciplinary character inherent of these incidents, that must be assessed through an intersection of approaches. Is in this meaning, the Law, more precisely the environmental civil liability, must be open to accept changes to response and redress decisions in order to solve oil spills conflicts. The payment of indemnification, as the main form damages reparation, seems not to attempt the real necessities from the environment, not even from the victim's interests. In line with this thought, it is believed that is possible to apply the legislation and the legal concepts considering other sciences contribution, and, in this way, aiming to a compatibility between the human justice and the ecological justice.
\end{abstract}

Key-words: Oil Spill - Environmental Damage - Sea - Civil Environmental Liability - Damage Remediation 



\section{LISTA DE TABELAS}

Tabela 1 - Participação por tipo de embarcação na frota marítima brasileira

Tabela 2 - Quantidades de embarcações por tipo, cadastradas nas organizações militares da

Marinha do Brasil distribuídas em todo território nacional

Tabela 3- Relação entre ocorrências e volume de óleo derramado no litoral de São Paulo

(2007 - 2018)

Tabela 4 - Manchas órfãs com características oleosas registradas (2007 - 2018)

Tabela 5- Principais convenções, protocolos e anexos ratificados pelo Brasil, segundo a IMO:

Tabela 6- Principais convenções internacionais aplicáveis aos derramamentos de óleo

Tabela 7- Legislação brasileira relacionada a derramamentos de óleo no mar

Tabela 8- Classificação dos danos ambientais .....

Tabela 9 - Danos que afetam interesses pessoais 188

Tabela 10 - Categorias de danos ambientais 209

Tabela 11 - Organismos afetados e danos biológicos ligados a derramamento de óleo

Tabela 12 - Sensibilidade ao óleo por tipo de ambiente afetado 240

Tabela 13 - Componentes da valoração econômica do recurso ambiental (VERA) 286

Tabela 14 - Métodos de valoração ambiental aplicáveis a ambientes marinhos 290 



\section{SIGLAS E ABREVIATURAS}

ACP Ação Civil Pública

AL Alagoas

ANP Agência Nacional do Petróleo

ANTAQ Agência Nacional de Transportes Aquaviários

APP Área de Preservação Permanente

BUNKER International Convention on Civil Liability for Bunker Oil Pollution Damage

CC Código Civil

CDC Código de Defesa do Consumidor

CEF Caixa Econômica Federal

CEMBRA Centro de Excelência para o Mar Brasileiro

CETESB Companhia de Tecnologia de Saneamento Ambiental

CF Constituição Federal

CIDE Contribuição de Intervenção no Domínio Econômico

CIRM Comissão Interministerial sobre os Recursos do Mar

CJF Conselho da Justiça Federal

CLC International Convention on Civil Liability for Oil Pollution Damage

CNJ Conselho Nacional de Justiça

CODESP Companhia Docas do Estado de São Paulo

CONAMA Conselho Nacional do Meio Ambiente

CONDIR Conselho Diretor

COP Conferência das Partes

COSIPA Companhia Siderúrgica Paulista

CPC Código de Processo Civil

DILIC Diretoria de Licenciamento Ambiental

DOALOS Divisão de Assuntos Oceânicos e Direito do Mar

DOE Diário Oficial do Estado

DOU Diário Oficial da União

EUA Estados Unidos da América 
FDD Fundo de Defesa de Direitos Difusos

FECAM Fundo Estadual de Conservação Ambiental e Desenvolvimento Urbano

FEHIDRO Fundo Estadual de Recursos Hídricos

FID Fundo Estadual de Defesa dos Interesses Difusos

FNDF Fundo Nacional de Desenvolvimento Florestal

FNMA Fundo Nacional do Meio Ambiente

FPBRN Fundo Especial de Despesa para a Preservação da Biodiversidade e dos Recursos Naturais

FUNDRHI Fundo Estadual de Recursos Hídricos

FUPAP Fundo de Financiamento a Projetos Ambientais Relacionados à Indústria de Petróleo e seus Derivados e do Gás e seus Derivados

GNL Gás Natural Liquefeito

IAP Instituto Ambiental do Paraná

IBAMA Instituto Brasileiro do Meio Ambiente e dos Recursos Naturais Renováveis

IBGE Instituto Brasileiro de Geografia e Estatística

ICMBio Instituto Chico Mendes de Conservação da Biodiversidade

IEMA Instituto Estadual de Meio Ambiente e Recursos Hídricos

IMO Organização Internacional Marítima

IN Instrução Normativa

INEA Instituto Estadual do Ambiente do Estado do Rio de Janeiro

INMETRO Instituto Nacional de Metrologia, Qualidade e Tecnologia

IOPC International Oil Pollution Compensation Fund

IPCA Índice de Preços ao Consumidor

IPIECA International Petroleum Industry Environmental Conservation Association

ISL I Índice de Sensibilidade Litorânea

LESTA Lei de Segurança do Tráfego Aquaviário

MARPOL International Convention for the Prevention of Pollution from Ships

MMA Ministério do Meio Ambiente

MP Ministério Público

MPF Ministério Público Federal

OILPOL Oil Pollution Convention 
ONU Organização das Nações Unidas

OPRC Oil Pollution Preparedness, Response and Co-operation

PA Plano de Área

PAE Plano Nacional de Ação de Emergência

PAM Plano de Ajuda Mútua

PCE Plano de Controle de Emergência

PEI Plano de Emergência Individual

P\&I Protection \& Indemnity

PETROBRÁS Petróleo Brasileiro S/A

PL Projeto de Lei

PNC Plano Nacional de Contingência para Incidentes de Poluição por Óleo em Águas sob Jurisdição Nacional

PNMA Política Nacional de Meio Ambiente

PPS Partido Popular Socialista

PR Paraná

PROCAM Programa de Ciência Ambiental

PSB Partido Socialista Brasileiro

RDC Revista de Direito do Consumidor

REB Registro Especial Brasileiro

SAO Sensibilidade Ambiental a Derramamentos de Óleo

SEA Secretaria Estadual de Ambiente do Rio de Janeiro

SENAD Secretaria Nacional de Políticas sobre Drogas

SIEQ Sistema de Informações sobre Emergências Químicas da CETESB

SNUC Sistema Nacional de Unidades de Conservação

SOLAS International Convention for the Safety of Life at Sea

SP São Paulo

STF Supremo Tribunal Federal

STJ Superior Tribunal de Justiça

SUSEP Superintendência de Seguros Privados

TAC Termo de Ajustamento de Conduta

TJ Tribunal de Justiça 
UNCLOS United Nations Conference on the Law of the Sea

UNCTAD Conferência das Nações Unidas sobre Comércio e Desenvolvimento

UNFCCC Convenção-Quadro das Nações Unidas sobre Mudança do Clima

VERA Valoração Econômica do Recurso Ambiental

VNU Valor de Não Uso

VO Valor de Opção

VUD Valor de Uso Direto

VUI Valor de Uso Indireto

ZC Zona Costeira

ZEE Zona Econômica Exclusiva 


\section{SUMÁRIO}

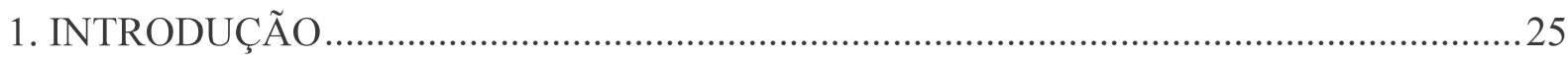

2. BREVES CONSIDERAÇÕES SOBRE OS CENÁRIOS DOS DERRAMAMENTOS DE

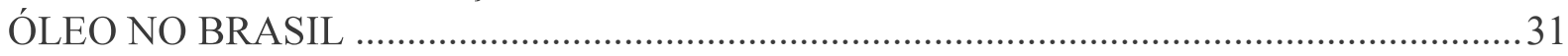

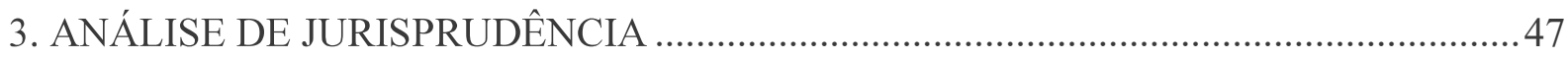

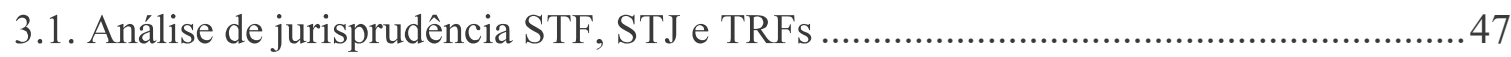

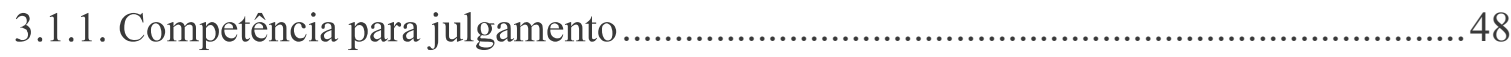

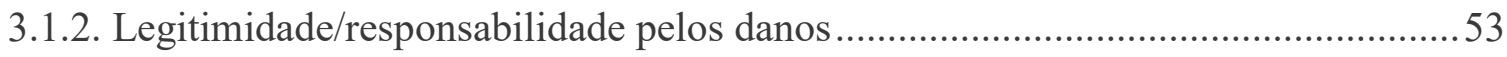

3.1.3. Reconhecimento dos danos morais / extrapatrimoniais .........................................58

3.1.3.1. Metodologia utilizada para valoração de danos ambientais materiais/ patrimoniais e morais/extrapatrimoniais

3.2. Análise jurisprudencial dos derramamentos mais expressivos ocorridos no Brasil... 62

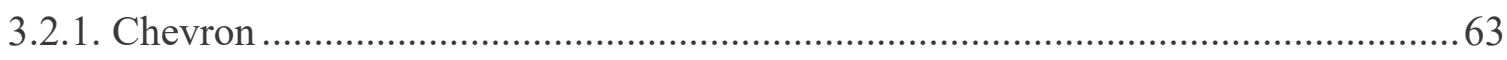

3.2.1.1 Ação Civil Pública n ${ }^{\circ}$ 0302525-83.2014.8.19.0001 - Justiça Estadual ................. 64

3.2.1.2. Ação Civil Pública n ${ }^{\circ}$ 0485873-12.2011.8.19.0001 - Justiça Estadual ................ 65

3.2.1.3. Ação Civil Pública n ${ }^{\circ}$ 0000558-74.2012.4.02.5103 - Justiça Federal .................. 65

3.2.1.4. Ação Civil Pública n ${ }^{\circ}$ 0002561-36.2011.4.02.5103 - Justiça Federal .................. 66

3.2.1.5. Agravo Regimental na Suspensão de Liminar e de Sentença n ${ }^{\circ} 1.639$ - RJ -

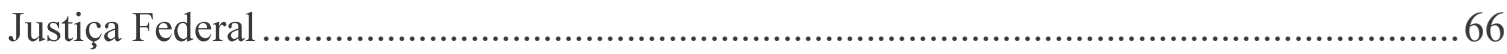

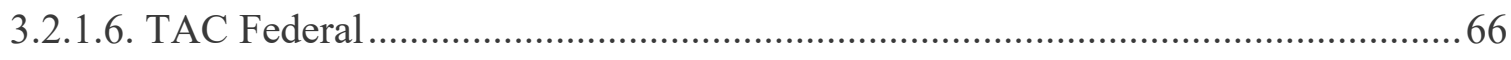

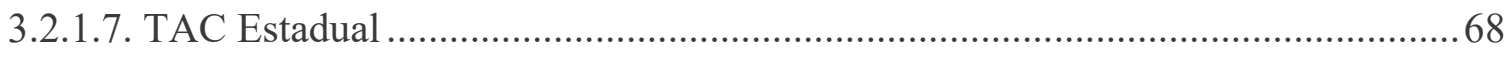

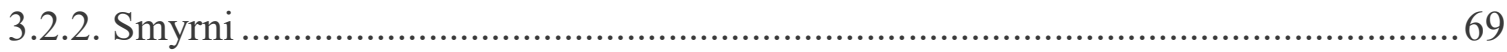

3.2.2.1. Ação Civil Pública n ${ }^{\circ}$ 0205282-08.1998.4.03.6104 - Justiça Federal .................. 69

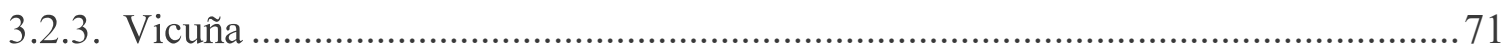

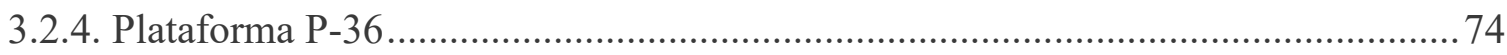

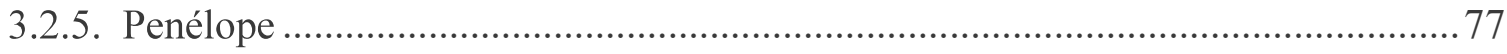

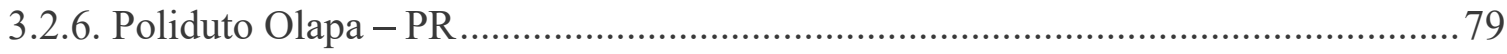

3.2.6.1. Ação Civil Pública nº 0000041-91.2010.404.7008 - Justiça Federal ................... 79

3.2.6.2. Ação Civil Pública n ${ }^{\circ}$ 2002.70.08.000260-1 - Justiça Federal ............................. 81

3.2.6.3. Apelação Cível no 5002394-14.2013.4.04.7008/PR - Justiça Federal.................. 83

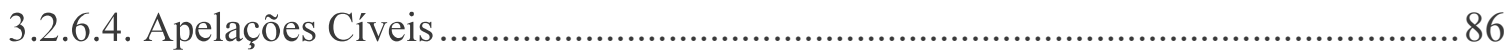

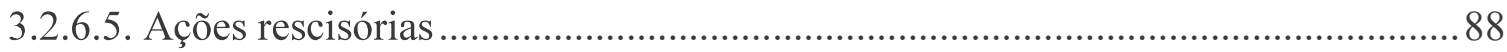

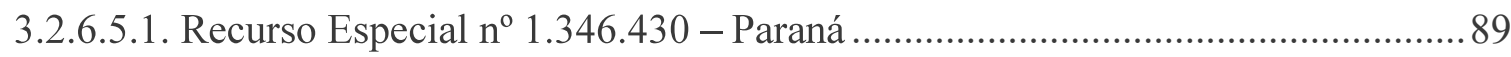

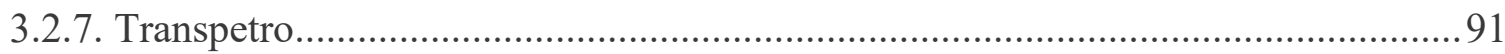

3.2.7.1. Medida Cautelar Inominada $n^{\circ}$ 0203627-98.2015.8.19.0001 .............................91 
3.2.7.2. TAC INEA n ${ }^{\circ} 02 / 16$, celebrado entre INEA/RJ e Petrobras Transporte S/A

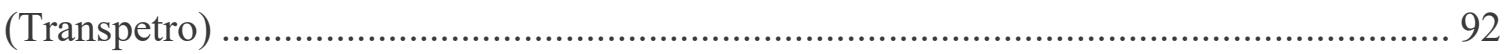

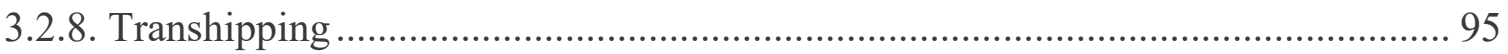

3.2.8.1. Ação Civil Pública $n^{\circ}$ 0064056-64-2005.8.19.0001 ............................................ 95

3.2.8.2. TAC celebrado entre Estado do Rio de Janeiro e Transhipping .......................... 97

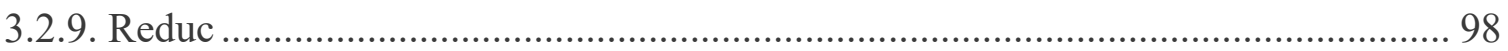

3.2.9.1. Apelação Cível no 2009.001.45387-Justiça Estadual........................................ 99

3.2.9.2. Apelação Cível no 0116673-93.2008.8.19.0001 - Justiça Estadual ................... 100

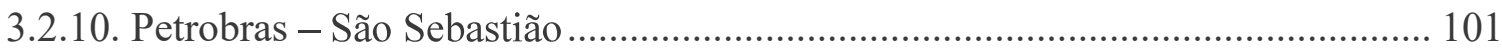

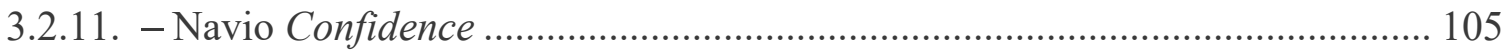

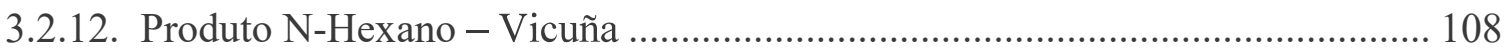

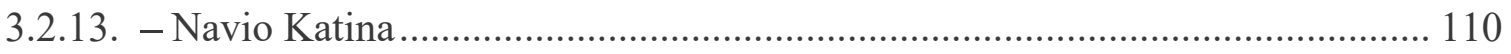

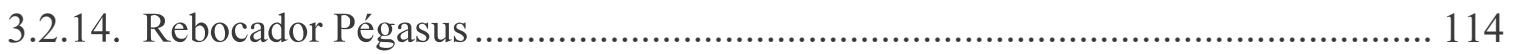

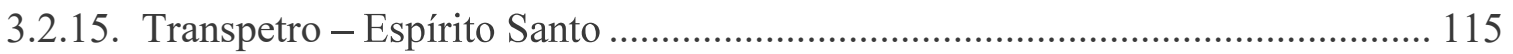

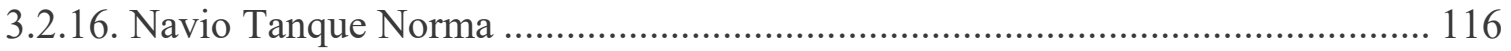

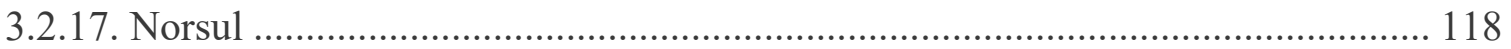

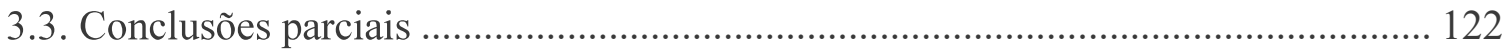

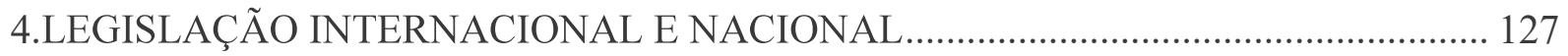

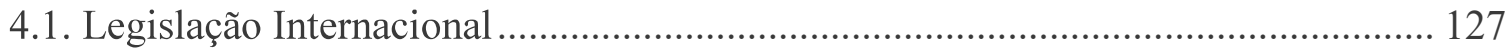

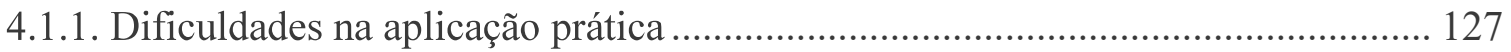

4.1.2. Tratados e Convenções Internacionais ................................................................ 128

4.1.2.1. Convenção Internacional para Prevenção de Poluição no Mar por Petróleo - Oil Pollution Convention, 1954 (OILPOL) ......................................................................... 136

4.1.2.2. Convenção Internacional Relacionada à Intervenção em Alto Mar em casos de Acidentes de Poluição por Óleo - International Convention Relating to Intervention on the High Seas In Cases of Oil Pollution Casualties, 1969 (INTERVENTION 69) ....... 138

4.1.2.3. Convenção Internacional sobre Responsabilidade Civil em Danos Causados por Poluição por Óleo - International Conventionon Civil Liability for Oil Pollution Damage, 1969 e 1992 (CLC/69 e CLC/92).

4.1.2.4. Convenção sobre Prevenção da Poluição Marinha por Alijamento de Resíduos e Outras Matérias - International Convention on the Prevention of Marine Pollution by Dumping of Wastes and other Matter, 1972 (LC/72)

4.1.2.5. Convenção Internacional para a Prevenção da Poluição proveniente de Navios International Convention for the Prevention of Pollution from Ships, 1973, modificada pelo Protocolo de 1978 (MARPOL 73/78).

4.1.2.6. Convenção Internacional para a Salvaguarda da Vida Humana no Mar -

International Convention for the Safety of Life at Sea (e emenda), 1974 (SOLAS 74). 149 
4.1.2.7. Convenção das Nações Unidas sobre o Direito do Mar - United Nations Conference on the Law of the Sea, Montego Bay, Jamaica, 1982 (UNCLOS/82)

4.1.2.8. Convenção Internacional sobre Preparo, Resposta e Cooperação em Caso de Poluição por Óleo- Oil Pollution Preparedness, Response and Co-operation, 1990 (OPRC 90)

4.1.2.9. Convenção sobre Responsabilidade Civil por Danos Causados pela Poluição por Combustíveis de Navios - International Conventionon Civil Liability for Bunker Oil Pollution Damage, 2001 (BUNKER/01)

4.1.2.10. Convenção Internacional de Hong Kong para a Reciclagem Segura e Ambientalmente Adequada de Navios - The Hong Kong International Convention for the Safe and Environmentally Sound Recycling of Ships, 2009 155

4.2. Legislação Brasileira 156

4.2.1. Panorama Geral 156

4.2.2. Prevenção de derramamentos de óleo 160

4.2.3. Plano Nacional de Contingência, Planos de Área, Planos de Emergência Individual

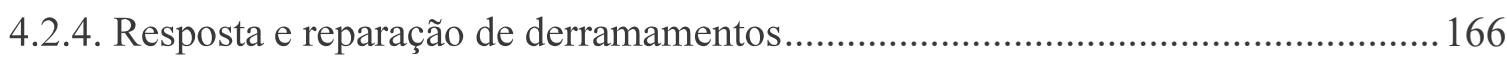

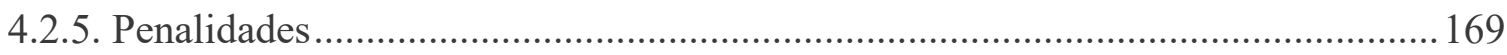

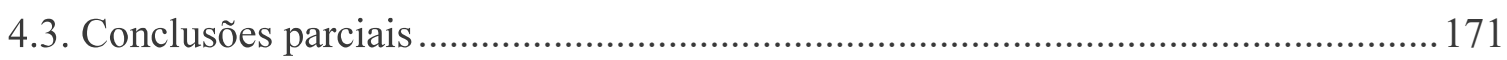

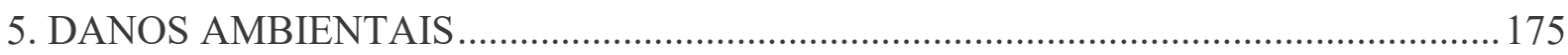

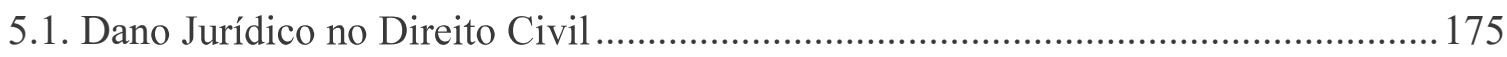

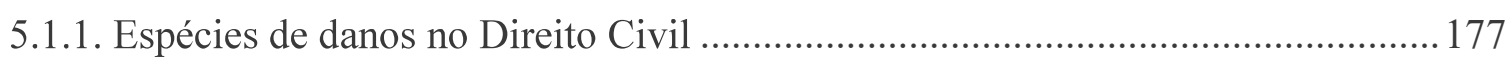

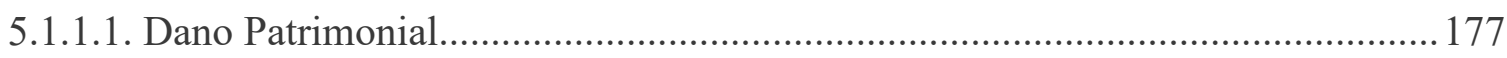

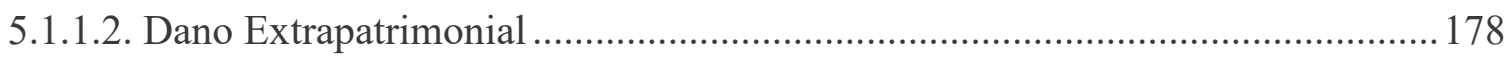

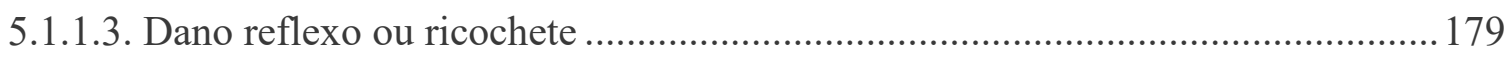

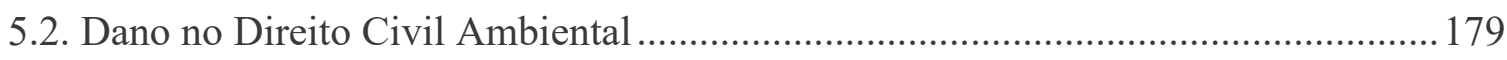

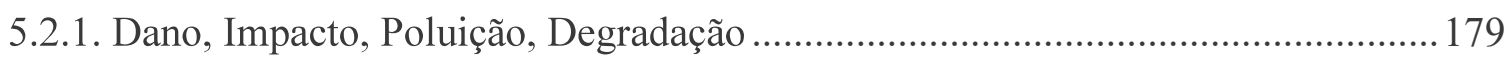

5.3. - Dano Jurídico versus Dano Ecológico ................................................................. 183

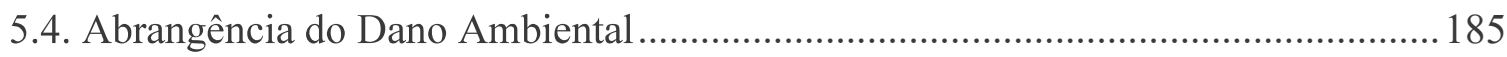

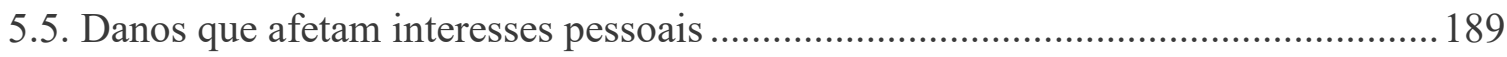

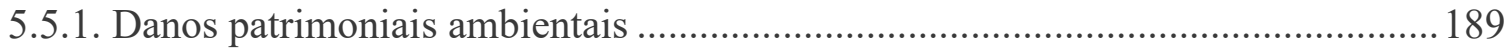

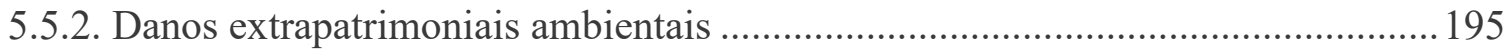

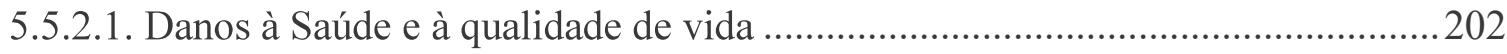

5.5.2.2. Danos extrapatrimoniais coletivos e sociais difusos ..........................................2. 205

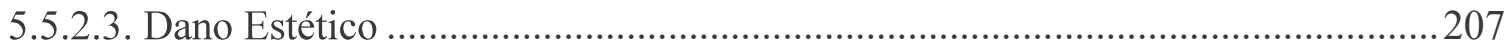

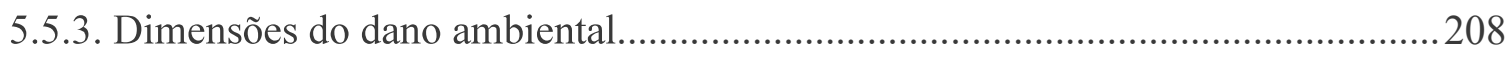

5.6. Danos restritos ao meio ambiente - ecológicos puros .............................................209 
5.6.1. Biodiversidade marinha brasileira 209

5.6.2. Classificação dos danos provocados por óleos em organismos marinhos 212

5.6.3 Danos Biológicos. 213

5.6.4. Danos à cadeia alimentar 220

5.6.5. Danos aos Ecossistemas: ambientes afetados ........................................................ 222

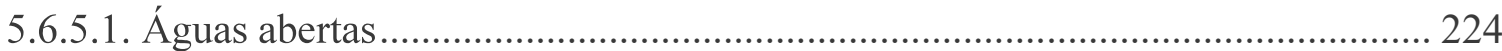

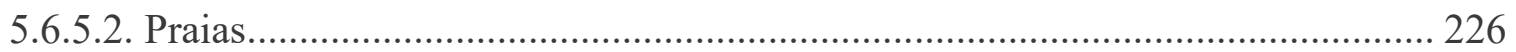

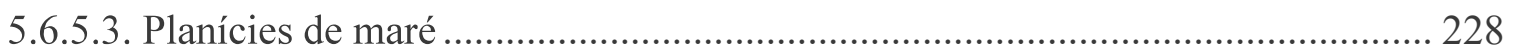

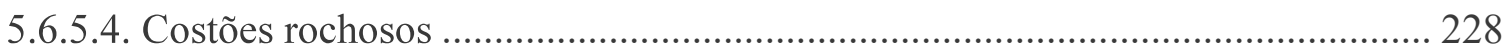

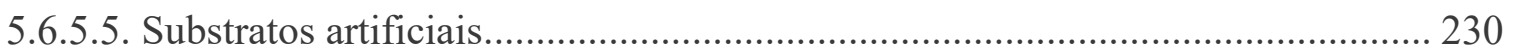

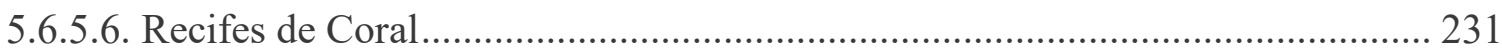

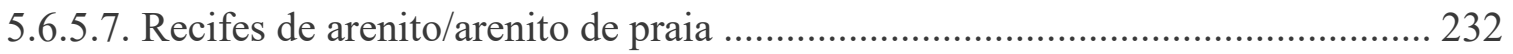

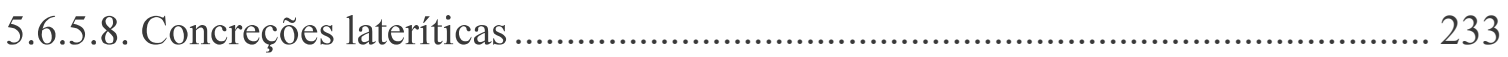

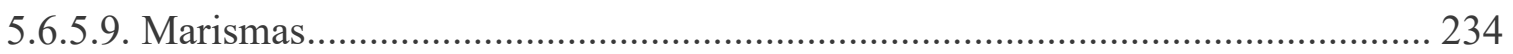

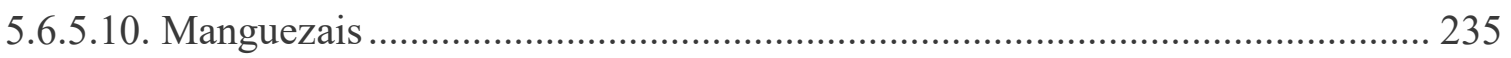

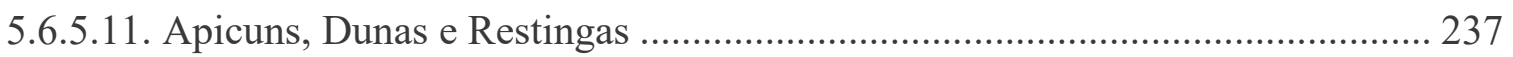

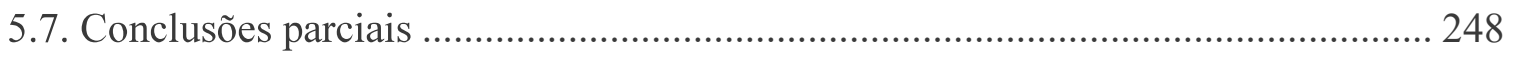

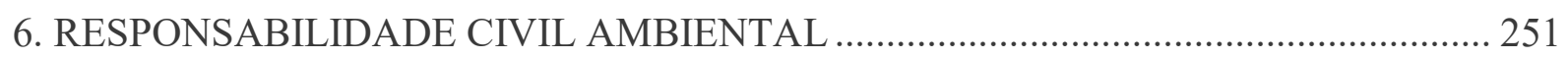

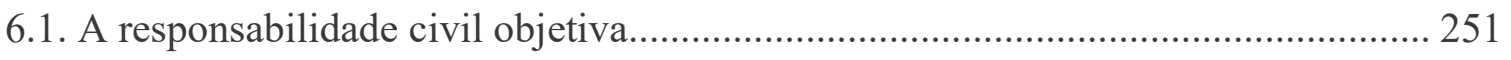

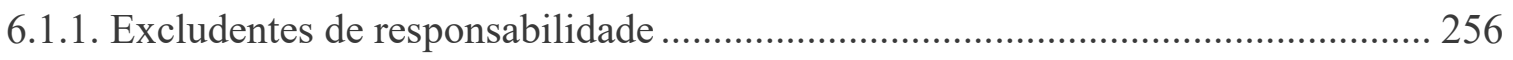

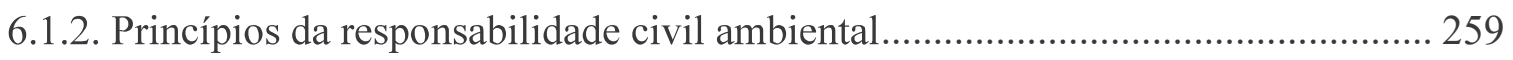

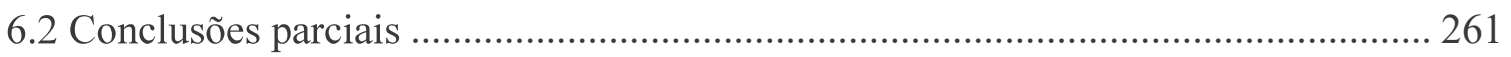

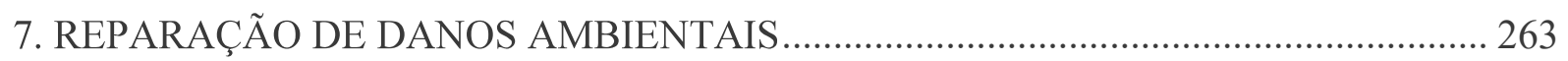

7.1. Restauração, Recuperação e Remediação como espécies de reparação ecológica.. 264

7.2. Os limites da restauração ecológica como forma de reparação ................................ 266

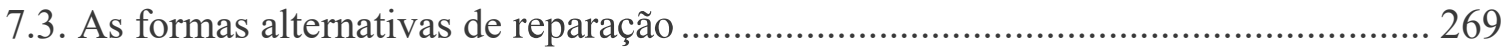

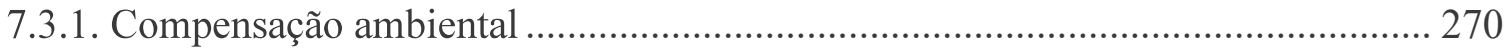

7.3.1.1. A compensação ambiental nos Termos de Ajustamento de Conduta................. 275

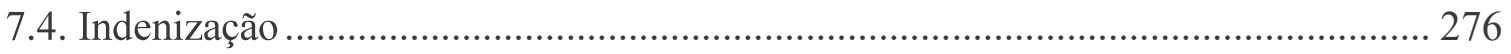

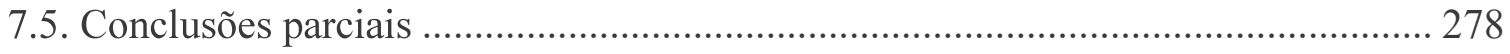

8. INDENIZAÇÃO PECUNIÁRIA NA RESPONSABILIDADE CIVIL POR

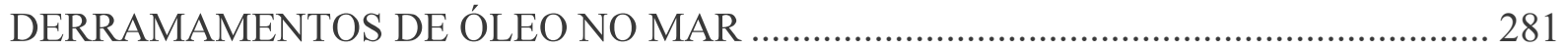

8.1. Aplicabilidade da indenização pecuniária no Direito Civil Ambiental ................... 281

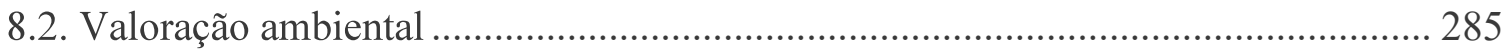

8.2.1. Valoração de recursos versus valoração de danos ................................................. 288 
8.2.2. Métodos de valoração.

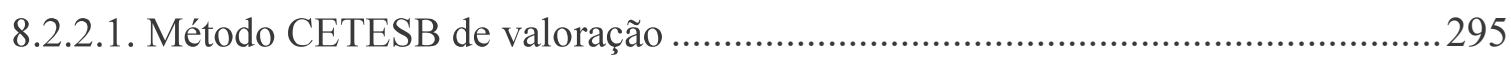

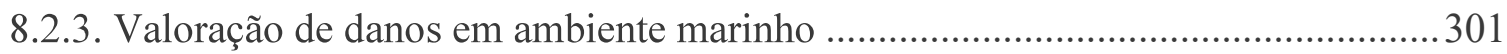

8.2.3.1. Valoração de danos ambientais ecológicos e patrimoniais e extrapatrimoniais 301

8.2.3.1.1. Valoração do dano ambiental reflexo patrimonial e extrapatrimonial .............302

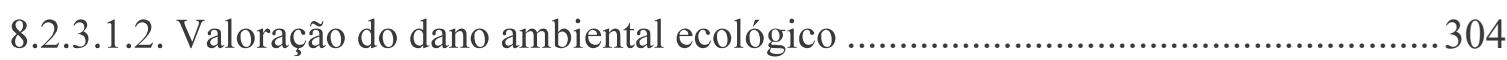

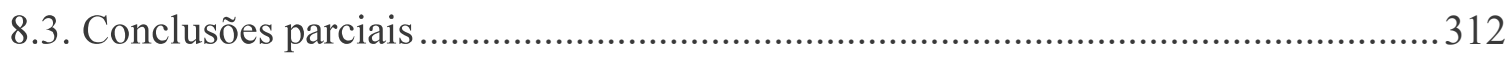

9. FUNDOS COMO SUBSÍDIO PARA A REPARAÇÃO DE DANOS POR DERRAMAMENTOS DE ÓLEO NO MAR .................................................................... 317

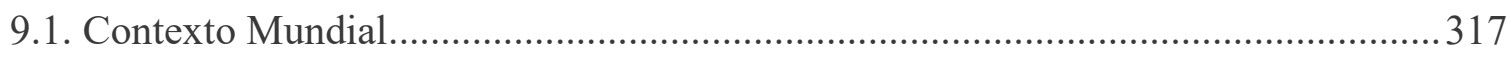

9.1.1. International Oil Pollution Compensation Fund ................................................. 317

9.1.2. Finnish Oil Pollution Compensation Fund (Finlândia) ........................................ 319

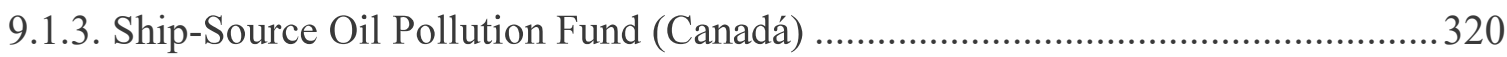

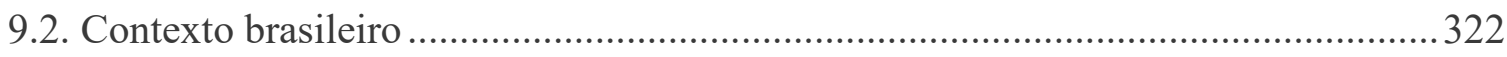

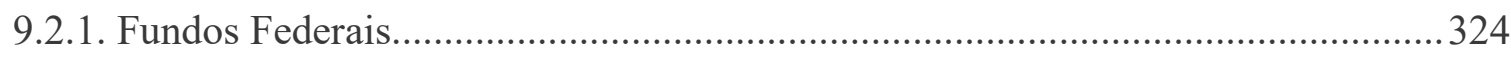

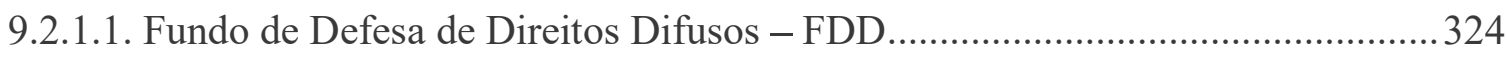

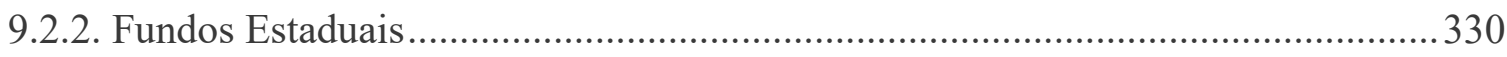

9.2.2.1. Fundo Estadual de Defesa dos Interesses Difusos (FID) - SP ............................ 330

9.2.2.2. Fundo Estadual de Recursos Hídricos (FEHIDRO) - SP ...................................331

9.2.2.3. Fundo Estadual de Conservação Ambiental e Desenvolvimento Urbano

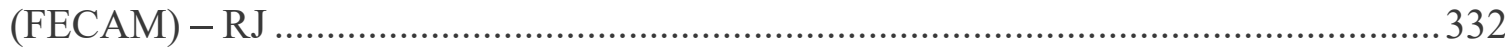

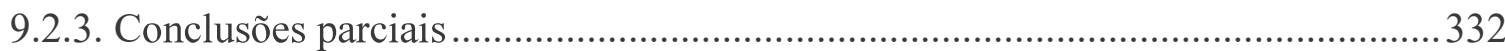

10. SEGUROS COMO GARANTIA PARA REPARAÇÃO DE DERRAMAMENTOS DE

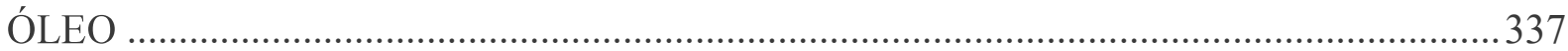

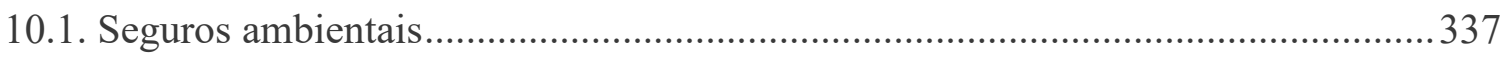

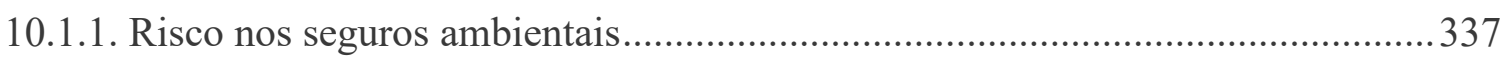

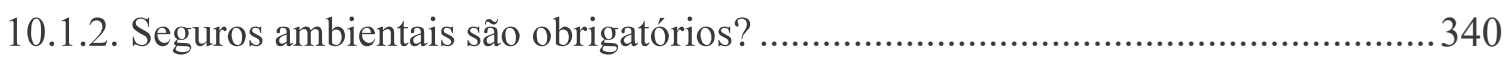

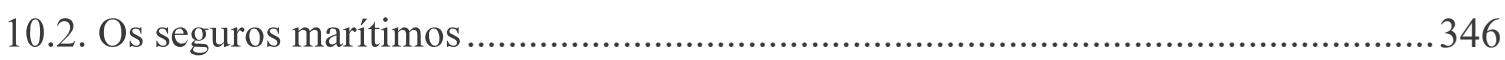

10.2.1. Seguros para embarcações, mercadorias, plataformas e operadores portuários .347

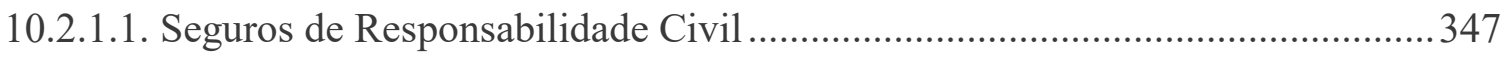

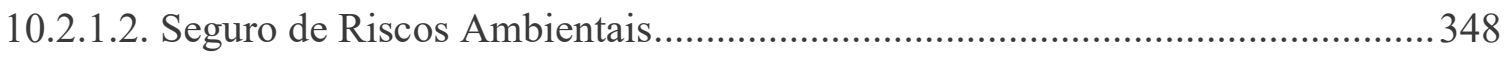

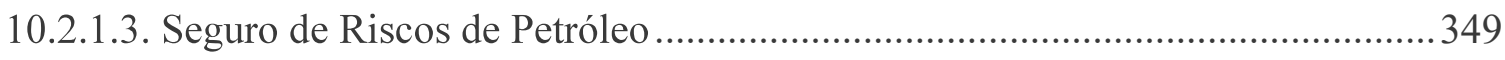

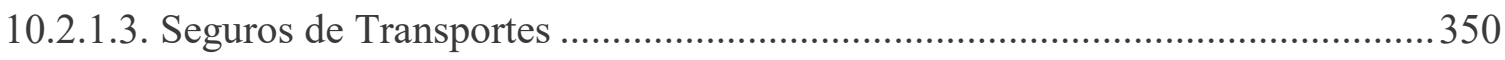

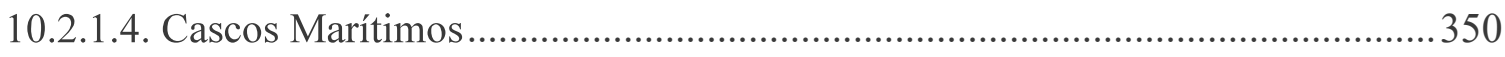

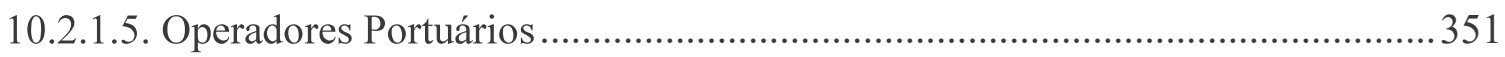

10.2.1.6. O Seguro de Proteção e Indenização, Protection \& Indemnity (P\&I)............... 352 


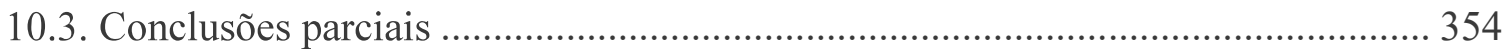

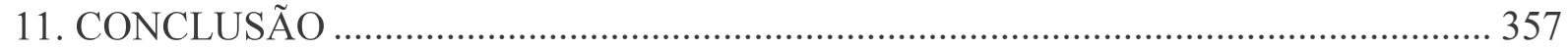

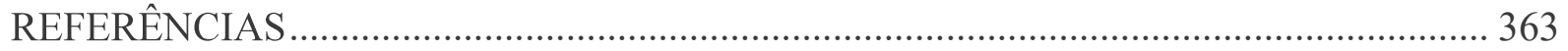




\section{INTRODUÇÃO}

Muito embora as formas de energias renováveis estejam sendo aprimoradas e cada vez mais ganhando mercados no mundo todo, a atividade petrolífera não só permanece abundante, mas, em alguns países, a exemplo do Brasil, mostra-se, inclusive, em expansão. Se, por um lado, o país é reconhecido por suas conquistas atreladas a descobertas de novas fontes de petróleo - sendo as mais recentes compreendidas pelo "pré-sal”, por outro lado, seu território é igualmente marcado pelos danos incalculáveis, causados por diversos tipos, dimensões de derramamentos envolvendo diferentes composições de óleos.

Ao contrário do que se pensa, o litoral brasileiro não é alvo apenas de fatalidades catastróficas, pontuais e raras veiculadas na mídia, como o caso "Chevron", que resultou no vazamento de aproximadamente 3.700 barris de óleo, no Campo do Frade, na Bacia de Campos, Rio de Janeiro, em novembro de 2011. A realidade, infelizmente, é marcada por constantes ocorrências de menor magnitude por todo o litoral do país. As chamadas manchas órfãs são o exemplo concreto da regularidade de derramamentos de óleo. Por serem relativamente pequenas e transitarem facilmente pelo oceano, com o auxílio de correntes e ventos, dificilmente são identificadas suas fontes geradoras.

Assim, são diversas as formas de derramamentos de óleo no mar. Podem ocorrer desde pequenos desvios operacionais, ocasionados por pequenas ou grandes embarcações, de passeio ou comerciais, até em decorrência de grandes acidentes. Com relação aos efeitos, a própria configuração do território brasileiro, com portos estratégicos, rodeados de manguezais e ecossistemas sensíveis, cria um cenário de grande risco ambiental. Desse modo:

Diante da eminência da liberação do óleo ao meio ambiente surge a necessidade de adotar medidas preventivas, corretivas e punitivas visando a segurança humana e a proteção ambiental. Diante da evidência das ocorrências surge também a necessidade de comprovar os efeitos desta poluição, provando a relação entre as causas e as consequências. ${ }^{1}$

Conforme pontuado, o próprio desenvolvimento das atividades relacionadas ao petróleo no Brasil naturalmente eleva os riscos de derramamentos. Porém, tais fatores devem ser acompanhados de estudos e investimentos, que visem ao aprimoramento da legislação e dos procedimentos que tratam tanto da prevenção, quanto da remediação de acidentes.

\footnotetext{
${ }^{1}$ POFFO, Í. R. F. Vazamentos de Óleo no Litoral Norte do Estado de São Paulo. Análise Histórica (19741999). Dissertação de Mestrado, PROCAM/USP - Programa de Pós-graduação em Ciências Ambientais da Universidade de São Paulo. 2000, p.3.
} 
Não somente o conhecimento profundo da legislação atinente aos casos aqui estudados, mas principalmente a sua correta aplicação é primordial para o desenvolvimento do presente trabalho. Ademais, o país aderiu a importantes tratados e convenções sobre o tema, que devem ser compreendidos e principalmente utilizados como subsídio, tanto para decisões judiciais pósocorrência dos danos, como para a elaboração de estratégias e estudos de prevenção. Por outro lado, entende-se que, para haver uma adequada prevenção, necessariamente, deve-se conhecer muito bem as características do dano a ser evitado.

Não se pode negar que os danos ambientais são ainda mais agravados nas hipóteses em que o óleo extrapola as águas oceânicas chegando à costa. Nessas situações, diversos interesses são lesados, além da proteção ao meio ambiente, uma vez que a saúde, bem-estar e economia local passam a ser atingidos. Além disso, deve-se ter em mente que danos decorrentes de derramamentos de óleo no mar são complexos e interdisciplinares.

Considera-se como maior empecilho à efetiva reparação do dano a sua abordagem limitada. A jurisprudência analisada no presente trabalho demonstra claramente que as decisões judiciais não promovem a real reparação dos danos em casos de derramamentos de óleo no mar, pois, além de outros fatores que serão estudados, os danos ambientais não são corretamente identificados.

Infelizmente o tema "derramamento de óleo no mar" ainda é estudado de forma segmentada. Por meio da realização de uma pesquisa preliminar sobre o assunto foi possível identificar uma significativa quantidade de publicações que abordam prevenção, reparação e remediação sob aspectos exclusivamente técnicos. Da mesma forma, quando focados sob um viés jurídico, dificilmente os trabalhos consultados recepcionam visões de outras ciências. Ademais, poucas publicações se dedicam ou a uma análise crítica da legislação existente ou a uma revisão sobre as formas de reparação encontradas pelo direito para o assunto em tela.

Até mesmo a presente tese foi impulsionada por conta da segmentação com que o tema é normalmente tratado. Ainda durante o curso de Biologia, com ênfase em gerenciamento costeiro cursado na Unesp de São Vicente, tive a oportunidade de estudar as técnicas de remediação de derramamentos de óleo no mar, concluindo que a legislação vigente à época não recepcionava os avanços técnicos e práticos. O interesse pelo assunto cresceu ao longo dos anos, sendo que na faculdade de Direito iniciei uma pesquisa sobre responsabilidade decorrente de derramamentos. Da mesma forma, foi possível notar que o Direito raramente recepcionava outras áreas de conhecimento para esses casos. 
Assim, diante da pesquisa prévia desenvolvida para a submissão de projeto de pesquisa ao Programa de Doutorado Direto, do Programa de Ciência Ambiental da Universidade de São Paulo, ficou mais evidente ainda a necessidade emergencial de desenvolvimento de um trabalho que tivesse como base o Direito Civil, mas que possibilitasse a incorporação de outras ciências, buscando demonstrar a viabilidade e necessidade do tema "reparação de danos decorrentes de derramamentos de óleo no mar" ser observado de forma interdisciplinar.

O recorte temático pelo foco na reparação e não na prevenção adotado se justifica pelos seguintes motivos: (i) a evolução da legislação brasileira ter demonstrado o aumento da adoção de medidas preventivas por parte dos potenciais causadores de derramamentos, a consequente diminuição dos incidentes; (ii) as pesquisas prévias ao desenvolvimento do presente trabalho sinalizaram que as formas de reparação adotadas pelo judiciário brasileiro não atendiam à reparação ecológica e social dos diversos danos identificados em decorrência dos derramamentos; (iii) o fator inovador que o trabalho poderia trazer ao propor um repensar da reparação jurídica por meio da contribuição de outras ciências

Dessa forma, no que tange à sua metodologia, cumpre esclarecer que o presente trabalho, muito embora tenha como objeto principal a análise das soluções jurídicas referentes à reparação de danos decorrentes de derramamentos de óleo no mar, buscou abordar o problema de forma interdisciplinar. Acredita-se aqui, que tais derramamentos não podem ser solucionados por uma única área de conhecimento, de forma isolada. Devido a esse fato, podese atribuir a presente tese o caráter exploratório, e investigatório, vez que se desenvolve, inicialmente, a partir de um levantamento extensivo tanto de dados diretos e indiretos associados aos derramamentos (dados estatísticos quantitativos e levantamento jurisprudencial quantitativo e qualitativo).

Os dados estatísticos permitiram, conforme será verificado no capítulo 02, um melhor entendimento do cenário que permeia os derramamentos de óleo no mar, tanto do ponto de vista das fontes, quanto dos padrões de derramamentos mais comuns nos últimos dez anos, de acordo com dados publicados pela Companhia Ambiental do Estado de São Paulo (CETESB).

A partir desses dados, partiu-se para um levantamento das soluções ofertadas pelos Tribunais Brasileiros aos derramamentos. No capítulo 03, o levantamento jurisprudencial foi realizado em duas etapas, a primeira consistiu em uma pesquisa por palavras - chave nos principais tribunais brasileiros (Supremo Tribunal Federal, Superior Tribunal de Justiça e Tribunais Regionais Federais), por meio da qual foram selecionados julgados que discutem a reparação dos danos decorrentes sob as regras inerentes à Responsabilidade Civil Ambiental. 
A segunda etapa da pesquisa jurisprudencial igualmente ocorreu considerando-se a Responsabilidade Civil Ambiental, porém a busca nos tribunais se deu a partir dos principais casos de derramamentos de óleo ocorridos no Brasil, cujos julgados estavam disponibilizados nas plataformas de busca. Para essa etapa, a pesquisa foi ampliada para abranger igualmente os Tribunas de Justiça Estaduais.

A análise tanto dos dados preliminares, quanto dos casos práticos permitiu a formulação de alguns questionamentos sobre a efetividade das medidas de reparação adotadas pelos Tribunais Brasileiros. $\mathrm{O}$ fato da grande maioria dos casos ser resolvida por meio de pagamento de indenizações destinadas aos fundos de interesses difusos, com raras exceções solucionadas por meio de Termos de Ajustamento de Conduta, impulsionou, primeiramente, a necessidade de um maior entendimento sobre os elementos que devem ser considerados em decisões como as estudadas.

Nesta lógica, o primeiro elemento considerado foi o legal. No capítulo 04, foram sistematizadas e brevemente contextualizadas as principais normas internacionais e brasileiras aplicáveis aos derramamentos de óleo no mar. A importância das convenções internacionais se justifica não somente para contextualizar a problemática de uma forma global, mas igualmente para identificar as obrigações e regras ratificadas pelo Brasil, para uma posterior avaliação acerca da pertinência, aplicabilidade e de eventuais conflitos com o ordenamento brasileiro. Tanto as convenções e tratados ratificados, quanto a legislação pátria são a base que deve nortear os limites dos julgamentos dos derramamentos. Nesse sentido, optou-se por não ignorar uma análise aprofundada desse primeiro elemento.

Em seguida, o trabalho foi desenvolvido considerando-se a ordem lógica de surgimento dos demais elementos em um caso prático qualquer de derramamento de óleo no mar. Logo após o evento, são verificados os danos; em seguida, escolhe-se a forma de responsabilização, determina-se as medidas de reparação, que, conforme apontado, geralmente resultam em pagamento de indenizações, destinadas a fundos, cujo valor pode ser coberto por seguros ambientais. Os seis elementos retratados foram divididos em capítulos exclusivos e desenvolvidos com base em revisão bibliográfica, tanto doutrinária, prioritariamente naqueles que tratam de aspectos jurídicos e econômicos, quanto de trabalhos empíricos, desenvolvidos por autores que analisaram principalmente aspectos biológicos e ecológicos dos derramamentos de óleo, ou aplicaram em campo metodologias de valoração de danos ambientais.

Assim, o capítulo 05 é considerado um dos principais para o presente estudo, vez que busca caracterizar os danos decorrentes dos derramamentos de uma forma abrangente e 
interdisciplinar. São discutidos tanto os aspectos jurídicos dos danos, quanto os ecológicos, os ecossistêmicos, os atinentes a saúde, bem-estar e estética, bem como os financeiros. O propósito maior desse capítulo é indicar a necessidade de que, mesmo em análises estritamente jurídicas, todos esses elementos sejam considerados por meio de uma adequada identificação dos danos ambientais.

Uma vez havendo a correta caracterização do dano, deve-se compreender as formas de reparação. Entretanto, foi necessário realizar uma escolha de abordagem quanto à forma de responsabilização a ser considerada. O capítulo 06 traz argumentos que justificam a escolha da responsabilidade civil ambiental, vez que, dentre as três formas existentes no ordenamento jurídico brasileiro, é a que busca, como principal objetivo, a reparação do dano.

Inclusive as formas de reparação de danos, apresentadas no capítulo 07, são baseadas na responsabilidade civil e, muito embora os conceitos venham do Direito, o principal objetivo a ser perseguido pela reparação, e que deve ser priorizado, é a restauração ecológica do ambiente afetado. Pois bem, nesse ponto do trabalho, os questionamentos que surgiram no capítulo 03 começam a ser confirmados, uma vez que se observa que nem sempre as formas de reparação de danos adotadas nos julgados resultam em ações práticas nos ambientes afetados.

Para uma maior compreensão da realidade prática das decisões, o capítulo 08 se destina a avaliar de forma interdisciplinar, considerando as abordagens jurídica, econômica e ecológica a aplicação prática da indenização como forma de reparação de danos. Em decorrência do pagamento das indenizações, o capítulo 09 avalia a destinação dos valores aos fundos de interesses difusos e, brevemente, apresenta outros fundos existentes em países estrangeiros, que aparentam ser mais eficientes, tanto para a reparação de danos decorrentes de derramamentos de óleo no mar, quanto para prevenção.

Por fim, o capítulo 10 se destina a apresentar os seguros ambientais aplicáveis aos derramamentos. Apesar do tema ser pouco explorado no Brasil, a opção por abordar esse tema se deu não apenas em decorrência de serem garantias de pagamento de indenizações de significativos derramamentos com custos elevados, mas também pela contribuição que os seguros podem dar na prevenção de desastres ou na mitigação dos efeitos dos derramamentos. 


\section{BREVES CONSIDERAÇÕES SOBRE OS CENÁRIOS DOS DERRAMAMENTOS DE ÓLEO NO BRASIL}

O Brasil abriga um dos mais extensos litorais intertropicais e subtropicais do mundo, estendendo-se por cerca de $8.000 \mathrm{~km}$ de $\operatorname{costa}^{2}$, abrigando 17 estados e mais de quatrocentos municípios. Já o mar territorial, se estende por 12 milhas náuticas, contadas a partir da linha da costa; e a Zona Marinha é composta, além da região costeira, pela plataforma continental marinha e pela Zona Econômica Exclusiva (ZEE). Após pleito junto à Organização das Nações Unidas (ONU), o Brasil foi contemplado com um acréscimo de $900 \mathrm{mil} \mathrm{km}^{2} \mathrm{em}$ pontos onde a Plataforma Continental vai além das 200 milhas náuticas, podendo chegar em até no máximo 350 milhas. Com isso, a área das águas jurisdicionais brasileiras abrange, hoje, aproximadamente 4,5 milhões de $\mathrm{km},{ }^{2}$ sendo nomeada pela Comissão Interministerial sobre os Recursos do Mar (CIRM) de Amazônia Azul. ${ }^{3}$

A Zona Costeira é formada por uma significativa diversidade de ecossistemas, que transitam entre ambientes terrestres e marinhos, de forma interativa. Da mesma forma que são extremamente importantes do ponto de vista ambiental, são igualmente frágeis e, por isso, o ordenamento jurídico brasileiro confere a eles proteção especial. A maior parte da população mundial habita as Zonas Costeiras, sendo a manutenção da qualidade ambiental dessas áreas fator essencial para a promoção de uma satisfatória qualidade de vida. Desse modo, não se pode excluir dessas áreas as regiões úmidas e estuarinas, bem como as correspondentes bacias de recepção e drenagem e as águas interiores próximas à costa. ${ }^{4}$

Entretanto, além da ocupação para moradia, a Zona Marinha Brasileira constitui um perfeito cenário de movimentação de inúmeras atividades econômicas, que, direta ou indiretamente, podem causar derramamentos de óleo no mar.

Quando o tema é abordado, não é difícil que automaticamente venha em mente os catastróficos acidentes ocorridos nas plataformas de petróleo, ou seja, decorrentes da atividade de exploração offshore, a exemplo dos ocorridos na plataforma P-36, ocorrido em 2001, no Brasil, e na Deepwater Horizon, em 2010, no Golfo do México. No caso brasileiro, após o início

\footnotetext{
${ }^{2}$ AB'SÁBER, A. N. Litoral do Brasil. São Paulo: Metalivros, p.287, 2001.

3 Informações retiradas do site do Ministério do Meio Ambiente. Disponíveis em: <www.mma.gov.br/biodiversidade/biodiversidade-aquatica/zona-costeira-e-marinha.html $>$. Acesso em: 15.06.2018.

4 BRASIL. Ministério do Meio Ambiente. Plano Nacional de Gerenciamento Costeiro (PNGC II). Aprovado pela Resolução n ${ }^{\circ} 005$ de 03 de dezembro de 1997 da CIRM - Comissão Interministerial para os Recursos do Mar. seção 1, pg. 46-49, Brasília, DF, Brasil. Publicado no DOU de 14/01/1998.
} 
de vigência da Lei ${ }^{0}$ 9.478/1997, que definiu o novo modelo de exploração e produção de petróleo no País, e com a consequente descoberta e rápida exploração do "pré-sal", a preocupação com esse tipo de atividade tornou-se ainda maior, tanto pelas incertezas acerca da nova modalidade de exploração, em profundidades até então pouco conhecidas, quanto pela celeridade e números expressivos, relativos a produção de petróleo, revelados nos últimos anos, a exemplo dos publicados pela Petrobras. A Empresa afirma que, até 1984, apenas 41 mil barris de petróleo eram obtidos por dia, em 4.108 poços de exploração, localizados nas camadas do "pós-sal". Já nos atuais 77 poços que compõem o "pré-sal", são obtidos diariamente 1,5 milhões de barris. $^{5}$

Assim, não se pode deixar de relacionar a guinada da exploração de petróleo no país, com o aumento do fluxo de embarcações no mar brasileiro de uma forma geral. O mar territorial e as ZEE nacionais são cortadas por diferentes rotas comerciais de navegação, com tráfego fortemente induzido, historicamente, pela própria atividade de produção de óleo. O transporte de mercadorias em geral, além do óleo, também é expressivo, além da pesca, tanto costeira, quanto oceânica, que cada vez mais avança para os limites da ZEE, chegando a águas internacionais. $^{6}$

No campo das grandes embarcações, principalmente ligadas ao ramo petrolífero, grande parte bandeiras estrangeiras, os afretamentos dessas são permitidos pela Agência Nacional de Transportes Aquaviários (ANTAQ), quando há indisponibilidade de embarcações de bandeira brasileira do mesmo tipo e porte adequados para o serviço pretendido. Em 2018, 8.400 embarcações foram autorizadas ou registradas, das quais 270 eram petroleiros e 19 eram navios

\footnotetext{
${ }^{5}$ Conforme texto disponível no website da Petrobras: "O pré-sal é uma sequência de rochas sedimentares formadas há mais de 100 milhões de anos, no espaço geográfico criado pela separação do antigo continente Gondwana. Mais especificamente, pela separação dos atuais continentes Americano e Africano, que começou há cerca de 150 milhões de anos. Entre os dois continentes formaram-se, inicialmente, grandes depressões, que deram origem a grandes lagos. Ali foram depositadas, ao longo de milhões de anos, as rochas geradoras de petróleo do pré-sal. Como todos os rios dos continentes que se separavam correram para as regiões mais baixas, grandes volumes de matéria orgânica foram ali depositados. À medida que os continentes se distanciavam, os materiais orgânicos então acumulados nesse novo espaço foram sendo cobertos pelas águas do Oceano Atlântico, que então se formava. Dava-se início, ali, à formação de uma camada de sal que atualmente chega a 2 mil metros de espessura. Essa camada de sal depositou-se sobre a matéria orgânica acumulada, retendo-a por milhões de anos, até que processos termoquímicos transformassem a camada orgânica em hidrocarbonetos (petróleo e gás natural)." Disponível em: $<\underline{\text { http://www.petrobras.com.br/pt/nossas-atividades/areas-de-atuacao/exploracao-e-producao-de-petroleo-e- }}$ gas/pre-sal/>. Acesso em 25.11.2018.

${ }^{6}$ BRASIL. MMA. Macrodiagnóstico da Zona Costeira e Marinha do Brasil. $2^{\circ}$ Macrodiagóstico da ZC - Óleo e Gás. Disponível em: $<\underline{\text { http://www.mma.gov.br/images/arquivo/80033/Macrodiagnosticocapitulos/xpre7.SPMacrodiagZonaEconmica }}$ Exclusiva p173-187.pdf. $>$. Acesso em: 06.02.2018.
} 
tanque. O gráfico abaixo demonstra o crescimento da frota estrangeira presente no Brasil desde 2010 .

Gráfico 1- Evolução da frota marítima estrangeira no Brasil (2010 - 2018)
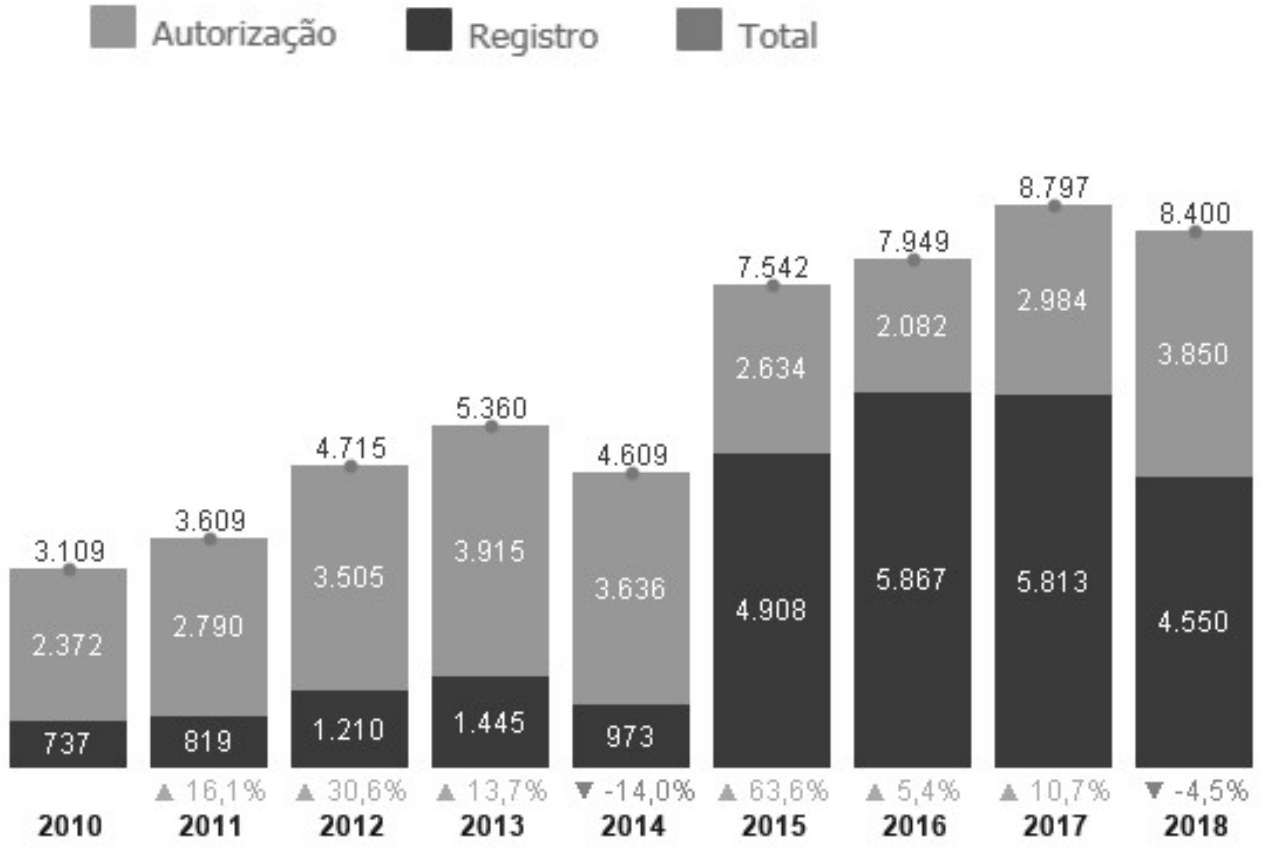

Fonte: elaboração própria com base em dados retirados do anuário da Antaq de 2018. Disponível em: $<$ http://web.antaq.gov.br/Anuario/>.

Acesso

em:

30.12.2018.

Conforme se pode observar, pelos números expressivos, se comparados à frota nacional, apresentada abaixo, a possibilidade de se ter um derramamento de óleo em águas nacionais proveniente de embarcação estrangeira é alta. Sendo assim, é inevitável que a reparação jurídica dos danos leve em conta convenções internacionais das quais o Brasil é parte. Ademais, um importante instrumento de garantia de reparação, que será abordado no capítulo 10, é o seguro ambiental, já havendo modalidades específicas para riscos associados ao petróleo.

Segundo a última atualização de 2018, realizada no anuário estatístico da Antaq, ${ }^{7}$ existe atualmente no Brasil uma frota de 2.516 embarcações marítimas nacionais. Esta contagem apontava em 2010 um total de 1.545 embarcações, o que demonstra um crescimento da frota de mais de $60 \%$ ao longo de 8 anos.

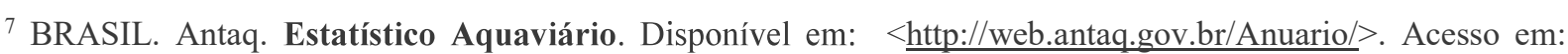
30.12.2018. 
O mesmo anuário aponta que a idade média destas embarcações é de 17 anos, estando abaixo da média mundial, que foi estimada em 20,8 anos pela Conferência das Nações Unidas sobre Comércio e Desenvolvimento (UNCTAD). ${ }^{8}$ A idade média das embarcações pode ser entendida como um dado associado à probabilidade de vazamentos de óleo por danos em cascos e estruturas, fatores que podem ser contornados com manutenções periódicas e adequadas. A idade média da frota registrada nos países em desenvolvimento continua sendo ligeiramente superior à registrada nos países desenvolvidos, mas essa diferença vem diminuindo ao longo dos anos. ${ }^{9}$

O gráfico apresentado abaixo, apresenta a evolução da frota marítima brasileira nos últimos 8 anos, demonstrando uma leve queda em 2018.

Gráfico 2- Evolução da frota marítima brasileira (2010 - 2018)

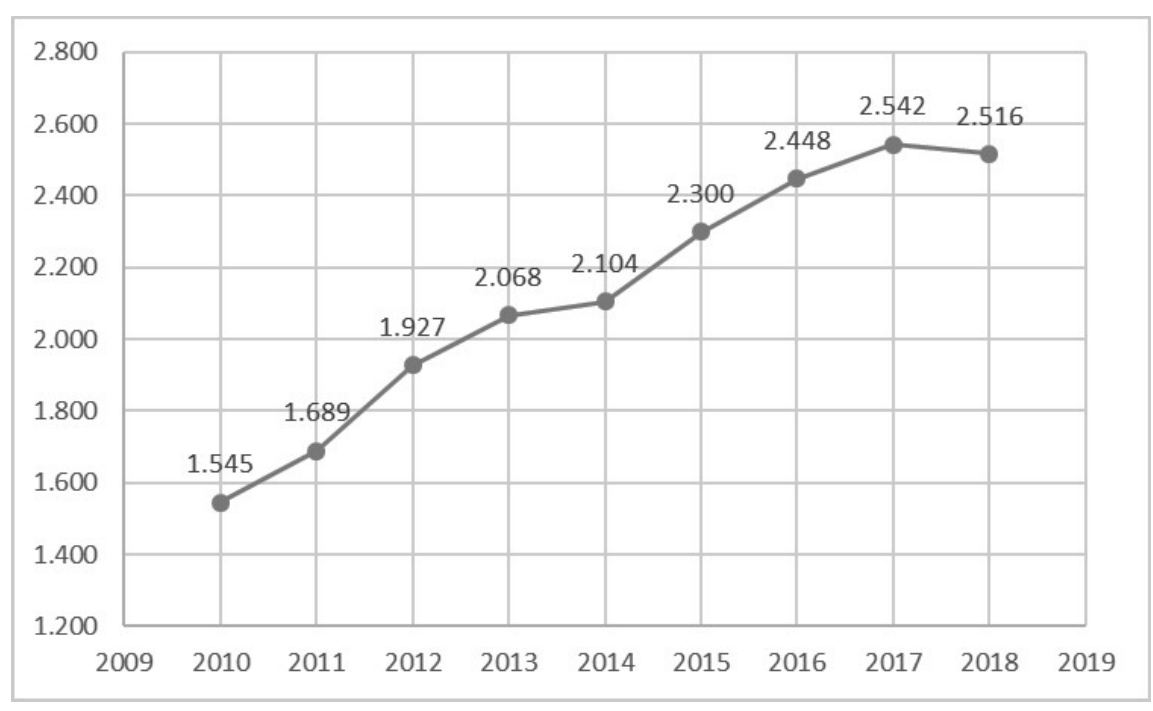

Fonte: elaboração própria com base em dados retirados do anuário da Antaq de 2018. Disponível em: $<$ http://web.antaq.gov.br/Anuario/>. Acesso em: 30.12.2018.

Se, por um lado, as plataformas e navios mercantes realmente podem representar, em magnitude, os derramamentos de óleo mais significativos; por outro, em termos de frequência,

${ }^{8}$ UNCTAD. Review of Maritime Transport 2018. United Nations Publication. New York and Geneva, 2018. Disponível em: $<$ https://unctad.org/en/PublicationsLibrary/rmt2018 en.pdf $>$. Acesso em: 22.12.2018.

${ }^{9}$ UNCTAD. Review of Maritime Transport 2018. United Nations Publication. New York and Geneva, 2018.

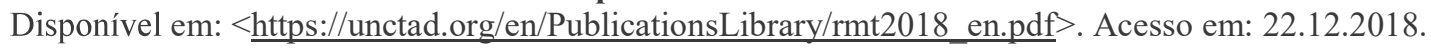


outras fontes são mais representativas, a exemplo de embarcações tanto comerciais, quanto de passeio.

Dentre o total da frota marítima brasileira em 2018, nota-se a grande representatividade numérica das pequenas e médias embarcações, como as lanchas, rebocadores/empurradores, supridores de plataformas marítimas e balsas, chegando a mais de $70 \%$ das embarcações, enquanto os petroleiros não chegam a totalizar $2 \% .^{10}$

Tabela 1 - Participação por tipo de embarcação na frota marítima brasileira

\begin{tabular}{|c|c|c|}
\hline Tipo Embarcação & $\begin{array}{c}\text { Total de } \\
\text { Embarcações } \\
\text { Marítimas }\end{array}$ & $\%$ \\
\hline Lancha & 739 & 29,37 \\
\hline Rebocador/Empurrador & 542 & 21,54 \\
\hline $\begin{array}{c}\text { Supridores De Plataformas } \\
\text { Marítimas (Supply) }\end{array}$ & 301 & 11,96 \\
\hline Balsa & 234 & 9,30 \\
\hline Bote & 129 & 5,13 \\
\hline Barcaça & 85 & 3,38 \\
\hline Traineira & 77 & 3,06 \\
\hline Flutuante & 67 & 2,66 \\
\hline Chata & 51 & 2,03 \\
\hline Carga Geral & 49 & 1,95 \\
\hline Outras Embarcações & 42 & 1,67 \\
\hline
\end{tabular}

(continua)

${ }^{10}$ BRASIL. Antaq. Estatístico Aquaviário. Disponível em: $<$ http://web.antaq.gov.br/Anuario/>. Acesso em: 30.12.2018. Acesso em: 30.12.2018. 
(conclusão)

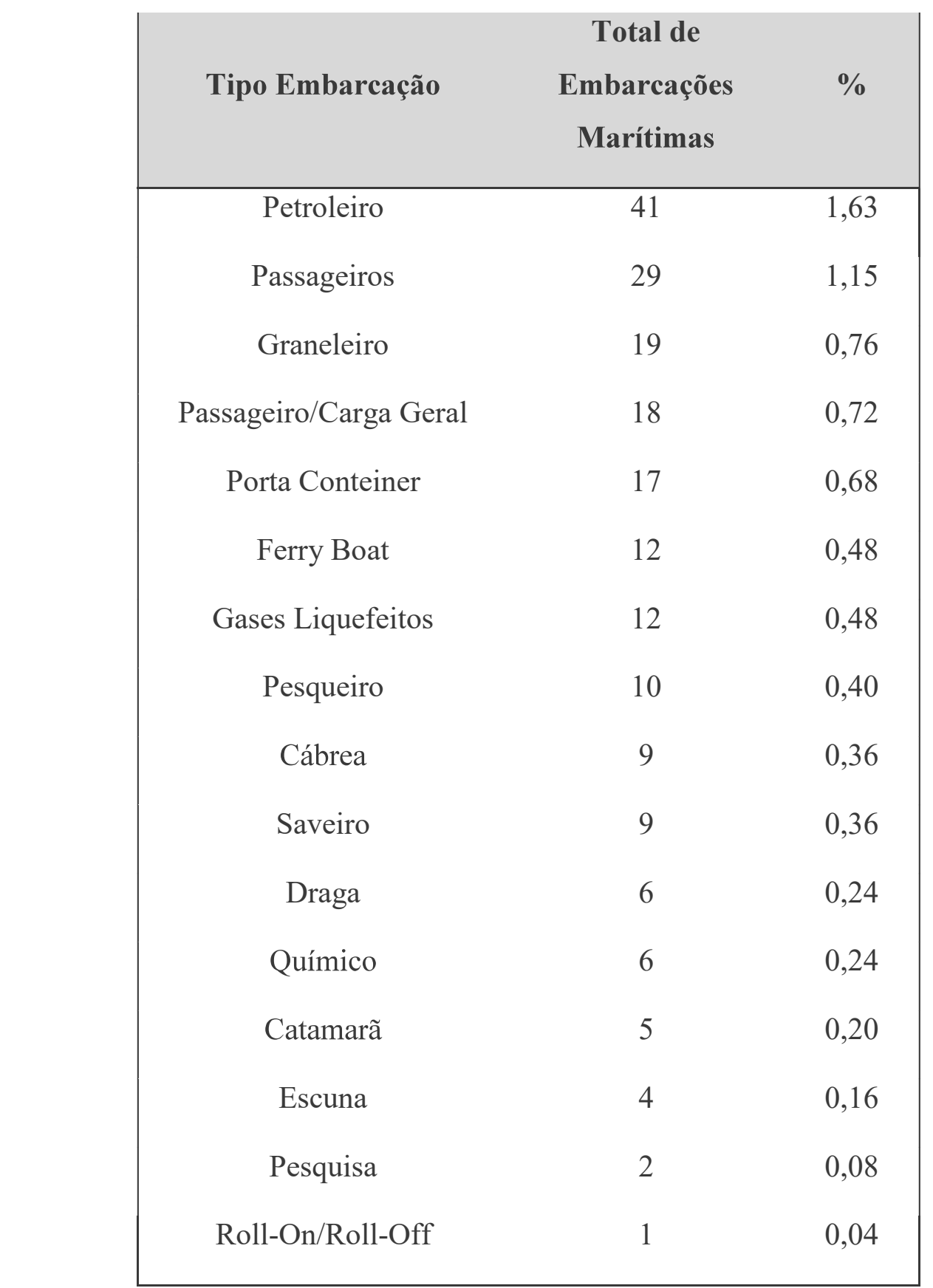

Fonte: elaboração própria com base em dados retirados do anuário da Antaq de 2018. Disponível em: $<$ http://web.antaq.gov.br/Anuario/>. Acesso em: 30.12.2018.

Entretanto, vale a ressalva de que, apesar de se configurarem como importantes indicadores sobre a frota marítima brasileira, nem todas as embarcações de bandeira brasileira estão regularmente registradas consideradas nas estatísticas da perante à Antaq. Se considerada a base de dados disponibilizados pela Marinha do Brasil (a qual não discrimina frotas de águas marítimas de águas interiores), são verificadas quantidades superiores de embarcações importantes para o diagnóstico do cenário de riscos de acidentes e derramamentos de óleo. 
Segundo a Marinha, existem no Brasil 200.487 lanchas, 3.505 rebocadores, 1.248 empurradores, 445 supridores e 5.775 balsas (apenas para listar as principais embarcações por quantidade identificadas no anuário estatístico da Antaq).

Observa-se também que grande parte destas embarcações podem estar restritas às águas interiores, visto que no Brasil o mercado náutico tem grande representatividade nestas áreas. Mas, mesmo considerando que apenas uma parcela disso se restringe a embarcações utilizadas na zona costeira, há uma disparidade significativa entre as duas fontes de informação, principalmente quando se trata de embarcações de lazer. Não obstante, tipologias como as lanchas e outras embarcações de lazer podem ser utilizadas tanto em águas interiores como em águas marítimas. Além destes tipos, destacam-se como relevantes registros nos dados da marinha a presença de 231 embarcações petroleiras, 123 navios tanque (transporte de granéis líquidos) e 26 plataformas fixas. ${ }^{11} \mathrm{~A}$ tabela abaixo apresenta os dados disponibilizados pela Marinha com as quantidades de embarcações por tipo, cadastradas nas organizações militares da Marinha do Brasil distribuídas em todo território nacional.

Tabela 2 - Quantidades de embarcações por tipo, cadastradas nas organizações militares da Marinha do Brasil distribuídas em todo território nacional ${ }^{12}$

\begin{tabular}{|cc|}
\hline TIPO DE EMBARCAÇÃO & QUANTIDADE \\
\hline Bote & 251.761 \\
Lancha & 200.487 \\
Outros & 113.937 \\
Moto-Aquática/similar & 97.590 \\
Canoa & 47.553 \\
Pesqueiro & 25.394 \\
Chata & 20.333 \\
Veleiro & 15.874 \\
Jangada & 12.958 \\
Passageiro/Carga Geral & 10.371 \\
Carga Geral & 7.643 \\
& (continua)
\end{tabular}

\footnotetext{
${ }^{11}$ Dados disponíveis em: <http://dados.gov.br/dataset/embarcacoes $>$. Acesso em: 03.01.2019. Dado criado em: 30.07.2018. Última atualização realizada em: 21.11.2018.

12 Dados disponíveis em: <http://dados.gov.br/dataset/embarcacoes $>$. Acesso em: 03.01.2019. Dado criado em: 30.07.2018. Última atualização realizada em: 21.11.2018.
} 
(continuação)

\begin{tabular}{|c|c|}
\hline TIPO DE EMBARCAÇÃO & QUANTIDADE \\
\hline Saveiro & 6.384 \\
\hline Draga & 5.831 \\
\hline Balsa & 5.775 \\
\hline Passageiro & 5.017 \\
\hline Barcaça & 4.191 \\
\hline Flutuante & 3.957 \\
\hline Rebocador & 3.505 \\
\hline Traineira & 2.035 \\
\hline Empurrador & 1.248 \\
\hline Multicasco (Catamarã, Trimarã, Tetramarã, etc.) & 1.227 \\
\hline Batelão & 1.144 \\
\hline Escuna & 989 \\
\hline Jet Boat & 906 \\
\hline Caique & 621 \\
\hline Iate & 534 \\
\hline Supridor (Supply) & 445 \\
\hline Graneleiro & 233 \\
\hline Petroleiro & 231 \\
\hline Roll-on / Roll-off Passageiro (Ferry Boat) & 167 \\
\hline Caiaque & 125 \\
\hline Tanque (transporte de granéis líquidos) & 123 \\
\hline Pesquisa & 94 \\
\hline Manuseio de Âncora (AHTS) & 87 \\
\hline Cábrea & 85 \\
\hline Hovercraft & 81 \\
\hline Laser & 69 \\
\hline Dique Flutuante & 64 \\
\hline Lançador de Linhas & 52 \\
\hline Apoio a Mergulho & 49 \\
\hline Alvarenga & 46 \\
\hline & (continua) \\
\hline
\end{tabular}


(conclusão)

\begin{tabular}{|c|c|}
\hline TIPO DE EMBARCAÇÃO & QUANTIDADE \\
\hline Plataforma Semi-Submersível & 39 \\
\hline Apoio à Manobra & 35 \\
\hline Transporte de Gases Liquefeitos & 34 \\
\hline Porta-Contentor & 28 \\
\hline Plataforma fixa & 26 \\
\hline $\begin{array}{l}\text { Floating, Production, Storage and Off-Loading Unit } \\
\text { (FPSO) }\end{array}$ & 25 \\
\hline Sonda & 20 \\
\hline Apoio a ROV & 19 \\
\hline Passageiro de Alta Velocidade (HSC Passageiro) & 13 \\
\hline Multipurpose & 13 \\
\hline Plataforma Auto-Elevável & 12 \\
\hline Oceonográfico & 12 \\
\hline Roll-on/Roll-off Carga & 11 \\
\hline Químico & 10 \\
\hline Curral & 10 \\
\hline Anfíbia & 10 \\
\hline Flotel & 9 \\
\hline Petroleiro e Químico & 8 \\
\hline $\begin{array}{c}\text { Transporte de Carga Pesada (Navio de Cargas } \\
\text { Especiais) }\end{array}$ & 5 \\
\hline Hidroavião & 5 \\
\hline Manuseio de Linhas & 5 \\
\hline Quebra-gelo & 3 \\
\hline Químico e Gaseiro & 3 \\
\hline Carga de Alta Velocidade (HSC Carga) & 1 \\
\hline Estimulador de Poço & 1 \\
\hline Total & 849.573 \\
\hline
\end{tabular}

Fonte: elaboração própria com base em dados retirados de $<$ http://dados.gov.br/dataset/embarcacoes $>$. Acesso em: 03.01.2019. Dado criado em: 30.07.2018. Última atualização realizada em: 21.11.2018

Corroborando o entendimento sobre a importância que as embarcações de pequeno e médio porte podem ter no cenário do risco de acidentes de vazamentos de óleo, tem-se que considerar que boa parte das embarcações de lazer utilizam como apoio estruturas informais. 
Segundo estudo sobre a Indústria Náutica Brasileira apresentado pela Associação Brasileira de Construtores de Barcos e seus Implementos (Acobar), estas estruturas irregulares abrigam uma quantidade equivalente a $20 \%$ das embarcações registradas nas marinas regulares.

Nestas estruturas, as quais podem inclusive abrigar pátios de postos de combustíveis, pode-se encontrar uma parcela expressiva das embarcações a motor com comprimento igual ou abaixo de 23 pés. O estudo aponta também que, além das marinas irregulares, há ainda os proprietários que mantêm suas embarcações em suas próprias casas ou em poitas fundeadas em baías, rios, lagoas e enseadas abrigadas. ${ }^{13}$ Portanto, não se pode deixar de citar as embarcações relacionadas a atividades de turismo e lazer, com vazamentos mais frequentes e dificilmente identificados, bem como a proliferação de marinas, como potenciais causadores de derramamentos de menores dimensões.

Este entendimento acerca da composição da frota brasileira se faz importante para melhor identificação dos reais riscos de derramamentos de óleo no Brasil. É comum por parte da sociedade a associação de riscos ou eventos de vazamentos aos grandes navios petroleiros, plataformas ou cargueiros. Segundo o Centro de Excelência para o Mar Brasileiro (CEMBRA):

(...) apesar de a poluição mais visível e familiar ser a do petróleo, provocada pelos acidentes com navios petroleiros, e de a escala e a visibilidade desses impactos serem mais conhecidas e divulgadas, diversas outras fontes e classes de contaminantes e vias de introdução de contaminantes são notáveis no meio marinho. ${ }^{14}$

Os dados obtidos do anuário estatístico da Antaq e do Portal de Acesso à informação do Governo Federal sobre a Marinha, mostram que as pequenas embarcações representam uma fonte de contaminação importante. Tal avaliação é agravada se consideradas as condições de regulação, controle e fiscalização destas pequenas embarcações, que, até mesmo pela quantidade e dificuldade de rastreamento, acabam sendo menos severas do que para embarcações comerciais. São inúmeras as embarcações de passeio que operam sob um regime de informalidade e irregularidade, e, principalmente, sem o comprometimento de comunicação aos órgãos ambientais e autoridades marítimas nos casos em que cometem danos ao meio ambiente, a exemplo dos derramamentos de óleo. Com isso, as pequenas embarcações acabam gerando um significativo passivo de manchas órfãs.

Nesse sentido, há uma grande preocupação acerca dos aspectos cumulativos e sinérgicos decorrentes dos eventuais derramamentos ocasionados por embarcações de menor porte, visto

\footnotetext{
${ }^{13}$ ACOBAR et. al. Indústria náutica brasileira: fatos e números 2012. Rio de Janeiro, [2012?].

${ }^{14}$ CEMBRA. O Brasil e o mar no século XXI: Relatório aos tomadores de decisão do País. FERNANDES, L.

P. da C. (Coord.). Niteroi: BHMN, 2a ed., 2012, p. 275.
} 
que comumente são encontradas atracando e navegando em áreas ecologicamente mais sensíveis, como próximo a praias ou adentrando baías e estuários.

A CETESB apresenta em seu portal da internet um banco de dados referentes às ocorrências de derramamentos de óleo no litoral brasileiro, obviamente com um foco mais acentuado aos incidentes verificados no litoral do Estado de São Paulo, visto que é um órgão ambiental estadual local. A tabela abaixo foi elaborada com base em consulta ao banco de dados sobre emergências químicas disponível na página da internet da CETESB. ${ }^{15}$

Foram consideradas as ocorrências registradas, entre 2007 e 2018, em que houve derramamento, na baixada santista, ou no litoral norte do Estado de São Paulo, de ao menos uma das seguintes substâncias no mar: diesel; combustível marítimo; resíduo oleoso; lubrificante; e/ou petróleo. Não foram consideradas as ocorrências em que estuário e mar não foram contaminados, nem mesmo aquelas em que a substância derramada não possuía característica oleosa. Como possíveis causas dos acidentes foram relatadas: problemas em tubulações ou tanques; transbordo; incêndios; falhas operacionais ou mecânicas; colisões; extravasamentos ou naufrágios.

Após análise dos dados compilados na tabela abaixo é possível compreender que, nos últimos dez anos, mesmo em decorrência de causas conhecidas e mais significativas, o volume de óleo vazado por ocorrência se mantém relativamente pequeno, sendo que, em apenas oito situações houve derramamento de mais de 500 litros no mar. Mais da metade das ocorrências correspondia a volumes abaixo de 50 litros.

${ }^{15}$ SÃO PAUlO (Estado). Companhia Ambiental do Estado de São Paulo (CETESB). Emergências Químicas: Sistema de Informações sobre Emergências Químicas da CETESB (SIEQ). Disponível em: $<$ http://sistemasinter.cetesb.sp.gov.br/emergencia/relatorio.php>. Acesso em: 01.11.2018. 
Tabela 3- Relação entre ocorrências e volume de óleo derramado no litoral de São Paulo (2007 - 2018)

\begin{tabular}{|c|c|}
\hline $\begin{array}{c}\text { VOLUME DE ÓLEO } \\
\text { DERRAMADO EM ÁGUAS } \\
\text { LITORÂNEAS } \\
\text { (Baixada Santista e Litoral } \\
\text { Norte de São Paulo) }\end{array}$ & $\begin{array}{c}\text { NÚMERO DE } \\
\text { OCORRÊNCIAS }\end{array}$ \\
\hline Até 2 litros & 2 \\
\hline De 2 Até 10 litros & 9 \\
\hline De 10 Até 15 litros & 1 \\
\hline De 15 Até 20 litros & 2 \\
\hline De 20 Até 30 litros & 1 \\
\hline De 30 Até 50 litros & 2 \\
\hline 100 litros & 2 \\
\hline 120 litros & 1 \\
\hline 160 litros & 1 \\
\hline 200 litros & 1 \\
\hline 250 litros & 1 \\
\hline 320 litros & 1 \\
\hline 500 litros & 1 \\
\hline 600 litros & 1 \\
\hline 1.000 litros & 2 \\
\hline 1.500 litros & 1 \\
\hline 2.000 litros & 3 \\
\hline Total & 33 \\
\hline
\end{tabular}

Fonte: elaboração própria com base em dados de ocorrências do Sistema de Informações sobre Emergências Químicas (SIEQ) da CETESB. Disponível em: $<$ http://sistemasinter.cetesb.sp.gov.br/emergencia/relatorio.php $>$. Acesso em: 10.10.2018. 
Para a tabela a seguir, igualmente foram consideradas as ocorrências registradas na Baixada Santista e no Litoral Norte do Estado de São Paulo, pelo mesmo período, de 2007 a 2018. Entretanto, foram sistematizados os dados referentes a manchas órfãs, com características oleosas, que atingiram mar, e/ou estuários. Para uma melhor comparação com a tabela anterior, não foram contempladas as manchas órfãs encontradas em substratos arenosos ou costões rochosos. Entretanto, frisa-se desde já a importância desses relatos visto que são ambientes de extrema relevância ecológica.

Para melhor compreensão dos dados, cabe uma contextualização a respeito das manchas órfãs. O termo "mancha órfã" refere-se a substâncias oleosas em águas marinhas, estuarinas ou fluviais, com origem desconhecida, que podem ser compostas por diferentes composições oleosas, a exemplo da gasolina, óleo combustível, diesel (terrestre e marítimo), óleos lubrificantes e residuais. ${ }^{16}$

Pelo fato de terem origem desconhecida, conforme se pode depreender de uma rápida verificação da tabela, na grande maioria das ocorrências não foi possível a identificação do volume de óleo derramado. Entretanto, outros fatores devem ser objeto de atenção.

Tabela 4 - Manchas órfãs com características oleosas registradas (2007 - 2018)

\begin{tabular}{|c|c|c|c|c|}
\hline Ano & $\begin{array}{c}\text { Baixada } \\
\text { Santista }\end{array}$ & $\begin{array}{c}\text { Litoral } \\
\text { Norte }\end{array}$ & $\begin{array}{c}\text { Total de } \\
\text { manchas }\end{array}$ & Volumes quando identificados \\
\hline $\mathbf{2 0 0 7}$ & 5 & 1 & 6 & 1 mancha de 200 litros de óleo \\
\hline $\mathbf{2 0 0 8}$ & 3 & 1 & 4 & 1 mancha de 10 litros de óleo \\
\hline $\mathbf{2 0 0 9}$ & 6 & 1 & 7 & $\begin{array}{c}1 \text { mancha de } 20 \text { litros de óleo } \\
\text { manchas de } 10 \mathrm{~m}^{3} \text { de óleo }\end{array}$ \\
\hline
\end{tabular}

(continua)

\footnotetext{
16 De acordo com a CETESB, "Supõem-se que estas manchas sejam provenientes de fontes terrestres e de embarcações. No caso terrestre, suspeita-se do descarte indevido de misturas e resíduos oleosos por parte de oficinas mecânicas, garagens de veículos pesados, postos e sistemas retalhistas de combustíveis, entre outros estabelecimentos. Este descarte chega à rede de drenagem de água pluvial ou em córregos, os quais desaguam nos rios, estuários ou mesmo no mar, dependendo da localização geográfica do município. Também suspeita-se do lançamento impróprio de postos de abastecimento de embarcações, estaleiros, marinas, iate clubes, pesqueiros, navios e outras embarcações, inclusive as de lazer." Disponível em: <https://cetesb.sp.gov.br/emergenciasquimicas/tipos-de-acidentes/vazamentos-de-oleo/manchas-orfas/>. Acesso em: 10.04.2018.
} 
(conclusão)

\begin{tabular}{|c|c|c|c|c|}
\hline Ano & Baixada & Litoral & Total de & Volumes quando identificados \\
Santista & Norte & manchas & \\
\hline $\mathbf{2 0 1 0}$ & 4 & - & 4 & 1 mancha de 20 litros de óleo \\
& 1 & 1 & 2 & mancha de $10 \mathrm{~m}^{3}$ de óleo \\
\hline $\mathbf{2 0 1 1}$ & 2 & - & 2 & 1 mancha de 20 litros de óleo \\
\hline $\mathbf{2 0 1 2}$ & 2 & - & 2 & 1 mancha de 20 litros de óleo \\
\hline $\mathbf{2 0 1 3}$ & - & 3 & 3 & Não identificados \\
\hline $\mathbf{2 0 1 4}$ & 4 & 1 & 5 & 1 mancha de 3 litros de óleo \\
\hline $\mathbf{2 0 1 5}$ & - & 2 & 2 & Não identificados \\
\hline $\mathbf{2 0 1 6}$ & 4 & - & 4 & 1 mancha de 5 litros de óleo \\
\hline $\mathbf{2 0 1 7}$ & 3 & 1 & 4 & Não identificados \\
\hline $\mathbf{2 0 1 8}$ & $\mathbf{3 4}$ & $\mathbf{1 1}$ & $\mathbf{4 5}$ & \\
\hline Total & & & & \\
\hline
\end{tabular}

Fonte: elaboração própria com base em dados de ocorrências do Sistema de Informações sobre Emergências (SIEQ) da CETESB. Disponível em: 〈http://sistemasinter.cetesb.sp.gov.br/emergencia/relatorio.php〉. Acesso em: 10.10.2018.

O primeiro aspecto de destaque, após análise mais atenta aos dados, deve-se ao fato de o número de ocorrências que relatam manchas órfãs ser superior às ocorrências em que as causas foram identificadas. Tal constatação é ainda mais preocupante pelo fato de que, conforme explanado, as manchas normalmente são causadas por embarcações, muitas vezes dispersadas rapidamente pela própria movimentação dos barcos e raramente comunicadas aos órgãos ambientais. Ou seja, as 45 ocorrências correspondem apenas àquelas em que a CETESB tomou conhecimento, muito provavelmente existindo inúmeras outras que não foram formalmente constatadas.

Entretanto, muito embora os dados técnicos sinalizem para uma maior atenção principalmente à questão da reparação dos danos causados por esses tipos de manchas, do ponto 
de vista jurídico, a não identificação de um causador específico dificulta os avanços em relação à punibilidade.

Apesar de a presente tese se debruçar nas discussões acerca das formas de reparação técnicas e jurídicas para os danos decorrentes de derramamentos de óleo com causas conhecidas, não se pode aqui ignorar a realidade das manchas órfãs. $\mathrm{O}$ fato é que, mesmo correspondendo a volumes pequenos de óleo, a frequência desses acontecimentos é expressiva.

Não se pode deixar de citar os rompimentos de dutos, como causa significativa de derramamentos de óleo que podem atingir estuário e mar, além de praias, costões e manguezais. Apesar do número de ocorrências envolvendo dutos não ser expressivo em comparação aos acidentes envolvendo transporte rodoviário de produtos perigosos, a malha dutoviária acaba passando próxima, aumentando o potencial de danos ambientais. Exemplo disso foi o vazamento ocorrido na Baía de Guanabara, no Rio de Janeiro, em janeiro de 2000, em que houve rompimento do oleoduto procedente da Refinaria Duque de Caxias, sentido Terminal da Ilha d'Água, devido à corrosão de uma parte que passava no interior do manguezal, liberando $1.300 \mathrm{~m}^{3}$ do produto. ${ }^{17}$

São inúmeras as causas conhecidas que podem levar aos derramamentos, tanto de forma direta, quanto indireta. Dentre elas destacam-se: falta de manutenção de cascos e equipamentos de embarcações, conforme já pontuado; erros operacionais; e influências de causas naturais, como tempestades e correntes. Entretanto, as causas humanas acabam sendo as mais presentes, sendo ou as desencadeadoras dos acidentes ou contribuindo para o agravamento dos efeitos.

No campo das causas humanas, são comuns: (i) cansaço e estresse, que reduzem a concentração e dificultam a tomada rápida de decisões; (ii) formação e experiência deficientes e insuficientes, levando muitas vezes à imperícia; (iii) comunicação inadequada, dificultando principalmente na identificação dos cenários que devem receber a rápida resposta; (iv) relativização de questões de segurança para diminuição de custos, dentre outras. De uma forma geral, raramente uma única causa será a responsável por um derramamento significativo, normalmente havendo uma conjuntura de fatores, humanos ou não. ${ }^{18}$

17 SÃO PAUlO (Estado). Companhia Ambiental do Estado de São Paulo (CETESB). Principais acidentes. Disponível em: <https://cetesb.sp.gov.br/emergencias-quimicas/tipos-de-acidentes/dutos/principais-acidentes/>. Acesso em: 10.11.2018.

${ }^{18}$ SARDINHA, A. M. Seguros no Transporte Marítimo. 44f. Dissertação de Mestrado em Direito e Economia do mar - Faculdade de Direito, Universidade Nova de Lisboa, Lisboa, dez. 2017, p.07-10. Disponível em: 
Sendo assim, todas as causas e formas de derramamentos são significativas e devem compor as análises que precedem as decisões acerca das formas de remediação. Da mesma forma, conforme pontuado por Poffo, ${ }^{19}$ não se pode ignorar ocorrências em que o volume de óleo derramado aparenta ser insignificante, visto que os danos ambientais não se limitam à quantidade de óleo que atinge o mar, sendo dependentes de fatores como toxicidade do produto, reincidência de derramamentos, vulnerabilidade dos ecossistemas, dentre inúmeros outros fatores que serão abordados no presente trabalho.

As análises acima propostas, indicam que o perfil dos derramamentos ocorridos nos últimos dez anos no Brasil caracteriza-se por pequenos, mas de certa forma frequentes volumes de óleos que atingem o mar. Não se pode negar que os avanços legislativos abrangendo regras de prevenção e de procedimentos de fiscalização reduziram em parte o risco dos conhecidos acidentes catastróficos com grandes embarcações e plataformas, o que contribuiu positivamente para o atual cenário. Porém, conforme será apresentado neste trabalho, ainda há grandes desafios no campo da reparação de danos causados pelos derramamentos de óleo, tanto no aspecto jurídico, quanto no ecológico.

Assim, tanto nos incidentes expressivos, ocasionados por grandes embarcações ou plataformas, quanto nos casos de pequenas manchas de óleo (com causas identificadas, ou órfãs), a reparação ambiental tem que ser vista como forma prioritária. Não se pode mais admitir uma atuação restrita ao campo jurídico, que não considere a interdisciplinaridade intrínseca a esse assunto.

É necessário que o operador de direito amplie seus horizontes para recepcionar outras ciências na definição de formas de reparação que atendam não somente à justiça humana, mas igualmente à ecológica.

$<$ https://transportemaritimoglobal.files.wordpress.com/2018/02/00-alvaro-sardinha-seguros-no-transportemarc3adtimo-tmg-mar-doc1.pdf $>$. Acesso em: 05.10.2010.

${ }^{19}$ POFFO, I. R. F. Vazamento de óleo no Litoral Norte do Estado de São Paulo: análise histórico (1974 a 1999). Dissertação de Mestrado - Programa de Ciência Ambiental (PROCAM), Instituto de Energia e Ambiente (IEE), Universidade de São Paulo (USP), São Paulo, dez. 2000, p.05. 


\section{ANÁLISE DE JURISPRUDÊNCIA}

\subsection{Análise de jurisprudência STF, STJ e TRFs}

O presente item se destina a uma análise genérica de julgados selecionados que abordam a aplicação da responsabilidade civil ambiental em casos de derramamento de óleo, afetando ambientes costeiros e marinhos. Referida análise limitou-se aos seguintes tribunais: Supremo Tribunal Federal (STF), Superior Tribunal de Justiça (STJ) e Tribunais Regionais Federais (TRFs) das cinco regiões do Brasil ${ }^{20}$.

Importante ressaltar que no início, a pesquisa também considerou os seguintes Tribunais de Justiça Estaduais: Tribunal de Justiça de São Paulo (TJSP), Tribunal de Justiça do Rio de Janeiro (TJRJ), Tribunal de Justiça do Rio Grande do Sul (TJRS), Tribunal de Justiça de Santa Catarina (TJSC), Tribunal de Justiça do Paraná (TJPR), Tribunal de Justiça do Espírito Santo (TJES), Tribunal de Justiça do Estado de Sergipe (TJSE). Entretanto, optou-se por descartar da presente análise genérica os julgados obtidos em Tribunais de Justiça Estaduais, pois grande parte da decisões ora proferidas era reformada em instâncias superiores, afetando, portanto, a análise qualitativa dos dados. Entretanto, conforme será visto mais adiante, a partir do item 3.2, foi realizada uma segunda pesquisa jurisprudencial, partindo de casos práticos de derramamentos de óleo emblemáticos no Brasil. Nestes casos, todos os Tribunais de Justiça Estaduais pertinentes foram considerados, e os julgados selecionados foram reportados.

A metodologia de escolha dos julgados consistiu em uma primeira etapa, por buscas considerando palavras-chave genéricas, a exemplo de "óleo" e "petróleo". Posteriormente, a depender do modo específico de indexação de cada Tribunal, a busca foi refinada por palavraschave específicas ou combinadas. Vale, desde já, a ressalva que até mesmo entre os TRFs há diferenças tanto nas possibilidades de pesquisas de julgados, quanto na forma de indexação. Tais fatores impossibilitaram a utilização das mesmas palavras-chave de modo uniforme para todas as plataformas de busca. Por isso a necessidade de refino em alguns Tribunais, por meio de uma segunda etapa de buscas ${ }^{21}$.

\footnotetext{
${ }^{20}$ Os Tribunais Regionais Federais estão divididos em 5 regiões, com as respectivas sedes em Brasília, Rio de Janeiro, São Paulo, Porto Alegre, e Recife.

${ }^{21}$ Em todos os Tribunais as buscas iniciaram-se pelas palavras-chave "óleo" e "petróleo", escolhidas por serem as mais mencionadas nas ementas e no inteiro teor dos acórdãos quando tratam de poluição por "óleo" ou "petróleo". A desvantagem dessas palavras deve-se à ocorrência em conjunto com outros temas não relacionados ao objeto da presente pesquisa em diversos acórdãos, a exemplo de royalties e questões econômicas e contratuais. Assim, a metodologia adotada considerou uma segunda etapa de pesquisa, em que foram acrescentadas às palavras "óleo"
} 
No total, foram selecionados 291 julgados ${ }^{22}$, sendo que desses, $93^{23}$ foram classificados como irrelevantes por tratarem de matéria de direito administrativo (responsabilidade administrativa pelos danos ambientais) ou meramente processual. Com isso, foram classificados como relevantes à temática proposta na presente tese 198 julgados $^{24}$.

Os 198 julgados foram analisados sob quatro aspectos: (i) competência para julgamento; (ii) legitimidade/responsabilidade pelos danos; (iii) reconhecimento de danos morais / extrapatrimoniais; (iv) metodologia utilizada para valoração de danos ambientais materiais/ patrimoniais e morais/extrapatrimoniais.

Há que se esclarecer também outra questão metodológica. A somatória do total de julgados relatados nos quatro tópicos acima identificados não corresponde ao número total de julgados considerados relevantes (199). Isto porque vários julgados foram analisados sob mais de um aspecto, pois abordam diferentes temas. Assim, a título exemplificativo, um mesmo julgado pode aparecer no tópico de "legitimidade/responsabilidade pelos danos" e no tópico "metodologia utilizada para valoração de danos ambientais ecológicos, materiais e morais".

\subsubsection{Competência para julgamento}

Foram analisados 69 julgados referentes à questão da competência. Para efeitos de exposição, este tópico foi dividido em duas temáticas. A primeira diz respeito à competência do juízo para processamento e julgamento de ações relacionadas a derramamentos de óleo no mar. A segunda, diz respeito à competência do Ministério Público para investigar e ajuizar ações visando reparar o meio ambiente.

Foram encontrados 12 julgados defendendo a competência da Justiça Federal para processar e julgar ações relacionadas a derramamentos de óleo no mar, apresentando as seguintes teses:

\footnotetext{
e "petróleo" uma ou mais palavras, a exemplo: ambiental, derramamento, meio ambiente, MARPOL, mar territorial, petróleo, poluição ou vazamento. Dessa forma, foi possível abarcar uma segura maioria, ou a totalidade, de acórdãos relacionados ao tema da presente pesquisa nas bases de jurisprudência dos Tribunais mencionados.

22 Dentre os 291 julgados analisados: (i) 17 foram emitidos pelo STF, (ii) 67 foram emitidos pelo STJ; (iii) 12 foram emitidos pelo TRF1; (iv) 26 foram emitidos pelo TRF2; (v) 99 foram emitidos pelo TRF3; (vi) 67 foram emitidos pelo TRF4; e (vii) 03 foram emitidos pelo TRF5.

${ }^{23}$ Dentre os 93 julgados considerados irrelevantes: (i) 15 foram emitidos pelo STF; (ii) 21 foram emitidos pelo STJ; (iii) 10 foram emitidos pelo TRF1; (iv) 18 foram emitidos pelo TRF2; (v) 15 foram emitidos pelo TRF3; (vi) 14 foram emitidos pelo TRF4; (vii) e nenhum foi emitido pelo TRF5.

${ }^{24}$ Dentre os 198 julgados considerados relevantes: (i) 02 foram emitidos pelo STF; (ii) 46 foram emitidos pelo STJ; (iii) 02 foram emitidos pelo TRF1; (iv) 8 foram emitidos pelo TRF2; (v) 84 foram emitidos pelo TRF3; (vi) 53 foram emitidos pelo TRF4; e (vii) 03 foram emitidos pelo TRF5.
} 
a) Acidente de trabalho que deu causa ao dano ambiental de grande dimensão (vazamento no oleoduto da Repar (Refinaria Presidente Getúlio Vargas) - 01 julgado; ${ }^{25}$

b) Reconhecimento da controvérsia ser regida pela Convenção Internacional sobre Responsabilidade Civil em Danos Causados por Poluição de Óleo - 05 julgados; ${ }^{26}$

c) Dano ocorreu, ou afetou bem público de propriedade da União (zona econômica exclusiva, zona portuária, unidade de conservação federal) -05 julgados; ${ }^{27}$

d) Presença do Ministério Público Federal no polo ativo da ação - 01 julgado; ${ }^{28}$

Na contramão dos argumentos em prol da competência da Justiça Federal ${ }^{29}$, há um interessante julgado do Tribunal Regional Federal da $3^{\circ}$ Região, que reconheceu a incompetência absoluta do Juízo "a quo", remetendo aos autos da Ação Civil Pública n 93.02.05445-4 à Justiça Estadual, apresentando os seguintes argumentos: (a) ações propostas por sociedades de economia mista só serão processadas e julgadas pela Justiça Federal com o ingresso de entidades autárquicas, ou empresas públicas; (b) intervenção do MPF basta para

${ }^{25}$ STF. Agravo Regimental no Recurso Extraordinário: ArRg no RE no 898.716/PR. Rel. Min. Rosa Weber. Primeira Turma. Julgado em 29/07/2015.

${ }^{26}$ STJ. Conflito de Competência: CC nº10.445-9/SP. Rel. Min. Demócrito Reinaldo. Primeira Seção. Julgado em 13/09/1994.

STJ. Conflito de Competência: CC n 16.863/SP. Rel. Min. Demócrito Reinaldo. Primeira Seção. Julgado em 26/06/1996.

STJ. Embargos de Declaração no Conflito de Competência: EDcl no CC n 2.374-0/SP. Rel. Min. Antônio de Pádua Ribeiro. Primeira Seção. Julgado em 20/04/1993.

STJ. Recurso Especial: REsp n ${ }^{\circ}$ 46.728-4/SP. Rel. Demócrito Reinaldo. Primeira Turma. Julgado em 20/11/1995. TRF2: Agravo de Instrumento: $\mathrm{Ag} \mathrm{n}^{\circ}$ 2007.02.01.004310-1. Rel. Reis Friede. Sétima Turma Especializada. Julgado em 03/10/2007.

${ }^{27}$ STJ: Recurso Especial: REsp no 1.057.878/RS. Rel. Min. Herman Benjamin. Segunda Turma. Julgado em 26/05/2009.

STJ. Recurso Especial: REsp n ${ }^{\circ} 1.100 .698 /$ PR. Rel. Min. Francisco Falcão. Primeira Turma. Julgado em 05/05/2009.

TRF1. Apelação Cível: AC nº 2004.37.00.001610-3/MA. Rel. Jirair Aram Meguerian. Sexta Turma. Julgado em 15.05.2017.

TRF2. Agravo de Instrumento: Ag n 2012.02.01.004075-2. Rel. Guilherme Diefenthaeler. Quinta Turma Especializada. Julgado em 31/07/2012.

TRF4. Agravo de Instrumento: Ag n 2005.04.01.041559-0/RS. Rel. Marga Inge Barth Tessler. Quarta Turma. DJ: $11 / 12 / 2007$.

${ }^{28}$ TRF2. Apelação Cível: AC no 2005.51.02.0063310. Rel. Luiz Paulo da Silva Araújo Filho. Sétima Turma Especializada. Julgado em 18/12/2013.

${ }^{29}$ Vale a menção a um julgado que, embora trate de vazamento de ácido sulfúrico e não de óleo, apresenta uma interessante solução para o conflito de competência, considerando o contrato de seguro e o art. 88 do CPC de 1973 : "A despeito de ter sido celebrado em país estrangeiro, à luz de legislação alienígena, o contrato de seguro marítimo produz efeitos além das fronteiras, uma vez que a embarcação assegurada percorre longas distâncias (cobertura internacional) e, consoante o disposto no artigo 88, incisos II e III, do CPC/1973, é competente a autoridade judiciária brasileira, quando no Brasil tiver de ser cumprida a obrigação e a ação originar-se de fato ocorrido ou de ato praticado no país". TRF4. Apelação Cível: AC no 5006075-38.2012.4.04.7101/RS. Rel. Vivian Josete Pantaleão Caminha. Quarta Turma. Julgado em 17/05/2017. 
ocorrer o reconhecimento da competência da Justiça Federal em detrimento da Estadual; (c) o fato do bem atingido ser de domínio da União não desloca a competência para a Justiça Federal, quando o pleito se destina exclusivamente ao resguardo dos interesses da coletividade, mas apenas para os pedidos de ressarcimento de danos causados à pessoa jurídica de direito público interno; (d) o art. 109, III da CF só se aplica quando o litígio tiver como foco discussão de tratado, ou contrato da União com Estado Estrangeiro ou organismo internacional. ${ }^{30}$

Além do julgado acima, foram encontrados 52 julgados contendo o entendimento sobre a competência para processar e julgar ações relativas à reparação de danos decorrentes de derramamentos de óleo no mar ser da Justiça Estadual, apresentando as seguintes razões:

a) Os pescadores artesanais afetados por derramamento de óleo são equiparados a consumidores, devendo se aplicar a regra do art. 101 do CDC, que faculta aos consumidores litigar pela indenização no foro do seu domicílio - 03 julgados; ${ }^{31}$

b) Se o dano ocorreu em comarca que não detém Vara Federal, ainda que comprovado interesse da União em seu deslinde, por aplicação do art. $2^{\circ}$ da Lei 7.347/85 c/c art. $109, \S \S 2^{\circ}$ e $3^{\circ} \mathrm{da} \mathrm{CF} / 88$, deve ser considerada a Vara estadual, evitando o deslocamento do feito para a Capital - 04 julgados; ${ }^{32}$

c) Não se aplica a Convenção Internacional Sobre Responsabilidade Civil em Danos Causados por Poluição por Óleo - CLC 69, pois sua aplicação diz respeito à poluição por óleo a granel, não alcançando a poluição por óleo combustível, decorrente de incidentes com navios cuja carga seja diversa, ou sem carga - 43 julgados; ${ }^{33}$

\footnotetext{
${ }^{30}$ TRF3. Agravo de Instrumento: Ag n 25116. Rel. Lucia Figueiredo. Quarta Turma. Julgado em 27/11/1996.

${ }^{31}$ STJ. Agravo Interno nos Embargos de Declaração no Conflito de Competência: Ag nos EDcl no CC $n^{\circ}$ 132.505/RJ. Rel. Min. Antonio Carlos Ferreira. Segunda Seção. Julgado em 23/11/2016

STJ. Agravo Interno nos Embargos de Declaração no Conflito de Competência: Ag nos EDcl no CC nº 143.516/RJ. Rel. Luis Felipe Salomão. Segunda Seção. Julgado em 23/11/2016.

STJ. Conflito de Competência: CC nº 143.204/RJ. Rel. Min. Ricardo Villas BôasCueva. Segunda Seção. Julgado em 13/04/2016.

${ }^{32}$ STJ. Conflito de Competência: CC n 2.473-0/SP. Rel. Min. Antônio de Pádua Ribeiro. Primeira Seção. Julgado em 26/05/1992.

STJ. Embargos de Declaração no Conflito de Competência: EDcl no CC nº 2.473-0/SP. Rel. Min. Antônio de Pádua Ribeiro. Primeira Seção. Julgado em 20/04/1993.

TRF3. Agravo de Instrumento: Ag nº 6057/SP. Rel. Manoel Álvares (juiz federal convocado). Quarta Turma. Julgado em 31/05/2000.

TRF3. Agravo de Instrumento: Ag n 10763/SP. Rel. Manoel Álvares (juiz federal convocado). Quarta Turma. Julgado em 31/05/2000.

${ }^{33}$ Conforme será observado no capítulo 04, o Brasil não ratificou o protocolo de 1992, referente à CLC de 69, que amplia a abrangência dos derramamentos àqueles em que o óleo derramado é o óleo combustível, e não o óleo transportado como carga.
} 
TRF4. Agravo de Instrumento: Ag n 0001227-27.2010.404.0000/SC. Rel. Marga Inge Barth Tessler. Quarta Turma. DJ: 30/03/2010

TRF4. Agravo de Instrumento: Ag no 0001229-94.2010.404.0000/SC. Rel. Marga Inge Barth Tessler. Quarta Turma. DJ: 27/04/2010

TRF4. Agravo de Instrumento: Ag nº 0001264-54.2010.404.0000/SC. Rel. Marga Inge Barth Tessler. Quarta Turma. DJ: 27/04/2010

TRF4. Agravo de Instrumento: Ag no 2009.04.00.041788-1/SC. Rel. Hermes da Conceição (juiz federal convocado). Quarta Turma. DJ: 30/03/2010.

TRF4. Agravo de Instrumento: Ag n 2009.04.00.041870-8/SC. Rel. Hermes da Conceição (juiz federal convocado). Quarta Turma. DJ: 30/03/2010.

TRF4. Agravo de Instrumento: Ag n 2009.04.00.041873-3/SC. Rel. Marga Inge Barth Tessler. Quarta Turma. DJ: 23/03/2010.

TRF4. Agravo de Instrumento: Ag n 2009.04.00.041922-1/SC. Rel. Marga Inge Barth Tessler. Quarta Turma. DJ: 23/03/2010.

TRF4. Agravo de Instrumento: Ag nº 2009.04.00.041971-3/SC. Rel. Marga Inge Barth Tessler. Quarta Turma. DJ: 30/03/2010.

TRF4. Agravo de Instrumento: Ag n 2009.04.00.041974-9/SC. Rel. Hermes da Conceição (juiz federal convocado). Quarta Turma. DJ: 30/03/2010.

TRF4. Agravo de Instrumento: Ag n 2009.04.00.042226-8/SC. Rel. Hermes da Conceição (juiz federal convocado). Quarta Turma. DJ: 30/03/2010.

TRF4. Agravo de Instrumento: Ag n 2009.04.00.042234-7/SC. Rel. Marga Inge Barth Tessler. Quarta Turma. DJ: 23/03/2010.

TRF4. Agravo de Instrumento: Ag n 2009.04.00.042249-9/SC. Rel. Hermes da Conceição (juiz federal convocado). Quarta Turma. DJ: 30/03/2010.

TRF4. Agravo de Instrumento: Ag n 2009.04.00.042264-5/SC. Rel. Hermes da Conceição (juiz federal convocado). Quarta Turma. DJ: 30/03/2010.

TRF4. Agravo de Instrumento: Ag n 2009.04.00.042303-0/SC. Rel. Hermes da Conceição (juiz federal convocado). Quarta Turma. DJ: 30/03/2010.

TRF4. Agravo de Instrumento: Ag nº 2009.04.00.042356-0/SC. Rel. Marga Inge Barth Tessler. Quarta Turma. DJ: 02/03/2010.

TRF4. Agravo de Instrumento: Ag n² 2009.04.00.042363-7/SC. Rel. Marga Inge Barth Tessler. Quarta Turma. DJ: 30/03/2010.

TRF4. Agravo de Instrumento: Ag n ${ }^{\circ}$ 2009.04.00.042367-4/SC. Rel. Hermes da Conceição (juiz federal convocado). Quarta Turma. DJ: 30/03/2010.

TRF4. Agravo de Instrumento: Ag nº 2009.04.00.043873-2/SC. Rel. Marga Inge Barth Tessler. Quarta Turma. DJ: 23/03/2010.

TRF4. Agravo de Instrumento: Ag n 2009.04.00.043874-4/SC. Rel. Marga Inge Barth Tessler. Quarta Turma. DJ: 23/03/2010.

TRF4. Agravo de Instrumento: Ag n² 2009.04.00.043962-1/SC. Rel. Marga Inge Barth Tessler. Quarta Turma. DJ: 23/03/2010.

TRF4. Agravo de Instrumento: Ag nº 2009.04.00.043969-4/SC. Rel. Marga Inge Barth Tessler. Quarta Turma. DJ: 23/03/2010.

TRF4. Agravo de Instrumento: Ag n² 2009.04.00.043972-4/SC. Rel. Marga Inge Barth Tessler. Quarta Turma. DJ: 23/03/2010.

TRF4. Agravo de Instrumento: Ag n 2009.04.00.044136-6/SC. Rel. Marga Inge Barth Tessler. Quarta Turma. DJ: 23/03/2010.

TRF4. Agravo de Instrumento: Ag nº 2009.04.00.044148-2/SC. Rel. Marga Inge Barth Tessler. Quarta Turma. DJ: 27/04/2010.

TRF4. Agravo de Instrumento: Ag nº 2009.04.00.044150-0/SC. Rel. Marga Inge Barth Tessler. Quarta Turma. DJ: 23/03/2010.

TRF4. Agravo de Instrumento: Ag nº 0008714-48.2010.404.0000/SC. Rel. Marga Inge Barth Tessler. Quarta Turma. DJ: 15/06/2010.

TRF4. Agravo de Instrumento: Ag nº 0008734-39.2010.404.0000/SC. Rel. Marga Inge Barth Tessler. Quarta Turma. DJ: 15/06/2010.

TRF4. Agravo de Instrumento: Ag nº 0008748-23.2010.404.0000/SC. Rel. Marga Inge Barth Tessler. Quarta Turma. DJ: 15/06/2010. 
d) Ajuizamento de demanda única e exclusivamente contra pessoas jurídicas de direito privado, não estando arroladas entre os réus quaisquer das entidades relacionadas no art. 109, I, da Constituição Federal - 02 julgados. ${ }^{34}$

Quanto à competência do Ministério Público, há 01 julgado do STF definindo que é competência do Ministério Público Estadual apurar supostas irregularidades que possivelmente estariam ligadas ao acidente na Plataforma P-36, da Petrobrás, ocorrido em 2001 na cidade do Rio de Janeiro, citando sua jurisprudência no sentido de que a simples presença de sociedade de economia mista ou empresa pública federal em procedimento investigatório não implica, por si só, a presunção de violação de interesse, econômico ou jurídico, da União, o que atrairia a competência do MPF. ${ }^{35}$

TRF4. Agravo de Instrumento: Ag nº 0008828-84.2010.404.0000/SC. Rel. Marga Inge Barth Tessler. Quarta Turma. DJ: 15/06/2010.

TRF4. Agravo de Instrumento: Ag nº 0008887-72.2010.404.0000/SC. Rel. Marga Inge Barth Tessler. Quarta Turma. DJ: 15/06/2010.

TRF4. Agravo de Instrumento: Ag no 0008894-64.2010.404.0000/SC. Rel. Marga Inge Barth Tessler., Quarta Turma. DJ: 15/06/2010.

TRF4. Agravo de Instrumento: Ag nº 0008912-85.2010.404.0000/SC. Rel. Marga Inge Barth Tessler. Quarta Turma. DJ: 15/06/2010.

TRF4. Agravo de Instrumento: Ag nº 0008913-70.2010.404.0000/SC. Rel. Marga Inge Barth Tessler. Quarta Turma. DJ: 15/06/2010.

TRF4. Agravo de Instrumento: Ag nº 0008994-19.2010.404.0000/SC. Rel. Marga Inge Barth Tessler. Quarta Turma. DJ: 15/06/2010.

TRF4. Agravo de Instrumento: Ag no 0009001-11.2010.404.0000/SC. Rel. Marga Inge Barth Tessler. Quarta Turma. DJ: 15/06/2010.

TRF4. Agravo de Instrumento: Ag no 0009050-52.2010.404.0000/SC. Rel. Marga Inge Barth Tessler. Quarta Turma. DJ: 15/06/2010.

TRF4. Agravo de Instrumento: Ag nº 0009053-07.2010.404.0000/SC. Rel. Marga Inge Barth Tessler. Quarta Turma. DJ: 15/06/2010.

TRF4. Agravo de Instrumento: Ag no 0009055-74.2010.404.0000/SC. Rel. Marga Inge Barth Tessler. Quarta Turma. DJ: 15/06/2010.

TRF4. Agravo de Instrumento: Ag nº 0009061-81.2010.404.0000/SC. Rel. Marga Inge Barth Tessler. Quarta Turma. DJ: 15/06/2010.

TRF4. Agravo de Instrumento: Ag no 0011413-12.2010.404.0000/SC. Rel. Marga Inge Barth Tessler. Quarta Turma. DJ: 15/06/2010.

TRF4. Agravo de Instrumento: Ag no 0011417-49.2010.404.0000/SC. Rel. Marga Inge Barth Tessler. Quarta Turma. DJ: 13/07/2010.

TRF4. Agravo de Instrumento: Ag no 0011435-70.2010.404.0000/SC. Rel. Marga Inge Barth Tessler. Quarta Turma. DJ: 15/06/2010.

TRF4. Agravo de Instrumento: Ag n 0011527-48.2010.404.0000/SC. Rel. Marga Inge Barth Tessler. Quarta Turma. DJ: 15/06/2010.

${ }^{34}$ TRF4: Agravo de Instrumento: Ag no 2009.04.00.041771-6/SC. Rel. Maria Lúcia Luz Leiria. Terceira Turma. DJ: 08/04/2010.

TRF4. Agravo de Instrumento: $\mathrm{Ag} \mathrm{n}^{\circ}$ 2009.04.00.041810-1/SC. Rel. Maria Lúcia Luz Leiria. Terceira Turma. DJ: 25/03/2010.

${ }^{35}$ STF. Ação Cível Originária no 1676/RJ. Rel. Min. Ricardo Lewandowski. Decisão monocrática. Julgado em 03/12/2016. 
Há também 02 julgados entendendo que é cabível o litisconsórcio ativo entre o Ministério Público Federal e o Ministério Público do Estado de São Paulo, nos termos do art. $127, \S 1^{\circ}, \mathrm{c} / \mathrm{c}$ art.129, III da CF/1988 e art. $5^{\circ}$ da Lei Federal n. ${ }^{\circ} 7.347 / 1985 .{ }^{36}$

Por fim, vale registrar que há 01 julgado reconhecendo legitimidade da União para figurar como autora de ação civil pública, nos termos do artigo $5^{\circ}$ da Lei Federal n 7.347/85. Apesar do processo ter sido extinto em relação ao Ministério Público Federal, autor originário, o ente fazendário ingressou na lide na condição de litisconsorte ativo. ${ }^{37}$

\subsubsection{Legitimidade/responsabilidade pelos danos}

Neste tópico serão abordados os julgados que tratam da legitimidade passiva nas Ações Civis Públicas e Ações Indenizatórias, bem aqueles que abordam a responsabilidade civil pelos danos ambientais. Estas duas matérias foram tratadas no mesmo tópico porque, na prática, elas se sobrepõem, visto que só terá legitimidade para figurar no polo passivo destas demandas aqueles considerados pelo Direito Civil Brasileiro como responsáveis pelos danos ambientais.

No total, foram considerados 58 julgados tratando das matérias, contendo os seguintes posicionamentos:

a) Aplicação da teoria do risco integral, com o entendimento de que devem figurar no polo passivo das demandas todos aqueles que contribuíram, ainda que indiretamente, para o dano, não admitindo excludentes de responsabilidade -24 julgados; ${ }^{38}$

\footnotetext{
${ }^{36}$ TRF3. Apelação Cível: AC nº 0002456-80.2004.4.03.6104/SP. Rel. André Nabarrete. Quarta Turma. DJ: 07/10/2015.

TRF3. Apelação Cível: AC no 0008377-78.2008.4.03.6104/SP. Rel. Mônica Nobre. Quarta Turma. DJ: 03/03/2016.

37 TRF3. Apelação Cível: AC nº 0205453-77.1989.4.03.6104/SP. Rel. André Nabarrete. Quarta Turma. DJ: $10 / 09 / 2012$.

${ }^{38}$ STJ. Agravo Regimental no Agravo em Recurso Especial: AgRg no AREsp n $71.324 / P R$. Rel. Min. Antonio Carlos Ferreira. Quarta Turma. Julgado em 26/02/2013.

STJ. Agravo Regimental no Agravo em Recurso Especial: AgRg no AREsp n ${ }^{\circ}$ 71.324/ PR. Rel. Min. Antonio Carlos Ferreira. Quarta Turma. Julgado em 26/02/2013.

STJ.Agravo Regimental no Agravo em Recurso Especial: AgRg no AREsp n 92.652/ PR. Rel. Min. Antonio Carlos Ferreira. Quarta Turma. Julgado em 26/02/2013.

STJ.Agravo em Recurso Especial: AREsp n ${ }^{\circ}$ 149.660/ PR. Rel. Min. Massami Uyeda. Terceira Turma. Julgado em 20/11/2012.

STJ.Agravo em Recurso Especial: AREsp nº 232.494/ PR. Rel. Min. Marco Buzzi. Quarta Turma. Julgado em 20/10/2015.

STJ.Agravo em Recurso Especial: AREsp nº 258.263/ PR. Rel. Min. Antonio Carlos Ferreira. Quarta Turma. Julgado em 12/03/2013.
} 
b) Aplicação da teoria do risco integral para expressamente considerar a compradora, vendedora e transportadora das mercadorias como solidariamente responsáveis pelos danos ambientais - 01 julgado; ${ }^{39}$

c) Contrariando o entendimento anterior, o reconhecimento de que as adquirentes da carga transportada pelo navio que ocasionou o derramamento não são responsáveis pelo dano ambiental, pois não há nexo causal entre suas atividades e o evento danoso -01 julgado; ${ }^{40}$

d) Reconhecimento da proprietária do navio como parte passiva legítima para responder à ação civil pública, sendo a comprovação do dano e de nexo causal matérias atinentes ao mérito da causa - 01 julgado ${ }^{41}$

STJ. Embargos de Declaração no Recurso Especial: EDcl no REsp n 1.346.430/PR. Rel. Min. Luis Felipe Salomão. Quarta Turma. Julgado em 05/02/2013.

STJ. Recurso Especial: REsp n 1.114.398/PR. Rel. Sidnei Beneti. Segunda Seção. Julgado em 08/02/2012.

STJ. Recurso Especial: REsp $n^{\circ} 1.346 .430 /$ PR. Rel. Min. Luis Felipe Salomão. Quarta Turma. Julgado em 18/10/2012.

TRF1. Apelação Cível: AC nº 2004.37.00.001610-3/MA. Rel. Jirair Aram Meguerian. Sexta Turma. Julgado em 15/05/2017.

TRF1. Apelação Cível: AC nº 0203724-40.1994.4.03.6104/SP. Rel. Marli Ferreira. Quarta Turma. DJ: 09/11/2010. TRF2. Apelação Cível: AC nº 2005.51.02.0063310. Rel. Luiz Paulo da Silva Araújo Filho. Sétima Turma Especializada. Julgado em 18/12/2013. TRF3. Apelação Cível: AC no 0000922-33.2006.4.03.6104/SP. Rel. Nelton dos Santos. Terceira Turma. Julgado em 18/08/2016.

TRF3. Apelação Cível: AC nº 0001913-38.2008.4.03.6104/SP. Rel. Antonio Cedenho. Terceira Turma. Julgado em 07/02/2018.

TRF3. Apelação Cível: AC no 89.03.004240-9. Rel. Oliveira Lima. Quarta Turma. DJ: 05/02/199.

TRF3. Apelação Cível: AC no 1999.03.99.016662-9/SP. Rel. Lazarano Neto. Sexta Turma. DJ: 16/03/2010.

TRF3. Apelação Cível: AC nº 0002051-49.2001.4.03.6104/SP. Rel. Johonsom Di Salvo. Sexta Turma. DJ: 19/05/2014.

TRF3. Apelação Cível: AC nº 0006567-68.2008.4.03.6104/SP. Rel. Nelton dos Santos. Terceira Turma. DJ: $07 / 12 / 2015$.

TRF3. Apelação Cível: AC nº 0006782-42.2011.4.03.6103/SP. Rel. Johonsom Di Salvo. Sexta Turma. DJ: 23/11/2015.

TRF3. Apelação Cível: AC no 0007231-60.2012.4.03.6104/SP. Rel. Mônica Nobre. Quarta Turma. DJ: $17 / 12 / 2015$.

TRF3. Apelação Cível: AC no 0008783-02.2008.4.03.6104/SP. Rel. Antonio Cedenho. Terceira Turma. DJ: 26/04/2018.

TRF3. Apelação Cível: AC nº 0009399-11.2007.4.03.6104/SP. Rel. Márcio Moraes. Terceira Turma. DJ: 31/03/2014.

TRF4. Apelação Cível: AC n 2005.71.01.001046-6/RS. Rel. Carlos Eduardo. Terceira Turma. DJ: 19/11/2007. TRF5. Apelação Cível: AC nº 0801665-62.2014.4.05.8500. Rel. Manoel de Oliveira Erhardt. Primeira Turma. Julgado em 20/02/2016.

${ }^{39}$ TRF4. Apelação Cível: AC no 0004155-95.2004.404.7101/RS. Rel. Carlos Eduardo Thompson Flores Lens. Terceira Turma. Publicado em 27/09/2010.

${ }^{40}$ STJ. Recurso Especial: REsp n ${ }^{\circ} 1.596 .081 /$ PR. Rel. Min. Ricardo Villas Bôas Cueva. Segunda Seção. Julgado em 25/10/2017.

${ }^{41}$ TRF3. Apelação Cível: AC nº 0201943-41.1998.4.03.6104/SP. Rel. Leonel Ferreira (juiz federal convocado). Turma "D". DJ: 02/05/2011. 
e) Entendimento de que a Convenção Internacional sobre Responsabilidade Civil por Danos Causados por Poluição por Óleo, ao se limitar a prever a responsabilidade do proprietário do navio com relação aos derramamentos de sua embarcação, não exclui, em tese, a responsabilidade de demais causadores do dano nos termos da legislação brasileira -02 julgados ${ }^{42}$

f) Reconhecimento como parte legítima para figurar no polo passivo empresa que assumiu o encargo de representar o navio de propriedade de outra empresa - 01 julgado; ${ }^{43}$

g) Reconhecimento do agente marítimo como parte legítima para responder solidariamente pelos danos ambientais decorrentes do derramamento de óleo em águas marítimas - 03 julgados; ${ }^{44}$

h) Reconhecimento do agente marítimo de bandeira estrangeira como responsável solidário pelos anos ambientais decorrentes do derramamento de óleo no mar 02 julgados; ${ }^{45}$

i) Não reconhecimento do agente marítimo como responsável quando ausente qualquer evidência de certeza de sua participação, ou de que representava pessoa jurídica estrangeira, sendo inaplicável a solidariedade ao pagamento da indenização - 01 julgado; ${ }^{46}$

\footnotetext{
${ }^{42}$ TRF3. Agravo de Instrumento: Ag n ${ }^{0}$ 96.03.010258-0/SP. Rel. Souza Pires. Quarta Turma. Julgado em 02/03/1999.

TRF3. Apelação Cível: AC nº 0401857-02.1992.4.03.6103/SP. Rel. Cotrim Guimarães. Segunda Turma. DJ: 19/10/2012.

${ }^{43}$ TRF3. Apelação Cível: AC nº 0204317-74.1991.4.03.6104/SP. Rel. Leonel Ferreira (juiz federal convocado). Turma "D". DJ: 02/05/2011.

${ }^{44}$ STJ. Recurso Especial: REsp n ${ }^{\circ}$ 945.593/SP. Rel. Min. Nancy Andrighi. Terceira Turma. Julgado em 14/12/2010. TRF3. Apelação Cível: AC nº 0202534-81.1990.4.03.6104/SP. Rel. Johonsom Di Salvo. Sexta Turma. DJ: 09/12/2014.

TRF3. Apelação Cível: AC no 96.03.044818-4 322073. Rel. André Nabarrete. Quinta Turma. Julgado em 04/12/2006.

${ }^{45}$ TRF3.: Apelação Cível: AC no 0004643-95.2003.4.03.6104/SP. Rel. Cecília Marcondes. Terceira Turma. DJ: $25 / 11 / 2013$

TRF3. Apelação Cível: AC nº 0203607-49.1994.4.03.6104/SP. Rel. Consuelo Yoshida. Sexta Turma. DJ: 03/11/2010.

${ }^{46}$ TRF3. Apelação Cível: AC $\mathrm{n}^{\circ}$ 0006757-75.2001.4.03.6104. Rel. André Nabarrete. Quarta Turma. DJ: $24 / 06 / 2015$
} 
j) Não reconhecimento da empresa responsável pelos danos quando não comprovada a causa do dano ambiental e tampouco for possível demonstrar quem poluiu - 01 julgado, ${ }^{47}$

k) Reconhecimento do armador e de seus prepostos como partes legítimas para responderem solidariamente pelos danos ambientais decorrentes do derramamento de óleo em águas marítimas -01 julgado; ${ }^{48}$

1) Reconhecimento da responsabilidade pela não mitigação dos danos ambientais empresa contratada pelos armadores do navio para prestar assistência ao capitão do navio, como agente protetor -02 julgados, ${ }^{49}$

m) Reconhecimento da condenação direta e solidária da companhia seguradora do transporte marítimo -01 julgado, ${ }^{50}$

n) Não reconhecimento do representante do segurador do navio como parte legítima para figurar no polo passivo de ação civil pública objetivando a responsabilização civil por dano ambiental, em decorrência de derramamento de óleo no mar, por falta de previsão legal - 01 julgado ${ }^{51}$

o) Não reconhecimento da responsabilidade do mandatário do proprietário da embarcação onde ocorreu o vazamento pelos danos causados, pois não há nexo causal entre sua ação e o evento danoso - 01 julgado; ${ }^{52}$

p) Entendimento de que a transação celebrada entre empresas causadoras do dano ambiental não aproveita às demais empresas devedoras solidárias que não

\footnotetext{
${ }^{47}$ TRF3. Apelação Cível: AC no 0204313-37.1991.4.03.6104/SP. Rel. Marli Ferreira. Quarta Turma. DJ: 22/12/2010

${ }^{48}$ TRF2. Apelação Cível: AC $n^{\circ}$ 462813. Rel. Marcelo Pereira (juiz federal convocado). Oitava Turma Especializada. Julgado em 27/04/2010.

${ }^{49}$ TRF3. Agravo de Instrumento: Ag no 97.03.006336-5/SP. Rel. Souza Pires. Quarta Turma. Julgado em 02/03/1999.

TRF3. Agravo de Instrumento: Ag n 98.03.105622-0. Rel. Cecília Hamati. Terceira Turma. Julgado em 07/12/1999.

${ }^{50}$ TRF4. Apelação Cível: AC no 5006075-38.2012.4.04.7101/RS. Rel. Vivian Josete Pantaleão Caminha. Quarta Turma. Julgado em 17/05/2017.

${ }^{51}$ TRF2. Apelação Cível: AC n 2005.50.01.003084-5. Rel. Reis Friede. Sétima Turma Especializada. Julgado em 27/04/2011.

${ }^{52}$ TRF3. Apelação Cível: AC nº 0203550-31.1994.4.03.6104/SP. Rel. Márico Moraes. Terceira Turma. DJ: 14/07/2014.
} 
assinaram o acordo. Porém, neste caso só se pode cobrar da devedora solidária ausente do acordo o remanescente da dívida - 01 julgado ${ }^{53}$

q) Entendimento de que o decurso do tempo e a ocorrência de recuperação natural da área de mangue degradada não eximem de responsabilidade o degradador do meio ambiente -02 julgados; ${ }^{54}$

r) Reconhecimento de que a prévia degradação do local onde o óleo foi derramado e o pequeno volume derramado não afastam a responsabilidade das empresas em ação civil pública visando reparação dos danos ambientais - 04 julgados $;{ }^{55}$

s) De forma contrária ao entendimento acima, o reconhecimento da aplicação do princípio da insignificância para considerar indevida a indenização de reparação por danos ambientais, em casos em que foi inexpressiva a quantidade de óleo derramada no mar -03 julgados; ${ }^{56}$

t) Entendimento de que outros acidentes da mesma época não excluem a responsabilidade da empresa, pois não colocam em dúvida a causalidade do fato danoso e sua gravidade -01 julgado ${ }^{57}$

u) Reconhecimento de que a adoção de medidas efetivas e imediatas evitou a ocorrência de dano, não sendo devida a indenização ou compensação - 01 julgado; ${ }^{58}$

\footnotetext{
${ }^{53}$ STJ. Recurso Especial: REsp n ${ }^{\circ} 1.079 .293 /$ PR. Rel. Carlos Fernando Mathias (juiz federal convocado do TRF $1^{\text {a }}$ Região). Quarta Turma. Julgado em 07/10/2008.

${ }^{54}$ TRF1. Apelação Cível: AC no 2002.01.00.001805-9/BA. Rel. Marcio Barbosa Maia. Quarta Turma. Julgado em 18/09/2012.

TRF1. Apelação Cível: AC nº 1998.37.00.006939-1/MA. Rel. João Batista Moreira. Sexta Turma. Julgado em 06/08/2018.

${ }^{55}$ TRF3. Apelação Cível: AC no 2002.03.99.013233-5788365/SP. Rel. Cecília Marcondes. Terceira Turma. Julgado em 18/12/2002.

TRF3. Apelação Cível: AC no 0002456-80.2004.4.03.6104/SP. Rel. André Nabarrete. Quarta Turma. DJ: 07/10/2015

TRF3. Apelação Cível: AC nº 98.03.067546-0 432487. Rel. Cecília Marcondes. Terceira Turma. Julgado em $18 / 12 / 2002$.

TRF3. Apelação Cível: AC nº 2002.03.99.016725-8. Rel. Cecília Marcondes. Terceira Turma. Julgado em $13 / 12 / 2004$.

${ }^{56}$ TRF3. Apelação Cível: AC n 0203549-46.1994.4.03.6104/SP. Rel. Regina Costa. Sexta Turma. DJ: 09/12/2011. TRF3. Embargos Infringentes $n^{\circ}$ 0203549-46.1994.4.03.6104/SP. Rel. Marli Ferreira. Segunda Seção. DJ: 28/03/2014.

TRF5. Apelação Cível: AC nº 572679. Rel. Paulo Machado Cordeiro. Terceira Turma. Julgado em 14/01/2016.

${ }^{57}$ TRF3. Apelação Cível: AC no 1999.03.99.009734-6/SP. Rel. Silva Neto (juiz federal convocado). Turma Suplementar da Segunda Seção. Julgado em 03/05/2007.

${ }^{58}$ TRF5. Apelação Cível: AC no 0805878-43.2016.4.05.8500. Rel. Rubens de Mendonça Canuto Neto. Quarta Turma. Julgado em 25/05/2018.
} 
v) Entendimento de que o pagamento de multa administrativa pelo fato lesivo não exclui a reparação civil de danos -01 julgado, ${ }^{59}$

w) Entendimento de que é parte legítima para figurar no polo passivo da demanda a empresa identificada como responsável pelo recolhimento da multa administrativa -01 julgado; ${ }^{60}$

x) O afastamento da condenação reparatória ou compensatória porque a empresa (no caso, a Petrobras) não descumpriu as obrigações de medição e monitoramento constantes da Resolução CONAMA n. 393/2007, que "dispõe sobre o descarte contínuo de água de processo ou de produção em plataformas marítimas de petróleo e gás natural" - 01 julgado; ${ }^{61}$

\subsubsection{Reconhecimento dos danos morais / extrapatrimoniais}

Foram selecionados 10 julgados em que houve o reconhecimento dos danos morais (individuais e coletivos) por parte dos magistrados, em decorrência de danos ambientais por derramamentos de óleo, com base nos seguintes fundamentos:

a) Dano moral individual por sofrimento e angústia dos pescadores artesanais em razão da privação das condições de trabalho - 06 julgados; ${ }^{62}$

b) Dano moral coletivo por lesão ao patrimônio ideal da coletividade - 03 julgados; ${ }^{63}$

\footnotetext{
${ }^{59}$ TRF3. Apelação Cível: AC n 96.03.014267-0 304590. Rel. Rubens Calixto (juiz federal convocado). Terceira Turma. Julgado em 01/08/2007.

${ }^{60}$ TRF3. Apelação Cível: AC nº 0013488-09.2009.4.03.6104/SP. Rel. Johonsom Di Salvo. Sexta Turma. DJ: 07/10/2013.

${ }^{61}$ TRF2. Remessa Ex Offício n ${ }^{\circ}$ 0114234-10.2015.4.02.5001. Rel. Aluísio Gonçalves de Castro Mendes. Quinta Turma Especializada. Julgado em 07/08/2018.

${ }^{62}$ STJ. Agravo Regimental no Agravo em Recurso Especial: AgRg no AREsp n 249.208/PR. Rel. Min. Marco Buzzi. Quarta Turma. Julgado em 18/12/2012.

STJ. Recurso Especial: REsp n 1.114.398. Rel. Min. Sidnei Beneti. Segunda Seção. Julgado em 08/02/2012.

STJ. Recurso Especial: REsp $n^{\circ} 1.346 .430 / P R$. Rel. Min. Luís Felipe Salomão. Quarta Turma. Julgado em 18/10/2012.

${ }^{63}$ TRF2. Apelação Cível: AC no 2005.51.02.0063310. Rel. Luiz Paulo da Silva Araújo Filho. Sétima Turma Especializada. Julgado em 18/12/2013.

TRF2. Apelação Cível: AC nº 0006782-42.2011.4.03.6103/SP. Rel. Johonsom Di Salvo. Sexta Turma. DJ: 23/11/2015.

TRF2. Apelação Cível: AC no 0007231-60.2012.4.03.6104/SP. Rel. Mônica Nobre. Quarta Turma. DJ: 17/12/2015.
} 
c) Dano moral coletivo por gerar prejuízo não só ao meio físico, como também à saúde humana, ao ambiente de trabalho e ao bem-estar da população - 01 julgado; ${ }^{64}$

Os danos extrapatrimoniais individuais e coletivos foram abordados de forma mais aprofundada no capítulo 5, inclusive, com a apresentação de julgados retirados, além dos tribunais acima identificados, dos Tribunais de Justiça Estaduais, visto que, na grande maioria dos casos, as demandas requerendo o reconhecimento de danos extrapatrimoniais são ajuizadas nos tribunais localizados nos domicílios de origem dos autores.

\subsubsection{Metodologia utilizada para valoração de danos ambientais materiais/ patrimoniais e morais/extrapatrimoniais}

Dos julgados selecionados, 68 trataram de metodologias de cálculo para valoração de danos materiais / patrimoniais e morais / extrapatrimoniais. Destes, 50 reconheceram a aplicação da metodologia "Proposta de Critério para Avaliação Monetária de Danos Causados por Derramamentos de Petróleo ou de seus Derivados no Ambiente Marinho”, desenvolvida pela CETESB.

Sendo que, apenas 05 aplicaram a metodologia antes de $2005^{65}$ e 45 aplicaram após 2005. Conforme será apresentado no capítulo 8, com maiores detalhes, a própria CETESB deixou de utilizar a metodologia em 2005, porém o judiciário permanece se valendo do método para fundamentar um número expressivo de decisões, contrariando o próprio órgão ambiental. ${ }^{66}$

\footnotetext{
${ }^{64}$ TRF4. Apelação Cível: AC no 5006075-38.2012.4.04.7101/RS. Rel. Vivian Josete Pantaleão Caminha. Quarta Turma. Julgado em 17/05/2017.

65 TRF3.Apelação Cível: AC no 96.03.067409-5 335080. Rel. Salette Nascimento. Sexta Turma. Julgado em $15 / 05 / 2002$.

TRF3. Apelação Cível: AC no 401518/SP. Rel. Salette Nascimento. Sexta Turma. Julgado em 23/05/2001.

TRF3. Apelação Cível: AC no 421143. Rel. Salette Nascimento. Quarta Turma. Julgado em 11/02/2004.

TRF3. Apelação Cível: AC n 432487. Rel. Cecília Marcondes. Terceira Turma. Julgado em 18/12/2002.

TRF3. Apelação Cível: AC nº 795909. Rel. Cecília Marcondes. Terceira Turma. Julgado em 13/12/2004.

${ }^{66}$ STJ. Agravo Interno no Recurso Especial: AREsp n 1.399.305/SP. Rel. Min. Assusete Magalhães. Segunda Turma. Julgado em 20/09/2018.

STJ. Agravo Regimental no Agravo em Recurso Especial: AgRg no AREsp n ${ }^{\circ} 778.589 /$ SP. Rel. Min. Mauro Campbell Marques. Segunda Turma. Julgado em 03/12/2015.

TRF3. Apelação Cível: AC nº 0000922-33.2006.4.03.6104/SP. Rel. Nelton dos Santos. Terceira Turma. DJ: 29/08/2016.

TRF3. Embargos de Declaração em Apelação Cível: EDcl em AC nº 0000922-33.2006.4.03.6104/SP. Rel. Nelton dos Santos. Terceira Turma. Publicado em 04/05/2017.

TRF3. Apelação Cível: AC nº 0001913-38.2008.4.03.6104/SP. Rel. Antonio Cedenho. Terceira Turma. DJ: 19/02/2018.

TRF3: Apelação Cível: AC nº 0006757-75.2001.4.03.6104/SP. Rel. Andre Nabarrete. Quarta Turma. DJ: 24/06/2015.

TRF3. Apelação Cível: AC nº 0208505-42.1993.4.03.6104/SP. Rel. Paulo Conrado. Turma A. DJ: 02/09/2011.
} 
TRF3. Agravo em Apelação Cível: Ag em AC nº 0002183-09.2001.4.03.6104/SP. Rel. Nery Junior. Terceira Turma. DJ: 15/04/2013.

TRF3. Agravo em Apelação Cível: Ag em AC nº 0011207-85.2006.4.03.6104/SP. Rel. Nery Junior. Terceira Turma. DJ: 17/02/2014.

TRF3. Apelação Cível: AC no 0000024-93.2001.4.03.6104/SP. Rel. Márcio Moraes. Terceira Turma. DJ: 31/01/2011.

TRF3. Apelação Cível: AC nº 97.03.064646-8/SP. Rel. Fabio Prieto. Quarta Turma. DJ: 26/05/2010.

TRF3. Apelação Cível: AC nº 0001635-81.2001.4.03.6104/SP. Rel. Cecilia Marcondes. Terceira Turma. DJ: 26/10/2010.

TRF3. Apelação Cível: AC nº 0001897-31.2001.4.03.6104/SP. Rel. Monica Nobre. Quarta Turma. DJ: 17/12/2015.

TRF3. Apelação Cível: AC n 1999.03.99.016662-9/SP. Rel. Lazarano Neto. Sexta Turma. DJ: 16/03/2010.

TRF3. Apelação Cível: AC nº 0002051-49.2001.4.03.6104/SP. Rel. Johonsom Di Salvo. Sexta Turma. DJ: $19 / 05 / 2014$.

TRF3. Apelação Cível: AC no 0002456-80.2004.4.03.6104/SP. Rel. André Nabarrete. Quarta Turma. DJ: 07/10/2015.

TRF3. Apelação Cível: AC n 0003659-43.2005.4.03.6104/SP. Rel. Cecília Marcondes. Terceira Turma. DJ: 01/10/2012.

TRF3. Apelação Cível: AC nº 0004742-21.2010.4.03.6104/SP. Rel. Marcelo Saraiva. Quarta Turma. DJ: 09/02/2018.

TRF3. Apelação Cível: AC nº 0004797-79.2004.4.03.6104/SP. Rel. André Nabarrete. Quarta Turma. DJ: 10/09/2012.

TRF3. Apelação Cível: AC nº 0006384-15.1999.4.03.6104/SP. Rel. Salette Nascimento. Quarta Turma. DJ: 05/04/2011.

TRF3. Apelação Cível: AC no 0006567-68.2008.4.03.6104/SP. Rel. Nelton dos Santos. Sexta Turma. DJ: 07/12/2015.

TRF3. Apelação Cível: AC nº 0006782-42.2011.4.03.6103/SP. Rel. Johonsom Di Salvo. Sexta Turma. DJ: 23/11/2015.

TRF3. Apelação Cível: AC no 0007231-60.2012.4.03.6104/SP. Rel. Mônica Nobre. Quarta Turma. DJ: 17/12/2015.

TRF3. Apelação Cível: AC no 0007251-22.2010.4.03.6104/SP. Rel. Mônica Nobre. Quarta Turma. DJ: 17/12/2015.

TRF3. Apelação Cível: AC nº 0008377-78.2008.4.03.6104/SP. Rel. Mônica Nobre. Quarta Turma. DJ: 03/03/2016.

TRF3. Apelação Cível: AC nº 0008783-02.2008.4.03.6104/SP. Rel. Antônio Cedenho. Terceira Turma. DJ: 26/04/2018.

TRF3. Apelação Cível: AC nº 0008838-65.1999.4.03.6104/SP. Rel. Alda Basto. Quarta Turma. DJ: 19/12/2012. TRF3. Apelação Cível: AC no 0009399-11.2007.4.03.6104/SP. Rel. Márcio Moraes. Terceira Turma. DJ: 31/03/2014.

TRF3. Apelação Cível: AC nº 0009548-94.2013.4.03.6104/SP. Rel. Carlos Muta. Terceira Turma. DJ: 14/09/2017. TRF3. Apelação Cível: AC no 0010607-88.2011.4.03.6104/SP. Rel. Roberto Jeuken. Terceira Turma. DJ: 12/11/2014.

TRF3. Apelação Cível: AC nº 0200639-41.1997.4.03.6104/SP. Rel. Consuelo Yoshida. Sexta Turma. DJ: $11 / 11 / 2011$.

TRF3. Apelação Cível: AC n 0201611-79.1995.4.03.6104/SP. Rel. Silva Neto. Turma "C" do Projeto Mutirão Judiciário. DJ: 27/01/2011.

TRF3. Apelação Cível: AC no 0201612-64.1995.4.03.6104/SP. Rel. Consuelo Yoshida. Sexta Turma. DJ: 25/11/2011.

TRF3. Apelação Cível: AC nº 0202534-81.1990.4.03.6104/SP. Rel. Johonsom Di Salvo. Sexta Turma. DJ: 09/12/2014.

TRF3. Apelação Cível: AC nº 0203725-25.1994.4.03.6104/SP. Rel. Alda Basto. Quarta Turma. DJ: 06/08/2010. TRF3. Apelação Cível: AC nº 0204723-32.1990.4.03.6104/SP. Rel. Paulo Conrado. Turma “A”. DJ: 07/10/2011. TRF3. Apelação Cível: AC n 0205123-65.1998.4.03.6104/SP. Rel. Silva Neto. Turma "C" do Projeto Mutirão Judiciário. DJ: 21/01/2011.

TRF3. Apelação Cível: AC no 0205453-77.1989.4.03.6104/SP. Rel. André Nabarrete. Quarta Turma. DJ: 10/09/2012. 
Importante ressaltar que, em nem todos os casos analisados se aplicou a metodologia da CETESB de forma isolada, mas sim como um parâmetro objetivo para realizar cálculos de indenizações. Ademais, a partir dos montantes calculados com base nesta metodologia, os Tribunais avaliaram outros fatores, como a boa-fé do ofensor, medidas mitigadoras e reparadoras do dano, bem como a proporcionalidade e razoabilidade do quantum indenizatório.

Quanto aos 09 julgados em que não foi utilizada a metodologia da CETESB, não fícou claro qual foi a metodologia utilizada, pois a forma de busca de julgados adotada no presente trabalho permitia o acesso apenas às decisões, sentenças e acórdãos de forma isolada, mas não às petições, laudos e demais documentos do processo. Esses julgados não mencionavam a metodologia utilizada, nem mesmo o juiz, ao rearbitrar o valor, apontou qual a metodologia foi utilizada para o rearbitramento, baseando-se apenas em princípios, como os da proporcionalidade, razoabilidade e vedação ao enriquecimento sem causa. ${ }^{67}$

Quanto à metodologia utilizada para calcular os danos morais decorrentes de derramamento de óleo, foram analisados 09 julgados extraídos do STJ. Destes, 07 reproduziram a jurisprudência da corte, no sentido de prestigiar o quantum indenizatório fixado pelo tribunal

TRF3. Apelação Cível: AC no 0206470-75.1994.4.03.6104/SP. Rel. Consuelo Yoshida. Sexta Turma. DJ: $03 / 11 / 2010$.

TRF3. Apelação Cível: AC no 0200640-26.1997.4.03.6104/SP. Rel. Consuelo Yoshida. Sexta Turma. DJ: $11 / 11 / 2011$.

TRF3. Apelação Cível: AC no 0206469-90.1994.4.03.6104/SP. Rel. Consuelo Yoshida. Sexta Turma. DJ: $11 / 11 / 2011$.

TRF3. Apelação Cível: AC n 322074. Rel. Salette Nascimento. Quarta Turma. DJ: 17/08/2005.

TRF3. Apelação Cível: AC no 330505. Rel. Salette Nascimento. Quarta Turma. Julgado em 11/05/2005.

TRF3. Apelação Cível: AC nº 430646. Rel. Salette Nascimento. Quarta Turma. Julgado em 18/05/2005.

TRF4. Apelação Cível: AC no 5013215-58.2014.4.04.7100/RS. Rel. Fernando Quadros da Silva. Terceira Turma. Julgado em 27/09/2016.

TRF5. Apelação Cível: AC nº 0801665-62.2014.4.05.8500. Rel. Manoel de Oliveira Erhardt. Primeira Turma. Julgado em 20/02/2016.

67 TRF3. Embargos de Declaração: EDcl no 2002.03.99.013233-5788365. Rel. Cecilia Marcondes. Terceira Turma. Julgado em 18/03/2003.

TRF3. Apelação Cível: AC n 304592/SP. Rel. Marli Ferreira. Sexta Turma. DJ: 26/01/2005.

TRF3. Apelação Cível: AC nº 0002549-96.2011.4.03.6104/SP. Rel. Marli Ferreira. Quarta Turma. DJ: 17/07/2018. TRF3. Apelação Cível: AC no 0013488-09.2009.4.03.6104/SP. Rel. Johonsom Di Salvo. Sexta Turma. DJ: 07/10/2013.

TRF3. Apelação Cível: AC no 0203553-25.1990.4.03.6104/SP. Rel. Consuelo Yoshida. Sexta Turma. DJ: $17 / 11 / 2010$.

TRF3. Apelação Cível: AC nº 0205088-76.1996.4.03.6104/SP. Rel. Salette Nascimento. Sexta Turma. Julgado em 18/10/2010.

TRF3. Apelação Cível: AC no 0205472-68.1998.4.03.6104/SP. Rel. Consuelo Yoshida. Sexta Turma. DJ: 27/04/2012.

TRF3. Apelação Cível: AC nº 96.03.014267-0 304590. Rel. Rubens Calixto. Terceira Turma. Julgado em 01/08/2007.

TRF4. Apelação Cível: AC nº 5001112-21.2011.404.7101/RS. Rel. Vivian Josete Pantaleão Caminha. Quarta Turma. Julgado em 05/08/2014. 
de origem, só revisando a indenização nos casos em que foi considerada teratológica, ou irrisória. ${ }^{68}$

Nos outros 02 julgados, os ministros permaneceram prestigiando o quantum fixado a título de danos morais pelo tribunal de origem, reforçando alguns critérios utilizados no arbitramento, dentre eles: (i) proporcionalidade entre valor e grau de culpa; (ii) nível socioeconômico do recorrido; (iii) porte econômico do recorrente; (iv) a vedação ao enriquecimento sem causa; (v) importância do valor ser suficiente para reparar a vítima, e suficiente para desestimular o ofensor. ${ }^{69}$

A partir das constatações acima, claramente o cálculo dos danos morais consideraram os conceitos clássicos, associados ao sofrimento, aborrecimento, ficando em segundo plano a ideia de danos extrapatrimoniais ambientais, associados a perda de qualidade de vida. Muito embora o capítulo 5 retome de forma aprofundada os conceitos aqui expostos, não se pode deixar de comentar que os critérios utilizados pelos magistrados em nenhum momento objetivaram o reestabelecimento do nível de qualidade de vida das vítimas, se limitando a fatores puramente econômicos de satisfação das mesmas.

\subsection{Análise jurisprudencial dos derramamentos mais expressivos ocorridos no Brasil}

Conforme previamente introduzido, no presente item serão reportados os resultados de uma segunda pesquisa jurisprudencial realizada para contextualizar o tratamento dos derramamentos de óleo no mar pelos Tribunais brasileiros. Se a primeira pesquisa reportada foi

\footnotetext{
${ }^{68}$ STJ. Agravo Regimental no Agravo de Instrumento: AgRg no Ag no 1.370.562/PR. Rel. Min. Massami Yueda. Terceira Turma. Julgado em 07/04/2011.

STJ. Agravo Regimental no Agravo de Instrumento: AgRg no Ag n 113.103/PR. Rel. Min. Sidnei Beneti. Terceira Turma. Julgado em 26/06/2012.

STJ. Agravo Regimental no Agravo de Instrumento: AgRg no Ag n 222.483/SP. Rel. Min. Benedito Gonçalves. Primeira Turma. Julgado em 18/11/2014.

STJ. Agravo Regimental no Agravo em Recurso Especial: AgRg no AREsp no 254.149/PR. Rel. Min. Sidnei Beneti. Terceira Turma. Julgado em 19/02/2013.

STJ. Agravo Regimental no Agravo em Recurso Especial: AgRg no AREsp no 430.850/SP. Rel. Min. Herman Benjamin. Segunda Turma. Julgado em 11/02/2014.

STJ. Agravo Regimental no Recurso Especial: AgRg no REsp n ${ }^{\circ}$ 1.133.842/PR. Rel. Min. Sidnei Beneti. Terceira Turma. Julgado em 15/12/2009.

STJ; Recurso Especial: REsp n ${ }^{\circ}$ 1.666.017/RJ. Rel. Min. Herman Benjamin. Segunda Turma. Julgado em 27/06/2017.

${ }^{69}$ STJ. Agravo Regimental no Agravo em Recurso Especial: AgRg no AREsp no 201.350/PR. Rel. Min. Marco Buzzi. Quarta Turma. Julgado em 01/10/2013.

STJ. Agravo Regimental no Agravo em Recurso Especial: AgRg no AREsp n 249.208/PR. Rel. Min. Marco Buzzi. Quarta Turma. Julgado em 18/12/2012.
} 
focada em temas abrangentes, e iniciadas por palavras-chave genéricas, para esta segunda foi adotada uma metodologia distinta.

Em consulta à documentos oficiais da CETESB, IBAMA, bem como a trabalhos acadêmicos e científicos, devidamente referenciados ao longo do presente trabalho, foram selecionados os principais derramamentos de óleo em mar, ou que atingiram o mar, no Brasil. A partir desse levantamento prévio, foi iniciada uma pesquisa preliminar em todos os Tribunais pertinentes, para a identificação de possíveis julgados acessíveis, tanto por meio de consulta aos sites oficiais dos Tribunais, quanto por meio de bibliotecas físicas, a exemplo da biblioteca do Ministério Público do Estado de São Paulo.

Entretanto, para algumas ocorrências práticas fora do Estado de São Paulo e mais antigas, não foi possível a obtenção de cópias de decisões, vez que persistiam em vias físicas, integrando processos arquivados, necessitando de um pedido oficial de desarquivamento e da presença pessoal para a obtenção de cópias.

Com isso, a pesquisa foi realizada com base em 17 casos práticos, em que todas, ou pelo menos parte das principais decisões judiciais foram acessadas. Ademais, poderá ser observado que, para boa parte dos casos, foi possível a obtenção de cópias inclusive de Termos de Ajustamento de Conduta, importante instrumento de solução de alguns derramamentos, possibilitando o direcionamento dos esforços em busca da reparação dos ambientes afetados.

\subsubsection{Chevron}

O caso Chevron é decorrente de dois incidentes de vazamento de petróleo, ocorridos em novembro de 2011 e março de 2012 no Campo de Frade. O primeiro incidente ocorreu devido a um influxo de óleo do reservatório de aproximadamente 4600 barris, dos quais se estima que foram lançados ao mar aproximadamente 3700 barris por exsudação no leito oceânico. ${ }^{70}$ Este influxo que ocasionou as fissuras do sedimento marinho que abriga o reservatório, chamado de kick, ocorreu, segundo avaliação da Agência Nacional do Petróleo (ANP), pois a empresa não foi capaz de interpretar corretamente a geologia e a fluidodinâmica do local, calculando de maneira equivocada a pressão do reservatório. Ainda, segundo a agência, o acidente poderia ter

\footnotetext{
${ }^{70}$ BRASIL. Ministério Público Federal (MPF). Termo de Compromisso de Ajustamento de Conduta (TAC) entre MPF, Chevron Brasil Upstream Frade Ltda, Chevron Latin America Marketing LLC e TRANSOCEAN BRASIL LTDA, assinado em 13 de setembro de 2013. Disponível em: < http://www.anp.gov.br/noticias/1533-anp-mpfibama-chevron-e-transocean-assinam-termo-de-ajustamento-de-conduta $>$. Acesso em: 14.12.18.
} 
sido evitado, caso a empresa tivesse conduzido suas operações em conformidade à regulamentação e ao seu próprio manual de procedimentos. ${ }^{71}$

O segundo vazamento, diretamente relacionado ao incidente de novembro de 2011, ocorreu a uma distância de $3 \mathrm{~km}$ do incidente inicial, resultando no vazamento de aproximadamente 25 barris por exsudação do leito oceânico. ${ }^{72}$ Nele, foram constatados cinco pontos de vazamento ao longo de uma fissura de 800 metros no solo marinho, na concessão do Frade. Este vazamento teve uma vazão reduzida em relação ao primeiro. Apesar disso, resultou no agravamento dos danos ambientais e implicou aumento dos danos causados à rocha reservatório. $^{73}$

No caso da Chevron, foram ajuizadas quatro ações civis públicas: (i) Ação Civil Pública $(\mathrm{ACP}) \mathrm{n}^{\circ}$ 0302525-83.2014.8.19.0001; (ii) ACP $\mathrm{n}^{\circ}$ 0485873-12.2011.8.19.0001; (iii) ACP $\mathrm{n}^{\circ}$ 0000558-74.2012.4.02.5103; e (iv) ACP $\mathrm{n}^{\circ}$ 0002561-36.2011.4.02.5103. Consta também a celebração de um Termo de Ajustamento de Conduta (TAC) entre o Estado do Rio de Janeiro e a Chevron, no âmbito da ACP no 0485873-12.2011.8.19.0001.

\subsubsection{Ação Civil Pública nº 0302525-83.2014.8.19.0001 - Justiça Estadual}

A Federação dos Pescadores do Estado do Rio de Janeiro ajuizou a Ação Civil Pública $\mathrm{n}^{\circ}$ 0302525-83.2014.8.19.0001 em face de Chevron Brasil Ltda., distribuída para a $6^{\mathrm{a}}$ Vara Cível do Tribunal de Justiça do Estado do Rio de janeiro (TJRJ), em 04 de setembro de 2014, pleiteando responsabilização da ré para arcar com indenização por danos morais e materiais, decorrentes do derramamento de óleo cru no mar na Bacia de Campos.

O TJRJ reconheceu a legitimidade ativa da Federação dos Pescadores do Estado do Rio de Janeiro para propor a Ação Civil Pública pelas seguintes razões: (i) segundo a decisão, tratava-se de defesa de direito individual homogêneo, assim definido no art. 81, inciso III do CDC; (ii) nestes casos, seria desnecessária autorização dos substituídos pela entidade, nos

\footnotetext{
${ }^{71}$ MACHADO, A. R.; SALEME, E. R. Tratamento jurídico dado ao vazamento de petróleo no campo de frade. Estudo de caso: responsabilidade civil e assinatura do termo de ajustamento de conduta. Artigo apresentado no III encontro de internacionalização do CONPEDI. Madrid, Publicações, v.1, n.12, 2015, p. 337-341.

${ }^{72}$ BRASIL. Ministério Público Federal (MPF). Termo de Compromisso de Ajustamento de Conduta (TAC) entre MPF, Chevron Brasil Upstream Frade Ltda, Chevron Latin America Marketing LLC e TRANSOCEAN BRASIL LTDA, assinado em 13 de setembro de 2013. Disponível em: < http://www.anp.gov.br/noticias/1533-anp-mpfibama-chevron-e-transocean-assinam-termo-de-ajustamento-de-conduta $>$. Acesso em: 14.12.18.

${ }_{73}$ MACHADO, A. R.; SALEME, E. R. Tratamento jurídico dado ao vazamento de petróleo no campo de frade. Estudo de caso: responsabilidade civil e assinatura do termo de ajustamento de conduta. Artigo apresentado no III encontro de internacionalização do CONPEDI. Madrid, Publicações, v.1, n.12, 2015, p. 341.
} 
termos do art. $8^{\circ}$, inciso III da CF/1988 c/c art. 82, inciso IV do CDC; (iii) da análise do Estatuto da Federação, verificou-se que há previsão expressa no sentido da representação das colônias de pescadores e pescadores filiados àquelas, constando também como sua finalidade a coordenação, representação e defesa dos direitos e interesses dos filiados. Diante de expressa previsão legal e estatutária, bem como da hipossuficiência dos substituídos, considerando ainda, se tratar de direito individual homogêneo, concluiu-se que a Federação agravada possuía legitimidade extraordinária para demandar em Juízo a tutela de direitos subjetivos individuais de seus filiados, atuando como substituto processual. ${ }^{74}$

O processo ainda aguarda julgamento final perante o juiz de primeira instância da $6^{\mathrm{a}}$ Vara Cível do TJRJ.

\subsubsection{Ação Civil Pública no 0485873-12.2011.8.19.0001 - Justiça Estadual}

O Estado do Rio de Janeiro ajuizou a ACP nº 0485873-12.2011.8.19.0001 em face da empresa Chevron Brasil Upstream Frade Ltda., perante a $6^{\text {a }}$ Vara da Fazenda Pública do TJRJ, discutindo a responsabilidade civil ambiental da ré pelos danos causados pelo derramamento de óleo no Campo de Frade.

Apesar do interesse do Ministério Público do Estado do Rio de Janeiro (MPRJ) na condução da ação por parte da Justiça Federal, o Tribunal de Justiça do Rio de Janeiro (TJRJ) entendeu que, em razão da ausência de interesse da União no feito, e do legítimo interesse do Estado do Rio de Janeiro em recompor os danos patrimoniais e extrapatrimoniais causados ao litoral e à população fluminense, bem como da extinção do processo em trâmite perante a Justiça Federal com a mesma causa de pedir, deveria ser mantida a competência da Justiça Estadual para processamento do feito. ${ }^{75}$

Em razão do TAC celebrado, o processo foi arquivado em 30 de setembro de 2016.

\subsubsection{Ação Civil Pública no 0000558-74.2012.4.02.5103 - Justiça Federal}

O MPF ajuizou ACP em face da Chevron Brasil Upstream Frade Ltda., distribuída em 30 de novembro de 2012 para a $1^{\text {a }}$ Vara Federal do Rio de Janeiro. Em 27 de setembro de 2013,

\footnotetext{
${ }^{74}$ TJRJ. Agravo de Instrumento: Ag no 0009120-09.2016.8.19.0000. Rel. Ferdinaldo Nascimento. 19ª Vara Cível. Julgado em 14/06/2014.

75 TJRJ. Agravo de Instrumento: Ag nº 0039335-07.2012.8.19.000. Rel. Valéria Dacheux. 13ª Câmara Cível. Julgado em 02/05/2016.
} 
o magistrado Mauro Souza Marques da Costa Braga homologou o TAC Federal, extinguindo o processo com resolução do mérito. O processo foi arquivado em 17 de abril de 2015.

\subsubsection{Ação Civil Pública no 0002561-36.2011.4.02.5103 - Justiça Federal}

O MPF ajuizou ACP em face da Chevron Brasil Upstream Frade Ltda., distribuída em 30 de novembro de 2012 para a 1 ${ }^{\text {a }}$ Vara Federal do Rio de Janeiro. Em 27 de setembro de 2013, o magistrado Mauro Souza Marques da Costa Braga homologou o TAC federal celebrado entre Chevron e IBAMA, ANP e MPF, extinguindo o processo com resolução do mérito. O processo foi arquivado em 17 de abril de 2015.

\subsubsection{Agravo Regimental na Suspensão de Liminar e de Sentença no ${ }^{0}$.639 - RJ - Justiça Federal}

A ANP interpôs agravo regimental em face de decisão do Superior Tribunal de Justiça (STJ), que, ao manter a decisão da Justiça Federal, determinou a imediata paralisação das atividades no Campo de Frade em razão do derramamento de óleo. O STJ reconsiderou parcialmente a decisão agravada para (i) permitir a continuidade das atividades da Transocean no Brasil em outras localidades que não no Campo de Frade; (ii) autorizar a Chevron a manter apenas as operações de mitigação dos danos decorrentes do acidente no Campo de Frade, sob a supervisão e coordenação da ANP, haja vista a exsudação diária na localidade.

O Tribunal autorizou a realização de determinadas operações de mitigação pela Chevron, visto que a ANP esclareceu que ainda havia óleo residual nas fissuras do subsolo (em média, exsudação de 40 litros por dia), e que necessitava da ação da Chevron para o seu recolhimento, pois não seria capaz de executar referida atividade. Assim, o Tribunal Determinou que tais operações deveriam se dar sob a supervisão e coordenação da ANP, para se assegurar a tutela de forma efetiva ao meio ambiente e, privilegiando o princípio da precaução.

\subsubsection{TAC Federal}

Trata-se de TAC celebrado em 13 de setembro de 2013, entre Chevron Brasil Upstream Frade Ltda. e MPF, com a interveniência da ANP e do IBAMA.

Quanto ao seu objeto, as cláusulas iniciais do TAC Federal esclarecem que: (i) o TAC tem por objeto as obrigações de natureza preventiva, de precaução e compensatórias assumidas pela Chevron decorrentes dos dois vazamentos de petróleo ocorridos no Campo de Frade, na 
Bacia de Campos do Estado do Rio de Janeiro (Cláusula 1); (ii) os danos reparados e compensados não compreendem eventuais danos à estrutura geológica das áreas em que ocorream ambos os acidentes (Cláusula 1.1); (iii) a constatação de novos e posteriores danos em tais áreas poderá recair em desdobramentos judiciais e extrajudiciais adicionais (Cláusula 1.1.1).

Quanto às obrigações, o TAC prevê um amplo leque de medidas, classificando-as em categorias. Na classe de "obrigações de natureza preventiva e de precaução", foram estipuladas como diretrizes gerais: (i) adoção de todas as medidas de prevenção e precaução de incidentes ambientais e de aperfeiçoamento do sistema de resposta, observadas as orientações do IBAMA e da ANP (Cláusula 2.1.1); (ii) responsabilidade integral e sem limitação financeira para a implementação das obrigações de prevenção e reparação (Cláusula 2.1.2); e, por fim, que (iii) independentemente do disposto no TAC, a ANP e o IBAMA, nos termos das normas pertinentes, poderão fazer constar as exigências contidas no TAC, além de outras nos processos de licenciamento a que a Chevron Brasil estiver envolvida sujeita para a condução de suas atividades.

Na categoria "obrigações de natureza preventiva relacionadas ao IBAMA" (Cláusula 2.1.5 e seus subitens), a Compromissária se obrigou, dentre outras obrigações, a: (i) instalar, a bordo do FPSO Frade e de pelo menos duas embarcações de resposta à emergência, sistema integrado de detecção e monitoramento de óleo no mar; ${ }^{76}$ funcionando continuamente durante 24 horas, independentemente das condições de visibilidade, além de sistema de detecção automática de vazamento por radar e sensor infravermelho, estabilizado em relação ao movimento das embarcações, com capacidade de estimar a espessura e volume do óleo; (ii) instalar equipamentos em número suficiente, de modo a atender situações de vazamento em qualquer ponto do campo; (iii) manter contrato com empresa/instituição especializada no fornecimento de imagens de satélite que garanta a cobertura de toda a área potencialmente afetada por vazamentos, incluindo as trajetórias prováveis da mancha de óleo.

Tais medidas, apesar de consideradas preventivas, não deixam de apresentar enorme importância no atendimento a emergências, sendo igualmente mitigadoras de danos.

\footnotetext{
${ }^{76} \mathrm{O}$ sistema instalado deverá ser complementado por equipamento dotado de luz de busca; possuir capacidade de integração com outras fontes de informação, tais como o posicionamento de embarcações e imagens de ROV; possuir capacidade de transmissão de informações online para terminais em terra, em tempo real. Pelo menos um terminal em terra deverá ser utilizado pela Chevron para melhoria da sua capacidade de resposta a emergências no Campo de Frade. Dois outros deverão ser instalados e mantidos para acesso permanente e irrestrito pelo IBAMA.
} 
Além disso, a Chevron obrigou-se também a (iv) realizar estudos e pesquisas com vistas a avaliar o comportamento físico e químico do petróleo no percurso entre o fundo do mar até a superfície marinha (vazamento em águas profundas), e a (v) instalar sistema integrado de aquisição de dados meteo-oceanográficos, contendo, no mínimo: estação meteorológica com sensores de vento, temperatura, pressão atmosférica e umidade relativa, e sensores oceanográficos com medidores de salinidade, perfil de intensidade e direção de correntes marinhas, no mínimo em superfície, ondas e dados de elevação da superfície do mar.

Na categoria "obrigações de natureza compensatória” (Cláusula 2.2 e seus subitens), a empresa se comprometeu a adotar as seguintes medidas: (i) executar medidas compensatórias no valor total de $\mathrm{R} \$ 95.160 .000$, que deverão representar benefícios imediatos e efetivos de natureza socioambiental; (ii) essas medidas compensatórias apresentam, como objetivos principais, entre outros, a conservação da biodiversidade no litoral, o uso sustentável dos recursos pesqueiros, o fortalecimento da pesca artesanal e educação ambiental; (iii) a disponibilização em siter de relatórios, no mínimo semestrais, de monitoramento e acompanhamento, até a implementação final dos projetos e medidas compensatórias.

Quanto à fiscalização, estabeleceu-se que o disposto no TAC não limita, impede ou suspende a fiscalização ampla, irrestrita e permanente da Chevron pelo MPF, ANP, e IBAMA, no exercício de suas atribuições e prerrogativas legais (Cláusula 4.2).

Quanto às penalidades, estipulou-se multa diária por desculprimento, no valor de $\mathrm{R} \$$ 1.000.000,00, em favor do Fundo de Defesa dos Direitos Difusos, regulamentado pelo Decreto $\mathrm{n}^{\circ} 1.306$, de 09 de novembro de 1994.

\subsubsection{TAC Estadual}

O TAC celebrado entre o Estado do Rio de Janeiro e a Chevron, em 26 de outubro de 2015, refere-se à ação Civil Pública $n^{\circ}$ 0485873-12.2011.8.19.000, e contou com interveniência do Instituto Estadual do Ambiente do Estado do Rio de Janeiro (INEA/RJ). Foi celebrado de forma adicional ao TAC Federal citado no ítem anterior.

No TAC estadual, a Chevron se comprometeu a promover: (a) destinação ao Estado do RJ de R \$ 5.000.000,00, para a realização de: (i) Projeto de Recuperação Ambiental dos Manguezais de Tubiacanga, na Baía de Guanabara; (ii) Projeto de Fortalecimento do Uso Público do Parque Natural Municipal de Barão de Mauá, com foco à Proteção de Manguezal da Baía de Guanabara (Cláusula 3.1.1), e (iii) a aplicação, da verba de R\$ 5.582.000,00 em área do Parque Nacional da Serra da Bocaina, localizada no Estado do Rio de Janeiro, como 
parte da verba relativa à Compensação Ambiental relacionada às atividades no Campo de Frade, atendendo ao art. 36, § $2^{\circ}$, da Lei 9.985/2000 (Cláusula 3.1.2).

Quanto ao monitoramento e controle, a Secretaria Estadual de Ambiente do Rio de Janeiro (SEA) e o INEA/RJ ficaram encarregados de verificar o cumprimento das obrigações estabelecidas no TAC, acompanhando e fiscalizando a execução dos projetos até a sua integral execução (Cláusula 6.2).

Quanto às penalidades por descumprimento, estabeleceu-se, em razão de possíveis descumprimentos, uma multa diária, que seria revertida em favor do Fundo Estadual de Conservação Ambiental (FECAM), no valor de R \$ 5.000.00.

\subsubsection{Smyrni}

Em julho de 1998, houve um abalroamento do navio cargueiro Elizabeth Rickmers, que navegava no canal do porto de Santos, com outros dois navios cargueiros, o Southern Juice e o Smyrni, atracados no cais do armazém 26 do Porto de Santos. A colisão foi originada por falhas mecânicas ocorridas no E. Rickmers, atingindo o tanque de óleo combustível marítimo do Smyrni. O vazamento foi estimado entre 40.000 e 70.000 litros, atingindo o estuário, costões rochosos, praias, manguezais e águas costeiras. ${ }^{77} \mathrm{O}$ óleo decorrente do vazamento do navio chegou às faixas de areia devido ao movimento das marés, alcançando dois dos sete quilômetros das praias de Santos. ${ }^{78}$

\subsubsection{Ação Civil Pública $n^{0}$ 0205282-08.1998.4.03.6104 - Justiça Federal}

O MPF ajuizou ACP em face da Agência Marítima Brasileira Ltda., B. Rickmers GMBH \& CIE, Cargo Trading Comércio Exterior Despachos de Serviços, Marbulk Shipp CO Ltda., Alvaro de Oliveira Fernandes e Wilson Sons Agência Marítima Ltda., em 31 de julho de 1998, em trâmite na $3^{\mathrm{a}}$ Vara Federal do Tribunal Regional Federal da $3^{\mathrm{a}}$ Região, na Comarca de Santos.

O MPF alegou que o produto derramado não foi contido a tempo, levando à poluição das praias do Município de Santos, Guarujá e São Vicente, além de manguezais e costões

77 POFFO, I. R. F. Gerenciamento de riscos socioambientais no complexo portuário de Santos na ótica ecossistêmica. 172f. Tese de doutorado - Programa de Ciência Ambiental (PROCAM), Universidade de São Paulo (USP), São Paulo, set. 2007, p. 107-108.

${ }^{78}$ CETESB. Operação Smyrni: Relatório Técnico. São Paulo: CETESB, 1998, 112p. 
rochosos. Justificando que os réus não adotaram medidas mitigadoras para evitar a dispersão do óleo, de modo a se configurar lesão aos meios físico, biológico, antrópico, cultural (lazer) e artificial (turismo, pesca, etc.). Alegou ainda que a CETESB, embora acionada, não possuía equipamentos suficientes, sendo obrigada a comunicar o Centro de Combate de Poluição da Petrobras, que, em seguida, implementou as medidas necessárias.

Requereu, então: (i) a retenção dos navios até o efetivo pagamento de caução estipulada em R \$ 20.000.000,00; (ii) a retenção dos passes de saída dos referidos navios; (iii) a adoção de medidas necessárias à remoção do óleo derramado e limpeza dos locais afetados; (iv) a destinação adequada dos resíduos sob pena de 1/30 da caução; (v) a condenação ao pagamento de indenização dos danos ao meio ambiente natural, cultural e artificial; (vi) a condenação ao pagamento de indenização por danos morais à imagem da região turística; (vii) a condenação à perda de incentivos e benefícios fiscais concedidos pelo Poder Público; (viii) a condenação em honorários sucumbenciais destinados ao Fundo de Reparação de Interesses Difusos; bem como, (ix) a fixação do quantum indenizatório com base no determinado pela CETESB.

Por meio de sentença publicada em 13 de abriu de 2012, decidiu-se, no mérito: (i) o reconhecimento das dimensões dos danos ambientais; (ii) o reconhecimento de danos ao patrimônio artificial, cultural e moral; (iii) a configuração de responsabilidade de todas as rés, sendo que a primeira e efetiva responsável pelo dano seria a proprietária do navio Elizabeth Rickmers, Reederei B. Rickmers GMBH \& CIE, já que deveria ter realizado vistorias preventivas necessárias. As demais foram responsabilizadas com base na teoria do risco integral (vide capítulo 6), por se beneficiarem economicamente da atividade desenvolvida, sendo potenciais causadoras de danos ambientais. Quanto ao prático Álvaro de Oliveira Fernandes, foi decidido que ele não concorreu para o dano, pois houve falha mecânica, além do fato de o réu não auferir lucros de tal atividade. No tocante à forma de cálculo da indenização, foi aplicado o método da CETESB de 1992; por fim, foi fixado o valor de R\$ 5.000.000,00 a ser revertido ao Fundo de Defesa dos Direitos Difusos Federal e Estadual, após eventual fase de liquidação de danos individualmente aferidos.

Entretanto, houve acordo firmado entre as partes, sendo extinta a ACP. Atualmente, o processo se encontra em fase de cumprimento do acordo homologado, tendo a última decisão do magistrado, de 06 de julho de 2018, autorizado a destinação do montante residual existente nos autos em favor da Marinha do Brasil e determinado a transferência do saldo total do depósito judicial, devidamente atualizado, para a conta de titularidade da Empresa Gerencial de Projetos Navais (EMGEPRON). 


\subsubsection{Vicuña}

O caso do Navio BTG Vicuña refere-se ao derramamento de óleo ocorrido no dia 15 de novembro de 2004, no Porto de Paranaguá, no estado do Paraná. A empresa Hexion Química Indústria e Comércio Ltda. celebrou, em 2004, contrato internacional de importação de metanol com a empresa Methanex Chile Limited. Na noite do acidente, o navio transportava aproximadamente 14,26 milhões de litros de metanol e o desembarque começou a ser feito no píer da Cattalini Terminais Marítimos Ltda., um terminal privado, localizado no porto de Paranaguá.

No momento em que o navio descarregava o líquido inflamável, ocorreram duas explosões seguidas entre as $19 \mathrm{~h} 30$ e as 20h. A ocorrência das explosões resultou em uma abertura no casco do navio, por meio da qual foram derramados no mar mais de 1,5 mil toneladas de óleo tipo bunker, que era utilizado como combustível da embarcação, bem como a própria substância química metanol. Segundo laudo da época, foram contaminadas as águas superficiais das baías de Paranaguá, Antonina e Laranjeiras, além das águas da plataforma continental. As áreas mais atingidas foram a Baía de Paranaguá e as ilhas da Cotinga e do Mel. Houve forte impacto nos manguezais, segundo os técnicos. Além do enorme prejuízo ambiental em decorrência do derramamento acima referido, este acidente também ocasionou a morte de 4 pessoas. $^{79}$

O Tribunal de Justiça do Estado do Paraná (TJPR) possui uma série de julgados referentes ao caso em tela. A seguir, serão destacados os principais entendimentos consagrados pelo TRPR. Ademais, foram selecionados quatro julgados do STJ referentes a este caso.

No Recurso Especial (REsp) $n^{\circ}$ 1.401.500/PR (Rel. Ministro Herman Benjamin, segunda turma, julgado em 16 de agosto de 2016), a empresa Hexion questionou a sua responsabilidade pelo pagamento da multa administrativa aplicada pelo Instituto Ambiental do Paraná (IAP), em razão do acidente, no valor de R\$12.351.500,00. O Ministro diferenciou a responsabilidade civil pelo dano ambiental, que é objetiva, da responsabilidade administrativa por dano ambiental, que exige demonstração de culpa, sendo subjetiva (vide capítulo 06). Em

${ }^{79}$ IBAMA. IAP. Laudo técnico do acidente do navio Vicunã, ocorrido em Paranaguá no dia 15 de novembro de 2004: Relatório Técnico. Paranaguá: IBAMA/IAP, mai. 2004. 67p + anexos. 
seguida, reafirmou o entendimento jurisprudencial do Tribunal ${ }^{80}$, no sentido de que, no caso, o proprietário da carga, deveria responder subjetivamente pela degradação ambiental causada pelo transportador.

Em um segundo (REsp), n 1.187.097/PR, (Rel. Ministro Marcos Buzzi, Quarta Turma, julgado em 16 de abriu de 2013), a empresa Sociedad Naviera Ultragás Ltda. questionou a indenização pleiteada por pescadores artesanais. Neste caso, o STJ se pronunciou sobre matéria de competência para processar e julgar a ação. O Tribunal decidiu que a competência para processar e julgar o caso específico é da Justiça Federal. A princípio, a competência seria da Justiça Estadual, pelos seguintes motivos: (i) a ação indenizatória não se encontra lastrada em qualquer convenção internacional; (ii) com ela não se objetiva a reparação de danos ambientais (causados a bens da União), mas sim o ressarcimento dos prejuízos suportados por particulares (pescadores), em face da impossibilidade de desenvolverem a pesca na região atingida pelo desastre ambiental; (iii) não se aplica a Súmula 150 do STJ, pois a União não manifestou, in casu, qualquer interesse voluntário em intervir na lide; (iv) eventual existência de demanda regressiva proposta pela União contra os responsáveis pelo dano ambiental, em razão do pagamento de benefício extraordinário aos pescadores (a título de seguro-desemprego), não traduz manifestação espontânea do ente político na presente contenda reparatória de danos morais e materiais.

Porém, o fator determinante para a se considerar o caso como competência da Justiça Federal foi a existência de pedido expresso de chamamento do IBAMA (uma autarquia federal) ao processo, demonstrando o interesse da União na causa.

Nos dois últimos julgados, (REsp) $n^{\circ} 1.602 .106 / \mathrm{PR}$, e (REsp) $\mathrm{n}^{\circ}$ 1.596.081/PR (Rel. Ministro Ricardo Villas Bôas Cueva, Segunda Seção, julgado em 25 de outubro de 2017), interposto pelas empresas Momentive Química do Brasil Ltda. e Arauco do Brasil S.A. em face da pescadora artesanal Simone Martins, discutiu-se a questão da responsabilidade das empresas adquirentes da carga transportada pelo Navio Vicuña pelos danos extrapatrimoniais causados à pescadora.

O acórdão recorrido concluiu pela procedência do pedido de indenização formulado pela pescadora sob o fundamento de se tratar de hipótese de responsabilidade objetiva, com

\footnotetext{
${ }^{80}$ STJ. Agravo Regimental no Agravo ao Recurso Especial: AgRg no AREsp nº 62.584/RJ. Rel. Ministro Sérgio Kukina. Primeira Turma. DJe: 07/10/2015.
} 
aplicação da teoria do risco integral, na qual o simples risco da atividade desenvolvida pelas demandadas configuraria o nexo de causalidade ensejador do dever de indenizar, fixando a indenização no valor de $\mathrm{R} \$ 5.000,00$.

O STJ não reconheceu a responsabilidade das empresas adquirentes da carga, pois, em seu entendimento, não houve demonstração da existência de nexo de causalidade entre o resultado lesivo efetivamente verificado na pescadora e as condutas das adquirentes da carga. Na visão do Tribunal, só poderiam ser responsabilizadas caso fosse demonstrado: (i) o comportamento omissivo das adquirentes; (ii) que o risco de explosão na realização do transporte marítimo de produtos químicos adquiridos fosse ínsito às atividades por elas desempenhadas; ou (iii) que estava ao encargo delas, e não da empresa vendedora, a contratação do transporte da carga que lhes seria destinada.

Assim, o STJ deu provimento ao recurso especial e fixou, neste julgado, a seguinte tese, para os fins do art. 1.040 do $\mathrm{CPC} / 2015$ :

As empresas adquirentes da carga transportada pelo navio Vicuña no momento de sua
explosão, no Porto de Paranaguá/PR, em $15 / 11 / 2004$, não respondem pela reparação
dos danos alegadamente suportados por pescadores da região atingida, haja vista a
ausência de nexo causal a ligar tais prejuízos (decorrentes da proibição temporária da
pesca) à conduta por elas perpetrada (mera aquisição pretérita do metanol
transportado). ${ }^{81}$

Por fim, vale mencionar também a Apelação Cível no 443.101-4-8, do Tribunal de Justiça do Estado do Paraná (TJPR), de relatoria do desembargador João Domingos Kuster Puppi, 8 a Câmara Cível, julgada em 13 de maio de 2008, contra sentença proferida em Ação de Indenização por Danos Morais $n^{\circ} 10606 / 04$, na qual o juiz a quo julgou extinto o processo em relação a Cattalini Terminais Marítimos Ltda., sem julgamento de mérito, condenando o autor e apelante (pescador Jacir Gonçalves do Rosário) ao pagamento das custas e despesas do processo, bem como dos honorários advocatícios da parte contrária, fixados em $10 \%$ do valor da condenação.

Primeiramente, vale mencionar um breve histórico do caso. Ocorrida a explosão do navio Vicuña, na baía de Paranaguá e, tendo havido vazamento de óleo, houve proibição da pesca por cerca de 60 dias. Em razão do acidente, o pescador Jacir Gonçalves do Rosário ajuizou indenizatória, objetivando indenização por danos morais pelo prejuízo causado. Posteriormente ao ajuizamento da demanda, o autor e a empresa proprietária do navio,

${ }^{81}$ STJ. Recurso Especial: REsp no 1.602.106/PR. Rel. Ministro Ricardo Villas Bôas Cueva. Segunda Seção. Julgado em 25/10/2017. 
Sociedade Navieira Ultragás Ltda. transacionaram. Homologada a transação realizada, o feito foi extinto em relação à Sociedade Naviera Ultragás Ltda. Com efeito, houve o prosseguimento do feito em relação à empresa ora apelada, Cattalini Terminais Marítimos Ltda., mas sobreveio sentença que julgou extinto o feito sem julgamento do mérito com base na ausência de interesse processual.

Diante deste histórico, o TJPR deu provimento ao recurso de apelação e decidiu o seguinte: (i) a competência é da Justiça Estadual, pois nas ações de reparação de dano sofrido em razão de delito ou acidente de veículos, o foro competente será o de domicílio do autor ou do local do fato, conforme a escolha da vítima, por força do art. 100, parágrafo único do CPC/1973; (ii) a empresa Cattalini é parte legítima para figurar no polo passivo da ação, por ter sido a mesma responsável pela extensão do derramamento de óleo, o qual não foi contido no momento adequado (aplicação da teoria do risco integral); (iii) a transação entre o apelante e a Sociedade Naviera Ultragás Ltda. não aproveita os demais devedores solidários, por força do art. 884, caput do Código Civil de 2002; (iv) a apelada era responsável pela contenção do óleo no caso, tinha o dever de responder de forma efetiva à poluição causada, nos termos dos arts. $5^{\circ}$ a $7^{\circ}$ da Lei Federal no 9.966/2000; (v) os danos extrapatrimoniais experimentados se consubstanciam pela consequência direta do evento danoso na vida daqueles pescadores, gerando alteração, seja na qualidade de vida, seja na saúde mental e física daqueles trabalhadores que se viram impossibilitados de exercer a própria profissão de forma inesperada; (vi) assim, no tocante ao dano moral, deve ser revista a decisão, mas levando em conta o valor transacionado junto à Ultragás, ou seja, tendo o autor concordado no recebimento da quantia de R\$ 656,25 cabe estender este valor também à Cattalini, buscando não fixar prestações desproporcionais entre as devedoras solidárias.

\subsubsection{Plataforma $P-36$}

A plataforma P-36 era, até o fatídico ano de 2001, a maior plataforma semi-submersa existente no mundo. De propriedade da Petrobras, estava localizada à uma distância de $130 \mathrm{~km}$ da costa do estado do Rio de Janeiro, mais especificamente, no campo do Roncador, na Bacia de Campos. O acidente ambiental que culminou com a submersão total da plataforma, teve início na madrugada do dia 15 de março de 2001, quando ocorreram em sequência três explosões em uma das colunas de sustentação da plataforma, que possuía 119 metros de altura e pesava 31 mil toneladas. De acordo com informações da ANP, a primeira explosão foi em um tanque de drenagem de emergência. O consequente vazamento de gás resultante desta explosão ocasionou a segunda e a terceira explosão, que deixaram 11 vítimas fatais. Após as explosões, 
a plataforma afundou completamente no dia 20 de março de 2001, contendo ainda em seu interior, conforme informações fornecidas pela Petrobras à época, mais de 1.500 toneladas de óleo. De acordo com o Relatório publicado pela ANP, no momento do acidente a plataforma P36 estava produzindo cerca 84.000 barris de petróleo e 1.300 .000 metros cúbicos de gás, por dia, oriundos de 6 poços interligados a ela. A interligação dos demais poços estava prevista para ser concluída em $2005 .^{82}$

Foram encontrados os seguintes julgados relevantes quanto a este caso:

Na Justiça Federal do Rio de Janeiro, constam dois julgados. O primeiro refere-se à Ação proposta $n^{\circ}$ 0012672-90.2008.4.02.5101 por Paulo Roberto Vianna, Cláudio Marinho Machado, Hélio Galvãode Menezes, Carlos José Macial Azeredo e Evanildo Souza Santos, em face da União, na qual questionam a conclusão apontada pelo Tribunal Marítimo quanto à apuração de responsabilidades e imposição de sanções em razão do acidente. Os autores pretendiam anular parcialmente a decisão proferida pelo Tribunal Marítimo, com relação à suposta co-responsabilidade dos mesmos pelo acidente, cancelando a penalidade imposta a eles e decretando a absolvição/exculpabilidade.

O juiz federal Maurício da Costa Souza, em sentença proferida em 23 de fevereiro de 2017, julgou improcedente o pedido dos autores, chancelando a decisão do Tribunal Marítimo, que responsabilizou os autores na esfera administrativa nos seguintes termos:

(i) Paulo Roberto Vianna era coordenador da plataforma (COPLAT) na época do acidente e foi responsabilizado:

(...) por permitir o armazenamento de alto percentual de mistura de água e óleo nos TDEs, pelo flangeamento do suspiro e da rede de esgoto do TDE de BE, mantendo a linha de admissão isolada apenas pela válvula de admissão (sem raqueteamento) e pela realização da operação de esgotamento sem seu acompanhamento direto.

Ou seja, considerou-se que houve negligência do empregado por ter conhecimento das deficiências na operação da plataforma P-36.

(ii) Cláudio Marinho Machado atuava como técnico de estabilidade e suas ações e omissões culminaram com o naufrágio da plataforma. O lastreamento dos tanques, a cargo do

\footnotetext{
${ }^{82}$ AgÊNCIA NACIONAL DO PETRÓleO, GÁS NATURAL E BIOCOMBUSTíVEIS. Análise do Acidente com a Plataforma P-36 - Relatório da Comissão de Investigação ANP/DPC: Relatório Técnico. Rio de Janeiro: ANP, jul. $2001.24 \mathrm{p}$ Disponível $<$ http://www.anp.gov.br/images/EXPLORACAO_E_PRODUCAO_DE_OLEO_E_GAS/Seguranca_Operacional /Relat_incidentes/Relatorio_P-36.pdf $>$. Acesso em: 16.12.2018.
} 
autor, da forma como realizado, fez com que fosse reduzida a reserva de flutuabilidade da plataforma. Ademais, não foram realizadas ações diretas para esgotar as áreas alagadas em consequência da primeira explosão, e o funcionário permitiu a retirada das elipses de acesso do tanque de lastro $26 \mathrm{~S}$ e da caixa de estabilidade $61 \mathrm{~S}$, alterando as condições de estanqueidade da embarcação por período excessivamente longo.

(iii) Hélio Galvão de Menezes atuava como Operador de Sistema, e também foi condenado em razão de sua imperícia. O erro ocorreu quanto ao exercício das funções de:

(...) flangear a rede de esgoto e o 'vent' atmosférico do TDE de BE, sabendo que estaria alterando as características estruturais de projeto do TDE, transformando-o em vaso de pressão, que não tardou a explodir, sendo que o representado foi o principal responsável pela primeira explosão - a mecânica.

Hélio, portanto, foi responsabilizado pela prática de ato que culminou com a primeira explosão na plataforma.

(iv) Carlos José Macial Azeredo e Evanildo Souza Santos, também operadores de sistema, foram condenados por imperícia no acompanhamento das possíveis consequências da demora da entrada em funcionamento da bomba de esgoto TDE de BB e a evolução dos níveis dos dois TDEs, após o início da drenagem, e por terem monitorado a sala de operações de modo deficiente.

Os autores interpuseram apelação, ainda não foi julgada até dezembro de 2018 pelo Tribunal de segunda instância.

O segundo julgado da Justiça Federal do Rio de Janeiro refere-se à ação nº 001726162.2007.4.02.5101, ajuizada pela Petrobras em face da União Federal, requerendo a anulação de decisão do Tribunal Marítimo. Em 02 de dezembro de 2013, o juiz federal Guilherme Bollorini Pereira, titular da $20^{\text {a }}$ Vara Federal do Rio de Janeiro, decidiu sobre o esgotamento de sua função jurisdicional no presente processo, razão pela qual a requerente, Petróleo Brasileiro S/A (Petrobras), deve formular petição junto à instância superior no processo $\mathrm{n}^{\circ}$ 2008.51.01.012672-4, citado anteriormente, pois versam sobre fatos comuns.

No Supremo Tribunal Federal, consta a Ação Cível Originária n ${ }^{0}$ 1.676/RJ, que trata de conflito negativo de atribuição entre o Ministério Público Federal e o Ministério Público do Estado do Rio de Janeiro a respeito de procedimento administrativo instaurado pelo Parquet Federal para apurar supostas irregularidades que possivelmente estariam ligadas ao acidente na Plataforma P-36. 
Em decisão monocrática proferida pelo Ministro Relator Ricardo Lewandowski, em 03 de dezembro de 2013, o STF decidiu pela competência do Ministério Público do Estado do Rio de Janeiro, citando sua jurisprudência no sentido de que a presença de sociedade de economia mista federal em procedimento investigatório não implica, por si só, a presunção de violação de interesse, econômico, ou jurídico da União.

Destaque-se, por fim, os Embargos de Declaração n ${ }^{\circ}$ 2007.02.01.011469-7, opostos pelo IBAMA em face da Petrobras, de Relatoria do desembargador Benedito Gonçalves, $6^{\text {a }}$ Turma Especializada do Tribunal Regional Federal da 2a Região, julgado em 14 de abriu de 2008, opostos em face de acórdão que deu provimento a agravo de instrumento interposto pela Petrobras, suspendendo a multa imposta pelo IBAMA em razão do derramamento de óleo na Plataforma P-36 e utilização de dispersante químico pela Petrobras para conter o vazamento. O Tribunal não deu provimento ao recurso, consignando que a suspensão da multa ambiental, bem como das sanções delas decorrentes, não causaria nenhum prejuízo à Administração até a solução final do litígio e preservaria a solvabilidade da Petrobras.

\subsubsection{Penélope}

O caso Penélope refere-se à colisão do navio petroleiro "Penélope" contra o petroleiro "Piquete" no Terminal Marítimo Almirante Barroso, em São Sebastião, ocorrida no dia 26 de maio de 1991, ocasionando o vazamento de 300 toneladas de óleo nas praias vizinhas. Os ambientes afetados por este derramamento foram as praias, costões rochosos e substratos artificiais. No município de Ilha Bela, o derramamento atingiu as praias de Ponta do Pequeá, praia do Pinto, Saco da Capela, Praia do Viana, Santa Teresa, Siriuba, Engenho d'água, Praia do Sino, Centro, Barreiros, Itaguassu, Pedra Miúda, Prainha da Ilha das Cabras, Armação, Barra Velha e Perequê. Já no município de São Sebastião, quatro praias foram atingidas: Praia Preta, Cabelo Gordo, Deodato e Araçã. ${ }^{83}$

A discussão acerca do Conflito de Competência ${ }^{\circ}{ }^{2.473-0 / S P}$ chegou ao STJ, e teve a relatoria do Ministro Antônio de Pádua Ribeiro, Primeira Seção, julgado em 26 de maio de 1992. O Tribunal decidiu que, quando o dano ambiental ocorrer em Comarca que não detém sede de Vara Federal, compete à Justiça Estadual em primeiro grau processar e julgar a Ação

${ }^{83}$ LOPES, C. F.; MILANELLI, J. C. C.; KADEKARU, N.; JOHNSCHER-FORNASARO, G. Efeitos ecológicos do derrame de óleo "Penélope" e da limpeza por jateamento a baixa-pressão nos costões rochosos da praia do Viana: Relatório Técnico. São Paulo: CETESB, p.84. 
Civil Pública, mesmo no caso de comprovado interesse da União no seu deslinde, por força da compatibilização do art. $2^{\circ}$ da Lei da ACP (Lei n ${ }^{\circ} 7.347$, de 24 de julho de 1985) com o art. 109, $\S \S 2^{\circ}$ e $3^{\circ}$ da Constituição Federal de 1988.

Contra esta decisão foram apresentados embargos de declaração. No julgamento dos embargos, de relatoria do mesmo Ministro Antônio de Pádua Ribeiro, Primeira Seção, julgado em 20 de abriu de 1993, o STJ reformou a decisão anterior para reconhecer a competência da Justiça Federal, e não mais da Justiça Estadual, em razão da incidência da Convenção Internacional sobre Responsabilidade Civil em Danos Causados por Poluição de Óleo, aprovada pelo Decreto Legislativo $\mathrm{n}^{\circ}$ 74/1976, promulgada pelo Decreto Federal $\mathrm{n}^{\circ}$ 79.437/1977 e regulamentada pelo Decreto Federal n ${ }^{\circ} 83.540 / 1979$, aplicando-se o art. 109, inciso III da CF/1988.

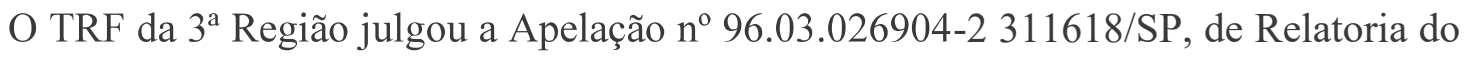
desembargador Federal Baptista Pereira, 3 ${ }^{\text {a }}$ Turma, julgada em 17 de dezembro de 2001, interposta pela empresa Horafa Shipping CO Ltda., em face de sentença que julgou improcedente a ação em que se objetivava anulação do auto de infração e imposição de multa, por infração ao Art. 1º, alínea "a", parágrafo único, da Lei Federal n 5.357/1967, ou seja, lançamento de óleo nas águas que se encontrem dentro de uma faixa de 6 milhas marítimas do litoral brasileiro, fixando a verba honorária em de $10 \%$ sobre o valor dado à causa.

O Tribunal negou provimento à apelação, pois considerou devida a aplicação da multa, vez que restou comprovado o dano ambiental decorrente do derramamento de óleo, especialmente em razão da apresentação de laudo do setor de Geoquímica da Petrobras. Este laudo foi elaborado a pedido da Delegacia da Capitania dos Portos, em São Sebastião, que, ao informar os resultados da análise de amostra de óleo, concluiu que as amostras coletadas no mar representavam uma correlação entre si, sendo a sua origem mais provável o óleo Bicudo, oriundo do Navio-Tanque Penélope.

Consignou ainda ser correta a aplicação da multa com base no parágrafo único, da alínea “a", do Art. 1º da Lei Federal n ${ }^{\circ}$ 5.357/1967, o qual prevê a aplicação em dobro em caso de reincidência, pois as provas dos autos demonstraram ser a apelante reincidente neste tipo de incidente.

O TRF da $3^{\mathrm{a}}$ Região julgou também o Agravo de Instrumento $\mathrm{n}^{\circ}$ 98.03.070731-0 69048/SP, de relatoria do juiz federal convocado Valdeci do Santos, 2a Seção, julgado em 17 de maio de 2007, interposto pela Petróleo Brasileiro S/A (Petrobras), tendo como agravado o 
Ministério Público Federal, contra decisão monocrática, proferida em ação civil pública, que não acolheu as preliminares de ilegitimidade passiva e carência da ação, pela falta de interesse de agir, arguidas pela agravante. Alega a agravante ser parte ilegítima para figurar no polo passivo da ação civil pública $n^{\circ} 91.401096-5$, vez que não era proprietária do navio em que houve o vazamento.

O Tribunal negou provimento ao agravo, reconhecendo a legitimidade passiva da Petrobras, vez que a empresa se utilizou dos serviços marítimos do navio Penélope por afretamento, para viabilizar a sua atividade de extração de óleo cru. Assim, decidiu-se por seu enquadramento na categoria de poluidor, prevista no artigo $14, \S 1^{\circ}$, da Lei Federal $n^{\circ}$ 6.938/1981, segundo o qual o poluidor é obrigado, independentemente da existência de culpa, a indenizar ou reparar os danos causados ao meio ambiente e a terceiros, afetados por sua atividade.

\subsubsection{Poliduto Olapa - PR}

O Poliduto Olapa (Sigla para Oleoduto Araucária-Paranaguá), pertencente à Petrobras, e está localizado no Estado do Paraná. Em fevereiro de 2001, sua estrutura sofreu uma ruptura ocasionando o vazamento de óleo diesel em uma área da Serra do Mar, em um volume estimado de $145 \mathrm{~m}^{3}$. Este volume vazado alcançou os cursos d'água da região e, por meio deles, cruzou diversos ambientes até atingir o Complexo Estuarino de Paranaguá. O derramamento resultou na mortandade da fauna aquática e na imediata proibição, imposta pelo Instituto Ambiental do Paraná e IBAMA, da pesca nos rios e baías de Antonina e Paranaguá, perdurando a proibição por mais de seis meses. ${ }^{84}$

\subsubsection{Ação Civil Pública nº 0000041-91.2010.404.7008 - Justiça Federal}

Trata-se da Ação Civil Pública n. ${ }^{\circ}$ 0000041-91.2010.404.7008, ajuizada pelo Instituto Ambiental do Paraná (IAP) contra Petróleo Brasileiro S/A (Petrobras), em 06 de abril de 2001, inicialmente perante a Vara Cível da Comarca de Morretes, sob o $\mathrm{n}^{\circ}$ 75/2011 (posteriormente autuado na Secretaria da Vara Federal de Paranaguá sob o número supra), em virtude do vazamento ocorrido em 16 de fevereiro de 2001, no oleoduto OLAPA, objetivando, liminarmente, a elaboração imediata, pela Petrobras, de Diagnóstico Ambiental sobre a área

${ }^{84}$ AlBarello, L. C.. O Vazamento do Oleoduto Olapa (Morretes, Paraná): Avaliação Ambiental e Reconstituição do Comportamento do Óleo, da Serra do Mar ao Complexo Estuarino de Paranaguá. 188p. Dissertação de Mestrado - Instituto de Geociências, UFRGS, Porto Alegre, 2012. 
atingida, a ser submetido à apreciação e aprovação do IAP, com cominação de multa diária por descumprimento. No mérito, requereu a condenação da ré à completa recomposição dos danos ambientais causados pelo acidente e, no caso de ser inviável a recomposição, pela determinação de indenização a ser apurada em liquidação de sentença.

Em 11 de abril de 2001 foi deferida a medida liminar para o fim de determinar à empresa ré a elaboração e apresentação em juízo, no prazo de 60 dias, de diagnóstico ambiental da área atingida, sob pena de multa de $\mathrm{R} \$ 1.500,00$ por dia de descumprimento, e ainda, determinou-se a citação da ré. A Petrobras apresentou contestação e agravou a decisão liminar, que foi mantida pelo Tribunal de Justiça do Estado do Paraná.

Chamado a se manifestar, o Ministério Público do Estado do Paraná pugnou pela necessidade de audiência preliminar, pedido acolhido pelo Juízo da Comarca, que marcou a audiência para o dia 29 de setembro de 2004. Na audiência, foi deferido à ré prazo para manifestação acerca dos documentos novos juntados pelo autor IAP. Em 11 de outubro de 2005, a ré pugnou pela suspensão da ação, em face da existência da ação civil pública $n^{\circ}$ 2002.70.08.000260-1, em trâmite perante a Vara Federal de Paranaguá, tratando do mesmo objeto.

Em 10 de maio de 2006, foi deferido o pedido e determinada a suspensão dos autos, em face da discussão no âmbito do TRF4 acerca da competência da ação civil pública proposta perante a Justiça Federal de Paranaguá. Recebidos os autos na Vara Federal, foram ratificados todos os atos praticados no Juízo Estadual, inclusive a decisão que deferiu o pedido liminar, ocasião em que se determinou a distribuição por dependência à Ação Civil Pública $\mathrm{n}^{\circ}$ 2002.70.08.000260-1, destacando-se que a instrução probatória seria realizada na ação conexa.

Em 20 de maio de 2010, o IAP alegou que a ré não havia cumprido a decisão liminar, e pugnou pela imposição de multa diária por descumprimento. Em 17 de novembro de 2010, foi proferida decisão reconhecendo o descumprimento da liminar por parte da empresa ré, e impondo multa no valor de $\mathrm{R} \$ 1.000,00$ por dia de descumprimento.

Em 03 de março de 2011, foi determinada a juntada, noss autos, da proposta de conciliação apresentada pela ré na ação conexa, e a remessa das duas ações aos autores para manifestação. A ré apresentou, para o fim de dar cumprimento à decisão liminar, dois volumes contendo a "Atualização do Diagnóstico Ambiental da Área Afetada Pelo Rompimento do Duto OLAPA - 2001". Foi proferida decisão nos seguintes termos: 
Esta magistrada sugeriu que os valores relativos ao enfrentamento dos desastres climáticos no litoral do Paraná, nos termos propostos pelo MPF no importe de até R \$ 30.000.000,00, fossem destinados a projetos exclusivos do Estado do Paraná, ficando claro que os projetos que serão apresentados serão submetidos à aprovação nos termos de todos os demais projetos que serão apresentados para uso nesta conta convênio. Com esta alteração o Estado do Paraná sinalizou positivamente ao acordo, aceitando as demais condições propostas pelo MPF e MP/PR, deixando apenas expresso que cabe ao Governador do Estado assinar o termo, ou emitir autorização específica para este fim. O MPF e o MP/PR retiram ainda a destinação específica de R\$ 6.000.000,00 para reforma do prédio da Justiça Federal, incorporando este saldo aos $\mathrm{R} \$$ $29.000 .000,00$, ditos residuais, cujo valor passa a ser $\mathrm{R} \$ 35.000 .000,00$, mas que serão destinados a projetos sócio-ambientais no litoral do Estado do Paraná. As partes ressaltaram ainda a necessidade de se ouvir a Caixa Econômica Federal para que fique certa sua participação na fiscalização do acordo. Ainda, fica registrado que a Petrobrás se compromete desde já a apresentar nos próximos 10 dias a atualização do diagnóstico ambiental da área de acordo com as diretrizes do IAP, bem como o plano de remediação e monitoramento da área, com o devido cronograma, com o objetivo de obter autorização ambiental, juntando cópia destes documentos e do protocolo e futuro licenciamento/autorização nos autos. A Petrobrás se compromete desde já a apresentar os estudos complementares solicitados pelo IAP para licenciamento/autorização e remediação.

Em 27 de abril de 2012, foi proferida sentença extinguindo o processo com resolução de mérito, homologando o acordo celebrado entre as partes. A sentença transitou em julgado na mesma data e o processo foi arquivado em 09 de maio de 2012.

\subsubsection{Ação Civil Pública no 2002.70.08.000260-1 - Justiça Federal}

Trata-se da Ação Civil Pública n. ${ }^{\circ}$ 2002.70.08.000260-1, ajuizada pelo MPF em conjunto com o Ministério Público do Estado do Paraná (MPPR), tendo inicialmente como assistente da parte autora a AGU, contra Petrobras, autuada em 21 de março de 2002, com o objetivo de responsabilizar a ré pelos danos causados ao meio ambiente pelo rompimento do oleoduto "Olapa.

Após longa instrução processual, em 08 de fevereiro de 2010, foi reconhecida a conexão destes autos com a Ação Civil Pública nº 75/2001, ajuizada pelo IAP, na Vara Cível da Comarca de Morretes em face da ré, Petrobras, tendo por objeto a recuperação ambiental da área afetada pelo acidente e, subsidiariamente, a sua conversão em perdas e danos no caso de impossibilidade de recomposição in natura. Aqueles autos foram então distribuídos por dependência a estes, recebendo a numeração 0000041-91.201.404.7008.

Em 16 de junho de 2010, visando adotar medidas de celeridade ao feito, por estar no rol de processos da Meta 2 do CNJ, e entendendo que a realização de uma perícia para se constatar a extensão dos danos ambientais ocorridos 9 anos antes seria de duvidosa eficiência, o juízo determinou a intimação dos autores para manifestarem interesse em acordo. 
MPF e MPPR deliberaram a favor de uma audiência de conciliação, que foi marcada para 02 de setembro de 2010. Intimadas as partes, a AGU requereu a desistência de sua atuação como assistente dos autores, alegando ser inadequada a sua permanência nesta ação. O pedido foi deferido pelo juízo e a União excluída do feito. Audiência realizada, não houve acordo entre as partes. A ré, Petrobras, insistiu na tentativa de conciliação e, finalmente, em audiência marcada para 26 de abril de 2012 foi homologado judicialmente o acordo envolvendo as demandas contidas nesta Ação e nos autos da Ação nº 0000041-91.201.404.7008 conexas. A sentença que extinguiu o processo e homologou o acordo transitou em julgado em 27 de abril de 2012.

Tal acordo foi dividido, basicamente, em duas partes, a saber: (i) recuperação ambiental integral da área atingida, sob a coordenação e supervisão do IAP, cujos custos foram estimados em R $\$ 12.000 .000,00$, assumindo a ré expressamente a responsabilidade pelo custeio desses valores e dos que excedessem esse limite; (ii) pagamento de indenização ambiental no montante de R\$ 90.000.000,00, a ser gerida pelos autores, com o auxílio da Caixa Econômica Federal (CEF).

Para destinação do valor da indenização, foram estabelecidas quatro modalidades: (i) R \$ 25 milhões seriam destinados ao Instituto Chico Mendes de Conservação da Biodiversidade (ICMBio), para investimentos na preservação de áreas de mangue; (ii) a Secretaria Nacional de Políticas sobre Drogas (Senad) ficaria com R\$ 5 milhões para promover atividades de enfrentamento ao uso de drogas nos municípios abrangidos pela Subseção Judiciária de Paranaguá; (iii) o governo do Paraná ficaria com R\$ 30 milhões para minimizar os problemas decorrentes das enchentes ocorridas em março do ano passado em municípios litorâneos; (iv) os outros R\$ 30 milhões, e ainda o eventual remanescente das destinações anteriores, seriam utilizados em projetos ambientais e socioambientais a serem apresentados por entidades interessadas nos autos.

Em 11 de junho de 2012, a ré, Petrobras, depositou judicialmente o valor da indenização de R\$ 90 milhões, que foi devidamente distribuído pela Caixa Econômica Federal em quatro contas distintas para cada modalidade de destinação dos recursos.

Foram autuadas quatro ações de cumprimento de sentença, cada qual vinculada a uma modalidade de destinação. Sucederam-se, então, várias manifestações direcionadas ao juízo, questionando o modo como seria executado o termo de acordo. Fato que levou o magistrado a avocar os autos, com o fim de organizar e garantir a plena execução dos recursos depositados. 
Na decisão, proferida em 17 de setembro de 2012, ficou decidido, resumidamente, que: (i) os interessados teriam 180 dias, contados da intimação da decisão ou da publicação do edital - conforme a modalidade de execução - para apresentar seus projetos diretamente ao Ministério Público Federal, para análise prévia acerca da sua exequibilidade; (ii) o MPF encaminharia os projetos para homologação judicial, se previamente aprovados; (iii) após a homologação judicial, o Ministério Público ou o próprio interessado poderia solicitar, mediante petição nos autos, a destinação dos recursos; (iv) o juízo determinaria à CEF que providenciasse o repasse da verba referente ao projeto em questão; (v) o Ministério Público, no âmbito Federal e Estadual, ficaria encarregado, com o auxílio da CEF, da fiscalização quanto ao andamento dos projetos, até a sua conclusão.

Desde então, o cumprimento de acordo vem sendo administrado, sobretudo, pelo juízo federal e pelo Ministério Público Federal, nos termos postos acima.

A Procuradoria da República no Estado do Paraná, por meio da Portaria n 22 de 08/05/2013, converteu o Procedimento Administrativo $\mathrm{n}^{\circ}$ 1.25.007.000192/2012-10 em Inquérito Civil Público, visando acompanhar a execução do termo de acordo judicial Petrobras S/A - ACP n 2002.70.08.000260-1 na modalidade III - "Projetos Socioambientais e Ambientais no Litoral Paranaense", E-PROC n 5001337-92.2012.404.7008, fundamentado no art. 129, VI, da Constituição da República c/c art. $6^{\circ}$, VII e $7^{\circ}$, I da Lei Complementar Federal $n^{\circ} 75 / 1993$ e art. $8^{\circ}, \S^{\circ}$ da Lei ${ }^{\circ} 7.437 / 1985$, bem como de acordo com o art. $2^{\circ}$, I da Resolução $n^{\circ}$ 23/2007, do Conselho Nacional do Ministério Público, art. 2 ${ }^{\circ}$ I da Resolução nº 87/2006 e art. $4^{\circ}, \S 4^{\circ}$ da mencionada Resolução (redação dada pela Resolução ${ }^{\circ} 106 / 2010$ ), do Conselho Superior do Ministério Público Federal.

\subsubsection{Apelação Cível $n^{0}$ 5002394-14.2013.4.04.7008/PR - Justiça Federal}

Cuida-se de Apelação Cível em ação anulatória de ato judicial, proposta pelo Ministério Público Federal contra Petrobras, Estado do Paraná, Instituto Ambiental do Paraná, Caixa Econômica Federal, Ministério Público do Estado do Paraná e Instituto Chico Mendes de Conservação da Biodiversidade (ICMBio), pleiteando a obtenção de provimento judicial que declare a nulidade do acordo homologado por sentença - lançada nos autos das ações civis públicas $n^{\circ}$ 2002.70.08.000261-1 e nº 0000041-91.2010.404.7008 - que extinguiu os feitos. A Petrobras também ajuizou apelação requerendo condenação do MPF em honorários sucumbenciais na Ação Civil Pública 
O TRF da $4^{\mathrm{a}}$ Região, sob a relatoria da desembargadora federal Salise Monteiro Sanchotene, em 25 de fevereiro de 2016, negou provimento às apelações, decidindo o seguinte: (i) ser correta a eleição da ação anulatória para veicular pretensão de anulação de sentença que homologou acordo envolvendo a Petrobras, a CEF, o Estado do Paraná, o Instituto Ambiental do Paraná, o Ministério Público do Estado do Paraná e o ICMBio; (ii) porém, reconheceu a impossibilidade jurídica do pedido de anulação do acordo homologado judicialmente, uma vez inexistente vício de consentimento, situação teratológica, ou alguma das hipóteses do art. 849 do Código Civil de 2002 (dolo, coação, erro essencial quanto à pessoa ou coisa controversa); (iii) quanto ao pleito formulado pela Petrobras, ser incabível a condenação do Ministério Público Federal em honorários em Ação Civil Pública, conforme precedentes do STJ e do próprio TRF da $4^{\mathrm{a}}$ Região.

Destaca-se, em especial, um trecho do julgado em que o Tribunal ponderou que, embora os acordos que visam tutelar o interesse coletivo devam, a princípio, apenas disciplinar a forma de cumprimento de obrigações que são pré-estipuladas na legislação, admite-se, na prática, uma dose de criatividade institucional para formular soluções que, embora não estejam previstas na lei, melhor atendam ao interesse protegido:

É claro que a doutrina majoritária se inclina por dizer que a disponibilidade admitida em acordos celebrados sobre direitos coletivos se limita ao estabelecimento da forma e do tempo para o cumprimento de imposições previamente estipuladas em lei, sem que se autorize dispor sobre a 'parte substantiva' da obrigação existente (v.g., MANCUSO, Rodolfo de Camargo. Ob. cit., p. 331; ALMEIDA, João Batista de. Aspectos controvertidos da ação civil pública. São Paulo: RT, 2001, p. 118; GOMES JR., Luiz Manoel. Curso de direito processual civil coletivo. $2^{\mathrm{a}}$ ed., São Paulo: SRS, 2008, p. 273).

Entretanto, não se pode negar que autorizar a disposição sobre o tempo e a forma do cumprimento da obrigação pode, em muitos casos, implicar sensível alteração no conteúdo do direito, o que refletirá, em grande medida, verdadeira disposição sobre o direito. Em síntese, portanto, o acordo celebrado em processos coletivos é um verdadeiro acordo, ainda que não autorize a disposição sobre a essência do direito protegido (assim, de certo modo, MAZZILLI, Hugo Nigro. A defesa dos interesses difusos em juízo. 12ª ed., São Paulo: Saraiva, 2001).

Aliás, nessa linha, prevê o art. 21, § $1^{\circ}$, da Resolução n. 87/2010, do Conselho Superior do Ministério Público Federal, que o celebrante do acordo deverá motivar a adequação das obrigações, dos prazos e das condições estabelecidas ao objeto da proteção coletiva. À vista desse comando, conclui-se que: a) é possível a fixação de obrigações, prazos e condições não previstas expressamente em lei para a tutela do bem protegido pelo Ministério Público Federal; e b) a legitimação dessas condições estará na dependência de sua relação com a boa tutela do bem jurídico protegido.

Assim, parece certo concluir que, em linhas gerais, o acordo celebrado em tutela coletiva também se sujeita aos mesmos parâmetros fixados pelo direito privado, ao menos em relação aos limites postos para sua invalidação.

Em outro trecho muito interessante, o Tribunal fez uma crítica à destinação do produto arrecadado a título de indenização por danos ambientais a Fundos de Direitos Difusos, 
reconhecendo a incapacidade destes fundos de utilizar os recursos para efetiva proteção ambiental. Na presente tese, a ineficiência dos Fundos de Direitos Difusos voltará a ser discutida no capítulo 9. Nesse sentido, o Tribunal manifestou-se no sentido da possibilidade de se adotar soluções alternativas e destinações específicas diferentes da destinação a fundos:

Não parece nem que seja inviável a destinação do produto arrecadado a fimm diverso daquele previsto no art. 13, da Lei n. 7.347/85, nem que a atuação do Judiciário e do Ministério Público Federal no acordo em tela desvirtue de suas finalidades.

3.3.1. Em relação à destinação do produto arrecadado na ação coletiva para outros fins, que não o Fundo de Direitos Difusos, observo que a medida é prática corrente, e tem sido recomendada pela doutrina nacional.

A doutrina brasileira tem constantemente apontado a imprestabilidade do Fundo de Direitos Difusos para a eficiente tutela dos direitos coletivos e individuais de massa. De fato, afirma Ronaldo Porto Macedo Junior: "infelizmente os chamados Fundos Especiais de Despesa de Reparação de Interesses Difusos Lesados (FEDRIDL), a despeito do considerável volume de recursos que já contabilizam, em particular no Estado de São Paulo, ainda não têm gerado os efeitos que deles se esperou no momento em que foram concebidos e constituídos. (...) Em São Paulo, onde o fundo estadual foi constituído em 1989, até hoje nem um centavo sequer deste fundo foi utilizado. É possível vislumbrar diversas razões para que tal tenha ocorrido. Certamente a mais importante parece ser a própria estrutura do órgão gestor do mencionado fundo, que não permitiu no passado a agilização das decisões, bem como a determinação de critérios para a identificação de prioridades entre os diversos interesses difusos protegidos. (...) Ademais, jamais foram tomadas as medidas necessárias no sentido da identificação da origem dos bens lesados de modo a garantir a sua aplicação prioritária na reparação dos bens ocorridos que deram origem aos recursos, critério, aliás, seguido tanto pela lei estadual em vigor como pela lei federal e também por deliberação do próprio Conselho Gestor do FDD" ('Propostas para a reformulação da lei que criou o fundo de reparação de interesses difusos lesados', Ação civil pública. Coord. Édis Milaré. São Paulo. RT 2001, p. 753).

Em sede doutrinária (ARENHART, Sérgio Cruz. 'A tutela de direitos individuais homogêneos e as demandas ressarcitórias em pecúnia'. Direito processual coletivo e o anteprojeto de código brasileiro de processos coletivos. São Paulo: RT, 2007), manifestei-me nesse mesmo sentido, ponderando que o Fundo de Direitos Difusos não destina - e nem tem condições de fazê-lo - os recursos obtidos na proteção dos direitos difusos, coletivos e individuais homogêneos, o que descaracteriza sua finalidade e, consequentemente, desaconselha a observância do art. 13, da Lei da Ação Civil Pública.

Na prática, diversas ações coletivas são resolvidas com a aplicação dessa técnica, destinando-se os recursos obtidos a fins outros, que não o Fundo de Direitos Difusos, exatamente tendo em conta que raramente os recursos lá depositados revertem para a proteção ou para a reconstituição dos bens lesados. Assim, vários acordos firmados com a ALL, pelo Ministério Público Federal, destinam recursos a municípios para a reconstituição de estações ferroviárias abandonadas; muitos outros acordos preferem estabelecer prestações de fazer, exatamente para evitar que recursos obtidos tenham de ser destinados ao Fundo de Direitos Difusos; no campo trabalhista, a jurisprudência tem chancelado a remessa de valores obtidos para o Fundo de Amparo ao Trabalhador (v.g., TST, 4 ${ }^{\text {a }}$ Turma. AIRR 63600-97.2009.5.05.0039. Rel. Min. Maria de Assis Calsing. DEJT 04.04.14).

Não há, por isso, qualquer ilegalidade na destinação prevista pelo acordo em tela, quanto aos valores arrecadados.

Em mais uma passagem digna de nota, o Tribunal consignou que o Poder Judiciário e as partes, inclusive o Ministério Público, diante de demandas complexas, especialmente aquelas 
que envolvem direitos difusos ou coletivos, devem exercer um papel mais criativo, procurando intervir em estruturas existentes para a melhor proteção do interesse em jogo:

De fato, o Brasil hoje começa a admitir as chamadas decisões estruturais, que consubstanciam técnicas processuais concebidas para a resposta jurisdicional diante de casos complexos, como é, obviamente, o presente. Nessas figuras, os sujeitos processuais, e especialmente o magistrado, passam a atuar quase em função política. O juiz, para a consecução dos objetivos da proteção coletiva, cria novas estruturas, intervém em políticas públicas e assume para si o papel de melhor tutelar o bem jurídico em debate.

Como escrevi, no âmbito doutrinário:

'Talvez um dos mais importantes instrumentos nessa direção sejam as chamadas structural injunctions, concebidas pela doutrina norte americana.

Percebeu-se que muitas decisões sobre questões coletivas exigem soluções que vão além de decisões simples a respeito de relações lineares entre as partes. Exigem respostas difusas, com várias imposições ou medidas que se imponham gradativamente. São decisões que se orientam para uma perspectiva futura, tendo em conta a mais perfeita resolução da controvérsia como um todo, evitando que a decisão judicial se converta em problema maior do que o litígio que foi examinado.

As questões típicas de litígios estruturais envolvem valores amplos da sociedade, no sentido não apenas de que há vários interesses concorrentes em jogo, mas também de que a esfera jurídica de vários terceiros pode (sic) ser afetados pela decisão judicial.' (ARENHART, Sérgio Cruz 'Decisões estruturais no direito processual civil brasileiro'. Revista de processo. São Paulo: RT, nov-2013. n. 225, p. 389 e ss.)

De fato, não há dúvida de que a tutela coletiva exige outra postura dos protagonistas judiciais, em contraste do que ocorre no campo individual. A transcendência do direito protegido e o interesse público que está em sua base impõem outra situação do magistrado e dos autores da demanda coletiva. E o processo também reclama nova feição, apta a lidar com essas peculiaridades.

Por isso é fundamental a participação mais presente do Judiciário e avulta o papel 'criativo' das partes e do magistrado.

O acórdão transitou em julgado em 07 de abriu de 2016 e foi arquivado na mesma data.

\subsubsection{Apelações Cíveis}

Em decorrência do acidente, algumas ações de indenização foram ajuizadas por pescadores profissionais contra a Petrobras, cujas decisões contribuíram para a formação da jurisprudência do TJPR no seguinte sentido: ${ }^{85}$ ( i) aplicando a teoria do risco integral à responsabilidade civil objetiva por dano ambiental, na qual são irrelevantes o fato de terceiro, a culpa concorrente da vítima, o caso fortuito, ou de força maior. Basta que o dano tenha

${ }^{85}$ TJPR. Apelação Cível: AC nº 0006035-20.2004.8.16.0129. Rel. Luiz Lopes. 10ª Câmara Cível. Julgado em 22/11/2018.

TJPR. Apelação Cível: AC nº 689.918-9. Rel. D’Artagnan Serpa Sá. 9a Câmara Cível. Julgado em 18/11/2010. TJPR. Apelação Cível: AC nº 0010767-10.2005.8.16.0129. Rel. Coimbra de Moura. $9^{\mathrm{a}}$ Câmara Cível. Julgado em 23/08/2018.

TJPR. Apelação Cível: AC nº 0011003-98.2001.8.16.0129. Rel. Vicente Del Prete Misurelli. $8^{a}$ Câmara Cível. Julgado em 21/07/2018. 
decorrido de atividade potencialmente degradadora, conforme entendimento fixado no julgamento de recursos repetitivos no STJ (Recurso Especial n ${ }^{\circ}$ 1.114.398/PR); (ii) reconhecendo que, uma vez comprovada a atividade pesqueira pelo autor da ação indenizatória, e sua interrupção pelos órgãos ambientais, é inquestionável a existência de danos morais; (iii) entendendo que o quantum indenizatório deve levar em conta os seguintes fatores: (a) amenizar sofrimento da vítima; (b) extensão do sofrimento; (c) capacidade econômica das partes; (d) efeito dissuasório no ofensor; (e) não pode acarretar enriquecimento ilícito dos afetados; (iv) firmando o entendimento de que juros moratórios incidem a partir da data do evento danoso, conforme Súmula 54 do STJ e entendimento fixado no julgamento de recursos repetitivos no STJ (Recurso Especial n $\left.{ }^{\circ} 1.114 .398 / \mathrm{PR}\right)$.

O TJPR possui inúmeros julgados que reproduzem os argumentos acima expostos, mas contando com algumas peculiaridades. Um primeiro leque de julgados com peculiaridades consiste naqueles em que o Tribunal (i) reconheceu lucros cessantes, fixando indenização no valor de um salário mínimo vigente à época dos fatos pelo período de 24 meses; (ii) entendeu que correção monetária deve incidir a partir da data do arbitramento. ${ }^{86}$

Em outros casos, constam as seguintes peculiaridades: ${ }^{87}$ (i) decidiu-se que prova oral produzida nos autos é suficiente para comprovar a qualidade de pescador artesanal à época dos fatos, em conjunto com carteira de pescador profissional; além de que (ii) é indevida a indenização a título de lucros cessantes pelo período superior a seis meses, se nada há nos autos que comprove a alegada redução da produtividade da atividade pesqueira, bem como a retração do mercado consumidor de pescado, neste período.

Em outro julgado, o TJPR entendeu que a ação de indenização deveria ser julgada no local da ocorrência dos danos, ainda que a causa material (prejuízoz no desenvolvimento da atividade pesqueira) tenha ocorrido em lugar diverso, nos termos da alínea "a", inciso V, do art. 100 do CPC. ${ }^{88}$

\footnotetext{
${ }^{86}$ TJPR. Apelação Cível: AC nº 714.534-4. Rel. D’Artagnan Serpa Sá. $9^{a}$ Câmara Cível. Julgado em 18/11/2010. TJPR. Apelação Cível: AC no 943.169-6. Rel. D’Artagnan Serpa Sá. $9^{a}$ Câmara Cível. Julgado em 23/08/2012.

${ }^{87}$ TJPR. Apelação Cível: AC nº 0005698-94.2005.8.16.0129. Rel. Albino Jacomel Guérios. $9^{a}$ Câmara Cível. Julgado em 05/07/2018.

TJPR. Apelação Cível: AC nº 0010185-10.2005.8.16.0129. Rel. Luis Sérgio Swiech. $8^{a}$ Câmara Cível. Julgado em 22/11/2018.

TJPR. Apelação Cível: AC nº 14096-64.2004.8.16.0129. Rel. Alexandre Barbosa Fabiani. Julgado em 12/07/2018. TJPR. Apelação Cível: AC no 1048863.2001.8.16.0129. Rel. Luiz Lopes. $10^{\mathrm{a}}$ Câmara Cível. Julgado em 12/07/2018.

${ }^{88}$ TJPR. Apelação Cível: AC nº 446.118-1. Rel. Sergio Luiz Pantitucci. 9a Câmara Cível. Julgado em 12/05/2018.
} 
O TJPR anulou as sentenças que julgaram a lide de forma antecipada sem que houvesse produção probatória na comprovação da condição de pescador pelos autores. De acordo com estes julgados, o exercício da atividade profissional não é presumido. Depende de efetiva instrução probatória e poderia ser comprovado de diversas formas no processo, como (a) pela juntada da carteira de pescador válida à época do sinistro; (b) pela indicação de ter recebido ajuda de custo; (c) pelo fato de constar seu nome na lista de Defeso do DRT, assim como nos registros do Tribunal Regional Eleitoral; (d) pelo fato de constar o nome dos autores como residentes na Colônia de Pescadores, conforme lista elaborada pelas assistentes sociais da Petrobras; (e) pela produção de prova testemunhal. Ademais, nos casos analisados, a carteira de Pescador Profissional teria sido emitida em 10 de novembro de 2003, após o sinistro, ocorrido em data de 16 de fevereiro de $2001 .^{89}$

No sentido contrário, em outros casos, o TJPR anulou as sentenças por entender que cercearam a defesa dos autores nas ações indenizatórias, por não lhe darem a oportunidade de produzir provas referentes a sua condição de pescador, uma vez que tanto os pescadores quanto suas testemunhas não foram regularmente intimados para comparecer à audiência. ${ }^{90}$

\subsubsection{Ações rescisórias}

O TJPR julgou procedente duas ações rescisórias interpostas em face de acórdãos que julgaram parcialmente procedente a ação de indenização por danos morais e materiais, mas que determinaram a incidência de juros de mora sobre a indenização por danos morais a partir da data de fixação do quantum indenizatório. O TJPR reformou tais acórdãos para determinar que os juros moratórios em caso de indenização por danos morais devem incidir a partir do evento danoso, nos termos da Súmula 54 do STJ e conforme tese consolidada no julgamento do Recurso Representativo da Controvérsia ${ }^{\circ} 1.114 .398 / \mathrm{PR}^{9}{ }^{91}$

\footnotetext{
${ }^{89}$ TJPR. Apelação Cível: AC nº 713.463-6. Rel. Arquelau Araújo Ribas. 1ª Vara Cível da Comarca de Paranaguá. Julgado em 22/02/2011.

TJPR. Apelação Cível: AC nº 780.440-2. Rel. Arquelau Araújo Ribas. 1ª Vara Cível da Comarca de Paranaguá. Julgado em 22/02/2011.

TJPR. Apelação Cível: AC nº 877.639-6. Rel. Arquelau Araújo Ribas. 1ª Vara Cível da Comarca de Paranaguá. Julgado em 14/07/2012.

${ }^{90}$ TJPR. Apelação Cível: AC nº 0008838-39.2005.8.16.0129. Rel. Ângela Khury. $10^{\text {a }}$ Câmara Cível. Julgado em 26/07/2018.

${ }^{91}$ TJPR. Ação Rescisória: AR nº 5000455-97.2016.8.16.0000. Rel. Francisco Luiz Macedo Junior. $9^{\text {a }}$ Câmara Cível. Julgado em 17/11/2016.

TJPR. Ação Rescisória: AR nº 5001164-35.2016.8.16.0000. Rel. Francisco Luiz Macedo Junior. 9ª Câmara Cível. Julgado em 17/11/2016.
} 
Constam ainda diversos julgamentos rejeitando embargos de declaração opostos contra acórdãos de ações rescisórias que chancelaram o acórdão rescindendo que julgou procedente o pedido de indenização por danos morais e/ou materiais, determinando apenas que os juros moratórios incidissem a partir da data do evento danoso. ${ }^{92}$

\subsection{Recurso Especial $n^{0} 1.346 .430$ - Paraná}

Este Recurso Especial tem sua origem em ação indenizatória formulada por pescador artesanal. Portanto, antes de analisar seu mérito, cabe aqui um breve resumo da trajetória processual. Odair José do Nascimento ajuizou ação de indenização em face da Petrobras, alegando ser pescador artesanal, prejudicado pelo vazamento do poliduto Olapa. Na peça inicial, afirma que a requerida reconheceu que houve vazamento de 48.500 litros de óleo e que, por decorrência de chuvas torrenciais, ocorreu rompimento das barreiras de contenção instaladas pela demandada, tomando o acidente graves proporções. Destaca ainda que o vazamento de óleo resultou na mortandade da fauna aquática e na imediata proibição, imposta pelo Instituto Ambiental do Paraná e IBAMA, à pesca nos rios e baías de Antonina e Paranaguá, perdurando a proibição por mais de seis meses. Sustenta ter sofrido danos de ordem moral e material, pois seu sustento advinha da pesca, tendo também ocorrido queda na produção, relativa à atividade extrativa, assim como retração do mercado consumidor.

O Juízo da Vara Cível da Comarca de Antonina, Paraná, julgou parcialmente procedentes os pedidos formulados na inicial, mas o Tribunal de Justiça do Paraná deu

\footnotetext{
92 TJPR. Embargos de Declaração: EDcl nº 5001470-67.2017.8.16.0000. Rel. Coimbra de Moura. 9ª Câmara Cível. Julgado em 10/08/2017.

TJPR. Embargos de Declaração: EDcl nº 5001469-82.2017.8.16.0000. Rel. Coimbra de Moura. 9ª Câmara Cível. Julgado em 10/08/2017.

TJPR. Embargos de Declaração: EDcl n 5001468-97.2017.8.16.0000. Rel. Coimbra de Moura. 9ª Câmara Cível. Julgado em 10/08/2017.

TJPR. Embargos de Declaração: EDcl nº 5001465-45.2017.8.16.0000. Rel. Coimbra de Moura. 9ª Câmara Cível. Julgado em 10/08/2017.

TJPR. Embargos de Declaração: EDcl nº 5001464-60.2017.8.16.0000. Rel. Coimbra de Moura. 9ª Câmara Cível. Julgado em 10/08/2017.

TJPR. Embargos de Declaração: EDcl nº 5001463-75.2017.8.16.0000. Rel. Coimbra de Moura. 9ª Câmara Cível. Julgado em 10/08/2017.

TJPR. Embargos de Declaração: EDcl nº 5000865-24.2017.8.16.0000. Rel. Coimbra de Moura. 9ª Câmara Cível. Julgado em 10/08/2017.

TJPR. Embargos de Declaração: EDcl nº 5000743-11.2017.8.16.0000. Rel. Coimbra de Moura. 9ª Câmara Cível. Julgado em 10/08/2017.

TJPR. Embargos de Declaração: EDcl n 5000742-26.2017.8.16.0000. Rel. Coimbra de Moura. 9ª Câmara Cível. Julgado em 10/08/2017.

TJPR. Embargos de Declaração: EDcl nº 5000605-44.2017.8.16.0000. Rel. Coimbra de Moura. 9ª Câmara Cível. Julgado em 10/08/2017.
} 
provimento ao recurso da ré para anular a sentença, reconhecendo cerceamento de defesa. Foi prolatada nova sentença julgando parcialmente procedentes os pedidos formulados na exordial para condenar a ré ao pagamento de: a) $\mathrm{R} \$ 3.624,00$, a título de lucros cessantes, estabelecendo que dessa verba deverá ser abatido todos os valores eventualmente recebidos pelo autor, tendo em vista acordo anteriormente firmado pelas partes; b) $\mathrm{R} \$ 16.000,00$, a título de danos morais; c) custas processuais e honorários advocatícios, no percentual de $15 \%$ sobre o valor da condenação.

Interpôs a Petrobras apelação para o Tribunal de Justiça do Paraná, que deu parcial provimento ao recurso para: a) determinar que a condenação por danos materiais fique limitada ao período de proibição da pesca, no valor de um salário mínimo, em vigor no período de restrição da pesca; b) abater do quantum indenizatório o defeso, caso recebido pelo pescador; c) redistribuir as verbas sucumbenciais entre as partes, na razão de $1 / 3$ para o autor e 2/3 para a ré.

Inconformados com a decisão colegiada, interpuseram as partes recursos especiais, ambos com fundamento no artigo 105, inciso III, alíneas "a" e "c", da Constituição Federal, não tendo sido admitido o recurso da ré, Petrobras, e determinado o sobrestamento do recurso interposto pelo autor, tendo em vista a decisão do Ministro Sidnei Beneti no REsp $\mathrm{n}^{\circ}$ 1.114.398/PR, determinando a suspensão dos feitos em que se discuta questão relativa ao termo inicial dos juros moratórios para reparação a título de danos morais.

O Recurso Especial n 95.453/PR, manejado pela Petrobras, foi convertido no Recurso Especial $n^{\circ}$ 1.346.430/PR. A Petrobras apresentou petição colacionando documentos aos autos, informando que outros 3.000 pescadores já haviam receberam suas verbas indenizatórias, não cabendo ao STJ a revisão do quantum indenizatório, sob pena de se transformar em terceira instância.

Pois bem. O STJ não deu provimento ao Recurso Especial n ${ }^{\circ} 1.346 .430 / \mathrm{PR}$, ora analisado, decidindo o seguinte: (i) no caso, configurou-se a responsabilidade objetiva da Petrobras, convicção formada pelas instâncias ordinárias com base no acervo fático-documental constante dos autos, que foram analisados à luz do disposto no art. $225, \S 3^{\circ}$, da Constituição Federal de 1988 e no art. 14, § 1º da Lei n. 6.938/1981; (ii) a Segunda Seção do STJ, no julgamento do REsp n 1.114.398/PR, da relatoria do Ministro Sidnei Beneti, sob o rito do art. 543-C do CPC, reconheceu a responsabilidade objetiva da Petrobras em acidentes semelhantes e caracterizadores de dano ambiental, responsabilizando-se o degradador em decorrência do princípio do poluidor-pagador, não cabendo, demonstrado o nexo de causalidade, a aplicação 
de excludente de responsabilidade; (iii) decidiu-se ainda que configura dano moral a privação das condições de trabalho em consequência de dano ambiental, fato que é, por si só, incontroverso quanto ao "prolongado ócio indesejado imposto pelo acidente, sofrimento, à angústia e à aflição gerados ao pescador, que se viu impossibilitado de pescar e imerso em incerteza quanto à viabilidade futura de sua atividade profissional e manutenção própria e de sua família". 93

\subsubsection{Transpetro}

Este caso se refere ao vazamento de aproximadamente 876 litros resíduo oleoso durante operação de lastreamento de uma embarcação atracada no Terminal Aquaviário de Angra dos Reis (TAAR-TEBIG), localizado no município de Angra dos Reis, no litoral sul do estado do Rio de Janeiro, no dia 16 de março de $2015 .{ }^{94} \mathrm{O}$ acidente ambiental teve como causa a operação de transferência de petróleo entre duas embarcações: navio Gothenburg e navio Buena Suerte. Houve a formação manchas de óleo nas baías de Ilha Grande e Sepetiba, bem como óleo também atingiu ilhas, praias, áreas ambientalmente protegidas, costões rochosos, além da fauna aquática da região. ${ }^{95}$

\subsubsection{Medida Cautelar Inominada $n^{0}$ 0203627-98.2015.8.19.0001}

Trata-se de Medida Cautelar Inominada ajuizada pela Petrobras Transporte S.A. (Transpetro) em face do INEA/RJ em 25 de maio de 2015, em trâmite na $7^{\text {a }}$ Vara da Fazenda Pública do Tribunal de Justiça do Rio de Janeiro, em que se pediu, liminarmente, a suspensão dos efeitos jurídicos da deliberação do Conselho Diretor do INEA (CONDIR), proferida em 06 de abriu de 2015, em sua 282 ${ }^{a}$ Reunião, de (i) cancelar a Licença de Operação (LO) IN 028947 de 2014 da Transpetro, referente à atividade de transbordo de óleo em mar entre navios (Ship to Ship), (ii) bem como proibir a atividade de transbordo de cargas entre navios no terminal denominado TEBIG.

\footnotetext{
93 STJ. Recurso Especial: REsp n 1346430/PR. Rel. Ministro Luis Felipe Salomão. Quarta Turma. DJe: 21/11/2012.

94 RIO DE JANEIRO (Estado). Instituto Estadual do Meio Ambiente (INEA). Termo de Compromisso de Ajustamento de Conduta (TAC) $n^{\circ}$ 02/2016 entre INEA e Petrobras Transporte S/A, assinado em 08 de abril de 2016. $<$ http://www.inea.rj.gov.br/cs/groups/public/documents/document/zwew/mtcx/ edisp/inea0171374.pdf $>$. Acesso em: 16.12.2018.

${ }^{95}$ INEA. Instituto Estadual do Ambiente, Relatório de Atendimento de emergências nº 300014/2015. 2015.
} 
O processo foi extinto com resolução de mérito em razão da celebração do TAC INEA $n^{\circ}$ 02/2016, celebrado entre INEA/RJ e Transpetro, e arquivado em definitivo em 10 de maio de 2017.

\subsubsection{TAC INEA $n^{0}$ 02/16, celebrado entre INEA/RJ e Petrobras Transporte S/A (Transpetro)}

Trata-se de TAC celebrado entre INEA/RJ e Transpetro no âmbito da Medida Cautelar Inominada $\mathrm{n}^{\circ}$ 0203627-98.2015.8.19.0001, em 08 de abriu de 2016, em razão do vazamento de resíduo oleoso ocorrido durante operação de lastreamento de embarcação atracada no Terminal Aquaviário de Angra dos Reis (TAAR-TEBIG), Município de Angra dos Reis/RJ, em 16 de março de 2015 .

O TAC tem como objeto estabelecer os prazos e condições para que a Transpetro promova, fiel e integralmente, as necessárias adequações de suas atividades em suas instalações mediante a execução de Plano de Melhorias para a Segurança Ambiental das Atividades do TEBIG, constante do anexo I do TAC, bem como determinar a execução de serviços de interesse socioambiental, na forma dos projetos do Anexo II do TAC (Cláusula 1.1).

Os projetos de interesse socioambientais deveriam ser apresentados ao INEA no prazo de 90 dias da assinatura do TAC (Cláusula 1.2). Após sua apresentação, a Transpetro teria o prazo de até 60 dias para elaborar Plano de Trabalho dos projetos que deveria conter cronogramas físicos de implementação (Cláusula 1.3). Findo este prazo, a Transpetro teria até 120 dias para iniciar a execução dos respectivos Planos de Trabalho.

Estipulou-se que o prazo de vigência do TAC seria de três anos, contados da data de sua assinatura, prorrogado por mais um ano, na forma do art. 101, $\S 1^{\circ}$ da Lei 3.467/2000.

A Cláusula 3.2, por sua vez, previu que a suspensão da exigibilidade de pagamento da multa administrativa, no valor de $\mathrm{R} \$ 36.488 .026,74$, aplicada através do Auto de Infração $\mathrm{n}^{\circ}$ COGEFISEAI/00143165, lavrado nos autos do Processo Administrativo $\mathrm{n}^{\circ}$ E-07/0023768/2015, permaneceria durante a vigência TAC, sendo extinta no cumprimento integral das obrigações assumidas pela Transpetro.

Firmou-se ainda que o montante de R \$ 22.616.026,74 seria revertido em Serviços de Interesse Socioambiental para área de influência do TEBIG (Cláusula 3.3).

A Transpetro se obrigou, por meio do TAC, a (Cláusula 4 e seus subitens): (i) implementar "Plano de Melhorias para a Segurança Ambiental das Atividades do TEBIG", 
indicado no Anexo I; (ii) executar projetos de interesse socioambiental a serem apresentados pelo INEA/RJ, de acordo com os prazos fixados no TAC; (iii) realizar, direta ou indiretamente, auditorias para demonstrar a evolução das ações previstas nos Anexos I e II, suportando o ônus e custos daí advindos e encaminhando relatórios trimestrais para o INEA/RJ; (iv) não realizar a operação Ship to Ship nas áreas localizadas no interior das águas da Baía da Ilha Grande e da Baía de Sepetiba; (v) comunicar ao INEA/RJ quaisquer alterações em seus dados, especialmente em seu endereço e em sua situação societária; (vi) renunciar a qualquer direito e ação relacionado ao Auto de Infração $n^{\circ}$ COGEFISEAI/00143165 emitido pelo INEA/RJ e à correspondente multa fixada, bem como desistir da ação cautelar $\mathrm{n}^{\circ}$ 020362795.3.8.2015.8.19.0001, em trâmite perante a $7^{\mathrm{a}}$ Vara da Fazenda Pública do Tribunal de Justiça do Rio de Janeiro, sem ônus sucumbenciais.

O "Plano de Melhorias para a Segurança Ambiental das Atividades do TEBIG", indicado no Anexo I, estipula as medidas necessárias ao atendimento de exigências impostas pelo INEA/RJ a fim de prevenir nova degradação ambiental. Ele prevê as seguintes medidas: (i) aquisição/instalação, manutenção de sistema de monitoramento para detecção de vazamentos de óleo (hidrocarbonetos) e geração de imagens em tempo real, $24 \mathrm{~h}$ do dia, sete dias na semana, através de geração de imagens da área de seu terminal aquaviário de armazenamento e transferência de hidrocarbonetos (Baía de Ilha Grande) e seu entorno. Prazo: 18 meses; (ii) aquisição e instalação de sistema de alerta, monitoramento de boias flutuantes de detecção de presença de hidrocarbonetos no espelho d'água, em áreas estratégicas (abaixo de seus píeres, por exemplo) do entorno de seus píeres de atracação de carregamento, descarregamento, movimentação, armazenagem de hidrocarbonetos com envio de alarme (sinal de rádio) a sala de controle do terminal. Prazo: 18 meses; (iii) permanência de cerco com barreiras de contenção no mar, pelo tempo em que perdurar a operação de transferência. Tal sistema poderá ser fixo (através de poitas providas de boias, dispostas e localizadas em local seguro que não interfira ou atrapalhe com a área de evolução do terminal) ou móvel através de parelhas de embarcações, formando grampo de contenção posicionado a proa ou popa das embarcações, de acordo com a direção de circulação de correntes de água local. Prazo: 12 meses; (iv) apresentação e qualificação da equipe da Petrobras, bem como de seu vínculo empregatício com a mesma, e extensão da capacitação ao corpo técnico do INEA, por instituição universitária de notório saber, para que, após, seja avaliada deliberação sobre a exigência de contratação de instituição universitária de notório saber. Prazo: 8 meses; (v) Atendimento das condicionantes contidas nas licenças tanto do INEA/RJ. 
Por outro lado, este TAC prevê também obrigações para o INEA/RJ, quais sejam (Cláusula 5 e seus subitens): (i) permitir o regular funcionamento do TEBIG, de suas unidades e sistemas com as operações de carregamento, descarregamento, abastecimento e transbordo dentro do terminal, mediante emissão de Autorização Ambiental de Funcionamento (AAF), que terá o prazo de validade de 18 meses; (ii) uma vez concluído e atendido plenamente o "Plano de Melhorias para a Segurança Ambiental das Atividades do TEBIG”, a licença ambiental correspondente ao processo de licenciamento $n^{\circ}$ e-07/002.5410/2014, em curso, será concedida, desde que atendidos os requisitos legais para sua concessão; (iii) tal licença deverá estipular como condição de validade o cumprimento integral do TAC, especificamente a obrigação da Transpetro em realizar os Projetos Socioambientais; (iv) suspender o procedimento administrativo de cobrança da multa administrativa até o integral cumprimento das obrigações assumidas pela Transpetro; (v) o INEA/RJ se exime de quaisquer ônus, direitos e obrigações relativos à legislação tributária, previdenciária, trabalhista ou securitária, bem como compromissos, indenizações ou danos da Transpetro e seus empregados, dirigentes prepostos e subordinados em face de terceiros.

Quanto à fiscalização, restou estabelecido que as obrigações previstas no TAC não limitam, impedem ou suspendem a fiscalização ampla, irrestrita e permanente do INEA e demais órgãos competentes na Transpetro (Cláusula 6.10).

O TAC prevê ainda que o valor total do investimento é de $\mathrm{R} \$ 36.488 .026,74$, de modo que R\$13.872.000,00 são referentes ao "Plano de Melhorias para a Segurança Ambiental das Atividades do TEBIG” e R $\$ 22.616 .026,74$ são referentes aos Projetos de interesse socioambiental (Cláusula 7.1). Este valor não contempla eventuais danos causados à terceiros em razão do incidente que deu razão ao TAC (Cláusula 7.2).

No caso de rescisão, o INEA/RJ deverá cancelar a Licença Ambiental, conforme o caso (Cláusula 8.2). Ademais, a ocorrência de caso fortuito ou força maior não exime de responsabilidade a Transpetro, tendo em vista que sua responsabilidade "é de risco integral e objetiva" (Cláusula 8.3). Caso ocorra alguma impossibilidade ou inexequibilidade do cumprimento das obrigações de caráter temporário, o INEA/RJ poderá prorrogar os prazos e metas durante o tempo em que perdurar o impedimento (Cláusula 8.4).

Quanto às multas, o instrumento prevê que o descumprimento poderá sujeitar a Transpetro, além da possibilidade de rescisão, as seguintes multas (Cláusula 9.1 e seus subitens): a) multa moratória de $10 \%$ ao mês, pro rata, do valor de $\mathrm{R} \$ 36.488 .026,74$,em caso de atraso no cumprimento de cada prazo previsto no TAC, até o trigésimo dia de atraso; b) a 
partir do trigésimo dia, a multa moratória passa a ser de 20\%; c) por fím, multa rescisória de $70 \%$ do mesmo valor, no caso de rescisão, sem prejuízo das multas previstas anteriormente. Por fim, estipulou-se que tais multas não têm caráter compensatório, ou seja, seu pagamento não exime a Transpetro da responsabilidade por perdas e danos decorrentes de infrações ao TAC ou à legislação ambiental (Cláusula 9.6).

\subsubsection{Transhipping}

Este acidente ocorreu em 30 de maio de 2005, quando foram detectadas manchas de óleo diesel no mar, retidas na área entre o cais de atracação do Porto do Rio de Janeiro e o navio egípcio Al Minufiyah. Esta mancha de óleo se estendeu pelos armazéns 7, 8 e 9 do referido porto. Posteriormente, constatou-se que a origem do vazamento advinha do casco do referido navio. Os órgãos ambientais, após avaliação da área afetada, concluíram que houve dano ambiental pela poluição das águas da Baía de Guanabara com o óleo diesel, em um volume estimado entre 500 e 1000 litros. $^{96}$

\subsubsection{Ação Civil Pública no ${ }^{0}$ 0064056-64-2005.8.19.0001}

Trata-se de ação civil pública ajuizada pelo Estado do Rio de Janeiro em face de Transhipping Agenciamento Marítimo, distribuída em 01 de junho de 2005, em trâmite na $5^{\text {a }}$ Vara da Fazenda Pública da Comarca da Capital do Tribunal de Justiça do Estado do Rio de Janeiro, objetivando a condenação da ré a conter vazamento de óleo do navio egípcio Al Minufiyah - cuja propriedade da embarcação é da empresa Egyptian Navigation Company, e da qual figura como agente marítimo a ré, Transhipping -, ocorrido em 30 de maio de 2005 na Baía de Guanabara - o que foi deferido liminarmente. Além disso, segundo a acusação, deveria a ré responder pelos custos eventualmente arcados pelo órgão ambiental, pela completa recomposição dos recursos ambientais atingidos e, sendo isso em parte inviável, a prestar indenização correspondente à recuperação das áreas degradadas e poluídas, pelo tempo que fosse necessário, conforme apurado em liquidação de sentença, com reversão ao Fundo Estadual de Conservação Ambiental (FECAM).

\footnotetext{
96 RIO DE JANEIRO (Estado). Procuradoria Geral do Estado do Rio de Janeiro. Termo de Compromisso de Ajustamento de Conduta (TAC) entre o Estado do Rio de Janeiro e a empresa Transhipping Agenciamento Marítimo Ltda., assinado em 23 de agosto de 2017. Disponível em: $<$ http://www.rj.gov.br/c/document_library/get file?uuid=aef08454-a8d1-41ae-b852$\underline{0 \mathrm{e} 212 \mathrm{f} 2 \mathrm{bf152 \& groupId}=132946>}$. Acesso em: 16.12 .2018 .
} 
Da decisão que deferiu a liminar, a ré interpôs agravo de instrumento, ao qual se negou seguimento. Na esteira de promoção ministerial, decidiu-se pela parcial procedência dos pedidos. O processo, todavia, restou parcialmente anulado no julgamento porque não decidido o agravo retido.

Retornados os autos à primeira instância, sobreveio sentença que, apreciando aquele recurso, para rejeitar a tese de ilegitimidade passiva ad causam, deu pela parcial procedência dos pedidos para confirmar a liminar e condenar a ré a adotar todas as medidas necessárias à contenção do vazamento, com o tamponamento do casco do navio e a colocação de barreiras para a contenção do óleo vazado, bem assim a responder pelos custos para a completa recomposição dos recursos ambientais atingidos, a serem apurados em liquidação de sentença, além de arcar com a integralidade das custas processuais e honorários de sucumbência.

Inconformada, a Transhipping ajuizou Apelação Cível contra a sentença, a qual teve seu provimento negado pelo Relator desembargador Fernando Foch, Terceira Câmara Cível, julgado em 09 de setembro de 2015.

O TJRJ fez as seguintes ponderações: (i) a apelante é parte legítima para figurar no polo passivo da ACP, pois se a ré é representante do armador do navio no qual houve o vazamento, deve responder pelos danos ambientais decorrentes desse fato; (ii) realização de medidas de contenção pela ré, por si só, não demonstra o cumprimento integral da obrigação determinada na liminar, pois a eficácia de tais medidas deve ser apurada na fase de liquidação, o que afasta a tese de falta de interesse processual; (iii) no transporte marítimo, o armador é aquele que arma a embarcação, deixando-a com condições necessárias para que possa ser empregada em sua finalidade comercial. (iv) o agente marítimo é o seu representante nos portos onde não tem delegações, durante a estadia no porto, ocupando-se também do reboque, pilotagem e reparações. Assim, é responsável pelos danos causados. (v) era do agente marítimo a responsabilidade de conter o vazamento, sendo evidente que a demora de mais de cinco dias agravou seriamente os danos ambientais. Uma vez demonstrado o agravamento de dano ambiental decorrente da demora na contenção do óleo derramado, o agente marítimo se enquadra no conceito de poluidor e deve reparar os danos causados (art. $3 .^{\circ}$, IV, e 14, caput, e $\S 1 .^{\circ}$, da Lei 6.938/1981); (vi) é irrelevante a demonstração do status quo ante dos recursos ambientais, o que há de ser apurado em liquidação; (vii) a natureza e a complexidade da demanda autorizam a cominação de honorários de sucumbência em R \$10.000,00. 
Com relação à alegação do nobre magistrado acerca da irrelevância da situação anterior dos recursos ambientais lesados na fase processual em que foi alegada, vale aqui uma ressalva. A presente tese, ao primar pela análise interdisciplinar dos danos ambientais, tratará da importância da caracterização prévia dos ambientes atingidos ao longo dos próximos capítulos, principalmente nos capítulos 5, 7, e 8. Acredita-se aqui que não é possível uma valoração justa de um dano ambiental sem que seja compreendida a real mudança que ele causa nos ecossistemas atingidos. A compreensão da realidade prévia dos cenários, antes de serem atingidos pelo óleo, é um grande instrumento de auxilio na caracterização fiel dos danos decorrentes dos derramamentos.

Inconformada, a apelante/ré opôs embargos de declaração e, aos quais o Tribunal negou provimento, e Recurso Especial, com fundamento no art. 105, III, alínea "a" da CF/1988, que não foi admitido pelo TJRJ, em decisão monocrática proferida pelo desembargador Celso Ferreira Filho, julgado em 14 de abriu de 2016. Contra esta decisão, a Transhipping interpôs agravo, tendo sido encaminhado ao STJ, o qual não conheceu do recurso por considerá-lo intempestivo. ${ }^{97}$

\subsubsection{TAC celebrado entre Estado do Rio de Janeiro e Transhipping}

O Estado do Rio de Janeiro (Compromitente) celebrou com a Transhipping Agenciamento Marítimo Ltda. (Compromissária), constando como interveniente anuente o Instituto Estadual do Ambiental (INEA), Termo de Ajustamento de Conduta, em 23 de agosto de 2017, no âmbito da ACP n 0064056-64-2005.8.19.0001, procedimentos administrativos E14/8272/2005 e E-14/001.43355/2015.

Assim, o TAC teve como objeto a prestação, pela Transhipping, de medidas visando a recomposição e a reparação dos danos ambientais apurados até a data da celebração do instrumento, oriundos do incidente marítimo acima relatado (Cláusula 1).

Quanto aos seus efeitos, vale destacar o seguinte: (i) possui eficácia de título executivo extrajudicial, nos termos do art. $5^{\circ}, \S 6^{\circ}$ da Lei Federal n ${ }^{\circ} 7.347 / 1985$ (Cláusula 6); (ii) uma vez cumpridas as obrigações estabelecidas, se esgotam e se encerram, em definitivo, todas e

\footnotetext{
${ }^{97}$ STJ. Agravo em Recurso Especial: AREsp n ${ }^{\circ}$ 995.868-RJ. Ministra Laurita Vaz. Decisão Monocrática. Julgado em 20/10/2016.
} 
quaisquer pretensões do Estado do Rio de Janeiro (por si e pelas pessoas a quem substitui ou representa) em relação à Transhipping (Cláusula 2.3).

Quanto às obrigações da Transhipping, o TAC estabeleceu o seguinte: (i) deveria depositar em favor do Fundo Estadual de Conservação Ambiental (FECAM) a quantia de R\$ 44.765,00, já atualizada, no prazo de 10 dias corridos contados da assinatura do TAC (Cláusula 3.1). Deveria também (ii) pagar, no mesmo prazo de 10 dias, à Procuradoria do Estado do Rio de Janeiro, a título de honorários advocatícios, o valor de $\mathrm{R} \$ 9.969,16$, equivalente a $10 \%$ do valor atribuído à demanda originária atualizado (Cláusula 3.1, in fine).

As partes se obrigaram também a juntar as cópias do TAC nos autos da ACP $\mathrm{n}^{\circ}$ 0064056-64-2005.8.19.0001, requerendo sua extinção. O processo, porém, ainda não foi extinto, conforme consulta ao site institucional do Tribunal de Justiça do Estado do Rio de Janeiro em 01 de dezembro de 2018.

Quanto à físcalização e ao monitoramento, ficou estabelecido que compete à Secretaria Estadual de Ambiente e ao INEA verificar o cumprimento das obrigações estabelecidas no TAC, não limitando, suspendendo ou impedindo a fisscalização da Transhipping pelo Estado do Rio de Janeiro, no exercício de suas atribuições e prerrogativas legais (Cláusula 4).

Quanto às penalidades, fixou-se que o descumprimento "voluntário e inescusável" do TAC implicará o pagamento de multa cominatória no valor de $\mathrm{R} \$ 1.000,00$ por dia de atraso, a qual será recolhida ao Fundo Estadual de Conservação Ambiental e Desenvolvimento Urbano, desde que observados os motivos do eventual inadimplemento, circunstâncias atenuantes e agravantes, bem como os princípios da razoabilidade, proporcionalidade e boa-fé objetiva (Cláusula 5 e seus subitens). Definiu-se ainda que as multas não possuem caráter compensatório, de modo que seu pagamento não exime a Transhipping da responsabilidade por perdas e danos decorrentes de infrações ao TAC ou à legislação ambiental (Cláusula 5.4).

\subsubsection{Reduc}

Em 18 de janeiro de 2000, ocorreu o vazamento de óleo combustível na região da Baía de Guanabara, no Rio de Janeiro, devido à corrosão, no interior do manguezal, de um dos nove oleodutos que ligam a Refinaria de Duque de Caxias (Reduc) ao terminal da Petrobras. ${ }^{98}$

\footnotetext{
${ }^{98}$ BERTOLI, A. L.; RIBEIRO, M. de S. Passivo ambiental: estudo de caso da Petróleo Brasileiro S.A. - Petrobrás.
} A repercussão ambiental nas demonstrações contábeis, em consequência dos acidentes ocorridos. Revista de 
Segundo a CETESB, ${ }^{99}$ devido à demora dos operadores na paralisação do bombeamento do oleoduto para identificar o local do vazamento, foram liberados $1.300 \mathrm{~m}^{3}$ de óleo no mar, impactando extensas áreas de praias, costões rochosos, manguezais, ilhas, obra do patrimônio histórico (porto de Visconde de Mauá), pontos turísticos (como a Ilha de Paquetá), materiais de pesca (redes, cerco, embarcações, remos e etc.), gerando a morte de dezenas de aves aquáticas.

\subsubsection{Apelação Cível no $2009.001 .45387-$ Justiça Estadual}

Trata-se de apelação cível ajuizada pela Petrobras contra sentença de primeiro grau, de relatoria da desembargadora Denise Levy Tredler, julgada em 24 de novembro de 2009, ajuizada por pescador em face da Petrobras

$\mathrm{Na}$ origem, trata-se de ação indenizatória ajuizada por Gedio Nunes Sena, pescador artesanal, em face de Petróleo Brasileiro S/A, em cuja inicial objetiva o autor a condenação da ré ao pagamento de danos materiais, na modalidade de lucros cessantes, e danos morais, decorrentes do derramamento que lhe impediu de exercer sua atividade laborativa de pescador.

A sentença proferida pelo juízo de primeiro grau julgou parcialmente procedente o pedido inicial, para o fim de condenar a ré ao pagamento de lucros cessantes no valor equivalente a um salário mínimo mensal, vigente na data do desastre ecológico e sujeito aos reajustes legais, até julho de 2000, inclusive, acrescido de correção monetária desde as datas em que os pagamentos deveriam ter sido feitos, e de juros de mora de $1 \%$ ao mês, a contar da citação, além do pagamento de indenização por danos morais no valor de $\mathrm{R} \$ 5.000,00$, acrescidos de correção monetária, a partir da sentença, e de juros de mora de $1 \%$ ao mês, a contar da citação. Condenou-a, ainda, ao pagamento das verbas da sucumbência (custas do processo e honorários advocatícios, estes últimos fixados em $20 \%$ do valor da condenação).

A ré, Petrobras, apelou, sustentando, em resumo, que a documentação acostada aos autos demonstra que 45 dias após o acidente ecológico, a pesca havia sido liberada pelo IBAMA, com a análise dos fatos pelo INMETRO. Demonstra também que houve violação ao princípio da ampla defesa, na medida em que a sentença ignorou as provas trazidas aos autos pela Petrobras. Indica ainda que o autor sequer comprovou que exercia a atividade de pescador,

Administração Contemporânea. Curitiba, v.10, n.2, abr.jun. 2006, p. 117 - 136. Disponível em: $<$ http://www.scielo.br/scielo.php?script=sci arttext\&pid=S1415-65552006000200007>. Acesso em: 14.12.18.

99 SÃO PAULO (Estado). Companhia Ambiental do Estado de São Paulo (CETESB). Principais acidentes. Disponível em: <https://cetesb.sp.gov.br/emergencias-quimicas/tipos-de-acidentes/dutos/principais-acidentes/>. Acesso em: 14.12.18. 
que não há prova dos danos materiais e que são descabidos os alegados danos morais. Além disso, demonstra que deve ser considerada a pública e notória poluição pré-existente na Baía de Guanabara e que inexiste nexo de causalidade entre os fatos narrados e os danos supostamente sofridos pelo autor. Por essas razões, pleiteia a reforma da sentença com a improcedência do pedido inicial, ou a redução da verba indenizatória do dano moral para os meses de paralisação da pesca, conforme determinado pelo IBAMA, com a dedução do valor pago anteriormente pela ré.

O autor também apelou, pleiteando a majoração das verbas arbitradas a título de danos morais e de lucros cessantes, devendo esta última ser fixada desde a data do evento e com a observância do laudo técnico do IBAMA constante nos autos, que atesta que o pescado levará mais de dez anos para se recompor na Baía de Guanabara.

No julgamento da Apelação Cível pelo Tribunal de Justiça do Rio de Janeiro, de relatoria da desembargadora Denise Levy Tredler, julgado em 24 de novembro 2009, a apelação da ré foi desprovida e a apelação do autor (pescador) foi parcialmente provida. O Tribunal decidiu o seguinte: (i) lucros cessantes seriam devidos com base no valor do salário mínimo profissional de pescador durante o período razoável de seis meses; (ii) o dano moral também seria devido em razão da angústia, insegurança e incertezas sofridas pelo autor durante o período em que ficou privado do exercício de sua atividade laborativa de pescador, com a qual provia o seu sustento e ode sua família; (iii) a verba indenizatória deveria ser majorada para $\mathrm{R} \$$ 10.000,00, a fim de melhor adequar-se ao fato e respectivo dano; (iv) a sucumbência seria exclusiva da ré, que deveria suportar o pagamento das custas processuais e dos honorários advocatícios.

\subsubsection{Apelação Cível nº 0116673-93.2008.8.19.0001 - Justiça Estadual}

$\mathrm{Na}$ origem, trata-se de ação de responsabilidade civil, pelo procedimento comum ordinário, ajuizada por Andrea Martins dos Santos e outros em face de Petróleo Brasileiro S/A (Petrobras), em razão dos danos materiais e morais suportados pelo derramamento de óleo contaminando a Baía de Guanabara, local onde exercem a atividade de pescador.

A sentença reconheceu a prescrição arguida pela ré e julgou improcedentes os pedidos formulados na inicial, com fundamento no artigo 269, IV, do CPC/1973, e condenou os autores ao pagamento das custas do processo e dos honorários advocatícios, fixados estes em $10 \%$ do valor da causa, observado o art. 12, da Lei Federal n 1060/1950. 
Os autores ajuizaram apelação, sustentando, em síntese, tratar-se de lesão de trato sucessivo, contando-se o termo inicial do prazo prescricional do término dos 10 anos que o meio ambiente precisará para se recuperar dos efeitos causados pelo vazamento de 1.292 toneladas de óleo na Baia Guanabara. Lesão esta que se propaga no tempo, continuando a afetar não apenas o meio ambiente, mas os pescadores que não podem, durante tal prazo, exercer seu trabalho e obter seu sustento. Requerem fosse afastada a prescrição e, em pedido subsidiário, que a prescrição atinja apenas as prestações vencidas após os últimos 5 anos.

No julgamento da Apelação Cível pelo Tribunal de Justiça do Rio de Janeiro, de relatoria da desembargadora Katya Maria Monnerat Moniz de Aragão Daguer, julgado em 09 de dezembro de 2010, foi negado seguimento. O Tribunal considerou que a pretensão estava prescrita, aplicando o prazo trienal previsto no art. 206, $\S 3^{\circ}$, inciso V do Código Civil de 2002, conforme se extrai do trecho abaixo:

O acidente responsável pelos prejuízos suportados pelas autoras ocorreu em 18/01/2000, portanto, ainda sob a vigência do Código Civil (LGL \2002\400) revogado, quando aplicava-se à pretensão indenizatória o prazo prescricional genérico das ações pessoais, de vinte anos, previsto em seu art. 177, diante da ausência de prazo específico.

Com o advento do atual Código Civil (LGL\2002\400), a prescrição da pretensão de reparação civil ganhou tratamento específico, sendo seu prazo reduzido de vinte para três anos conforme art. 206, $\S 3^{\circ}$, V, do Código Civil (LGL\2002\400) de 2002. Novo prazo que, conforme a regra de transição trazida no art.2028, do novo Código Civil (LGL 12002\400), iniciou-se na data da entrada em vigor do novo diploma, em $11 / 01 / 2003$, uma vez que ainda não havia transcorrido mais da metade do prazo anterior, previsto no Código Civil (LGL\2002\400)/16.

Na hipótese dos autos, tendo o vazamento ocorrido em 18/01/2000 e não havendo decorrido mais da metade daquele prazo vintenário em 11/01/2003, deve ser aplicado o prazo trienal, a partir da entrada em vigor do novo Código Civil (LGL \2002\400). Logo, a prescrição da pretensão de reparação em virtude do evento perfez-se em 1101-2006, e tendo a apresente ação sido ajuizada em 14-05-2008, inequívoco e imperioso é o reconhecimento da prescrição.

(...)

Dessa feita, não se sustenta a alegação de que o prazo prescricional somente deveria ter início em 2010, quando supostamente teria ocorrido a plena recuperação do ecossistema local, porque o que buscam os recorrentes não é a reparação do ecossistema prejudicado, mas sim serem reparados pelos danos decorrentes do acidente.

\subsubsection{Petrobras - São Sebastião}

Este caso se refere a um acidente ocorrido em área terrestre que, por meio da contaminação aos cursos d'água, alcançou ambientes de praia e costões rochosos do município de São Sebastião/SP. 
Foi encontrado apenas um julgado relacionado a este caso. Trata-se da Ação Civil Pública n ${ }^{\circ}$ 0001042-02.2014.4.03.6135, ajuizada em 28/11/2014 na $1^{\text {a }}$ Vara da Justiça Federal de Caraguatatuba/São Paulo, proposta pelo MPF e pelo Ministério Público do Estado de São Paulo (MPSP) em face de Petrobras; Petrobras Distribuidora S/A (Distribuidora BR) e Cooperativa de Transportes Rodoviários do ABC.

Alegam, em síntese, que no dia 06 de setembro de 2012, por volta das 17:00 horas, no município de São Sebastião, Km 156 da Rodovia BR-55 (trecho de Serra de Maresias), ocorreu o tombamento de um caminhão-tanque da Cooperativa de Transportes Rodoviários $\mathrm{ABC}$, contratada pela Petrobras Distribuidora S/A para transporte de óleo diesel marítimo de propriedade da Petrobras, ocasião em que 15 mil litros de óleo vazaram e atingiram o córrego Canto do Moreira, vindo a desembocar algumas horas depois no mar da Praia de Maresias e costão rochoso local. Alegam ainda que o fato ocasionou danos ambientais, e que o método de prevenção das rés foi falho.

Requerem, então: (a) que as rés Petróleo do Brasil S/A (Petrobras) e Petrobras Distribuidora S/A (Distribuidora BR) sejam condenadas na obrigação de fazer consistente em reavaliar e reestruturar seus planos de prevenção a acidentes ambientais decorrentes de suas atividades em trecho terrestre, assim como planos e procedimentos para atendimento a emergências ambientais visando a rápida e eficaz reparação e mitigação das lesões causadas ao meio ambiente; (b) todas as rés, solidariamente, sejam condenadas ao pagamento de indenização por danos causados ao meio ambiente, no valor de $\mathrm{R} \$ 5.000 .000,00$, a ser destinado ao Fundo de Defesa dos Direitos Difusos; (c) todas as rés, solidariamente, sejam condenadas ao pagamento de indenização pelos danos morais coletivos causados, no valor de $\mathrm{R} \$$ 5.000.000,00, a ser destinado ao Fundo de Defesa dos Direitos Difusos; (d) todas as rés, solidariamente, sejam condenadas ao pagamento de indenização pelos danos patrimoniais individuais eventualmente causados aos moradores das unidades residenciais unifamiliares e do condomínio pelo qual passa o córrego Canto do Moreira, bem como aos banhistas que comprovarem ter sofrido lesões pela contaminação da água da praia nos dias subsequentes à data dos fatos.

$\mathrm{Na}$ sentença publicada em 17 de agosto de 2018, o magistrado federal decidiu o seguinte:

a) a competência neste caso seria da Justiça Federal, pois, ao menos potencialmente, o acidente poderia gerar danos a praia e mar territorial, ambos, bens da União, nos 
termos do art. 20, IV e VI da Constituição Federal, o que traduz o interesse federal, a rigor do artigo 109, I da Constituição Federal;

b) o litisconsórcio ativo entre o Ministério Público Federal e Estadual seria plenamente aceitável pela jurisprudência do Superior Tribunal de Justiça, desde que houvesse motivo a tanto, e, no caso concreto, o suposto dano ocorreu em mar territorial (bem federal) e Córrego Canto Moreira (águas locais, estadual ou municipal, não se sabe ao certo o curso total do córrego), justificando a atuação conjunta dos dois MPs;

c) o Ministério Público seria legitimado para defesa de direitos individuais homogêneos dos moradores do condomínio e ribeirinhos às margens do córrego atingido pelo derramamento de óleo de potencial dano;

d) a ré, Petróleo Brasileiro S/A, não seria legítima para figurar no polo passivo da demanda, pois o produto (óleo) derramado era de propriedade da corré, Petrobras Distribuidora S/A, e foi transportado pela outra corré, Cooperativa de Transportes Rodoviários do $\mathrm{ABC}$, não havendo qualquer elemento que possa atribuir conduta da corré, Petróleo Brasileiro S/A, aos fatos, pois o produto transportado não era seu; não foi ela a transportadora; não foi ela a contratante da transportadora;

e) ainda afastou a alegação de impossibilidade jurídica do pedido de indenização por danos morais coletivos, pois a jurisprudência vem reconhecendo a possibilidade, em tese, de danos morais coletivos;

f) decidiu que a indenização deveria ser a via subsidiária da inviabilidade da efetiva recuperação do dano, ou, mesmo, do desgaste material e moral que é necessário se suportar para buscar da recuperação da área degradada. Assim, analisar o dano ambiental, mesmo sendo ele vertente da responsabilidade objetiva, não significa apenas provar o ato lesivo. Envolve provas de impossibilidade de recuperação ambiental. Ainda que recuperável, envolve provas de quem suportou o custo, material e moral, da recuperação. Neste último ponto, a teoria que se adota é a teoria do risco integral: aquele que provoca dano ambiental tem o dever de recuperá-lo, diante da teoria do risco integral de sua atividade, devendo arcar com os custos, que não podem ser impostos a terceiros, sob pena de ter que indenizá-los;

g) antes mesmo do ingresso da ação, vale dizer, a área já estava recuperada. Pelas avaliações técnicas realizadas, pode-se perceber a ausência de toxidade derivada do acidente. Os resultados da avaliação de bioindicadores (camarões) indicam que, 
passados 10 meses da ocorrência e cerca de 7 meses após a primeira campanha de campo, houve um sensível aumento da população de crustáceos decápodes nos pontos afetados, indicando a ocorrência do restabelecimento progressivo da qualidade ambiental nas áreas afetadas.Com base nos ensaios ecotoxicológicos realizados nesta segunda campanha, comparando-os com os resultados da primeira campanha, percebe-se também significativa melhoria da qualidade ambiental dos corpos d'água avaliados, onde os poucos efeitos ecotoxicológicos agora observados não indicam comprometimento da qualidade das águas e sedimentos do córrego Canto do Moreira. Com relação ao ambiente marinho, o diesel vazado não está ainda em concentração capaz de gerar toxidade à amostra de água. O que se verifica, portanto, é que já em 2013 a área já estava recuperada, do ponto de vista ambiental.

h) Toda a recuperação da área foi arcada por pelas rés, e promovida por sua iniciativa. Em poucos dias, após o acidente, o prejuízo havia sido consideravelmente mitigado, e o monitoramento posterior comprovou que não restaram danos ambientais. Não se pode falar, assim, em indenização por danos materiais ambientais.

i) Não se pode falar, também, em danos morais ambientais. Verifica-se dano moral ambiental quando resta atingido pela conduta do poluidor toda uma série de valores ambientais, intangíveis, de uma determinada coletividade, prejudicando sua qualidade de vida. Não é o que o caso dos autos, pelo resultado da recuperação da área.

j) O pedido de reestruturação e reavaliação dos procedimentos adotados também não foi acolhido, pois o resultado da recuperação da área é a prova da correção da conduta. Houve um trabalho que produziu um resultado efetivo, do ponto de visto de se evitar um desastre ambiental. O óleo foi contido no córrego e retirado. A área foi monitorada e recuperada.

k) Julgou-se extinto o processo, sem resolução do mérito, com fulcro no art. 485, VI do CPC. Julgou-se também extinto o feito com relação a Petrobras, por ilegitimidade passiva, e, com resolução de mérito, nos termos do art. 487, I do CPC; e julgaramse improcedentes os pedidos com relação a Petrobras Distribuidora S/A e Cooperativa de Transportes Rodoviários do ABC.

1) Concluiu-se a sentença sem condenação em honorários nos termos do artigo 18 da Lei Federal n 7.347/1985. 
A sentença ainda não havia transitado em julgado em 10 de dezembro de 2018.

\subsubsection{1. - Navio Confidence}

O julgado se refere ao derramamento de 50 litros de óleo diesel nas águas do Estuário de Santos, durante operação de carregamento e deslastreamento do Navio N/T Confidence, ocorrido no dia 31 de maio de 1999. No dia 31 de maio de 1999, referido navio, de bandeira de Singapura e de propriedade de Confidence Shipping Private Limited, fretado pela Petrobras para fazer transporte de gasolina, estava atracado na altura do Pier 2 do Terminal da Alemoa no Porto de Santos, em operação de carregamento de deslastreamento, quando constatou-se a presença de óleo no mar na região de popa-bombordo. O Terminal e as autoridades portuárias foram informados e as operações de carregamento do lote de gasolina e de deslastreamento foram paralisadas. Para conter o vazamento, foram utilizadas barreiras de contenção pela Companhia Docas do Estado de São Paulo (CODESP) e pela Petrobras, além de um caminhão a vácuo da CODESP para sugar o óleo derramado no mar. O MPF alegou que o vazamento de óleo do navio teve origem em um dos tanques de lastro da embarcação, no qual se verificou a existência de ruptura, fazendo comunicação com o tanque slop que continha óleo diesel originário da última descarga. ${ }^{100}$

Foi encontrada apenas uma ação judicial para o caso em questão, com decisões em primeira e segunda instância.

Trata-se da Ação Civil Pública n ${ }^{\circ}$ 0004703-58.2009.4.03.6104, ajuizada na $1^{\text {a }}$ Vara da Justiça Federal de Santos, pelo MPF, em face de Pandibra-Mclintock Services Ltda, Swedish P \& I Club, Petróleo Brasileiro S/A, Triaina Agência Marítima LTDA (EPP), com o objetivo de condená-las ao pagamento de indenização por danos causados ao meio ambiente natural, no valor estimado de US\$125.892,54, bem como ao pagamento de indenização por danos morais, estimada em valor equivalente ao calculado para os danos ambientais, acrescidos das verbas da sucumbência, de juros de mora e correção monetária, até a data do efetivo depósito em favor do Fundo de Reparação de Interesses Difusos Lesados.

A sentença de $1^{\circ}$ grau, publicada em 26 de julho de 2018, julgou parcialmente procedentes os pedidos formulados na inicial, nos seguintes termos:

\footnotetext{
100 Conforme autos da Ação Civil Pública: JUSTIÇA FEDERAL. Seção Judiciária de São Paulo. Ação Civil Pública n ${ }^{\circ}$ 004703-58.2009.4.03.6104, ajuizada na $1^{\mathrm{a}}$ Vara da Justiça Federal de Santos.
} 
a) Reconheceu-se a responsabilidade de todas as rés pelo evento danoso, pois tinham o dever de vigilância nos procedimentos da operação. A Petrobras fretou o navio em questão para o transporte de gasolina, tendo celebrado contrato de afretamento com a empresa Confidence Shipping Private Limited. E justamente na atividade de transporte de gasolina verificou-se o derramamento de óleo no Estuário de Santos. Desta forma, utilizou o navio em sua atividade de risco, que ocasionou o dano ambiental em questão. Em relação às corrés Pandibra e Swedish P\&I Club, em virtude da teoria do risco integral adotada pelo ordenamento jurídico brasileiro em matéria de responsabilização civil por danos ambientais, também respondem pelo dano ambiental discutido, pois integram a cadeia produtiva que aufere lucro com a atividade que causou danos ao meio ambiente. A condição de seguradora e de correspondente comunica a elas a responsabilidade pela indenização ambiental. Já em relação à corré Triaina, verificouse que, à época dos fatos, era agente da proprietária da embarcação. E foi justamente uma ruptura no tanque de lastro do navio que ocasionou o vazamento em questão;

b) Não se pode, nos termos da inicial, minimizar a responsabilidade pelo simples fato de o derramamento ter ocorrido em área de poluição crônica;

c) Além disso, a circunstância de terem sido tomadas providências imediatas para minimizar as consequências do acidente ambiental não isenta as rés do dever de indenizar pelo ocorrido;

d) Entendeu-se assim, razoável, a princípio, a aplicação do critério de valoração do dano ambiental apresentado pela CETESB, apesar do magistrado reconhecer várias lacunas nele;

e) Ao utilizar como parâmetro o valor apurado - US\$ 125.892,54/ R\$261.227,02 - como indicativo para a efetiva fixação do valor da indenização devida, considerou as ações positivas adotadas por parte do poluidor como medidas atenuantes. Reduziu o valor em um terço, resultando em R\$174.151,35;

f) Quanto aos danos morais coletivos, reconheceu divergência em sede jurisprudencial no quanto a sua admissibilidade. Isso porque, a Segunda Turma do Superior Tribunal de Justiça sempre tendeu a admiti-lo, fato consubstanciado pelos votos do Ministro Herman Benjamin, ao passo que a Primeira Turma sempre tendeu a negá-lo, com base nos votos do Ministro do Supremo Tribunal Federal Luiz Fux e do falecido Ministro Teori Zavascki; 
g) Entendeu-se ser mais adequada ao princípio da integral reparação a teoria da existência de danos morais coletivos quando os fatos possam atingir uma coletividade indistinta ou grupos humanos específicos, cujos membros sejam indistintamente considerados em sua relação com o evento danoso. No caso dos autos, entendeu-se que não há quaisquer elementos que indiquem que a população tenha passado por algum desconforto fora do cotidiano ou por efetivo incômodo qualificável como dano moral transindividual, projetado sobre os sentimentos individualmente manifestados, mas coletivamente considerado, seja pelas condições pessoais de cada um dos habitantes afetados em sua saúde;

h) Não se condenou as rés na perda de incentivos e benefícios fiscais concedidos pelo Poder Público, nem na participação em linhas de financiamento em estabelecimentos oficiais de crédito, em razão da pronta tomada de providências por parte das mesmas para neutralizar as consequências do acidente;

i) Enfim, as rés foram condenadas, solidariamente, unicamente ao pagamento de indenização material fixada na quantia de $\mathrm{R} \$ 174.151,35$, nos termos do disposto no artigo 13 da Lei $n^{\circ} 7.347 / 1985$, revertida ao Fundo de Direitos Difusos regulamentado pelo Decreto $n^{\circ}$ 1.306/1994 e acrescida, até a data do efetivo depósito, de juros de mora à taxa de $1 \%$ ao mês desde a data da ocorrência do dano - 31 de maio de 1999 (Súmula 54 do STJ), e correção monetária desde a data da propositura da ação - 08 maio de 2009 - pelos critérios da Resolução 267/2013 do Conselho da Justiça Federal (CJF) ou de outra que a substitua.

Ademais, ainda com relação a este caso, o TRF da $3^{a}$ Região julgou agravo interposto pela Petrobras admitindo o litisconsórcio facultativo entre o MPF e o MP estadual, conforme autorizado pelo art. $5^{\circ}, \S 5^{\circ}$ da Lei Federal $n^{\circ} 7.347 / 1985$, fixando o seguinte entendimento:

3. É possível o litisconsórcio ativo facultativo entre os diversos ramos do Ministério Público da União e os Ministérios Públicos dos Estados, em se tratando de ação civil pública que tenha por objeto a responsabilidade por danos morais e patrimoniais causados ao meio-ambiente, ao consumidor, a bens e direitos de valor artístico, estético, histórico e paisagístico, à ordem econômica e urbanística, bem como a qualquer outro interesse difuso ou coletivo, inclusive de natureza trabalhista. Precedentes. 101

101 TRF3. Agravo de Instrumento: Ag nº 0017917-90.2012.4.03.0000/SP, Rel. Hélio Nogueira, Primeira Turma, julgado em 25/10/2016. 


\subsubsection{Produto N-Hexano - Vicuña}

No dia 02 de maio de 1999, o navio mercante de bandeira chilena Vicuña, agenciado pela apelante Wilson Sons Agência Marítima Ltda., derramou no estuário do Porto de Santos/SP entre 3.000 e 5.000 litros do produto químico COPERAF-1 (n-hexano), durante o procedimento de transferência da substância para o terminal da empresa Brasterminais Armazéns Gerais S/A, atualmente Vopak Brasil S/A.

O MPF ajuizou a Ação Civil Pública n ${ }^{\circ}$ 0003577-46.2004.4.03.6104 em face deWilson Sons Agência Marítima Ltda. e Vopak Brasil S/A, requerendo a condenação das empresas em (i) obrigação de fazer, consistente na recuperação dos danos causados ao meio ambiente, indenizando-se os irrecuperáveis; (ii) perda de incentivos e benefícios fiscais concedidos pelo Poder Público e a participação em linhas de financiamento em estabelecimentos oficiais de crédito; (iii) pagamento de verbas em favor do Fundo de Reparação de Interesses Difusos Lesados; (iv) condenação da empresa Vopak Brasil S/A a obrigação de fazer, consistente na adoção de medidas de segurança em suas instalações.

O processo foi distribuído a $3^{\text {a }}$ Vara Federal de Santos/SP, em 14 de abriu de 2004. A empresa Wilson Sons Agência Marítima Ltda. interpôs o agravo de instrumento $\mathrm{n}^{\circ}$ 2005.03.00.02614-2 contra a decisão que afastou a preliminar de ilegitimidade passiva arguida em sede de contestação. O TRF da $3^{\mathrm{a}}$ Região, sob a relatoria do Desembargador Federal Lazarano Neto, indeferiu o pedido de efeito suspensivo e, na sequência, negou provimento ao recurso.

Em 19 de setembro de 2008, adveio a sentença de parcial procedência em desfavor da empresa Wilson Sons Agência Marítima Ltda., condenada a indenizar os danos ao meio ambiente, em valor a ser apurado em fase de liquidação por arbitramento, que nos termos do artigo 13 da Lei $n^{\circ} 7.347 / 1985$, revertido ao Fundo de Direitos Difusos (Decreto Federal $n^{\circ}$ 1.306/1994), acrescido de juros legais a partir do trânsito em julgado, mais correção monetária. A empresa também foi condenada ao ressarcimento dos honorários periciais pagos pela corré.

A empresa Wilson Sons Agência Marítima Ltda. apelou, alegando (i) ausência de responsabilidade pelo evento, considerando que na condição de agente marítimo tem atuação limitada aos procedimentos burocráticos relacionados a entrada/saída do navio; (ii) que a empresa Vopak Brasil S/A, na condição de operador portuário, é encarregada pelas operações de carga/descarga do navio e foi no seu terminal que ocorreu o vazamento químico; bem como (iii) inexistir evidência de efetivo dano ao meio ambiente. 
O MPF também apelou, pleiteando a responsabilização solidária da empresa Vopak Brasil S/A, além da condenação à reparação ao dano ambiental, à perda dos incentivos e benefícios fiscais e ao pagamento de honorários e custas. O TRF da $3^{\mathrm{a}}$ Região deu parcial provimento ao recurso do Ministério Público Federal e negou provimento ao recurso da empresa Wilson Sons Agência Marítima Ltda., nos termos descritos a seguir:

a) Aplicou a teoria do risco integral, entendendo que basta a comprovação de ação ou omissão do poluidor, a ocorrência do dano e o nexo causal entre ambos, sendo dispensável indagar-se a respeito da licitude da atividade originariamente desenvolvida, não se admitindo quaisquer excludentes;

b) Foi o dano ambiental comprovado: lançamento em águas públicas de produto químico COPERAF-1 (n-hexano) descrito na documentação técnica como substância de aspecto líquido volátil, incolor e parafínico, altamente inflamável, deletério ao meio ambiente, em especial aos veios hídricos, por inutilizar a água para consumo. Ademais, é tóxico ao ser humano por ingestão, inalação e absorção através da pele, podendo causar irritação das vias respiratórias, depressão do sistema nervoso central e parada respiratória;

c) Sob a ótica da Teoria do Risco Integral, desde que pessoas vinculadas as duas empresas (Wilson Sons Agência Marítima Ltda. e Vopak Brasil S/A) tenham se envolvido no nexo do acidente ambiental, a responsabilidade de ambas é objetiva e integral na forma do comando emergente do $\S 1^{\circ}$ do ar. 14 da Lei $n^{\circ}$ 6.938/1981. Entendeu-se, portanto, ser impossível eximir a corré, Vopak Brasil $\mathrm{S} / \mathrm{A}$, de qualquer culpa pelo acidente ecológico;

d) Entendeu-se que o fato de a empresa Wilson Sons Agência Marítima Ltda., agente marítimo, apenas intermediar as questões burocráticas da embarcação não minimiza sua responsabilizada pelo acidente ecológico, uma vez que se compromissou perante a Capitania dos Portos em Santos/SP por todos os atos referentes ao navio Vicuña, atracado em 02 de janeiro de 1999, tanto que foi lavrado em seu desfavor o auto de infração, com aplicação de multa de R\$ 1.600,00. Consignou ainda que existe orientação da Sexta Turma do TRF da $3^{\mathrm{a}}$ Região na responsabilização também do agente marítimo em caso de dano ecológico; 
e) Entendeu-se, porém, que não prospera o pedido de recuperação da área atingida, pois considerou que os malefícios decorrentes do vazamento do produto químico COPERAF-1 (n-hexano) nas águas do estuário do Porto de Santos/SP são imateriais, razão pela qual a indenização já cominada é suficiente em termos de medida repressiva;

f) E, por fim, restou entendido que não cabe a condenação da parte vencida ao pagamento de honorários advocatícios em favor do Ministério Público, consoante o disposto no art. 18 da Lei Federal $n^{0} 7.347 / 1985$, por critério de simetria. ${ }^{102}$

A corré Vopak Brasil S/A opôs embargos de declaração em face do acórdão acima, aos quais o Tribunal negou provimento. ${ }^{103}$

\subsubsection{3. - Navio Katina}

O caso trata de vazamento de petróleo ao mar, com causa não identificada, ocorrido no Terminal Marítimo Almirante Barroso (TEBAR), em 13 de agosto de 1991. Foram identificados $60 \mathrm{~m}^{3}$ de substância vazada, que afetou diretamente quatro ambientes de praia do município de Ilha Bela, além de Unidades de Conservação, águas costeiras utilizadas para fundeio, pesca e esportes náuticos e subaquáticos, além de estabelecimentos comerciais. ${ }^{104}$

Foi ajuizada a Ação Civil Pública n ${ }^{\circ}$ 0402100-77.1991.4.03.6103, com pedido liminar pela Prefeitura Municipal da Instância Balneária de Ilhabela, em 20 de setembro de 1991, em face de Petróleo Brasileiro S/A e Katina Shipping Co. Requereu que: (1) a condenação da Petrobras em indenizar os prejuízos causados ao meio ambiente e à população local em quantum a ser apurado em liquidação de sentença; (2) seja a Petrobras instada a formar uma carteira de seguro de poluição ambiental, específica para o fim de custear os prejuízos havidos com a poluição por petróleo e seus derivados, na região do Canal de São Sebastião e adjacências; (3) seja a Petrobras obrigada a indenizar a autora pelos referidos prejuízos, danos diretos, orçados em U\$50.000.000, considerado todo o período de vinte anos de derramamento

102 TRF3. Apelação Cível: AC nº 0003577-46.2004.4.03.6104/SP. Rel. Johonsom Di Salvo. Sexta Turma. Julgado em 13/03/2014.

103 TRF3. Embargos de Declaração em Apelação Cível: EDcl em AC nº 0003577-46.2004.4.03.6104/SP. Rel. Johonsom Di Salvo. Sexta Turma. Julgado em 03/07/2014.

104 POFFO, I. R. F.. Vazamentos de Óleo no Litoral Norte do Estado de São Paulo: Análise histórica (1974 1999). Dissertação de Mestrado. PROCAM. 2000, p. 73. 
de petróleo no mar e praias locais; (4) ambos os requeridos sejam condenados ao pagamento de indenização a ser fixada em liquidação de sentença por arbitramento, correspondente ao custo integral da completa recomposição do complexo ecológico atingido até a data da efetiva cessação das atividades reputadas nocivas, de modo a retornar ao estado original.

Liminarmente, a autora requereu que: (a) fossem impedidos os atracamentos dos navios tanques no Terminal Marítimo Almirante Barroso (TEBAR), com tempos de uso superior a quinze anos, sem vistoria prévia de suas condições de navegabilidade e operabilidade e, uma vez ocorrido derramamento de óleo no mar, fosse estipulada multa diária no valor de um dia de afretamento do navio envolvido, multiplicado pelo número de dias em que o óleo permanecesse no mar, ou espalhado por qualquer praia de Ilhabela, revertendo a multa à autora; (b) fosse feita a interdição do TEBAR, caso constatada na cautelar de antecipação de provas qualquer irregularidade ou precariedade de suas instalações; bem como (c) fosse realizado o bloqueio do desatracamento do N/T Katina, inclusive para o fim de servir como garantia do pagamento da indenização.

Foi proferida sentença pela $2^{\mathrm{a}}$ Vara Federal de São José dos Campo. O Tribunal Regional Federal da $3^{\text {a }}$ Região anulou a sentença proferida, considerando-a citra petita, e determinando a prolação de novo julgamento.

Na nova sentença, publicada em 18 de janeiro de 2017 pela $1^{\text {a }}$ Vara da Justiça Federal de Caraguatatuba, restou decidido que seria:

a) acolhida a preliminar de impossibilidade jurídica do pedido em face da Petrobras, apenas no tocante à formação de carteira de seguro para custear os prejuízos com a poluição por petróleo e seus derivados. Entendeu-se que, embora a Lei Federal $n^{\circ}$ 6.938/1981 estabeleça o seguro ambiental como instrumento econômico da Política Nacional de Meio Ambiente (art. $9^{\circ}$, inciso XIII), este mecanismo foi criado após os fatos apurados, pela Lei $\mathrm{n}^{\circ} 11.284$ de 2006, e não há regulamentação para sua aplicação. Ademais, não se poderia compelir a sociedade de economia mista, vinculada por lei a seus fins institucionais, à contratação de seguros;

b) Foi rejeitada a preliminar da falta de interesse de agir superveniente, em razão da assinatura de Termo de Ajustamento de Conduta entre o Ministério Público Federal, a CETESB, a Transpetro-TEBAR e a corré, Petrobrás S/A. Segundo o magistrado, o TAC deve sempre incluir proposta integral de reparação do dano, 
admitindo-se a transação apenas no tocante ao modo, tempo e lugar de cumprimento das obrigações, mas não sobre o direito subjacente, porque indisponível e de titularidade difusa. O Termo de Ajustamento teve por objeto o estabelecimento de condicionantes ambientais a serem cumpridas pela Petrobras e Transpetro-TEBAR, visando à obtenção de licença de operação da CETESB para as atividades relativas aos equipamentos e instalações da TranspetroTEBAR prevendo o "investimento" de R \$ 115.099.342,00 para atendimento de condicionantes ambientais. Porém, não se pode considerar o investimento acima mencionado como forma de reparação ambiental;

c) Constou da sentença ainda que a empresa Katina Shipping Co é proprietária do navio envolvido, sendo responsável direta pelo vazamento;

d) Com relação à Petrobras, a responsabilidade da empresa corré no evento é indireta porque proprietária do petróleo derramado pelo navio Katina. Para o fim de apuração do nexo de causalidade no dano ambiental, equiparam-se a quem faz aqueles que deveriam agir, os financiadores da atividade e, sobretudo, aqueles que dela se beneficiaram;

e) A Convenção Internacional sobre Responsabilidade Civil e Danos Causados por Poluição por Óleo em nenhum momento estabelece a responsabilidade exclusiva da empresa proprietária do navio em casos de acidentes. Ao contrário disso, tem por escopo prover os Estados de um instrumento para responsabilizar o proprietário do navio, ainda que estrangeiro, pelo óleo derramado no mar territorial nacional. Sendo assim, convenção não é norma especial sobre a Lei ${ }^{\circ}$ $6.938 / 1981$, porque não pretendeu regulamentar de forma exaustiva todo e qualquer evento danoso em decorrência do derramamento de óleo ao mar;

f) Entendeu-se razoável a aplicação do trabalho científico de autoria da CETESB para quantificação de valores, porquanto leva em conta o volume de petróleo derramado, a vulnerabilidade da área atingida, a toxicidade do produto e a persistência do produto vazado no meio aquático;

g) Já com relação ao pedido de pagamento de indenização no valor de US\$ 50.000.000,00, entendeu-se que não há fundamentação fática ou jurídica a sustentá-lo, pois a autora não comprovou que no período mencionado 
experimentou diminuição de arrecadação fỉscal, prejuízos com a limpeza das praias e outros danos provenientes do vazamento de óleo no TEBAR;

h) Enfim, foram julgados parcialmente procedentes os pedidos, com fundamento no artigo 487, inciso I, do Código de Processo Civil, condenando Petrobras e Katina Shipping Co., solidariamente, ao pagamento de indenização pelos danos causados ao meio ambiente em valor a ser apurado em liquidação por arbitramento, que deverá corresponder ao valor mínimo encontrado pela CETESB, facultando ao órgão ambiental o uso do trabalho científico "Proposta de Critério para Valoração Monetária de Danos Causados por Derramamentos de Petróleo ou de seus Derivados no Ambiente Marinho". Determinou que o valor da reparação será revertido ao Fundo de Reparação de Direitos Difusos Lesados (art. 13 da Lei $n^{\circ} 7.347 / 1985$ ), acrescido de juros legais e correção monetária, conforme o Manual de Orientação de Procedimentos para Cálculos na Justiça Federal aprovado pelo Conselho da Justiça Federal;

i) Foram condenadas ainda as empresas rés ao pagamento de custas e honorários advocatícios, arbitrado em $\mathrm{R} \$ 10.000,00$ para cada uma, nos termos do artigo $85,8^{\circ}$ c. c $2^{\circ}$ do CPC.

A Petrobras opôs recurso de embargos de declaração à sentença. O magistrado acolheu e deu provimento aos embargos de declaração (decisão publicada em 08 de fevereiro de 2018) para fins de retificar a sentença de mérito e especificar os critérios a serem levados em consideração quando do arbitramento de indenização, mantendo integralmente o restante da sentença. De acordo com a decisão, a parte dispositiva da sentença passou a ostentar a seguinte redação (reprodução apenas da parte alterada):

1 - Diante do exposto, julgo parcialmente procedente o pedido deduzido na inicial, condenando a ré Petrobrás S.A. e Katina Shipping Co. ao pagamento de indenização pelos danos causados ao meio ambiente em virtude do derramamento de petróleo, ocorrido em 13 de agosto 1991, em valor a ser apurado em liquidação por arbitramento, que deverá corresponder ao valor mínimo encontrado pela CETESB, facultando ao órgão ambiental o uso do trabalho científico "Proposta de Critério para Valoração Monetária de Danos Causados por Derramamentos de Petróleo ou de seus Derivados no Ambiente Marinho". Esse valor mínimo deve levar em consideração: (1) o volume de óleo derramado; (2) o grau de sensibilidade da área atingida; (3) a toxicidade do produto; (4) a persistência do produto no ambiente; e (5) a mortalidade de seres da fauna local, atingida .Esse "valor mínimo" será acrescido dos valores que não são objeto da referida "Proposta de Critério para Valoração Monetária de Danos Causados por Derramamentos de Petróleo ou de seus Derivados no Ambiente Marinho", da CETESB e que se referem a aspectos como, por exemplo: (1) custos de operações de contenção; (2) remoção ou neutralização dos produtos derramados; (3) prejuízos econômicos decorrentes da queda de atividades turísticas; (4) redução de atividades pesqueiras; (5) prejuízo à imagem e reputação do município; (6) transtorno 
causado aos munícipes; (7) interferência na forma de prestação de serviços públicos (interrupção de aulas em escolas, aumento dos atendimentos médicos...) etc. Os juros moratórios incidirão desde o(s) evento(s) danoso(s), conforme Súmula $n .^{\circ} 54$ do STJ.

\subsubsection{Rebocador Pégasus}

O caso consiste no derramamento de óleo ocorrido no dia 2 de maio de 2007, decorrente do naufrágio do rebocador "Pégasus", no canal de Santos entre o Forte Itapema e os Armazéns 12-15 do Porto de Santos, estimando-se entre 862 e 5.862 litros de óleo vazados no mar.

O MPF em litisconsórcio ativo com o MPSP ajuizou, em agosto de 2013, a Ação Civil Pública $n^{\circ}$ 0007249-47.2013.4.03.6104, na $1^{\text {a }}$ Vara da Justiça Federal de Santos/SP, contra as empresas Saveiros Camuyrano Serviços Marítimos S/A e Wilson Sons-Comércio, Indústria e Agência De Navegação Ltda. visando a condenação destas ao pagamento de indenização por danos ambientais.

O magistrado de primeiro grau julgou o pedido parcialmente procedente, em 19 de setembro de 2018, e condenou as rés ao pagamento de indenização por danos ambientais no valor de R \$372.141.55 24, com base nos seguintes fundamentos:

a) rejeitou a preliminar de ilegitimidade passiva da ré Wilson Sons pelos seguintes argumentos: o contrato social abarca as duas empresas, porquanto sócias pertencentes ao mesmo grupo econômico; a própria arguente Wilson Sons foi quem contratou a empresa Ecosorb para realizar trabalhos de contenção ao derramamento de óleo no mar; e os representantes da Wilson Sons participaram de inúmeras reuniões sobre o evento.

b) O dano ambiental restou verificado e a contaminação dele decorrente considerada "alta" ou "alarmante". Além disso, socioeconomicamente, o vazamento pode a afetar a população que vive da extração de recursos da região, a qual depende não só da boa qualidade das águas do mar, como da qualidade de seus frutos. Especialmente em relação à contaminação constatada nos arredores da Ilha Diana, é oportuno indicar que publicamente abrange área de mangue, sendo área de preservação permanente, de acordo com o artigo $4^{\mathrm{a}}$, inciso VII, do Código Florestal (Lei n ${ }^{\circ}$ 12.651, de 25 de maio de 2012);

c) $\mathrm{Na}$ fixação do quantum indenizatório, levou em consideração os seguintes fatores: as requeridas tomaram as providências que lhe cabiam logo após a constatação do dano ambiental; o laudo pericial judicial, que fixou várias balizas para a valoração do dano ambiental, tais como: 
- efíciência e rapidez dos procedimentos de contenção e recolhimentos;

- volume derramado;

- procedimentos adotados para a limpeza dos ambientes afetados, entre outros.

d) Incidência de correção monetária e juros (desde a data da citação) sobre o valor ora fixado; porém, sem condenação em custas e honorários advocatícios, em razão da sucumbência recíproca.

\subsubsection{Transpetro - Espírito Santo}

Este acidente foi decorrente de uma falha na operação do Terminal Norte Capixaba (TNC), uma unidade da Transpetro de armazenagem e escoamento de petróleo. A operação era de descarregamento do petroleiro, atividade não licenciada, e ocasionou o derramamento de aproximadamente 2 mil litros de petróleo. Ao todo, 6 quilômetros de ambientes de praia foram atingidos e a balneabilidade do mar no local foi temporariamente comprometida. A praia impactada, Praia do Degredo, fica 40 quilômetros ao sul do TNC, abrigando um importante ecossistema de restinga, além de sítios de desova de tartarugas marinhas ameaçadas de extinção. Sendo área de banhistas e pescadores. ${ }^{105}$

A Petrobras Transporte S/A (Transpetro) ajuizou ação anulatória de auto de infração contra o Instituto Estadual de Meio Ambiente e Recursos Hídricos (IEMA), e o magistrado de primeiro grau julgou o pedido improcedente. A Transpetro interpôs apelação contra sentença prolatada pelo Juízo da Vara da Fazenda Pública Estadual, Registros Públicos e Meio Ambiente de Cariacica a apelação cível nº 0025537-17.2010.8.08.

Nas razões de apelação, a recorrente afirmou, em síntese, que: (i) o Instituto Estadual de Meio Ambiente e Recursos Hídricos é incompetente para aplicar sanções por danos ambientais ocorridos em mar territorial; (ii) tratando-se de bem pertencente à União, somente o ente federal pode exercer o poder de polícia e aplicar, se for o caso, as penalidades cabíveis; (iii) a Lei Complementar no 97/1999 e a Lei Federal no 9.966/2000 atribuem competência exclusiva à Marinha do Brasil para implementar e fiscalizar o cumprimento das leis e regulamentos no mar e nas águas interiores; (iv) a União foi o primeiro ente a lavrar o auto de

${ }^{105}$ ESPÍRITO SANTO. Instituto Estadual de Meio Ambiente e Recursos Hídricos (IEMA). Transpetro é multada em mais de RS 6 milhões por acidente ambiental no Espírito Santo. Disponível em: $\leq$ https://iema.es.gov.br/transpetro-e-multada-em-mais-de-r-6-milhoes-p $>$. Acesso em: 16/12/2018. 
infração, por intermédio da Capitania dos Portos, não se podendo admitir a subsistência do auto lavrado pelo ente estadual, sob pena de bis in idem; (v) a notificação que deu início à contagem do prazo recursal na esfera administrativa foi nula, porque remetida a endereço incorreto, prejudicando seu direito de defesa, já que o recurso não foi conhecido por intempestividade; (vi) a emissão de laudo técnico deveria ter precedido à lavratura do auto de infração, uma vez que a dimensão do dano orienta a dosimetria da multa; (vii) a penalidade imposta pela autoridade estadual é desarrazoada, devendo ser reduzido o valor de $\mathrm{R} \$ 6.270 .000,00$, tendo em vista a imediata reparação do dano.

O Tribunal de Justiça do Espírito Santo (TJES) julgou o recurso parcialmente procedente e decidiu que: (i) a multa aplicada pela Capitania dos portos, em decorrência de derramamento de óleo, não exclui a possibilidade de aplicação de multa pelo IEMA, pois a mesma conduta pode gerar danos a diferentes bens jurídicos. Não há que se falar, portanto, em bis in idem, como sustentado na tese defendida pela Transpetro; (ii) a Transpetro realizou ações efetivas para contenção e reparação do dano, tendo êxito na correção da conduta degradadora, razão pela qual o valor da multa aplicada pelo IEMA foi reduzido para R $200.000,00$, preservando assim a razoabilidade e proporcionalidade da condenação. ${ }^{106}$

O IEMA opôs embargos de declaração contra o acórdão acima relatado. O TJES conheceu e deu parcial provimento aos embargos para suprir a omissão relativa à circunstância agravante da reincidência específica e majorar a multa ambiental para $\mathrm{R} \$ 600.000,00 .{ }^{107}$

A Petrobras opôs embargos de declaração contra a decisão anterior. O TJES, desta vez, conheceu os agravos e lhes negou provimento por considerar que não havia obscuridade, contradição ou omissão na decisão embargada. ${ }^{108}$

\subsubsection{Navio Tanque Norma}

O caso se refere ao acidente ocorrido em 18 de outubro de 2001, no qual o navio tanque N/T Norma, de bandeira e propriedade da Petrobras, carregando 22 milhões de litros de nafta petroquímica, colidiu com o local conhecido como "Pedra da Palangana", quando estava em movimento defronte ao cais do Porto de Paranaguá, encalhando naquele ponto. A colisão

106 TJES. Apelação Cível: AC nº 0025537-17.2010.8.08. Rel. Samuel Meira Brasil Junior. $3^{\text {a }}$ Câmara Cível.DJ: $16 / 12 / 2016$.

107 TJES. Embargos de Declaração na Apelação Cível: EDcl em AC nº 0025537-17.2010.8.08. Rel. Samuel Meira Brasil Junior. $3^{\mathrm{a}}$ Câmara Cível. DJ:27/03/2018.

108 TJES. Embargos de Declaração nos Embargos de Declaração na Apelação Cível: EDcl nos EDcl da AC nº 0025537-17.2010.8.08. Rel. Samuel Meira Brasil Junior. 3ª Câmara Cível. DJ: 03/07/2018. 
resultou no vazamento do citado produto, contaminando as águas da baía, num raio de 1,5 km de extensão, a partir do navio, existindo, inclusive, risco de explosão. Em razão do acidente foi proibida a atividade pesqueira nas baías de Paranaguá e Antonina, pelo IBAMA, por meio de Portaria publicada no dia seguinte ao acidente.

Foram selecionados diversos julgados em que o TJPR se manifestou em apelações cíveis interpostas pela Petrobras contra sentenças proferidas nos autos de Ações de Indenização por Danos Morais ajuizadas por pescadores, julgando procedentes os pedidos iniciais para condenar a empresa ao pagamento da quantia (variando entre $R \$ 2.000,00$ e $R \$ 3.000,000$ ) a título de danos morais.

No julgamento de tais ações, o TJPR negou provimento aos recursos da Petrobras, decidindo que: ${ }^{109}$ (i) é suficiente para a comprovação da condição de pescador profissional a apresentação de carteira de registro de pescador profissional, expedida pelo Ministério da Agricultura e do Abastecimento ou pelo órgão público competente para tanto; (ii) aplicaria de teoria do risco integral (afastando a teoria do risco criado), sendo inadmissível a exclusão de responsabilidade por fato de terceiro; (iii) houve dano moral em razão da efetiva interdição da pesca e proibição de comercialização dos produtos pelo pescador, tendo como causa o acidente; (iv) manteria o valor fixado, por entender suficiente para arcar com as funções ressarcitória e repreensora da indenização;(v) haveria incidência de juros moratórios a partir da data do evento danoso, conforme Súmula 54 do STJ.

Vale observar que, em outros casos, o TJPR aplicou o mesmo entendimento para o pleito de pescador profissional requerendo condenação somente em danos materiais, ou cumulativamente danos morais e materiais. ${ }^{110}$

Em outro caso, o TJPR manteve o entendimento acima mencionado, mas como o julgamento se deu após o caso paradigma do STJ sobre a matéria (REsp nº 1.114.398/PR), julgado sob o rito de recursos repetitivos, o Tribunal paranaense mencionou tal julgado como fundamento para sua decisão. ${ }^{111}$

109 TJPR. Apelação Cível: AC nº 691.230-1. Rel. D’Artagnan Serpa Sá. 1ª Vara Cível. Julgado em 18/11/2010. TJPR. Apelação Cível: AC nº 694.173-3. Rel. D’Artagnan Serpa Sá. $1^{a}$ Vara Cível. Julgado em 23/09/2010. TJPR. Apelação Cível: AC nº 696.702-2. Rel. D’Artagnan Serpa Sá. 1ª Vara Cível. Julgado em 23/09/2010. ${ }^{110}$ TJPR. Apelação Cível: AC nº 821.625-3. Rel. D’Artagnan Serpa Sá. 1 ${ }^{a}$ Vara Cível. Julgado em 17/11/2011. TJPR. Apelação Cível: AC nº 956.355-7. Rel. D’Artagnan Serpa Sá. $1^{a}$ Vara Cível. Julgado em 18/10/2012. 111 TJPR. Apelação Cível: AC nº 0014849-21.2004.8.16.0129. Rel. Rafael Vieira de Vasconcellos Pedroso. $1^{\text {a }}$ Vara Cível da Comarca de Paranaguá. Julgado em 16/08/2018. 
Em mais um caso peculiar, também tratando de ação de indenização por danos materiais ajuizada por pescador profissional, o TJPR também aplicou a teoria do risco integral, mas deu solução diversa ao caso, (i) determinando ser devida indenização por lucros cessantes (ganhos que o pescador deixou de auferir) e (ii) fixando a indenização por danos materiais em um salário mínimo, pelo período de 24 meses (ou três ciclos), tempo mínimo para recomposição da vida marinha. ${ }^{112}$

Em caso mais recente, o TJPR não condenou a Petrobras a arcar com danos morais e materiais requeridos pelo autor de ação de indenização, aplicando o julgado paradigma do Superior Tribunal de Justiça (REsp n ${ }^{\circ} 1.114 .398 / P R$ ), segundo o qual, para a comprovação do efetivo exercício da pesca à época do acidente, faz-se necessária a presença concomitante de: (i) Carteira de Pescador Profissional, cuja a primeira inscrição remonte período anterior ao acidente; além da (ii) demonstração de que a parte recebeu atenção do poder público devido a consequências profissionais do acidente. No caso, o TJPR verificou que o apelante realizou o primeiro registro como Pescador Profissional perante o Ministério da Agricultura e Abastecimento em 15 de outubro de 1999, ou seja, em data anterior ao acidente ambiental ocorrido em 18 de outubro de 2001. Entretanto, conforme informações prestadas pelo Ministério do Trabalho, o Apelante não recebeu o seguro-defeso no ano de 2001, condição necessária para o reconhecimento do exercício da pesca profissional concomitante à época do acidente. Considerou também insuficiente prova testemunhal, pois ela afirmou que o apelante pescava em região diversa da afetada, e auferia renda trabalhando no sítio da família. ${ }^{113}$

\subsubsection{Norsul}

Este evento, ocorrido em janeiro de 2008, teve inicio com o vazamento de óleo e outros produtos contaminantes de uma barcaça na baía de Babitonga, em São Francisco do Sul, Santa Catarina, causando impactos sociais, ambientais e econômicos.

O Tribunal de Justiça do Estado de Santa Catarina (TJSC) possui diversos julgados referentes a pedidos de indenização ajuizados por pescadores no caso Norsul, que trata do vazamento de 107 toneladas de óleo do comboio oceânico da Companhia de Navegação Norsul

112 TJPR. Apelação Cível: AC nº 821.671-5. Rel. Francisco Luiz Macedo Junior. $1^{\text {a }}$ Vara Cível da Comarca de Paranaguá. Julgado em 20/10/2011.

TJPR. Embargos de Declaração: EDcl n 475.312-4. Rel. Carvílio da Silveira Filho. 2 ${ }^{\mathrm{a}}$ Vara Cível da Comarca de Paranaguá. Julgado em 07/02/2013.

113 TJPR. Apelação Cível: AC nº 011887-25.2004.8.16.0129. Rel. Alexandre Barbosa Fabiani. $8^{a}$ Vara Cível. Julgado em 29/11/2018. 
Ltda., contratada pela Arcelormittal Brasil S/A para transportar bobinas de aço até o porto situado no município e comarca de São Francisco do Sul/SC.

Visando dar uniformidade ao julgamento das múltiplas ações indenizatórias, o TJSC firmou jurisprudência no sentido de reconhecer a prevenção do órgão julgador para o qual foi distribuído o primeiro recurso de apelação, em razão da conexão entre os litígios, que, apesar de serem distintos, possuem objetos idênticos. O TJSC ressaltou a necessidade de se prezar por decisões congruentes, em cumprimento ao art. 54 do seu Regimento Interno, dando primazia à segurança jurídica aos jurisdicionados. ${ }^{114}$

Quanto às soluções dadas às questões materiais, optou-se aqui por dividir as inúmeras decisões em blocos de julgados (pois muitas apresentam o mesmo entendimento).

Em um primeiro bloco, o TJSC decidiu-seque: ${ }^{115}$ (i) é suficiente para legitimar o pescador à pretensão de auferir indenização oriunda de dano ambiental coletivo os documentos (carteira profissional expedida antes do acidente e registro de embarcação artesanal), que comprovam que, à época dos fatos, estava oficialmente autorizado a praticar a pesca profissional no ecossistema atingido, o que foi corroborado por prova testemunhal; (ii) não há cerceamento de defesa quando o julgamento antecipado da lide se pautar em elementos que são necessários e suficientes para a convicção do julgador, dando primazia ao princípio da razoável duração do processo; (iii) faria aplicação da teoria do risco integral na responsabilidade civil ambiental, tanto no plano coletivo (danos a interesses coletivos ou difusos) como no plano individual (danos morais e materiais individuais); (iv) há legitimidade passiva da proprietária da carga transportada, porquanto concorreu indiretamente para a ocorrência do dano ambiental, enquadrando-se no conceito de poluidor do art. $3^{\circ}$, IV da PNMA;(v) incide os lucros cessantes

\footnotetext{
${ }^{114}$ TJSC. Apelação Cível: AC nº 2012.015604-3. Rel. Jorge Luis Costa Beber. $4^{\text {a }}$ Câmara de Direito Civil. Julgado em 13/08/2012.

TJSC. Apelação Cível: AC nº 2012.008131-3. Rel. Jorge Luis Costa Beber. $4^{a}$ Câmara de Direito Civil. Julgado em 13/08/2012.

TJSC. Apelação Cível: AC no 2012.007073-6. Rel. Victor Ferreira. 4a Câmara de Direito Civil. Julgado em 08/04/2013.

115 TJSC. Apelação Cível: AC nº 2013.035004-6. Rel. João Batista Góes Ulysséa. 2 ${ }^{\mathrm{a}}$ Câmara Cível. Julgado em 20/08/2013.

TJSC. Apelação Cível: AC nº 2013.021367-6. Rel. João Batista Góes Ulysséa. 2 $2^{\text {a }}$ Câmara Cível. Julgado em 20/08/2013.

TJSC. Apelação Cível: AC nº 2012.016763-7. Rel. João Batista Góes Ulysséa. 2 $2^{\mathrm{a}}$ Câmara Cível. Julgado em 20/08/2013.

TJSC. Apelação Cível: AC nº 2012.009360-0. Rel. João Batista Góes Ulysséa. 2 $2^{\text {a }}$ Câmara Cível. Julgado em 20/08/2013.

TJSC. Apelação Cível: AC nº 2012.007064-0. Rel. João Batista Góes Ulysséa. 2 $2^{\text {a }}$ Câmara Cível. Julgado em 20/08/2013.
} 
(fixados em um salário mínimo por mês) de um para três anos, pois é o tempo em que a Baía da Babitonga levaria para se recuperar, desde a data do evento danoso; (vi) há dano moral devido a aflição do pescador artesanal que retira o sustento de sua família do ecossistema violentado negligentemente em razão do derramamento de óleos e demais substâncias químicas poluidoras; (vii) o quantum da indenização por abalo à moral deve ser estipulado levando em consideração os seguintes fatores: (a) proporcionar ao ofendido a satisfação do dano sofrido, levando-se em conta sua condição social e econômica; (b) a condição social e econômica do ofensor obrigado; (c) não ensejar obtenção de vantagem excessiva, a teor do que prescreve o art. 884 do Código Civil.

Em um segundo bloco, há pequena variação para o primeiro, com a única diferença de que se determinou que os lucros cessantes não incidirão no período em que o autor recebe seguro desemprego em razão da pesca no período de defeso, pois, em tais meses, não experimenta prejuízo em razão da diminuição da atividade de pesca. ${ }^{116}$

No terceiro bloco de julgados, o TJSC manifestou os seguintes entendimentos ${ }^{117}$ : (i) que aplicaria a teoria do risco integral na responsabilidade civil ambiental, obrigando solidariamente os entes da mesma cadeia reprodutiva. Assim, reconheceu expressamente a legitimidade passiva da empresa transportadora (Companhia de Navegação Norsul Ltda.), pois intimamente ligada à fabricante, pois realiza a tarefa para esta de escoar, em grande escala e em via marítima, a produção, e da empresa proprietária da carga que contratou a transportadora (Arcelor Mittal Brasil S/A); (ii) os lucros cessantes seriam reconhecidos em razão da diminuição do volume e desvalorização do preço do pescado. Porém, eles devem ser apurados (valor e duração) em fase de liquidação de sentença; (iii) que não havia comprovação de danos

116 TJSC. Apelação Cível: AC nº 2013.039462-2. Rel. Gilberto Gomes de Oliveira. 2ª Câmara de Direito Civil. Julgado em 25/07/2013.

TJSC. Apelação Cível: AC no 2013.029909-2. Rel. Gilberto Gomes de Oliveira. 2a Câmara de Direito Civil. Julgado em 11/07/2013.

117 TJSC. Apelação Cível: AC nº 2013.046349-1. Rel. Ronei Danielli. 6a Câmara de Direito Civil. Julgado em 10/12/2013.

TJSC. Apelação Cível: AC nº 2013.041498-6. Rel. Ronei Danielli. 6ª Câmara de Direito Civil. Julgado em $15 / 08 / 2013$.

TJSC. Apelação Cível: AC nº 2013.032911-3. Rel. Ronei Danielli. 6a Câmara de Direito Civil. Julgado em 18/07/2013.

TJSC. Apelação Cível: AC no 2013.020769-7. Rel. Ronei Danielli. 6a Câmara de Direito Civil. Julgado em 18/07/2013.

TJSC. Apelação Cível: AC no 2012.008077-5. Rel. Ronei Danielli. 6 ${ }^{\mathrm{a}}$ Câmara de Direito Civil. Julgado em 18/07/2013.

TJSC. Apelação Cível: AC no 2012.006972-6. Rel. Ronei Danielli. 6a Câmara de Direito Civil. Julgado em $18 / 07 / 2013$. 
emergentes, pois não demonstrada efetiva diminuição patrimonial, considerando-se sua prévia situação econômica em comparação à atual; (iv) que se reconhecia dano moral, pois o acidente não apenas ameaça a subsistência do pescador, mas também seu modo de vida; (v) que, na fixação do quantum a título de danos morais, deve-se levar em conta os critérios de razoabilidade e proporcionalidade em observância às circunstâncias em que o ato ilícito foi cometido, às consequências da ofensa ao lesado, o grau de culpa do ofensor e à situação econômica das partes, resultando em verba que represente um desestímulo ao lesante ao mesmo tempo em não pode causar enriquecimento ilícito àquele que suportou o dano. Mantido o valor de R \$ 12.000,00; (vi) que juros moratórios devem incidir desde a data do evento danoso, como propõe a Súmula 54 do STJ.

O quarto bloco é uma pequena variação do segundo. Neste, o TJPR manifestou os mesmos entendimentos, com apenas uma diferença: considerou que os lucros cessantes foram suficientemente reparados pelo recebimento de benefício previsto no Termo de Ajustamento de Conduta na ação civil pública $n^{\circ}$ 2008.72.01.000630-2, aforada pelo Ministério Público Federal e Ministério Público de Santa Catarina. ${ }^{118}$

Em um quinto bloco, o TJSC manifestou os mesmos entendimentos que o terceiro grupo, com a única diferença de que fixou previamente os lucros cessantes em 12 salários mínimos vigentes à época do acidente e minorou o valor indenizatório, a título de danos morais em $\mathrm{R} \$ 6.540,00$, devendo ainda ser deduzido o valor recebido $(\mathrm{R} \$ 2.700,00)$ recebido pelo autor em Ação Civil Pública na Justiça Federal. ${ }^{119}$

\footnotetext{
118 TJSC. Apelação Cível: AC nº 2013.037744-4. Rel. Ronei Danielli. 6a Câmara de Direito Civil. Julgado em 18/07/2013.

119 TJSC. Apelação Cível: AC n 2013.045499-7. Rel. Saul Steil. 3 ${ }^{\text {a }}$ Câmara de Direito Civil. Julgado em 27/08/2013.

TJSC. Apelação Cível: AC nº 2013.039507-1. Rel. Saul Steil. $3^{a}$ Câmara de Direito Civil. Julgado em 03/09/2013. TJSC. Apelação Cível: AC ñ 2013.038064-7. Rel. Saul Steil. $3^{\text {a }}$ Câmara de Direito Civil. Julgado em 06/08/2013. TJSC. Apelação Cível: AC nº 2013.034898-6. Rel. Saul Steil. $3^{a}$ Câmara de Direito Civil. Julgado em 03/09/2013. TJSC. Apelação Cível: AC nº 2013.032971-1. Rel. Saul Steil. $3^{a}$ Câmara de Direito Civil. Julgado em 27/08/2013. TJSC. Apelação Cível: AC nº 2013.029910-2, Rel. Saul Steil, $3^{a}$ Câmara de Direito Civil. Julgado em 18/06/2013. TJSC. Apelação Cível: AC nº 2013.012858-0. Rel. Saul Steil. $3^{a}$ Câmara de Direito Civil. Julgado em 03/09/2013. TJSC. Apelação Cível: AC nº 2013.002279-0. Rel. Saul Steil. $3^{a}$ Câmara de Direito Civil. Julgado em 14/05/2013. TJSC. Apelação Cível: AC nº 2012.089148-4. Rel. Saul Steil. $3^{a}$ Câmara de Direito Civil. Julgado em 18/06/2013. TJSC. Apelação Cível: AC nº 2012.063458-5. Rel. Saul Steil. $3^{\text {a }}$ Câmara de Direito Civil. Julgado em 30/10/2012. TJSC. Apelação Cível: AC nº 2012.056621-3. Rel. Saul Steil. $3^{a}$ Câmara de Direito Civil. Julgado em 06/08/2013. TJSC. Apelação Cível: AC nº 2012.026480-7. Rel. Saul Steil. $3^{a}$ Câmara de Direito Civil. Julgado em 24/09/2013. TJSC. Apelação Cível: AC nº 2012.016605-1. Rel. Saul Steil. $3^{a}$ Câmara de Direito Civil. Julgado em 02/10/2012. TJSC. Apelação Cível: AC nº 2012.016537-2. Rel. Saul Steil. $3^{a}$ Câmara de Direito Civil. Julgado em 12/06/2012. TJSC. Apelação Cível: AC nº 2012.016460-0. Rel. Saul Steil. $3^{\text {a }}$ Câmara de Direito Civil. Julgado em 26/06/2012. TJSC. Apelação Cível: AC nº 2012.016330-9. Rel. Saul Steil. $3^{a}$ Câmara de Direito Civil. Julgado em 18/07/2013. TJSC. Apelação Cível: AC nº 2012.012397-2. Rel. Saul Steil. $3^{a}$ Câmara de Direito Civil. Julgado em 05/02/2013.
} 
O sexto bloco contempla interessante decisão que reconheceu divergência de soluções entre diferentes Câmaras do TJSC. Nos julgamentos realizados na Segunda Câmara de Direito Civil, os lucros cessantes foram majorados de um salário mínimo pelo período de 1 ano, para um período de 3 anos e os danos morais majorados para R \$30.000,00. Já na Sexta Câmara de Direito Civil, em relação aos lucros cessantes foi afastado o salário mínimo como base de cálculo e relegada a apuração para a liquidação de sentença, enquanto os danos morais foram majorados para $\mathrm{R} \$ 12.000,00$.

Considerando-se que todos os julgamentos são decorrentes do mesmo fato, o Tribunal suspendeu o julgamento do processo e instaurou, de ofício, incidente de uniformização de jurisprudência, com o encaminhamento dos autos ao egrégio Grupo de Câmaras deste Tribunal, órgão competente de acordo com o artigo 158 do seu Regimento Interno. ${ }^{120}$

\subsection{Conclusões parciais}

A análise da jurisprudência brasileira atinente aos derramamentos de óleo no mar mostra-se essencial, não somente para se compreender as formas com que o judiciário usualmente resolve os conflitos decorrentes dos incidentes, mas, principalmente, para que seja traçado um panorama quanto a três aspectos:(i) tipos de derramamentos que chegam ao judiciário; (ii) compreensão e reconhecimento pelos magistrados acerca dos diferentes tipos de danos resultantes dos derramamentos; (iii) formas de reparação de danos determinadas nas decisões.

Com relação ao primeiro aspecto, os julgados analisados no presente capítulo se restringiam, em sua grande maioria, a derramamentos de proporções significativas. Até mesmo na primeira parte da pesquisa, direcionada por palavras-chave abrangentes, sem filtros de casos específicos, não foram verificadas decisões abrangendo pequenos volumes de óleo derramados, tão pouco apurando eventuais responsáveis por manchas órfãs. Ou seja, pode-se concluir que

TJSC. Apelação Cível: AC nº 2012.008311-1. Rel. Saul Steil. $3^{a}$ Câmara de Direito Civil. Julgado em 05/06/2012. TJSC. Apelação Cível: AC nº 2012.008306-3. Rel. Saul Steil. $3^{a}$ Câmara de Direito Civil. Julgado em 05/06/2012. TJSC. Apelação Cível: AC nº 2012.008131-3. Rel. Saul Steil. $3^{a}$ Câmara de Direito Civil. Julgado em 02/10/2012. TJSC. Apelação Cível: AC nº 2012.007126-4. Rel. Saul Steil. $3^{a}$ Câmara de Direito Civil. Julgado em 06/08/2013. TJSC. Apelação Cível: AC nº 2012.007073-6. Rel. Saul Steil. $3^{a}$ Câmara de Direito Civil. Julgado em 11/06/2013. TJSC. Apelação Cível: AC nº 2012.005251-8. Rel. Saul Steil. $3^{a}$ Câmara de Direito Civil. Julgado em 19/06/2012. TJSC. Apelação Cível: AC nº 2012.003881-7. Rel. Saul Steil. $3^{\text {a }}$ Câmara de Direito Civil. Julgado em 13/08/2013. 120 TJSC. Apelação Cível: AC nº 2013.041385-0. Rel. Saul Steil. $3^{\text {a }}$ Câmara de Direito Civil. Julgado em 03/09/2018. 
chegam à justiça brasileira apenas os derramamentos mais expressivos, fato que ficará mais claro após análise dos próximos capítulos.

Apesar das manchas órfãs, em conjunto com os pequenos derramamentos serem os mais frequentes na costa brasileira, responsáveis por danos cumulativos e crônicos, nos primeiros casos muitas vezes empresas de maior porte, localizadas no entorno das manchas, acabam assumindo sua remediação. Já nos segundos casos, por serem dificilmente detectados e fiscalizados, acabam passando impunes, ou seja, não chegam a ser apuradas no juridiário, corroborando com as constatações acima apontadas.

Nesse sentido, observa-se desde já a necessidade de que políticas públicas e investimentos sejam realizados para que haja uma maior fiscalização e rigor no trato dos derramamentos menos expressivos em volume e dimensões.

Já em relação ao segundo aspecto, cabe a ressalva que o magistrado deve se limitar aos fatos apresentados a ele. Ou seja, o não reconhecimento de algum dano significativo pode ocorrer pelo simples fato de não ter sido apresentado pelo autor em suas alegações, ou por não ter sido abrangido em eventual fase pericial.

De qualquer forma, a análise de jurisprudência acaba sendo um olhar sintético acerca do que ocorreu ao longo de ações judiciais. Assim, foi possível observar que os julgados se limitam a três formas abrangentes de danos: dano ambiental, dano patrimonial, e dano extrapatrimonial. Sendo que, na grande maioria das decisões, não há o reconhecimento do dano extrapatrimonial ambiental propriamente dito, ligado à perda de qualidade de vida (vide capítulo 5), mas sim, do dano moral tradicionalmente contextualizado pelo Direito Civil.

Com relação aos danos ambientais, além de terem sido por vezes confundidos com danos patrimoniais ou materiais, foram especificados emraros julgados, mas apenas no tocante à identificação de alguns dos ambientes afetados, com maior destaque para praias e manguezais.

Por fim, com relação ao terceiro aspecto, a partir do momento em que não há uma identificação adequada de todos, ou da maior parte dos danos que decorreram de um derramamento, a definição das medidas de reparação torna-se prejudicada. Dessa forma, praticamente em todos os julgados há a determinação de pagamento de indenização, geralemente destinada a fundos de interesses difusos, como medida de reparação de danos. Muitos deles foram baseados na metodologia criada pela CETESB (abordada no capítulo 8). Não foi observado nenhum julgado que se restringisse a determinar a adoção de medidas técnicas de reparação dos danos, buscando a recuperação direta dos ambientes degradados. 
Conforme será defendido ao longo do presente trabalho, acredita-se que o pagamento de indenizações, em virtude de danos ambientais, não atende aos reais fins da reparação de danos conceituada no Direito Civil Ambiental, qual seja: a busca do retorno ao ambiente anteriormente impactado.

Como alternativa à tradicional solução de conflitos realizada por meio da determinação de pagamento de indenizações aos fundos, por meio do presente estudo de jurisprudência, foi possível analisar algumas ações judiciais cujo desfecho contou com a celebração de acordos, em grande parte sendo Termos de Ajustamento de Conduta (TACs).

Importante desde já ressaltar que, o presente capítulo apresentou as obrigações contidas nos TACs analisados de forma detalhada, justamente para se dar ênfase prática às formas de reparação de danos alternativas à mera indenização. Nota-se que o próprio Termo de Ajustamento de Conduta permite que a destinação dos valores seja direcionada a ações específicas, que possam trazer benefícios efetivos aos ambientes afetados. Na presente tese, muito se discutirá a respeito dos mecanismos tradicionais de destinação de verbas indenizatórias. Diante das análises dos casos práticos solucionados por meio de Termos de Ajustamento de Conduta, não restam dúvidas de que tal via se mostra infinitamente mais benéfica ao meio ambiente do que os valores indenizatórios depositados em fundos de interesses difusos, além de trazer maior celeridade nas soluções jurídicas dos derramamentos.

Outro ponto positivo dos acordos é que, por meio deles, parte dos valores arbitrados a título de indenização podem ser previamente destinados às medidas de prevenção de danos, ou mitigadoras, como foi possível observar em diversos TACs acima relatados. No caso da Transpetro, por exemplo, foram adotadas medidas para detecção de óleo no mar, como parte de um Plano de Melhorias para a Segurança Ambiental das Atividades do Terminal, que foi implementado graças ao acordo realizado.

Entretanto, deve-se compreender que as obrigações dos acordos não podem ser decidias sem parâmetros. Devem sempre ser priorizadas medidas que visem à melhoria dos ambientes afetados, ou à melhoria da qualidade de vida da população afetada pelos derramamentos. Entende-se que, primeiramente, deve-se esgotar as possibilidades de investimentos em ambas as categorias, tanto de forma direta, a exemplo de campanhas de monitoramento dos ambientes afetados, ou programas de educação para populações caiçaras, quanto indiretas, a exemplo de projetos macro de preservação de manguezais ao longo do Brasil, como se verificou no caso do acordo realizado em decorrência do acidente ocorrido com o Poliduto Olapa, no Paraná. Assim, apenas o excedente dos valores previstos a título de reparação deveriam ser direcionados a 
outros programas, mesmo que ambientais, mas que não possuam ligação nenhuma com o incidente ocorrido.

Essa crítica merece ser feita desde já, pois, como sera verificado no capítulo 09, o sistema tradicional de fundos de interesses difusos, ao receber indenizações de condenações judiciais por derramamentos de óleo no mar já destinam grande parte das verbas para projetos sem relação nenhuma com os ambientes afetados. Os acordos, a exemplo dos TACs, devem ser inovadores e vistos como uma saída ambientalmente mais adequada do que os tradicionais fundos. 


\section{LEGISLAÇÃO INTERNACIONAL E NACIONAL}

\subsection{Legislação Internacional}

\subsubsection{Dificuldades na aplicação prática}

Conforme já exposto, a presente tese tratará da responsabilidade civil por derramamentos de óleo no mar no Brasil. Por esse motivo, pode causar estranhamento o presente capítulo ser apresentado logo no início do trabalho, antes mesmo da própria legislação brasileira. Pois bem, cumpre de pronto esclarecer que a temática central aqui tratada é objeto de inúmeras convenções e tratados internacionais, dos quais o país é signatário (ou deveria ser). Com isso, boa parte da legislação nacional, das formas de valoração dos danos decorrentes dos derramamentos e até mesmo dos seguros que apresentam coberturas aos acidentes foram influenciados por normas internacionais, ou delas derivam diretamente.

O conhecimento e a avaliação da legislação pertinente aos derramamentos de óleo no mar são primordiais para o presente trabalho, pois, antes mesmo de se analisar criticamente a aplicação da responsabilidade civil preventiva e reparatória no Brasil, é necessário o conhecimento dos instrumentos legais disponíveis para tanto.

Inicialmente, cumpre destacar que há dificuldade em se aplicar as convenções e tratados na prática jurídica por alguns motivos, dos quais destacam-se: (i) o desconhecimento das convenções e tratados pelos juristas, principalmente, ao lidarem com um tema tão específico; e (ii) a dificuldade de interpretação e adaptação dos textos internacionais à realidade territorial brasileira, que apresenta um litoral de grande dimensão, cercado por ecossistemas diversificados e peculiares. Ambos os fatores apontados acabam gerando certa insegurança na aplicação das normas internacionais às situações de poluição por óleo no Brasil.

Normalmente, neste tema, a forma mais acessível de consulta aos tratados e convenções se dá pelo acesso aos Decretos brasileiros, que internalizam as normas mundiais. Entretanto, esses Decretos trazem apenas a tradução dos textos ratificados pelo país, sem apresentarem maiores explicações sobre aplicação ou origem das normas.

Da mesma forma, os estágios precisos de assinatura, ratificação, existência de anexos, apêndices, atualizações e ressalvas referentes aos tratados e convenções não são esclarecidos e atualizados constantemente nas plataformas de informações brasileiras. Não há uma unificação de informações fornecidas pelos Ministério do Meio Ambiente, Marinha do Brasil, Ministério das Relações Internacionais, Ministério da Fazenda e outros institutos locais. Por meio de pesquisas realizadas nas páginas dos referidos órgãos, disponibilizadas na internet, foi possível 
constatar certa discrepância de suas informações, que, além disso, encontram-se muitas vezes desatualizadas.

Vale ainda destacar que, nem mesmo a plataforma oficial de legislação brasileira, acessada no site oficial do Planalto, na internet, ${ }^{121}$ apresenta resultados precisos para buscas que incluam palavras-chave como "óleo", "petróleo", "derrames", "vazamentos", e "derramamentos". Para o levantamento da legislação nacional e das convenções e tratados ratificados e internalizados por Decretos, foi necessário o acesso às plataformas pagas de legislação brasileira.

Devido a esse fato, para a elaboração do presente capítulo, optou-se pela consulta aos textos de normas internacionais em suas versões originais, em idioma inglês, retiradas de sites de internet estrangeiros oficiais, a exemplo do site da International Maritime Organization (IMO). ${ }^{122}$ Observou-se que as convenções e tratados apresentam textos complexos, com definições de competências, anexos, atualizações e apêndices. Para que haja o entendimento pleno dos textos principais, é necessário conhecer o contexto de sua gênese, além do cenário de discussões que os norteiam.

Sendo assim, foi possível observar na prática a dificuldade que um jurista pode encontrar ao desejar se embasar em tratados internacionais para fundamentar teses e decisões que envolvam poluição por óleo no mar e na zona costeira. Por esse motivo, entendeu-se como pertinente a elaboração de um capítulo específico para tratados e convenções, inclusive a título de contribuição, para auxiliar e facilitar o acesso aos profissionais, da área do Direito e de outras áreas técnicas, na compreensão dos tratados e convenções relacionados aos derramamentos de óleo no mar.

\subsubsection{Tratados e Convenções Internacionais}

De um modo geral, a consciência internacional em relação ao meio ambiente foi sendo desenvolvida grande parte em resposta a grandes catástrofes. Em quase todas as áreas do Direito Ambiental foi necessária a ocorrência de danos severos para que se iniciasse a normatização das formas de reparação e prevenção. No âmbito do tema poluição marítima, especificamente por derramamento de óleo, também não foi diferente.

\footnotetext{
${ }^{121}$ Disponível em: $<$ http://www4.planalto.gov.br/legislacao/>. Acesso em: 01.09.2018.

${ }^{122}$ Disponível em: $<$ http://www.imo.org/en/About/Conventions/ListOfConventions/Pages/Default.aspx $>$. Acesso em: 01.09.2018.
} 
A preocupação com os danos ambientais decorrentes dos derramamentos de óleo foi demonstrada, mesmo que genericamente, a partir da Resolução de Luxemburgo, de $1937 .{ }^{123}$ Esta é considerada a primeira norma atinente à matéria, por introduzir o assunto das "Práticas Danosas para a Vida Marinha" entre seus dispositivos, citando como exemplos o petróleo e outras substâncias. $^{124}$

Apesar de ter permanecido por quinze anos como a principal norma a tratar de poluição marinha, a temática somente ganhou significativa importância com a ocorrência dos grandes acidentes, com destaque ao ocorrido com o Navio Torrey Canyon, em 1967, no Reino Unido. ${ }^{125}$ Mesmo antes desse evento, no entanto, em 1954, foi publicada a Convenção Internacional para Prevenção de Poluição no Mar por Petróleo, Oil Pollution Convention, (OILPOL), em 1954.

A história da evolução desses tratados e convenções está, de fato, intimamente atrelada aos grandes acidentes que resultaram em vazamentos de hidrocarbonetos nos oceanos. Isso porque, a repercussão das ocorrências foi expressiva ao ponto de despertar a necessidade de aprimoramento das normas internacionais sobre o tema.

No âmbito internacional, as principais convenções, tratados e acordos que versam sobre poluição por óleo foram desenvolvidas no âmbito da International Maritime Organization (IMO), ${ }^{126}$ Agência Internacional dedicada desde 1948 exclusivamente a assuntos relacionados a segurança marítima, eficiência da navegação e prevenção e controle da poluição marítima causada pelos navios. ${ }^{127}$

Importante ressaltar que o Brasil, além de ser Estado-membro da IMO, é signatário de algumas convenções relacionadas à derramamento de óleo. Entretanto, a temática é abrangida por uma infinidade de outros tratados e convenções. Buscando uma maior fidelidade a discussão aqui proposta, cujo foco principal é o território brasileiro, serão priorizadas as convenções e

${ }^{123}$ ROLIM, M. H. F. de S. Poluição Marítima por Óleo. Justitia, São Paulo, v.115, n.43, out./dez. 1981, p.134. ${ }^{124}$ ROLIM, M. H. F. de S. Poluição Marítima por Óleo. Justitia, São Paulo, v.115, n.43, out./dez. 1981, p.122. ${ }^{125}$ VAUGHAN, A. T. Canyon disaster: the UK's worst-ever oil spill 50 years on. The Guardian, London, March 18, 2017. Disponível em: <https://www.theguardian.com/environment/2017/mar/18/torrey-canyon-disaster-ukworst-ever-oil-spill-50tha-anniversary>.

BARKHAM, P. Oil Spills: Legacy of the Torrey Canyon. The Guardian, London, June 10, 2010.

${ }^{126}$ Uma descrição sobre a International Maritime Organization (IMO) pode ser encontrada em seu site oficial, na seção "What it is". Disponível em: < $\underline{\text { http://www.imo.org/en/About/Documents/What it is Oct } 2013 \text { Web.pdf> }}$. Acesso em: 02.02.2016.

${ }^{127}$ Uma rápida narrativa sobre história da organização pode também ser encontrada em seu site oficial, na seção "Brief History of IMO". Disponível em: $<\underline{\mathrm{http}} / / / \mathrm{www} . \mathbf{i m o . o r g} / \mathrm{en} /$ About/HistoryOfIMO/Pages/Default.aspx $>$. Acesso em: 01.02.2016. 
acordos adotados pelo Brasil, e apresentados de forma sucinta outros instrumentos normativos internacionais de relevância ao tema.

Grande parte dos tratados e convenções a seguir abordados não se restringem apenas aos derramamentos de óleo no mar, mas, de certa forma, abordam o tema, ao disporem sobre regras atinentes à embarcações, responsabilidades e poluição marinha de uma forma geral. Não se pretende, portanto, o desenvolvimento de uma abordagem exaustiva acerca do conteúdo de cada norma, visto que muitas delas apresentam inúmeros anexos e objetivos mais abrangentes do que o foco do presente trabalho.

Antes mesmo de se adentrar nas especificidades de cada tratado ou convenção aplicável a derramamentos por óleo no mar, é importante a identificação de quais são os principais diplomas normativos e o estágio de internalização pelo Brasil. A elaboração das tabelas abaixo foi realizada por meio de informações obtidas inicialmente em consulta aos relatórios apresentados no site oficial da IMO, e confirmadas posteriormente em buscas via website do Planalto - consideradas as fontes oficiais principais e, portanto, as mais seguras e atualizadas para o tema. Com relação às convenções, protocolos e anexos apresentados pela IMO, o Brasil ratificou, atualmente, 28 entre os 59 instrumentos disponíveis. A tabela a seguir reúne tais instrumentos para melhor sistematização:

Tabela 5- Principais convenções, protocolos e anexos ratificados pelo Brasil, segundo a IMO:

\begin{tabular}{|l|}
\hline \multicolumn{1}{|c|}{ CONVENTIONS } \\
\hline IMO Convention 48 \\
SOLAS Convention 74 \\
SOLAS Protocol 78 \\
LOAD LINES Convention 66 \\
TONNAGE Convention 69 \\
COLREG Convention 72 \\
CSC Convention 72
\end{tabular}

(continua) 
(conclusão)

\begin{tabular}{|l|}
\multicolumn{1}{|c|}{ CONVENTIONS } \\
STWC Convention 78 \\
SAR Convention 79 \\
IMSO Convention 76 \\
FACILITATION Convention 65 \\
MARPOL 73/78 (Annex I/II) \\
MARPOL 73/78 (Annex III) \\
MARPOL 73/78 (Annex IV) \\
MARPOL 73/78 (Annex V) \\
MARPOL Protocol 97 (Annex VI) \\
ANTI FOULING 2001 \\
SONDON Convention 72 \\
SATE Convention 88 \\
INTERVENTION Protocol 73 \\
CLC Convention 69
\end{tabular}

Entretanto, importante frisar que nem todos aqueles ratificados pelo Brasil tratam de derramamentos; e, por outro lado, há outros importantes instrumentos da IMO que tratam de derramamentos de óleo, mas que não foram recepcionados pela legislação brasileira. Ademais, 
além dos instrumentos indicados pela IMO, também foram identificados outros Tratados sobre o tema em pesquisa realizada via website do Planalto, conforme apresentado na tabela a seguir:

Tabela 6- Principais convenções internacionais aplicáveis aos derramamentos de óleo

\begin{tabular}{|c|c|c|}
\hline $\begin{array}{c}\text { CONVENÇÕES E } \\
\text { TRATADOS } \\
\text { INTERNACIONAIS }\end{array}$ & RATIFICADO PELO BRASIL? & STATUS \\
\hline $\begin{array}{l}\text { Convenção } \\
\text { Internacional à } \\
\text { Intervenção em Alto } \\
\text { Mar em casos de } \\
\text { Acidentes de } \\
\text { Poluição por Óleo - } \\
\text { International } \\
\text { Convention Relating } \\
\text { to Intervention on the } \\
\text { High Seas In Cases of } \\
\text { Oil Pollution } \\
\text { Casualties } \\
\text { (INTERVENTION } \\
\text { 69), 1969 }\end{array}$ & $\begin{array}{l}\text { 1. INTERVENTION } 69 \text { ratificada, sendo } \\
\text { promulgada pelo Decreto Federal } \mathrm{n}^{\circ} \\
6.478 / 2008 \text {. Texto aprovado pelo Decreto } \\
\text { Legislativo } \\
\mathrm{n}^{\circ} \\
305 / 2007 . \\
\text { 2. INTERVENTION } 73 \text { ratificada, sendo } \\
\text { promulgada pelo mesmo Decreto. Texto } \\
\text { aprovado pelo mesmo Decreto Legislativo. }\end{array}$ & 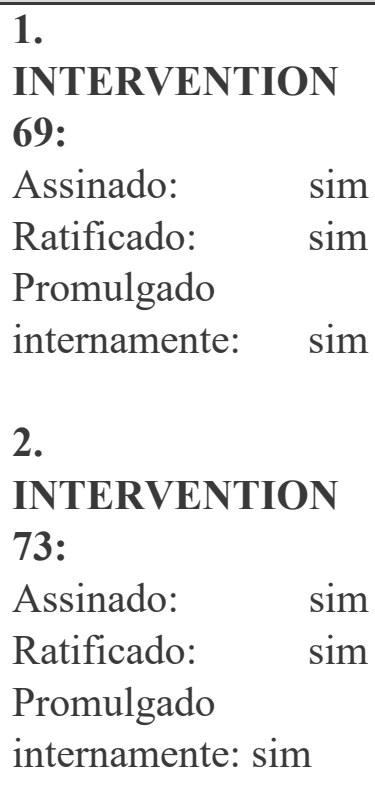 \\
\hline 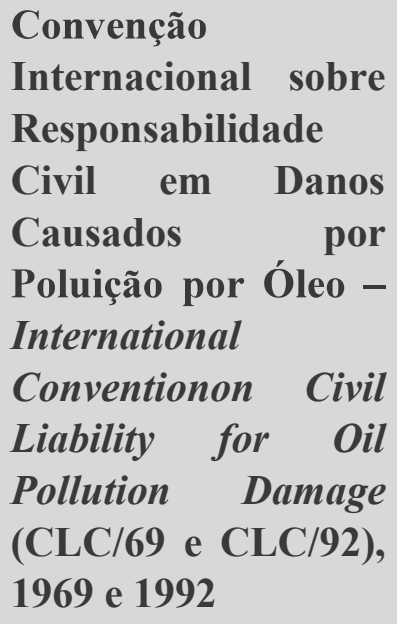 & $\begin{array}{l}\text { 1. CLC/1969 ratificada, sendo promulgada } \\
\text { pelo Decreto Federal } \mathrm{n}^{\circ} 79.437 / 1977 . \\
\text { Posteriormente, o Decreto Federal } \mathrm{n}^{\circ} \\
83.540 / 1979 \text { regulamenta a aplicação da } \\
\text { CLC/1969. Texto aprovado pelo Decreto } \\
\text { Legislativo } \\
\mathrm{n}^{\circ} \\
\text { 2. O Protocolo de } 92 \text { não foi ratificado, } \\
\text { conforme tabela da IMO e resultados dos } \\
\text { bancos de legislação federal. }\end{array}$ & $\begin{array}{ll}\text { 1. CLC } & \text { 69: } \\
\text { Assinado: } & \text { sim } \\
\text { Ratificado: } & \text { sim } \\
\text { Promulgado } & \\
\text { internamente: } & \text { sim } \\
\text { 2. CLC } & \text { 92: } \\
\text { Assinado: } & \text { não } \\
\text { Ratificado: } & \text { não } \\
\text { Promulgado } & \\
\text { internamente: não }\end{array}$ \\
\hline
\end{tabular}

(continua) 
(continuação)

\begin{tabular}{|c|c|c|}
\hline $\begin{array}{c}\text { CONVENÇÕES E } \\
\text { TRATADOS } \\
\text { INTERNACIONAIS }\end{array}$ & RATIFICADO PELO BRASIL? & STATUS \\
\hline $\begin{array}{l}\text { Convenção } \\
\text { Prevenção } \\
\text { Poluição } \\
\text { por Alijamento de } \\
\text { Resíduos e Outras } \\
\text { Matérias } \\
\text { International } \\
\text { Convention on the } \\
\text { Prevention of Marine } \\
\text { Pollution } \\
\text { Dumping of Wastes } \\
\text { and other Matter } \\
\text { (LC/72), 1972 }\end{array}$ & $\begin{array}{l}\text { 1. London Convention } 72 \text { ratificada, sendo } \\
\text { promulgada pelo Decreto Federal } \mathrm{n}^{\circ} \\
87.566 / 1982 \text {. Texto aprovado pelo Decreto } \\
\text { Legislativo } \\
\mathrm{n}^{\circ} \\
\text { 2. Posteriormente, as emendas aos Anexos da } \\
\text { LC/1972 foram ratificadas, sendo } \\
\text { promulgadas pelo Decreto Federal } \mathrm{n}^{\circ} \\
\text { 6.511/2008. Texto aprovado pelo Decreto } \\
\text { Legislativo } \mathrm{n}^{\circ} 303 / 2007 \text {. }\end{array}$ & $\begin{array}{ll}\text { Assinado: } & \text { sim } \\
\text { Ratificado: } & \text { sim } \\
\text { Promulgado } & \\
\text { internamente: sim }\end{array}$ \\
\hline $\begin{array}{l}\text { Convenção } \\
\text { Internacional para a } \\
\text { Prevenção da } \\
\text { Poluição proveniente } \\
\text { de Navios - } \\
\text { International } \\
\text { Convention for the } \\
\text { Prevention of } \\
\text { Pollution from Ships } \\
\text { (MARPOL 73/78), } \\
\text { 1973 e 1978 }\end{array}$ & $\begin{array}{l}\text { 1. MARPOL } 73 \text {, bem como seu Protocolo de } \\
78 \text {, suas Emendas de } 84 \text { e seus Anexos } \\
\text { Opcionais III, IV e V foram ratificados, } \\
\text { sendo promulgados pelo Decreto Federal } \mathrm{n}^{\circ} \\
2.508 / 1998 \text {. Textos aprovados, com } \\
\text { ressalvas, pelo Decreto Legislativo }{ }^{\circ} 4 / 1987 \\
\text { (Anexos III, IV e V). }\end{array}$ & $\begin{array}{ll}\text { Assinado: } & \text { sim } \\
\text { Ratificado: } & \text { sim } \\
\text { Promulgado } & \\
\text { internamente: } & \text { sim }\end{array}$ \\
\hline
\end{tabular}


(continuação)

\begin{tabular}{|c|c|c|}
\hline $\begin{array}{l}\text { CONVENÇÕES E } \\
\text { TRATADOS } \\
\text { INTERNACIONAIS }\end{array}$ & RATIFICADO PELO BRASIL? & STATUS \\
\hline $\begin{array}{l}\text { Convenção } \\
\text { Internacional para a } \\
\text { Salvaguarda da Vida } \\
\text { Humana no Mar - } \\
\text { Internationa } \\
\text { lConvention for the } \\
\text { Safetyof Life at Sea } \\
\text { (SOLAS 74), } 1974\end{array}$ & $\begin{array}{l}\text { 1. SOLAS } 74 \text { ratificada, sendo promulgada } \\
\text { pelo Decreto Federal } \mathrm{n}^{\circ} 87.186 / 1982 \text {. Texto } \\
\text { aprovado pelo Decreto Legislativo } \mathrm{n}^{\circ} \\
\text { 11/1980. } \\
\text { 2. Protocolo SOLAS } 78 \text { ratificado, sendo } \\
\text { promulgado pelo Decreto Federal } \mathrm{n}^{\circ} \\
\text { 92.610/1986. Texto aprovado pelo Decreto } \\
\text { Legislativo } \mathrm{n}^{\circ} \\
\text { 3. Texto do Protocolo SOLAS } 88 \text { aprovado } \\
\text { pelos Decretos Legislativos } \mathrm{n}^{\circ} 978 / 2009 \text { e } \mathrm{n}^{\circ} \\
\text { 562/2010. Contrariamente ao que indicado } \\
\text { pela tabela IMO, não foi localizado, no banco } \\
\text { de legislação federal, resultados sobre a } \\
\text { ratificação e internalização da Convenção. } \\
\text { 4. SOLAS } 96 \text { não foi ratificada, conforme } \\
\text { tabela da IMO. }\end{array}$ & $\begin{array}{lr}\text { 1. SOLAS } & \mathbf{7 4 :} \\
\text { Assinado: } & \text { sim } \\
\text { Ratificado: } & \text { sim } \\
\text { Promulgado } & \\
\text { internamente: } & \text { sim } \\
\text { 2. SOLAS } & \mathbf{7 8 :} \\
\text { Assinado: } & \text { sim } \\
\text { Ratificado: } & \text { sim } \\
\text { Promulgado } & \\
\text { internamente: } & \text { sim } \\
\text { 3. SOLAS } & \mathbf{8 8 :} \\
\text { Assinado: } & \text { sim } \\
\text { Ratificado: } & \text { não } \\
\text { localizado. } & \\
\text { Promulgado } & \\
\text { internamente: } & \text { não } \\
\text { localizado. } & \\
\text { 4. SOLAS } & \text { 96: } \\
\text { Assinado: } & \text { não } \\
\text { Ratificado: } & \text { não } \\
\text { Promulgado } & \\
\text { internamente: não }\end{array}$ \\
\hline $\begin{array}{l}\text { Convenção } \\
\text { Internacional sobre } \\
\text { Preparo, Resposta e } \\
\text { Cooperação em Caso } \\
\text { de Poluição por Óleo, } \\
\text { de } 1990-\text { Oil } \\
\text { Pollution } \\
\text { Preparedness, } \\
\text { Response and Co- } \\
\text { operation (OPRC } \\
\text { 90), de } 1990\end{array}$ & $\begin{array}{l}\text { ORPC } 90 \text { ratificada, sendo promulgada pelo } \\
\text { Decreto Federal } n^{\circ} \quad 2.870 / 1998 \text {. Texto } \\
\text { aprovado pelo Decreto Legislativo } n^{\circ} \\
43 / 1998 \text {. }\end{array}$ & $\begin{array}{ll}\text { Assinado: } & \text { sim } \\
\text { Ratificado: } \quad \text { sim } \\
\text { Promulgado } \\
\text { internamente: } \operatorname{sim}\end{array}$ \\
\hline
\end{tabular}


(continuação)

\begin{tabular}{|c|c|c|}
\hline $\begin{array}{c}\text { CONVENÇÕES E } \\
\text { TRATADOS } \\
\text { INTERNACIONAIS }\end{array}$ & RATIFICADO PELO BRASIL? & STATUS \\
\hline \begin{tabular}{lr} 
Convenção & \multicolumn{2}{c}{ sobre } \\
Responsabilidade & \\
Civil por & Danos \\
Causados & pela \\
Poluição & por \\
Combustíveis & de \\
Navios & - \\
International & \\
Conventionon & Civil \\
Liability for & Bunker \\
Oil Pollution Damage & (BUNKER 01$),$ de \\
2001 &
\end{tabular} & Não foi ratificada, conforme tabela da IMO. & $\begin{array}{l}\text { Assinado: não } \\
\text { Ratificado: não } \\
\text { Promulgado } \\
\text { internamente: não }\end{array}$ \\
\hline $\begin{array}{l}\text { Convenção } \\
\text { Internacional de } \\
\text { Hong Kong para a } \\
\text { Reciclagem Segura e } \\
\text { Ambientalmente } \\
\text { Adequada de Navios } \\
\text { - The Hong Kong } \\
\text { International } \\
\text { Convention for the } \\
\text { Safe and } \\
\text { Environmentally } \\
\text { Sound Recycling of } \\
\text { Ships, de } 2009\end{array}$ & Não foi ratificada, conforme tabela da IMO. & $\begin{array}{l}\text { Assinado: não } \\
\text { Ratificado: não } \\
\text { Promulgado } \\
\text { internamente: não }\end{array}$ \\
\hline $\begin{array}{l}\text { Protocolo ao Tratado } \\
\text { da Antártida sobre } \\
\text { Proteção ao Meio } \\
\text { Ambiente, de } 1991\end{array}$ & $\begin{array}{l}\text { Protocolo ao Tratado da Antártida ratificado, } \\
\text { sendo promulgado pelo Decreto Federal } \mathrm{n}^{\circ} \\
2.742 / 1998 \text {. Texto aprovado pelo Decreto } \\
\text { Legislativo } \mathrm{n}^{\circ} 88 / 1985 \text {. }\end{array}$ & $\begin{array}{ll}\text { Assinado: } & \operatorname{sim} \\
\text { Ratificado: } & \operatorname{sim} \\
\text { Promulgado } & \\
\text { internamente: } & \text { sim }\end{array}$ \\
\hline $\begin{array}{l}\text { Convenção das } \\
\text { Nações Unidas sobre } \\
\text { o Direito do Mar, de } \\
1982\end{array}$ & $\begin{array}{l}\text { Convenção das Nações Unidas sobre o } \\
\text { Direito do Mar ratificada, sendo promulgada } \\
\text { e colocada em vigor pelo Decreto Federal } \mathrm{n}^{\circ} \\
\text { 1.530/1995. Texto aprovado pelo Decreto } \\
\text { Legislativo } \mathrm{n}^{\circ} 5 / 1987 \text {. }\end{array}$ & $\begin{array}{ll}\text { Assinado: } & \text { sim } \\
\text { Ratificado: } & \text { sim } \\
\text { Promulgado } & \\
\text { internamente: } & \text { sim }\end{array}$ \\
\hline
\end{tabular}


(conclusão)

\begin{tabular}{|c|c|c|}
\hline $\begin{array}{c}\text { CONVENÇÕES E } \\
\text { TRATADOS } \\
\text { INTERNACIONAIS }\end{array}$ & RATIFICADO PELO BRASIL? & STATUS \\
\hline 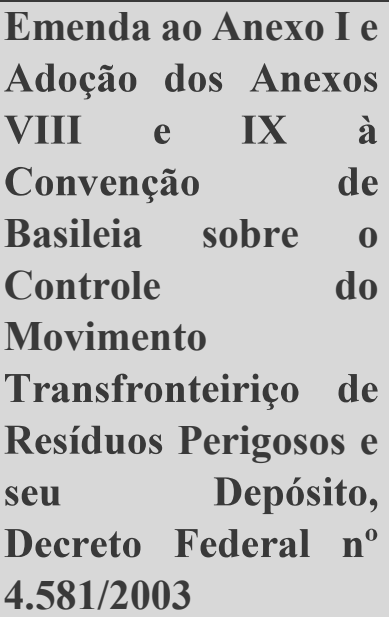 & $\begin{array}{l}\text { A Emenda ao Anexo I e Adoção dos Anexos } \\
\text { VIII e IX à Convenção de Basiléia sobre o } \\
\text { Controle do Movimento Transfronteiriço de } \\
\text { Resíduos Perigosos e seu Depósito foi } \\
\text { ratificada, sendo promulgada pelo Decreto } \\
\text { Federal } n^{\circ} 4.581 / 2003 \text {. Texto aprovado pelo } \\
\text { Decreto Legislativo } n^{\circ} 463 / 2001 \text {. }\end{array}$ & $\begin{array}{ll}\text { Assinado: } & \text { sim } \\
\text { Ratificado: } & \text { sim } \\
\text { Promulgado } & \\
\text { internamente: } & \text { sim }\end{array}$ \\
\hline
\end{tabular}

Fonte: Elaboração própria, a partir de informações disponibilizadas em: INTERNATIONAL MARITIME ORGANIZATION. Status of IMO Treaties: Comprehensive information on the status of multilateral Conventions and instruments in respect of which the International Maritime Organization or its SecretaryGeneral performs depositary or other functions. UK: IMO, 16 de novembro de 2018. Disponível em: $<$ http://www.imo.org/en/About/Conventions/StatusOfConventions/Documents/Status\%20-\%202018.pdf>

Acesso em: 20.11.2018.

Uma vez identificadas as principais convenções, protocolos e anexos, apenas os instrumentos relacionados diretamente com os derramamentos de óleo no mar serão detalhados a seguir, a fim de compreender as especificidades de cada instrumento. Para melhor compreensão histórica da temática em nível internacional, as normas abaixo foram abordadas considerando o critério cronológico.

\subsubsection{Convenção Internacional para Prevenção de Poluição no Mar por Petróleo - Oil Pollution Convention, 1954 (OILPOL)}

A Convenção Internacional para Prevenção de Poluição no Mar por Petróleo, conhecida internacionalmente como "OILPOL", foi fruto da Conferência Internacional sobre poluição do 
Mar por óleo, que ocorreu em Londres, em 1954. Entretanto, a Convenção somente entrou em vigor em 26 de julho de 1958, ${ }^{128}$ sendo alterada por três vezes (em 1962, 1969 e 1971). ${ }^{129}$

A convenção tratava principalmente de poluição advinda da operação de petroleiros e da descarga de misturas oleosas de embarcações. Em suas definições, deixava claro que o termo "óleo" seria empregado para: petróleo bruto, óleo combustível, óleo diesel pesado e óleo lubrificante. ${ }^{130}$

Os principais avanços promovidos pelo texto da convenção foram no estabelecimento de condições específicas para o lançamento do óleo no mar. Dentre as condições, destacam-se a criação das "zonas proibidas", que seriam as 50 milhas a partir da terra, e o dispositivo acrescentando que o descarte deveria ocorrer o mais longe possível da terra. As alterações promovidas pela IMO, aprovadas em 1969, foram responsáveis pelo aumento das restrições acerca das descargas operacionais de óleo a partir de navios petroleiros e de máquinas contidas em outros navios. ${ }^{131} \mathrm{Ou}$ seja, verifica-se uma preocupação, mesmo que implícita, com os ambientes costeiros.

Outra condição a ser destacada se refere à composição da mistura oleosa descartada no oceano. Proibiu-se o descarte de misturas cuja concentração fosse superior a 100 partes de óleo por milhão, sendo necessária a criação de instalações para a recepção de águas oleosas e resíduos não descartados.

A preocupação por poluição por navios foi agravada em 1967, após o acidente com o petroleiro Torrey Canyon, quando 120.000 toneladas de petróleo foram derramadas no mar. ${ }^{132}$ O desastre ocorreu no Reino Unido e gerou uma série de questionamentos acerca das medidas preventivas atinentes a poluição por hidrocarbonetos provenientes de navios.

Após o acidente, em 1971, a IMO alterou a OILPOL de 1954, conferindo maior proteção à Grande Barreira de Corais da Austrália, além de limitar o tamanho dos tanques dos petroleiros,

128 TAM, A. K.-J. Vessel-Source Marine Pollution: The Law and Politics of International Regulation. New York> Cambridge University Press, 2006, p.184.

129 TAM, A. K.-J. Vessel-Source Marine Pollution: The Law and Politics of International Regulation. New York $>$ Cambridge University Press, 2006, p.184

${ }^{130}$ IMO. International Convention for the Prevention of Pollution of the Sea by Oil, London, 12 de maio 1954. Disponível em: $<$ http://sedac.ciesin.org/entri/texts/pollution.of.sea.by.oil.1954.html $>$ Acesso em 10.05.2016.

${ }^{131}$ Essas informações podem ser acessadas no site oficial da IMO, na seção "History of Marpol". Disponível em: $<$ http://www.imo.org/en/KnowledgeCentre/ReferencesAndArchives/HistoryofMARPOL/Pages/default.aspx $>$. Acesso em: 03.03.2016.

132 JURAS, I. da A. G. M. Estudo - Dezembro/2002: Medidas de Prevenção de Acidentes com Navios Petroleiros. Brasília: Câmara dos Deputados, Consultoria Legislativa, dez/2002, p. 03. 
minimizando assim a quantidade de óleo que poderia ser derramado em caso de uma colisão ou encalhe. Em 1973, a IMO promoveu uma conferência internacional, visando à preparação de um novo acordo internacional com maiores restrições sobre a contaminação do mar, terra e ar por navios. $^{133}$

A conferência Internacional de 1973 resultou na criação da Convenção Internacional para a Prevenção da Poluição por Navios (MARPOL), que incorporou boa parte do texto final da OILPOL a seu "anexo I", que trata especificamente do tema óleo. Destaca-se que a MARPOL possui tema mais abrangente e trata de outras formas de poluição do mar, conforme será apresentado a seguir.

\subsubsection{Convenção Internacional Relacionada à Intervenção em Alto Mar em casos de} Acidentes de Poluição por Óleo - International Convention Relating to Intervention on the High Seas In Cases of Oil Pollution Casualties, 1969 (INTERVENTION 69)

A Convenção Internacional Relacionada à Intervenção em Alto Mar em casos de Acidentes de Poluição por Óleo, "INTERVENTION 69", foi criada em 29 de novembro de 1969, mas apenas em 06 de maio de 1975 entrou em vigor.

A INTERVENTION 69 confere ao Estado Costeiro o direito de interferir em casos de poluição por óleo em alto mar que afetem a sua zona econômica exclusiva ou seu litoral. "Tratase da garantia do direito de autoproteção em situações de extrema emergência, capazes de produzir danos ecológicos de graves repercussões", nas palavras de Poffo. ${ }^{134}$

A Convenção afirma, portanto, o direito de um Estado Costeiro de exercer medidas para prevenir, atenuar ou eliminar danos ambientais decorrentes da poluição por óleo causada por um acidente marítimo, que ameace o seu litoral. Não se pode negar o avanço que a referida Convenção traz com relação à definição de competências do Estado, que não só passa a ter o direito de intervir, mas igualmente assume o dever de agir.

O Estado costeiro, entretanto, não possui poderes ilimitados. De acordo com o texto da convenção, este deve consultar os Estados interessados no caso concreto, incluindo aqueles

\footnotetext{
${ }^{133}$ Essas informações também podem ser acessadas no site oficial da IMO, na seção "History of Marpol". Disponível em:

<http://www.imo.org/en/KnowledgeCentre/ReferencesAndArchives/HistoryofMARPOL/Pages/default.aspx $>$. Acesso em: 03.03.2016.

134 POFFO, I. R. F. Vazamento de óleo no Litoral Norte do Estado de São Paulo: análise histórico (1974 a 1999). Dissertação de Mestrado - Programa de Ciência Ambiental (PROCAM), Instituto de Energia e Ambiente (IEE), Universidade de São Paulo (USP), São Paulo, dez. 2000, p.79.
} 
responsáveis pelas bandeiras dos navios envolvidos, ou pelas cargas. ${ }^{135}$ Importante ainda ressaltar que a INTERVENTION 69 se aplica a todos os navios de mar, com exceção de navios de guerra e navios que estejam a serviço público. ${ }^{136}$

A Convenção de 1969 inicialmente tratava apenas de casos de poluição por óleo. Entretanto, em 1973, durante a Conferência de Londres sobre a Poluição Marinha, foi aprovado um protocolo relativo à Intervenção em Alto Mar para Casos de Poluição Marinha causada por outras substâncias químicas que não fossem hidrocarbonetos. Tal protocolo passou a complementar a Convenção de 1969, entrando em vigor em 1983 e sendo alterado posteriormente, tornando a INTERVENTION 69 mais abrangente.

\subsubsection{Convenção Internacional sobre Responsabilidade Civil em Danos Causados por} Poluição por Óleo - International Conventionon Civil Liability for Oil Pollution Damage, 1969 e 1992 (CLC/69 e CLC/92)

A CLC foi originalmente elaborada em 29 de novembro de 1969. Sua promulgação ocorreu apenas em 19 de junho de 1975. Conforme será explicado, em 1992, a convenção não apenas foi reformulada, como houve a criação de um protocolo, que entrou em vigor em 1996. Entretanto, cumpre ressaltar que, muito embora o Brasil tenha ratificado a CLC de 69, aprovada pelo Decreto Legislativo ${ }^{\circ} 74$ de 1976, internalizada pelo Decreto Federal n 79.437/1977 e regulamentada a sua aplicação pelo Decreto Federal $n^{\circ} 83.540 / 1979$, o país não ratificou o protocolo de 1992. Nesse sentido, os decretos citados se referem ao texto original de 1969, que, pelo fato de ter sido amplamente reformulado, apresenta vários trechos em desuso por muitos países integrantes da IMO.

Pois bem, a observação acima é de extrema importância para a compreensão dos motivos pelos quais as convenções internacionais, mesmo quando ratificadas pelo Brasil, não são amplamente utilizadas pelos profissionais do Direito. Sendo assim, a análise da CLC 69 e de suas posteriores alterações será realizada em comparação com os Decretos Federais $n^{\circ}$

${ }^{135}$ IMO International Convention Relating to Intervention on the High Seas in Cases of Oil Pollution Casualties, $29 \quad$ de novembro $\quad$ de $1969 . \quad$ Disponível $<$ http://www.imo.org/en/About/Conventions/ListOfConventions/Pages/International-Convention-Relating-toIntervention-on-the-High-Seas-in-Cases-of-Oil-Pollution-Casualties.aspx $>$. Acesso em: 15.02.2016. ${ }^{136}$ IMO. International Convention Relating to Intervention on the High Seas in Cases of Oil Pollution Casualties, de novembro $\quad$ de $1969 . \quad$ Disponível em: $<$ http://www.imo.org/en/About/Conventions/ListOfConventions/Pages/International-Convention-Relating-to-

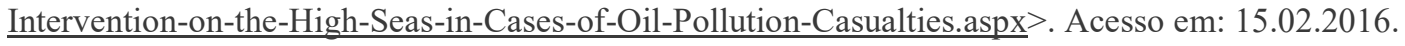


79.437/1977 e $n^{\circ}$ 83.540/1979, para melhor entendimento sobre o que seria aplicável ao contexto brasileiro.

Em 1969, a criação da CLC foi motivada pela necessidade de se compensar pessoas que sofreram com os danos resultantes dos derramamentos de óleos no mar. Desta forma, de acordo com a CLC de 69, a responsabilidade por tais danos é atribuída ao proprietário do navio que derramou o óleo. A Convenção original protege os Estados Parte alvos dos derramamentos de óleos persistentes e é aplicável apenas a navios que transportam óleo a granel como carga. ${ }^{137}$

A CLC representa um marco na evolução da responsabilidade civil ambiental internacional, sobretudo, ao adotar o caráter objetivo da atribuição de responsabilidade. Ademais, há ainda a formalização do conceito de inversão do ônus da prova, pois reconhece que a produção da prova deve ser feita pelo proprietário do navio. Outra grande inovação da CLC é a exigência de que os navios que transportem mais de 2.000 toneladas de óleo possuam seguro, ou garantia financeira contra acidentes, ${ }^{138}$ cuja cobertura abranja o valor total de reparação. ${ }^{139}$ Ocorre que, muito embora o Brasil tenha recepcionado a regra de exigência dos seguros por meio dos Decretos, os limites de cobertura são questionáveis, visto que o país não aderiu ao protocolo de 1992, por meio do qual foram definidos os limites de compensação.

Ocorre que, em 16 de maio de 1998, as Partes do Protocolo de 1992 deixaram de ser Partes na CLC de 1969. Porém, vários Estados não ratificaram o regime de 1992, ou seja, não aderiram a regras de extrema importância sistematizadas a seguir:

137 INTERNATIONAL MARITIME ORGANIZATION. International Convention on Civil Liability for Oil Pollution Damage (CLC). Texto original de 29 de novembro de 1969 . Disponível em: $<\underline{\text { http://www.imo.org/en/About/Conventions/ListOfConventions/Pages/International-Convention-Relating-to- }}$ Intervention-on-the-High-Seas-in-Cases-of-Oil-Pollution-Casualties.aspx $>$. Acesso em: 01.08.2018.

${ }^{138}$ Não se aplica mesma exigência aos navios de guerra ou outros navios de propriedade ou operados por um Estado à serviços do Governo. Porém, mantém-se a aplicação das disposições de responsabilidade e jurisdição aos navios de propriedade de um Estado, mas utilizados para fins comerciais, a exemplo de transporte de petróleo. A única exceção em relação a esses navios é que eles não são obrigados possuírem seguro. Em vez disso, eles devem portar um certificado emitido pela autoridade competente do Estado de seu registro declarando que a responsabilidade do navio sob a Convenção está coberta. Tal disposição acaba sendo motivo de discussão acerca da obrigatoriedade ou não do seguro para navios da Petrobras.

139 INTERNATIONAL MARITIME ORGANIZATION. International Convention on Civil Liability for Oil Pollution Damage (CLC). Texto original de 29 de novembro de 1969 . Disponível em: $<\underline{\text { http://www.imo.org/en/About/Conventions/ListOfConventions/Pages/International-Convention-on-Civil- }}$ Liability-for-Oil-Pollution-Damage-(CLC).aspx $>$. Acesso em: 01.11.18. 
Tabela 03 - Inovações da CLC de 1992 e emenda de 2000, não recepcionadas pelo Brasil

\begin{tabular}{|c|c|c|}
\hline & CLC A PARTIR DE $1992^{140}$ & SITUAÇÃO DO BRASIL \\
\hline $\begin{array}{l}\text { Limites da } \\
\text { responsabilidade }\end{array}$ & $\begin{array}{l}\text { Para um navio que não exceda } \\
5.000 \quad \text { toneladas, } \\
\text { responsabilidade é limitada a } \\
4,51 \text { milhões de SDR (U\$ } 5,78 \\
\text { milhões). } \\
\text { Para um navio de } 5.000 \text { a } \\
140.000 \text { toneladas de arqueação } \\
\text { bruta: o passivo é limitado a } 4,51 \\
\text { milhões de SDR, mais } 631 \text { SDR } \\
\text { para cada unidade adicional de } \\
\text { tonelagem. } \\
\text { Para um navio com mais de } \\
140.000 \text { toneladas de arqueação } \\
\text { bruta: o passivo é limitado a } \\
89,77 \text { milhões de SDR. }\end{array}$ & $\begin{array}{l}\text { Responsabilidade limitada a um } \\
\text { montante total de } 2000 \text { (dois mil) } \\
\text { francos por tonelada da tonelagem } \\
\text { do navio, não podendo exceder } \\
210 \text { (duzentos e dez) milhões de } \\
\text { francos - art. V da CLC } 69 \text {, nos } \\
\text { termos do Decreto Federal n } \\
79.437 / 1977 \text {. } \\
\text { Caso o total das indenizações } \\
\text { devidas ultrapasse o limite de } \\
\text { responsabilidade estabelecida na } \\
\text { CLC 69, haverá rateio da } \\
\text { importância entre aqueles que } \\
\text { sofreram perdas ou danos } \\
\text { decorrentes da poluição por óleo- } \\
\text { art. } 13 \text { do Decreto Federal } n^{\circ} \\
83.540 / 1979 \text {. }\end{array}$ \\
\hline $\begin{array}{l}\text { Limites } \\
\text { cobertura }\end{array}$ & $\begin{array}{l}\text { Cobertura dos danos por poluição } \\
\text { causados na zona econômica } \\
\text { exclusiva (ZEE) ou área } \\
\text { equivalente de um Estado Parte. }\end{array}$ & $\begin{array}{l}\text { Cobertura dos danos por poluição } \\
\text { exclusivamente nos territórios dos } \\
\text { Estados Partes, incluindo o mar } \\
\text { territorial - art. II, da CLC 69, nos } \\
\text { termos do Decreto Federal } n^{\circ} \\
79.437 / 1977 \text {. }\end{array}$ \\
\hline
\end{tabular}

(continua)

\footnotetext{
140 Informações retiradas de: INTERNATIONAL OIL POLLUTION COMPENSATION FUNDS (IOPC FUNDS). Liability and compensation for oil pollution damage. Texts of the 1992 Civil Liability Convention, the 1992 Fund Convention and the Supplementary Fund Protocol. London. 2018. Disponível em:

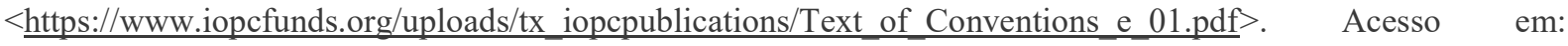
01.11.18. Ver também: INTERNATIONAL MARITIME ORGANIZATION. International Convention on Civil Liability for Oil Pollution Damage (CLC). Texto original de 29 de novembro de 1969. Disponível em: $<$ http://www.imo.org/en/About/Conventions/ListOfConventions/Pages/International-Convention-on-CivilLiability-for-Oil-Pollution-Damage-(CLC).aspx $>$ Acesso em: 01.11.18.
} 
(continuação)

\begin{tabular}{|c|c|c|}
\hline & CLC A PARTIR DE $1992^{141}$ & SITUAÇÃO DO BRASIL \\
\hline $\begin{array}{ll}\text { Limites } & \text { da } \\
\text { compensação } & \end{array}$ & $\begin{array}{l}\text { Compensação pelo dano } \\
\text { ambiental é limitada aos custos } \\
\text { incorridos para medidas } \\
\text { razoáveis para restabelecer o } \\
\text { ambiente contaminado. }\end{array}$ & $\begin{array}{l}\text { Apesar de "Medidas Preventivas" } \\
\text { serem definidas como "quaisquer } \\
\text { medidas razoáveis, tomadas por } \\
\text { qualquer pessoa após ter ocorrido } \\
\text { um incidente, visando prevenir ou } \\
\text { minimizar o dano causado pela } \\
\text { poluição", não há previsão de } \\
\text { limitar a compensação dos danos } \\
\text { ambientais aos custos incorridos } \\
\text { com medidas razoáveis para } \\
\text { restabelecer o meio ambiente na } \\
\text { CLC } 69 \text { - art. I da CLC 69, nos } \\
\text { termos do Decreto Federal n } \\
79.437 / 1977 \text {. }\end{array}$ \\
\hline
\end{tabular}

(continua)

141 Informações retiradas de: INTERNATIONAL OIL POLLUTION COMPENSATION FUNDS (IOPC FUNDS). Liability and compensation for oil pollution damage. Texts of the 1992 Civil Liability Convention, the 1992 Fund Convention and the Supplementary Fund Protocol. London. 2018. Disponível em: $<$ https://www.iopcfunds.org/uploads/tx_iopcpublications/Text of Conventions_e 01.pdf $>$. Acesso em: 01.11.18. Ver também: IMO. International Convention on Civil Liability for Oil Pollution Damage (CLC). Texto original de 29 de novembro de 1969. Disponível em:

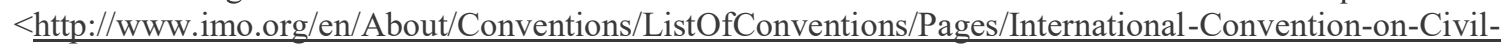
Liability-for-Oil-Pollution-Damage-(CLC).aspx $>$ Acesso em: 01.11.18. 
(continuação)

\begin{tabular}{|c|c|c|}
\hline & CLC A PARTIR DE $1992^{142}$ & SITUAÇÃO DO BRASIL \\
\hline $\begin{array}{l}\text { Recuperação de } \\
\text { despesas } \\
\text { incorridas }\end{array}$ & $\begin{array}{l}\text { Permite que as despesas } \\
\text { incorridas para medidas } \\
\text { preventivas sejam recuperadas, } \\
\text { mesmo quando não ocorre } \\
\text { derramamento de óleo, desde que } \\
\text { haja ameaça grave e iminente de } \\
\text { dano por poluição. }\end{array}$ & $\begin{array}{l}\text { Apesar da previsão de que as } \\
\text { reclamações relativas às despesas } \\
\text { razoavelmente realizadas ou } \\
\text { sacrifícios feitos voluntariamente } \\
\text { pelo proprietário com o fim de } \\
\text { evitar ou minimizar os danos de } \\
\text { poluição figurarão em igualdade } \\
\text { com outras reclamações contra o } \\
\text { fundo, não há previsão, na CLC } \\
69 \text {, de recuperação das despesas } \\
\text { incorridas com medidas } \\
\text { preventivas, mesmo quando não } \\
\text { ocorrer o derramamento de óleo, } \\
\text { para os casos de grave e iminente } \\
\text { ameaça de poluição - art. V da } \\
\text { CLC } 69 \text {, nos termos do Decreto } \\
\text { Federal no } 79.437 / 1977 \text {. }\end{array}$ \\
\hline
\end{tabular}

(continua)

${ }^{142}$ Informações retiradas de: IOPC FUNDS. Liability and compensation for oil pollution damage. Texts of the 1992 Civil Liability Convention, the 1992 Fund Convention and the Supplementary Fund Protocol. London. 2018.

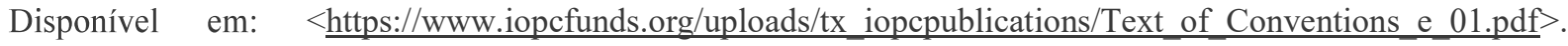
Acesso em: 01.11.18. Ver também: INTERNATIONAL MARITIME ORGANIZATION. International Convention on Civil Liability for Oil Pollution Damage (CLC). Texto original de 29 de novembro de 1969. Disponível em: $\quad$ http://www.imo.org/en/About/Conventions/ListOfConventions/Pages/InternationalConvention-on-Civil-Liability-for-Oil-Pollution-Damage-(CLC).aspx $>$ Acesso em: 01.11.18. 
(conclusão)

\begin{tabular}{|c|c|c|}
\hline & CLC A PARTIR DE $1992^{143}$ & SITUAÇÃO DO BRASIL \\
\hline \begin{tabular}{l}
\multicolumn{3}{l}{ Responsabilidade } \\
por tanques \\
carga, em por \\
derramamentos \\
de óleo \\
combustível do \\
navio
\end{tabular} & $\begin{array}{l}\text { Cobertura de derramamentos de } \\
\text { embarcações marítimas } \\
\text { construídas ou adaptadas para } \\
\text { transportar óleo a granel como } \\
\text { carga. } \\
\text { A responsabilidade passa a } \\
\text { abranger tanques com carga e } \\
\text { sem carga, incluindo } \\
\text { derramamentos de óleo } \\
\text { combustível desses navios. }\end{array}$ & $\begin{array}{l}\text { Resumidamente, entende-se por } \\
\text { "dano por poluição" a perda, ou } \\
\text { dano, causados fora do navio } \\
\text { transportador de óleo devido à } \\
\text { contaminação resultante de um } \\
\text { derramamento ou descarga de óleo } \\
\text { desse navio. Por sua vez, "navio" é } \\
\text { utilizado para definir toda a } \\
\text { embarcação marítima, ou engenho } \\
\text { flutuante, qualquer que seja o tipo, } \\
\text { que transporte efetivamente óleo a } \\
\text { granel como carga - art. I da CLC } \\
69 \text {, nos termos do Decreto Federal } \\
\text { n } 79.437 / 1977 \text {. Não abrange, } \\
\text { portanto, derramamentos de } \\
\text { combustíveis }\end{array}$ \\
\hline \begin{tabular}{l}
\multicolumn{3}{c}{ Responsabilidade } \\
em caso de \\
omissão e de \\
imprudência
\end{tabular} & $\begin{array}{l}\text { Sob o Protocolo de } 1992 \text {, um } \\
\text { armador responderá de forma } \\
\text { ilimitada caso comprovado que o } \\
\text { dano causado pela poluição } \\
\text { resultou do ato ou omissão, } \\
\text { cometido com a intenção de } \\
\text { causar tal dano, ou por } \\
\text { imprudência e e com } \\
\text { conhecimento de que tal dano } \\
\text { provavelmente ocorreria. }\end{array}$ & $\begin{array}{l}\text { Não há menções, no texto da CLC } \\
69 \text {, promulgada pelo Decreto } \\
\text { Federal } \mathrm{n}^{\circ} 79.437 / 1977 \text {, ou no } \\
\text { Decreto Federal } \mathrm{n}^{\circ} 83.540 / 1979 \text {, } \\
\text { sobre a responsabilidade ilimitada } \\
\text { caso comprovado que o dano } \\
\text { causado pela poluição resultou de } \\
\text { ato ou omissão cometido com a } \\
\text { intenção de causar tal dano ou por } \\
\text { imprudência e com conhecimento } \\
\text { de que tal dano provavelmente } \\
\text { ocorreria. }\end{array}$ \\
\hline
\end{tabular}

Fonte: elaboração própria, a partir dos documentos citados.

${ }^{143}$ Informações retiradas de: IOPC FUNDS. Liability and compensation for oil pollution damage. Texts of the 1992 Civil Liability Convention, the 1992 Fund Convention and the Supplementary Fund Protocol. London. 2018. Disponível em: < $\quad$ https://www.iopcfunds.org/uploads/tx_iopcpublications/Text_of_Conventions e _01.pdf $>$. Acesso em: 01.11.18. Ver também: IMO. International Convention on Civil Liability for Oil Pollution Damage (CLC). Texto original de 29 de novembro de 1969. Disponível em:

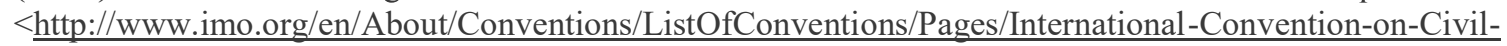
Liability-for-Oil-Pollution-Damage-(CLC).aspx $>$ Acesso em: 01.11.18. 
Conforme é possível observar a partir do quadro acima, o Brasil não recepcionou importantes modificações ocorridas em 1992 ao texto da CLC 69, que poderiam gerar maior segurança ambiental ao território marítimo nacional. Como consequência, não se pode deixar de ressaltar a insegurança jurídica interna e externa em decorrência dessa não adesão. A convenção é clara ao estabelecer que as regras se aplicam apenas aos Estados-partes. Em outras palavras, mesmo que o navio estrangeiro seja proveniente de um Estado-parte da CLC92, o Brasil não poderá ser contemplado pelos mesmos mecanismos, se limitando ao disposto na CLC69. Entretanto, as embarcações brasileiras, ao buscarem navegação por águas estrangeiras, muito provavelmente deverão se adequar às regras atinentes à CLC 92. Ao considerar esse tipo de conflito, o próprio Protocolo de 1992 permite que seus Estados-partes possam emitir certificados a navios registrados em Estados que não sejam partes. ${ }^{144}$

A Convenção de Fundos, de 1992, é baseada no novo regime trazido pela Convenção sobre Responsabilidade Civil do mesmo ano suplementar à primeira, de 1969. Nela, foi criado o Fundo Internacional de Compensação para Poluição de Petróleo (IOPC). Até 09 de julho de 2018, 137 Estados haviam ratificado a Convenção de Responsabilidade Civil e 115 tinha ratificado ou aderido ao Fundo de 1992. O assunto será tratado com maiores detalhes no capítulo 9, específico sobre fundos. ${ }^{145}$

\subsubsection{Convenção sobre Prevenção da Poluição Marinha por Alijamento de Resíduos e Outras Matérias - International Convention on the Prevention of Marine Pollution by Dumping of Wastes and other Matter, 1972 (LC/72)}

A Convenção sobre Prevenção da Poluição Marinha por Alijamento de Resíduos e Outras Matérias (LC/72) foi elaborada em novembro de 1972, e entrou em vigor em 30 de agosto de 1975. Conta com um protocolo adotado em 7 de novembro de 1996, que entrou em vigor em 24 de março de 2006. A LC/72 é conhecida como "Convenção de Londres", pois surgiu em uma Conferência Intergovernamental ocorrida em Londres, em 1972, mas desde 1977 a convenção vem sendo administrada pela IMO.

${ }^{144}$ IMO. International Convention on Civil Liability for Oil Pollution Damage (CLC), 29 de novembro de 1969. Disponível em: <http://www.imo.org/en/About/Conventions/ListOfConventions/Pages/InternationalConvention-on-Civil-Liability-for-Oil-Pollution-Damage-(CLC).aspx $>$ Acesso em: 01.08.2018.

${ }^{145}$ IOPC FUNDS. Liability and compensation for oil pollution damage: Texts of the 1992 Civil Liability Convention, the 1992 Fund Convention and the Supplementary Fund Protocol. London: International Oil Pollution Compensation Funds, 2018.

Disponível

$<$ https://www.iopcfunds.org/uploads/tx iopcpublications/Text of Conventions_e 01.pdf $>$. 09.08.2018.

Acesso

em: em: 
A Convenção de Londres contribui para o controle internacional e para a prevenção da poluição marinha, proibindo alijamento de alguns resíduos perigosos no mar e impondo restrições para o alijamento de outros tipos de resíduos. Na LC/72, a palavra Dumping foi definida como a descarga deliberada no mar de resíduos ou outras matérias a partir de embarcações, aeronaves, plataformas ou outras estruturas feitas pelo homem, bem como a eliminação intencional dessas embarcações ou das próprias plataformas. ${ }^{146}$

O objetivo da Convenção de Londres é promover o controle efetivo de todas as fontes de poluição marinha. As Partes Contratantes devem tomar medidas eficazes para evitar a poluição do ambiente marinho causada pelo alijamento de resíduos no mar. Os resíduos são agrupados em listas: "negra" - cujo alijamento é proibido - e "cinza" - cujo alijamento é permitido, mas com restrições. Já o objetivo do protocolo é semelhante ao da Convenção, mas o protocolo é mais restritivo, uma vez que propõe listas reversas, indicando que todo e qualquer despejo é proibido, a menos que explicitamente permitido. Ademais, há a expressa proibição para incineração de resíduos no mar e para a exportação de resíduos, tanto para efeitos de alijamento, quanto para incineração no mar. ${ }^{147}$

Importante ainda destacar que, os atuais 87 Estados Parte da LC/72 recentemente começaram a adotar práticas para a mitigação dos impactos decorrentes do aumento das concentrações de CO2 na atmosfera e, consequentemente, no ambiente marinho. ${ }^{148}$ As novas práticas são de extrema importância para a regulação ecológica dos oceanos como um todo e traduzem muito do discutido recentemente, na Conferência das Partes (COP-21) da ConvençãoQuadro das Nações Unidas sobre Mudança do Clima (UNFCCC), ocorrida ao final de 2015 em Paris.

\footnotetext{
${ }^{146}$ IMO. Convention on the Prevention of Marine Pollution by Dumping of Wastes and Other Matter, de 1972. Disponível em: $<$ http://www.imo.org/en/About/Conventions/ListOfConventions/Pages/Convention-on-thePrevention-of-Marine-Pollution-by-Dumping-of-Wastes-and-Other-Matter.aspx $>$. Acesso em: 09.08.2018.

${ }_{147}$ IMO. Convention on the Prevention of Marine Pollution by Dumping of Wastes and Other Matter, de 1972. Disponível em: $<$ http://www.imo.org/en/About/Conventions/ListOfConventions/Pages/Convention-on-thePrevention-of-Marine-Pollution-by-Dumping-of-Wastes-and-Other-Matter.aspx $>$. Acesso em: 09.08.2018.

${ }_{148}$ IMO. Convention on the Prevention of Marine Pollution by Dumping of Wastes and Other Matter, de 1972. Disponível em: $<$ http://www.imo.org/en/About/Conventions/ListOfConventions/Pages/Convention-on-thePrevention-of-Marine-Pollution-by-Dumping-of-Wastes-and-Other-Matter.aspx $>$. Acesso em: 09.08.2018.
} 


\subsubsection{Convenção Internacional para a Prevenção da Poluição proveniente de Navios -} International Convention for the Prevention of Pollution from Ships, 1973, modificada pelo Protocolo de 1978 (MARPOL 73/78)

A Convenção Internacional para a Prevenção da Poluição por Navios (MARPOL) foi elaborada em 02 de novembro de 1973, mas somente entrou em vigor em 02 de outubro de 1983, juntamente com seu primeiro protocolo, elaborado em 1978. Em 26 de setembro de 1997 um segundo protocolo foi elaborado, acrescentando o Anexo VI à Convenção. Entretanto, igualmente entrou em vigor tardiamente, apenas em 19 de maio de 2005.

O Protocolo de 1978 surgiu em resposta a uma série de acidentes com petroleiros acorridos em 1976 e em 1977. Como a Convenção MARPOL 1973 ainda não tinha entrado em vigor, o protocolo de 1978 absorveu a Convenção original. Sendo assim, o instrumento final é o resultado da combinação entre a Convenção original e seu primeiro protocolo, ficando conhecido como Convenção Internacional para a Prevenção da Poluição Marinha por Navios, de 1973, alterada pelo Protocolo de 1978 (MARPOL 73/78). ${ }^{149}$

Dentre os principais objetivos da convenção destaca-se a completa eliminação da poluição do meio ambiente por óleo e outras substâncias provenientes de navios, principalmente por meio da descarga acidental no meio ambiente marinho. O próprio texto da MARPOL reconhece a importância da Convenção Internacional para a Prevenção da Poluição do Mar por Óleo (OILPOL), de 1954, como sendo o primeiro instrumento internacional visando a proteção do meio ambiente, "apreciando a importante contribuição que aquela Convenção deu ao preservar os mares e o meio ambiente costeiro contra a poluição."150

Porém, a MARPOL passou a ser a principal Convenção internacional que visa à prevenção da poluição do ambiente marinho por navios, tanto por causas operacionais, quanto

149 Essas informações também podem ser acessadas no site oficial da IMO, na seção "History of Marpol". Disponível em: $<$ http://www.imo.org/en/KnowledgeCentre/ReferencesAndArchives/HistoryofMARPOL/Pages/default.aspx $>$. Acesso em: 03.03.2016.

150 COMISSÃO COORDENADORA DOS ASSUNTOS DA INTERNATIONAL MARITIME ORGANIZATION. Convenção Internacional para a Prevenção da Poluição por Navios. Brasília, versão traduzida para o português, 1973 , Disponível em:

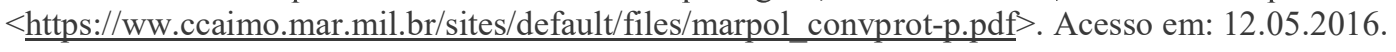


por acidentes. Poffo descreve resumidamente as principais medidas abrangidas pela MARPOL. ${ }^{151}$

Dentre as principais medidas trazidas pela MARPOL, destacam-se aquelas preventivas, associadas principalmente às modificações estruturais das embarcações, a exemplo da separação da água de lastro e do óleo por diferentes compartimentos, evitando-se a contaminação da água descartada nos oceanos. Outra importante contribuição foi mediante a adoção de procedimentos e equipamentos aliados à prevenção, dentre eles, a obrigação do navio possuir um livro de registro de óleo, apresentar sistemas de monitoramento, controle e filtragem do óleo, além de ser submetido a vistorias periódicas de suas instalações. ${ }^{152}$

Os Anexos Opcionais da MARPOL evidenciam o caráter amplo da proteção contra a poluição, pois abrangem além da poluição por petróleo, a poluição por outros produtos químicos, substâncias nocivas em embaladas, além de esgoto e lixo, organizados da seguinte forma: Anexo I - Regulamentação para prevenção da poluição por óleo; Anexo II Regulamentação para controle da poluição por substâncias líquidas não óxidas em embarcações graneleiras; Anexo III - Prevenção da poluição por substâncias nocivas embaladas; Anexo IV

${ }^{151}$ Em suas palavras: "As principais medidas acordadas referem-se à (ao): - necessidade de realizar vistorias iniciais, periódicas e intermediárias nos navios; - proibição da descarga de óleo ou misturas oleosas no mar, a menos que o petroleiro esteja a mais de 50 milhas náuticas da terra mais próxima, navegando em sua rota; que o regime de descarga do conteúdo não exceda $60 \mathrm{~L}$ por milha náutica. A descarga poderá ser feita desde que o navio possua sistemas de monitoramento e controle de descarga de óleo e separador de água/óleo em operação; proibição da descarga de óleo ou misturas oleosas no mar para os demais navios, com arqueação maior ou igual a 400 ton., proveniente dos tanques de combustíveis e dos porões de compartimentos de máquinas, a menos que estejam a mais de 12 milhas náuticas da terra mais próxima, navegando em sua rota, que o conteúdo seja menor ou igual a 100 ppm. e que possua em operação sistema de monitoramento e controle de descarga de óleo, equipamento e sistema de filtragem de óleo entre suas instalações; - comprometimento dos governos dos países signatários em assegurar a instalação de equipamentos e meios de recebimento da descarga de resíduos de óleo e misturas oleosas como sobras de petroleiros e de outros navios, nos terminais de carregamento de petróleo e derivados, nos portos de reparo entre outros tipos de portos; - necessidade de dotar os petroleiros novos, isto é, cujo contrato de construção tenha sido assinado após 31/12/75, de tonelada maior ou igual a 70 mil, de tanques de lastro segregado ou seja, tanques diferenciados, completamente separados dos sistemas de óleo de carga e combustível, destinado ao transporte de lastro ou outras cargas que não sejam óleo, misturas oleosas e substâncias nocivas; - obrigatoriedade de possuir o livro de registro de óleo, seja como parte ou não do diário náutico, no qual serão feitas anotações relativas a todas as movimentações de óleo, lastro e misturas oleosas, inclusive as entregas efetuadas às instalações de recebimento. Isto é válido para os petroleiros de arqueação bruta maior ou igual a 150 ton. e nos cargueiros de arqueação maior ou igual a 400 ton. Todas essas operações deverão ser assinadas pelo oficial ou pelo tripulante responsável pelas mesmas." Cf. POFFO, I. R. F. Vazamento de óleo no Litoral Norte do Estado de São Paulo: análise histórico (1974 a 1999). Dissertação de Mestrado - Programa de Ciência Ambiental (PROCAM), Instituto de Energia e Ambiente (IEE), Universidade de São Paulo (USP), São Paulo, dez. 2000, p.8.

152 COMISSÃO COORDENADORA DOS ASSUNTOS DA INTERNATIONAL MARITIME ORGANIZATION. Convenção Internacional para a Prevenção da Poluição por Navios. Brasília, versão $\begin{array}{llllll}\text { traduzida } & \text { para } & \text { o } & \text { português, } & 1973 . & \text { Disponível }\end{array}$

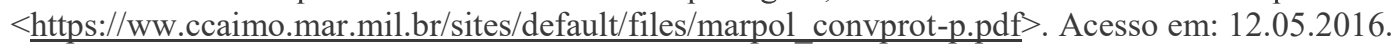


- Prevenção da poluição por esgoto da embarcação; Anexo V - Prevenção da poluição por lixo da embarcação; e Anexo VI - Prevenção da poluição do ar por embarcações. ${ }^{153}$

Por sua vez, o Brasil, ratificou e promulgou a MARPOL 73, bem como seu Protocolo de 78, suas Emendas de 84 e seus Anexos Opcionais com ressalvas. Isso porque a Convenção, cujo texto foi aprovado pelo Decreto Legislativo $n^{\circ} 4 / 1987$, posteriormente promulgada pelo Decreto Federal n 2.508/1998, aprovou apenas 3 (três) dos Anexos Operacionais da MARPOL, quais sejam: III, IV e V.

Portanto, o Brasil apenas adere à MARPOL no tocante a: (i) prevenção da poluição por substâncias nocivas embaladas; (ii) prevenção da poluição por esgoto da embarcação e (iii) prevenção da poluição por lixo da embarcação.

\subsubsection{Convenção Internacional para a Salvaguarda da Vida Humana no Mar - International Convention for the Safety of Life at Sea (e emenda), 1974 (SOLAS 74)}

A Convenção Internacional para a Salvaguarda da Vida Humana no Mar (SOLAS) surgiu em 01 de novembro de 1974 e entrou em vigor em 25 de maio de 1980, mas foi alterada por diversas vezes posteriormente. Trata-se de um dos mais importantes instrumentos internacionais para a garantia da segurança dos navios mercantes e cuida, entre outros assuntos, da segurança da navegação, abordando aspectos como equipamentos de comunicação, aberturas de porão e portos de refúgio. ${ }^{154}$

A SOLAS traz em seus capítulos normas para a segurança dos navios, especificamente referentes à construção, equipamentos, operação, além de trazer a previsão de que os navios devem estar preparados para responderem a acidentes - como incêndios, por exemplo, visto que devem possuir sistema de alerta de segurança. Os portos igualmente devem seguir a Convenção, assegurando a adequação de suas instalações e a eficiência de seus planos de segurança.

A versão atual da Convenção possui um anexo contendo capítulos, iniciado com Disposições Gerais e seguido com obrigações específicas. Destaca-se o mais recente Capítulo

\footnotetext{
${ }^{153}$ IMO. International Convention for the Prevention of Pollution from Ships (MARPOL), London, 1973. Disponível em: $\quad<$ http://www.imo.org/en/About/Conventions/ListOfConventions/Pages/InternationalConvention-for-the-Prevention-of-Pollution-from-Ships-(MARPOL).aspx > . Acesso em: 12.05.2016.

${ }_{154}$ BRASIL. Convenção Internacional sobre Responsabilidade Civil em Danos Causados por Poluição por Óleo. 1969. Disponível em: <http://www.antaq.gov.br/portal/MeioAmbiente_Convencoes_Internacionais.asp $>$. Acesso em: 01.08.2018.
} 
XIII, que torna obrigatória a partir de primeiro de janeiro de 2016 a implantação do Sistema de Auditoria dos Estados membros da IMO. Para tanto, os Estados devem desenvolver um plano de comunicação à IMO, que informe o controle dos navios nos portos, incluindo medidas como o atraso, a detenção, restrição de operações, a movimentação, além da expulsão de um navio do porto. ${ }^{155}$

Ademais, os Estados são responsáveis por assegurar que os navios sob sua bandeira cumpram com as exigências da SOLAS. Assim, a Convenção traz a previsão de emissão de certificados. Por fim, os Estados-partes podem inspecionar navios de outros Estados-partes, uma vez constatados indícios de que os navios ou seus equipamentos não estejam em conformidade com as exigências da Convenção.

\subsubsection{Convenção das Nações Unidas sobre o Direito do Mar - United Nations Conference on the Law of the Sea, Montego Bay, Jamaica, 1982 (UNCLOS/82)}

A UNCLOS/82 foi assinada em 10 de dezembro de 1982, em Montego Bay, na Jamaica. Entrou em vigor em âmbito internacional em 16 de novembro de 1994 e no Brasil, em 1995, com o Decreto $\mathrm{n}^{\circ} 1.530$, datado de 22 de junho de $1995 .{ }^{156}$

A UNCLOS/82 foi a terceira tentativa de Convenção a tratar do "direito do mar". Outras duas, datadas de 1958 e 1960, não conseguiram definir o território marítimo quanto a sua largura e soberania. Os avanços vieram em 1982, por meio da UNCLOS/82, dividida em XVII Partes com 320 artigos e VIII anexos. ${ }^{157}$

Note-se que, diferentemente da maioria das Convenções, aqui tratadas, que foram criadas no âmbito da IMO, a UNCLOS/82 foi fruto da Terceira Conferência das Nações Unidas sobre o Direito do Mar. As Nações Unidas permanecem monitorando os desdobramentos da Convenção, prestando assistência aos Estados-membros, com o objetivo de ajudá-los a utilizarem os seus recursos marinhos em um ambiente relativamente livre de conflitos e propício para o desenvolvimento. Neste contexto, a Divisão de Assuntos Oceânicos e Direito do Mar (DOALOS), do Escritório das Nações Unidas de Assuntos Jurídicos, ajuda a coordenar atividades e programas da Organização sobre temas marinhos. As Nações Unidas também

155 IMO. International Convention for the Safety of Life at Sea (SOLAS). London. 1974. Disponível em: $<$ http://www.imo.org/en/About/Conventions/ListOfConventions/Pages/International-Convention-for-the-Safetyof-Life-at-Sea-(SOLAS),-1974.aspx> . Acesso em: 01.08.2018.

${ }^{157}$ ZANIN, R. O direito do mar e a legislação brasileira. Revista Brasileira de Direito Constitucional (RBDC), São Paulo, n.16, jul./dez. 2010, p.89. 
fornecem assistência às outras duas instituições: a Autoridade Internacional dos Fundos Marinhos e do Tribunal Internacional do Direito do Mar. ${ }^{158}$

A UNCLOS/82, conforme disposto em seu texto, "é uma tentativa sem precedentes por parte da comunidade internacional para regular todos os aspectos dos recursos do mar e usos do oceano, e assim trazer uma ordem estável à própria fonte da vida da humanidade". ${ }^{159}$ Dentre seu conteúdo vasto, ela define limites da zona econômica exclusiva, do mar territorial, da zona contígua, da plataforma continental, além de regras de prevenção da poluição marinha. Ademais, inova abordando ambientes marinhos profundos, impondo a necessidade de realização de pesquisas científicas no ambiente marinho, defendendo a promoção e a transferência de tecnologias.

A Convenção aborda seis principais fontes de poluição dos oceanos, quais sejam: atividades terrestres e costeiras; perfuração em plataforma continental; mineração em mares e oceanos; despejos de substâncias nos oceanos; poluição por navios; e poluição a partir ou através da atmosfera.

A Convenção é extensa e detalhista. Para o presente trabalho, destacam-se alguns capítulos de relevante importância. Na Parte XII, a referida Convenção trata da Proteção e da Preservação do Ambiente Marinho. Mais precisamente o artigo 139 aborda a obrigação dos Estados Partes em zelar pelas áreas em que empresas estatais, pessoas físicas ou jurídicas realizem suas atividades. $\mathrm{O}$ artigo vai além, estabelecendo as regras de responsabilidade do Estado parte.

Já o artigo 145, ao tratar especificamente da Proteção do meio marinho deixa clara a necessidade de prevenir, reduzir e controlar possíveis danos ao meio marinho, incluindo o litoral, destacando especial atenção à necessidade de proteção contra os efeitos nocivos de algumas atividades, como a perfuração, o lançamento de detritos, a construção, funcionamento ou a manutenção de instalações nesses ambientes.

Ainda tratando do ambiente marinho e costeiro, o artigo 146 se desvincula do dano ecológico puro e aborda a Proteção à vida humana, que claramente é afetada pelas atividades

\footnotetext{
${ }^{158}$ ONU. The United Nations Convention on the Law of the Sea, Montego Bay, Jamaica,1982. Disponível em: $<$ http://www.un.org/depts/los/convention_agreements/convention_historical_perspective.htm> Acesso em: Acesso em: 01.08.2018.

${ }^{159}$ ONU. The United Nations Convention on the Law of the Sea, Montego Bay, Jamaica,1982. Disponível em: $<$ http://www.un.org/depts/los/convention_agreements/convention_historical_perspective.htm> Acesso em: Acesso em: 01.08.2018.
} 
econômicas desenvolvidas nesses ambientes, principalmente no quesito saúde. O artigo impõe que a autoridade competente deverá adotar normas, regulamentos e procedimentos apropriados que complementem os tratados internacionais sobre a matéria.

Já o artigo 221, ao abordar as "Medidas para evitar a poluição resultante de acidentes marítimos", traz a definição de acidente marítimo: "significa um abalroamento, encalhe ou outro incidente de navegação ou acontecimento a bordo de uma embarcação ou no seu exterior, de que resultem danos materiais ou ameaça iminente de danos materiais à embarcação ou à sua carga".

Note-se que o conceito de acidente marítimo se baseia apenas em incidentes que possam levar a danos materiais às embarcações ou à carga, não sendo abordados os possíveis danos ambientais. $\mathrm{O}$ conceito, à primeira vista, parece contraditório, pois traz a seguinte dúvida prática: um incidente entre embarcações, em que não se observa danos à carga ou à embarcação, mas gera danos ambientais, não seria considerado "acidente marítimo"?

A dúvida acima explicitada demonstra uma dificuldade prática de se delimitar as causas da poluição marinha, principalmente quando se pretende tipificá-las para o estabelecimento das respectivas responsabilidades para a reparação dos danos ocorridos. Pela definição indicada acima, a colidência de embarcações com respectivo vazamento de óleo não seria necessariamente um acidente marítimo, quando não resulta em danos à embarcação ou à carga nela contida.

Já o artigo 229 assegura que o direito de ingresso com eventual ação de responsabilidade civil por perdas ou danos causados pela poluição do meio marinho é supremo, não podendo ser afetado nem mesmo pelas disposições da presente Convenção.

Aqui, novamente, surge uma dúvida de interpretação a partir da leitura do artigo 229. Ao abordar a responsabilidade civil por perdas e danos, a redação parece assegurar apenas a busca da indenização de particulares por danos aparentemente materiais. A princípio, o artigo não abranger ações de responsabilidade civil por danos ambientais que visem uma reparação ecológica.

A dúvida acima apresentada é reforçada pelo artigo 230, que dispõe sobre as "penas pecuniárias e respeito dos direitos reconhecidos dos acusados". O artigo dispõe sobre as regras de imposição de penas pecuniárias nos casos de infrações de regras nacionais e internacionais que visem à prevenção, redução e controle da poluição do ambiente marinho proveniente de 
embarcações estrangeiras além do mar territorial. Novamente, a sanção aplicada seria a pena pecuniária e não a reparação do dano.

O artigo 235 apresenta, finalmente, a possibilidade de reparação do dano, mesmo que alternativa à indenização, ao determinar que: "Os Estados devem assegurar através do seu direito interno meios de recurso que permitam obter uma indenização pronta e adequada ou outra reparação pelos danos resultantes da poluição do meio marinho por pessoas físicas ou jurídicas sob sua jurisdição". Entretanto, sua redação avança impondo aos Estados a "elaboração de critérios e procedimentos para o pagamento de indenizações adequadas, tais como o seguro obrigatório ou fundos de indenização".

Deste modo, a convenção infelizmente não apresenta a concepção mais moderna no tema, segundo a qual a reparação efetiva do dano ambiental deve ser primordialmente ecológica e não por vias de indenizações pecuniárias, que, por sua vez, deveriam ser consideradas subsidiárias.

Por fim, não se pode deixar de citar o artigo 293 da UNCLOS/82. De extrema importância para a presente tese, e que será retomado nos próximos capítulos, uma vez que estabelece que: "a corte ou tribunal que tiver jurisdição nos termos desta seção deve aplicar a presente Convenção e outras normas de direito internacional que não forem incompatíveis com esta Convenção". Note-se que o presente artigo preza pela aplicação não só da UNCLOS/82, mas das demais normas de direito internacional, mesmo para a solução de casos que envolvam poluição marinha em territórios locais, pertencentes aos Estados-membros. O artigo 293 impõe não só a necessidade de serem internalizadas as convenções, mas sim aplicadas na solução de casos concretos, o que raramente ocorre no território brasileiro, fato que será comprovado adiante, por meio de análise de jurisprudência.

\subsubsection{Convenção Internacional sobre Preparo, Resposta e Cooperação em Caso de Poluição por Óleo- Oil Pollution Preparedness, Response and Co-operation, 1990 (OPRC 90)}

A OPRC foi criada em Londres, em 30 de novembro de 1990. Pode ser considerada uma Convenção extremamente abrangente, pois não se limita apenas à poluição por óleo decorrente de incidentes com navios. Pelo contrário, estende-se aos incidentes ou vazamentos operacionais ocorridos tanto em plataformas oceânicas, quanto em portos marítimos. Entretanto, como a maioria das convenções, não se aplica aos navios de guerra, nem mesmo àqueles que operam exclusivamente para serviços governamentais. 
A OPRC/90 foi promulgada no Brasil pelo Decreto $\mathrm{n}^{\circ} 2.870$, de 10 de dezembro de $1998^{160}$ e traz como principais objetivos: (i) a cooperação internacional e ajuda mútua em caso de acidentes; (ii) a necessidade de notificação de acidentes e comunicação de riscos aos países vizinhos; (iii) a necessidade dos planos de emergência possibilitando o controle da poluição por óleo para navios, operadores de plataformas oceânicas, autoridades e operadores encarregados dos portos marítimos e instalações que operam com óleo; e (iv) a criação de sistemas de respostas imediatas à acidentes.

Dentre os sistemas de respostas aos acidentes, a OPRC 90 traz uma importante contribuição para a reparação de danos por derramamentos de óleo, pois aborda a exigência de "planos de emergência para controle da poluição por óleo", voltados a: "(i) navios-tanque e outros navios; (ii) instalações ou estruturas de exploração, produção de óleo ou gás, de carregamento e descarregamento de óleo e (iii) instalações de portos ou terminais que apresentem riscos de acidentes e poluição por óleo". ${ }^{161}$

Os planos de emergência, quando bem elaborados, retratando as reais condições dos ambientes sensíveis ao óleo e, principalmente, quando levam em consideração mapas de sensibilidade aos derramamentos, são os principais aliados de uma reparação ecológica efetiva.

Nesse sentido, a convenção não só obriga os navios a possuírem planos de emergência individuais, mas igualmente os Estados-partes devem estabelecer um sistema nacional para responder a incidentes de poluição por óleo, além de fornecerem toda assessoria técnica e equipamentos para a serem empregados no combate da poluição por óleo.

Em 2000, foi criado o Protocolo sobre preparo, resposta e cooperação para incidentes de poluição por substâncias potencialmente perigosas e nocivas, visando a ampliar o escopo da OPRC 90, que considerava apenas poluição por óleo e não os casos de poluição por Substâncias potencialmente perigosas e nocivas.

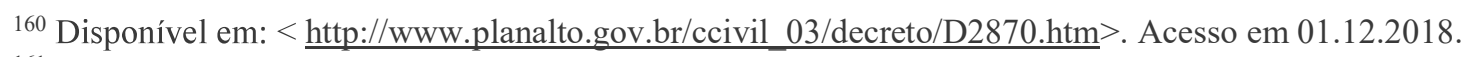

161 BRASIL. Ministério Público Federal. Formulário descritivo da norma internacional: Convenção Internacional para Preparo, Resposta e Cooperação em Caso de Poluição por Óleo (OPCR-90). Disponível em: $<$ http://www.mpf.mp.br/atuacao-tematica/ccr4/dados-da-atuacao/documentos/tratadosinternacionais/docs/formulario convencao poluicao oleo.pdf $>$ Acesso em: 01.08.2018.
} 


\subsubsection{Convenção sobre Responsabilidade Civil por Danos Causados pela Poluição por} Combustíveis de Navios - International Conventionon Civil Liability for Bunker Oil Pollution Damage, 2001 (BUNKER/01)

A BUNKER/01 foi adotada em 23 de março de 2001, mas entrou em vigor apenas em 21 de novembro de 2008. O principal objetivo da convenção foi assegurar a compensação adequada e célere referente aos danos ambientais causados por derramamentos de petróleo transportado como combustível em tanques nos navios. A abrangência da Convenção é restrita aos danos causados no território dos Estados-partes, incluindo o mar territorial e as zonas econômicas exclusivas.

A inovação trazida pela Convenção está no fato de que abrange apenas danos causados pela poluição advinda do derramamento. Nesse sentido, separa muito bem o que seria indenização por prejuízo material e indenização por dano ambiental, ao passo que define que a indenização pela deterioração do ambiente deve ser calculada com base nos custos das medidas de recuperação razoáveis efetivamente tomadas ou a serem tomadas. Dessa forma, é excluída a perda de lucros resultante dessa deterioração.

A BUNKER/01 foi baseada na Convenção Internacional sobre a Responsabilidade Civil por Danos da Poluição por Hidrocarbonetos, 1969, havendo a previsão do seguro obrigatório para o navio. Entretanto, pela BUNKER/01 os pedidos de indenização por danos causados pelo derramamento de óleo podem ser apresentados diretamente contra a seguradora. Para tanto, os proprietários de navios que possuam tonelagem bruta acima de 1.000 toneladas devem manter um seguro ou outra garantia financeira em valor igual aos limites da responsabilidade prevista no regime nacional ou internacional aplicável, não podendo ser superior ao disposto na Convenção sobre a limitação da Responsabilidade em Sinistros Marítimos de $1976{ }^{162}$

\subsubsection{Convenção Internacional de Hong Kong para a Reciclagem Segura e} Ambientalmente Adequada de Navios - The Hong Kong International Convention for the Safe and Environmentally Sound Recycling of Ships, 2009

A Convenção Internacional de Hong Kong para a Reciclagem Segura e Ambientalmente Adequada de Navios surgiu em maio de 2009. Muito embora seu objeto

\footnotetext{
${ }^{162}$ IMO International Convention on Civil Liability for Bunker Oil Pollution Damage (BUNKER). London, 2008. Disponível em: <http://www.imo.org/en/About/Conventions/ListOfConventions/Pages/InternationalConvention-on-Civil-Liability-for-Bunker-Oil-Pollution-Damage-(BUNKER).aspx $>$ Acesso em: 01.08.2018.
} 
principal não seja exatamente o tema aqui tratado, é importante mencioná-la pois integra o quadro das Convenções que apresentam medidas preventivas de poluição no mar.

A Convenção de Hong Kong aborda a problemática da desmontagem de navios inservíveis, que normalmente são levados para o litoral de países subdesenvolvidos e lá são abandonados ou desmontados de forma precária. Nesses termos, a Convenção busca minimizar os riscos à saúde humana e ao meio ambiente, além de propor uma alternativa de destinação adequada que envolve a reciclagem segura e ecológica dos resíduos do desmanche.

Diante do contexto, não se pode negar que o desmanche inadequado de embarcações representa uma atividade potencialmente poluidora, principalmente com relação ao risco de derramamento de óleo no mar de compartimentos internos, assim como de combustíveis residuais.

\subsection{Legislação Brasileira}

\subsubsection{Panorama Geral}

A Constituição da República Federativa do Brasil de $1988^{163}$ - Constituição Federal, em seu artigo art. $20, \S 1^{\circ}$-, estabelece que os recursos naturais da plataforma continental e da Zona Econômica Exclusiva, o mar territorial e os recursos minerais, inclusive os do subsolo são bens da União. Já o artigo 177 determina que, muito embora sejam de monopólio da União, as seguintes atividades poderão ser desenvolvidas por empresas estatais ou privadas: (i) pesquisa e a lavra das jazidas de petróleo, gás natural e outros hidrocarbonetos fluidos; (ii) refino de petróleo; (iii) importação e exportação de petróleo, seus produtos e do gás; e (iv) transporte marítimo ou por dutos de petróleo, produtos e gás natural.

Por sua vez, a Lei $n^{\circ}$ 9.478/1997, que dispõe sobre a Política Energética Nacional e exploração de petróleo e de gás natural, além de manter a possibilidade de concessão para atividades de exploração e produção de petróleo e gás natural criou a Agência Nacional de Petróleo (ANP), autarquia federal de regime especial, vinculada ao Ministério de Minas e Energia, que tem a atribuição de contratar, regular e fiscalizar as atividades do setor. Juntamente com a flexibilização do monopólio houve o aumento da preocupação com o meio ambiente, que aparece como um dos princípios da citada Lei.

163 BRASIL. Constituição da República Federativa do Brasil. Brasília, DF, 1988. Disponível em:

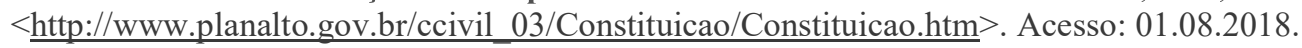


A Legislação Nacional relacionada à prevenção e a reparação de derramamentos de óleo no mar foi, assim como em outros países, em parte influenciada pelos incidentes que ocorreram no país. Algumas convenções foram ratificadas e internalizadas, conforme já abordado no item anterior - motivo pelo qual não serão aqui retomadas.

Visando sistematizar e abordar de forma genérica as principais normas relacionadas diretamente ou indiretamente com derramamentos, foi elaborada a tabela abaixo. Dentre as normas retratadas, foram selecionadas aquelas que tratam de prevenção, planos de emergência, comunicação de vazamentos e penalidades aplicáveis aos incidentes em que o óleo é derramado no mar, as quais serão detalhadas na sequência.

Tabela 7- Legislação brasileira relacionada a derramamentos de óleo no mar

\begin{tabular}{|c|c|}
\hline NORMA & ASSUNTO \\
\hline $\begin{array}{l}\text { Portaria da Agência Nacional } \\
\text { de Petróleo no 170/1998 }\end{array}$ & $\begin{array}{l}\text { Regulamentação para a construção, a ampliação e a } \\
\text { operação de instalações de transporte ou de } \\
\text { transferência de petróleo, seus derivados e gás natural, } \\
\text { inclusive liquefeito (GNL) }\end{array}$ \\
\hline Portaria ANP n ${ }^{0} 25 / 2002$ & Regulamento de Abandono de Poços Perfurados \\
\hline $\begin{array}{l}\text { Lei Federal } n^{\circ} 9.605 / 1998 \text {, art. } \\
6^{\circ} \text { a } 15^{\circ}, 23^{\circ} \text { e } 54^{\circ}\end{array}$ & Lei de Crimes Ambientais \\
\hline Lei Federal no 9.966/2000 & Lei do óleo e de substâncias nocivas \\
\hline $\begin{array}{l}\text { Decreto Federal } n^{0} 4.136 / 2002 \text { : } \\
\text { art. } 47\end{array}$ & $\begin{array}{l}\text { Estabelece penalidades (e suas condições) para o caso } \\
\text { de entidades indicadas pela norma não } \\
\text { comunicarem qualquer incidente que possa provocar } \\
\text { poluição das águas sob jurisdição nacional }\end{array}$ \\
\hline Lei Federal $n^{0} 12.815 / 2013$ & Lei dos Portos \\
\hline $\begin{array}{l}\text { Lei Federal n. }{ }^{\circ} 9.719 / 1998 \text { e NR } \\
29 / 1997 \text {, itens: } 29.1 .6,29.6 .3 .4 \text { e } \\
29.6 .6\end{array}$ & $\begin{array}{l}\text { Norma Regulamentadora de Segurança e Saúde no } \\
\text { Trabalho Portuário }\end{array}$ \\
\hline
\end{tabular}


(continuação)

\begin{tabular}{|c|c|}
\hline NORMA & ASSUNTO \\
\hline $\begin{array}{lll}\text { Resolução } & \text { CONAMA } & n^{0} \\
398 / 2008\end{array}$ & $\begin{array}{l}\text { Plano de Emergência Individual para incidentes de } \\
\text { poluição por óleo em águas sob jurisdição nacional }\end{array}$ \\
\hline Decreto Federal n ${ }^{0} 8.127 / 2013$ & $\begin{array}{l}\text { Plano Nacional de Contingência para Incidentes de } \\
\text { Poluição por óleo em águas sob jurisdição nacional }\end{array}$ \\
\hline $\begin{array}{lll}\text { Resolução } & \text { CONAMA } & n^{0} \\
482 / 2017 & \end{array}$ & $\begin{array}{l}\text { Utilização da técnica de queima controlada } \\
\text { emergencial como ação de resposta a incidentes de } \\
\text { poluição por óleo no mar }\end{array}$ \\
\hline $\begin{array}{lll}\text { Resolução } & \text { CONAMA } & n^{0} \\
472 / 2015 & \end{array}$ & Aplicação de dispersantes químicos \\
\hline IN IBAMA nº 16/2013 & $\begin{array}{l}\text { Procedimentos técnicos e administrativos para a } \\
\text { emissão da autorização Ambiental para a realização de } \\
\text { Operações Ship-to-Ship em águas jurisdicionais } \\
\text { brasileiras }\end{array}$ \\
\hline $\begin{array}{l}\text { Portaria do Ministério dos } \\
\text { Transportes } n^{0} 124 / 1980\end{array}$ & Prevenção da poluição origem terrestre \\
\hline Lei Federal $n^{0} 6.938 / 1981$ & Política Nacional de Meio Ambiente \\
\hline Lei Federal no 9.537/1997 & Lei de Segurança do Tráfego Aquaviário (LESTA) \\
\hline $\begin{array}{l}\text { NORMAM164 08, com } \\
\text { alterações, sendo a mais } \\
\text { recente até o momento, por } \\
\text { meio da Portaria n. }{ }^{\circ} 131 / \mathrm{DPC} \text {, } \\
\text { DE } 11 \text { DE ABRIL DE 2018. }\end{array}$ & $\begin{array}{l}\text { Procedimentos para transferência de óleo entre } \\
\text { embarcações }\end{array}$ \\
\hline $\begin{array}{lll}\text { Resolução } & \text { CONAMA } & n^{0} \\
265 / 2000 & \end{array}$ & $\begin{array}{l}\text { Avaliação pelo IBAMA e órgãos estaduais de meio } \\
\text { ambiente, com o acompanhamento dos órgãos } \\
\text { municipais e entidades ambientalistas não- } \\
\text { governamentais, sob a supervisão do Ministério do } \\
\text { Meio Ambiente, das ações de controle e prevenção e } \\
\text { do processo de licenciamento ambiental das } \\
\text { instalações industriais de petróleo e derivados } \\
\text { localizadas no território nacional }\end{array}$ \\
\hline
\end{tabular}

(continua)

164 Normam: Normas da Autoridade Marítima Para Tráfego e Permanência de embarcações em Águas Jurisdicionais Brasileiras. 
(continuação)

\begin{tabular}{|c|c|}
\hline NORMA & ASSUNTO \\
\hline IN IBAMA n ${ }^{0} \mathbf{1} / \mathbf{2 0 0 0}$ & $\begin{array}{l}\text { Combate a derrames de petróleo e seus derivados no } \\
\text { mar - comércio e uso de dispersantes }\end{array}$ \\
\hline IN IBAMA nº 07/2001 & Testes de toxicidade de dispersantes \\
\hline Decreto Federal $n^{\circ} 4.871 / 2003$ & $\begin{array}{l}\text { Combate à poluição por óleo em águas sob jurisdição } \\
\text { nacional }\end{array}$ \\
\hline $\begin{array}{l}\text { Nota Técnica CGPEG IBAMA } \\
\text { DILIC } n^{0} 3 / 2008\end{array}$ & $\begin{array}{l}\text { Otimização do processo de licenciamento ambiental } \\
\text { dos empreendimentos marítimos de exploração e } \\
\text { produção de petróleo e gás }\end{array}$ \\
\hline $\begin{array}{l}\text { Nota Técnica CGPEG IBAMA } \\
\text { DILIC } n^{0} 1 / 2011\end{array}$ & $\begin{array}{l}\text { Implementação do Projeto de Controle da Poluição } \\
\text { (PCP) exigido nos processos de licenciamento } \\
\text { ambiental dos empreendimentos marítimos de } \\
\text { exploração e produção de petróleo e gás, bem como } \\
\text { para apresentação das Metas desse Projeto e dos } \\
\text { respectivos Relatórios de implementação }\end{array}$ \\
\hline Portaria IBAMA no $28 / 2001$ & $\begin{array}{l}\text { Programa Nacional de Vigilância para Prevenção e } \\
\text { Monitoramento de Derrames de Óleo }\end{array}$ \\
\hline Lei Federal no 7.347/1985 & Ação Civil Pública por Danos Ambientais \\
\hline Decreto Federal no 83.540/1979 & $\begin{array}{l}\text { Regulamenta a aplicação da Convenção Internacional } \\
\text { sobre a Responsabilidade Civil de Danos Causados por } \\
\text { Poluição por Óleo (CLC 69) }\end{array}$ \\
\hline Decreto Federal $n^{0} 6.514 / 2008$ & $\begin{array}{l}\text { Sanções aplicáveis às condutas e atividades lesivas ao } \\
\text { meio ambiente }\end{array}$ \\
\hline $\begin{array}{l}\text { Decreto Federal } \mathrm{n}^{0} 4.136 / 2002 \\
\text { (dispositivos alterados pelo } \\
\text { Decreto Federal } \mathrm{n}^{\circ} 8.127 / 2013 \text { ) }\end{array}$ & $\begin{array}{l}\text { Sanções às infrações previstas na Lei Federal } n^{\circ} \\
9.966 / 2000\end{array}$ \\
\hline Portaria IBAMA n ${ }^{0} \mathbf{2 4 / 2 0 0 7}$ & $\begin{array}{l}\text { Emissão de laudos técnicos ambientais nos incidentes } \\
\text { de derramamento de óleo e derivados em águas sob } \\
\text { jurisdição nacional, nos termos das sanções } \\
\text { especificadas no Decreto n }{ }^{\circ} 4.136 / 2002 \text {, pela Marinha } \\
\text { do Brasil }\end{array}$ \\
\hline
\end{tabular}


(conclusão)

\begin{tabular}{|c|c|}
\hline NORMA & ASSUNTO \\
\hline $\begin{array}{l}\text { Resolução } \quad \text { CONAMA } \quad n^{\circ} \\
237 / 1997\end{array}$ & Licenciamento Ambiental \\
\hline $\begin{array}{l}\text { Lei Federal } \mathrm{n}^{\circ} 9.478 / 1997 \\
(\text { dispositivos alterados pela Lei } \\
\left.\text { Federal } \mathrm{n}^{\circ} 12.351 / 2010\right)\end{array}$ & $\begin{array}{l}\text { Política energética nacional, atividades relativas ao } \\
\text { monopólio do petróleo, institui o Conselho Nacional } \\
\text { de Política Energética e a Agência Nacional do } \\
\text { Petróleo }\end{array}$ \\
\hline $\begin{array}{l}\text { NORMAM-07/DPC: } \quad \text { Portaria } \\
\text { DPC n }{ }^{\circ} 105 / 2003\end{array}$ & $\begin{array}{l}\text { Normas da Autoridade Marítima para Atividades de } \\
\text { Inspeção Naval }\end{array}$ \\
\hline $\begin{array}{l}\text { NORMAM-09/DPC: } \quad \text { Portaria } \\
\text { DPC n }{ }^{\circ} 107 / 2003\end{array}$ & $\begin{array}{l}\text { Normas da Autoridade } \text { Marítima para Inquéritos } \\
\text { Administrativos sobre Acidentes e Fatos da } \\
\text { Navegação }\end{array}$ \\
\hline $\begin{array}{llr}\text { Resolução } & \text { CONAMA } & \mathrm{n}^{\circ} \\
306 / 2002 & \text { (alterada } & \text { pela } \\
\text { Resolução } & \text { CONAMA } & \mathrm{n}^{\circ} \\
381 / 2006) & & \end{array}$ & $\begin{array}{l}\text { Requisitos mínimos para a realização de auditoria } \\
\text { ambiental }\end{array}$ \\
\hline $\begin{array}{lll}\text { Resolução } & \text { CONAMA } & n^{\circ} \\
393 / 2007 & \end{array}$ & $\begin{array}{l}\text { Descarte contínuo de água de processo ou de } \\
\text { produção em plataformas marítimas de petróleo e gás } \\
\text { natural }\end{array}$ \\
\hline Decreto Federal n ${ }^{\circ} 99.348 / 1990$ & $\begin{array}{l}\text { Cria Grupo de Trabalho com o objetivo de avaliar a } \\
\text { legislação relativa à poluição hídrica causada pelo } \\
\text { derrame de óleo e substâncias nocivas }\end{array}$ \\
\hline Portaria MMA n ${ }^{\circ} 422 / 2011$ & $\begin{array}{l}\text { Procedimentos para o licenciamento ambiental } \\
\text { federal de atividades e empreendimentos de } \\
\text { exploração e produção de petróleo e gás natural no } \\
\text { ambiente marinho e em zona de transição terra-mar }\end{array}$ \\
\hline Resolução CONAMA nº 23/1994 & Licenciamento ambiental para perfuração de poços \\
\hline
\end{tabular}

\subsubsection{Prevenção de derramamentos de óleo}

No tocante à prevenção de derramamentos, houve um grande avanço nas normas brasileiras, conforme será demonstrado a seguir. Muito embora não seja o foco principal do presente trabalho, não se pode ignorar o fato de que nem sempre a fonte poluidora se encontra localizada no mar, a exemplo de plataformas e embarcações. Do mesmo modo, muitas vezes a 
contaminação do mar se dá de forma indireta, nos casos em que rios ou estuários recebem a carga poluidora e carregam os contaminantes até o mar. Nesse sentido, a Portaria do Ministério de Estado do Interior $n^{0} 124 / 1980^{165}$ estabelece normas para a localização de indústrias potencialmente poluidoras próximas a cursos hídricos, visando à prevenção de acidentes.

A Política Nacional de Meio Ambiente, instituída pela Lei Federal no 6.938/1981, ${ }^{166}$ de uma forma geral, dispõe sobre regras que objetivam a preservação, a melhoria e a recuperação da qualidade ambiental. Em seu anexo VIII, traz como primeira atividade potencialmente poluidora e utilizadora de recursos naturais a "perfuração de poços e produção de petróleo e gás natural". Mais adiante, por meio do código 18, o mesmo anexo indica como atividades de alto grau de potencial de poluição aquelas relacionadas ao transporte e depósito de petróleo e derivados, bem como marinas, portos e dutos.

Com relação à Segurança do Tráfego Aquaviário sob jurisdição nacional, a Lei Federal $n^{\circ} 9.537 / 1997^{167}$ dispõe sobre as regras gerais, inclusive, abordando o conceito de embarcação, em seu art. $2^{\circ}$, inciso $5^{\circ}$, sendo "qualquer construção, inclusive as plataformas flutuantes e, quando rebocadas, as fixas, sujeita a inscrição na autoridade marítima e suscetível de se locomover na água, por meios próprios ou não, transportando pessoas ou cargas". A Lei determina ainda que deve ser aplicada às embarcações brasileiras, com exceção das de guerra, mesmo quando transitarem além das águas sob jurisdição brasileira, respeitada, em águas estrangeiras, a soberania do Estado costeiro.

Um dos mais recentes avanços na esfera legislativa no tema prevenção de derramamentos de óleo no mar se deu pela Lei Federal n 9.966/2000, conhecida por "Lei do óleo". ${ }^{68}$ Esta Lei, de forma abrangente, estabelece regras para a movimentação de óleo tanto em portos organizados e instalações portuárias, quanto em plataformas e navios em águas sob jurisdição nacional.

A Lei do óleo, logo em seu início, esclarece que a sua aplicação deve se dar, em caráter complementar à Marpol 73/78, a todas as embarcações nacionais ou internacionais em águas brasileiras, portos organizados, instalações portuárias, dutos, plataformas e suas instalações de

\footnotetext{
165 Portaria do Ministério de Estado do Interior $\mathrm{n}^{\circ}$ 124/1980, consultada em:

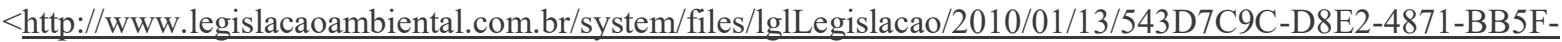
83624DA6E575.pdf>. Acesso em: 01.08.2018.

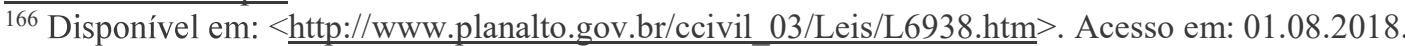

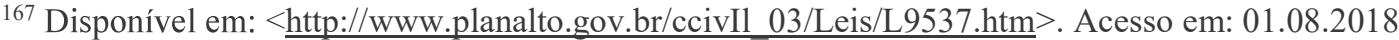

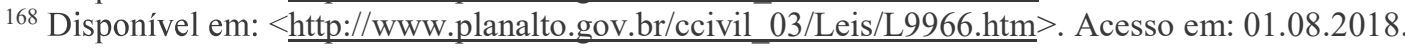


apoio. Impõe ainda aos responsáveis por portos, suas instalações e plataformas, a elaboração de "manual de procedimento interno para o gerenciamento dos riscos de poluição", e de "planos de emergência individuais para o combate à poluição por óleo e substâncias nocivas ou perigosas" a serem aprovados pelo órgão ambiental competente. Em complementação, a todos é exigida a realização de auditoria ambiental bienal nas instalações, de forma independente, como medida preventiva de possíveis acidentes.

Ademais, proíbe a descarga de óleo, misturas oleosas e lixo em águas sob jurisdição nacional, exceto nas situações permitidas pela Marpol 73/78, após aprovação do órgão ambiental competente e não havendo ameaça a ambientes ecologicamente sensíveis.

Entretanto, poderá ser necessária a realização de transferência de óleo entre embarcações ou barcaças, para transferência de carga, abastecimento ou, ainda, para a prevenção de acidentes, como nos casos em que uma embarcação danificada transfere o óleo para outra para evitar o derramamento no mar. Em situações como essas, deve-se respeitar o disposto na NORMAM 08, alterada por diversas vezes, tendo ocorrida a última alteração por meio da Portaria ${ }^{\circ}$ 131/DPC, de 11 de abril de 2018.

Dentre as exigências contidas na Normam 08 para a transferência de óleo, destaca-se a obrigatoriedade de uma embarcação acompanhar a operação munida de material absorvente e barreiras de contenção prontos a serem lançadas ao mar por pessoal qualificado em caso de acidentes. Ademais, essa mesma embarcação será responsável por acionar o Plano de Emergência Individual (PEI) do porto. Destaca-se que tanto a autoridade marítima pode solicitar medidas adicionais de prevenção da poluição hídrica, quanto o armador pode optar por sua adoção.

Em decorrência do derramamento de óleo ocorrido na Baía de Guanabara em 2000, ${ }^{169}$ rapidamente foi publicada a Resolução CONAMA n ${ }^{\circ} 265^{170}$ em 27 de janeiro do mesmo ano, considerando a necessidade de serem estabelecidas estratégias seguras de prevenção e gestão de impactos ambientais decorrentes de eventuais derramamentos. Com isso, determinou-se que

\footnotetext{
${ }^{169} \mathrm{O}$ acidente ocorreu a partir do rompimento do oleoduto que transportava óleo procedente da Refinaria Duque de Caxias, no Rio de Janeiro. $1.300 \mathrm{~m}^{3}$ de óleo atingiram a Baía de Guanabara, impactando extensas áreas de praias, costões rochosos, manguezais, ilhas, pontos turísticos, além de embarcações, material de pesca e a fauna local. Informação disponível no site da CETESB, na seção: "Síntese dos principais acidentes atendidos pela CETESB". Disponível em: $<$ https://cetesb.sp.gov.br/emergencias-quimicas/tipos-de-acidentes/dutos/principaisacidente>. Acesso em: 01.08.2018.

${ }^{170}$ Disponível em: $<$ http://www2.mma.gov.br/port/conama/legiabre.cfm?codlegi=263 $>$. Acesso em: 01.08.2018.
} 
o IBAMA e os órgãos estaduais de meio ambiente, com o acompanhamento dos órgãos municipais de meio ambiente e de entidades ambientalistas não governamentais deveriam realizar, no prazo de 240 dias, sob a supervisão do Ministério do Meio Ambiente, a avaliação das ações de controle e prevenção e do processo de licenciamento ambiental das instalações industriais de petróleo e derivados localizadas no território nacional.

Foi determinado ainda que a Petrobrás deveria, em seis meses, auditar de forma independente todas as suas instalações industriais, marítimas e terrestres, de petróleo e derivados, localizadas no Estado do Rio de Janeiro. Já as autoridades competentes deveriam elaborar, ou revisar, em doze meses o plano de contingência nacional e os planos de emergência regionais, estaduais e locais para acidentes ambientais causados pela indústria de petróleo e derivados.

Por fim, não se pode deixar de mencionar os avanços na legislação atinentes à fiscalização e ao licenciamento como importantes ferramentas para prevenção de poluição marinha.

Com relação ao licenciamento, a já citada Lei Federal n. ${ }^{\circ} 6.938 / 1981,{ }^{171} \mathrm{em}$ seu artigo 10, determina que as atividades que utilizam recursos ambientais e que podem poluir ou causar degradação ambiental devem ser submetidas ao licenciamento ambiental. No mesmo sentido, a Resolução CONAMA n ${ }^{\circ}$ 23/1994 ${ }^{172}$ trata especificamente do licenciamento ambiental para as atividades de perfuração de poços e de produção de combustíveis líquidos e de gás natural.

Além das normas já especificadas, destacam-se, por fim, o Programa Nacional de Vigilância para Prevenção e Monitoramento de Derramamentos de Óleo, criado pela Portaria IBAMA n 28/2001; além do o Projeto de Controle da Poluição (PCP) exigido nos processos de licenciamento ambiental dos empreendimentos marítimos de exploração e produção de petróleo e gás, por meio da Nota Técnica CGPEG IBAMA DILIC nº 01/2011.

\subsubsection{Plano Nacional de Contingência, Planos de Área, Planos de Emergência Individual}

O Plano Nacional de Contingência, além dos Planos de Área e de Emergência Individual podem ser considerados os maiores avanços na legislação brasileira nos últimos quinze anos tanto na prevenção de derramamentos, como, principalmente, no que diz respeito às respostas aos acidentes.

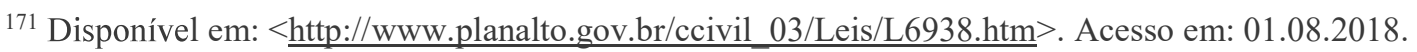

172 Disponível em: $<$ http://www2.mma.gov.br/port/conama/legiabre.cfm?codlegi=164>. Acesso em: 01.08.2018. 
Com relação à prevenção, destaca-se que ao elaborar os planos, toma-se conhecimento sobre as áreas mais sensíveis aos derramamentos de óleo. Nesse sentido, as ações visando o não atingimento dessas áreas são intensificadas. A Lei Federal no 9.966/2000, "Lei do Óleo", determinou que o Ministério do Meio Ambiente identificasse e limitasse as áreas ecologicamente sensíveis ao óleo. Em decorrência, foram elaboradas as Cartas de Sensibilidade Ambiental a Derramamentos de Óleo (Cartas SAO), ${ }^{173}$ indicando a sensibilidade ao óleo para os seguintes parâmetros: (i) Litoral; (ii) Recursos biológicos, e (iii) Atividades socioeconômicas.

Em decorrência, os Planos de Área para o combate à poluição por óleo em águas sob jurisdição nacional passaram a abranger em seu conteúdo mapas de sensibilidade ambiental, atendendo as normas técnicas para elaboração das Cartas SAO. Igualmente, os Planos de Emergência Individuais (PEI) adotaram como parte do conteúdo mínimo as cartas SAO. ${ }^{174}$

O Decreto Federal $n^{\circ} 4.871 / 2003^{175}$ instituiu a criação dos Planos de Áreas para o combate à poluição por óleo em águas sob jurisdição nacional. Os Planos de Área são documentos que apresentam informações sobre uma determinada área contendo "portos organizados, instalações portuárias, terminais, dutos ou plataformas e suas respectivas instalações de apoio". ${ }^{176}$ São planos mais abrangentes, que aglutinam e interligam os Planos de Emergência Individuais existentes para o combate de incidentes de poluição por óleo. Desse modo, os Planos de Área vão auxiliar na resposta aos acidentes que ultrapassem os limites dos Planos Individuais ou possuam origem desconhecida.

Nos casos de manchas órfãs, o Decreto Federal 4.871/2003 determina que deve ser estruturado um plano de ação de emergência integrado que atenda esse tipo de demanda, delineado em comum acordo por autoridades portuária, marítima, ambiental e municipal, em conjunto com terminais e operadores portuários.

${ }^{173}$ Conforme texto disponível no site do MMA: "As Cartas de Sensibilidade Ambiental a Derramamentos de Óleo (Cartas SAO), constituem ferramentas essenciais e fonte primária de informações para o planejamento de contingência e para a implementação de ações de resposta a incidentes de poluição por óleo, permitindo identificar os ambientes com prioridade de proteção e as eventuais áreas de sacrifício, possibilitando o correto direcionamento dos recursos disponíveis e a mobilização adequada das equipes de contenção e limpeza. Além disto, as mesmas têm um enorme potencial para emprego no planejamento ambiental da zona costeira e marinha, reforçando os instrumentos políticos e administrativos de ordenamento territorial." Disponível em: $<$ http://www.mma.gov.br/seguranca-quimica/cartas-de-sensibilidade-ao-oleo

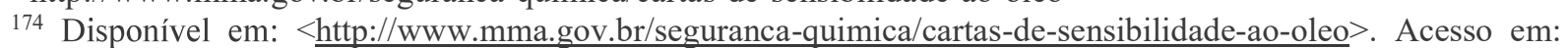
01.08.2018.

${ }^{175}$ Disponível em: $<$ http://www.planalto.gov.br/ccivil 03/decreto/2003/D4871.htm>. Acesso em: 01.08.2018.

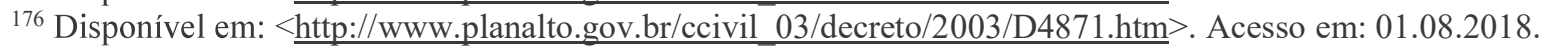


A responsabilidade pela elaboração desses planos é das entidades gerenciadoras de portos organizados e instalações portuárias, plataformas e respectivas instalações de apoio. E a coordenação e aprovação se dá pelo órgão ambiental competente.

Já o Plano de Emergência Individual está previsto na Resolução CONAMA n ${ }^{\circ}$ 398/2008, e deve conter as medidas adequadas de resposta aos incidentes de poluição por óleo em águas sob jurisdição nacional, que ocorram em "portos organizados, instalações portuárias, terminais, dutos, sondas terrestres, plataformas e suas instalações de apoio, refinarias, estaleiros, marinas, clubes náuticos e instalações similares". ${ }^{177}$ Conforme o nome indica, cada Plano deve ser elaborado de forma individual, e apresentado ao órgão ambiental para a obtenção das licenças ambientais. Importante ressaltar que a Resolução CONAMA 398/2008 está sendo discutida, novamente, desde 2017, e até a finalização do presente trabalho não foram verificadas publicações contendo alterações.

Por fim, o Plano Nacional de Contingência para incidentes de poluição por óleo em águas sob jurisdição nacional (PNC), foi instituído por meio do Decreto Federal n ${ }^{\circ}$ 8.127/2013. Seu conteúdo estabelece as responsabilidades, as diretrizes, os procedimentos e as ações em respostas aos derramamentos, coordenando a atuação conjunta de órgãos da administração pública e de entidades públicas e privadas, e visando minimizar os danos ambientais e à saúde pública.

O PNC deverá ser acionado nos casos em que o acidente for de grande dimensão e classificado como de significância nacional pelo Grupo de Acompanhamento e Avaliação, que compõe a estrutura organizacional do PEI. O Plano Nacional será colocado em prática após esgotados os recursos do Plano de Emergência Individual (PEI) das instituições envolvidas ou afetadas e do Plano de Área. Desse modo, a estrutura organizacional do plano permite uma grande articulação de instituições, com o envolvimento de até 17 ministérios, com vistas a otimizar as respostas ao derramamento. ${ }^{178}$

A Coordenação Operacional é responsável pelo comando das ações imediatas ao o acidente, e deverá ser exercida pelos seguintes órgãos: "pela Marinha, para incidentes em águas

\footnotetext{
${ }^{177}$ Disponível em: <http://www2.mma.gov.br/port/conama/legiabre.cfm?codlegi=575>. Acesso em: 01.08.2018.

${ }^{178}$ Informações sobre o PNC estão disponíveis em: $<$ https://www.ibama.gov.br/emergencias-ambientais/petroleoe-derivados/pnc $>$. Acesso em: 01.08.2018.
} 
marítimas, pelo Ibama, para incidentes em águas interiores e pela Agência Nacional do Petróleo (ANP) nos casos que envolvam estruturas submarinas de perfuração e produção de petróleo". ${ }^{179}$

Importante ressaltar que o Decreto Federal $n^{\circ} 8127 / 2013$ deixa claro que o poluidor permanece sendo o responsável pelas ações de resposta e reparação de danos por ele causados, inclusive nos casos de ser acionado o PNC. Situação em que deve o poluidor ressarcir todos os custos e despesas incorridos.

Com relação especificamente aos portos, a administração é originalmente realizada pela União. Entretanto, pode ser delegada ou assumida pelas concessionárias. A Lei Federal $n^{\circ}$ $12.815 / 2013$, por meio do artigo $17, \S 1^{\circ}, \mathrm{VI}$, determina que cabe à Autoridade Portuária (administradora do porto) zelar pela segurança e pelo meio ambiente no desenvolvimento das atividades. $^{180}$

Já a Norma Regulamentadora de Segurança e Saúde no Trabalho Portuário: Lei Federal n. ${ }^{\circ}$ 9.719/1998 e NR 29/1997, ${ }^{181}$ nos itens 29.1.6, 29.6.3.4 e 29.6.6, determina que também cabe à autoridade portuária a elaboração de dois planos, quais sejam: Plano de Controle de Emergência (PCE) e Plano de Ajuda Mútua (PAM). Tais Planos devem ser elaborados em resposta aos seguintes incidentes: incêndio ou explosão; vazamento de produtos perigosos; queda de homem ao mar; condições adversas de tempo que afetem a segurança das operações portuárias; poluição ou acidente ambiental; e socorro a acidentados. Os trabalhadores do porto devem ser constantemente treinados para estarem aptos a participarem da implementação prática dos planos no caso de um acidente.

Por fim, cumpre citar a existência de um último plano, mais específico elaborado pelo Ibama, visando a proteção da fauna brasileira em casos de derramamento de óleo, denominado Plano Nacional de Ação de Emergência para Fauna Impactada por Óleo (PAE Fauna).

\subsubsection{Resposta e reparação de derramamentos}

A eficiência da reparação de um derramamento se mede desde a comunicação do incidente. Muito embora a legislação internacional já tenha sido abordada na primeira parte do

\footnotetext{
179 Disponível em: < https://www.ibama.gov.br/emergencias-ambientais/petroleo-e-derivados/pnc $>$. Acesso em: 01.08.2018.

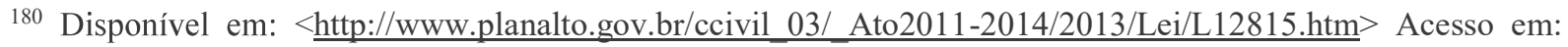
01.08.2018.

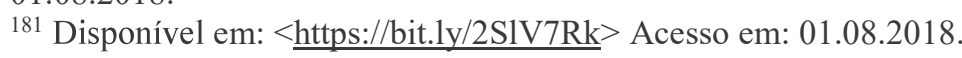


presente capítulo, vale retomar parte do disposto no Decreto Federal $n^{\circ} 83.540 / 1979$, que Regulamenta a CLC 69.

De acordo com seu artigo $8^{\circ}, \S 1^{\circ}$, imediatamente após o conhecimento do incidente que possa resultar em poluição por óleo, a Capitania dos Portos ou órgão a ela subordinado deve ser comunicado. ${ }^{182}$

Da mesma forma, a Portaria da Agência Nacional de Petróleo nº 170/1998, em seu art. 13 impõe a empresa autorizada o dever de comunicar imediatamente à ANP qualquer ocorrência que resulte em riscos à saúde pública, à segurança e ao meio ambiente, inclusive, informando as causas e as ações adotadas para mitigar ou sanar o impacto. ${ }^{183}$

Em plena harmonia com os dispositivos anteriormente citados, a Lei Federal $\mathrm{n}^{\circ}$ 9.966/2000, "Lei do óleo", em seu artigo 22 vai além, ao apontar que todos os acidentes ocorridos em "portos organizados, instalações portuárias, dutos, navios, plataformas e suas instalações de apoio", que possuam potencial de poluir águas nacionais, deverão ser informados não somente à Capitania dos Portos e à ANP, mas também ao órgão ambiental competente.

A importância da comunicação é tamanha que, inclusive, quando realizada de forma adequada, é reconhecida como circunstância atenuante de penas por meio do artigo 14 da Lei de Crimes Ambientais (Lei Federal $n^{\circ}$ 9.605/1998). Por outro lado, o Decreto Federal $n^{\circ}$ 4.136/2002, em seu art. 47 apresenta a previsão de multa pelo descumprimento do dever de informar, exposto pelo artigo 22 da "Lei do óleo", podendo chegar a até R\$50.000.000,00. ${ }^{184}$

Com relação às formas e técnicas específicas para a reparação dos ambientes afetados pelo óleo derramado, estas serão tratadas com mais detalhes no Capítulo 7. Como será demonstrado, cada tipo de ambiente apresenta um índice próprio de sensibilidade ao óleo. Sendo assim, não somente a caracterização do ambiente, mas as especificidades tanto do local, quanto do momento do acidente (a exemplo de correntes marítimas e ventos) serão determinantes para a escolha das formas mais adequadas de reparação dos danos. Ademais, não se pode deixar de pontuar que as respostas aos incidentes não são vistas somente como formas de reparação, mas igualmente de prevenção dos danos, uma vez que, sendo certeiras, reduzem

\footnotetext{
182 Disponível em: <http://www2.camara.leg.br/legin/fed/decret/1970-1979/decreto-83540-4-junho-1979432843-publicacaooriginal-1-pe.html > Acesso em: 01.08.2018.

183 Disponível em: <http://www.ibama.gov.br/sophia/cnia/legislacao/AGENCIAS/ANP/PT0170-261198.PDF> Acesso em: 01.08.2018.

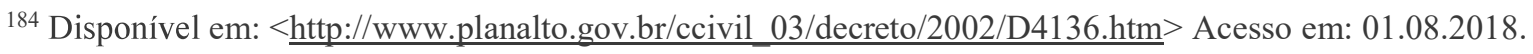


as chances de o óleo atingir os mais sensíveis ambientes, mitigando e evitando maiores impactos.

Entretanto, por se tratar de um capítulo de legislação, não se pode deixar de mencionar dois assuntos recentemente regulamentados no Brasil e que foram objeto de muitas discussões acerca de suas consequências: o uso de dispersantes químicos e a queima controlada do óleo.

O uso de dispersantes químicos é objeto de duas Instruções Normativas do IBAMA (IN IBAMA), sendo a primeira de 2000 e a segunda de 2001. A IN IBAMA n ${ }^{\circ}$ 1/2000 estabelece os critérios observados pelo IBAMA para a concessão de registro de dispersantes químicos a serem utilizados em derramamentos de petróleo e seus derivados no mar. ${ }^{185}$ Já a IN IBAMA 07/2001 trata dos testes de toxicidade que devem ser realizados nos dispersantes para que seja autorizada a sua utilização em águas nacionais. Por fim, a Resolução CONAMA 472/2015 ${ }^{186}$ dispõe sobre a necessidade de comunicação ao IBAMA acerca da decisão de utilização de dispersante químico em manchas de óleo no mar e, caso a mancha possa atingir a costa, o órgão ambiental competente deve igualmente ser comunicado. A Resolução vai além, impondo como regra que o uso de dispersantes somente será permitido quando outras técnicas mecânicas de remoção da mancha ou mesmo a não intervenção não apresentarem resultados satisfatórios. Ademais, são apresentadas as áreas de proibição ou restrição do uso, além dos critérios que devem ser observados como propícios para a aplicação, a exemplo das características da mancha de óleo alvo.

Já a Resolução CONAMA n 482/2017 $7^{187}$ trata de outra técnica polêmica, a "queima controlada emergencial como ação de resposta a incidentes de poluição por óleo no mar". A regra geral, semelhante à do uso dos dispersantes, nos termos do artigo $3^{\circ}$, Resolução CONAMA $n^{\circ} 482 / 2017$, considera que a queima será permitida apenas:

(...) quando a não intervenção ou a aplicação de técnicas mecânicas de contenção, recolhimento e dispersão se mostrarem não efetivas, inaplicáveis ou insuficientes e quando ocorrer ao menos uma das seguintes hipóteses:

I - incidentes de poluição por óleo no mar considerados de significância nacional;

II - incidentes de poluição por óleo no mar de descarga contínua com volumes relevantes;

${ }^{185}$ Disponível em: < http://www.ibama.gov.br/sophia/cnia/legislacao/IBAMA/IN0001-140700.PDF>. Acesso em: 01.08.2018.

${ }^{186}$ Disponível em: $<$ http://www2.mma.gov.br/port/conama/legiabre.cfm?codlegi=718 > . Acesso em: 01.08.2018.

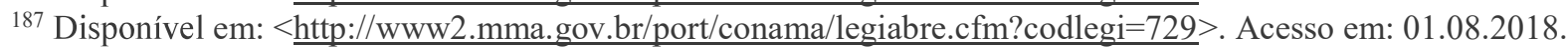


III - incidentes de poluição por óleo onde a mancha estiver se deslocando ou puder se deslocar para áreas designadas como ambientalmente sensíveis, conforme indicação meteoceanográfica ou dados pretéritos locais.

São ainda definidas regras sobre as áreas de proibição e de restrição à queima, em que consideram as áreas sensíveis delimitadas em Cartas SAO, a exposição de seres humanos e animais marinhos, dentre outros critérios. Ademais, dentre outras disposições, importante ressaltar a necessidade de o uso da técnica estar previsto no Plano de Emergência Individual (PEI) ou no Plano de Área (PA). Nos casos em que, pela natureza da atividade, não haja obrigação de apresentação prévia de PEI ou de sua inserção em PA, a técnica de queima controlada só poderá ser utilizada mediante prévia autorização do IBAMA.

\subsubsection{Penalidades}

Conforme será melhor detalhado ao longo do presente trabalho, o derramamento de óleo no mar pode ser avaliado à luz de três formas de responsabilidade: civil, administrativa e criminal, que possuem penalidades diversas. Ou seja, a mesma conduta pode ser enquadrada nas três formas de responsabilidade e as respectivas penalidades podem ser aplicadas de forma independente e cumulativa.

A Política Nacional de Meio Ambiente, instituída pela Lei Federal n ${ }^{\circ} 6.938 / 1981,{ }^{188} \mathrm{em}$ seu artigo 14, determina que aqueles que não cumprem com as medidas de prevenção e reparação de danos adequadamente estão sujeitos às seguintes penalidades: multa simples ou diária; perda ou restrição de incentivos e benefícios fiscais concedidos pelo Poder Público; perda ou suspensão de participação em linhas de financiamento em estabelecimentos oficiais de crédito; e/ou suspensão de sua atividade. O parágrafo $1^{\circ}$ do mesmo artigo determina que a obrigação de reparar ou indenizar os danos independe da existência de culpa, isto é, é objetiva. Ademais, os Ministérios Públicos da União e dos Estados possuem legitimidade para propor Ações Judiciais de responsabilidade civil ${ }^{189}$ e /ou criminal, por danos causados ao meio ambiente.

O Decreto Federal $n^{\circ} 83.540 / 1979,{ }^{190}$ que regulamenta a aplicação da Convenção Internacional sobre a Responsabilidade Civil de Danos Causados por Poluição por Óleo (CLC

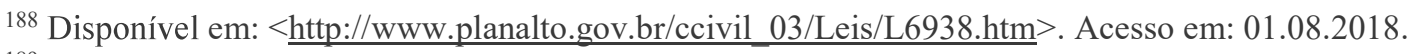

189 Ação Civil Pública por Danos Ambientais é disciplinada pela Lei Federal no 7.347/1985 e tem por objeto a condenação em dinheiro ou o cumprimento de obrigação de fazer ou não fazer. Disponível em: $<$ http://www.planalto.gov.br/ccivil 03/leis/L7347orig.htm>. Acesso em: 01.08.2018.

190 Disponível em: <http://www2.camara.leg.br/legin/fed/decret/1970-1979/decreto-83540-4-junho-1979432843-publicacaooriginal-1-pe.html > . Acesso em: 01.08.2018.
} 
69), em seu artigo $2^{\circ}$ impõe a responsabilidade civil por danos causados pela poluição por óleo ao proprietário de um navio, ao transportar óleo a granel como carga. Entretanto, há a previsão de isenção de responsabilidade no $\S 2^{\circ}$, do artigo $3^{\circ}$, do texto da Convenção ora regulamentada, fundamentada por hipótese de "culpa de terceiro", contrariamente à corrente majoritária defendida nos tribunais brasileiros, conforme será apresentado no capítulo 6 .

A Lei de Crimes Ambientais, Lei Federal $n^{\circ} 9.605 / 1998,{ }^{191}$ ao tratar do crime de poluição, aborda casos específicos nos incisos I ao $\mathrm{V}$ do $\S 2^{\circ}$, do artigo 54 , que podem ser associados aos derramamentos de óleo: I) tornar uma área imprópria para a ocupação humana; II) causar poluição atmosférica que provoque a desocupação das áreas afetadas ou que cause danos diretos à saúde da população; III) causar poluição hídrica interrompendo o abastecimento público de água; IV) dificultar ou impedir o uso público das praias; V) lançar óleos ou substâncias oleosas em desacordo com as exigências legais. Nesses casos, a pena é de reclusão de um a cinco anos, podendo ser igualmente aplicada àqueles que deixam de adotar medidas de precaução em caso de risco de dano ambiental grave ou irreversível.

O Decreto Federal $n^{\circ} 6.514 / 2008^{192}$, em seu artigo $2^{\circ}$, define como infração administrativa ambiental toda ação ou omissão que viole "regras jurídicas de uso, gozo, promoção, proteção e recuperação do meio ambiente", e apresenta as respectivas sanções aos casos de derramamentos de óleo no mar sendo passível a aplicação de: I) advertência; II) multa simples; III) multa diária; IV) apreensão de instrumentos, petrechos, equipamentos ou veículos de qualquer natureza utilizados na infração; VII) embargo de atividade e suas respectivas áreas; IX) suspensão parcial ou total das atividades; e X) restritiva de direitos.

Por fïm, a Lei Federal no 9.966/2000, "Lei do óleo", ${ }^{193}$ determina que a entidade exploradora de porto organizado ou de instalação portuária, o proprietário ou operador de plataforma ou de navio, e o concessionário ou empresa autorizada a exercer atividade pertinente à indústria do petróleo, responsáveis pela descarga de material poluente em águas sob jurisdição nacional, são obrigados a ressarcir os órgãos competentes pelas despesas por eles despendidas para o controle ou minimização da poluição causada, independentemente de prévia autorização e de pagamento de multa. Mesmo nos casos em que a descarga dos poluentes for autorizada,

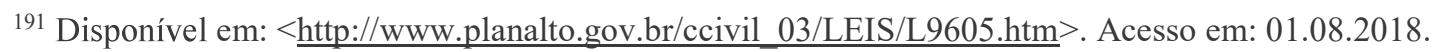

192 Disponível em: <http:/www.planalto.gov.br/ccivil_03/ ato2007-2010/2008/decreto/d6514.htm>. Acesso em: 01.08.2018.

${ }^{193}$ Disponível em: < http://www.planalto.gov.br/ccivil 03/Leis/L9966.htm>. Acesso em: 01.08.2018. 
permanece ao proprietário a obrigação de reparar os danos causados ao meio ambiente e de indenizar as atividades econômicas e o patrimônio público e privado pelos prejuízos decorrentes dessa descarga.

Nesse quesito, a "Lei do óleo" vai além do estabelecido pela Marpol, ao abarcar por meio desse dispositivo a responsabilidade de reparação do dano independentemente de culpa ou dolo, estendendo tal responsabilidade até mesmo para os casos em que a atividade que resulta em poluição seja autorizada, em plena concordância com o sistema de responsabilização civil vigente no Brasil.

No caso de descarga por navio não possuidor do certificado exigido pela CLC/69, a embarcação será retida e só será liberada após o depósito de caução como garantia para pagamento das despesas decorrentes da poluição.

Esta Lei possui penalidades que variam entre multa, multa simples e suspensão imediata das atividades da empresa transportadora em situação irregular. $\mathrm{O}$ valor da multa pode variar entre o mínimo de $\mathrm{R} \$ 7.000,00$ (sete mil reais) e o máximo de $\mathrm{R} \$ 50.000 .000,00$ (cinquenta milhões de reais).

A aplicação das penas previstas neste artigo não isenta o agente de outras sanções administrativas e penais previstas na Lei Federal n ${ }^{\circ}$ 9.605/1998 e em outras normas específicas que tratem da matéria, nem da responsabilidade civil pelas perdas e danos causados ao meio ambiente e ao patrimônio público e privado.

\subsection{Conclusões parciais}

Conforme apresentado no presente capítulo, as convenções internacionais aplicáveis aos derramamentos de óleo no mar são complexas e diversas. Muito embora nem todas as Convenções acima abordadas tenham sido internalizadas pelo Brasil, não se pode negar que os aspectos preventivos e reparatórios descritos em cada norma são de extrema importância.

Algumas das convenções abordadas apresentam disposições importantes atinentes à compensação, à reparação e principalmente à definição de regras de responsabilização em decorrência de derramamentos de óleo, seja por acidentes, seja em decorrência de operações regulares. Dentre as convenções, merecem destaque neste tema: Convenção Internacional sobre Responsabilidade Civil em Danos Causados por Poluição por Óleo (CLC/69 e CLC/92) e a Convenção sobre Responsabilidade Civil por Danos Causados pela Poluição por Combustíveis de Navios (BUNKER/01). 
As principais inovações trazidas pelas convenções no tocante à garantia pela reparação dos danos se dão devido às previsões de criação de fundos destinados para esse fim, além da obrigatoriedade de seguro por parte das embarcações.

Apesar de o Brasil ser signatário de algumas de grande importância, conforme apresentado acima, sendo os textos inclusive internalizados e integrantes da legislação brasileira, na prática o uso dessas convenções não se dá de forma expressiva. A análise mais aprofundada desenvolvida no presente capítulo demonstrou que muitos dos textos internacionais se baseiam em formas de responsabilidade incompatíveis com a adotada pelo Direito Brasileiro, mas especificamente com o Direito Civil Ambiental. Um exemplo claro dessa incongruência de sistemas jurídicos ocorre pela previsão de excludentes de responsabilidade baseada na ausência de dolo ou culpa do poluidor pelo derramamento causado. No Brasil, conforme será demonstrado nos capítulos a seguir, a responsabilidade civil por dano ambiental é objetiva, o que significa que o poluidor responde por seus atos independentemente de dolo ou culpa.

A legislação brasileira ao longo dos últimos quinze anos avançou bastante, principalmente, com relação a prevenção e resposta a acidentes decorrentes da exploração de petróleo e temas correlatos, em decorrência tanto das novas descobertas do pré-sal, como também de incidentes, a exemplo do ocorrido na Baía de Guanabara. Nos últimos 10 anos, graças à Resolução CONAMA 398/2008 e ao Decreto 8.127/2013, as empresas passaram a elaborar os seus planos de emergência, tornando-se mais capacitadas a reagirem a situações de acidentes.

Esses fatores corroboraram para a diminuição de vazamentos em quantidades mais expressivas, permanecendo mais constantes aqueles de menor volume, originados por pequenas embarcações, que não são contempladas em parte pela legislação que dispõe sobre o tema.

De uma forma geral, entende-se que o regramento brasileiro de prevenção a acidentes é bem detalhado e eficiente. Da mesma forma, por meio dos processos de aprovação dos planos de emergência individuais os órgãos ambientais influenciam as empresas a se adequarem à legislação e exerce uma fiscalização prévia aos acidentes. Com isso, mesmo com a diminuição do número de vazamentos, conforme pontuado, em grande parte por conta da legislação vigente, quando estes ocorrem ainda se verificam incongruências acerca das formas de reparação adotadas: tanto na esfera técnica, quanto principalmente na judicial. 
Diante desse fato, conclui-se a legislação brasileira e as convenções internacionais não bastam para a garantia de uma reparação eficiente de danos decorrentes de derramamentos de óleo. Há, portanto, a necessidade de compreensão mais profunda acerca dos danos, tanto nos aspectos ecológicos e biológicos, quanto jurídicos. 


\section{DANOS AMBIENTAIS}

\subsection{Dano Jurídico no Direito Civil}

Preliminarmente, antes de se iniciar um aprofundamento acerca das características do dano ambiental, não se pode deixar de abordar o tema do "dano", inserido no contexto do Código Civil de 2002 de forma geral. O Artigo 186 do Código Civil de 2002 preceitua que: "Aquele que, por ação ou omissão voluntária, negligência ou imprudência, violar direito e causar dano a outrem, ainda que exclusivamente moral, comete ato ilícito".

Miragem, ao discorrer sobre o disposto no artigo explica a necessidade de se configurar o dano como injusto para que se tenha o dever de indenizar:

Dano é consequência da violação de um direito. Como pressuposto da responsabilidade civil, note-se que só se pode referir à indenização e ao dever de indenizar na medida em que haja dano injusto. É a existência do dano injusto que se configura causa de atribuição patrimonial para que determinado valor pecuniário se transfira do patrimônio do autor do dano ou de quem responda pelo dever de indenizar para a vítima. ${ }^{194}$

Ademais, nota-se que, para o conceito clássico de dano se leva em consideração a vontade, além da culpa. Entretanto, cumpre desde já esclarecer que, para os danos ambientais especificamente a responsabilidade será objetiva, ou seja, independentemente de culpa. ${ }^{195}$ Sendo assim, nos termos de Schreiber:

A ampliação da responsabilidade objetiva vem eliminar, em definitivo, o peso atribuído à ilicitude na usual conceituação do dano. Com efeito, nos casos de responsabilidade sem culpa, a ilicitude encontra-se ausente, havendo, no máximo, de se cogitar de antijuridicidade no resultado do comportamento, isto é, com a geração do dano em si. ${ }^{196}$

Pois bem, um segundo ponto a ser extraído do artigo 186 se refere à correlação direta entre o dano e o ato ilícito. Conforme esclarece Pontes de Miranda, "não há responsabilidade sem prejuízo", sendo o dano "toda desvantagem que experimentamos em nossos bens jurídicos (patrimônio, corpo, vida, saúde, honra, crédito, bem-estar, capacidade de aquisição)",

${ }^{194}$ MIRAGEM, B. N. B.. Direito Civil: responsabilidade civil. São Paulo: Saraiva, 2015, p. 156.

195 Nas palavras de Melo: "Nesse sentido, dano é a agressão ou a violação de qualquer direito, material ou imaterial que, provocado com dolo ou culpa pelo agente (responsabilidade subjetiva) ou em razão da atividade desenvolvida (responsabilidade objetiva, cause a uma pessoa, independentemente de sua vontade, uma diminuição de valor de um bem juridicamente protegido, seja de valor pecuniário, seja de valor moral ou até mesmo de valor afetivo". MELO, N. D. de. Responsabilidade civil por erro médico: doutrina e jurisprudência. São Paulo: Atlas, 2008, p.29.

${ }^{196}$ SCHREIBER, A. Novos paradigmas da responsabilidade civil. São Paulo: Atlas, 2007, p.100. 
resultando em reparação ${ }^{197}$. Assim, pontua o autor que o dano será o elemento essencial à responsabilidade, sendo ela objetiva ou subjetiva, tanto nos atos ilícitos, quanto nos lícitos. ${ }^{198}$

Note-se que, o patrimônio, ${ }^{199}$ no sentido material, é apenas um dos possíveis alvos de danos. Carlos Roberto Gonçalves defende a adoção de um conceito mais abrangente de dano, que seria “(...) diminuição ou subtração de um 'bem jurídico', para abranger não só o patrimônio, mas a honra, a saúde, a vida, suscetíveis de proteção" ${ }^{200}$ Nesse sentido, o dano ou prejuízo pode ser conceituado como "lesão a um interesse jurídico tutelado - patrimonial ou não -, causado por ação ou omissão do sujeito infrator.",201

Importante esclarecer que a partir do momento em que o dano reflete em perda de "bens e direitos de que seja titular a pessoa", ou seja, afeta interesses juridicamente protegidos, ${ }^{202}$ a primeira ideia que se tem é a delimitação restrita do dano ou a interesses materiais ou a interesses personalíssimos (isto é, extrapatrimoniais). ${ }^{203}$ Entretanto, o dano pode igualmente ser “a diminuição ou supressão de uma situação favorável reconhecida ou protegida pelo direito". 204 Nesse caso, o bem afetado por um dano pode perfeitamente ser de tutela transindividual, de interesse difuso ${ }^{205}$, a exemplo do meio ambiente.

197 O parágrafo único do artigo 927 do Código Civil de 2002 aborda a necessidade de reparação do dano: "Art. 927. Aquele que, por ato ilícito (arts. 186 e 187), causar dano a outrem, fica obrigado a repará-lo. Parágrafo único. Haverá obrigação de reparar o dano, independentemente de culpa, nos casos especificados em lei, ou quando a atividade normalmente desenvolvida pelo autor do dano implicar, por sua natureza, risco para os direitos de outrem".

${ }^{198}$ MIRANDA, P. de. Direito das obrigações: direito das obrigações, fatos ilícitos absolutos, atos-fatos ilícitos absolutos, responsabilidade, danos causados por animais, coisas inanimadas e danos, estado e servidores, profissionais. Rui Stoco (Atual.). São Paulo: RT, 2012, p.284.

${ }^{199}$ Nos termos de Santos: "Pode se dizer, hoje em dia, que patrimônio é o complexo de bens, direitos e interesses que se prende a uma determinada pessoa. E dano é a lesão injusta que provoque abalo ou diminuição nesse patrimônio." SANTOS, R. B. dos. Teoria Geral da Responsabilidade Civil. In: ARAÚJO, V. D. (Coord.); HIRONAKA, G. M. F. (Orient.). Direito Civil: Responsabilidade Civil. São Paulo: RT, v.5, 2008, p.45.

${ }^{200}$ GONÇALVES, C. R.. Direito Civil Brasileiro: responsabilidade civil. São Paulo, Saraiva, v.4, $7^{\text {a }}$ ed., 2012 , p. 357.

${ }^{201}$ GAGLIANO, P. S.; PAMPLONA FILHO, R. Novo curso de Direito Civil: Responsabilidade Civil. São Paulo: Saraiva, v.3, $9^{\text {a }}$ ed., 2011, p. 78.

${ }^{202}$ MIRAGEM, B. N. B.. Direito Civil: responsabilidade civil. São Paulo: Saraiva, 2015, p. 155.

${ }^{203}$ GAGLiANO, P. S.; PAMPLONA FILHO, R. Novo curso de Direito Civil: Responsabilidade Civil. São Paulo: Saraiva, v.3, $9^{\text {a }}$ ed., 2011, p.78.

${ }^{204}$ MIRAGEM, B. N. B.. Direito Civil: responsabilidade civil. São Paulo: Saraiva, 2015, p. 155.

${ }^{205}$ O Código de Defesa do Consumidor, Lei n ${ }^{\circ}$ 8078, de 1990, dispõe sobre interesses difusos: Art. 81. "A defesa dos interesses e direitos dos consumidores e das vítimas poderá ser exercida em juízo individualmente, ou a título coletivo. Parágrafo único. A defesa coletiva será exercida quando se tratar de: I - interesses ou direitos difusos, assim entendidos, para efeitos deste código, os transindividuais, de natureza indivisível, de que sejam titulares pessoas indeterminadas e ligadas por circunstâncias de fato; II - interesses ou direitos coletivos, assim entendidos, para efeitos deste código, os transindividuais, de natureza indivisível de que seja titular grupo, categoria ou classe de pessoas ligadas entre si ou com a parte contrária por uma relação jurídica base; III - interesses ou direitos individuais homogêneos, assim entendidos os decorrentes de origem comum." 


\subsubsection{Espécies de danos no Direito Civil}

Tradicionalmente, o Direito Civil divide os danos entre patrimoniais (ou materiais), e extrapatrimoniais (ou morais). ${ }^{206}$ Desde já é importante ressaltar que, mais à frente, o presente capítulo irá retomar a aplicação dos conceitos de dano patrimonial e extrapatrimonial sob o contexto do Direito Civil Ambiental, mais precisamente, dos derramamentos de óleo. Entretanto, entende-se como necessária à construção lógica desta tese a apresentação primeiramente de ambos os conceitos de forma geral, considerando-se exclusivamente o contexto do Código Civil de 2002.

\subsubsection{Dano Patrimonial}

Os danos Patrimoniais ou materiais estão igualmente previstos no Código Civil de 2002, nos artigos 402 e 403, que tratam das perdas e danos. ${ }^{207}$ De acordo com Tartuce, os danos patrimoniais são caracterizados por "prejuízos, perdas que atingem o patrimônio corpóreo de uma pessoa natural, pessoa jurídica ou ente despersonalizado". ${ }^{208}$

A doutrina divide essas perdas em danos emergentes e lucros cessantes. Os danos emergentes são medidos pela perda do que se tinha como certo, ou seja, "pela efetiva diminuição do patrimônio da vítima". ${ }^{209}$ Já os lucros cessantes se referem ao que se deixou de ganhar devido ao dano, "é a frustração da expectativa de lucro. É a perda de um ganho esperado". 210

Em poucas palavras, o que se mede nos danos patrimoniais é "aquilo que efetivamente se perdeu e aquilo que se deixou de lucrar: o dano emergente e o lucro cessante". ${ }^{211}$ Sendo assim, a reparação dos danos patrimoniais se dará pela reposição do que se perdeu, a partir da valoração do prejuízo.

${ }^{206}$ GONÇALVES, C. R.. Direito Civil Brasileiro: responsabilidade civil. São Paulo, Saraiva, v.4, $7^{\mathrm{a}}$ ed., 2012 , p. 360.

${ }^{207}$ Redação dos artigos 402 e 403 do Código Civil de 2002: Art. 402: "Salvo as exceções expressamente previstas em lei, as perdas e danos devidas ao credor abrangem, além do que ele efetivamente perdeu, o que razoavelmente deixou de lucrar". Art. 403. "Ainda que a inexecução resulte de dolo do devedor, as perdas e danos só incluem os prejuízos efetivos e os lucros cessantes por efeito dela direto e imediato, sem prejuízo do disposto na lei processual".

${ }^{208}$ TARTUCE, F. Direito Civil: direito das obrigações e responsabilidade civil. Rio de Janeiro: Forense, v.2, $12^{\mathrm{a}}$ ed., 2012, p.390.

${ }^{209}$ TARTUCE, F. Direito Civil: direito das obrigações e responsabilidade civil. Rio de Janeiro: Forense, v.2, 12 ${ }^{\mathrm{a}}$ ed., 2012, p.391.

${ }^{210}$ GONÇALVES, C. R.. Direito Civil Brasileiro: responsabilidade civil. São Paulo, Saraiva, v.4, $7^{\mathrm{a}}$ ed., 2012 , p. 364.

${ }^{211}$ MIRANDA, P. de. Direito das obrigações: direito das obrigações, fatos ilícitos absolutos, atos-fatos ilícitos absolutos, responsabilidade, danos causados por animais, coisas inanimadas e danos, estado e servidores, profissionais. Rui Stoco (Atual.). São Paulo: RT, 2012, p.284. 


\subsubsection{Dano Extrapatrimonial}

O dano extrapatrimonial - mais utilizado como dano moral ${ }^{212}$ em contextos genéricos do Direito Civil - está presente no texto do artigo $5^{\circ}, \mathrm{X}$, da Constituição Federal de 1988. Trata-se de uma consequência de ofensas que atingem "bens, valores de ordem interna ou anímica como, apenas exemplificativamente, a honra, a imagem, o bom nome, a intimidade, a privacidade e, enfim, todos os atributos da personalidade. ${ }^{\prime 213}$ Ou seja, nesse caso, há uma ofensa direta à pessoa e não a seu patrimônio. ${ }^{214}$ Já no Código Civil de 2002, o dano moral se traduz como lesão aos direitos da personalidade nos artigos 11 a 21.

Miragem pontua que apenas alguns atributos da personalidade justificam a ofensa passível de reparação por danos extrapatrimoniais. São eles: vida, integridade física, integridade e estabilidade psíquica, honra, intimidade, privacidade e imagem. ${ }^{215}$

Com relação à reparação dos danos extrapatrimoniais, deve-se admitir que o prejuízo indenizável "poderá decorrer - não somente da violação do patrimônio economicamente aferível - mas também da vulneração de direitos inatos à condição de homem, sem expressão pecuniária essencial". ${ }^{216}$ Entretanto, é certo que não há meios de se valorar o sofrimento, sendo assim, a reparação deve ser "um meio para atenuar, em parte, as consequências do prejuízo imaterial". 217

Há situações em que os danos morais atingem direitos de personalidade homogêneos, ou coletivos, de várias pessoas, podendo ser determinadas ou determináveis. Nesse caso, temos os danos morais coletivos ou difusos. ${ }^{218}$ Para esses casos, a ligação entre dano extrapatrimonial

\footnotetext{
212 A expressão "dano moral" deve ser reservada exclusivamente para designar a lesão que não produz qualquer efeito patrimonial. Se há consequências de ordem patrimonial, ainda que mediante repercussão, o dano deixa de ser extrapatrimonial. GONÇALVES, C. R.. Direito Civil Brasileiro: responsabilidade civil. São Paulo, Saraiva, v.4, $7^{\mathrm{a}}$ ed., 2012 , p. 360 .

213 MIRANDA, P. de. Direito das obrigações: direito das obrigações, fatos ilícitos absolutos, atos-fatos ilícitos absolutos, responsabilidade, danos causados por animais, coisas inanimadas e danos, estado e servidores, profissionais. Rui Stoco (Atual.). São Paulo: RT, 2012, p.284.

${ }^{214}$ SCHREIBER, A. Novos paradigmas da responsabilidade civil. São Paulo: Atlas, 2007, p.100.

${ }^{215}$ MIRAGEM, B. N. B. Direito Civil: responsabilidade civil. São Paulo: Saraiva, $5^{\text {a }}$ ed., 2015.

${ }^{216}$ GAGLIANO, P. S.; PAMPLONA FILHO, R. Novo curso de Direito Civil: Responsabilidade Civil. São Paulo: Saraiva, v.3, $9^{\text {a }}$ ed., 2011, p.79.

217 TARTUCE, F. Direito Civil: direito das obrigações e responsabilidade civil. Rio de Janeiro: Forense, v.2, 12 ${ }^{\mathrm{a}}$ ed., 2012, p.405.

${ }^{218}$ TARTUCE, F. Direito Civil: direito das obrigações e responsabilidade civil. Rio de Janeiro: Forense, v.2, 12 ${ }^{\mathrm{a}}$ ed., 2012, p.447.
} 
e dor e/ou sofrimento humano deve ser repensada. ${ }^{219}$ A dor, segundo Gagliano, seria apenas a consequência de um dano extrapatrimonial e não o dano em si. ${ }^{220}$

Um exemplo de dano extrapatrimonial difuso, é o dano ambiental, uma vez que a titularidade do meio ambiente pertence a todos, ${ }^{221}$ por previsão legal, mais especificamente por conta do artigo 225 da Constituição Federal de 1988. Com relação à reparação dos danos extrapatrimoniais difusos, entende-se que, pela titularidade, todos deveriam ser contemplados. Entretanto, nos casos de interesses difusos, a reparação por meio de indenização nem sempre é revertida ao bem comum, principalmente quando destinada à fundos nos moldes brasileiros.

\subsubsection{Dano reflexo ou ricochete}

O dano pode ser ainda classificado como direto e indireto (sendo igualmente reconhecido por reflexo ou ricochete). No dano ricochete "uma pessoa sofre o reflexo de um dano causado a outrem". ${ }^{222}$ Ocorre quando alguém, que não é a vítima direta da atuação ilícita, é prejudicada de forma reflexa. ${ }^{223}$ Em situações como essa, o prejudicado indiretamente pode ingressar com ação contra o real causador do dano, visto que há como comprovar a correlação entre o seu prejuízo e o evento danoso. 224

Conforme será verificado à frente, diversos casos de danos ambientais, ${ }^{225}$ inclusive de derramamentos de óleo, os prejuízos se dão justamente por efeito ricochete.

\subsection{Dano no Direito Civil Ambiental}

\subsubsection{Dano, Impacto, Poluição, Degradação}

Antes mesmo de avançar nas características do dano ambiental, vale esclarecer as diferenças conceituais entre dano, impacto, poluição e degradação. Importante destacar que,

\footnotetext{
${ }^{219}$ MIRAGEM, B. N. B. Direito Civil: responsabilidade civil. São Paulo: Saraiva, 5ํa ed., 2015, p. 206

${ }^{220}$ GAGLIANO, P. S.; PAMPLONA FILHO, R. Novo curso de Direito Civil: Responsabilidade Civil. São Paulo: Saraiva, v.3, 9a ed., 2011, p. 123-124.

${ }^{221}$ MIRAGEM, B. N. B. Direito Civil: responsabilidade civil. São Paulo: Saraiva, 5a ed., 2015, p. 206.

${ }^{222}$ GONÇALVES, C. R. Direito Civil Brasileiro: responsabilidade civil. São Paulo, Saraiva, v.4, $7^{\mathrm{a}}$ ed., 2012 , p. 360 .

${ }^{223}$ GAGLIANO, P. S.; PAMPLONA FILHO, R. Novo curso de Direito Civil: Responsabilidade Civil. São Paulo: Saraiva, v.3, $9^{\mathrm{a}}$ ed., 2011, p.87.

${ }^{224}$ GONÇALVES, C. R. Direito Civil Brasileiro: responsabilidade civil. São Paulo, Saraiva, v.4, $7^{\mathrm{a}}$ ed., 2012 , p. 360 .

${ }^{225}$ Para Pinho: "O dano individual ambiental, também denominado dano reflexo, em ricochete ou "por intermédio" do meio ambiente, tem em vista unicamente o interesse individual, protegendo-se a saúde e o patrimônio pessoal da vítima individual. Ele sempre existiu, mesmo quando não se cogitava de proteção jurídica ambiental autônoma. O objetivo primordial é a tutela dos interesses próprios dos lesados, não havendo uma proteção imediata do meio ambiente, apenas de forma parcial, limitada e reflexa." PINHO, H. G.. Prevenção e Reparação de danos ambientais: as medidas de reposição natural, compensatórias e preventivas e a indenização pecuniária. Rio de Janeiro: GZ Ed; Stuttgart, Alemanha: R. Bosch, 2010, p. 141.
} 
para o presente trabalho, foram adotados os conceitos jurídicos e não técnicos, visto que, conforme demonstrado por Cerri Neto, em sua dissertação, ${ }^{226}$ as duas áreas de conhecimento nem sempre parecem chegar a um acordo conceitual. Das 27 definições técnicas sobre poluição analisadas pelo autor, somente uma se assemelhava à jurídica. Do mesmo modo, dos 23 conceitos técnicos de impacto por ele levantados, apenas dois correspondiam ao definido por lei. Devido a essa discrepância, não é incomum a utilização da palavra impacto como sinônimo de dano pela área técnica. Entretanto, para o direito, tratam-se de conceitos diferentes.

Sendo assim, de acordo com artigo $1^{\circ}$ da Resolução CONAMA 01/1986, ${ }^{227}$ por impacto entende-se:

(...) qualquer alteração das propriedades físicas, químicas e biológicas do meio ambiente, causada por qualquer forma de matéria ou energia resultante das atividades humanas que, direta ou indiretamente, afetam: I - a saúde, a segurança e o bem-estar da população; II - as atividades sociais e econômicas; III - a biota; IV as condições estéticas e sanitárias do meio ambiente; V - a qualidade dos recursos ambientais.

O conceito, ao abordar a palavra "alteração", indica a possibilidade de o impacto ser tanto negativo, quanto positivo, visto que nem toda a alteração é prejudicial. Um possível exemplo de impacto positivo seria o aumento de permeabilidade de um terreno objeto de um empreendimento, nos casos em que a construção histórica que lá havia tornava o solo totalmente impermeável.

Com relação ao conceito de dano, não há um conceito legal na legislação brasileira, entretanto, para Benjamim, pode-se conceituar "dano ambiental" como "a alteração, deterioração ou destruição, parcial ou total, de quaisquer dos recursos naturais, afetando adversamente o homem e/ou a natureza". 228

O dano é, portanto, o impacto negativo que não foi absorvido pelo meio ambiente. ${ }^{229}$ Conforme explica Sánchez: "o dano ambiental é uma perda ou deterioração da qualidade

${ }^{226}$ CERRI NETO, M. Impacto ambiental, degradação ambiental, poluição, contaminação e dano ambiental: comparação entre conceitos legal e técnico. 125f. Dissertação de Mestrado - Instituto de Geociências Exatas da Universidade Estadual Paulista, Rio Claro, 2008. Disponível em: $<$ http://hdl.handle.net/11449/92757 $>$. Acesso em 20.08.2018.

${ }^{227}$ Disponível em: <http://www2.mma.gov.br/port/conama/legislacao/CONAMA_RES_CONS_1986_001.pdf > Acesso em 01.08.2018.

${ }^{228}$ BENJAMIN, A. H. V. Responsabilidade civil pelo dano ambiental. In: MILARÉ, E.; MACHADO, P. A. L. (Org.). Direito Ambiental: responsabilidade em matéria ambiental. São Paulo: RT, v.5, 2011, p. 132.

${ }^{229}$ Nas palavras de Milaré: "É dizer: não se confundem as noções de impacto, em sentido estrito, e de dano ambiental, propriamente dito: o primeiro decorre dos efeitos que qualquer atividade humana causa ao ambiente; o 
ambiental ". ${ }^{230}$ Ou seja, diferentemente do impacto, o dano apresenta um caráter de perda ambiental, negativo e ambivalente. ${ }^{231}$ Há uma lesão ao direito fundamental, previsto no artigo 225 da Constituição Federal de 1988, ao "meio ambiente ecologicamente equilibrado", ao mesmo tempo em que afeta a saúde das pessoas e seus interesses particulares. ${ }^{232}$

Para o dano a ser reparado, ele tem que ser identificado. Assim, entende Catalá que não corresponderia à realidade reconhecer que qualquer alteração do meio natural realizada pelo homem constitui por si um dano ecológico. Do mesmo modo, em termos de Justiça ecológica, não seria considerável reconhecer como dano apenas eventos catastróficos, a exemplo de grandes acidentes com superpetroleiros. ${ }^{233}$

$\mathrm{Na}$ realidade, ocorrerá dano a partir do momento que haja desrespeito de regras que resultem em prejuízos ao equilíbrio ambiental. Porém, muito embora o conceito de dano aqui adotado seja jurídico, não se pode negar que ele sofre influência de inúmeros fatores para além dos limites da lei, podendo ser, por exemplo, de ordem física, química ou ecológica. ${ }^{234}$ Devese ainda considerar o poder discricionário da autoridade competente na configuração do dano para cada caso específico, sempre balizada por competência técnica e revestida de razoabilidade e proporcionalidade em suas decisões. ${ }^{235}$

Ademais, no que diz respeito à efetivação do dano, aplica-se o critério do limite de tolerabilidade, sendo um "mecanismo de proteção ao meio ambiente, tendente a estabelecer certo equilíbrio entre as atividades interventivas do homem e o respeito às leis naturais e aos valores culturais que regem os fatores ambientais condicionantes da vida." ${ }^{236}$ Estando dentro dos limites de tolerabilidade, as interferências no meio ambiente, mesmo que maléficas, serão consideradas apenas impactos.

segundo decorre do grau maior, isto é, de agravos mais sensíveis que essa mesma atividade acarreta". MILARÉ, E. Direito do Ambiente, $10^{\mathrm{a}}$ ed., Editora Revista dos Tribunais, 2015, p. 320.

${ }^{230}$ SANCHEZ, L. E. Avaliação de impacto ambiental: conceitos e métodos. São Paulo: Ofícina de Textos, $2^{\mathrm{a}}$ ed., 2013, p.29-35.

${ }^{231}$ Segundo Lemos: "O dano ao meio ambiente será toda a degradação ambiental que atinja o homem, sua saúde, sua segurança ou seu bem-estar; todas as formas de vida animal ou vegetal; o meio ambiente em si, tanto em seu aspecto natural como cultural e artificial". LEMOS, P. F. I. Meio ambiente e responsabilidade civil do proprietário: responsabilidade civil e proteção ao meio ambiente. São Paulo: RT, 2a ed., 2012, p. 116.

${ }^{232}$ LEITE, J. R. M.; AYALA, P. de. Dano ambiental: do individual ao coletivo extrapatrimonial. Teoria e Prática. São Paulo: RT, $5^{\text {a }}$ ed., 2012, p. 92.

${ }^{233}$ CATALÁ, L. G.. Responsabilidad por Daños al Medio Ambiente. Madrid: Arazandi Editorial, 1998 , p. 75.

${ }^{234}$ GRANZIERA, M. L. M. Direito Ambiental. São Paulo: Atlas, $4^{\mathrm{a}}$ ed., 2015, p. 724.

${ }^{235}$ GRANZIERA, M. L. M. Direito Ambiental. São Paulo: Atlas, 4 a ed., 2015, p. 725-726.

${ }^{236}$ MIRRA, A. L. V. Ação civil pública e a reparação do dano ao meio ambiente. São Paulo: Juarez de Oliveira, $2^{\mathrm{a}}$ ed., 2004, p.101-102. 
Na configuração do dano ao meio ambiente, contrariamente aos danos gerais previstos no Código Civil, e abordados no início do presente capítulo, não se distingue ato lícito, ato ilícito e abuso do direito. Nesse sentido, explica Patrícia Iglecias Lemos:

(...) os danos ao meio ambiente podem decorrer de ato ou atividade lícita, como nas situações em que o empreendedor tem uma licença e desenvolve sua atividade dentro dos limites desta e, mesmo assim, pode ser responsabilizado se o meio não absorver os impactos da atividade. Adota-se a teoria do risco da atividade, afastando a possibilidade de alegação de excludentes de responsabilidade. ${ }^{237}$

A impossibilidade da alegação de excludentes de responsabilidades no Direito Civil Ambiental é um ponto recorrentemente abordado no presente trabalho, visto que algumas convenções internacionais e apólices de seguros que abrangem derramamentos de óleo apresentam em seus textos excludentes de responsabilidade, havendo expressa incongruência com o Direito Pátrio. Ademais, mesmo advindo de uma atividade lícita, o dano injusto se caracterizaria pela degradação do meio ambiente, havendo, portanto, desrespeito a um preceito legal ambiental. Igualmente pode haver dano injusto por ato que seja configurado abuso do direito de propriedade. Nesse sentido, defende Pinho que "a degradação ambiental que causar ruptura do equilíbrio ecológico e/ou ambiental, configura dano ambiental ressarcível, podendo ensejar as consequências previstas no inciso III do art. $3^{\circ}$, da Lei $n^{\circ} 6.938 / 81$ ou outras não listadas neste dispositivo." 238

Ao se adotar os conceitos acima expostos para o objeto da presente tese, seria considerado dano ambiental o derramamento de óleo que resulte em alterações negativas ao meio ambiente, ou que tais alterações não sejam absorvidas pelo meio. Havendo qualquer indício de perda de qualidade de vida, não necessariamente humana, a possibilidade de caracterização de dano ambiental será significativa.

Com relação aos demais conceitos, a Política Nacional de Meio Ambiente, Lei $6.938 / 1981,{ }^{239}$ os define da seguinte forma:

Art. $3^{\circ}$ Para os fins previstos nesta Lei, entende-se por:

II - degradação da qualidade ambiental, a alteração adversa das características do meio ambiente;

III - poluição, a degradação da qualidade ambiental resultante de atividades que direta ou indiretamente:

237 LEMOS, P. F. I. Meio ambiente e responsabilidade civil do proprietário: responsabilidade civil e proteção ao meio ambiente. São Paulo: RT, $2^{\text {a }}$ ed., 2012, p. 106.

${ }^{238}$ PINHO, H. G. Prevenção e Reparação de danos ambientais: as medidas de reposição natural, compensatórias e preventivas e a indenização pecuniária. Rio de Janeiro: GZ Ed; Stuttgart, Alemanha: R. Bosch, 2010, p. 139.

${ }^{239}$ Disponível em: $<$ http://www.planalto.gov.br/ccivil 03/Leis/L6938.htm>. Acesso em 01.08.2018. 

a) prejudiquem a saúde, a segurança e o bem-estar da população;
b) criem condições adversas às atividades sociais e econômicas;
c) afetem desfavoravelmente a biota;
d) afetem as condições estéticas ou sanitárias do meio ambiente;
e) lancem matérias ou energia em desacordo com os padrões ambientais estabelecidos;

Já o poluidor, conforme dispõe o art. 3º, IV, da Lei 6938/1981 (PNMA), “é a pessoa física ou jurídica, de direito público ou privado, responsável, direta ou indiretamente, por atividade causadora de degradação ambiental". Segundo Pizzato e Pizzato, os conceitos são relacionados, visto que o Dano ambiental "pode resultar tanto na degradação da qualidade ambiental (alteração adversa das características do meio ambiente), quanto na poluição, que a Lei define como a degradação da qualidade ambiental resultante de atividade humana". ${ }^{240}$

\section{3. - Dano Jurídico versus Dano Ecológico}

Conforme será apresentado, devido à complexidade que reveste os danos associados a derramamentos de óleo, eles podem ser enquadrados em várias classificações. Nesse sentido, seria possível identificá-los, em uma primeira forma, tanto no âmbito ecológico, quanto no jurídico.

$\mathrm{Na}$ segunda parte do presente capítulo serão apresentados os danos ambientais sob o ponto de vista técnico, que se dedica a avaliar as consequências dos derramamentos nos diversos ecossistemas atingidos, servindo para a identificação posterior das melhores técnicas de reparação. Pois bem, tais danos são considerados danos ecológicos puros, e podem se caracterizar tanto pelas alterações causadas pelo homem nas qualidades físicas, químicas ou biológicas do ambiente, quanto por agressões diretas aos bens naturais, podendo ser a água, o solo, o ar, a fauna e a flora. Além disso, a dimensão dos danos ecológicos pode ser global, a exemplo das alterações na camada de ozônio, regional (poluição nos mares, ou rios), ou local, como nos casos de uma contaminação que não se propagou. ${ }^{241}$

O dano ambiental, sob o ponto de vista ecológico, acaba sendo aquele que, de alguma forma, fere as principais funções da ecologia, quais sejam: (i) a interdependência; (ii) a

\footnotetext{
${ }^{240}$ PIZZATTO, L.; PIZZATTO, R. Dicionário Socioambiental brasileiro. São Paulo: Editora Ambiente Brasil, 2009, p. 98.

${ }^{241}$ Nos termos de Sendim: "Nesse ângulo, parece-nos que o dano ecológico se pode caracterizar, tendencialmente, como uma perturbação do patrimônio natural - enquanto conjunto dos recursos bióticos (seres vivos) e abióticos e da sua interacção - que afecte a capacidade funcional ecológica e a capacidade de aproveitamento humano de tais bens tutelada pelo sistema jurídico - ambiental". SENDIM, J. de S.C. Responsabilidade Civil por Danos Ecológicos: da reparação do dano através da restauração natural. Coimbra: Coimbra Editora, 1998, p.130.
} 
capacidade de autorregulação; (iii) a capacidade de autorregeneração; (iv) a capacidade funcional ecológica; e (v) a capacidade de uso dos bens naturais. ${ }^{242}$

Inegável o fato de que as atividades econômicas que resultam em contaminação são um claro exemplo de ameaça humana ao equilíbrio ecológico da natureza. Quando tal contaminação de uma área causa distúrbios ecológicos, além de ameaças à saúde, o responsável deve promover a remediação.

Já o dano jurídico é caracterizado por uma ofensa ou ameaça de ofensa a bens jurídicos determinados, no caso, o meio ambiente. Segundo Sendim, ${ }^{243}$ é importante que haja uma abordagem jurídica do dano, além daquela ecológica, uma vez que apenas sob o ponto de vista do direito é que se pode identificar qual é o bem jurídico que deve ser protegido contra o dano. Assim, o dano ambiental sob o aspecto jurídico protege bens tutelados juridicamente, e deve ser tratado de acordo com o caso concreto, devido as suas diversas características. ${ }^{244}$

Para François Ost, o direito, ao traçar limites do permitido, serve-se de definições com contornos nítidos e critérios estáveis. Já "a ecologia reclama conceitos englobantes e condições evolutivas". Se, por um lado, "a ecologia fala em termos de ecossistema e de biosfera", por outro, "o direito responde em termos de limites e de fronteiras". Nesses termos, conclui: "uma desenvolve o tempo longo, por vezes extremamente longo, dos seus ciclos naturais, o outro impõe o ritmo curto das previsões humanas". ${ }^{245}$

Nesse sentido, é de suma importância que se considere tanto o viés jurídico, quanto o ecológico dos danos causados por derramamento de óleo, para que, no momento em que se for determinar a remediação desses danos, tal procedimento seja capaz não apenas de promover a reparação jurídica, que atenda a padrões e ditames legais; mas também que se atenda a reparação ecológica, buscando o verdadeiro reequilíbrio do ambiente e, acima de tudo, respeitando a própria resposta dos ecossistemas aos distúrbios.

Ainda no tocante a remediação ecológica, destacamos a necessidade de que se respeitem as técnicas e os estudos desenvolvidos para tanto. Nesse sentido, conforme visto, as decisões judiciais ainda precisam ser aprimoradas, uma vez que muitas vezes impõem formas de

242 STEIGLEDER, A. M. Responsabilidade civil ambiental: as dimensões do dano ambiental no direito brasileiro. Porto Alegre: Livraria do Advogado, $2^{\text {a }}$ ed., 2011, p.107.

243 SENDIM, J. de S. C.. Responsabilidade Civil por Danos Ecológicos: da reparação do dano através da restauração natural. Coimbra: Coimbra Editora, 1998, p. 130.

244 PINHO, H. G.. Prevenção e Reparação de danos ambientais: as medidas de reposição natural, compensatórias e preventivas e a indenização pecuniária. Rio de Janeiro: GZ Ed; Stuttgart, Alemanha: R. Bosch, 2010, p. 138.

${ }^{245}$ OST, F. A natureza à margem da lei: A ecologia à prova do direito. Lisboa: Instituto Piaget, 1995, p.111. 
remediação que, na prática, não são as que melhor atendem a verdadeira recuperação ecológica do ambiente afetado.

Nesse sentido, é interessante a aplicação do conceito tradicional do Direito Civil da "perda de uma chance" para danos ambientais, proposto por Pinho. Segundo a autora, há uma frustração por não se ter da natureza o esperado, uma vez que ela deixou de exercer suas funções e a prover os seus benefícios à sociedade. Assim, o meio ambiente terá que se adaptar, podendo ter uma diminuição da sua diversidade biológica. Com isso, entende-se que "se trata de uma chance real e séria, porém não detém grau de certeza". ${ }^{246}$

\subsection{Abrangência do Dano Ambiental}

Conforme abordado, o dano ambiental é fruto de alterações negativas ao meio ambiente, sendo que seus efeitos podem afetar a saúde das pessoas, além de seus interesses. ${ }^{247}$ As consequências de uma contaminação são tão amplas, que, seguindo a classificação proposta por Mirra, é possível considerar uma área contaminada tanto como um dano ambiental propriamente dito, como um dano "por intermédio do meio ambiente". 248

Para o autor, o dano ambiental consiste na lesão ao meio ambiente, abrangente dos elementos naturais, artificiais e culturais, como bem de uso comum do povo, juridicamente protegido. Significa, ainda, a violação do direito de todos ao meio ambiente ecologicamente equilibrado, direito humano fundamental, de natureza difusa. Por outro lado, nas palavras de Mirra, o dano por intermédio do meio ambiente seria "o prejuízo causado às pessoas e aos seus bens que tem em alguns dos componentes da natureza (a água, o ar, o solo) o elemento condutor". 249

Os danos ambientais tratados pela presente tese assumem diversas classificações, pois, nos casos de derramamentos, seus efeitos são amplos, ilimitados, atingindo inúmeros ambientes e bens jurídicos tutelados, além da vida humana. Ou seja, os danos ambientais causados pelos derramamentos de óleos abrangem aspectos ecológicos, econômicos, de saúde pública e, claro, jurídicos. Ademais, um importante fator a ser considerado na caracterização dos danos é que,

\footnotetext{
246 PINHO, H. G.. Prevenção e Reparação de danos ambientais: as medidas de reposição natural, compensatórias e preventivas e a indenização pecuniária. Rio de Janeiro: GZ Ed; Stuttgart, Alemanha: R. Bosch, 2010 , p. 172.

${ }^{247}$ LEITE, J. R. M.; AYALA, P. de. Dano ambiental: do individual ao coletivo extrapatrimonial. Teoria e Prática.

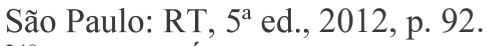

${ }^{248}$ MIRRA, Á. L. V. Ação civil pública e reparação do dano ao meio ambiente. São Paulo: Juarez Oliveira, 2002, p. 90.

${ }^{249}$ MIRRA, Á. L. V. Ação civil pública e reparação do dano ao meio ambiente. São Paulo: Juarez Oliveira, 2002, p.69.
} 
neste caso, são derivados de acidentes, muitas vezes de catástrofes, fator que contribui para o agravamento de seus efeitos, tanto no que diz respeito à extensão territorial, quanto a amplitude, durabilidade e incerteza que revestem estes efeitos.

De acordo com Morato Leite e Ayala ${ }^{250}$, danos ambientais podem ainda ser divididos em três categorias, quais sejam: (i) danos ecológicos puros, ${ }^{251}$ (ii) danos ambientais lato sensu, e (iii) danos ambientais individuais ou reflexos. Entende-se por dano ecológico puro aquele que afeta diretamente bens integrantes da natureza, ou seja, elementos naturais do ecossistema. Os bens culturais e artificiais seriam excluídos dessa classificação. O dano ambiental lato sensu, possui um caráter abrangente, atingindo os interesses difusos da coletividade de uma forma geral, abrangendo bens materiais e imateriais, ecológicos ou humanos. Por fim, o dano individual ambiental ou reflexo atinge os interesses próprios do indivíduo.

As três classificações acima propostas podem ser aplicadas aos derramamentos de óleos, principalmente nos casos em que não são contidos rapidamente, tomando proporções que fogem às previsões e modelagens. Com isso, diversos interesses e bens podem ser afetados, tanto ecológicos quanto humanos. Principalmente nesses casos, o caráter multifacetado do dano deve ser identificado e corretamente classificado para que sejam impostas medidas de reparação adequadas a cada tipo de bem lesado.

Infelizmente, ainda nos deparamos com confusões e equívocos atinentes à classificação dos danos derivados dessa espécie de acidentes em decisões judiciais. A consequência direta acaba sendo o não reconhecimento dos reais interesses lesados. Já a consequência indireta se reflete na reparação inadequada ou tardia desses danos.

Para tanto, se faz necessário aqui demonstrar que a abrangência de danos decorrentes de derramamentos de óleo, dos aparentemente mais insignificantes, aos catastróficos. Inclusive, abordando os danos que podem ser acumulados ao longo do tempo. Pinho adota em sua obra uma classificação para os danos ambientais considerando três acepções distintas, que foram utilizadas para a estruturação do quadro abaixo:

\footnotetext{
${ }^{250}$ LEITE, J. R. M.; AYALA, P. de. Dano ambiental: do individual ao coletivo extrapatrimonial. Teoria e Prática.

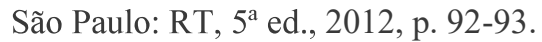

${ }^{251}$ Archer argumenta que: "assim, existe um dano ecológico quando um bem jurídico ecológico é perturbado, ou quando um de terminado estado-dever de um componente do ambiente é alterado negativamente." ARCHER, A. B. Direito do Ambiente e Responsabilidade Civil. Coimbra: Almedina, 2009, p. 21.
} 
Tabela 8- Classificação dos danos ambientais

\begin{tabular}{|l|l|}
\hline $\begin{array}{l}\text { CRITÉRIOS DE } \\
\text { CLASSIFICAÇÃO }\end{array}$ & TIPO DE DANO \\
\hline Sentido jurídico & $\begin{array}{l}\text { - dano ecológico puro } \\
\text { - dano ao meio ambiente cultural } \\
\text { - dano individual ambiental }\end{array}$ \\
\hline Consequências & $\begin{array}{l}\text { - dano patrimonial ambiental } \\
\text { - dano moral ambiental }\end{array}$ \\
\hline Dimensão temporal & - dano emergente \\
& - dano futuro \\
& - dano histórico \\
\hline
\end{tabular}

Fonte: elaboração própria com base na classificação proposta por Pinho. ${ }^{252}$

Uma vez identificados os diversos efeitos decorrentes dos derramamentos de óleo, imediatos, no presente trabalho, optou-se pela divisão inicial dos danos em dois grandes grupos: $^{.253}$ (i) danos que afetam a interesses pessoais (patrimoniais, extrapatrimoniais e à saúde) e, (ii) danos restritos ao meio ambiente, mais precisamente os danos ecológicos puros.

O primeiro grupo aqui proposto se refere aos efeitos dos derramamentos que atingem a população de forma direta ou indireta. São os casos em que há comprovada afetação da saúde da população atingida, que o alimento consumido esteve contaminado, que a atividade econômica de sustento de famílias locais foi afetada, como a pesca e o ecoturismo, ou mesmo que houve perda da qualidade de vida de uma forma geral.

Nesses casos, de imediato, podemos admitir uma subdivisão dentro da primeira categoria proposta de danos: que afetam interesses pessoais. Seriam divididos em "danos patrimoniais ambientais" e "danos extrapatrimoniais ambientais".

\footnotetext{
252 PINHO, H. G.. Prevenção e Reparação de danos ambientais: as medidas de reposição natural, compensatórias e preventivas e a indenização pecuniária. Rio de Janeiro: GZ Ed; Stuttgart, Alemanha: R. Bosch, 2010, p. 140.

${ }^{253}$ Conforme assevera Benjamin: "De tudo o que dissemos, percebe-se que os danos ambientais são gênero, nos quais vamos localizar danos pessoais (patrimoniais e morais) e ecológicos (também conhecidos por ambientais stricto sensu, ecológicos puros ou contra a natureza) (...)." BENJAMIN, A. H. V. Responsabilidade civil pelo dano ambiental. In: MILARÉ, E.; MACHADO, P. A. L. (Org.). Direito Ambiental: responsabilidade em matéria ambiental. São Paulo: RT, v.5, 2011, p. 135.
} 
Tabela 9 - Danos que afetam interesses pessoais

\begin{tabular}{|l|l|}
\hline $\begin{array}{l}\text { TIPO DE DANOS } \\
\text { INTERESSES PESSOAIS }\end{array}$ & EXEMPLOS \\
\hline Danos patrimoniais & - perda, ou desvalorização de patrimônio \\
& material \\
& - prejuízos, em atividades comerciais \\
& - gastos com reparação de bens materiais \\
& - despesas associadas a prejuízos à saúde \\
\hline Danos extrapatrimoniais & $\begin{array}{l}\text { - perda de qualidade de vida } \\
\text { - danos à saúde }\end{array}$ \\
& - sofrimentos e abalos psíquicos e emocionais \\
& danos estéticos \\
\hline
\end{tabular}

Fonte: elaboração própria

O dano patrimonial ambiental é compreendido como um dano individual reflexo. Atinge o microbem ambiental, caracterizado por ser um interesse da pessoa, de natureza material ou econômica, refletindo diretamente o patrimônio do lesado. ${ }^{254}$

Já o dano extrapatrimonial ambiental ou moral, segundo Morato Leite e Ayala, pode ser conceituado como "prejuízo não patrimonial ocasionado à sociedade ou ao indivíduo, em virtude de lesão do meio ambiente", ${ }^{255}$. Ao considerar tanto o indivíduo, quanto a sociedade alvo do dano, os autores indicam a possibilidade de os danos serem tanto individuais, quanto coletivos. Para Pinho, o dano ambiental puro, ao atingir um direito de personalidade, pode resultar em dano extrapatrimonial por efeito ricochete. ${ }^{256}$

A seguir serão melhor detalhados os danos patrimoniais e extrapatrimoniais no contexto dos derramamentos de óleo no mar.

${ }^{254}$ LEITE, J. R. M.; AYALA, P. de. Dano ambiental: do individual ao coletivo extrapatrimonial. Teoria e Prática.

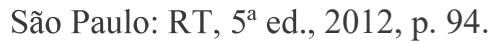

${ }^{255}$ LEITE, J. R. M.; AY ALA, P. de. Dano ambiental: do individual ao coletivo extrapatrimonial. Teoria e Prática.

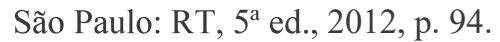

256 PINHO, H. G.. Prevenção e Reparação de danos ambientais: as medidas de reposição natural, compensatórias e preventivas e a indenização pecuniária. Rio de Janeiro: GZ Ed; Stuttgart, Alemanha: R. Bosch, 2010, p. 185. 


\subsection{Danos que afetam interesses pessoais}

\subsubsection{Danos patrimoniais ambientais}

O dano ambiental patrimonial individual se caracteriza pelo reflexo que indivíduos sofrem, em decorrência de um dano ecológico. Utiliza-se portanto a denominação "por intermédio do meio ambiente" para tais danos, uma vez que agressões ao meio ambiente vão repercutir em ofensa a interesses individuais protegidos, a exemplo do patrimônio material e da saúde. ${ }^{257}$ Com isso, uma degradação ambiental pode gerar desvalorização ou modificação negativa do patrimônio que o circunda, ameaçando direitos personalíssimos. ${ }^{258}$

O dano ambiental patrimonial pode ser tanto emergente, produzindo efeitos imediatos, quanto futuro, em decorrência de os efeitos atingirem momentos posteriores ou ocorrerem por efeito cascata. Pode, ainda, configurar lucros cessantes e até mesmo perda de uma chance ambiental. $^{259}$

Para melhor compreensão acerca dos danos patrimoniais decorrentes de derramamentos de óleo no mar, vale, mais uma vez, contextualizar brevemente o cenário econômico característico da costa brasileira. Inicialmente, deve-se entender que o Brasil é um país de história colonial, sendo que a ocupação de seu território ocorreu a partir do litoral, avançandose posteriormente para o interior. Tal estrutura condicionou uma concentração populacional e de atividades econômicas na zona costeira.

Os próprios ambientes marinhos e costeiros brasileiros, abundantes em biodiversidade e recursos, são propícios ao desenvolvimento da economia e de atividades sociais e de lazer. Ademais, o país ainda conta com uma significativa atividade pesqueira e seus portos são a principal porta de entrada para produtos estrangeiros.

De acordo com o último censo realizado pelo IBGE, em 2010, ${ }^{260}$ o Brasil apresenta $26,6 \%$ da população localizada em municípios da zona costeira. São aproximadamente 50,7 milhões de habitantes que, de forma direta ou indireta, desenvolvem atividades econômicas relacionadas aos setores: petrolíferos, portuários, agroindustriais, de aquicultura, carcinicultura,

257 CARVALHO, D. W. de. O dano ambiental futuro: da assimilação dos riscos ecológicos pelo direito à formação de vínculos jurídicos intergeracionais. 255f. Tese de Doutorado em Direito - Programa de PósGraduação em Direito da Universidade Vale do Rio dos Sinos. Rio Grande do Sul, 2006, p. 156.

${ }^{258}$ GOLDENBERG, I. H. CAFERATTA, N. A. Danõ ambiental: problemática de la determinación causal. Buenos Aires: Abeldo-Perrot, 2001, p.11.

${ }^{259}$ PINHO, H. G. Prevenção e Reparação de danos ambientais: as medidas de reposição natural, compensatórias e preventivas e a indenização pecuniária. Rio de Janeiro: GZ Ed; Stuttgart, Alemanha: R. Bosch, 2010, p. 182.

${ }^{260}$ Disponível em: < https://censo2010.ibge.gov.br/> . Acesso em: 01.09.2018. 
pesca, extração mineral, extração vegetal, pecuária, reflorestamento, turismo, salinas e recreação.

Por esses motivos, facilmente se nota que acidentes nessas regiões, sobretudo os derramamentos de óleo, implicam diretamente em prejuízos e entraves à economia em seus diversos seguimentos, sendo a pesca comercial e o turismo os setores mais afetados. ${ }^{261}$ No aspecto socioeconômico, destacam-se ainda a maricultura, o lazer, a prática de esportes náutico, além da imagem dos municípios afetados. ${ }^{262}$

No que diz respeito à reparabilidade dos danos patrimoniais, os interessados que foram vítimas de qualquer lesão devem ser indenizados diretamente. Entretanto, é importante esclarecer quais critérios que devem ser considerados para o cálculo das indenizações. Com relação aos danos patrimoniais, conforme já explicado, os artigos 402 e 403 do Código Civil tratam sobre os danos emergentes e lucros cessantes, sendo o ponto de partida para o cálculo da indenização.

Por meio da análise jurisprudencial realizada no capítulo 3, verificou-se que os principais danos patrimoniais emergentes gerados por derramamentos de óleo são referentes aos prejuízos sofridos pela pesca e turismo. ${ }^{263} 264$

Em seu julgado paradigma em matéria de danos ambientais decorrentes de derramamento de óleo no mar (sob o rito de recursos repetitivos), o Superior Tribunal de Justiça (STJ) reconheceu, inclusive, a legitimidade ativa dos pescadores profissionais artesanais registrados no Departamento de Pesca e Aquicultura do Ministério do Meio Ambiente para ajuizarem ações de indenização em razão das "consequências profissionais do acidente":

(...) b) Legitimidade ativa ad causam.- É parte legítima para ação de indenização supra referida o pescador profissional artesanal, com início de atividade profissional registrada no Departamento de Pesca e Aquicultura do Ministério da Agricultura, edo

${ }^{261}$ ITOPF. Effects of oil pollution on social and economic activities. Technical Information Paper (TIP 12). London, v.12, 2011, p.02. Disponível em: < $\underline{\text { http://www.itopf.com/knowledge-resources/documents- }}$ guides/document/tip-12-effects-of-oil-pollution-on-social-and-economic-activities/>. Acesso em: 15.12.2016.

${ }^{262}$ POFFO, I. R. F. Vazamento de óleo no Litoral Norte do Estado de São Paulo: análise histórico (1974 a 1999). Dissertação de Mestrado - Programa de Ciência Ambiental (PROCAM), Instituto de Energia e Ambiente (IEE), Universidade de São Paulo (USP), São Paulo, dez. 2000.

${ }^{263}$ No caso de prejuízos à pesca, dentre os acórdãos pesquisados: no Superior Tribunal de Justiça (STJ), 22 casos envolveram danos patrimoniais emergentes decorrentes do prejuízo experimentado por pescadores afetados pelo derramamento de óleo. No Tribunal Regional Federal da $3^{\text {a }}$ Região, em 3 casos o tribunal reconheceu expressamente os danos patrimoniais emergentes à atividade pesqueira. No Tribunal Regional Federal da $4^{\mathrm{a}}$ Região, há 4 casos neste sentido; enquanto o Tribunal Regional Federal da $5^{\text {a }}$ Região reúne 5 casos sobre a matéria. ${ }^{264}$ No caso de prejuízos ao turismo, dentre os acórdãos pesquisados, os números são os seguintes: 2 casos, no Tribunal Regional da $3^{\mathrm{a}}$ Região; 1 caso no Tribunal Regional da $4^{\mathrm{a}}$ Região; 2 casos no Tribunal Regional da $5^{\mathrm{a}}$ Região; 7 casos no Tribunal de Justiça do Estado do Rio Grande do Sul; e 1 caso no Tribunal de Justiça do Estado de São Paulo. 
Abastecimento anteriormente ao fato, ainda que a emissão da carteira de pescador profissional tenha ocorrido posteriormente, não havendo a ré alegado e provado falsidade dos dados constantes do registro e provado haver recebido atenção do poder público devido a consequências profissionais do acidente. ${ }^{265}$

Em outro interessante e abrangente caso, Tribunal Regional Federal (TRF) da $3^{a}$ Região reconheceu o dano ambiental sem mencionar expressamente o prejuízo à atividade pesqueira ou ao turismo, mas mencionando a criação de condições adversas às atividades sociais e econômicas, bem como às condições estéticas do meio ambiente:

6. Induvidoso que houve efetivo dano ambiental, na medida que tal fato causou poluição, ou seja, "degradação da qualidade ambiental resultante de atividades que direta ou indiretamente: a) prejudiquem a saúde, a segurança e o bem-estar da população; b) criem condições adversas às atividades sociais e econômicas; c) afetem desfavoravelmente a biota; $\mathbf{d}$ ) afetem as condições estéticas ou sanitárias do meio ambiente; e) lancem matérias ou energia em desacordo com os padrões ambientais estabelecidos;", nos termos do artigo $3^{\circ}$, III, da Lei $n^{\circ}$ 6.938/01.(Grifos nossos). ${ }^{266}$

Em outro caso digno de nota, o Tribunal Regional Federal da $3^{\text {a }}$ Região reconheceu dano ambiental em razão do prejuízo ao sustento dos pescadores artesanais que realizavam suas atividades em local afetado pelo derramamento:

Por outro lado, além da contaminação do meio ambiente marítimo que se constitui em
"bem de uso comum do povo e essencial à sadia qualidade de vida, impondo-se ao
Poder Público e à coletividade o dever de defendê-lo e preservá-lo para as presentes
e futuras gerações", como consagra o dispositivo constitucional mencionado, a ação
de responsabilidade da ré também contribui para agravar os problemas de ordem
social nesta região, prejudicando a atividade de pesca artesanal ali existente,
vivendo os pescadores da colônia "Floriano Peixoto", estimada em cerca de 600
profissionais, da pesca comercial no Estuário de Santos.

Não há, pois, atividade econômica, por mais importante que seja, que justifique os seguidos derramamentos de óleo e outros dejetos químicos no Estuário de Santos, ocasionando e superdimensionando os já existentes danos ao ecossistema marinho, bem como agravando os problemas sociais, não somente em relação aos pescadores artesanais que retiram o seu sustento dessas águas poluídas, como também de saúde pública causados pelos previsíveis males à saúde daqueles que consomem o pescado nelas capturado.(Grifos nossos). ${ }^{267}$

Ao se analisar a jurisprudência do Tribunal de Justiça (TJ) do Estado de São Paulo sobre o tema, foi ainda possível identificar o reconhecimento pelos magistrados de danos à atividade de aquicultura praticada no local afetado (notadamente cultivo e produção de mexilhões e mariscos), como se vê nos dois casos abaixo mencionados:

RESPONSABLIDADE CIVIL - Pedido de indenização por danos materiais e morais - Produção de mexilhões prejudicada por vazamento de óleo - Responsabilidade objetiva da TRANSPETRO, por ser a administradora do Terminal em que ocorreu o

${ }^{265}$ STJ. REsp n ${ }^{\circ}$ 1.114.398 - PR, Rel. Min. Sidnei Beneti, Segunda Seção, DJe 16/02/2012.

266 TRF. $3^{a}$ Região. Apelação Cível no 0001913-38.2008.4.03.6104 - SP, Rel. Antonio Cedenho, D.E. 19/02/2018.

${ }^{267}$ TRF. $3^{a}$ Região. Apelação Cível nº 0203607-49.1994.4.03.6104 - SP, Rel. Consuelo Yoshida, D.E. 03/11/2010. 
vazamento, assumindo o risco do negócio - Responsabilidade solidária da PETROBRÁS, por ser a controladora da TRANSPETRO - Danos materiais configurados - Necessidade de substituição da estrutura de cultivo de mariscos Necessidade, também, de pagamento de lucros cessantes ao autor Ressarcimento a ser feito pelo prazo estritamente necessário - Valor da renda média que o autor deixou de receber demonstrada através de relatório do Instituto de Pesca - Idoneidade do documento reconhecida - Danos morais caracterizados - Litigância em má-fé por parte do autor configurada pela tentativa de se enriquecer ilicitamente - Multa mantida, devendo, contudo, ser afastada a indenização, ante a ausência de provas de prejuízo sofrido pelas rés - RECURSOS PARCIALMENTE PROVIDOS. (Grifos nossos). ${ }^{268}$

Apelação Cível - Indenização por danos materiais e morais - Prejuízos experimentados em decorrência de vazamento de óleo em duto de responsabilidade da apelante localizado no Terminal Aquaviário Almirante Barroso - Vazamento que teria comprometido a estrutura física de suporte para o manejo de atividade de aquicultura desenvolvida no local - Danos decorrentes do vazamento que restaram suficientemente demonstrados - Notório comprometimento de produção dos maricultores de fazendas localizadas na Praia de Cocanha - Prejuízo calculado através de dados obtidos junto ao Instituto da Pesca -Cálculo elaborado levando em consideração informações prestadas pelos produtores que não representa prova documental unilateral - Danos morais bem delineados, não se duvidando dos transtornos causados ao apelado em decorrência do incidente - Prejuízos imateriais que se apresentam "in re ipsa" - Suficiente a comprovação de que foi afetado o negócio e a imagem comercial do mexilhão cultivado na região de Caraguatatuba Recurso improvido. (Grifos nossos). ${ }^{269}$

No que tange especificamente aos danos patrimoniais emergentes reconhecidos em razão dos prejuízos à atividade turística, merece destaque interessante julgado do TRF da $3^{\mathrm{a}}$ Região, em que tais danos foram reconhecidos em razão dos cancelamentos de reservas de empreendimento hoteleiro:

Trata-se de apelação em ação de indenização por dano material ajuizada por Itapemar Hotelaria e Turismo Ltda em face da Petrobrás S/A e de Katina Shipping Co Ltda, em virtude de vazamento de óleo no Canal de São Sebastião e do consequente cancelamento de reserva de 40 apartamentos para o período de 25 de agosto a 01 de setembro de 1.991, totalizando prejuízo de CR\$ 9.840.000,00 (nove milhões e oitocentos e quarenta mil cruzeiros).

$(\ldots)$

Diante do exposto, dou provimento à apelação para condenar a empresa Katina Shipping Co Ltda e a Petrobrás a indenizar os danos experimentados pela apelante, na forma pleiteada na exordial, com correção monetária e juros a incidirem a partir do ato ilícito, nos termos das Súmulas 43 e 54 do STJ. Deverão ser observadas, ainda, as diretrizes previstas no Manual de Cálculos da Justiça Federal vigente à época da liquidação. (Grifo nosso). ${ }^{270}$

${ }^{268}$ TJSP. Apelação Cível: AC n 0012083-10.2013.8.26.0126, Rel. Elcio Trujillo, $10^{\mathrm{a}}$ Câmara de Direito Privado, DJe 01/09/2016.

${ }^{269}$ TJSP. Apelação Cível: AC nº 1001703-71.2014.8.26.0126, Rel. José Joaquim dos Santos, $2^{\text {a }}$ Câmara de Direito Privado, DJe 03/08/2016.

270 TRF3. Apelação Cível: AC nº 0401857-02.1992.4.03.6103 - SP, Rel. Cotrim Guimarães, D.E. 19/10/2012. 
Em caso semelhante, o Tribunal de Justiça do Rio Grande do Sul tratou de pedido de indenização de danos patrimoniais formulado por indivíduo que alegava realizar atividade de comércio e veraneio e ter sua atividade prejudicada em razão do baixo movimento de turistas motivado pelo derramamento de óleo na região. Neste caso, porém, a corte entendeu que o autor não logrou demonstrar os eventuais prejuízos sofridos e traçou uma diferença importante entre danos patrimoniais emergentes e expectativa de direito, conforme se vê abaixo:

(...) 4. Releva ponderar, ainda, que, quando da ocorrência de um dano material, duas subespécies de prejuízos exsurgem desta situação, os danos emergentes, ou seja, aquele efetivamente causado, decorrente da diminuição patrimonial sofrida pela vítima; e os lucros cessantes, o que esta deixou de ganhar em razão do ato ilícito, o que inocorreu no caso dos autos.

5.É oportuno destacar que o pleito de dano material formulado na inicial, não veio corroborado pelo devido suporte probatório, porquanto a parte postulante se limita a pleitear o ressarcimento da quantia referente a dez dias de veraneio em cada casa/quarto, sem trazer aos autos qualquer documento que demonstre que eventuais prejuízos ocorridos naqueles três dias sejam capazes de gerar o dever de ressarcir o equivalente aos dez dias pretendidos.

6. Não é juridicamente possível indenizar expectativa de direito, tendo em vista que os prejuízos de ordem material devem ser devidamente comprovados, o que não ocorreu no caso em tela. (Grifos nossos). ${ }^{271}$

Na maioria dos casos enfrentados pelo Tribunal de Justiça do Rio Grande do Sul as discussões abordam os prejuízos sofridos pelos permissionários de quiosques, a exemplo daqueles residentes município litorâneo de Tramandaí. Nestes casos, o tribunal não reconheceu os danos patrimoniais emergentes em razão da não demonstração de prejuízos financeiros, ou redução de turistas no local, como ilustra com clareza o seguinte julgado:

APELAÇÃO CÍVEL. SUBCLASSE RESPONSABILIDADE CIVIL. AÇÃO DE REPARAÇÃO MATERIAL E MORAL. DERRAMAMENTO DE ÓLEO NO LITORAL NORTE DO ESTADO, EM 26/01/2012. AUSÊNCIA DE COMPROVAÇÃO DOS DANOS ALEGADOS. SENTENÇA DE IMPROCEDÊNCIA MANTIDA.

1. Caso envolvendo pretensões de reparação material e moral articuladas por permissionários de quiosques do município litorâneo de Tramandaí, em face do vazamento de óleo ocorrido em 26/01/2012. Demanda semelhante a outras ajuizadas na justiça comum e nos juizados especiais. Precedentes que, sem exceção, sempre chegaram a conclusão pela improcedência dos pedidos, sob fundamento principal de ausência de prova do(s) dano(s) sofrido(s). 2. Situação dos autos que não difere dos demais casos, em que o autor não demonstra ter tido qualquer prejuízo financeiro - muito menos o alegado -, em função do incidente acontecido, também não demonstrando a ocorrência de qualquer fato concreto de maior repercussão a justificar a compreensão de que o evento violou algum direito personalíssimo seu. 3. De fato, restou evidenciado que o movimento de turistas não diminuiu no período indicado na inicial e que o alegado vazamento não teve a dimensão alegada, diante da pronta e eficaz atuação da ré, devidamente

${ }^{271}$ TJRS. Apelação Cível: AC n ${ }^{\circ}$ 70066439845, Rel. Jorge Luiz Lopes do Canto, 5 a Câmara Cível, publicado em 04/02/2016. 
noticiada nos autos. 4. Diante dos elementos trazidos aos autos, igualmente não é caso de se considerar os alegados danos morais individuais. 5. Sentença de improcedência dos pedidos que, então, vai mantida. Apelação desprovida. (Grifos nossos). ${ }^{272}$

No caso enfrentado pelo Tribunal de Justiça do Estado de São Paulo, foram pleiteados tanto danos morais quanto danos materiais relativos aos prejuízos sofridos por comerciante de produtos alimentícios na beira da praia, em razão da baixa presença de turistas. Neste caso, o Tribunal entendeu que o autor não logrou demonstrar concretamente os danos materiais sofridos. Por outro lado, curiosamente, o tribunal encontrou uma solução interessante: reconheceu a título de dano moral a paralisação repentina das atividades. Confira-se:

RESPONSABILIDADE CIVIL. Danos morais e materiais. Preliminares de nulidade da r. sentença, rejeitadas. MÉRITO. Comerciantes que tiveram suas atividades de venda de produtos alimentícios na beira da praia paralisadas, diante de contaminação do local por óleo, causada pela Transpetro. Pressupostos da responsabilidade civil evidenciados. Danos materiais, contudo, indevidos, posto que os comerciantes não trouxeram prova mínima acerca dos prejuízos alegados. Ônus que lhes competia com exclusividade. Arts. 333, I do CPC/73 e 944, caput do CC. Impossibilidade de arbitramento por equidade. Danos morais caracterizados. Paralização repentina das atividades das vítimas, das quais retiravam o seu sustento, que extrapola aos limites do mero aborrecimento. Majoração da indenização para R\$ 8.000,00 para cada um dos comerciantes. Sentença reformada. Recursos parcialmente providos. (Grifos nossos). ${ }^{273}$

Com relação ao conceito de lucros cessantes, apesar de ser extraído do Direito Civil, sendo exclusivamente associado a um prejuízo financeiro em decorrência de um dano que continua produzindo efeitos no tempo, há autores que associam o termo à perda de funções ecológicas em decorrência de um dano intercorrente. Nesse sentido, Pinho considera como lucro cessante ambiental "o lapso de tempo em que as funções ecológicas ficaram comprometidas para os outros recursos naturais". A autora entende que o período em que houve esse prejuízo ao ecossistema deva ser valorado economicamente, a título de reparação ambiental. ${ }^{274}$

Entretanto, é de suma importância a diferenciação da natureza dos danos ambientais aqui discutidos. Muito embora seja utilizada a expressão "lucro cessante" para uma perda ecossistêmica, não se trata de um dano patrimonial, mas sim de um dano ecológico puro. Desde já deve-se frisar que para danos dessa natureza a indenização deve ser adotada como forma de

${ }^{272}$ TJRS. Apelação Cível: AC nº 70071641260, Rel. Eugênio Facchini Neto, 9ª Câmara Cível, julgado em $14 / 12 / 2016$.

${ }^{273}$ TJSP. Apelação Cível: AC nº 0002294-59.2013.8.26.0587, Rel. Teixeira Leite, $28^{\mathrm{a}}$ Câmara Extraordinária de Direito Privado, DJe 04/10/2017.

274 PINHO, H. G.. Prevenção e Reparação de danos ambientais: as medidas de reposição natural, compensatórias e preventivas e a indenização pecuniária. Rio de Janeiro: GZ Ed; Stuttgart, Alemanha: R. Bosch, 2010, p. 165. 
reparação tão somente nos casos em que não há como restaurar os elementos ambientais perdidos ou mesmo compensá-los. Diferentemente dos danos ecológicos puros, os patrimoniais só admitem como forma de reparação a indenização, principalmente para os lucros cessantes conceituados nos artigos 402 e 403 do Código Civil brasileiro. Sendo assim, a adoção do termo para danos intercorrentes ecológicos pode ser um entrave na aplicação da reparação in situ, pela necessária aplicação de uma indenização.

\subsubsection{Danos extrapatrimoniais ambientais}

De acordo com a classificação dos danos acima apresentada, dentre os danos que afetam interesses pessoais são inseridos os danos extrapatrimoniais ambientais ou danos morais ambientais. No presente trabalho será adotada a primeira terminologia, conforme será melhor explicado. Os danos extrapatrimoniais ambientais se subdividem em: (i) danos extrapatrimoniais ambientais individuais e (ii) danos extrapatrimoniais ambientais coletivos.

O caput do artigo 225 da Constituição Federal preceitua que: "todos tem direito a um meio ambiente ecologicamente equilibrado, indispensável à sadia qualidade de vida". Em outras palavras, a sadia qualidade de vida é um direito que deriva do meio ambiente ecologicamente equilibrado. Uma vez afetado o meio ambiente, de forma secundária, há a geração de um dano à qualidade de vida.

$\mathrm{O}$ próprio artigo 225 igualmente indica o motivo de se adotar a palavra "extrapatrimonial" e não "moral" para danos ambientais, ao relacioná-los à "sadia qualidade de vida". O dano extrapatrimonial seria um dano derivado do dano principal, ecológico, mas que, diferentemente dos danos patrimoniais, afeta interesses imateriais, a exemplo da saúde, bem-estar e qualidade de vida. "Daí que o direito humano fundamental à qualidade de vida é de natureza imaterial e somente será ressarcido se reconhecida à dimensão extrapatrimonial do ambiente", como conclui Steigleder. ${ }^{275}$

O Direito Ambiental contemporâneo passou a reconhecer a diferenciação entre os conceitos de "dano moral", clássico do Direito Civil, e dano extrapatrimonial, aplicável à casos ambientais. A utilização da expressão "dano extrapatrimonial", em substituição a "dano moral" faz sentido no Direito Ambiental, pois, ao caracterizarmos o dano moral como um sentimento de dor, tristeza ou vergonha, não contemplamos as perturbações aos direitos de personalidade, difusos e coletivos, que nem sempre se caracterizam por reações psicológicas de sofrimento. A

275 STEIGLEDER, A. M. Responsabilidade civil ambiental: as dimensões do dano ambiental no direito brasileiro. Porto Alegre: Livraria do Advogado, $2^{\mathrm{a}}$ ed., 2011, p.161. 
expressão extrapatrimonial abrange, além do sofrimento, qualquer lesão à qualidade de vida do indivíduo, ou da coletividade.

O próprio Enunciado n ${ }^{\circ} 445$ da VII Jornada de Direito Civil esclarece que "O dano moral indenizável não pressupõe necessariamente a verificação de sentimentos humanos desagradáveis como dor ou sofrimento".276

Portanto, é mais apropriada a expressão "dano extrapatrimonial ambiental" do que a expressão "dano moral ambiental", uma vez que a primeira é menos restritiva, enquanto a segunda está ligada a certo subjetivismo. Como asseveram Leite e Ayala: “(...) afirma-se ser mais condizente o critério negativista, que considera dano extrapatrimonial toda lesão que não tem uma concepção econômica". ${ }^{277}$

Nos casos de derramamentos de óleo, o reconhecimento do dano extrapatrimonial ambiental tardou a ocorrer. Ainda hoje, nos deparamos com contradições em decisões judiciais que insistem em interpretar o dano extrapatrimonial como essencialmente decorrente de sofrimento. $^{278} \mathrm{O}$ seguinte julgado paradigma do Superior Tribunal de Justiça reforça a associação do dano extrapatrimonial ao sofrimento dos afetados pelo derramamento de óleo, em sua maioria pescadores:

(...) d) Configuração de dano moral. -Patente o sofrimento intenso de pescador profissional artesanal, causado pela privação das condições de trabalho, em consequência do dano ambiental, é também devida a indenização por dano moral, fixada, por equidade, em valor equivalente a um salário-mínimo.

(...) Presente, sem dúvida, além do dano material, o dano moral, pois, como é assente na jurisprudência desta Corte, deve ser composto o dano moral se do acidente resulta sofrimento de monta para o lesado.

(...) O sofrimento acentuado, diferente de mero incômodo, é verdadeiramente irrecusável, no caso de trabalhador profissional da pesca que resta, em virtude do fato, sem possibilidade de realização de seu trabalho. (Grifos nossos). ${ }^{279}$

${ }^{276}$ CONSELHO DE JUSTIÇA FEDERAL. Jornadas de Direito Civil I, III, IV e V: enunciados aprovados. AGUIAR JÚNIOR, R. R. de (Coord.). Brasília: CENTROS DE Estudos Judiciários, 2012. Disponível em: $<\underline{\text { http://www.cjf.jus.br/cjf/corregedoria-da-justica-federal/centro-de-estudos-judiciarios-1/publicacoes- }}$ 1/jornadas-cej/EnunciadosAprovados-Jornadas-1345.pdf $>$. Acesso em: 10.10.2016.

${ }^{277}$ LEITE, J. R. M.; AYALA, P. de. Dano ambiental: do individual ao coletivo extrapatrimonial. Teoria e Prática. São Paulo: RT, $5^{\mathrm{a}}$ ed., 2012, p. 270

${ }^{278}$ De acordo com a pesquisa jurisprudencial realizada no capítulo 3, foram encontrados os seguintes julgados nos tribunais brasileiros tratando os danos extrapatrimoniais como sofrimento: Superior Tribunal de Justiça, 5 casos; Tribunal de Justiça do Estado do Paraná, 13 casos; Tribunal de Justiça do Estado do Rio de Janeiro, 12 casos; Tribunal de Justiça do Estado de São Paulo, 8 casos.

${ }^{279}$ STJ. Recurso Especial: REsp n 1.114.398 - PR, Rel. Min. Sidnei Beneti, Segunda Seção, DJe 16/02/2012. 
Como se percebe, nesse caso, o Superior Tribunal de Justiça considera que o dano extrapatrimonial decorre do sofrimento acentuado (que é de ordem mais intensa que um mero incômodo ou aborrecimento) experimentado pelo pescador em razão da privação das condições de trabalho. Não se aborda o conceito de perda de qualidade de vida no julgado.

O mesmo entendimento é reproduzido em outros julgados da mesma corte superior:

3. Configura dano moral a privação das condições de trabalho em consequência de dano ambiental - fato por si só incontroverso quanto ao prolongado ócio indesejado imposto pelo acidente, sofrimento, à angústia e à aflição gerados ao pescador, que se viu impossibilitado de pescar e imerso em incerteza quanto à viabilidade futura de sua atividade profissional e manutenção própria e de sua família.

(...)

No caso, a Corte local apurou que o recorrido foi submetido, por longo período (superior a 6 meses) ao ócio, à angústia, sofrimento e aflição e se viu imerso em incerteza quanto à viabilidade futura de sua atividade profissional, dado aos danos ambientais causados na região de onde extrai o seu sustento. (Grifos nossos). ${ }^{280}$

No caso do acidente ocorrido na Baía de Guanabara, no Rio de Janeiro, duas câmaras diferentes expressaram entendimentos antagônicos a partir de um mesmo fato gerador. A primeira não configurou o dano moral por ausência de "lesão ao sentimento", enquanto a segunda reconheceu o dano moral em valores próximos aos lucros cessantes arbitrados:

Responsabilidade civil - Petrobras - Dano ambiental - Dano material Caracterização - Ressarcimento dos Danos - Dano Moral - Não Configuração Obrigação de indenizar - Inexistência. "Responsabilidade civil - Baía de Guanabara. Acidente ecológico, por vazamento de óleo na orla marítima de Mauá causando danos materiais aos ecossistemas e às pessoas da região, notadamente, aos pescadores. Os danos materiais foram ressarcidos, proporcionalmente à renda média do pescador, no período impedido de pesca, demonstrado nos autos. Tal fato, em si, não se afigura lesão de sentimento, nem ofensivo à honra do autor, subsumindo-se tal acontecimento na moldura de aborrecimentos. Situação não indenizáveis a título de danos morais, embora lamentável, sob todos os aspectos. Desprovimento do recurso". (Grifos nossos). ${ }^{281}$

Petrobras - Responsabilidade civil - Dano ambiental - Trabalhador autônomo Suspensão da atividade - Dano moral - Lucros cessantes - Responsabilidade objetiva. "Ação ordinária. Indenização. Petrobras. Responsabilidade objetiva. Derramamento de óleo na baía de Guanabara. A Petrobras responde objetivamente pelos danos morais e lucros cessantes ocasionados ao autor, profissional da pesca, que em razão do derramamento de óleo na baía de Guanabara, decorrente do rompimento de um dos dutos da empresa, viu-se prejudicado em seu sustento e de seus familiares. Mantémse a quantificação definida no decisium, em valores equivalentes a 18 salários

280 STJ. Recurso Especial: REsp n 1346430 - PR, Rel. Luis Felipe Salomão, Quarta Turma, DJe 21/11/2012.

${ }^{281}$ TJRJ. Apelação Cível: AC nº 2002.001.02504, $12^{\text {a }}$ Câm. Cível. Relator: Des. Roberto de Abreu e Silva. Diário Oficial do Estado do Rio de Janeiro. 21/05/2002. 
mínimos a título de lucros cessantes e 60 salários mínimos para os danos morais. Recursos conhecidos e improvidos. (Grifos nossos). ${ }^{282}$

Uma das maiores motivações para o reconhecimento do dano extrapatrimonial ambiental é a comprovação da condição de pescador profissional. Afinal, como explicado acima, se o dano extrapatrimonial ainda é considerado pela maioria dos julgados analisados como sofrimento, e o sofrimento decorre da privação das condições de trabalho, somente os pescadores profissionais teriam direito ao reconhecimento do dano extrapatrimonial. Nesse sentido, caso o dano extrapatrimonial fosse amplamente considerado pelos magistrados como perda de qualidade de vida, certamente haveria um aumento no numero de pleitos por indenização até mesmo por não pescadores. Entretanto, há de se reconhecer a dificuldade de comprovação da perda da qualidade de vida de um indivíduo, visto que não se da por critérios objetivos, a exemplo da apresentação de registro de pesca.

Os julgados do Tribunal de Justiça do Estado do Paraná não reconheceram os danos extrapatrimoniais pleiteados, sob a justificativa de que os autores não comprovaram sua condição de pescador profissional:

(...) 9) a prova do exercício da profissão pelo autor à época dos fatos é condição sine qua non para demonstrar o direito ao recebimento da indenização, mas não se confunde com a legitimidade ativa, decorrência da aplicação da teoria da asserção.

10) Ao reconhecer responsabilidade das empresas no evento danoso, mister averiguar se a parte autora teve o prejuízo moral alegado na inicial (se é titular desse direito). A concessão/recusa da indenização pautada na prova de exercer a profissão indicada, com base exclusivamente no que consta nos autos, certamente irá cercear a defesa de um ou outro litigante. Daí porque a necessidade de ser anulada a r. sentença com o retorno dos autos à origem para instrução do feito, eis que ainda não maduro para receber julgamento.

(...)

Com todo o respeito ao entendimento singular, mas, mesmo com amparo na teoria adequadamente empregada, se no plano ideal resta caracterizada a legitimidade, para que o autor faça jus a reparação do prejuízo, é necessário que venha aos autos a prova destes fatos (que é pescador ou exerce atividade correlata e sofreu prejuízo), pois se a legitimidade é aferida no plano ideal, da simples narrativa e afirmação, o direito de haver a indenização não prescinde desta prova.

A procedência do pedido, vale dizer, depende da comprovação dos fatos afirmados na inicial. (Grifos no original). ${ }^{283}$

INDENIZAÇÃO POR DANOS MORAIS E MATERIAIS. DERRAMAMENTO DE ÓlEO NA BAÍA DE PARANAGUÁ. EXPLOSÃO DO NAVIO TANQUE VICUÑA. DECLARAÇÕESUNILATERAIS DAS AUTORAS QUE NÃO COMPROVAM ACONDIÇÃO DE MARISQUEIRAS À ÉPOCA DO

${ }^{282}$ TJRJ. Agravo de Instrumento: Ag nº 2002.002.03893, $10^{\text {a }}$ Câm. Cível. Relator: Des. Jayro S. Ferreira. Rio de Janeiro, RJ, 21/01/2002.

283 TJPR. Apelação Cível: Ac nº 1305861-0, Rel. Carlos Henrique Licheski Klein, 10ª Câmara Cível, publicação em 21/01/2016. 
ACIDENTE.OPORTUNIZADA A INSTRUÇÃO PROBATÓRIA. A ausência de provas que as autoras exerciam a atividade de marisqueira à época dos fatos conduz à improcedência da indenização, nos termos do art. 333, inciso I, do Código de Processo Civil. APELAÇÃO NÃO PROVIDA. AGRAVO RETIDO PREJUDICADO. (Grifos no original). ${ }^{284}$

Esta lógica subjaz, inclusive, o julgado paradigma do Superior Tribunal de Justiça em matéria de danos ambientais decorrentes do derramamento de óleo no mar, ao exigir que o pescador profissional artesanal comprove "início de atividade profissional registrada no Departamento de Pesca e Aquicultura do Ministério da Agricultura e do Abastecimento anteriormente ao fato":

(...) b) Legitimidade ativa ad causam.- É parte legítima para ação de indenização supra referida o pescador profissional artesanal, com início de atividade profissional registrada no Departamento de Pesca e Aquicultura do Ministério da Agricultura, e do Abastecimento anteriormente ao fato, ainda que a emissão da carteira de pescador profissional tenha ocorrido posteriormente, não havendo a ré alegado e provado falsidade dos dados constantes do registro e provado haver recebido atenção do poder público devido a consequências profissionais do acidente. ${ }^{285}$

Assim, a correta classificação dos danos decorrentes de derramamentos de óleo é imprescindível para que sejam identificadas as adequadas formas de reparação. Aos danos ambientais puros deve ser priorizada a recuperação ecológica do ambiente ao máximo possível, cabendo medidas compensatórias e indenizatórias ao dano impossível de ser reparado. Já os danos patrimoniais devem ser indenizados de acordo com o prejuízo real sofrido pelos lesados. Por fim, os extrapatrimoniais igualmente devem ser indenizados, mas nem sempre há um critério objetivo para o cálculo, podendo o valor ser arbitrado a título pedagógico.

A Súmula 37 do STJ deixa claro que: "São cumuláveis as indenizações por dano material e dano moral oriundos do mesmo fato". Basta a identificação e o cálculo corretos dos valores a serem indenizáveis. Desse modo, esclarece Iglecias Lemos que, além dos danos materiais, os extrapatrimoniais devem ser reparados "a título de justa indenização". Avança a autora defendendo que deve o magistrado arbitrar um valor somente nos casos em que inexiste critérios seguros para o cálculo dos valores. ${ }^{286}$

Outro ponto interessante levantado pela autora se refere às funções da indenização para danos extrapatrimoniais ambientais. Se, por um lado, a reparação do dano ambiental ecológico

\footnotetext{
284 TJPR. Apelação Cível: AC nº 661410-0, Rel. Nilson Mizuta, 10ª Câmara Cível, julgado em 04/11/2010.

${ }^{285}$ STJ. Recurso Especial: REsp no 1.114.398 - PR, Rel. Min. Sidnei Beneti, Segunda Seção, DJe 16/02/2012.

${ }^{286}$ LEMOS, P. F. I. Direito Ambiental: Responsabilidade civil e proteção do meio ambiente. São Paulo: RT, $2011,3^{\text {a }}$ ed., p. 166.
} 
visa a recomposição do ambiente, por outro, nos casos dos danos extrapatrimoniais, admite-se o caráter punitivo e pedagógico, intimidando o cometimento de reincidências. ${ }^{287}$

Entretanto, até mesmo nos casos de danos extrapatrimoniais discute-se se a indenização seria a única forma de reparação. O próprio Enunciado n ${ }^{\circ} 589$ da VII Jornada de Direito Civil afirma que: “A compensação pecuniária não é o único modo de reparar o dano extrapatrimonial, sendo admitida a reparação in natura, na forma de retratação pública ou outro meio". ${ }^{288}$ Desse modo, entende-se no presente trabalho que até mesmo nos casos de danos extrapatrimoniais ambientais pode-se admitir formas alternativas de reparação, além da indenização, principalmente para aqueles danos coletivos, que serão detalhados a seguir. ${ }^{289}$

Com relação à abrangência dos danos extrapatrimoniais, admite-se o caráter individual e coletivo. Quando forem lesados os direitos da personalidade, o dano será individual. Já nos casos de lesão aos interesses difusos ou coletivos, o dano moral será coletivo. O reconhecimento do dano extrapatrimonial ambiental coletivo igualmente afasta a ideia de sofrimento e de dor. Assim, como argumenta Carvalho Ramos, "o ponto-chave para a aceitação do chamado dano moral coletivo está na ampliação de seu conceito, deixando de ser o dano moral um equivalente da dor psíquica, que seria exclusividade de pessoas físicas". 290

Para um caso específico de derramamento de óleo em que uma comunidade tradicional que habita a região é lesada, não haveria como identificar o sofrimento coletivo, mas, por outro lado, a perda da qualidade de vida de um grupo pode facilmente ser observada. Desta forma, o conceito de dano extrapatrimonial coletivo ambiental torna-se ainda mais distante da ideia tradicional do direito civil para a caracterização do dano moral.

Tal importância somente reforça a necessidade de aceitação do dano moral coletivo, já que a dor psíquica que alicerçou a teoria do dano moral individual acaba cedendo lugar, no caso

${ }^{287}$ LEMOS, P. F. I. Direito Ambiental: Responsabilidade civil e proteção do meio ambiente. São Paulo: RT, 2011, $3^{\mathrm{a}}$ ed., p. 166.

${ }^{288}$ CONSELHO DE JUSTIÇA FEDERAL. Jornadas de Direito Civil I, III, IV e V: enunciados aprovados. AGUIAR JÚNIOR, R. R. de (Coord.). Brasília: CENTROS DE Estudos Judiciários, 2012. Disponível em: $<$ http://www.cjf.jus.br/cjf/corregedoria-da-justica-federal/centro-de-estudos-judiciarios-1/publicacoes1/jornadas-cej/EnunciadosAprovados-Jornadas-1345.pdf $>$. Acesso em: 10.10.2016.

${ }^{289}$ Deve-se ainda mencionar a possibilidade de pleito de indenização por danos extrapatrimoniais futuros, segundo posicionamento de Gomes. GOMES, C.A. De que falamos quando falamos de dano ambiental: direito, mentiras e críticas. Actualidad Jurídica Ambiental, 15 de mar. 2010, p. 11.

${ }^{290}$ CARVALHO RAMOS, A. de. A ação civil pública e o dano moral coletivo. RDC. São Paulo: RT, v.25, 1998, p. 82 . 
do dano moral coletivo, a um sentimento de desapreço e de perda de valores essenciais que afetam negativamente toda uma coletividade. ${ }^{291}$

Nesse sentido, a aferição de indenização por dano extrapatrimonial coletivo ambiental deve necessariamente ser feita em um cenário em que se identifica a lesão a um elemento indispensável a toda uma coletividade. ${ }^{292}$ Os derramamentos de óleo no mar, tanto pela sua dimensão, quanto pelos ambientes normalmente afetados, são casos típicos em que é possível a lesão a um elemento indispensável à sadia qualidade de vida, por exemplo, a água, ou ainda a praia.

Assim, haverá dano ambiental de natureza moral coletiva a ser indenizado nas situações de exposição da população à poluição nas suas mais diversas formas (ruído, poluição atmosférica, hídrica, e assim por diante), percebendo-se que a saúde, a tranquilidade e a qualidade de vida da coletividade sofre um decréscimo, e, mesmo que reparado o dano ecológico puro, a reparação não será integral se não considerada esta dimensão imaterial, de lesão à qualidade de vida. ${ }^{293}$

Ainda, não se pode negar que os ecossistemas e seus elementos são bens de interesse público, retornando ao artigo 225 da Constituição Federal, "todos tem direito a um meio ambiente ecologicamente equilibrado", ou seja, qualquer intervenção que cause desiquilíbrio ecológico e, consequentemente afete negativamente a qualidade de vida daqueles atingidos, deve ser vista como dano coletivo. ${ }^{294}$

Com relação aos tipos de danos extrapatrimoniais, destacam-se os danos à saúde, à qualidade de vida, os danos sociais e os estéticos, que serão abordados a seguir.

${ }^{291}$ CARVALHO RAMOS, A. de. A ação civil pública e o dano moral coletivo. RDC. São Paulo: RT, v.25, 1998, p.83.

${ }^{292}$ Nas palavras de Gomes: "Poderá conceber-se que, para além da restauração natural - que demorará vários anos e poderá nunca alcançar o estado anterior à lesão, por extinção de espécies -, haja pagamento de quantias à comunidade por perda de fruição de um bem colectivo? (...) Trata-se aqui de ressarcir danos morais de categorias de indivíduos cujo traço identificativo se prende com a especial intensidade de fruição de um dado recurso. Seriam como que, e passe o pleonasmo jurídico, interesses difusos homogéneos: interesses na fruição de um bem colectivo cujo desaparecimento ou amputação de qualidades provoca um sentimento de perda de idêntica natureza num determinado universo de "usuários". GOMES, C. A.. De que falamos quando falamos de dano ambiental: direito, mentiras e críticas. Actualidad Jurídica Ambiental, 15 de mar. 2010, p. 10.

293 STEIGLEDER, A. M. Responsabilidade civil ambiental: as dimensões do dano ambiental no direito brasileiro. Porto Alegre: Livraria do Advogado, $2^{\mathrm{a}}$ ed., 2011, p.165.

${ }^{294}$ Segundo Steigleder: "Para viabilizar o reconhecimento da existência de danos morais coletivos nos casos de danos ecológicos puros, desvinculados de interesses pessoais de indivíduos determinados, a doutrina vem sustentando que o dano moral identifica-se com o dano ao bem de interesse público, voltando-se para a proteção das dimensões éticas do ambiente e da vida humana (...)". STEIGLEDER, A. M. Responsabilidade civil ambiental: as dimensões do dano ambiental no direito brasileiro. Porto Alegre: Livraria do Advogado, $2^{\mathrm{a}}$ ed., 2011, p. 160. 


\subsubsection{Danos à Saúde e à qualidade de vida}

Em todas as fases do processo produtivo do petróleo, desde a prospecção nos campos até o início do processo de refino, há o risco potencial de geração de impactos à saúde da população. Em cada etapa desses processos há a geração de emissões atmosféricas, efluentes líquidos e resíduos sólidos, a exemplo de água de produção, que acompanha o óleo cru, resíduos de perfuração (cascalho e fluidos), emulsões oleosas, esgoto sanitário, aditivos químicos, entre outros.

A contaminação humana pode ocorrer de diversas formas, podendo ser ocupacional ou ambiental. A presença de metais pesados na composição dos vários tipos de óleos pode chegar aos seres humanos de forma direta ou indireta, a exemplo do consumo de animais contaminados. ${ }^{295}$ Estes compostos apresentam a característica de serem bioacumuladores. Dito de outro modo, permanecem em animais e plantas, sendo transmitidos a toda cadeia trófica, sendo absorvidos pelo homem pela ingestão. Tanto a água, quanto os alimentos contaminados, se consumidos, podem provocar intoxicação química. ${ }^{296}$

Deve-se ter em mente que a contaminação ambiental por derramamentos de petróleo e derivados é um problema que não se restringe apenas ao impacto local ambiental. A preocupação com as consequências da contaminação por óleos à saúde humana já ocorre há tempos.

A maior parte dos estudos toxicológicos se dedica a identificação dos efeitos do óleo nos organismos aquáticos. Quando realizados com o objetivo de avaliar os efeitos da exposição ao óleo na saúde humana, a maioria deles se concentra em efeitos agudos e sintomas psicológicos. ${ }^{297}$ Entretanto, alguns estudos realizados nas últimas três décadas, avaliaram os efeitos do óleo derramado tanto em residentes das áreas afetadas, quanto nos indivíduos que trabalharam nas ações de limpeza dos locais atingidos pelos derramamentos. ${ }^{298}$ Foram

\footnotetext{
${ }^{295}$ Os compostos aromáticos mais solúveis penetram na corrente sanguínea a partir da pele ou da ingestão, podendo ser filtrados pelo sistema excretor e eliminados na urina. Os aromáticos têm potencial capacidade de causar danos nas células sanguíneas, nos tecidos ósseos (medula óssea) e no sistema nervoso. Causam irritações e dermatite na pele, mucosas e olhos, podendo também afetar de forma análoga os tecidos de vertebrados marinhos após um derrame de óleo. Informações disponíveis no site da CETESB, que podem ser acessadas em $<\underline{\text { https://cetesb.sp.gov.br/emergencias-quimicas/tipos-de-acidentes/vazamentos-de-oleo/caracteristicas-do- }}$ oleo/aspectos-toxicologicos/> Acesso em: 18.11.2018.

${ }^{296}$ GURGEL, A. M.; MEDEIROS, A. C. L. V.; ALVES, P. C. et al. Framework dos cenários de riscos no contexto da implantação de uma refinaria de petróleo em Pernambuco. Ciência \& Saúde Coletiva. Rio de Janeiro, v.14, n.6, p. 2027-2038, 2009.

${ }^{297}$ AGUILERA, F.; MÉNDEZ, J.; PÁSARO, E.; LAFFON, B.. Review on the effects of exposure to spilled oils on human health. Journal of Applied Toxicology. V.30, p. 291-301, mai. 2010.

${ }^{298}$ Aqueles que participam das atividades de limpeza do óleo derramado compõem o grupo de maior risco, uma vez que entram em contato direto com produtos químicos perigosos, sendo, além do próprio óleo, dispersantes
} 
evidenciados diversos danos à saúde, a exemplo de problemas respiratórios, lesões na pele, danos ao sistema nervoso, além de alterações nos níveis de biomarcadores inflamatórios e genotóxicos. ${ }^{299}$ Inclusive, danos genotóxicos, além de alterações endócrinas, foram evidenciados em indivíduos expostos ao óleo derramado pelo Prestige. ${ }^{300}$ Ademais, foram igualmente observadas consequências neurotóxicas, resultando em efeitos adversos à saúde mental. ${ }^{301}$

O petróleo bruto contém diversos componentes tóxicos considerados carcinógenos humanos. Os efeitos a longo prazo sobre a saúde humana devem igualmente ser avaliados, principalmente relacionados ao desenvolvimento de câncer e doenças degenerativas resultantes dessa exposição. ${ }^{302}$

Apesar de existirem trabalhos relacionando efeitos do óleo à saúde, realizados desde a década de 1980, as plataformas de buscas de artigos sobre o tema consultadas na presente tese, evidenciam que grande parte dos estudos se intensificou após o acidente da Deepwater Horizon, ocorrido em 2010 nos Estados Unidos.

Interessante o fato de que nos casos dos acidentes mais antigos, os prejuízos à saúde, principalmente daqueles que atuaram nas ações de limpeza, se justificavam em grande parte pela ausência do uso de equipamentos de proteção individual. Entretanto, os estudos aqui analisados demonstram que mesmo no recente caso do acidente da Deepwater Horizon, ainda foram evidenciados danos à saúde dos trabalhadores.

Sendo assim, é de extrema importância a colocação feita por Mina e Hae-Kwan, ao apontarem que os efeitos adversos à saúde são, em vários casos, ocasionados por negligências observadas nos primeiros momentos de resposta a acidentes. Nesse sentido, devem ser sempre cumpridos procedimentos de prevenção, como: a evacuação de populações vulneráveis; o fornecimento de equipamentos de proteção adequados aos trabalhadores; além da orientação acerca dos possíveis riscos à saúde decorrentes da exposição ao óleo.

químicos e soluções de limpeza, como benzeno, tolueno e etilbenzeno. Xileno, 2-butoxietanol e propilenoglicol podem causar problemas respiratórios e dores de cabeça. KWOK, R. K. at al. Mental health indicators associated with oil spill response and clean-up: cross-sectional analysis of the GuLF STUDY cohort. The Lancet Public Health, v.2, n.12, dez. 2017, p. 560-567.

${ }^{299}$ ZOCK, J. P. Some clues for studying long-term health effects of oil spills. Occupational and Environmental Medicine (BJM Journals). London, v.75, 2018, p.165-175.

${ }^{300}$ AGUILERA, F.; MÉNDEZ, J.; PÁSARO, E.; LAFFON, B.. Review on the effects of exposure to spilled oils on human health. Journal of Applied Toxicology. V.30, p. 291-301, mai. 2010.

${ }^{301}$ KWOK, R. K. at al. Mental health indicators associated with oil spill response and clean-up: cross-sectional analysis of the GuLF STUDY cohort. The Lancet Public Health, v.2, n.12, dez. 2017, p. 560-567.

${ }^{302}$ HA, M.; CHEONG, H-K..Oil spill clean-up: a trade-off between human health and ecological restoration?. The Lancet Public Health, v.2, n.12, p. ee534 - e535, dez. 2017. 
Além dos problemas genéticos e fisiológicos, já se pode falar em problemas psicossociais de saúde, como transtornos mentais pós-traumáticos, relacionados àqueles que vivenciaram os acidentes e suas perdas relacionadas. Esses indivíduos podem desenvolver ansiedade generalizada, além de sintomas depressivos.

As maiores deficiências de estudos realizados até 2010 relacionavam-se à ausência de avaliação dos efeitos a médio e longo prazo do óleo na saúde, bem como da eficácia dos dispositivos de proteção utilizados. ${ }^{303}$ Alguns estudos recentes, datados de 2017 e 2018 se dedicaram a avaliar os desdobramentos na saúde de pessoas que tiveram contato com o óleo derramado em 2010 pela Deepwater Horizon Gulf. Destaca-se o estudo desenvolvido por D’Andrea e Reddy, publicado no início de 2018, que concluiu que alguns indivíduos envolvidos nas operações de limpeza sofreram alterações persistentes ou agravamento das suas funções hematológicas, hepáticas, pulmonares e cardíacas, até sete anos após a exposição ao óleo. ${ }^{304}$

Diante das informações aqui apresentadas, torna-se claro que os óleos por si só apresentam toxicidade que pode afetar as pessoas até mesmo durante atividades laborais, atinentes ao processo produtivo, havendo controle de manuseio e contato. Entretanto, o cenário que reveste um acidente proporciona um risco muito maior à contaminação, inclusive pela imprevisibilidade das dimensões de seus efeitos.

Sendo assim, não há dúvidas no que diz respeito à possibilidade de relação direta de efeitos danosos entre o estado do meio ambiente e o bem-estar físico, emocional e social das pessoas envolvidas. Entretanto, com relação à reparabilidade, não se pode confundir o dano à saúde, que compreende perda de qualidade de vida, com o ressarcimento de despesas médicas. Enquanto o primeiro reflete um dano extrapatrimonial, cuja valoração não possui parâmetros, vez que o valor de uma vida é inestimável; o segundo se refere a um valor a ser reembolsado, passível de ser comprovado, de cunho exclusivamente material.

Nesse sentido, Pontes de Miranda diferencia dano concreto ou real de dano contabilístico, cujas definições podem ser aproveitadas para os danos à saúde e para os prejuízos consequentes. Desse modo, dano concreto ou real, sem suas palavras, "é o que se expressa em perda ou alteração de algum bem, ou lesão corporal ou psíquica, ou ofensa à saúde, ou outro

\footnotetext{
${ }^{303}$ AGUILERA, F.; MÉNDEZ, J.; PÁSARO, E.; LAFFON, B.. Review on the effects of exposure to spilled oils on human health. Journal of Applied Toxicology. V.30, p. 291-301, mai. 2010.

${ }^{304}$ No estudo foram avaliadas "as alterações nos níveis de glóbulos brancos, plaquetas, hemoglobina, hematócrito, nitrogênio ureico sanguíneo, creatinina, fosfatase alcalina (ALP), aspartato amino transferase (AST), alanina amino transferase (ALT), bem como suas funções pulmonares e cardíacas." (tradução nossa). D'ANDREA, M. A.; REDDY, G. K. The Development of Long-Term Adverse Health Effects in Oil Spill Cleanup Workers of the Deepwater Horizon Offshore Drilling Rig Disaster. Front Public Health, v.6, n.117. Published online. 2018.
} 
bem jurídico. O dano à honra ou a reputação é dano concreto ou real”. Já o dano contabilístico seria o dano que a pessoa sofre, físico ou psicológico, mas a expressão se dá em dinheiro. Mais uma vez, em seus termos: "O que em verdade se perdeu ou o que em verdade se reduziu foi o valor do patrimônio ou das coisas de valor patrimonial futuro. Inclusive de produção". ${ }^{305}$ Nesse último caso, pode ser enquadrada a indenização por invalidez.

\subsubsection{Danos extrapatrimoniais coletivos e sociais difusos}

Os episódios de derramamentos de óleo em larga escala preocupam a comunidade jurídica internacional, principalmente com relação à proteção dos interesses difusos ou coletivos que, quando violados, devem ser passíveis de ressarcimento, assim como os interesses individuais o são. Entretanto, nesses casos, os beneficiários devem ser toda a sociedade ou a coletividade atingida. ${ }^{306}$

Nesse contexto, nasce o conceito de dano social. De acordo com o professor Junqueira de Azevedo, os danos sociais são lesões à sociedade por diminuição da qualidade de vida, que devem ser punidos com o objetivo de desestimular condutas que afetem a população. Sendo assim, o valor da indenização deve ser destinado a um fundo de proteção de interesses difusos. ${ }^{307} \mathrm{O}$ autor defende que o juiz deve reconhecer os danos sociais independentemente dos danos materiais e morais, visto que se trata de uma obrigação de segurança autônoma, que representa e protege um valor social. ${ }^{308}$

No mesmo sentido, o enunciado $\mathrm{n}^{\circ} 456$, aprovado na V Jornada de Direito Civil, remete ao artigo 944 do Código Civil, e esclarece que a “expressão 'dano' no art. 944 abrange não só os danos individuais, materiais ou imateriais, mas também os danos sociais, difusos, coletivos e individuais homogêneos a serem reclamados pelos legitimados para propor ações coletivas." 309

\footnotetext{
${ }^{305}$ MIRANDA, P. de. Direito das obrigações: consequências do inadimplemento; exceções de contrato não adimplido, ou adimplido insatisfatoriamente, e de inseguridade; enriquecimento injustificado; estipulação a favor de terceiro; eficácia protectiva de terceiro; mudanças de circunstâncias; compromisso. Ruy Rosado de Aguiar Júnior e Nelson Néry Jr (Atual.). São Paulo: RT, tomo 26, 2012, p.94.

${ }^{306}$ SCHREIBER, A. Novos paradigmas da responsabilidade civil. São Paulo: Atlas, 2007, p. 82.

307 AZEVEDO, A. J. de. Por uma nova categoria de dano na responsabilidade civil: o dano social. In: . Novos estudos e pareceres de direito privado. São Paulo: Saraiva, 2009, p. 378.

$\overline{308}$ AZEVEDO, A. J. de. Por uma nova categoria de dano na responsabilidade civil: o dano social, in O Código Civil e a sua interdisciplinaridade: reflexos do Código Civil nos demais ramos do direito, cit., p. 374-376

309 CONSELHO DE JUSTIÇA FEDERAL. Jornadas de Direito Civil I, III, IV e V: enunciados aprovados. AGUIAR JÚNIOR, R. R. de (Coord.). Brasília: CENTROS DE Estudos Judiciários, 2012. Disponível em: $<\underline{\text { http://www.cjf.jus.br/cjf/corregedoria-da-justica-federal/centro-de-estudos-judiciarios-1/publicacoes- }}$ 1/jornadas-cej/EnunciadosAprovados-Jornadas-1345.pdf $>$. Acesso em: 10.10.2016.
} 
Já os danos extrapatrimoniais coletivos atingem direitos de personalidade, individuais homogêneos, de várias pessoas, ou coletivos em sentido estrito. As vítimas são determináveis, ou determinadas e devem receber diretamente a indenização. ${ }^{310}$ Nesses casos, a principal via para o ressarcimento das vítimas seria a ação coletiva. ${ }^{311}$

Em dois dos julgados analisados abaixo, o dano moral coletivo foi reconhecido de forma dissociada ao sofrimento humano. No primeiro caso, o TRF da $2^{a}$ Região considerou que o dano moral coletivo decorre de lesão ao patrimônio ideal e prejuízo à qualidade de vida:

10. Cabível a condenação em indenização por dano moral coletivo, eis que a conduta da apelada acarretou "lesão ao valor proporcionado a patrimônio ideal da coletividade, relacionado à manutenção do equilíbrio ambiental e da qualidade de vida" (José Rubens Morato Leite e Patryck de Araújo Ayala, Dano Ambiental Do individual ao coletivo extrapatrimonial, RT, 2011, p. 291). ${ }^{312}$

Já no caso extraído do TRF da $3^{\mathrm{a}}$ Região, não se mencionou expressamente perda da qualidade de vida, mas reconheceu-se o dano extrapatrimonial coletivo em razão do prejuízo a um bem de uso comum do povo, onde a atividade turística era forte:

7. A ré deve ser condenada a pagar indenização por dano moral coletivo, porquanto a sua conduta prejudicou 120 quilômetros da costa norte do Estado de São Paulo, especialmente a Praia da Lagoa em Ubatuba/SP, a qual, como é de conhecimento comum, embora seja deserta é grande atração turística especialmente à causa da presença de golfinhos nas suas águas azuis; as praias são bem de uso comum do povo e por isso mesmo qualquer lesão ambiental contra elas representa dano coletivo que deve ser reparado pelo poluidor.

Por outro lado, sobre a existência do dano moral coletivo, este depende da ofensa a interesses legítimos, valores e patrimônio ideal de uma coletividade que devam ser protegidos. Na definição de Carlos Alberto Bittar Filho, o dano moral coletivo é entendido sob a seguinte ótica:

(...) O dano moral coletivo é a injusta lesão da esfera moral de uma dada comunidade, ou seja, é a violação antijurídica de um determinado círculo de valores coletivos. Quando se fala em dano moral coletivo, está-se fazendo menção ao fato de que o patrimônio valorativo de uma certa comunidade (maior ou menor), idealmente considerado, foi agredido de maneira absolutamente injustificável do ponto de vista jurídico: quer isso dizer, em última instância, que se feriu a própria cultura, em seu aspecto imaterial. Tal como se dá na seara do dano moral individual, aqui também não há que se cogitar de prova da culpa, devendo-se responsabilizar o agente pelo simples fato da violação (damnum in re ipsa). (BITTAR FILHO, Carlos Alberto. Do dano moral coletivo no atual contexto jurídico brasileiro. Disponível em http://www.egov.ufsc.br/portal/sites/default/files/anexos/30881-33349-1-PB.pdf). ${ }^{313}$

310 TARTUCE, F. Manual de direito civil. São Paulo: Método, $3^{\mathrm{a}}$ ed., 2013.

${ }^{311}$ GAGLIANO, P. S.; PAMPLONA FILHO, R. Novo curso de Direito Civil: Responsabilidade Civil. São Paulo: Saraiva, v.3, $9^{\text {a }}$ ed., 2011, p. 89.

312 TRF2. Apelação Cível: AC n ${ }^{\circ}$ 2005.51.02.0063310, Rel. Luiz Paulo da Silva Araújo Filho, $7^{\mathrm{a}}$ Turma Especializada, DJe 12/02/2014.

313 TRF3. Apelação Cível: AC nº 0006782-42.2011.4.03.6103, Rel. Johonsom Di Salvo, Sexta Turma, e-DFJ3 $19 / 11 / 2015$. 
Entretanto, recente julgado do TRF da $3^{\mathrm{a}}$ Região ainda considera a dimensão de perda de qualidade de vida aliada ao sentimento individual, mesmo para danos morais coletivos:

Entretanto, no presente caso, não vislumbro a ocorrência de dano moral coletivo. Conforme observado na r. sentença, "não há quaisquer elementos que indiquem que a população tenha passado por algum desconforto fora do cotidiano ou por efetivo incômodo qualificável como dano moral transindividual, seja pelo desapreço que tal provoca à condição ou ao valor de habitabilidade dos locais vizinhos, projetado sobre os sentimentos individualmente manifestados, mas coletivamente considerado, seja pelas circunstâncias pessoais de cada uma dos habitantes afetados pela saúde. ${ }^{314}$

\subsubsection{Dano Estético}

Os danos estéticos vêm sendo tratados tanto pela doutrina quanto pela jurisprudência separadamente dos danos extrapatrimoniais. ${ }^{315}$ Para Teresa Ancona Lopez, o dano estético é "qualquer modificação duradoura ou permanente na aparência externa de uma pessoa, modificação esta que lhe acarreta um 'enfeiamento' e lhe causa humilhações e desgostos, dando origem, portanto, a uma dor moral". 316 A modalidade de dano, portanto, está associada a integridade da aparência, ${ }^{317}$ e se configura pelo caráter de permanência das sequelas. ${ }^{318}$

Assim, diferentemente da interpretação de alguns, não se objetiva aqui proteger a beleza física, até mesmo pelo fato de não ser possível estereotipá-la. Antes disso, busca-se a proteção de um patrimônio subjetivo do indivíduo. ${ }^{319} \mathrm{O}$ dano estético não se limita a um abalo de sentimentos dos indivíduos, ${ }^{320}$ tanto que pode originar dupla indenização, a primeira, de aspecto patrimonial, para se reparar o que foi lesado, por meio, por exemplo, de uma cirurgia; e a segunda, por dano moral. Assim, a Súmula n 387 do STJ esclarece ser "lícita a cumulação das indenizações de dano estético e dano moral".

A doutrina mais avançada considera a hipótese de os danos estéticos igualmente serem aplicados à prejuízos ambientais que resultam em degradação da paisagem. ${ }^{321}$ Benjamim, por

314 TRF3. Apelação Cível: AC nº 0007233-30.2012.4.03.6104, Rel. Mônica Nobre, Quarta Turma, e-DJF3 $14 / 09 / 2016$.

315 TARTUCE, F. Direito Civil: direito das obrigações e responsabilidade civil. Rio de Janeiro: Forense, v.2, 12a ed., 2012, p.437.

${ }^{316}$ LOPEZ, T. A. O dano estético: responsabilidade civil. São Paulo: RT, 1999, p.38.

${ }^{317}$ SILVA FILHO, A. M. da. A responsabilidade civil e o dano estético. In: Nery Junior, N.; Nery, R. M de A. (Org.) Responsabilidade Civil: Teoria Geral. São Paulo: RT, v.1, 2010, p.843.

318 MELO, N. D. de. Responsabilidade civil por erro médico: doutrina e jurisprudência. São Paulo: Atlas, 2008, p.37.

${ }^{319}$ MELO, N. D. de. Responsabilidade civil por erro médico: doutrina e jurisprudência. São Paulo: Atlas, 2008, p.37.

${ }^{320}$ MIRAGEM, B. N. B. Direito Civil: responsabilidade civil. São Paulo: Saraiva, 5a ed., 2015, p. 200.

${ }^{321}$ Nos termos de Schreiber: "À parte essa expansão quantitativa, verifica-se, em todo mundo, e de modo ainda mais marcante, uma expansão qualitativa, na medida em que novos interesses, sobretudo de natureza existencial e coletiva, passam a ser considerados pelos tribunais como merecedores de tutela, consubstanciando-se a sua violação em novos danos ressarcíveis. De fato, o reconhecimento da necessidade de tutela dos interesses 
exemplo, defende a "importância da paisagem no discurso político, cultural, ético e jurídico da proteção ao meio ambiente." 322 Ademais, a própria Política Nacional de meio ambiente, 6.938/1981, também aponta no mesmo sentido ao definir, em seu artigo $3^{\circ}$, III, d, poluição como sendo a degradação da qualidade ambiental resultante de atividades que direta ou indiretamente "afetem as condições estéticas ou sanitárias do meio ambiente." Reconhece, portanto, a importância do fator estético. Catalá defende ainda o fato de as paisagens protegidas serem uma categoria de "espaços naturais protegidos", sendo a preservação da paisagem parte da preservação do meio ambiente. ${ }^{323}$

Sendo assim, torna-se importante a reflexão acerca da titularidade do dano estético ligado à paisagem. Entende-se aqui que, diferentemente do dano estético de natureza individual, quando se trata de meio ambiente, todos deveriam ser beneficiados, sendo possível por exemplo, o reconhecimento do dano estético em decorrência do prejuízo a uma paisagem coberta por óleo.

\subsubsection{Dimensões do dano ambiental}

Os danos ambientais podem ainda ser classificados de acordo com suas dimensões, tanto de grandeza, quanto temporal. Essa forma de classificação é importante principalmente para os casos de derramamentos de óleo, cujos danos nem sempre são visíveis e imediatos.

Entende-se dano imediato a resposta instantânea de um bem à ofensa. Já o dano mediato se manifesta em momento posterior ao evento, podendo permanecer quando a lesão é constante, muitas vezes dificultando a sua mensuração ou a identificação dos atingidos. ${ }^{324}$

Semelhante ao dano mediato, o dano futuro só se manifestará em um tempo posterior ao dano presente, que inclusive, ao ser perfeitamente identificado fornece elementos para que os tribunais possam avaliar previamente o prejuízo que ainda virá. Trata-se, portanto, de uma

existenciais atinentes à pessoa humana, e, de outro lado, a verificação de danos demasiado abrangentes, identificados com interesses transindividuais ou supra individuais, que passam a ser considerados dignos de proteção, vieram exigir o repensar da estrutura individualista e eminentemente patrimonial das ações de reparação". SCHREIBER, A. Novos paradigmas da responsabilidade civil. São Paulo: Atlas, 2007, p.81.

${ }^{322}$ BENJAMIN, A. H.. Paisagem, natureza e direito: uma homenagem a Alexandre Kiss. In:

(Org). Paisagem, natureza e direito. São Paulo: Instituto O Direito por um Planeta Verde, v.2, 2005.

323 CATALÁ, L. G. Responsabilidad por Daños al Medio Ambiente. Madrid: Arazandi Editorial, 1998, p.7273.

324 MIRANDA, P. de. Direito das obrigações: consequências do inadimplemento; exceções de contrato não adimplido, ou adimplido insatisfatoriamente, e de inseguridade; enriquecimento injustificado; estipulação a favor de terceiro; eficácia protectiva de terceiro; mudanças de circunstâncias; compromisso. Ruy Rosado de Aguiar Júnior e Nelson Néry Jr (Atual.). São Paulo: RT, tomo 26, 2012, p. 94. 
"consequência previsível da ação, ${ }^{325}$ de algo que ainda não existe, mas que certamente existirá. ${ }^{326}$ Há quem defenda que os danos futuros são incertos. Os danos certos seriam aqueles precisos. Já os incertos se baseariam em critérios de mensuração. ${ }^{327}$

Catalá define em sua obra outras quatro categorias de danos, que podem ser aproveitados a presente tese pois são plenamente aplicáveis à caracterização dos danos provenientes de derramamentos de óleo no mar. O quadro a seguir sintetiza esta classificação:

Tabela 10 - Categorias de danos ambientais

\begin{tabular}{|l|l|}
\hline \multicolumn{1}{|c|}{$\begin{array}{c}\text { TIPO DE } \\
\text { DANO }\end{array}$} & \multicolumn{1}{c|}{ CARACTERIZAÇÃO } \\
\hline Histórico & $\begin{array}{l}\text { Não foi caracterizado como dano no momento da sua ocorrência, por } \\
\text { estar dentro dos limites de tolerabilidade na época. }\end{array}$ \\
\hline Acumulado & $\begin{array}{l}\text { O dano foi se acumulando durante o tempo ultrapassando os limites } \\
\text { de tolerabilidade, deixando de ser mero impacto. }\end{array}$ \\
\hline $\begin{array}{l}\text { Crônico ou } \\
\text { progressivo }\end{array}$ & Atos sucessivos ou atividades cumuladas resultam em dano grave. \\
\hline $\begin{array}{l}\text { Permanente } \\
\text { ou continuado }\end{array}$ & Um único evento produz efeitos ao longo do tempo. \\
\hline
\end{tabular}

\subsection{Danos restritos ao meio ambiente - ecológicos puros}

\subsubsection{Biodiversidade marinha brasileira}

O Brasil encontra-se entre os países com maiores áreas litorâneas do mundo, detentor de uma Zona Costeira e Marinha com aproximadamente 4,5 milhões de $\mathrm{km}^{2}$ ao longo de 7.400 $\mathrm{km}$ de linha de costa sob sua jurisdição (ou $10.400 \mathrm{~km}$ se consideradas as suas saliências e reentrâncias), sendo chamada de "Amazônia Azul" pela corte Interministerial sobre Recursos do Mar (CIRM) devido a sua grande biodiversidade. Esta ampla área tem contato com vários biomas e abriga diversos ecossistemas, como os manguezais, recifes de corais, dunas, restingas,

${ }^{325}$ ARAÚJO, V. D. de. Generalidade sobre o dano. In: ARAÚJO, V. D. (coord.); HIRONAKA, G. M. F. (orient.) Direito Civil: Responsabilidade Civil. São Paulo: Editora Revista dos Tribunais, v.5, 2008, p. 75.

${ }^{326}$ MIRAGEM, B. N. B. Direito Civil: responsabilidade civil. São Paulo: Saraiva, 5a ed., 2015, p. 160.

${ }^{327}$ ARAÚJO, V. D. de. Generalidade sobre o dano. In: ARAÚJO, V. D. (coord.); HIRONAKA, G. M. F. (orient.) Direito Civil: Responsabilidade Civil. São Paulo: Editora Revista dos Tribunais, v.5, 2008, p. 75.

${ }^{328}$ CATALÁ, L. G. Responsabilidad por Daños al Medio Ambiente. Madrid: Arazandi Editorial, 1998, p.88. 
praias arenosas, costões rochosos, lagoas e estuários; os quais abrigam inúmeras espécies de flora e fauna, sendo muitas delas endêmicas e algumas ameaçadas de extinção. ${ }^{329}$

Esta diversidade biológica não se encontra, contudo, igualmente distribuída ao longo da costa. A abrangência latitudinal e o vasto território implicam variedade climática e geomorfológica, ambos os fatores promotores desta diversidade de espécies e de ecossistemas existentes ao longo do litoral brasileiro. ${ }^{330}$ Além disso, ocorrem fenômenos regionais que definem condições climatológicas e oceanográficas e criam habitats distintos e ricos em biodiversidade, a exemplo dos recifes de corais no litoral da região nordeste e as áreas de ressurgência no litoral sul. ${ }^{331}$

Aspectos locais também são importantes para caracterização biológica dos ambientes costeiros. As praias arenosas e dunas são consideradas sistemas de baixa diversidade, com fauna e flora pouco diversificada devido à escassez de matéria orgânica. As planícies de maré lodosas igualmente apresentam baixa diversidade, com fauna predominantemente formada por invertebrados. Os costões rochosos, são sujeitos a alto dinamismo e intempéries (energia das ondas e ventos), sendo habitados apenas por aquelas espécies adaptadas e resistentes a estas condições. ${ }^{332}$ Já os manguezais abrigam elevada diversidade estrutural e funcional, oferecendo inúmeros serviços ecossistêmicos às espécies dos ambientes vizinhos. ${ }^{333}$, sendo que muitas se utilizam temporariamente dos manguezais em certas fases da vida. Finalmente, os recifes de corais são ambientes de alta diversidade de espécies, comparáveis a ambientes ricos como as florestas tropicais úmidas, e reconhecidos como um dos ambientes mais diversos do planeta. ${ }^{334}$ Ainda podem ser citados como ambientes costeiros os estuários, deltas e baías. ${ }^{335}$

${ }^{329}$ BRASIL. Ministério do Meio Ambiente, Secretaria de Biodiversidade e Florestas. Áreas Prioritárias para Conservação, Uso Sustentável e Repartição de Benefícios da Biodiversidade Brasileira: Atualização - Portaria MMA n 9, de 23 de janeiro de 2007. Brasília: MMA, 2007, p. 101.

${ }^{330}$ BRASIL. Ministério do Meio Ambiente. Gerência de Biodiversidade Aquática e Recursos Pesqueiros. Panorama da conservação dos ecossistemas costeiros e marinhos no Brasil. Brasília: MMA/SBF/GBA, 2010, p. 14.

331 AMARAL, A. C. Z; JABLONSKI, S. Conservação da biodiversidade marinha e costeira no Brasil. Megadiversidade, v.1, n.1, jul. 2005, p. 44.

332 CEMBRA. O Brasil e o mar no século XXI: Relatório aos tomadores de decisão do País. FERNANDES, L. P. da C. (Coord.). Niteroi: BHMN, 2a ed., 2012, p. 256.

333 BRASIL. Ministério do Meio Ambiente. Gerência de Biodiversidade Aquática e Recursos Pesqueiros. Panorama da conservação dos ecossistemas costeiros e marinhos no Brasil. Brasília: MMA/SBF/GBA, 2010, p.14.

${ }^{334}$ REAKA-KUDLA, M. L. The global biodiversity of coral reefs: a comparison with rain forests. In: REAKAKUDLA, M. L.; WILSON, E. D.; WILSON, E. O. (Ed.). Biodiversity II: understanding and protecting our biological resources. Washington: J. H. Press, 1997, p.83-108.

${ }^{335}$ CEMBRA. O Brasil e o mar no século XXI: Relatório aos tomadores de decisão do País. FERNANDES, L. P. da C. (Coord.). Niteroi: BHMN, $2^{\mathrm{a}}$ ed., 2012, p.256. 
Apesar de reconhecidamente ser uma das regiões mais biodiversas do planeta, com importância ecológica e econômica para o país (abrigando uma população de aproximadamente 36 milhões de habitantes ${ }^{336}$ ), a biodiversidade da costa brasileira é ainda relativamente pouco conhecida.

Segundo Amaral e Jablonski, até 2005, tinham sido registradas pouco mais de 1.300 espécies de invertebrados bentônicos na costa sudeste do Brasil, com elevado grau de endemismo. Contudo, carecem estudos sobre estes animais em outras regiões e ambientes, sendo o número de espécies registradas ainda muito inferior ao conhecido em outras regiões marinhas do mundo. O conhecimento da fauna de invertebrados pelagial, composta principalmente por plânctons e crustáceos e moluscos pelágicos, é também muito escasso no litoral brasileiro. No caso dos vertebrados, segundo os autores, o grupo mais estudado abrange os peixes, que somam estimativas de aproximadamente 750 espécies marinhas ${ }^{337}$.

Ainda, de acordo com dados de 2010 do Ministério do Meio Ambiente, não sendo atualizados até dezembro de 2018, o litoral brasileiro abriga, ainda, 54 espécies de mamíferos, sendo 53 espécies de cetáceos e uma de sirênio (peixe-boi). Em relação às aves, foram registradas mais de 100 espécies associadas aos sistemas costeiros e marinhos brasileiros. Destas, algumas são residentes, outras são migratórias oriundas dos hemisférios norte e de outras de regiões mais ao sul. Outro grupo bem estudado e conhecido é constituído pelos quelônios. No Brasil, ocorrem 5 espécies de tartarugas marinhas (das 7 conhecidas no mundo). Além dos grupos acima citados, destacam-se também grande diversidade de corais e plantas presentes ao longo de toda a costa. ${ }^{338}$

Toda esta biodiversidade, aqui resumidamente descrita, está vulnerável a eventos de derramamentos de óleo, sendo sensível, em diferentes níveis, aos seus efeitos. O conhecimento sobre os tipos e níveis de danos causados pelo óleo sobre estes organismos e ecossistemas é de extrema importância, sendo fundamento inicial para se determinar a forma de reparação mais adequada a cada caso.

${ }^{336}$ CEMBRA. O Brasil e o mar no século XXI: Relatório aos tomadores de decisão do País. FERNANDES, L. P. da C. (Coord.). Niteroi: BHMN, $2^{\mathrm{a}}$ ed., 2012, p. 279.

337 AMARAL, A. C. Z.; JABLONSKI, S. Conservação da biodiversidade marinha e costeira no Brasil. Megadiversidade, v.1, n.1, jul. 2005, p. 47.

338 BRASIL. Ministério do Meio Ambiente. Gerência de Biodiversidade Aquática e Recursos Pesqueiros. Panorama da conservação dos ecossistemas costeiros e marinhos no Brasil. Brasília: MMA/SBF/GBA, 2010, p. 23. 
Assim como foram caracterizados e diferenciados os danos jurídicos, devem ser primeiramente conhecidos, e posteriormente caracterizados e diferenciados os danos ecológicos puros.

\subsubsection{Classificação dos danos provocados por óleos em organismos marinhos}

O óleo possui uma série de características físicas e químicas que determinam o seu comportamento no ambiente, assim como os seus possíveis efeitos aos ecossistemas e seres vivos. $^{339}$

O óleo pode sofrer intemperismo ao entrar em contato com a água, apresentando cores e aspectos diferentes dependendo do seu tipo, podendo se tornar manchas escuras, coloridas "iridescentes", ou prateadas e brilhantes. Os Óleos leves, de baixa densidade, a exemplo da gasolina e nafta, apresentam maior toxicidade à vida aquática, já que se degradam naturalmente e rapidamente, por ação do sol, dos ventos e das correntes marinhas de superfície, penetrando na coluna d'água. Já os óleos pesados, como o óleo combustível marítimo ou "bunker", apresentam densidades mais altas, sendo mais persistentes, levando maior tempo para sofrer ações do intemperismo. Portanto, seus efeitos serão de característica mais física do que química, causando recobrimento de fauna e flora, levando a sufocamento, por exemplo. ${ }^{340}$

Já os ecossistemas marinhos são estruturados de formas complexas e um derramamento de óleo terá um impacto diferente em cada um deles. Apesar das particularidades de cada ecossistema, os estudos sobre os derramamentos pretéritos permitem a identificação de alguns fatores chaves que influenciam na abrangência dos danos causados pelo óleo nos ecossistemas marinhos e costeiros. Um dos principais fatores é a composição química e a quantidade do óleo ao qual os organismos estão expostos. Por outro lado, as características ecológicas e biológicas de certas espécies podem as tornar mais propensas a efeitos mais danosos ao petróleo do que outras. ${ }^{341}$

339 LOPES, C. F.; Milanelli, J. C. C.; POFFO, I. R. F. Ambientes costeiros contaminados por óleo: procedimentos de limpeza. Manual de Orientação. São Paulo: Secretaria de Estado do Meio Ambiente, 2007, p.13. ${ }^{340}$ SÃO PAULO (Estado). Companhia Ambiental do Estado de São Paulo (CETESB). Manchas Órfãs. Disponível em: <https://cetesb.sp.gov.br/emergencias-quimicas/tipos-de-acidentes/vazamentos-de-oleo/manchas-orfas/>. Acesso em: 10.04.2018.

${ }^{341}$ CHANG, S. E. et. al. Consequences of oil spills: a review and framework for informing planning. Ecology and Society, v.2, n.19, article 26, 2014, p.4. 
De modo geral, os danos constatados em animais marinhos podem ser divididos em Diretos e Indiretos. São exemplos de Impactos Diretos (primários), segundo proposta de modelo de avaliação elaborado pelo Ibape: ${ }^{342}$

Sufocamento: Quando animais com coberturas, pêlos ou penas, e mesmovegetais, ficam cobertos por óleo impossibilitando-os de realizar as trocas necessárias com o meio ambiente, como respiração, fotossíntese, transpiração, etc.

Exposição tóxica: os efeitos tóxicos diretos podem afetar os animais através da ingestão, absorção e inalação direta dos hidrocarbonetos. A mortalidade das plantas pode ocorrer pelo contato ou exposição direta com o óleo ou pela absorção do óleo presente nos sedimentos contaminados, através das raízes. A toxicidade aguda (exposição em curto período de tempo, mas em elevadas concentrações) e a toxicidade crônica (exposição longa, e com baixas concentrações) geram respostas diferentes nos organismos e na comunidade como um todo.

Estes dois exemplos resumem os principais impactos diretos causados pelo óleo aos organismos marinhos, lembrando que eles não são excludentes, ou seja, podem ocorrer ao mesmo tempo sobre os seres vivos afetados.

Já o Impacto Indireto (secundário) é aquele ocasionado pela perda do habitat ou fonte de alimentação. Como exemplo, temos a seguinte situação: quando o vazamento de óleo causa a mortalidade das plantas, ou animais de níveis tróficos inferiores e afetando indiretamente animais e plantas que dependem dos mesmos (direta ou indiretamente) para obtenção de alimentação ou para o seu habitat. ${ }^{343}$ Ressalta-se, portanto, que, observando-se os processos ecológicos que envolvem a teia alimentar do ecossistema marinho, estes impactos indiretos podem ter efeitos estendidos e prolongados para escalas regionais, ou até globais.

\subsubsection{Danos Biológicos}

Algumas características biológicas tornam certas espécies mais propensas a sofrerem os danos de vazamentos de óleo do que outras. A avifauna, especialmente a costeira, é a comunidade biológica mais vulnerável aos derramamentos de óleo. ${ }^{344}$ Consequentemente, representam um dos recursos biológicos que atraem a maior preocupação da sociedade. Os estudos realizados para levantamento do número de aves marinhas que foram vítimas fatais dos efeitos do contato ao óleo são considerados altamente especulativos, visto que tais estimativas

\footnotetext{
342 IBAPE. Sistema de Identificação do Dano Ambiental Decorrente de Vazamento de Petróleo: uma proposta de modelo de avaliação. XV Congresso Brasileiro de Engenharia de Avaliações e Perícia, Trabalho de Perícia, 2009 , p.8.

${ }^{343}$ IBAPE. Sistema de Identificação do Dano Ambiental Decorrente de Vazamento de Petróleo: uma proposta de modelo de avaliação. XV Congresso Brasileiro de Engenharia de Avaliações e Perícia, Trabalho de Perícia, 2009, p. 8 .

${ }^{344}$ LOPES, C. F.; MILANELli, J. C. C.; POFFO, I. R. F. Ambientes costeiros contaminados por óleo: procedimentos de limpeza. Manual de Orientação. São Paulo: Secretaria de Estado do Meio Ambiente, 2007, p.13.
} 
normalmente são obtidas das contagens de número de carcaças encontradas na costa, o que representa um dado pouco confiável, visto que dependem da área de abrangência do vazamento e da acessibilidade aos locais atingidos para realização dos levantamentos. Além disso, há preocupações sobre a não contabilização nestes resultados dos números de aves que acabam falecendo em locais distantes da costa. ${ }^{345}$

Estudos comparativos de casos corroboram a característica especulativa das estimativas de aves afetadas, indicando que há pouca relação entre o tamanho de um derramamento de óleo e o número de vítimas de aves marinhas. Por exemplo, mais de 35.000 carcaças de aves marinhas foram recuperadas depois que o Exxon Valdez derramou 35.000 toneladas de óleo ao mar. Por outro lado, apenas 1.500 aves mortas foram contadas após o acidente de Braer, embora o derramamento de Braer fosse quase duas vezes e meia maior do que o Exxon Valdez. ${ }^{346}$ Assim, mais uma vez ressalta-se a importância de uma avaliação de dano sob varias perspectivas. Não basta olhar apenas para o individuo possivelmente afetado, sem observar sua relação com o ambiente do entorno.

A alta vulnerabilidade das aves em relação aos demais organismos que vivem em áreas marinhas (áreas de mar aberto) é atribuída a facilidade com que estes animais sofrem danos por manchas de óleo flutuantes. Embora o óleo ingerido possa ser letal, a causa mais comum de morte da avifauna marinha é o afogamento, a fome, e a perda de calor do corpo após a plumagem ser coberta pelo óleo. Aves costeiras, notavelmente pernaltas, também estão em risco, embora sejam menos propensas a se tornarem letais do que as espécies de hábito marinho que vivem e se alimentam em mar aberto. ${ }^{347}$ Outros estudos sobre a avaliação dos impactos de vazamentos de óleo nas aves marinhas relatam que a exposição ao óleo pode ter efeitos prejudiciais sobre a saúde e o comportamento das aves e, quando consumido, pode causar danos aos pulmões, fígado e rim. ${ }^{348}$ Estas pesquisas também reforçam a conclusão de que um dos

\footnotetext{
${ }^{345}$ KINGSTON, P. F. Long-term Environmental Impact of Oil Spills, Spill Science \& Technology Bulletin, v.7, n. 1-2, 2002, p. 56.

${ }^{346}$ KINGSTON, P. F. Long-term Environmental Impact of Oil Spills, Spill Science \& Technology Bulletin, v.7, n. 1-2, 2002, p. 56.

${ }^{347}$ DICKS, B.. The environmental impact of marine oil spills- effects, recovery and compensation. International seminar on tanker safety, pollution prevention, spill response and compensation, Rio de Janeiro, Brasil, 6 nov., 1998, p.4

348 ADZIGBLI L.; YUEWEN D. Assessing the Impact of Oil Spills on Marine Organisms. Journal of Oceanography and Marine Research6: 179. 2018, p. 3.
} 
impactos comuns do petróleo nas aves é a degradação de suas penas, com alteração da sua microestrutura e perda de funcionalidade. ${ }^{349}$

Em comparação com as aves marinhas, os mamíferos marinhos têm sido menos documentados como afetados durante incidentes de derramamento de óleo, e consequentemente, os efeitos diretos e indiretos sobre essas espécies são menos estudados. ${ }^{350}$ Estes animais apresentam menor vulnerabilidade, pois, devido à sua capacidade de mobilidade, conseguem migrar para áreas vizinhas livres de óleo. ${ }^{351}$ No entanto, o risco de impactos potenciais é significativo, visto que as espécies como as baleias, golfinhos e focas acessam frequentemente a interface entre água e atmosfera, onde o óleo é encontrado. ${ }^{352}$ Em relação aos mamíferos marinhos que se alimentam e vivem na costa, estes estão mais propensos a serem atingidos pelo petróleo. ${ }^{353}$ As espécies costeiras de distribuição restrita a ambientes específicos, como é o caso, aqui no Brasil, dos peixes-boi, são as mais vulneráveis aos vazamentos de óleo.

Ao contrário dos pinípedes, no caso dos cetáceos o petróleo adere bem à superfície de sua pele, devido à falta de pelos e à frequente descamação de células. Também se espera que o óleo não penetre a pele dos cetáceos, pois estes animais possuem uma epiderme espessa. No entanto, cetáceos podem ser expostos ao óleo e compostos através do contato direto com os olhos, boca (ingestão) e vias aéreas (inalação), potencialmente levando a inflamação e congestão pulmonar. ${ }^{354}$

Os principais efeitos nocivos estão ligados à ingestão de óleo ou à inalação de vapores, quando os animais acessam a superfície para respirar. ${ }^{355}$ Em geral, a maioria dos pinípedes e

${ }^{349}$ O'HARA P. D.; MORANDIN L. A. Effects of sheens associated with offshore oil and gas development on the feather microstructure of pelagic seabirds. Mar Pollut Bull, v.60, n.5, p. 672-678, 2010.

${ }^{350}$ ZICCARDI, M. H., WILKIN, S. M.; ROWLES, T. K.; JOHNSON, J. Pinniped and Cetacean Oil Spill Response Guidelines. NOAA Technical Memorandum NMFS (OPR-52). Washington: U.S. Department of Commerce, v.52, 2015, p.4.

${ }^{351}$ DICKS, B. The environmental impact of marine oil spills- effects, recovery and compensation. International seminar on tanker safety, pollution prevention, spill response and compensation, Rio de Janeiro, Brasil, 6 nov., 1998, p. 4

${ }^{352}$ ZICCARDI, M. H., WILKIN, S. M.; ROWLES, T. K.; JOHNSON, J. Pinniped and Cetacean Oil Spill Response Guidelines. NOAA Technical Memorandum NMFS (OPR-52). Washington: U.S. Department of Commerce, v.52, 2015, p.4.

353 DICKS, B.. The environmental impact of marine oil spills- effects, recovery and compensation. International seminar on tanker safety, pollution prevention, spill response and compensation, Rio de Janeiro, Brasil, 6 nov., 1998 , p. 4.

${ }^{354}$ AICHINGER DIAS, L.; LITZ, J.; GARRISON, L.; MARTINEZ, A.; BARRY, K.; SPEAKMAN, T.. Exposure of cetaceans to petroleum products following the Deepwater Horizon oil spill in the Gulf of Mexico. Endang Species Res. V.33, p. 120, 2017. Disponível em: <https://doi.org/10.3354/esr00770> Acesso em: 08.08.2018.

355 IMO. Manual on Chemical Pollution - Section 1: Problem Assessment and Response Arrangements. London: International Maritime Organization. London, 1987. 
cetáceos dependem de camadas espessas de gordura para manter a temperatura corporal normal em seus ambientes aquáticos, portanto, apresentam baixo risco para os efeitos térmicos agudos do óleo externo, quando comparado às aves marinhas. No entanto, mamíferos marinhos que dependem de uma densa camada de pelos para este controle térmico, como as lontras marinhas e focas, após o contato com o produto perdem esta capacidade de regulação da temperatura corporal, pois a aderência do óleo aos pelos prejudica o seu isolamento térmico. Isto pode levar o animal a hipotermia e a problemas fisiológicos associados. Outros efeitos podem ser a redução da sua flutuabilidade, movimentação, natação e, consequentemente, prejuízos a sua capacidade de busca por alimentos. Por fim, o contato direto da pele com derivados de petróleo também pode resultar em irritação, queimação e/ou ulceração, especialmente em tecidos sensíveis como os olhos e membranas mucosas e também pode interferir na audição se acumulado nos canais auditivos. $^{356}$

Os répteis marinhos, sendo de principal interesse para este estudo as tartarugas marinhas, também se encontram susceptíveis a contaminação em áreas onde a superfície estiver contaminada por óleo, visto que passam tempo nela para respirar, descansar, se aquecer e se alimentar. ${ }^{357}$ As potenciais formas de contaminação ocorrem, portanto, por contato dérmico, inalação e ingestão do óleo. As tartarugas podem ingerir óleo pela boca ou ser expostas através de outros orifícios (por exemplo, narinas) quando o óleo está flutuando e misturado na água. Tartarugas também pode consumir o óleo em presas contaminadas ou bolas de piche confundidas como presas. A inalação ou aspiração de óleo ou seus compostos também é uma provável rota de exposição. ${ }^{358}$

Outro grupo de vertebrados vulneráveis aos vazamentos de óleo, que além da relevância ecológica se destaca pela sua importância econômica, são os peixes. Derramamentos de óleo podem afetá-los de várias maneiras, incluindo o aumento da mortalidade, danos subletais a ovos e larvas de peixes, deformidades morfológicas e aumento da vulnerabilidade a predadores. Também se destacam impactos como a degradação do habitat, incrustação de

${ }^{356}$ ZICCARDI, M. H., WILKIN, S. M.; ROWLES, T. K.; JOHNSON, J. Pinniped and Cetacean Oil Spill Response Guidelines. NOAA Technical Memorandum NMFS (OPR-52). Washington: U.S. Department of Commerce, v.52, 2015, p.4.

357 WALLACE, B. P. et al. Estimating sea turtle exposures to Deepwater Horizon oil. Endang Species Res, v.33, p.52. Disponível em: $<$ https://doi.org/10.3354/esr00728>. Acesso em: 08.08.2018.

${ }^{358}$ MITCHELMORE, C. L.; BISHOP, C. A.; COLLIER, T. K. Toxicological estimation of mortality of oceanic sea turtles oiled during the Deepwater Horizon oil spill. Endang Species Res, v.33, p. 39-50, jan. 2017 , p.40.

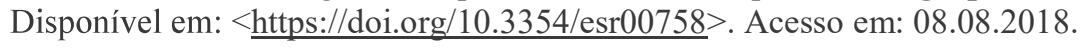


estruturas branquiais e prejuízos na sua reprodução, crescimento, desenvolvimento, alimentação e respiração. ${ }^{359}$

Ainda deve-se ressaltara sensibilidade que as populações de peixes apresentam, pois, diversas espécies, em parte do seu ciclo de vida, compõem a comunidade planctônica. As ovas e larvas de peixes são tipicamente vulneráveis aos compostos de óleo tóxico devido ao seu pequeno tamanho, membranas mal desenvolvidas e sistemas de desintoxicação, bem como sua posição na coluna de água. ${ }^{360}$ Assim, impactos sobre os peixes nas suas formas de vida preliminares levam um tempo maior para serem superados. Estudos mostram que o estoque de peixes foi apresentam risco grandes derramamentos de óleo, principalmente pela alta susceptibilidade das suas fases iniciais, isto é, ovos e larvas. ${ }^{361}$

Tão importantes quanto a avifauna, a mastofauna e a herpetofauna marinha são os organismos planctônicos. Este grupo representa as primeiras espécies que sofrem os danos causados pelo óleo, os plânctons e fitoplânctons, as quais não possuem poder de locomoção própria e por isso ficaram vulneráveis a contaminação. Estes seres aquáticos microscópicos são a base da cadeia alimentar, sendo responsáveis por todo o sustento das comunidades oceânicas e ainda é o maior produtor de oxigênio mundial. Por ocorrerem predominantemente nas camadas mais superficiais do oceano, se colocam em alto risco de exposição e contato ao produto. ${ }^{362}$

As zonas pelágicas dos mares e oceanos suportam uma grande quantidade de organismos planctônicos, sendo eles bactérias, plantas (fitoplâncton) e animais (zooplâncton). Este último grupo, conforme já mencionado, inclui os ovos e larvas de peixes e invertebrados, incluindo aqueles que eventualmente se estabelecem no leito do mar ou litoral. O plâncton naturalmente sofre níveis extremamente altos de mortalidade, principalmente através da predação. Porém, são organismos extremamente sensíveis a mudanças ambientais e aspectos sazonais, apresentando uma alta taxa reprodutiva, a qual é potencializada quando encontra condições favoráveis. Tal superprodução típica destes organismos pode fornecer uma

\footnotetext{
${ }^{359}$ ADZIGBLI, L.; YUEWEN, D.. Assessing the Impact of Oil Spills on Marine Organisms. J Oceanogr Mar Res 6: 179, 2018, p. 1 .

${ }^{360}$ LANGANGEN, $\varnothing$. et al. The effects of oil spills on marine fish: Implications of spatial variation in natural mortality. Marine pollution bulletin, jun. 2017, p.1. Disponível em: $<$ https://doi.org/10.1016/j.marpolbul.2017.03.037>. Acesso em: 08.08.2018.

361 ADZIGBLI, L.; YUEWEN, D.. Assessing the Impact of Oil Spills on Marine Organisms. J Oceanogr Mar Res 6: 179, 2018, p. 12.

${ }^{362}$ LOPES, C. F.; MILANELli, J. C. C.; POFFO, I. R. F. Ambientes costeiros contaminados por óleo: procedimentos de limpeza. Manual de Orientação. São Paulo: Secretaria de Estado do Meio Ambiente, 2007, p.13.
} 
oportunidade para recrutamento de áreas adjacentes não afetadas pelo derramamento, suficiente para compensar perdas de ovos e estágios larvais. ${ }^{363}$

Os principais danos do óleo à comunidade planctônica se dão no contato direto com o produto, ou pela sua ingestão (no caso do zooplâncton), causando a morte por toxicidade aguda. Indiretamente, destaca-se o recobrimento da superfície impedindo a penetração da luz, ocasionando a morte dos organismos fotossintetizantes. ${ }^{364}$

Lembrando que, além das espécies citadas acima, também são importantes organismos marinhos os crustáceos e moluscos, com algumas espécies compondo a fauna planctônica e outras a fauna pelágica e costeira, e os recifes de corais, abrigando grande diversidade de seres vivos invertebrados e representando habitat para diversas espécies.

Não se pode deixar de pontuar que, assim como os humanos, conforme apresentado no item 5.5.2.1, vários dos organismos citados sofrem principalmente os efeitos tóxicos do óleo. A toxicidade é a medida do potencial tóxico de uma substância e pode ser classificada de acordo com o seu tempo de resposta (aguda, subcrônica ou crônica) e sua severidade (leve, moderada ou severa). ${ }^{365}$ Inúmeros estudos relatam os efeitos da toxicidade do óleo em organismos aquáticos, demonstrando não somente a possibilidade de mortalidade destes seres como o desenvolvimento de alterações genéticas, comportamentais, reprodutivas, imunológicas, entre outras anomalias.

O quadro a seguir apresenta uma síntese dos organismos afetados pelos derramamentos de óleo e os principais danos verificados.

\footnotetext{
${ }^{363}$ ITOPF. Technical Information Paper 13 (TIP 13): Effects of Oil Pollution on the Marine Environment. London: International Tanker Owners Pollution Federation, v. 13, 2014, 19 mai. 2014, p. 3.

${ }^{364}$ LOPES, C. F.; MILANELLI, J. C. C.; POFFO, I. R. F. Ambientes costeiros contaminados por óleo: procedimentos de limpeza. Manual de Orientação. São Paulo: Secretaria de Estado do Meio Ambiente, 2007, p.13. ${ }^{365}$ DUX, J. P., STALZER, R. F.. Managing Safety in the Chemical Laboratory. Van Nostrand Reinhold, New York, 1988.
} 
Tabela 11 - Organismos afetados e danos biológicos ligados a derramamento de óleo

\begin{tabular}{|c|c|}
\hline $\begin{array}{l}\text { ORGANISMOS } \\
\text { AFETADOS }\end{array}$ & $\begin{array}{l}\text { DANOS BIOLÓGICOS POR SENSIBILIDADE AO ÓLEO } \\
\text { DERRAMADO }\end{array}$ \\
\hline Plâncton & $\begin{array}{l}\text { Impacto direto devido a exposição tóxica pelo contato ou ingestão } \\
\text { do óleo ou indireto por meio da redução da incidência da luz e } \\
\text { eliminação da sua fonte de alimentação (fitoplâncton). }\end{array}$ \\
\hline Peixes & $\begin{array}{l}\text { Contaminação por exposição tóxica pela ingestão do óleo. Efeito } \\
\text { narcotizante das frações hidrossolúveis do óleo, tornando os peixes } \\
\text { mais susceptíveis a predação ou prejudicando a busca por alimentos, } \\
\text { causando assim um efeito negativo indireto. }\end{array}$ \\
\hline \multirow{3}{*}{$\begin{array}{l}\text { Répteis } \\
\text { Marinhos }\end{array}$} & $\begin{array}{l}\text { Danos causados pela ingestão do óleo ou inalação dos seus vapores, } \\
\text { causando assim a exposição tóxica. }\end{array}$ \\
\hline & $\begin{array}{l}\text { Danos biológicos pela contaminação dos locais de desovas, } \\
\text { ocasionando ingestão de óleo por tartarugas adultas, contato dérmico } \\
\text { nas mucosas nasais e oculares. }\end{array}$ \\
\hline & $\begin{array}{l}\text { Danos biológicos causados aos filhotes após o contato com o óleo } \\
\text { derramado durante o seu processo de desova e percurso até o mar. }\end{array}$ \\
\hline \multirow{4}{*}{ Aves Marinhas } & $\begin{array}{l}\text { Óleo nas penas: dificuldade de locomoção, de alimentação e perda } \\
\text { de isolamento térmico, diminuindo a temperatura corporal. }\end{array}$ \\
\hline & $\begin{array}{l}\text { Aumento de gasto energético para manutenção da temperatura } \\
\text { corporal, não repondo adequadamente os nutrientes gastos. }\end{array}$ \\
\hline & $\begin{array}{l}\text { Bioacumulação por ingestão de alimentos contaminados ou de óleo } \\
\text { por limpeza de penas com a boca. }\end{array}$ \\
\hline & Redução de postura e dificuldade de incubação de ovos. \\
\hline
\end{tabular}


(conclusão)

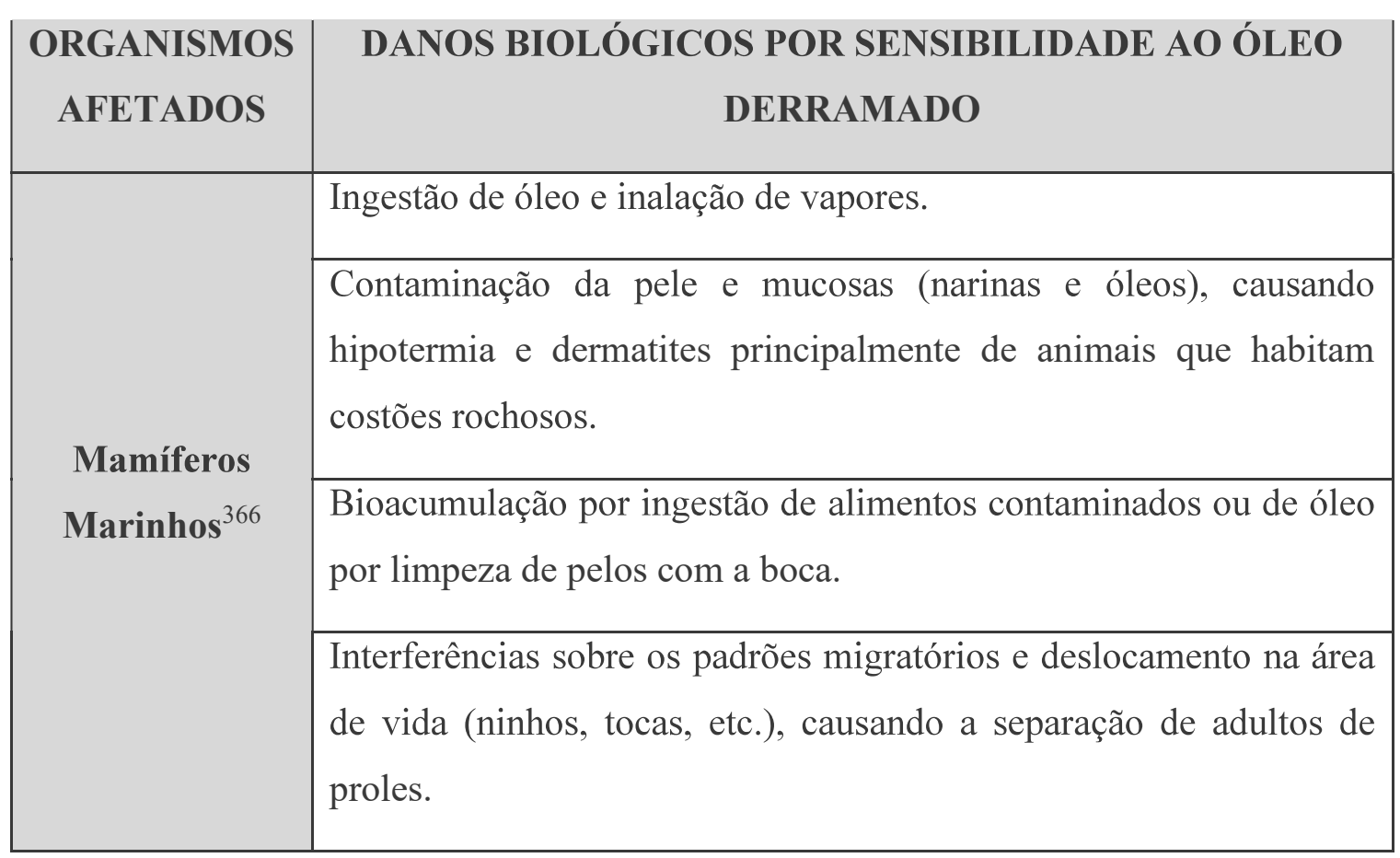

Fonte: Adaptado de LOPES, C. F.; MILANELli, J. C. C.; POFFO, I. R. F.. Ambientes costeiros contaminados por óleo: procedimentos de limpeza - manual de orientação. São Paulo: Secretaria de Estado do Meio Ambiente, 2007.

\subsubsection{Danos à cadeia alimentar}

As cadeias alimentares são sequências interligadas em forma de rede que indicam a transferência de energia alimentar entre os seres vivos, os quais consomem e/ou são consumidos, a depender da sua posição nesta rede. ${ }^{367}$ É a representação de um processo ecológico que forma as bases para a vida em equilíbrio de todas as espécies de seres vivos, sendo assim, um conceito de extrema importância para avaliação dos danos provocados pelo vazamento de óleo nos ambientes marinhos.

Basicamente, uma cadeia alimentar é dividida em três níveis tróficos, os produtores primários (organismos fotossintetizantes), consumidores primários (herbívoros) e consumidores secundários (carnívoros). No ambiente marinho, os produtores primários (que formam a base da cadeia alimentar e sustentam todo o ecossistema) são representados pela

366 SHORT, M. K. J.. Guanabara Bay Oil Spill 2000, Brazil - Cetacean Response. International Oil Spill Conference, Vancouver, 2003, n.1, p.1035-1036.

${ }^{367}$ ODUM, E. P. Ecologia. Rio de Janeiro: Guanabara, 1983, p.77. 
comunidade planctônica. Qualquer dano ou variação na sua população afeta diretamente os animais que se alimentam destes organismos, como, por exemplo, os peixes e baleias.

Estudos mostram que as interações tróficas da cadeia alimentar são um importante mecanismo para a perpetuação de impactos indiretos em efeito cascata. Os danos biológicos de derramamentos de óleo em espécies marinhas podem levar a efeitos indiretos que afetam outros componentes da cadeia alimentar. O papel de uma espécie nas respostas de uma teia alimentar a um fator de perturbação dependerá de dois aspectos: (i) a sua sensibilidade ao estressor e (ii) a sua importância para a alimentação dentro da estrutura e dinâmica da cadeia alimentar. Uma espécie é importante quando está altamente conectada com os demais membros da cadeia ou quando é a única representante do seu nível trófico. Por exemplo, se um táxon é sensível e importante na teia alimentar, então os efeitos negativos sobre este táxon (redução da sua abundância) podem ter consequências em cascata em toda a cadeia alimentar. Estes são os taxa (como plural de táxon) de maior preocupação no caso de vazamentos de óleo, pois têm o potencial para alterar ou desestabilizar toda teia alimentar. Por outro lado, algumas espécieschaves apresentam alto poder de resiliência a processos de perturbação (como é o caso dos plânctons) e assim podem proteger o ecossistema de danos maiores. Já as espécies que desempenham papel de menor importância na cadeia alimentar (visto que dividem sua função na rede com outras espécies) causam efeitos indiretos menos expressivos no ecossistema. ${ }^{368}$

Segundo estudos de avaliação das respostas do ecossistema em longo prazo, realizados após o derramamento de óleo do navio Exxon Valdez, o exemplo mais convincente do efeito de cascata trófica na ecologia marinha, com consequências radicais na comunidade, vem do ecossistema de algas Kelps do Golfo do Alasca. Antes do acidente, a população de lontras marinhas era responsável pelo controle de ouriços-do-mar, os quais se alimentavam dos bancos de alga kelps da região. Estes bancos de algas servem como habitat para uma diversidade de organismos marinhos (peixes e invertebrados). Com o evento do derramamento de óleo houve danos expressivos sobre a população de lontras marinhas da região ocasionando a redução do consumo de ouriços por estes animais e, consequentemente, no aumento da sua população. Por fim, os ouriços livres do controle exercido pelo seu principal predador, tiveram a sua população

${ }^{368}$ MCCANN, M. et al. Key taxa in food web responses to stressors: The Deepwater Horizon oil spill. Frontiers in Ecology and the Environment, v.15, n.3, p. 142-149, 2017. 
aumentada e consumiram em excesso a comunidade de algas, alterando significativamente as condições ambientais do ecossistema local. ${ }^{369}$

Outro exemplo de danos à cadeia que podem se perpetuar ao longo dos níveis tróficos (inclusive com potencial de alcançar a população humana) é a bioacumulação. É classificado como um efeito subletal. Os hidrocarbonetos de petróleo se bioacumulam nos tecidos dos organismos marinhos, principalmente nos organismos filtradores, como os moluscos bivalves. É sabido que animais como os mexilhões irão concentrar contaminantes acima dos níveis ambientais através de seus mecanismos de alimentação por filtragem, porém, colocados em condições isentas de hidrocarbonetos, os contaminantes são rapidamente depurados. Por exemplo, mexilhões colocados em água contaminada com óleo bruto disperso irão rapidamente acumular o óleo em seus tecidos bioconcentrando-o a níveis acima do ambiente.

No entanto, quando o animal é devolvido à água limpa, a depuração também é rápida, os níveis teciduais caem para menos de $10 \%$ do valor máximo em oito dias, e quase de volta a situação normal em 16 dias. Este comportamento da bioacumulação nos seres marinhos é de extrema importância para avaliação dos impactos sobre a cadeia alimentar. O contaminante, com potencial efeito tóxico, é transferido dá água para um bivalve e dele para outro organismo de nível trófico superior, como os peixes, tartarugas, golfinhos, aves, e assim por diante. ${ }^{370}$ Dessa maneira, podem atingir a população humana através da atividade da pesca, visto que grande parte da população mundial se alimentam dos peixes e outros organismos provenientes do ambiente marinho, inclusive do próprio mexilhão. Componentes do plâncton também podem bioacumular estes contaminantes, por meio da ingestão de pequenas partículas de óleo e assim transferi-los aos seus predadores até os níveis tróficos superiores. ${ }^{371}$

\subsubsection{Danos aos Ecossistemas: ambientes afetados}

Conforme já apresentado no presente trabalho, a costa brasileira é composta por diversos ecossistemas, a exemplo das praias, manguezais, dunas, costões rochosos e restingas, dentre outros, que se autorregulam, desenvolvendo um equilíbrio amplo e recíproco.

369 PETERSON C. H. et al. Long-term ecosystem response to the Exxon Valdez oil spill. Science, v.302, dez. 2003, p.2085.

${ }^{370}$ KINGSTON, P. F. Long-term Environmental Impact of Oil Spills, Spill Science \& Technology Bulletin, v.7, n. 1-2, 2002, p., p. 58-59.

371 LOPES, C. F.; MILANELLI, J. C. C.; POFFO, I. R. F. Ambientes costeiros contaminados por óleo: procedimentos de limpeza. Manual de Orientação. São Paulo: Secretaria de Estado do Meio Ambiente, 2007, p.13. 
A poluição por petróleo e derivados nos ambientes marinho e estuarino pode vir a atingir todos os ecossistemas, mesmo que de forma indireta, ou a longo prazo, uma vez que uma tonelada de petróleo pode se espalhar sobre a superfície de $112 \mathrm{~km}^{2}$ de oceano e os hidrocarbonetos podem persistir no meio por até uma década, dependendo do volume derramado, das características do produto e da sensibilidade dos ecossistemas atingidos, entre outros fatores. ${ }^{372}$ Assim, mesmo que os impactos visuais de um grande acidente tenham ficado restritos a apenas um pequeno espaço no oceano, ou a uma praia, os efeitos indiretos podem ser percebidos em locais distantes dos da origem do incidente.

Como também já explicado nos itens anteriores, os organismos marinhos e costeiros sofrem duplamente os efeitos do óleo, primeiramente pelo efeito físico resultante do recobrimento e, posteriormente, pelo efeito químico, associado à toxicidade dos compostos presentes. Todos os danos ambientais observados serão resultantes de um e/ou de outro efeito. É importante ressaltar que os efeitos não são excludentes e podem ocorrer simultaneamente em um vazamento de óleo. A diferença está centrada na combinação entre densidade e toxicidade do óleo derramado e de sua variação com o tempo. Nos óleos de alta densidade, o efeito físico de recobrimento é predominante, enquanto que nos óleos de baixa densidade o efeito químico é o mais representativo. ${ }^{373}$

O óleo, mesmo quando o derramamento ocorre em alto mar, inicia os seus efeitos nocivos contaminando a própria água e as formas de vida que lá se desenvolvem. Ademais, a toxicidade principalmente dos hidrocarbonetos causa efeitos químicos, que indiretamente, interferem na fotossíntese, respiração e ciclagem de minerais. Os efeitos físicos são evidenciados, principalmente, pela cobertura de superfícies animais e vegetais, resultando em asfixia.

Ao chegar aos manguezais, ambientes extremamente sensíveis, sendo considerados verdadeiros berçários e regiões de reprodução, o óleo causa a redução do habitat de muitas espécies, implicando em maior competição pelo alimento e predação. A recuperação deste ecossistema é extremamente dificultosa, conforme evidenciado no caso do acidente ocorrido na Baía de Guanabara, oportunidade em que 1,3 milhões de litros de óleo foram derramados.

${ }^{372}$ SCHAEFFER-NOVELLI, Y. Vulnerabilidade do litoral norte do Estado de São Paulo a vazamentos de petróleo e derivados. II Simpósio sobre Ecossistemas da Costa Sul e Sudeste Brasileira: Síntese de conhecimentos, 2, 1990. São Paulo: Anais Academia de Ciêncas do Estado de São Paulo (ACIESP). São Paulo: Acadeia de Ciências do Estado, 1990, p. 375-399.

373 Informação disponível no website da CETESB, na seção "Aspectos Toxicológicos" de "Vazamento de óleo". Disponível em: $\quad \underline{\text { https://cetesb.sp.gov.br/emergencias-quimicas/tipos-de-acidentes/vazamentos-de- }}$ oleo/caracteristicas-do-oleo/aspectos-toxicologicos/>. Acesso em: 01.08.2018. 
Análises de sedimento do manguezal realizadas dezessete meses após o ocorrido demonstraram que os três pontos de amostragem mais próximos do local do acidente permaneceram altamente poluídos. $^{374}$

$\mathrm{Na}$ identificação dos danos ecológicos, até mesmo aqueles decorrentes da própria remediação devem ser verificados. Os métodos empregados para a remoção do óleo devem ser muito bem avaliados. A recuperação estética muitas vezes pode resultar em danos à comunidade biológica.

Os danos biológicos e ecológicos são os mais complexos, devendo ser avaliados tecnicamente e minuciosamente. A escolha da técnica de reparação deve levar em conta as particularidades de cada ecossistema afetado, além dos danos indiretos, que muitas vezes são imperceptíveis a olho nu.

Havendo a constatação de um dano ecológico, outros danos decorrentes podem ser verificados, a exemplo dos danos econômicos, sociais e à saúde. Ou seja, os danos ambientais não se restringem apenas à morte da fauna ou da flora estuarina e marinha, que em sua maioria não possui valor de mercado. Possui, antes, grande valor de existência, considerando-se as funções ecológicas que desempenham nos ecossistemas insubstituíveis para toda a teia alimentar estuarina/marinha e humana, bem como para a biodiversidade do planeta. ${ }^{375}$

O Índice de Sensibilidade Litorânea (ISL) é uma classificação elaborada pelo Ministério do Meio Ambiente que representa a sensibilidade ambiental da costa a derramamentos de óleo. Esta categorização leva em consideração o conhecimento das características geomorfológicas do litoral, examinando-se aspectos como o tipo de substrato, declividade do litoral e grau de exposição à energia de ondas e marés. ${ }^{376}$

A seguir é apresentada uma síntese das características dos ambientes costeiros e sua respectiva classificação, de acordo com ISL.

\subsubsection{1. Águas abertas}

As águas abertas são os ambientes que abrangem toda a coluna d'água, compreendendo as águas costeiras, inseridas entre a linha de costa até os limites da plataforma continental (200

\footnotetext{
${ }^{374}$ MACIEL-SOUZA, M. do C. et al. Chemical and microbiological characterization of mangrove sediments after a large oil-spill in Guanabara Bay - RJ - Brazil. Braz. J. Microbiol. São Paulo, v.37, n.3, p. 262-266, set. 2006.

375 POFFO, Í. R. F. Vazamentos de Óleo no Litoral Norte do Estado de São Paulo: análise histórica (1974 a 1999). In: ABRAMOVAY, R. (Org.). Construindo a Ciência Ambiental. São Paulo: Annablume, 2002, p.254

376 BRASIL. MMA. Especificações e normas técnicas para elaboração de cartas de sensibilidade ambiental para derramamentos de óleo: cartas SAO. Brasília, 2004, p. 107.
} 
metros de profundidade ou 50 a $200 \mathrm{~km}$ de distância) e as águas oceânicas, presentes a partir da plataforma continental (com profundidade superior a 200 metros).Por não compreenderem um ambiente litorâneo, não há classificação no ISL elaborada pelo Ministério do Meio Ambiente para estas áreas. Contudo, apesar de a cadeia alimentar pelágica ser menos vulnerável aos danos decorrentes dos vazamentos de óleo em relação aos ambientes costeiros, as suas áreas mais próximas à costa da zona pelágica apresentam significativa sensibilidade, principalmente em ambientes de baixa profundidade e circulação de água reduzida, como as baías, canais e enseadas abrigadas. Os principais organismos afetados nestas áreas são o fitoplâncton, o zooplâncton e os peixes. ${ }^{377}$

Já em relação às águas oceânicas, um aspecto relevante a ser considerado é o fato de que as principais formas de exploração de petróleo são realizadas nestas áreas. A perfuração de petróleo em águas oceânicas representa uma atividade com potencial para ocasionar danos ambientais de grande escala, principalmente pela conectividade hidrodinâmica do ecossistema marinho, pela dificuldade nas ações emergências para se conter estas liberações acidentais de hidrocarbonetos, bem como pela complexidade técnica e desafiadora de se perfurar no fundo do mar a grandes profundidades. ${ }^{378}$

Uma situação que evidenciou a importância do conhecimento sobre estes ambientes em eventos de derramamento de óleo e a dificuldade de se conter estas liberações acidentais (conforme mencionado acima) foi o acidente da plataforma Deepwater Horizon, o qual lançou em ambiente de águas oceânicas (a fonte do vazamento estava em uma profundidade aproximada de 1500 metros) um volume estimado de 68000 barris por dia de petróleo por um período de 87 dias até a contenção do vazamento. Estudos realizados para analisar os impactos decorrentes deste evento reportaram que este acidente ocasionou uma duradoura cobertura por óleo de áreas de desova de grandes predadores dos ambientes oceânicos - como o atum de barbatana azul e o marlim azul -, e de zonas de alimentação de grandes predadores de plâncton - o tubarão baleia -, ${ }^{379}$ espécies que desempenham papéis cruciais na cadeia alimentar. Em face

377 LOPES, C. F.; MILANELli, J. C. C.; POFFO, I. R. F. Ambientes costeiros contaminados por óleo: procedimentos de limpeza. Manual de Orientação. São Paulo: Secretaria de Estado do Meio Ambiente, 2007, p. 31-32.

378 STIEGLITZ, J. D. Effects of the Deepwater Horizon Oil Spill on Pelagic Fish Species of the Gulf of Mexico. 117f. PhD dissertation - Marine Biology and Fisheries (Marine), University of Miami, Miani, sep. 2014 , p.1. Disponível em: $<$ https://scholarlyrepository.miami.edu/oa dissertations/1317>. Acesso em: 01.08.2018.

379 JOHANSSON, S.; LARSSON, U.; BOEHM, P. The Tsesis oil spill. Impact on the pelagic ecosystem. Marine Pollution Bulletin, v.11, n.10, p. 284-293, out. 1980. 
deste caso, observa-se a importância de estudar as suas consequências tendo em vista que o Brasil tem como sua principal fonte de petróleo o pré-sal.

\subsubsection{Praias}

São os ambientes costeiros formados por material inconsolidado (geralmente areia) com diversas granulometrias. ${ }^{380}$ São áreas naturalmente expostas, sendo parte da sua dinâmica natural receber e acumular os materiais provenientes do oceano. Algumas praias são bem conhecidas por atuarem como locais de coleta natural de algas, e o petróleo é transportado de maneira semelhante. Estes padrões complexos de movimento da água próximos às costas podem influenciar na concentração de petróleo em certas áreas. ${ }^{381}$

Assim, por estarem adjacentes aos ambientes de mares, estuários e outros ecossistemas costeiros, e sendo resultante da complexa interação de fatores com ambientes, são os locais mais vulneráveis aos efeitos dos derramamentos de óleo. ${ }^{382}$ Não obstante, recebem grande atenção da mídia e da sociedade, por representarem áreas onde são desempenhadas diversas atividades socioeconômicas.

Quando o petróleo atinge as praias, seu comportamento depende de uma série de fatores como a topografia praia, a sua composição, o seu nível de exposição à energia das ondas e das marés, bem como as características do óleo quando ele chega. ${ }^{383}$ Esta composição de fatores irá determinar o quão sensível a praia poderá ser aos danos do óleo derramado.

O grau de retenção de óleo por uma costa afeta consideravelmente o impacto de curto prazo e a duração do dano. A retenção depende da condição do tipo de óleo e das características dos sedimentos da praia tais como, rocha, areia, cascalho, sedimentos lodosos, e outros. Óleos com maior viscosidade tendem a ser retidos em maior quantidade do que os óleos menos viscosos. Linhas de costa quebradas, irregulares e levemente inclinadas com uma grande faixa de maré podem conter mais óleo do que praias com margens íngremes e lisas com uma pequena amplitude de maré. Já as praias com alto dinamismo, com maior exposição à ação das ondas e

\footnotetext{
${ }^{380}$ LOPES, C. F.; Milanelli, J. C. C.; POFFO, I. R. F. Ambientes costeiros contaminados por óleo: procedimentos de limpeza. Manual de Orientação. São Paulo: Secretaria de Estado do Meio Ambiente, 2007, p.45. 381 IPIECA-IOGP. Good Practice Guide Series: Good practice guidelines for incident management and emergency response personnel - Impacts of oil spills on shorelines. London: IPIECA-IOGP, $2^{\mathrm{a}}$ ed., 2016, p. 8-9.

382 DICKS, B. The environmental impact of marine oil spills- effects, recovery and compensation. International seminar on tanker safety, pollution prevention, spill response and compensation, Rio de Janeiro, Brasil, 6 nov., 1998, p. 5-6.

383 IPIECA-IOGP. Good Practice Guide Series: Good practice guidelines for incident management and emergency response personnel - Impacts of oil spills on shorelines. London: IPIECA-IOGP, 2a ed., 2016, p. 8-9.
} 
aos efeitos de erosão das correntes de maré, estão entre os habitats mais resilientes aos efeitos de um derramamento, pois tendem a limpar-se de forma relativamente rápida. Essas linhas costeiras geralmente têm comunidades de espécies altamente adaptadas, especialmente herbívoros e filtradores. Em contrapartida, as praias mais protegidas e que apresentam sedimentos finos (areias finas e lama), são ambientes altamente produtivos, como por exemplos as praias de estuários. Elas suportam grandes populações de aves migratórias e também funcionam como áreas de berçário para algumas espécies. Enquanto o óleo pode exercer efeitos tóxicos e sufocantes imediatos aos animais que vivem nestes ambientes, a penetração do óleo em camadas mais profundas é rara. ${ }^{384}$

Em relato de ocorrência da CETESB sobre vazamento ocorrido em São Sebastião, litoral norte de São Paulo, onde as praias atingidas tinham granulometria variável entre fina e grossa, houve registro de uma penetração significativa do produto no sedimento, especialmente nas partes superiores da zona entremarés, onde naturalmente há o maior acúmulo de óleo, devido à ação de subida e descida das marés. Os relatos deste evento registram que ocorreu maior acúmulo de óleo nas praias com areia grossa (praia de Olaria e Pontal da Cruz), principalmente nas camadas internas do sedimento. Já as praias de sedimento fino (praia do Arrastão), não houve acúmulo de óleo significativo. Os relatos também indicam que, por serem praias abrigadas da ação das ondas (protegidas pela Ilha de São Sebastião), houve a ampliação do período de residência do óleo, prejudicando os processos de recuperação natural dos ambientes atingidos. 385

A classificação do Índice de Sensibilidade Litorânea (ISL) para as praias varia de ISL 3 a 9, de acordo com o seu tipo de sedimento e o grau de exposição das ondas, e os principais métodos de limpeza recomendados para este ambiente são a limpeza natural, o recolhimento manual e o uso de absorventes naturais granulados. ${ }^{386}$

\footnotetext{
${ }^{384}$ DICKS, B. The environmental impact of marine oil spills- effects, recovery and compensation. International seminar on tanker safety, pollution prevention, spill response and compensation, Rio de Janeiro, Brasil, 6 nov., 1998, p. 5-6.

${ }^{385}$ POFFO, I. R. F(coord.); LOPES, C. F.; MILANELLI, J. C. C; AVENTURATO, H. Operação Tebar VI - Emissário Submarino. São Paulo: CETESB, 1999, p. 13.

${ }^{386}$ BRASIL. MMA. Especificações e normas técnicas para elaboração de cartas de sensibilidade ambiental para derramamentos de óleo: cartas SAO. Brasília, 2004, 107 p. Anexos. P. 51
} 


\subsubsection{Planícies de maré}

As planícies de maré são ambientes intimamente ligados às praias, sendo muitas vezes confundidas como tais. Contudo, compreendem outra tipologia de ecossistema costeiro caracterizada pela presença de sedimentos lamosos compostos por partículas muito finas que se acumulam em terraços de baixa-mar. São áreas muito planas e protegidas das ações das ondas e, portanto, favoráveis à deposição de sedimentos. São ambientes tpicamente ricos em biodiversidade, pois apresentam estabilidade física, favorecendo a criação de um ambiente de alta produtividade, rico em matéria orgânica. Esta condição resulta em um ambiente que atrai diversas espécies, seja para estabelecer residência (como os invertebrados bentônicos); seja para se alimentar, como as aves que se aproveitam da maré baixa para consumir os invertebrados; seja ainda para se reproduzir, caso das espécies de peixes que se aproveitam da proteção oferecida por estas áreas. ${ }^{387}$

Assim, são áreas vulneráveis aos derramamentos de óleo, porém menos sensíveis em relação a penetração do contaminante nos seus substratos. Em contrapartida, por ser pouco exposta às intempéries, acaba retendo mais o óleo, gerando danos físicos e químicos ao seu ambiente e danos biológicos às espécies que o frequentam. ${ }^{388}$

O ISL traz 3 classificações a este ambiente, sendo ISL 7 em planícies de maré arenosa exposta, ISL 9 as planícies de maré arenosas/lamosas em áreas abrigadas e terraços de baixamar lamosos abrigados e ISL 10 em terraços alagadiços. ${ }^{389}$ As técnicas de limpeza recomendadas para estes ambientes são a limpeza natural, o recolhimento manual e a utilização de absorventes naturais granulados. ${ }^{390}$

\subsubsection{Costões rochosos}

Os costões rochosos são ambientes geralmente caracterizados por um alto dinamismo e, em decorrência disto, colonizados por uma grande variedade de algas marinhas e animais adaptados a um ambiente estressante. Fala-se em ambiente estressante, pois, dependendo de onde vive um organismo adaptado aos costões rochosos, ele estará submetido a níveis variados

387 LOPES, C. F.; MILANELli, J. C. C.; POFFO, I. R. F. Ambientes costeiros contaminados por óleo: procedimentos de limpeza. Manual de Orientação. São Paulo: Secretaria de Estado do Meio Ambiente, 2007, p.51. 388 LOPES, C. F.; MILANELli, J. C. C.; POFFO, I. R. F. Ambientes costeiros contaminados por óleo: procedimentos de limpeza. Manual de Orientação. São Paulo: Secretaria de Estado do Meio Ambiente, 2007, p.52. ${ }^{389}$ BRASIL. MMA. Especificações e normas técnicas para elaboração de cartas de sensibilidade ambiental para derramamentos de óleo: cartas SAO. Brasília, 2004, 107 p. Anexos p. 53.

${ }^{390}$ LOPES, C. F.; MILANELLI, J. C. C.; POFFO, I. R. F. Ambientes costeiros contaminados por óleo: procedimentos de limpeza. Manual de Orientação. São Paulo: Secretaria de Estado do Meio Ambiente, 2007, p.52. 
de dessecação, temperaturas, salinidades, batimentos físicos por ondas, longos períodos sem comida e níveis variáveis de predação. Em resposta a esses fatores, os organismos da costa rochosa se adaptaram para lidar com determinados regimes ambientais, se distribuindo em zonas verticais de ocupação das rochas distintas e com alterações muito substanciais entre as comunidades nas costas expostas às ondas e aquelas nas costas protegidas por ondas. ${ }^{391}$

Assim como observado em outros ambientes, o grau de exposição do costão rochoso influencia sua vulnerabilidade e sensibilidade aos derramamentos de óleo. Os costões abrigados figuram entre os ambientes costeiros mais sensíveis ou mais vulneráveis a vazamentos, especialmente devido a maior sensibilidade da biota que o habita, a maior persistência do óleo no ambiente e à dificuldade de limpeza sem causar danos adicionais à comunidade. Além disso, a recuperação de um costão rochoso abrigado pode levar muitos anos, pois são áreas com menor ação intempérica. Por outro lado, os costões expostos estão entre os ambientes costeiros de menor sensibilidade, pois há nele intensa atividade do intemperismo, o qual atua como agente de limpeza natural. As ondas protegem os organismos que vivem aderidos as rochas do recobrimento físico do óleo, removendo-o, configurando também um ambiente com menor persistência do produto. Os costões rochosos da região de São Sebastião, litoral norte do Estado de São Paulo, por exemplo, por apresentarem proximidade com uma área portuária que atua no transporte de óleo, foram avaliados para melhor conhecimento dos danos causados pelo óleo.

Os monitoramentos realizados mostram que, em decorrência das condições de mar relativamente mais calmas da região, a ação hidrodinâmica sobre os costões do interior do Canal é pequena em relação às áreas abertas da costa. De modo geral, as análises e os monitoramentos realizados no local mostram que os costões de locais abrigados, como os do interior do Canal de São Sebastião, são classificados como altamente vulneráveis. Já os costões expostos, contrariamente, são pouco vulneráveis, uma vez que a ação das ondas constitui agente efetivo na remoção natural do óleo. No entanto, apesar da capacidade de autolimpeza eficiente, populações de costões batidos podem também sofrer intensos impactos agudos em contato com óleo leve e tóxico. ${ }^{392}$

${ }^{391}$ IPIECA. IPIECA report series - Biological impacts of oil pollution: rocky shores. London: IPIECA, v.7, 1995 , p.6.

392 MILANELLI, J. C. C. Biomonitoramento de costões rochosos - instrumento para avaliação de impactos gerados por vazamentos de óleo na região do Canal de São Sebastião - São Paulo. 293f. Tese de Doutorado em Ciências - Instituto de Oceonagrafia, Universidade de São Paulo, 2003, p. 44-45. 
A vulnerabilidade do costão rochoso à contaminação por óleo também depende de sua topografia e composição, bem como de sua posição em relação à água (reta, inclinada, plana, etc.). Em um extremo, uma parede de rocha vertical exposta à onda provavelmente permanecerá desobstruída se uma mancha de óleo for retida pela ação das ondas refletidas. No outro extremo, um costão de rochas gradualmente inclinadas em uma área abrigada pode reter enormes quantidades de óleo.

A classificação dos costões rochosos pelo ISL varia de acordo com as características descritas nos parágrafos acima. Classificam-se como ISL 1 os costões rochosos homogêneos de elevada declividade expostos à ação hidrodinâmica e as falésias expostas à ação hidrodinâmica. Enquadram-se como ISL 2 os costões rochosos homogêneos de média a baixa declividade, expostos à ação hidrodinâmica. Já compreendendo áreas mais sensíveis, classificam-se como ISL 6 os costões formados por matacões; e como ISL 8 os costões rochosos de superfície homogênea ou não homogênea de baixa energia hidrodinâmica. ${ }^{393}$

Os métodos de limpeza recomendados para estes locais também consideram o grau de exposição do costão rochoso à ação das intempéries. Em locais abrigados, recomenda-se: a limpeza natural; o bombeamento à vácuo; a remoção manual; a aplicação de absorventes granulados na água adjacente, de barreiras absorventes e pompons; a lavagem sem pressão; e o jateamento a baixa pressão. Em locais expostos ao intemperismo, recomenda-se a limpeza natural exercida por ele. ${ }^{394}$

\subsubsection{Substratos artificiais}

São ambientes antrópicos, ou seja, criados pela ação humana, normalmente construídos para dar suporte a atividades socioeconômicas que se desenvolvem nas regiões costeiras. Objetivam facilitar o acesso do homem e seus equipamentos ao espelho d'água. Sua composição é variável e tem relação direta com a sua sensibilidade ao óleo. Podem ser feitos de materiais como as rochas, madeiras, concreto, e assim por diante.

Quando o material que compreende este substrato tem superfície lisa e localiza-se em áreas de maior exposição ao hidrodinamismo, configuram-se como locais de menor sensibilidade aos danos provocados pelo óleo. Isto, pois tais características, além de facilitarem

${ }^{393}$ BRASIL. MMA. Especificações e normas técnicas para elaboração de cartas de sensibilidade ambiental para derramamentos de óleo: cartas SAO. Brasília, 2004. 107 p. Anexos. P. 56p.56.

394 LOPES, C. F.; MILANELLI, J. C. C.; POFFO, I. R. F. Ambientes costeiros contaminados por óleo: procedimentos de limpeza. Manual de Orientação. São Paulo: Secretaria de Estado do Meio Ambiente, 2007, p.58. 
a limpeza natural, são menos favoráveis a fixação de organismos. Já os substratos localizados em áreas de menor exposição e com superfícies fragmentadas propiciam condições ao desenvolvimento de organismos como os poríferos, cnidários, moluscos, crustáceos, tunicados e macroalgas. 395

Assim, de acordo com as características do local, têm-se as seguintes classificações do ISL: Estruturas artificiais lisas e expostas são ISL 1; Enrocamentos expostos são ISL 6; e Enroncamentos e outras estruturas não lisas em áreas abrigadas, ISL 8. ${ }^{396}$

\subsubsection{Recifes de Coral}

Os recifes de corais são considerados as comunidades marinhas de maior diversidade e complexidade, que exercem um papel fundamental no balanço de massa geoquímica dos oceanos, pois são responsáveis por fixar o cálcio trazido para os oceanos pelos rios, segundo o International Petroleum Industry Environmental Conservation Association (IPIECA). Além disso, são mencionados como de significativa importância para o contexto das mudanças climáticas, pois também capturam o carbono (mais de 111 milhões de toneladas de carbono por ano). Destaca-se também a importância socioeconômica destes ecossistemas, pois atuam como barreiras que protegem a costa da erosão, e são importantes para regulação de diversas espécies de peixes de interesse econômico. Além disso, são cobiçadas áreas para aproveitamento turístico. ${ }^{397}$

Entre as suas diversas e complexas exigências ambientais, os recifes de corais dependem da incidência de luz para o desenvolvimento de algas simbióticas (zooxantelas) que vivem dentro dos corais. Outros fatores ambientais como a salinidade, temperatura e oxigenação são responsáveis pela regulação deste ecossistema, fazendo com que o mesmo apenas ocorra em regiões onde tais aspectos, em conjunto, ofereçam um ambiente favorável ao seu desenvolvimento. ${ }^{398}$

Em relação aos efeitos do óleo, os corais são organismos altamente sensíveis que podem levar muito tempo para se recuperar dos danos. O óleo quando disperso, seja pela ação natural

\footnotetext{
395 LOPES, C. F.; MILANELli, J. C. C.; POFFO, I. R. F. Ambientes costeiros contaminados por óleo: procedimentos de limpeza. Manual de Orientação. São Paulo: Secretaria de Estado do Meio Ambiente, 2007, p.60. 396 BRASIL. MMA. Especificações e normas técnicas para elaboração de cartas de sensibilidade ambiental para derramamentos de óleo: cartas SAO. Brasília, 2004, 107 p. Anexos, p. 56.

397 IPIECA. IPIECA Report Series - Biological impacts of oil pollution: coral reefs., v.3, 2a ed., 2004, p. 4.

398 LOPES, C. F.; MILANELLI, J. C. C.; POFFO, I. R. F. Ambientes costeiros contaminados por óleo: procedimentos de limpeza. Manual de Orientação. São Paulo: Secretaria de Estado do Meio Ambiente, 2007, p.63.
} 
das intempéries sejapela aplicação de produtos dispersantes, apresenta o maior risco de danos aos recifes de coral, pois nessa condição o mesmo pode se sedimentar sobre os recifes. Além do próprio coral, as comunidades que o habitam também são sensíveis ao óleo. Por esta razão, o uso de dispersantes que causam a sua dissolução não é recomendado em áreas próximas a recifes de corais. ${ }^{399}$

Além da sedimentação do óleo disperso ou dissolvido, há outras maneiras que o produto pode entrar em contato e causar danos aos recifes de corais. Algumas áreas dos recifes podem estar expostas durante as marés baixas, principalmente durante as marés de sizígia. Esta situação, quando associada a um derramamento de óleo, pode causar contato direto do óleo com os corais e resultar em seu sufocamento e/ou dano por toxicidade aguda. Outro mecanismo que leva ao contato do produto com o coral é a aglutinação do óleo a partículas minerais e sua sedimentação. Essas partículas oleosas podem danificar os corais. O processo de intemperismo também pode fazer com que o óleo afunde e entre em contato com corais mais profundos. Outra maneira de contato seria quando o óleo produzido em áreas costeiras próximas a áreas de recifes flui pela costa e continuam submerso, sufocando os recifes mais rasos. ${ }^{400}$

Apesar de constarem entre os ecossistemas costeiros mais sensíveis ao óleo, os recifes de corais não são contemplados nos mapeamentos e na classificação do ISL realizado pelo Ministério do Meio Ambiente, pois é tratado como um ecossistema submerso e por isso distinto dos ecossistemas litorâneos tratados pelo documento. As técnicas de limpeza recomendadas para os recifes de corais são o bombeamento à vácuo, a aplicação de absorventes, barreiras de contenção e skimmers, a remoção manual, bem como a limpeza natural. ${ }^{401}$

\subsubsection{Recifes de arenito/arenito de praia}

No Brasil, a maioria dos recifes apresenta pequenas formações calcárias que crescem em rochas areníticas. ${ }^{402}$ Estes recifes cobrem um extenso trecho da costa e são ecossistemas

\footnotetext{
399 ITOPF. Technical Information Paper 13 (TIP 13): Effects of Oil Pollution on the Marine Environment. London: International Tanker Owners Pollution Federation, v. 13, 2014, 19 mai. 2014, p. 6. Disponível em: $<$ https://www.itopf.org/knowledge-resources/documents-guides/document/tip-13-effects-of-oil-pollution-on-themarine-environment/>. Acesso em: 01.08.2018.

${ }^{400}$ IPIECA. IPIECA Report Series - Biological impacts of oil pollution: coral reefs., v.3, 2a ed., 2004, p. 8.

${ }^{401}$ LOPES, C. F.; MILANELLI, J. C. C.; POFFO, I. R. F. Ambientes costeiros contaminados por óleo: procedimentos de limpeza. Manual de Orientação. São Paulo: Secretaria de Estado do Meio Ambiente, 2007, p.13. 71.

402 MAIDA, M.; FERREIRA, B. Coral Reefs of Brazil: Overview and Field Guide. Proceedings of the 8th International Coral Reef Symposium, v.1, p. 263-274, 1997.
} 
ecologicamente únicos que mostram uma composição e formação de recifes diferentes de muitos outros recifes de coral em todo o mundo. ${ }^{403}$

Estes recifes de arenito são comuns no litoral da costa nordeste brasileira, ficando dispostos paralelamente a linha de praia, próximos a zonas entremarés - e, por isso, ficando parcialmente submersos -, ou um pouco mais distante da praia - formando uma barreira de proteção contra as ondas e em boa parte permanentemente submersos. Estes ambientes apresentam uma comunidade biológica rica, de espécies tanto da biota aquática (como invertebrados, peixes e quelônios) como da biota terrestre (principalmente as aves, terrestres e costeiras). ${ }^{404}$

Esta característica, aliada à sua exposição nas áreas entremarés, os torna tipicamente sensíveis aos derramamentos de óleo. Assim, de acordo com as cartas de sensibilidade, são classificados como ISL 2, quando compreendidos por terraços areníticos emersos bem consolidados; como ISL 5, quando representados por recifes areníticos em franja, localizados adjacentes à costa; e ISL 9, quando caracterizados por recifes areníticos que servem de substrato a corais biogênicos. ${ }^{405}$

Recomenda-se para estes ambientes as técnicas de limpeza de bombeamento a vácuo, a remoção manual, a utilização de absorventes (almofadas, mantas ou cordões), a utilização de barreiras absorventes e pompons, e, por fim, a limpeza natural. ${ }^{406}$

\subsubsection{Concreções lateríticas}

São ambientes caracterizados pela existência de sedimentos laterizados de origem continental. Ou seja, sua formação ocorreu em período anterior ao local se tornar um ambiente costeiro ou marinho. Ocorrem principalmente nas áreas de entremarés, servindo de barreira as forças das ondas. É um ambiente comumente habitado por espécies de invertebrados, como os moluscos e crustáceos (cracas e carangueijos). Por apresentarem superfície irregular e com diversas deformidades causadas pela erosão, são refúgio para diversos organismos. Pelo mesmo

\footnotetext{
${ }^{403}$ LEAO, Z.; DOMInGUEZ, J.. Tropical Coast of Brazil. Marine Pollution Bulletin, v.41, n.1-6, p.112-122, jun. 2000.

404 LOPES, C. F.; MILANELli, J. C. C.; POFFO, I. R. F. Ambientes costeiros contaminados por óleo: procedimentos de limpeza. Manual de Orientação. São Paulo: Secretaria de Estado do Meio Ambiente, 2007, p.74. ${ }^{405}$ BRASIL. MMA. Especificações e normas técnicas para elaboração de cartas de sensibilidade ambiental para derramamentos de óleo: cartas SAO. Brasília, 2004. 107 p. Anexos. p. 56.

406 LOPES, C. F.; MILANELLI, J. C. C.; POFFO, I. R. F. Ambientes costeiros contaminados por óleo: procedimentos de limpeza. Manual de Orientação. São Paulo: Secretaria de Estado do Meio Ambiente, 2007, p.75.
} 
motivo, permitem a retenção e aderência do óleo em ocasiões de vazamentos, tornando-os mais sensíveis aos danos por ele provocados. ${ }^{407}$

Por estas características, são classificados como moderada a altamente sensíveis: ISL6. ${ }^{408}$

Os métodos de limpeza recomendados são o bombeamento a vácuo, a remoção manual, a utilização de absorventes (almofadas, mantas e cordões, a utilização de barreiras absorventes e pompons e a limpeza natural. ${ }^{409}$

\subsubsection{Marismas}

Os marimas são zonas úmidas dominadas por uma vegetação herbácea que se estende acima da água ou de solos muito úmidos. Existem muitos tipos diferentes de marismas, mas todos são inundados com água por longos períodos de tempo ou regularmente. As plantas dos marismas possuem adaptações que lhes permitem crescer em solos encharcados e para lidar com o estresse salino. ${ }^{410}$ Geralmente, estão associados às margens de baías, enseadas, barras, desembocaduras de rios e reentrâncias costeiras, ou seja, tipicamente em ambientes abrigados e de baixo dinamismo, sendo dessa forma vulneráveis, pois a limpeza natural causada pelo intemperismo tem baixa atuação nestes ambientes. Isto também torna o tempo de permanência do óleo maior. ${ }^{411}$

Os marismas sustentam uma comunidade biológica rica e diversificada, servindo como importantes habitat de nidificação, reprodução, desova, criação e alimentação para muitas espécies de aves, mamíferos, répteis, anfíbios, peixes, mariscos e outros invertebrados. Também prestam serviços ecossistêmicos, sendo base para cadeias alimentares, inclusive cadeias detritívoras permitindo a reciclagem de nutrientes, filtrando a água com a retenção de

\footnotetext{
${ }^{407}$ ALBINO, J. Processos de sedimentação atual e morfodinâmica das praias de Bicanga a Povoação, ES. 1999. 175 f. Tese (Doutorado em geologia sedimentar) - Instituto de Geociências, Universidade de São Paulo, 1999. P.13.

${ }^{408}$ BRASIL. MMA. Especificações e normas técnicas para elaboração de cartas de sensibilidade ambiental para derramamentos de óleo: cartas SAO. Brasília, 2004, 107p, Anexos. p. 56

409 LOPES, C. F.; MILANELLI, J. C. C.; POFFO, I. R. F. Ambientes costeiros contaminados por óleo: procedimentos de limpeza. Manual de Orientação. São Paulo: Secretaria de Estado do Meio Ambiente, 2007, p..77. ${ }^{410}$ MICHEL, J.; RUTHERFORD, N. Oil spills in marshes. Planning, responses and considerations. Washington: National Oceanic and Atmospheric Administration (NOAA) and American Petroleum Institute (API), 2013, p.11. 411 LOPES, C. F.; MILANELLI, J. C. C.; POFFO, I. R. F. Ambientes costeiros contaminados por óleo: procedimentos de limpeza. Manual de Orientação. São Paulo: Secretaria de Estado do Meio Ambiente, 2007 , p.81.
} 
sedimentos e de águas pluviais e estabilizam a linha de costa oferecendo proteção contra tempestades. Por isso, quando um derramamento de óleo os afeta, os danos podem ser graves. ${ }^{412}$

Estão entre os ecossistemas costeiros mais sensíveis, classificados como ISL 10, o índice máximo de avaliação da sensibilidade dos ecossistemas. ${ }^{413}$

Em relação às técnicas de limpeza recomendadas, observa-se que para este ambiente os impactos de métodos de resposta inadequados podem agravar os danos e retardar a recuperação do ecossistema. ${ }^{414}$ Recomenda-se a utilização de barreiras flutuantes e skimmers, barreiras absorventes, o bombeamento a vácuo e a limpeza natural para os marismas compostos por canais e águas adjacentes. Já para os marismas formados por bosques, recomenda-se a limpeza natural e o corte controlado da vegetação. ${ }^{415}$

\subsubsection{Manguezais}

Os manguezais são ecossistemas de transição localizados entre os ambientes terrestre e marinho, típicos de regiões tropicais e subtropicais. Sua ocorrência está sujeita ao regime de marés, sendo constituído por espécies vegetais adaptadas a variações de salinidade, fixadas sobre sedimentos lodosos, com baixo teor de oxigênio. ${ }^{416}$

São habitats extremamente ricos e diversificados, importantes pelas suas diversas funções ecossistêmicas, como a proteção da costa contra a erosão e sua alta produtividade biológica. As águas que os circundam são locais ideais para reprodução e berçário para peixes jovens e camarões, enquanto as raízes aéreas típicas de suas árvores e o substrato lamoso, também característica deste ecossistema, abrigam uma fauna variada, com ostras, cracas, caranguejos e outros invertebrados. A parte superior dos manguezais também representa um ambiente importante para outros grupos da fauna, como as aves, mamíferos e insetos. ${ }^{417}$

Os manguezais se desenvolvem em regiões estuarinas, nas margens de águas tropicais, sendo cobertos por árvores e arbustos adaptados ao ambiente salobro. As estruturas complexas

\footnotetext{
412 MICHEL, J.; RUTHERFORD, N. Oil spills in marshes. Planning, responses and considerations. Washington: National Oceanic and Atmospheric Administration (NOAA) and American Petroleum Institute (API), 2013.

${ }^{413}$ BRASIL. MMA. Especificações e normas técnicas para elaboração de cartas de sensibilidade ambiental para derramamentos de óleo: cartas SAO. Brasília, 2004, 107p, Anexos. P.56.

${ }^{414}$ MICHEL, J.; RUTHERFORD, N. Oil spills in marshes. Planning, responses and considerations. Washington: National Oceanic and Atmospheric Administration (NOAA) and American Petroleum Institute (API), 2013, p.11. 415 LOPES, C. F.; MILANELli, J. C. C.; POFFO, I. R. F. Ambientes costeiros contaminados por óleo: procedimentos de limpeza. Manual de Orientação. São Paulo: Secretaria de Estado do Meio Ambiente, 2007, p.85. ${ }^{416}$ SCHAEFFER-NOVELLI, Y. Manguezal: Ecossistema entre a Terra e o Mar. São Paulo: Caribbean Ecological Research. 64p. 1995, p.1.

${ }^{417}$ IPIECA. Biological impacts of oil pollution: Mangrooves [S.L.].IPIECA Report Series, 4, , 1992, p. 5.
} 
das raízes destas árvores e arbustos aprisionam e estabilizam os sedimentos, reduzindo assim a erosão das linhas costeiras e minimizando a deposição de sedimentos terrestres em outros ambientes marinhos, como os recifes de coral. As árvores que fornecem a estrutura dessa comunidade são facilmente prejudicadas se o óleo chegar a cobrir suas raízes respiratórias, ou se os componentes tóxicos do óleo penetrarem nos sedimentos. Assim como os ambientes de marismas, eles podem ser facilmente danificados por tentativas inadequadas de limpeza, e as evidências científicas sugerem que, geralmente, é melhor não serem perturbados. ${ }^{418}$

Dada a sua localização em áreas costeiras abrigadas, são ambientes altamente vulneráveis a derramamentos de óleo. As manchas de óleo adentram as florestas de mangue com a subida da maré, depositando-se, conforme a maré baixa, nas raízes aéreas e na superfície do sedimento. Esta deposição acontece de maneira irregular ao longo da área do mangue, tornando mais difícil avaliar a sua extensão. ${ }^{419}$

Os organismos que vivem nos manguezais podem ser afetados tanto pelos efeitos diretos do óleo quanto pela perda de habitat. A recuperação natural pode levar muito tempo, visto que são áreas protegidas de ação de intempéries (como a ação das ondas). Estudos sobre os efeitos do óleo sobre os manguezais classificam os danos a partir de três dicotomias conceituais: agudo ou crônico; imediato ou inicial; e de curto ou de longo prazo. O efeito agudo pode ocorrer durante o primeiro mês ou durar meses. Já o efeito a longo prazo ou crônico geralmente ocorre após o efeito agudo. ${ }^{420}$

Estudos sobre os danos de longo prazo causados pelo óleo em manguezais da Baixada Santista, por exemplo, mostraram que, apesar de terem demonstrado certa resiliência, o prazo para esta recuperação foi longo, ultrapassando os sete anos, e mesmo assim a vegetação recuperada ainda apresentava um desenvolvimento estrutural inferior e uma composição de espécies distintas de áreas livres dos danos. Os estudos observam também que a recuperação depende do fluxo de maré que remove o óleo do ambiente, o que deixa as áreas de mangues

418 ITOPF. Technical Information Paper 13 (TIP 13): Effects of Oil Pollution on the Marine Environment. London: International Tanker Owners Pollution Federation, v. 13, 2014, 19 mai. 2014, p. 8. Disponível em: $<$ https://www.itopf.org/knowledge-resources/documents-guides/document/tip-13-effects-of-oil-pollution-on-themarine-environment/>. Acesso em: 01.08.2018.

419 IPIECA. IPIECA report series - Biological impacts of oil pollution: Mangrooves. London: IPIECA, v.4, 1992, p. 5.

${ }^{420}$ LAMPARELLI C. C.; RODRIGUES , F. O.; MOURA, D. O.. Long-term assessment of an oil-spill in a mangrove forest in Sao Paulo, Brazil. In: KJERFVE, B.; LACERDA L. D.; DIOP, E. H. S.(ed.). Mangrove ecosystem studies in Latin America and Africa. Paris: UNESCO, 1997, p. 193. 
mais internas dos estuários com a recuperação natural prejudicada e mais sensíveis aos vazamentos. ${ }^{421}$

A alta sensibilidade dos manguezais aos efeitos do óleo resulta em uma classificação como ISL 10. ${ }^{422}$ Esta sensibilidade é agravada pelo fato de os manguezais da costa brasileira estarem, em grande parte, muito próximos a empreendimentos portuários e zonas industriais. Por serem áreas de difícil acesso e limpeza, as técnicas de limpeza devem priorizar a utilização de métodos para contenção e remoção do óleo de águas adjacentes. Nestas áreas, são recomendadas ações de isolamento com barreiras de contenção, utilização de skimmers, bombeamento a vácuo, uso de barcaças recolhedoras, aplicação de barreiras absorventes, absorventes naturais e produtos dispersantes. Para as áreas de floresta e bosques de mangues, geralmente não se recomenda aplicação de nenhuma técnica, apenas a deixar o local exposto a limpeza natural. ${ }^{423}$

\subsubsection{Apicuns, Dunas e Restingas}

Os apicuns, dunas e restingas, apesar serem ambientes de inseridos na zona costeira brasileira não estão necessariamente conectados a linha de costa ou a zona entremarés. Contudo, por estarem associados aos demais ecossistemas costeiros se faz importante a sua consideração na avaliação e ação de prevenção aos impactos ocasionados pelo derramamento de óleo. Salienta-se ainda que, em muitos casos, são ambientes afetados pelas ações de limpeza, visto que necessitam serem atravessados para permitir o acesso a áreas do litoral que possam estar contaminadas. Por esta razão, são ambientes contemplados pela classificação de sensibilidade litorânea definida pelo Ministério do Meio Ambiente. ${ }^{424}$

Os apicuns se localizam nas áreas menos inundadas do manguezal, configurando-se como um ambiente de transição para a terra firme (normalmente para as vegetações de restinga). É normalmente desprovido de vegetação arbórea. Em alguns locais, o apicum também é conhecido como salgado. É um ambiente de alta salinidade que ocorre devido à evaporação da

\footnotetext{
${ }^{421}$ SANTOS, L. C. M. et. al. Long-term Effects of Oil Pollution in Mangrove Forests (Baixada Santista, Southeast Brazil) detected using a gis-based multitemporal analysis of aerial photographs. Brazilian Journal of Oceanography. São Paulo, v.60, n.2, jun. 2012, p.169.

${ }^{422}$ BRASIL. Ministério do Meio Ambiente. Especificações e normas técnicas para elaboração de cartas de sensibilidade ambiental para derramamentos de óleo: cartas SAO. Brasília, 2004, 107p, Anexos. p. 56.

${ }^{423}$ LOPES, C. F.; MILANELLI, J. C. C.; POFFO, I. R. F. Ambientes costeiros contaminados por óleo: procedimentos de limpeza. Manual de Orientação. São Paulo: Secretaria de Estado do Meio Ambiente, 2007, p.91. ${ }^{424}$ LOPES, C. F.; MILANELLI, J. C. C.; POFFO, I. R. F. Ambientes costeiros contaminados por óleo: procedimentos de limpeza. Manual de Orientação. São Paulo: Secretaria de Estado do Meio Ambiente, 2007, p 97.
} 
água remanescente no substrato, após a preamar de sizígia, aliada a uma baixa pluviosidade. ${ }^{425}$ São categorizados como ISL $10 .{ }^{426}$

As dunas são ambientes formados por depósitos arenosos em decorrência das ações dos ventos, estando associadas às praias, as quais fornecem o material arenoso para sua formação. São ambientes dinâmicos, em constante processo de modificação devido a elevada mobilidade das areias que as formam, principalmente quando desprovidas de cobertura vegetal. ${ }^{427}$ Os campos de dunas expostas são classificados como ISL 3 pelo Ministério do Meio Ambiente, sendo, portanto, ambientes menos sensíveis aos danos de vazamentos de óleo. ${ }^{428}$

Por fim, são definidas no Brasil como restingas as comunidades biológicas que prosperam em depósitos costeiros arenosos (dunas e planícies de praia) acumulados como resultado de progradação costeira. A vegetação é composta de gramíneas, arbustos e pequenas árvores, apresenta adaptação a solos pobres em nutrientes e exibem características xeromórficas e halófitas, que lhes permitem sobreviver em substrato arenoso e obter nutrientes da maresia (spray de sal) trazida pelo vento ${ }^{429}$ (o qual também é um fator ambiental significativo neste ambiente).Restingas, assim como as dunas, são classificadas como ISL $3 .{ }^{430}$

Para estes ambientes, não há técnica específica recomendada para sua limpeza, visto que dificilmente são alcançados pelo óleo. Contudo, são indicadas ações de precaução para minimizar os impactos que as atividades de descontaminação de outros ambientes costeiros podem ocasionar nestes ecossistemas de transição, como: evitar o desmatamento para criação de acessos, impedir a circulação de veículos fora dos acessos, apenas criar novos acessos quando não restar alternativas, adotar ações de prevenção de assoreamento, e outras. ${ }^{431}$

\footnotetext{
${ }^{425}$ SCHMIDT, A. J.; BEMVENUTI, C. E.; DIELE, K.. Sobre a definição da Zona de Apicum e sua importância ecológica para populações de Caranguejo-Uçá Ucidescordatus (LINNAEUS, 1763). Bol. Téc. Cient. CEPENE, Tamandaré, v.19, n.1, 2013, p. 10.

${ }^{426}$ BRASIL. MMA Especificações e normas técnicas para elaboração de cartas de sensibilidade ambiental para derramamentos de óleo: cartas SAO. Brasília, 2004, 107p, Anexos, p. 56.

${ }^{427}$ LOPES, C. F.; MILANELLI, J. C. C.; POFFO, I. R. F. Ambientes costeiros contaminados por óleo: procedimentos de limpeza. Manual de Orientação. São Paulo: Secretaria de Estado do Meio Ambiente, 2007, p 97.

${ }^{428}$ BRASIL. MMA. Especificações e normas técnicas para elaboração de cartas de sensibilidade ambiental para derramamentos de óleo: cartas SAO. Brasília, 2004, 107p, Anexos, p. 56.

${ }^{429}$ LEAO, Z.; DOMInGUEZ, J.. Tropical Coast of Brazil. Marine Pollution Bulletin, v.41, n.1-6, p.112-122, jun. 2000.

${ }^{430}$ BRASIL. MMA. Especificações e normas técnicas para elaboração de cartas de sensibilidade ambiental para derramamentos de óleo: cartas SAO. Brasília, 2004, 107p, Anexos, p.56.

431 LOPES, C. F.; MILANELLI, J. C. C.; POFFO, I. R. F. Ambientes costeiros contaminados por óleo: procedimentos de limpeza. Manual de Orientação. São Paulo: Secretaria de Estado do Meio Ambiente, 2007, p 101.
} 
A tabela a seguir sintetiza as características de cada ambiente afetado explicado acima, bem como sua sensibilidade ao óleo e o índice ISL que lhe foi conferido. 
Tabela 12 - Sensibilidade ao óleo por tipo de ambiente afetado

\begin{tabular}{|c|c|c|c|}
\hline $\begin{array}{l}\text { AMBIENTES } \\
\text { AFETADOS }\end{array}$ & CARACTERÍSTICAS DO AMBIENTE & SENSIBILIDADE AO ÓLEO & $\begin{array}{c}\text { ISL - ÍNDICE DE } \\
\text { SENSIBILIDADE } \\
\text { LITORÂNEA (MMA) }\end{array}$ \\
\hline Águas Costeiras & $\begin{array}{l}\text { Faixas de mar entre a zona entremarés e a plataforma } \\
\text { continental. Comportam a maioria dos organismos } \\
\text { marinhos. Ambientes de alta produtividade, com } \\
\text { abundância de plânctons, peixes, aves, mamíferos e } \\
\text { répteis marinhos. }\end{array}$ & $\begin{array}{l}\text { Os efeitos dos óleos nestes } \\
\text { ambientes podem ser graves } \\
\text { devido a circulação de água } \\
\text { reduzida e maior permanência do } \\
\text { produto em contato com os } \\
\text { organismos. Os principais grupos } \\
\text { afetados são o fitoplâncton, } \\
\text { zooplâncton e os peixes. }\end{array}$ & Sem classificação. \\
\hline Águas Oceânicas & $\begin{array}{l}\text { Águas além da plataforma continental. Ambiente pobre } \\
\text { em nutrientes e comunidades biológicas. }\end{array}$ & $\begin{array}{l}\text { Menor sensibilidade devido a alta } \\
\text { circulação de águas ocasionada } \\
\text { pelas correntes oceânicas. } \\
\text { Ambiente de rápida diluição e } \\
\text { dispersão do óleo. Pouca } \\
\text { probabilidade de afetar } \\
\text { significativamente a fauna pelágica } \\
\text { e a fauna planctônica. }\end{array}$ & Sem classificação. \\
\hline
\end{tabular}


(continuação)

\begin{tabular}{|c|c|c|c|c|}
\hline $\begin{array}{l}\text { AMBIENTES } \\
\text { AFETADOS }\end{array}$ & CARACTERÍSTICAS DO AMBIENTE & SENSIBILIDADE AO ÓLEO & $\begin{array}{c}\text { ISL - ÍNDICE DE } \\
\text { SENSIBILIDADE } \\
\text { LITORÂNEA (MMA) }\end{array}$ & \\
\hline \multirow{6}{*}{ Praias } & \multirow{6}{*}{$\begin{array}{l}\text { Ambientes costeiros contíguos aos mares formados por } \\
\text { substrato mineral inconsolidado. }\end{array}$} & \multirow{6}{*}{$\begin{array}{l}\text { Baixa a moderada sensibilidade } \\
\text { aos derrames de óleo. }\end{array}$} & $\begin{array}{l}\text { Praias dissipativas de } \\
\text { areia média a fina, } \\
\text { expostas. }\end{array}$ & 3 \\
\hline & & & $\begin{array}{l}\text { Praias de areia grossa, } \\
\text { praias intermediárias de } \\
\text { areia fina a média, } \\
\text { expostas, praias de areia } \\
\text { fina a média, abrigadas. }\end{array}$ & 4 \\
\hline & & & $\begin{array}{l}\text { Praias mistas de areia e } \\
\text { cascalho, ou conchas e } \\
\text { fragmentos de corais. }\end{array}$ & 5 \\
\hline & & & $\begin{array}{l}\text { Praias de cascalho (seixos } \\
\text { e calhaus). }\end{array}$ & 6 \\
\hline & & & Terraço de baixa-mar. & 7 \\
\hline & & & $\begin{array}{l}\text { Terraço de baixa-mar } \\
\text { lamoso abrigado. }\end{array}$ & 9 \\
\hline
\end{tabular}

(continua) 
(continuação)

\begin{tabular}{|c|c|c|c|c|}
\hline $\begin{array}{l}\text { AMBIENTES } \\
\text { AFETADOS }\end{array}$ & CARACTERÍSTICAS DO AMBIENTE & SENSIBILIDADE AO ÓLEO & $\begin{array}{l}\text { ISL - ÍNDICE DE } \\
\text { SENSIBILIDADE } \\
\text { LITORÂNEA (MMA }\end{array}$ & \\
\hline \multirow{3}{*}{ Planícies de Marés } & \multirow{3}{*}{$\begin{array}{l}\text { Ambientes de declive suave, com zona entremarés } \\
\text { extensa e favorável a deposição de sedimentos finos. } \\
\text { Ricos biologicamente e propício ao desenvolvimento de } \\
\text { comunidades de invertebrados bentônicos. }\end{array}$} & \multirow{3}{*}{$\begin{array}{l}\text { Impactos ambientais decorrentes } \\
\text { do derramamento de óleo podem } \\
\text { ser severos nestes ambientes, } \\
\text { devido principalmente ao seu baixo } \\
\text { dinamismo. }\end{array}$} & $\begin{array}{l}\text { Planície de maré arenosas } \\
\text { exposta. Terraço de } \\
\text { baixa-mar. }\end{array}$ & 7 \\
\hline & & & $\begin{array}{c}\text { Planície de maré arenosas } \\
\text { / lamosa abrigada. }\end{array}$ & 9 \\
\hline & & & Terraços alagadiços. & 10 \\
\hline
\end{tabular}

(continua) 
(continuação)

\begin{tabular}{|c|c|c|c|c|}
\hline $\begin{array}{l}\text { AMBIENTES } \\
\text { AFETADOS }\end{array}$ & CARACTERÍSTICAS DO AMBIENTE & SENSIBILIDADE AO ÓLEO & $\begin{array}{c}\text { ISL - ÍNDICE DE } \\
\text { SENSIBILIDADE } \\
\text { LITORÂNEA (MMA) }\end{array}$ & \\
\hline \multirow{4}{*}{ Costões Rochosos } & \multirow{4}{*}{$\begin{array}{l}\text { Afloramentos de rochas cristalinas na linha do mar, } \\
\text { sujeito às ações das ondas, correntes e ventos. } \\
\text { Apresentam rica e complexa comunidade. }\end{array}$} & \multirow{4}{*}{$\begin{array}{l}\text { Sensibilidade é variável, a } \\
\text { depender do grau de exposição das } \\
\text { rochas as ondas e correntes } \\
\text { marinhas. Áreas abrigadas são } \\
\text { muito vulneráveis, enquanto páreas } \\
\text { expostas favorecem a recuperação } \\
\text { natural do ambiente e por isso são } \\
\text { menos sensíveis. }\end{array}$} & $\begin{array}{c}\text { Costões rochosos } \\
\text { homogêneos de elevada } \\
\text { declividade, em locais } \\
\text { expostos à ação } \\
\text { hidrodinâmica; falésias } \\
\text { formadas por rochas } \\
\text { sedimentares expostas a } \\
\text { hidrodinâmica. }\end{array}$ & 1 \\
\hline & & & $\begin{array}{l}\text { Costões rochosos } \\
\text { homogêneos de média a } \\
\text { baixa declividade, } \\
\text { expostos à ação } \\
\text { hidrodinâmica. }\end{array}$ & 2 \\
\hline & & & $\begin{array}{c}\text { Encostas rochosas } \\
\text { formadas por matacões. }\end{array}$ & 6 \\
\hline & & & $\begin{array}{c}\text { Costões rochosos de } \\
\text { superfície homogênea ou } \\
\text { não homogênea em locais } \\
\text { de baixa energia } \\
\text { hidrodinâmica. }\end{array}$ & 8 \\
\hline
\end{tabular}

(continua) 
(continuação)

\begin{tabular}{|c|c|c|c|c|}
\hline $\begin{array}{l}\text { AMBIENTES } \\
\text { AFETADOS }\end{array}$ & CARACTERÍSTICAS DO AMBIENTE & SENSIBILIDADE AO ÓLEO & $\begin{array}{c}\text { ISL - ÍNDICE DE } \\
\text { SENSIBILIDADE } \\
\text { LITORÂNEA (MMA) }\end{array}$ & \\
\hline \multirow{3}{*}{ Substratos Artificiais } & \multirow{3}{*}{$\begin{array}{l}\text { Estruturas antrópicas formadas por materiais } \\
\text { consolidados diversos como rochas, concreto, madeira e } \\
\text { outros. }\end{array}$} & \multirow{3}{*}{$\begin{array}{l}\text { Sensibilidade também varia de } \\
\text { acordo com seu grau de exposição. }\end{array}$} & $\begin{array}{c}\text { Estruturas artificiais lisas } \\
\text { e expostas. }\end{array}$ & 1 \\
\hline & & & Enrocamentos expostos. & 6 \\
\hline & & & $\begin{array}{l}\text { Enrocamentos e outras } \\
\text { estruturas não lisas } \\
\text { abrigados. }\end{array}$ & 8 \\
\hline Recifes de Corais & $\begin{array}{l}\text { Estruturas calcárias restritas a locais de pequena } \\
\text { profundidade que dão suporte a diversos organismos } \\
\text { marinhos. }\end{array}$ & $\begin{array}{l}\text { Ambientes de alta sensibilidade, } \\
\text { susceptíveis a grande diversidade } \\
\text { de impactos diretos ou indiretos do } \\
\text { vazamento do óleo. Por serem } \\
\text { dependentes da luz, são } \\
\text { vulneráveis aos derrames de óleo } \\
\text { que ocasionam o bloqueio da luz. } \\
\text { Também estão sujeitos ao contato } \\
\text { direto seja pela variação da maré, } \\
\text { seja pela deposição seja pela } \\
\text { solubilização dos componentes do } \\
\text { óleo. }\end{array}$ & Sem classificação. & \\
\hline
\end{tabular}


(continuação)

\begin{tabular}{|c|c|c|c|c|}
\hline $\begin{array}{c}\text { AMBIENTES } \\
\text { AFETADOS }\end{array}$ & CARACTERÍSTICAS DO AMBIENTE & SENSIBILIDADE AO ÓLEO & $\begin{array}{r}\text { ISL - ÍNDICE DE } \\
\text { SENSIBILIDADE } \\
\text { LITORÂNEA (MMA }\end{array}$ & \\
\hline \multirow{3}{*}{$\begin{array}{l}\text { Recifes de Arenito / } \\
\text { Arenito de Praia }\end{array}$} & \multirow{3}{*}{$\begin{array}{l}\text { São estruturas areníticas, normalmente localizados em } \\
\text { áreas superficiais próximos a praia. Contribuem para } \\
\text { proteção da costa, formando barreiras naturais que } \\
\text { absorvem grande parte da energia das ondas. } \\
\text { Apresentam comunidade biológica rica. }\end{array}$} & \multirow{3}{*}{$\begin{array}{l}\text { São ambientes muito sensíveis aos } \\
\text { derrames de óleo e apresentam alta } \\
\text { vulnerabilidade por ocuparem } \\
\text { regiões entremarés. }\end{array}$} & $\begin{array}{l}\text { Terraços Areníticos } \\
\text { emersos bem } \\
\text { consolidados. }\end{array}$ & 2 \\
\hline & & & $\begin{array}{l}\text { Recifes Areníticos em } \\
\text { franja, localizados } \\
\text { adjacentes à costa. }\end{array}$ & 5 \\
\hline & & & $\begin{array}{l}\text { Recifes Areníticos } \\
\text { servindo de substrato a } \\
\text { corais biogênicos. }\end{array}$ & 9 \\
\hline $\begin{array}{l}\text { Concreções } \\
\text { Lateríticas }\end{array}$ & $\begin{array}{l}\text { Sedimentos laterizados encontrados nas regiões de } \\
\text { entremarés. A superfície erodida pelo intemperismo } \\
\text { forma um ambiente heterogêneo com muitas } \\
\text { reentrâncias, fendas e concavidades. }\end{array}$ & $\begin{array}{l}\text { São classificadas como moderada a } \\
\text { altamente sensíveis. }\end{array}$ & 6 & \\
\hline
\end{tabular}


(continuação)

\begin{tabular}{|c|c|c|c|}
\hline $\begin{array}{c}\text { AMBIENTES } \\
\text { AFETADOS }\end{array}$ & CARACTERÍSTICAS DO AMBIENTE & SENSIBILIDADE AO ÓLEO & $\begin{array}{c}\text { ISL - ÍNDICE DE } \\
\text { SENSIBILIDADE } \\
\text { LITORÂNEA (MMA) }\end{array}$ \\
\hline Marismas & $\begin{array}{l}\text { São áreas úmidas frequentemente inundadas com } \\
\text { vegetação herbácea adaptada a solos saturados. Possuem } \\
\text { diversos componentes biológicos (vegetação, macro e } \\
\text { microfauna) Estão normalmente associados a margens } \\
\text { de baías, enseadas, barras, desembocaduras de rios, } \\
\text { lagunas e reentrâncias costeiras. }\end{array}$ & $\begin{array}{l}\text { Estão entre os ecossistemas } \\
\text { costeiros mais sensíveis ao óleo. } \\
\text { Juntamente com os manguezais, } \\
\text { são os mais vulneráveis. }\end{array}$ & 10 \\
\hline Manguezais & $\begin{array}{l}\text { Sistemas costeiros de transição entre os ambientes } \\
\text { terrestres e marinhos, ricos em matéria orgânica. São } \\
\text { constituídos por espécies vegetais lenhosas típicas e } \\
\text { adaptadas ao ambiente salobro e um sedimento } \\
\text { predominantemente lodoso. }\end{array}$ & 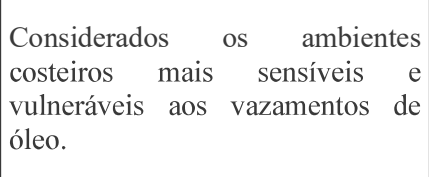 & 10 \\
\hline Apicuns & $\begin{array}{l}\text { Ambientes de ecótono estritamente associados aos } \\
\text { manguezais, constituídos por uma área salgada } \\
\text { desprovida de vegetação, salvo algumas espécies } \\
\text { herbáceas, configurando locais de baixa diversidade. }\end{array}$ & $\begin{array}{l}\text { Recebem impactos indiretos dos } \\
\text { vazamentos de óleo, } \\
\text { principalmente das ações de } \\
\text { limpeza. }\end{array}$ & $\begin{array}{l}\text { Vegetação adaptada ao } \\
\text { meio salobro, ou salgado; } 10 \\
\text { apicum. }\end{array}$ \\
\hline
\end{tabular}


(conclusão)

\begin{tabular}{|c|l|l|l|}
\hline $\begin{array}{c}\text { AMBIENTES } \\
\text { AFETADOS }\end{array}$ & \multicolumn{1}{|l|}{$\begin{array}{l}\text { CARL - ÍNDICE DE } \\
\text { SENSIBILIDADE }\end{array}$} \\
\hline LITORANEA (MMA)
\end{tabular}

Fonte: elaboração própria 


\subsection{Conclusões parciais}

O presente capítulo se dedicou a uma caracterização quase exaustiva das possibilidades de danos decorrentes de derramamentos de óleo no mar. O objetivo principal dessa caracterização foi demonstrar a grande diversidade de danos que podem ser observados em virtude desses incidentes. Não se pode chegar a discutir formas de responsabilização e de reparação sem antes haver a compreensão sobre o que recairá a responsabilidade e o que realmente deve ser reparado.

Do ponto de vista jurídico, muito embora os danos sejam aparentemente conhecidos, e determináveis, tanto a análise de jurisprudência quanto da doutrina consultada indicaram divergências de entendimentos acerca, por exemplo, da conceituação e do reconhecimento dos danos extrapatrimoniais, principalmente, no que tange à reparação daqueles considerados coletivos. O que se observa é que não basta o entendimento dos danos conforme o Direito Civil tradicional os apresenta. Para a temática aqui tratada, é imprescindível a completa compreensão acerca do que seria um dano ambiental, e mais, quais seriam as suas variações e possibilidades diante de eventos tão complexos, como os derramamentos de óleo no mar.

Entretanto, não se pretende aqui diminuir a importância da abordagem jurídica. Muito pelo contrário. O direito é essencial para que, após uma correta classificação dos danos, seja possível a identificação de todos os bens jurídicos lesados, e que são protegidos pelo ordenamento pátrio. Esta é uma etapa de extrema importância para a definição das formas de reparação.

Porém, o capítulo procurou enfatizar a necessidade de se recepcionar a caracterização dos danos por outras ciências. Os danos ecológicos estritos são aqueles que realmente vão revelar o quanto o meio ambiente foi afetado em todos os seus aspectos, considerando principalmente as perdas de funções ecossistêmicas, muitas vezes invisíveis. Se, por um lado, a compreensão desses danos leva à maior consciência de que são praticamente impossíveis de serem valorádos, dado ao alto grau de complexidade, por outro lado, apenas a partir do conhecimento aprofundado pode-se começar a pensar as possibilidades de formas alternativas de reparação, diferentes da indenização.

Ademais, o próprio conhecimento acerca dos aspectos biológicos e ecológicos dos danos pode ser um grande auxílio na solução das dúvidas jurídicas. Por exemplo, foi aqui demonstrado que a maioria da doutrina moderna considera o dano extrapatrimonial ambiental associado à perda de qualidade de vida, e não ao sofrimento. Mas como pode o magistrado 
determinar uma medida de reparação à perda de qualidade de vida sem entender quais fatores levaram a isso, ou o que isso seria exatamente?

Provavelmente, se ele considerar as análises de outras ciências sobre os mesmos danos, talvez seja mais fácil o estabelecimento de correlação entre os efeitos do óleo aos ecossistemas, à paisagem, ao lazer, e os reflexos de todos eles na perda da qualidade de vida de um grupo de indivíduos.

Assim, o que se entende aqui como cenário ideal é a aproximação de múltiplas abordagens na solução dos conflitos jurídicos. Não se pode mais considerar um dano ambiental a partir de uma única visão simplista de valoração econômica arbitrada. Apenas a partir da recepção de visões interdisciplinares de caracterização de danos será possível uma maior aproximação de justiça, que realmente promova a reparação de todos, ou da maioria dos bens lesados. 


\section{RESPONSABILIDADE CIVIL AMBIENTAL}

\subsection{A responsabilidade civil objetiva}

Preliminarmente, deve ser justificada a escolha realizada no presente trabalho pela abordagem dos danos decorrentes de derramamentos de óleo no mar a partir da Responsabilidade Civil Ambiental. Para tanto, cabe a ressalva inicial de que uma mesma conduta, ou atividade considerada lesiva ao meio ambiente pode ser alvo de responsabilização em três esferas distintas, conforme previsto no ordenamento jurídico brasileiro, ${ }^{432}$ quais sejam: civil, administrativa e penal. Assim, a preferência pelo estudo da responsabilização civil por danos ambientais se dá, principalmente, por conta de suas finalidades, em especial, de sua função reparatória. ${ }^{433}$

O principal objetivo desse estudo é investigar e analisar criticamente como o ordenamento jurídico busca garantir a reparação efetiva dos ambientes marinhos poluídos por óleo. Tendo em vista que o Direito Civil Ambiental prioriza a reparação à indenização, ${ }^{434}$ as reflexões aqui propostas não poderiam ser desenvolvidas em outro contexto, muito embora se reconheça a relevância das responsabilidades administrativa e criminal para os derramamentos de óleo, principalmente no que diz respeito ao caráter educativo que assumem - com finalidade última de atingir a prevenção de novas lesões ao meio ambiente.

Outro ponto decisivo na escolha da abordagem civil foi a possibilidade de se abranger a pluralidade de danos decorrentes dos derramamentos: ecológicos puros, patrimoniais e extrapatrimoniais. Conforme apresentado no capítulo anterior, é de extrema importância a

\footnotetext{
432 Art. 225, $\S 3^{\circ}$, da Constituição Federal de 1988: “Todos têm direito ao meio ambiente ecologicamente equilibrado, bem de uso comum do povo e essencial à sadia qualidade de vida, impondo-se ao Poder Público e à coletividade o dever de defendê-lo e preservá-lo para as presentes e futuras gerações. (...)§ $3^{\circ}$ As condutas e atividades consideradas lesivas ao meio ambiente sujeitarão os infratores, pessoas físicas ou jurídicas, a sanções penais e administrativas, independentemente da obrigação de reparar os danos causados".

${ }^{433}$ Nos termos de Machado: "A CF/88, com grande acuidade, agasalha os princípios da restauração, recuperação e reparação do meio ambiente no art. 225 . Em seu $\S 1^{\circ}$, I, aponta a obrigação de 'restaurar os processos ecológicos essenciais.' Esta disposição traduz a ideia de reencontrar a dinâmica que existia antes. No $\S 3^{\circ}$ do art. 225 consta a obrigação de reparar o dano causado ao meio ambiente. Acentua este parágrafo que a obrigação de reparar é independente da aplicação de sanções penais e administrativas." MACHADO, P. A. L. Direito Ambiental Brasileiro. São Paulo: Malheiros, $25^{\text {a }}$ ed., 2017, p. 428.

${ }^{434}$ Para Salles, nos termos registrados pelo Boletim Informativo da Escola Superior do Ministério Público de São Paulo: "Uma medida compensatória consiste em substituição por equivalente em valor pecuniário, não cumpre a função de restituir a característica coletiva do bem. Constata-se não interessar remédios judiciais de simples compensação. Medidas desse teor transformam em dinheiro valores sociais de natureza diversa, que não encontram correspondência nos parâmetros de mercado. Para cumprir sua função nessa esfera, os mecanismos processuais devem ser compreendidos e aplicados de maneira a conduzir à adoção de soluções capazes de impor condutas, de maneira a evitar o dano ou a reconstituir o bem lesado". SALLES, C. A. Execução judicial em matéria ambiental, Boletim Informativo da Escola Superior do Ministério Público de São Paulo. São Paulo, 15/8-12, out. 1998.
} 
correta caracterização dos danos ambientais para que a reparação não só jurídica, mas ecológica seja efetiva. Entretanto, antes mesmo de se adentrar às formas de reparação dos danos decorrentes de derramamentos de óleo, cumpre aqui melhor contextualizar os pressupostos, requisitos e princípios da responsabilidade civil ambiental.

Inicialmente, o instituto da responsabilidade civil foi pautado pela a ideia de vingança, de modo que a própria vítima buscava reparar o dano sofrido, por meio da chamada autotutela. Posteriormente, passou-se a buscar um equilíbrio entre o dano sofrido e a reação da vítima. A proporcionalidade entre conduta e o castigo se iniciou com a Lei de Talião: "olho por olho, dente por dente". Em seguida, a autotutela, mesmo que proporcional ao dano sofrido, cedeu espaço para a compensação pecuniária, tornando o patrimônio do autor um instrumento para a responsabilização pelos danos causados, com a finalidade de sancionar o ofensor e satisfazer o ofendido. $^{435}$

No entanto, a distinção entre os conceitos de "pena" e de "reparação" começou a ser pensada apenas pelos romanos, ao diferenciarem delitos públicos e privados, e o Estado passar a assumir, de forma exclusiva, a função de punir - e não mais a vítima. Esse contexto permitiu o surgimento da ação de indenização, e a responsabilidade civil foi devidamente separada da responsabilidade penal. ${ }^{436}$

Atualmente, o sistema de responsabilidade civil geral adotado pelo Código Civil brasileiro de 2002, baseia-se em três pilares: culpa, dano e nexo causal. ${ }^{437}$ Desse modo, para configurar a responsabilidade civil e, consequentemente, haver imposição do dever de indenizar, ou reparar um dano, é necessário demonstrar: (i) a culpa do ofensor e (ii) o nexo de causalidade entre a conduta danosa e o dano ocorrido - chamados de "filtros da responsabilidade civil", por funcionarem como potenciais óbices para o ressarcimento devido. ${ }^{438}$

435 ROSENVALD, N. As funções da responsabilidade civil: a reparação e a pena civil. São Paulo: Atlas, $2^{\mathrm{a}}$ ed., 2014, p.19-20.

${ }^{436}$ GONÇALVES, C. R. Responsabilidade civil: doutrina, jurisprudência. São Paulo: Saraiva, 6a ed., 1995, p. 4.

${ }^{437}$ SCHREIBER, A. Novos Paradigmas da Responsabilidade Civil: da erosão dos filtros da reparação à diluição dos danos. São Paulo: Atlas, $6^{\mathrm{a}}$ ed., 2015, p.11.

${ }^{438}$ SCHREIBER, A. Novos Paradigmas da Responsabilidade Civil: da erosão dos filtros da reparação à diluição dos danos. São Paulo: Atlas, 6ª ed., 2015, p.11. 
São observadas, contudo, incompatibilidades entre a construção do conceito clássico de responsabilidade civil e a complexa e dinâmica estrutura das sociedades atuais. ${ }^{439} \mathrm{Em}$ outras palavras, embora a responsabilidade civil tenha sido tradicionalmente construída com base no conceito de culpa, a necessidade de sua prova para responsabilização do ofensor acabava por deixar uma larga escala de danos sem cobertura jurídica, e sem a consequente indenização. Com isso, foi necessário reconhecer que alguns tipos de danos poderiam ser reparáveis sem a caracterização da culpa. ${ }^{440}$

Nesse sentido, portanto, há de se esclarecer que a responsabilidade civil pode ser dividida em contratual - que deriva de um contrato - e extracontratual ou aquiliana - atrelada ao descumprimento de norma. Por sua vez, a responsabilidade extracontratual subdivide-se em subjetiva ou delitual - baseada em culpa - e objetiva - que prescinde de culpa. ${ }^{441}$

A partir dessa evolução no Direito Civil, surgiu a responsabilidade civil objetiva, que torna irrelevante a intenção do agente de causar danos. Assim, o parágrafo único do artigo $927^{442}$ do Código Civil de 2002, prevê a obrigação de reparação do dano, independente de culpa, nos casos de atividade de risco ou especificados em lei. ${ }^{443}$ Nesse sentido, o mero fato de se exercer uma atividade de risco impõe o dever de reparar os danos dela originados, quando comprovado o nexo de causalidade com tal atividade, não sendo necessário, para tanto, comprovar a culpa. ${ }^{444}$ Porém, há de se entender que, pelo caráter alternativo da regra do artigo 927, "atividade de risco" não é elemento necessário, pois também há configuração da responsabilidade civil objetiva nos casos de expressa previsão legal.

Este é o caso da seara ambiental, na qual adota-se a responsabilidade civil objetiva, com fundamento na previsão legal dada pelo $\S 1^{\circ}$ do art. 14 da Lei Federal $n^{\circ}$ 6.938/1981, que

\footnotetext{
${ }^{439}$ Nas palavras de Hironaka: "No momento atual dessa mesma história, o conceito se encontra numa crise que decorre, não exatamente de suas falhas sutis de consistência, mas da incompatibilidade natural entre o conceito clássico (isto é, da passagem do século XVIII para o XIX) de responsabilidade civil e a estrutura extremamente dinâmica das sociedades atuais". HIRONAKA, G. M. F. N. Responsabilidade Pressuposta. São Paulo: Del Rey, 2005, p. 29-30.

440 PEREIRA, C. M. da S.. Instituições de direito civil, vol. 3: Contratos. Rio de Janeiro: Forense, 2012, p.542.

${ }^{441}$ AZEVEDO, A.V. Responsabilidade Civil em Sede de Poluição. Culpa do Poder Público. Ausência de Nexo Causal, Na Atividade das Poluidoras, e de Solidariedade entre elas. In: Doutrinas Essenciais. Responsabilidade Civil. Nelson Nery Junior e Rosa Maria de Andrade Nery. São Paulo: RT, v.8, 2010, p. 37.

${ }^{442}$ Art. 927 do Código Civil de 2002: "Aquele que, por ato ilícito (arts. 186 e 187), causar dano a outrem, fica obrigado a repará-lo. Parágrafo único. Haverá obrigação de reparar o dano, independentemente de culpa, nos casos especificados em lei, ou quando a atividade normalmente desenvolvida pelo autor do dano implicar, por sua natureza, risco para os direitos de outrem."

${ }^{443}$ LEMOS, P. F. I. Direito Ambiental: Responsabilidade civil e proteção do meio ambiente. São Paulo: RT, 2011, 3 a ed., p. 127.

${ }^{444}$ MILARÉ, É. Direito do ambiente. São Paulo: RT, $10^{\mathrm{a}}$ ed., 2015, p.420.
} 
estabelece a Política Nacional do Meio Ambiente (PNMA). Esse dispositivo obriga o poluidor a indenizar ou reparar os danos causados ao meio ambiente e/ou a terceiros que tenham sido afetados por sua atividade, independentemente da existência de culpa.

A PNMA, apesar de ser anterior à Constituição Federal de 1988, foi recepcionada integralmente pelo texto constitucional. Assim, nos casos de danos ao meio ambiente não se exige a demonstração da culpa do causador do dano, permanecendo somente os seguintes pressupostos imprescindíveis para a responsabilização: a ação/omissão, o dano e o nexo de causalidade. $^{445}$

No campo da ação ou omissão, cabe esclarecer que é irrelevante determinar a legalidade ou ilegalidade do ato, assim como identificar se a causa é principal ou assessória para incidir a responsabilidade civil ambiental. Ademais, de acordo com o art. 942 do Código Civil de $2002,{ }^{446}$ todos aqueles que contribuíram direta ou indiretamente para a ocorrência do dano respondem solidariamente. ${ }^{447}$

Assim, existindo mais de um agente causador de determinado dano, todos serão solidariamente responsáveis. Daí a importância de se adotar uma teoria do nexo de causalidade eficiente, que consiga delimitar adequadamente todas as (con)causas e, consequentemente, os causadores do dano ambiental. ${ }^{448}$

Isso significa que, na prática, cada um dos copoluidores poderá ser demandado para responder, sozinho, pela totalidade do dano ambiental, sendo-lhe facultado o direito de interpor ação regressiva contra os demais responsáveis solidários. A fundamentação legal da solidariedade passiva na reparação aos danos ambientais decorre do art. $3^{\circ}$, III, da PNMA, e do

\footnotetext{
${ }^{445}$ Para Cruz: "No campo da responsabilidade civil, o nexo causal cumpre uma dupla função: por um lado, permite determinar a quem se deve atribuir um resultado danoso, por outro, é indispensável na verificação da extensão do dano a se indenizar, pois serve como medida da indenização. Durante muito tempo, predominou o entendimento de que era a culpabilidade, e não a causalidade, que determinava a medida da responsabilidade. 'Tratava-se, contudo, de ponto de vista despido de conteúdo científico'. Para a determinação da extensão do dano indenizável, o que importa não é a gravidade ou o peso da culpa, mas o nexo de causalidade. (...) Na responsabilidade objetiva, em face da ausência dos parâmetros da ilicitude e da culpa, o nexo causal assume particular relevo. Nesse plano, a causalidade '(...) resulta de a origem dos danos se localizar na zona de risco normativamente definida'". CRUZ, G. S. da. O problema do nexo causal na responsabilidade civil. Rio de Janeiro: Renovar, 2005, p. 22-24.

446 A art. 942 do Código Civil de 2002: "Os bens do responsável pela ofensa ou violação do direito de outrem ficam sujeitos à reparação do dano causado; e, se a ofensa tiver mais de um autor, todos responderão solidariamente pela reparação".

${ }^{447}$ LEMOS, P. F. I. Direito Ambiental: Responsabilidade civil e proteção do meio ambiente. São Paulo: RT, $2011,3^{\text {a }}$ ed., p. 123 e ss..

${ }^{448}$ De acordo com Benjamim, em função da multiplicidade das causas, fontes e comportamentos, temos vivenciado o fenômeno da dispersão do nexo causal. BENJAMIN, A. H.V. Responsabilidade civil pelo dano ambiental. Revista de Direito Ambiental, São Paulo: RT, n.9, jan./mar., 1998, p. 5-52.
} 
art. 225, caput, da Constituição Federal de 1988, ao estabelecerem que são responsáveis pelo dano ambiental os poluidores diretos e indiretos, cabendo ao poder público e à coletividade a proteção do meio ambiente. ${ }^{449}$

Nesse sentido, é importante apontar que o Estado, ao deter o poder de licenciar, autorizar e fiscalizar as atividades consideradas como potencialmente poluidoras instaladas no país, pode ser responsabilizado solidariamente junto ao particular, ${ }^{450}$ quando deixar de cumprir seu poder de polícia de forma adequada.

Com relação ao dano, apesar da responsabilidade civil objetiva tradicional ser baseada na ausência de culpa, tal fator não exclui a necessidade da comprovação do dano concreto para o pleito de indenização, mesmo que haja violação de dever jurídico. ${ }^{451} \mathrm{O}$ capítulo 5 , anterior a este, tratou de caracterizar os diferentes tipos de danos ambientais, tanto em seus aspectos ecológicos, quanto jurídicos.

Por fim, apesar da doutrina e dos tribunais pátrios ainda não apresentarem um consenso acerca da teoria aplicável para delimitar o nexo causal nos casos de danos ao meio ambiente sendo várias as aplicáveis -, o presente trabalho adota a teoria do escopo da norma jurídica violada. ${ }^{452} \mathrm{~A}$ escolha se faz pelo fato de se acreditar que, principalmente para os casos de derramamentos de óleo em mar, o fator "risco" não é determinante, visto que, todas as possíveis atividades que possam resultar em derramamentos apresentam um considerável grau de risco ambiental. Da mesma forma, não se vislumbra uma causa adequada a produzir o dano, que seja a mais apropriada para formar o nexo causal. Antes disso, o ponto focal é o próprio dano.

\footnotetext{
${ }^{449}$ PINHO, H. G.. Prevenção e reparação e danos ambientais: as medias de reposição natural, compensatórias e preventivas e a indenização pecuniária. Rio de Janeiro: GZ Ed., 2010, pp. 160-161.

${ }^{450}$ LEMOS, P. F. I. Direito Ambiental: Responsabilidade civil e proteção do meio ambiente. São Paulo: RT, 2011, 3를. ed., p. 290-291.

${ }^{451}$ GONÇALVES, C. R. Direito Civil Brasileiro: responsabilidade civil. São Paulo, Saraiva, v.4, $7^{\mathrm{a}}$ ed., 2012 , p. 358.

${ }^{452}$ Nas palavras de Lemos: "Segundo essa teoria, a distinção entre os danos indenizáveis e não indenizáveis não deve tomar por base a causalidade adequada do fato, mas sim os reais interesses tutelados pelo fim do contrato ou pelo fim da norma legal. A teoria toma por base o fato de que não há um único critério válido para aferição do nexo causal, o que exige que o julgador considere a função da norma violada, para verificar se o evento danoso está sob sua proteção.”. LEMOS, P. F.I.. Meio ambiente e responsabilidade civil do proprietário. São Paulo: Revista dos Tribunais: 2008, p. 136. Cruz, por sua vez, assevera que: "Esta teoria - também conhecida como Teoria da Relatividade Aquiliana - se funda no pressuposto de que não é possível individualizar um critério único e válido para se aferir o nexo causal em todas as hipóteses de responsabilidade civil. Propõe-se, então, que o julgador se volte para a função da norma violada, para verificar se o evento danoso recai em seu âmbito de proteção. Por ouras palavras, quando o ilícito consiste na violação de regra imposta com o escopo de evitar a criação de um risco irrazoável, a responsabilidade estende-se somente aos eventos danosos que sejam resultado do risco em consideração do qual a conduta é vedada." CRUZ, G.S.O problema do nexo causal na responsabilidade civil. Rio de Janeiro: Renovar, 2005, p. 86-87.
} 
Sendo assim, as teorias que são fundamentadas no "risco criado", não são aplicáveis às hipóteses fáticas aqui analisadas. Ademais, é importante, contudo, diferenciar análise do risco para a responsabilidade por danos ambientais, da análise do risco como pressuposto para criação de apólices de seguros abrangendo danos por derramamentos, assunto abordado no capítulo 10 . Do mesmo modo, as teorias fundadas na causalidade também não se aplicam perfeitamente ao objeto desse estudo.

\subsubsection{Excludentes de responsabilidade}

Excludentes de responsabilidade civil são condições que afastam a obrigação de reparação do dano. Para Patrícia Iglecias Lemos, são requisitos necessários às excludentes de responsabilidade: a previsão legal, a configuração no caso concreto e a supressão da responsabilidade ao imputado. ${ }^{453}$ De acordo com o artigo 188 e seguintes do Código Civil brasileiro, são excludentes de responsabilidade: o caso fortuito e a força maior, os casos de legítima defesa, o exercício regular de um direito e a deterioração ou destruição de coisa alheia para afastar perigo iminente. Ademais, segundo o artigo 929 do mesmo código, sendo o dono da coisa deteriorada ou destruída culpado, o próprio deve arcar com as consequências. ${ }^{454}$

Os casos fortuitos ocorrem por interferência humana. Já a força maior é uma manifestação exclusiva da natureza, superior ao controle humano. ${ }^{455}$ No caso em que há fato de terceiro, pode haver exclusão da responsabilidade legal pela atividade perigosa, pois o dano é causado por um terceiro, que se torna responsável pelo prejuízo. ${ }^{456}$

São duas as teorias atreladas ao risco, que se relacionam à possibilidade de excludentes de responsabilidades. A primeira delas - adianta-se, adotada pela minoria dos magistrados brasileiros - é conhecida como "teoria do risco criado". Segundo esta teoria, aquele que desenvolve atividade que cria perigo ou expõe indivíduos a riscos de danos responde pelas consequências. Portanto, não há a necessidade de se verificar se a atividade voltava-se à obtenção de lucro, mas basta se averiguar o potencial danoso da atividade, de acordo com o artigo 927 do Código Civil de 2002. ${ }^{457}$

${ }^{453}$ LEMOS, P. F. I. Direito Ambiental: Responsabilidade civil e proteção do meio ambiente. São Paulo: RT, 2011, $3^{\text {a }}$ ed., p. 133.

${ }^{454}$ LEMOS, P. F. I. Direito Ambiental: Responsabilidade civil e proteção do meio ambiente. São Paulo: RT, 2011, $3^{\text {a }}$ ed., p. 133.

${ }^{455}$ MILARÉ, É. Direito do ambiente. São Paulo: RT, $10^{\mathrm{a}}$ ed., 2015, p.96.

${ }^{456}$ STOCO, R. Responsabilidade Civil e sua interpretação jurisprudencial. São Paulo: RT, $4^{a}$ ed., 1999, p.94.

${ }^{457}$ STOCO, R. Tratado de Responsabilidade Civil: doutrina e jurisprudência. São Paulo: RT, 7ª ed., 2007, p.161. 
Por meio dessa teoria, admite-se a quebra do nexo de causalidade que liga a atividade e o dano, quando identificadas as excludentes de responsabilidade civil. ${ }^{458}$ Portanto, é possível se eximir do dever de reparar o dano, quando constatado o caso fortuito, a força maior, o fato de terceiro, ou a culpa exclusiva da vítima.

Já a segunda teoria, majoritariamente adotada pelo Superior Tribunal de Justiça (STJ), é denominada "teoria do risco integral":

A teoria do risco integral constitui uma modalidade extremada da teoria do risco em
que o nexo causal é fortalecido de modo a não ser rompido pelo implemento das
causas que normalmente o abalariam (v.g. culpa da vítima; fato de terceiro, força
maior). Essa modalidade é excepcional, sendo fundamento para hipóteses legais em
que o risco ensejado pela atividade econômica também é extremado, (...). O mesmo
ocorre com o dano ambiental (art. 225 , caput e $\S 3^{\circ}$, da CF e art. 14 , $\S 1^{\circ}$, da Lei
$6.938 / 1981$ ), em face da crescente preocupação com o meio ambiente. ${ }^{459}$

Conforme claramente exposto pelo Min. Paulo de Tarso Sanseverino, para o STJ, a responsabilidade civil ambiental não se comporta em pleno acordo com a responsabilidade civil geral. Pelo contrário, apresenta "regras próprias e especiais sobre o assunto, que, no caso, não incluem qualquer norma mitigadora da reparação integral do dano". 460

Nesse sentido, o Direito Civil Ambiental Brasileiro não recepciona as hipóteses de excludentes de responsabilidades acima indicadas. Assim, em regra, se o dano foi gerado por atividade potencialmente degradadora, deve ao responsável o dever de reparar os danos, ressalvada sempre a hipótese de ação regressiva. ${ }^{461}$

Tal entendimento é recepcionado na presente tese para os casos específicos de derramamentos de petróleo no mar, uma vez que, já demonstrados o potencial lesivo e a amplitude de consequências espaciais e no tempo em decorrência desses danos, a reparação deve ser perseguida acima de tudo, não devendo ser admitidas hipóteses que excluam a responsabilidade. Deve-se ter em mente que as respostas aos danos precisam, na prática, ser imediatas e assumidas até mesmo de forma preventiva por aqueles que possuem o dever legal de reparação ambiental.

458 STEIGLEDER, A. M. Responsabilidade civil ambiental: as dimensões do dano ambiental no direito brasileiro. Porto Alegre: Livraria do Advogado, $2^{\mathrm{a}}$ ed., 2011, p.181.

${ }^{459}$ STJ. REsp 1.373.788-SP, Rel. Min. Paulo de Tarso Sanseverino, julgado em 6/5/2014.

${ }^{460}$ MIRRA, A. L. V. Ação civil pública e a reparação do dano ao meio ambiente. São Paulo: Juarez de Oliveira, $2^{a}$ ed., 2004.

461 BENJAMIN, H. Responsabilidade Civil pelo Dano Ambiental. In: NERY JUNIOR, N; NERY, R. M. de A. (Org.). Direito ambiental. São Paulo: RT, 2010, p. 501. 
A adoção da teoria do risco integral pela doutrina e jurisprudência majoritária deve, inclusive, ser observada na internalização de tratados e convenções, conforme brevemente pontuado no capítulo 4, visto que, por exemplo, a Convenção Internacional sobre Responsabilidade Civil em Danos Causados por Poluição por óleo, internalizada no Brasil pelo Decreto Legislativo $\mathrm{n}^{\circ} 74$, de 1976 , prevê claramente em seu artigo $3^{\circ}$, a possibilidade de o proprietário do navio ser eximido de responsabilidade por poluição no caso seja comprovado que o dano:

a) resultou de um ato de guerra, de hostilidade, de uma guerra civil, de uma insurreição ou de um fenômeno natural de caráter excepcional inevitável e irresistível, ou b) resultou totalmente de um ato ou omissão praticado por um terceiro com intenção de produzir danos, ou c) resultou integralmente de negligência ou de ato prejudicial de um governo ou de outra autoridade responsável pela manutenção de faróis de outros auxílios à navegação, no exercício dessa função.

Outro ponto importante, que será apresentado no capítulo 10, refere-se a apólices de seguros elaboradas por seguradoras estrangeiras e muitas vezes adotadas por embarcações brasileiras, que costumam contemplar em seus textos hipóteses de excludentes de responsabilidade civil. Nesses casos, o poluidor pode ser responsabilizado pelo judiciário brasileiro a reparar o dano por conta da teoria do risco integral, mesmo nos casos em que a seguradora não paga o prêmio por entender que alguma excludente prevista na apólice foi configurada.

Um último ponto que cabe aqui ser levantado seria referente às manchas órfãs. Conforme pontuado nos capítulos 2 e 4, os planos de área devem abranger o atendimento a esse tipo de ocorrência. Ou seja, muito embora terminais e operadores portuários não tenham dado causa às manchas oleosas, devem se responsabilizar pelas medidas de reparação. Tal situação se assemelha em parte à responsabilidade propter rem, defendida pelo Direito Civil, em que o proprietário, possuidor, ou usufrutuário de uma área deve responder por danos internos a ela, mesmo que não os tenha causado. Nesse caso, não se vislumbra excludente de responsabilidade. Ao contrário, há uma flexibilização de nexo causal ao se impor uma responsabilidade àquele que não deu causa ao dano.

O tratamento de manchas órfãs parece ir no mesmo sentido da responsabilidade propter rem, podendo, inclusive, gerar desdobramentos negativos a empresas que, ao assumirem a remediação de uma mancha, cometerem algum erro operacional, agravando os danos. Nesse caso, poderiam responder judicialmente não somente pela mancha, como pelos danos decorrentes de sua atuação. 


\subsubsection{Princípios da responsabilidade civil ambiental}

A responsabilidade civil ambiental é conduzida por princípios sociais, ${ }^{462}$ essenciais para a consolidação das funções propostas, como a de prevenção e a de reparação de danos. Dentre os princípios aplicáveis destacam-se: (i) prevenção; (ii) precaução; (iii) poluidor-pagador; (iv) desenvolvimento sustentável; e (iv) reparação integral.

Ambos os princípios da prevenção e da precaução buscam a adoção de medidas que impeçam ou atenuem a ocorrência de danos ambientais. Enquanto o princípio da prevenção é aplicado para atividades conhecidas, em que há certeza científica sobre os efeitos negativos para o meio ambiente; o princípio da precaução é utilizado para atividades cujas consequências não são conhecidas, havendo, portanto, incertezas científicas que devem ser sopesadas. ${ }^{463}$

O princípio da prevenção busca atuar antes mesmo do início do desenvolvimento da atividade potencialmente poluidora, impondo medidas que são tecnicamente conhecidas como mitigadoras para aqueles danos prováveis. Já o princípio da precaução será determinante nos casos em que não há conhecimento suficiente para saber o potencial danoso da atividade, mas há indícios de que os seres humanos podem ser efetivamente impactados. ${ }^{464}$

Ambos os princípios, apesar de apresentarem sutis diferenças, conferem ao Direito Civil Ambiental a função primária de imposição de responsabilidade antes mesmo à consumação do dano. "Ou seja, diante da pouca valia da simples reparação, sempre incerta e, quando possível, excessivamente onerosa, a prevenção é a melhor, quando não a única, solução", nos termos defendidos por Milaré. ${ }^{465}$

Já o princípio do poluidor-pagador pode ser entendido como a adoção pelo poluidor de todos os custos relacionados tanto à poluição, quanto à prevenção. Em outras palavras, além de impor ao poluidor os custos da reparação dos danos, deve ele arcar com todas as medidas necessárias para a prevenção de danos futuros ao meio ambiente. No entendimento de Herman Benjamin, ${ }^{466}$ o maior objetivo deste princípio é que os preços dos produtos fruto das atividades

462 STEIGLEDER, A. M. Responsabilidade civil ambiental: as dimensões do dano ambiental no direito brasileiro. Porto Alegre: Livraria do Advogado, 2a ed., 2011, p.156.

${ }^{463}$ LEMOS, P. F. I. Direito Ambiental: Responsabilidade civil e proteção do meio ambiente. São Paulo: RT, 2011, 3ㅜㅡ ed., p. 174-176.

464 MILARÉ, É.. Direito do ambiente. $10^{\mathrm{a}}$ ed., São Paulo: Revista dos Tribunais: 2015, pp. 263-265.

465 MILARÉ, É.. Direito do ambiente.10ª ed., São Paulo: Revista dos Tribunais: 2015, pp. 263-265.

${ }^{466}$ BENJAMIN, A. H.V..O princípio poluidor-pagador e a reparação do dano ambiental. In: BENJAMIN, A. H.

V.. (Coord.). Dano ambiental: prevenção, reparação e repressão. São Paulo: RT,1993. 
potencialmente poluidoras abarquem os custos das ações de proteção ao meio ambiente que foram adotadas.

Esse princípio reflete, segundo Milaré, a função "redistributiva do Direito Ambiental e se inspira na teoria econômica de que os custos sociais externos que acompanham o processo produtivo (v.g., o custo resultante dos danos ambientais) precisam ser internalizados".Com isso, o poluidor passa a assumir também as consequências sociais de seus atos, recaindo a ele a responsabilidade pelo dano ecológico em si, além dos danos reflexos. ${ }^{467}$

A expressão "desenvolvimento sustentável” surgiu publicamente em 1979, no simpósio das Nações Unidas sobre meio ambiente e desenvolvimento, com o objetivo de demonstrar que o crescimento econômico deveria ocorrer sem ultrapassar os limites da natureza; isto é, satisfazendo "as necessidades presentes, sem comprometer a capacidade das gerações futuras de suprir suas próprias necessidades." 468

O princípio foi abordado exaustivamente na Conferência das Nações Unidas sobre Meio Ambiente e Desenvolvimento, ocorrida no Rio de Janeiro, em 1992, inclusive sendo citado em 12 dos 27 os princípios da Declaração do Rio do mesmo ano. ${ }^{469}$ Ademais, mesmo antes disso, a Lei ${ }^{\circ}$ 6.938/1981 - Política Nacional de Meio Ambiente, principalmente em seu artigo 4º já havia declarado que o desenvolvimento econômico-social deve ser compatibilizado com a preservação da qualidade do meio ambiente e do equilíbrio ecológico. Também a Constituição Federal, de 1988, em seu artigo 170, inserido no Capítulo que trata da Ordem Econômica e Financeira, promove o desenvolvimento econômico e social desde que realizados em respeito a defesa do meio ambiente.

Nas palavras de Cristiane Derani, o desenvolvimento sustentável seria:

Um desenvolvimento harmônico da economia e ecologia que devem ser ajustados numa correlação de valores onde o máximo econômico reflita igualmente um máximo ecológico. Na tentativa de conciliar a limitação dos recursos naturais com o ilimitado

${ }^{467}$ MILARÉ, É.. Direito do ambiente. $10^{\text {a }}$ ed, São Paulo: Revista dos Tribunais: 2015, p. 268.

${ }^{468}$ A expressão "se tornou mundialmente conhecida quando foi adotada como principal bordão do "Nosso futuro comum", mais conhecido por "Relatório Brundtland". Esse documento foi apresentado em 1987 à Assembleia Geral das Nações Unidas pela Comissão Mundial sobre Meio Ambiente e Desenvolvimento. A partir de então, o termo "desenvolvimento sustentável" foi se legitimando como o maior desafio desse século. E saiu inteiramente consagrado da Conferência Rio-92". VEIGA, J. E. da; ZATZ, L. Desenvolvimento sustentável, que bicho é esse? Campinas: Autores Associados, 2008, p.38-39.

${ }^{469}$ ONU. Report of the United Nations Conference on Environment and Development. A/CONF.151/26. Rio de Janeiro: ONU, v.1. jun. 1992, p.3-14. Disponível em: < http://www.un.org/documents/ga/conf151/aconf15126-

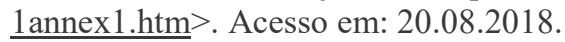


crescimento econômico, são condicionadas à consecução do desenvolvimento sustentável mudanças no estado da técnica e na organização social. ${ }^{470}$

Por fim, o princípio da reparação integral do dano ambiental pode ser entendido como a necessidade de se promover a máxima recomposição do ambiente degradado e será melhor abordado no capítulo a seguir, ao se discorrer sobre a reparação dos danos ambientais no Direito Civil.

\subsection{Conclusões parciais}

Este capítulo buscou contextualizar a escolha da abordagem da responsabilidade civil ao presente trabalho por ser a modalidade que persegue a reparação do dano. No caso ora analisado, o conceito tradicional de responsabilidade civil, baseado na culpa, não se aplica à temática aqui proposta, sendo necessário o entendimento dos mecanismos específicos que regem a responsabilidade civil ambiental.

O fato da reparação dos danos ser o principal elemento da responsabilidade civil ambiental faz com que ela deva ser garantida, independentemente de discussões acerca dos possíveis responsáveis. Fato esse que permite, inclusive, o reconhecimento da solidariedade. Entretanto, esse mesmo fator não admite possibilidades de exclusão de responsabilidade. Por isso, a teoria do risco integral é amplamente adotada nos julgados analisados.

Nesse sentido, as regras da responsabilidade civil ambiental devem ser muito bem compreendidas, inclusive no que tange (i) às normas jurídicas, as quais devem ser interpretadas dentro dos contextos em que são aplicadas; (ii) aos tratados e convenções recepcionados pelo país; (iii) aos seguros ambientais comercializados, muitas vezes elaborados com base nesses tratados, prevendo excludentes de responsabilidade

Há, entretanto, de atentar-se para o alargamento exacerbado da aplicação dessa responsabilidade na busca pela garantia da reparação indiscriminadamente. Conforme citado mais de uma vez ao longo do presente trabalho, no caso das manchas órfãs, há atribuição de responsabilidade à agentes que não apresentam nexo causal algum com o ocorrido. Tal fato pode, inclusive, ser alvo de questionamentos sobre uma eventual transferência de responsabilidade do Estado, que deveria zelar pelo meio ambiente, à terceiros. Obviamente, é notório que o Estado não possui estrutura, nem recursos, para a fiscalização e reparação de todas as manchas órfãs que surgem no litoral brasileiro.

${ }^{470}$ DERANI, C. Direito ambiental e econômico. São Paulo: Editora Max Limonad, 1997, p. 56. 
Porém, a iniciativa privada não tem o dever de assumir danos aos quais não apresenta relação alguma. Talvez, uma possível solução para essa lacuna possa ser a criação de fundos de arrecadação prévia, melhor detalhados no capítulo 9. 


\section{REPARAÇÃO DE DANOS AMBIENTAIS}

A reparação do dano ambiental surge na Constituição Federal de 1988 de forma expressa, por meio de seu art. $225,{ }^{471} \S 2^{\circ}$ e $\S 3^{\circ}$, e anteriormente já havia sido prevista no art. $4^{\circ}$, VII, $\S 1^{\circ}$ da Lei no 6.938/1981, que trata da Política Nacional do Meio Ambiente. É orientada especialmente pelos princípios do poluidor pagador, prevenção e reparação integral do dano. $\mathrm{O}$ item anterior, que tratou de responsabilidade civil por danos ambientais, abordou os três princípios e foi finalizado, de forma intencional, com uma breve introdução acerca da reparação integral. Exatamente esse último princípio é o principal fundamento utilizado pela doutrina brasileira para construção da visão civilista da reparação de danos ambientais, e será melhor aprofundado no presente capítulo.

Para o presente trabalho, o termo "Reparação", deve ser entendido lato sensu, como qualquer forma de reparação de danos. Em uma analogia à taxonomia das ciências biológicas, a Reparação seria classificada como "família", abrigando abaixo dela dois gêneros, o primeiro, seria a reparação ecológica e o segundo as formas alternativas de reparação. Por consequência, as espécies da reparação ecológica seriam: a restauração, a recuperação e a remediação. Já as espécies das formas alternativas de reparação seriam: a compensação ambiental (por equivalente, ou ecológica) e a indenização.

${ }^{471}$ Segundo o artigo 225, § $3^{\circ}$, da Constituição Federal do Brasil, de 1988: "as condutas e atividades consideradas lesivas ao meio ambiente sujeitarão os infratores, pessoas físicas ou jurídicas, a sanções penais e administrativas, independentemente da obrigação de reparar os danos causados." 
Figura 1 - Taxonomia da reparação ambiental.

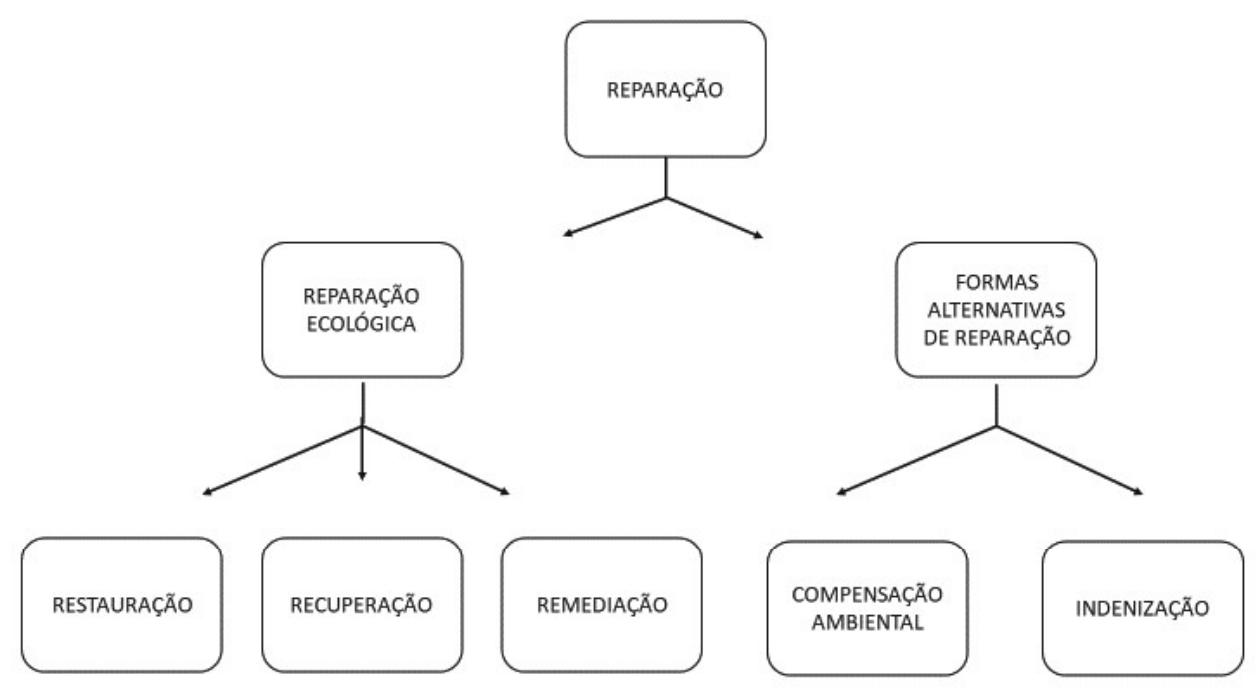

Fonte: elaboração própria

Entretanto, para melhor compreensão acerca da reparação ambiental, cumpre conceituar, inicialmente, as espécies de reparação ecológica: restauração, recuperação e remediação, as quais, muito embora apresentem semelhantes na grafia, expressam consideráveis diferenças práticas.

\subsection{Restauração, Recuperação e Remediação como espécies de reparação ecológica}

O termo Restauração é expressamente conceituado por meio do art. $2^{\circ}$, XIV, da Lei Federal $n^{\circ}$ 9.985/2000, sendo entendido como a "restituição de um ecossistema, ou de uma população silvestre degradada o mais próximo possível da sua condição original". No mesmo sentido, a Constituição Federal de 1988, no art. 225, parágrafo $1^{\circ}$, inciso I, ao determinar que os processos ecológicos essenciais sejam restaurados, sugere que se retome situação anterior ao dano, conhecido como status quo ante. Sendo assim, por meio da restauração ecológica buscase a restituição do ambiente a uma situação mais semelhante possível daquela originalmente identificada, antes da ocorrência do dano, visando a restauração do equilíbrio ecológico e ambiental. $^{472}$

Já o termo Recuperação, também presente na Lei Federal n 9.985/2000, porém no art. $2^{\circ}$, inciso XIII, seria a "restituição de um ecossistema ou de uma população silvestre degradada

\footnotetext{
472 PINHO, H. G. Prevenção e reparação de danos ambientais: as medidas de reposição natural, compensatórias e preventivas e a indenização pecuniária. Rio de Janeiro: GZ Ed, 2010, pp. 319-320.
} 
à uma condição não degradada, que pode ser diferente de sua condição original.". Por meio da recuperação se admite uma atuação mais concreta, dentro dos limites do possível, afastando-se da ideia utópica de se atingir uma condição de ambiente intocado.

Por sua vez, a remediação pode ser considerada uma terceira forma de "reparação" do dano ambiental. De acordo com o artigo $6^{\circ}$, XVII da Resolução CONAMA n 420/2009, seria "uma das ações de intervenção para reabilitação de área contaminada, que consiste em aplicação de técnicas, visando a remoção, contenção ou redução das concentrações de contaminantes".

A remediação, portanto, igualmente não visa à restauração in natura, mas sim, busca atender os limites de certos padrões de aceitabilidade de compostos químicos no solo e águas, permitindo a autorregulação ecológica do ambiente e o seu aproveitamento pelo homem de forma a não causar posteriores danos. Com isso, nem sempre as técnicas de remediação implicam na paralisação das atividades que originaram o dano.

A necessidade de se caracterizar as diferentes formas de reparação como alternativas possíveis, além da restauração se deve, principalmente, devido a dois fatores: o primeiro deles consiste na necessidade de que local afetado pelos danos permaneça sendo produtivo; e o segundo se dá pela dificuldade de se chegar a um nível de descontaminação próximo a zero.

Sabe-se que o ideal, principalmente para ambientes costeiros, tão frágeis e com tamanha importância ecológica, seria a aplicação da restauração pós derramamento de óleo. Entretanto, não se pode deixar de considerar que tais ambientes por si só já são alvos de contaminações históricas, além de serem parte integrante de rotas imutáveis de importância econômica para o país. Sendo assim, seria inviável a busca, por exemplo, da restauração ecológica plena de um estuário na região do Porto de Santos. Primeiramente, pelo fato de ser uma região que recebe há tempos aportes de diversos outros contaminantes além do óleo, não se sabendo quais seriam as reais condições naturais da área. Ademais, para se restaurar plenamente tal estuário, as atividades do porto e correlatas deveriam ser cessadas, o que é inviável do ponto de vista econômico.

Entretanto, muito embora a adoção da remediação para níveis aceitáveis aparente ser um processo simples e objetivo, acaba gerando algumas indagações. A primeira delas se dá em torno do seguinte aspecto: como determinar os padrões adequados para que a remediação seja uma medida ecologicamente eficiente?

Essa é a grande premissa que norteia todas as técnicas de remediação. Muito embora elas já sejam baseadas em alguns padrões pré-estabelecidos, devem respeitar as características típicas de cada ambiente específico. Sabe-se que muitos dos padrões e técnicas são adotados de 
experiências estrangeiras, a exemplo das técnicas de queima in situ e de uso de dispersantes para óleo no mar. Foram necessários longos debates e o desenvolvimento de estudos realizados de acordo com o perfil dos ecossistemas brasileiros, para que as técnicas fossem finalmente regulamentadas no Brasil. ${ }^{473}$

Entretanto, deve-se ter em mente que medidas de combate à poluição devem ser submetidas a estudos de melhoramento continuado. A eficiência ecológica de uma técnica de remediação deve sempre ser progressiva, de forma a se buscar cada vez mais o ideal de equilíbrio. Os padrões adotados, a princípio, podem ser baseados em uma tolerabilidade, mas devem sempre objetivar a melhoria da qualidade ambiental.

Para tanto, é indispensável o conhecimento dos amplos efeitos de substâncias químicas, que devem considerar, além das suas características próprias, a exemplo dos diferentes tipos de viscosidade do óleo e composições, os efeitos particulares em cada variação de ambiente, a exemplo do comportamento do óleo em relação às diferentes granulometrias de areias das praias.

Nas palavras de Thomas Berry, as técnicas devem ser aplicadas considerando um contexto regional, e não simplesmente cenários nacionais ou globais. Avança o autor, defendendo que "[a] Terra não nos é dada em uma só e global igualdade de condições: ela se articula em regiões diferenciadas". 474

\subsection{Os limites da restauração ecológica como forma de reparação}

A restauração ecológica do bem ambiental pode ser vista como a aplicação prática do princípio da reparação integral no seu aspecto ecológico, e deve ser a primeira das alternativas de reparação do dano, buscando a recomposição do ambiente ao status anterior à lesão. ${ }^{475}$

Entretanto, cumpre ressaltar que o princípio da reparação integral é mais abrangente, sendo considerado o princípio mais importante da responsabilidade civil ambiental, segundo Savi, ${ }^{476}$ uma vez que é fundamento no art. 225 da Constituição Federal de 1988, e no art. 14, § $1^{\circ}$, da Lei ${ }^{\circ} 6.938$, de 1981.Visa a reparação do dano em todos os seus aspectos, e permanece

\footnotetext{
${ }^{473} \mathrm{O}$ capítulo 4 do presente trabalho, ao tratar da legislação brasileira aplicável a derramamentos de óleo no mar aborda a Instrução Normativa do IBAMA n ${ }^{\circ}$ 07/2001, que trata dos testes de toxicidade que devem ser realizados nos dispersantes para que seja autorizada a sua utilização em águas nacionais, além da Resolução CONAMA ${ }^{\circ}$ 482/2017, que trata da "queima controlada emergencial como ação de resposta a incidentes de poluição por óleo no mar".

${ }^{474}$ BERRY, T. O Sonho da Terra. ALVES, Ephraim Ferreira (Trad.). Petrópolis: Editora Vozes, 1991, p.78-79.

${ }^{475}$ MILARÉ, É. Direito do ambiente. São Paulo: RT, $10^{\mathrm{a}}$ ed., 2015, p. 334.

${ }^{476}$ SAVI, S. Responsabilidade civil por perda de uma chance. São Paulo: Atlas, 2006, p.88.
} 
restrita aos seus limites, visto que a reparação não deve ir além do prejuízo sofrido, mas sim, ressarcir o dano produzido em consequência do fato danoso. ${ }^{477}$

O Direito Ambiental Brasileiro não recepciona o disposto no art. 944, $§ 1^{\circ}$, do Código Civil, que prevê, na hipótese de excessiva desproporção entre a gravidade da culpa e o dano, que possa o juiz minorar a indenização, não sendo admitidas causas que justifiquem a exclusão da reparação do dano ambiental. ${ }^{478}$ Mesmo porque o dano ambiental deve ser analisado dentro do sistema de responsabilidade civil objetiva.

Assim, o dano deve ser totalmente reparado, em respeito igualmente ao principio do poluidor pagador, cabendo ao causador do dano internalizar as externalidades negativas, assumindo todos os custos necessários à reparação dos bens ambientais lesados. ${ }^{479}$ Afinal, o Direito Ambiental tem como objetivo preservar o que já existe e recuperar o que deixou de existir, "garantindo a prevalência do interesse público ambiental (protegido de forma específica) face a outros interesses que não lhe são contrapostos". ${ }^{4} 0$

Entretanto, conforme pontuado, a reparação integral do dano ambiental não pode se restringir a restauração ecológica uma vez que, conforme explicado no capítulo 5, os danos ambientais são abrangentes e geram, além dos efeitos ecológicos e biológicos, perda de qualidade de vida, danos à saúde, extrapatrimoniais no geral e patrimoniais.

Nesse sentido, a reparação integral do dano ao meio ambiente não deve se limitar ao recurso ambiental diretamente atingido, mas sim, deve abarcar todos os possíveis danos produzidos em consequência do fato danoso, até mesmo as perdas de qualidade ambiental que se deram no lapso temporal entre o fato danoso e a efetiva recomposição do meio degradado, além dos danos futuros, e dos danos irreversíveis à qualidade ambiental. ${ }^{481}$

\footnotetext{
${ }^{477}$ Nos termos de Leite e Ayala: “A integralidade do dano ambiental pode implicar reparação superior à capacidade financeira do degradador. Todavia, a eventual aniquilação da capacidade econômica do agente não contradiz o princípio da reparação integral, pois este assumiu o risco de sua atividade e todos os ônus inerentes a esta". LEITE, J. R. M.; AYALA, P. de. Dano ambiental: do individual ao coletivo extrapatrimonial. Teoria e Prática. São Paulo:

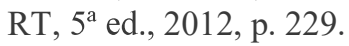

478 PINHO, H. G.. Prevenção e reparação de danos ambientais: as medias de reposição natural, compensatórias e preventivas e a indenização pecuniária. Rio de Janeiro: GZ Ed, 2010, pp. 327-330.

479 STEIGLEDER, A. M. Responsabilidade civil ambiental: as dimensões do dano ambiental no direito brasileiro. Porto Alegre: Livraria do Advogado, $2^{\mathrm{a}}$ ed., 2011, p.235.

${ }^{480}$ SENDIM, J. de S. C. Responsabilidade civil por danos ecológicos. Coimbra: Almedina, 2002, p.165-167.

${ }^{481}$ MIRRA, A. L. V. Ação Civil Pública e a Reparação do Dano Ambiental, $2^{\mathrm{a}}$ ed., São Paulo, Editora Juarez de Oliveira, 2004, p. 315.
} 
Sendo assim, a diversidade de possíveis danos diretos ou indiretos da lesão aos bens ambientais nem sempre será reparável por meio de uma restauração ecológica, até mesmo devido às dificuldades naturais em se identificar o cenário anterior ao dano, ou mesmo de recriálo novamente.

Para Pinho, "a degradação do meio ambiente é definitiva, porque o ambiente seja no meio natural ou cultural não pode jamais ser restabelecido com retorno ao estado inicial, em função de sua unicidade e irrepetibilidade". Restaria, portanto, a possibilidade de reparação aproximando o meio ambiente ao estágio anterior ao dano, e não às condições exatas em que se encontrava. Assim, avança a autora afirmando que o real foco deve ser "a restauração do equilíbrio ecológico e ambiental". 482

Do mesmo modo, Morato Leite expõe que "a natureza, ao ter suas composições física e biológica modificadas por agressões que ela não consegue tolerar, não pode jamais ser verdadeiramente restabelecida, do ponto de vista ecológico." Entretanto, o autor assegura que "a quase inviabilidade da recomposição do dano ambiental não redunda na irreparabilidade do mesmo". 483

Desse modo, deve-se entender a reparação integral no sentido de abrangência de todos os danos causados pela lesão ao meio ambiente ou em decorrência desta. A restauração seria apenas uma das formas de reparação, porém a mais difícil de se atingir, ao se basear no retorno ao status quo ante. Na inviabilidade de sua aplicação, ainda cabem a recuperação do ambiente aos limites possíveis, além da remediação dos danos. Apenas na impossibilidade das duas alternativas é que serão adotadas as formas alternativas de reparação, ou nos casos de danos patrimoniais e extrapatrimoniais.

Nesse sentido, é de extrema importância a superação da ideia que defende a adoção da indenização logo quando constatada a inviabilidade da restauração natural. Não se pode esquecer que, principalmente para os casos de danos ecológicos, deve sempre ser priorizada a reparação ecológica, sendo por meio da recuperação ou da remediação.

Principalmente para os casos de derramamentos de óleo no mar, a restauração ecológica nem sempre é possível, devido às diversas fontes de poluição além do óleo derramado. Os danos

\footnotetext{
482 PINHO, H. G.. Prevenção e reparação de danos ambientais: as medias de reposição natural, compensatórias e preventivas e a indenização pecuniária. Rio de Janeiro: GZ Ed, 2010, pp. 319-320.

${ }^{483}$ LEITE, J. R. M.; AYALA, P. de. Dano ambiental: do individual ao coletivo extrapatrimonial. Teoria e Prática.

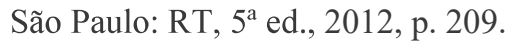


ambientais costumam ser em parte irreversíveis ou de difícil reparação. A restauração ecológica é dependente de conhecimento científico apurado tanto acerca das funções ecológicas danificadas, quanto das técnicas necessárias a resgatá-las integralmente, o que dificulta a obtenção de pleno sucesso em sua aplicação. Entretanto, as demais formas de reparação existem para que pelo menos uma parcela dos danos ecológicos seja recuperada, possibilitando ainda, uma reparação jurídica eficiente. ${ }^{484}$

Nesses casos, conforme exposto no capítulo 5, ao se tratar dos danos ecológicos, são adotadas técnicas que buscam minimizar os efeitos do derramamento, sendo pela retirada do óleo ou pela aplicação de dispersantes, por exemplo; ou mesmo pela técnica do do nothing, que considera o reestabelecimento natural do ambiente. Com isso, claramente o ambiente não é restaurado, mas é reparado até o possível. Assim, as formas alternativas de reparação deveriam vir como complementação à parcela dos danos não reparáveis por meio de restauração, recuperação ou remediação.

\subsection{As formas alternativas de reparação}

A partir do exposto nos itens acima, torna-se evidente a quase impossibilidade de se aplicar em um ambiente degradado a restauração ecológica, sendo, por vezes ainda viável a recuperação, ou remediação dos danos. Isso ocorre, simplesmente pelo fato da "natureza, ao ter suas composições física e biológica modificadas por agressões que ela não consegue tolerar, não pode jamais ser verdadeiramente restabelecida, do ponto de vista ecológico". ${ }^{485}$ Mirra, ao realizar tal constatação, faz uma analogia com monumentos históricos que, mesmo restaurados, não serão os mesmos monumentos, apresentando valores artísticos e históricos reduzidos.

Pois bem, com relação a bens ambientais, a situação seria ainda pior, pois os valores até poderiam ser mantidos, tanto que os métodos de valoração ambiental, que serão tratados no capítulo 8, buscam exatamente essa compensação. Entretanto, o que se perde muitas vezes são as funções ecossistêmicas dos ambientes, quando, por exemplo, um manguezal é massivamente degradado por um derramamento de óleo. A perda de funções ecossistêmicas é, inclusive, incalculável, além de acompanhada por danos que surgem tardiamente por conta de tal

\footnotetext{
${ }^{484}$ PINHO, H. G.. Prevenção e reparação de danos ambientais: as medias de reposição natural, compensatórias e preventivas e a indenização pecuniária. Rio de Janeiro: GZ Ed, 2010, p. 593.

${ }^{485}$ MIRRA, Á. L. V.. A reparação do dano ambiental. Trad. L'action civile publique du droit bresilien et la resparation du damage cause a l'environnement. Tradução atualizada pelo autor. Estrasburgo, França.Dissertação de Mestrado em Direito Ambiental, Faculdade de Direito, Universidade de Estraburgo, 1997, pp. 26-27.
} 
deficiência do ecossistema no geral. Ou seja, as medidas de reparação ainda deverão contemplar os danos futuros. ${ }^{486}$

Assim, para Morato Leite, até mesmo as formas de reparação ecológica do meio ambiente seriam um sucedâneo, por conta da grande dificuldade em se conseguir a restituição completa do bem lesado. Mesmo sendo uma forma de se compensar o prejuízo ambiental sofrido, defende o autor que "a quase inviabilidade da recomposição do dano ambiental não redunda na irreparabilidade do mesmo". Nesse sentido, surgem os meios jurisdicionais de reparação ambiental. ${ }^{487}$

Assim, admite-se que a reparação dos danos, em seu sentido abrangente, pode ocorrer de três formas, que serão possíveis, ou não, a partir da avaliação do caso concreto. A primeira delas, já demonstrada no presente capítulo, busca a restituição do ambiente ao estado anterior da lesão, ou a um estado próximo. Na impossibilidade da primeira, propõe-se a compensação pelo prejuízo (ambiental ou financeiro) sofrido. Por fim, na impossibilidade das duas primeiras, há uma última alterativa que busque a satisfação da vítima, ${ }^{488}$ por meio do pagamento de indenização pecuniária.

\subsubsection{Compensação ambiental}

Antes de se adentrar a compensação ambiental aqui proposta, como modalidade de reparação ambiental, cumpre ressaltar a diferença conceitual em relação à Compensação Ambiental definida no Artigo 36 da Lei Federal n 9.985/2000 (Sistema Nacional de Unidades de Conservação - SNUC), regulamentada pelo Decreto Federal n ${ }^{\circ} 4.340 / 2002$. A compensação ambiental do SNUC determina que, nos casos de licenciamento ambiental de empreendimentos de significativo impacto ambiental, o empreendedor é obrigado a apoiar a implantação e

\footnotetext{
${ }^{486}$ Nos termos de Ayala, Rodrigues e Silveira: "A influência de um princípio de prevenção ou de precaução na responsabilidade civil situaria uma dimensão alargada para a reparação de danos potenciais, por meio da antecipação da reparação de danos futuros, permitindo reconhecer um dever de reparação de danos não confirmados no presente, mas sobre os quais existe elevada probabilidade de concretização. Sua importância é ressaltada particularmente nos casos em que o conhecimento científico disponível não permite estabelecer uma conclusão sobre a periculosidade da atividade, processo ou produto, os quais, no futuro, poderão se revelar nocivos, como em casos de saúde e meio ambiente". AYALA, P. A.; RODRIGUES, E. de M. W.;SILVEIRA, P. G. Cumulação de Obrigação de Fazer, Não Fazer e de Indenizar: Comentários da Doutrina ao REsp 1.198.727-MG (Rel. Min. Herman Benjamin). Revista do Superior Tribunal de Justiça, Brasília: Superior Tribunal de Justiça, v. 239, tomo 1, p. 41-50, jul/ago/set 2015.

${ }^{487}$ LEITE, J. R. M.; AYALA, P. de. Dano ambiental: do individual ao coletivo extrapatrimonial. Teoria e Prática. São Paulo: RT, $5^{\text {a }}$ ed., 2012, p. 207.

${ }^{488}$ FARIAS, C. C. de; BRAGA NETTO, F. P.; ROSENVALD, N. Novo tratado de responsabilidade civil. São Paulo: Atlas, 2015, p.42.
} 
manutenção de Unidade de Conservação do Grupo de Proteção Integral, ou, no caso do empreendimento afetar uma Unidade de Conservação específica ou sua zona de amortecimento, ela deverá ser uma das beneficiárias da compensação ambiental mesmo que não pertença ao Grupo de Proteção Integral.

Assim, diferentemente dos critérios de compensação ambiental previstos no SNUC, ao se falar de compensação como forma de remediação defende-se que, quando tecnicamente a restauração natural é declarada impossível, deve-se considerar, primeiramente, a compensação por equivalente, que, nas palavras de Milaré, seria a "substituição do bem afetado por outro que lhe corresponda funcionalmente, em área de influência, de preferência direta, da degradada (restauração ex situ)" ${ }^{489}$ Desse modo, sempre que o bem ambiental lesado não for plenamente reabilitado, deve ser considerada a sua substituição por outro, dentro do possível, funcionalmente equivalente, buscando a reposição da qualidade ambiental que foi perdida. ${ }^{490}$

A compensação por equivalente, ${ }^{491}$ portanto, apresenta a equivalência por composição e a equivalência por função, devendo ser priorizadas áreas localizadas na mesma microbacia, e, se não for possível, o mais próximo possível do ambiente degradado. Quando não há a possibilidade de compensação por equivalente, aplica-se a compensação ecológica alternativa, que busca a reparação de um outro ambiente, sem equivalência em relação ao bem afetado, mas cujas funções e serviços ecossistêmicos que serão recuperados são importantes ao local originalmente degradado. ${ }^{492}$

\footnotetext{
${ }^{489}$ MILARÉ, É.. Direito do Ambiente, 10 edição. 2015. São Paulo. Revista dos Tribunais, p. 334.

${ }^{490}$ LEITE, J. R. M.; AYALA, P. de. Dano ambiental: do individual ao coletivo extrapatrimonial. Teoria e Prática. São Paulo: RT, $5^{\text {a }}$ ed., 2012, p. 211.

${ }^{491}$ Nos termos de documento elaborado pela Procuradoria Geral de Justiça: "A equivalência por composição tem como base o conjunto de espécies que compõem um centro de endemismo (espécies que se encontram em uma localidade) e suas comunidades biológicas. A equivalência por função deve levar em consideração as funçães ecossistêmicas. As diretrizes para o estabelecimento da equivalência funcional entre ambientes deve levar em conta critérios relacionados com os processos ecológicos essenciais, entendidos como aqueles que garantem a persistência e higidez das características típicas de composição, estrutura e funcionalidade do meio ambiente, envolvendo fluxos de energia, ciclos de matéria e relações funcionais estabelecidas no âmbito da estrutura biótica e abiótica, em constantes interações." BRASIL. Procuradoria Geral de Justiça. Ato PGJ n ${ }^{0}$ 36, de 06 de maio de 2011. Cria grupo de trabalho para análise e fixação de premissas relativas à valoração de dano ambiental. Diário Oficial da República Federativa do Brasil, Brasília, 07 de maio de 2011. Seção I, p. 28. Disponível em $<$ http://biblioteca.mpsp.mp.br/PHL_IMG/ATOS/036-2011.pdf>. Acesso em: 01.08.2018.

${ }^{492}$ BRASIL. Procuradoria Geral de Justiça. Ato PGJ n ${ }^{\circ}$ 36, de 06 de maio de 2011. Cria grupo de trabalho para análise e fixação de premissas relativas à valoração de dano ambiental. Diário Oficial da República Federativa do Brasil, Brasília, 07 de maio de 2011. Seção I, p. 11. Disponível em

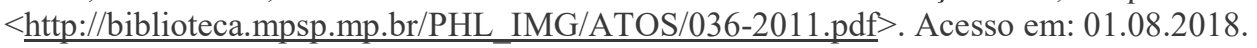


A compensação ambiental deve, portanto, ser considerada um instrumento subsidiário, ou complementar à restauração ecológica, ${ }^{493}$ mas que, apesar de ser uma forma de tutela ressarcitória, diferentemente da indenização, se dá por equivalente não-pecuniário, ${ }^{494}$ possibilitando que o meio ambiente receba diretamente uma medida de reparação.

O Código de Defesa do Consumidor (CDC), Lei Federal n ${ }^{\circ}$ 8078/1990, em seu artigo Art. 84, trata das obrigações de fazer, oferecendo medidas alternativas que possibilitem resultados práticos equivalentes à obrigação principal, impondo o ressarcimento em dinheiro como última opção:

Art. 84: Na ação que tenha por objeto o cumprimento da obrigação de fazer ou não fazer, o juiz concederá a tutela específica da obrigação ou determinará providências que assegurem o resultado prático equivalente ao do adimplemento. $\S 1^{\circ} \mathrm{A}$ conversão da obrigação em perdas e danos somente será admissível se por elas optar o autor ou se impossível a tutela específica ou a obtenção do resultado prático correspondente.

Tal premissa trazida pelo CDC é plenamente adaptável à obrigação de reparação de dano, entendendo-se a compensação como providências alternativas ou complementares à restauração natural, que asseguram o resultado prático de forma equivalente. Assim, a compensação deverá ser aplicada nas situações "de irrestaurabilidade do bem ambiental, ou de restauração ecológica ou ambiental parcial, com a persistência de remanescentes irrecuperáveis", como sintetiza Pinho. ${ }^{495}$

A compensação por equivalente ecológico, passa a ser uma possibilidade que deve ser priorizada à indenização pecuniária, pois ainda garante de certa forma a fruição do bem ambiental, vez que o valor econômico não é capaz de substituir a existência do meio ambiente ecologicamente equilibrado, nem mesmo a fruição desse direito fundamental garantido pelo artigo 225 da Constituição Federal de 1988. ${ }^{496}$

Entretanto, na aplicação prática da compensação ambiental, seja ecológica seja por equivalente, como modalidade de reparação de danos, os ambientes eleitos não podem ser plenamente preservados, visto que o objetivo é justamente "a reconstituição ou melhoria de

${ }^{493}$ LEITE, J. R. M.; AYALA, P. de. Dano ambiental: do individual ao coletivo extrapatrimonial. Teoria e Prática.

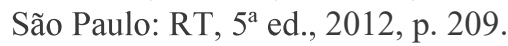

${ }^{494}$ PINHO, H. G. Prevenção e reparação de danos ambientais: as medidas de reposição natural, compensatórias e preventivas e a indenização pecuniária. Rio de Janeiro: GZ Ed, 2010, p. 593.

${ }^{495}$ PINHO, H. G. Prevenção e reparação de danos ambientais: as medidas de reposição natural, compensatórias e preventivas e a indenização pecuniária. Rio de Janeiro: GZ Ed, 2010, pp. 593-594.

${ }^{496}$ MILARÉ, É. Direito do ambiente. São Paulo: RT, 10a ed., 2015, p.334-335. 
outro bem ou sistema ambiental equivalente ao afetado". Deve, portanto, ser possível a restituição de funções e serviços ecossistêmicos. ${ }^{497}$

A escolha da forma de compensação deve partir, obrigatoriamente, da caracterização do dano e de suas consequências. Devem ser analisados os bens, as funções e os serviços ecossistêmicos afetados, tanto do ponto de vista quantitativo, quanto qualitativo, considerando os meios físico, biótico e socioeconômico. Não se pode ignorar ainda, características do dano como cumulatividade, sinergia, ou se ele é agudo ou crônico, temporário ou permanente. Devese sempre visar ao reestabelecimento dos processos ecológicos essenciais. ${ }^{498}$

Ademais, as medidas escolhidas para a compensação devem atender aos princípios de equivalência, razoabilidade e proporcionalidade. ${ }^{499}$ Outro ponto de destaque se refere ao fato de a compensação ser integral ou complementar a alguma forma de reparação. Conforme pontuado, a prioridade seria sempre a reparação ecológica. A escolha da compensação pode ocorrer tanto na impossibilidade da reparação ecológica, como a título de medida complementar. A Diretiva 2004/35/CE da União Europeia aborda quatro tipos de medidas de reparação de danos ambientais causados "à água, às espécies e habitats naturais protegidos, sendo: medidas de reparação primária, complementar, reparação compensatória e perdas transitórias". 500 A reparação compensatória seria exatamente aquela complementar a alguma

\footnotetext{
${ }^{497}$ BRASIL. Procuradoria Geral de Justiça. Ato PGJ no 36, de 06 de maio de 2011. Cria grupo de trabalho para análise e fixação de premissas relativas à valoração de dano ambiental. Diário Oficial da República Federativa do Brasil, Brasília, 07 de maio de 2011. Seção I, p. 21. Disponível em $<$ http://biblioteca.mpsp.mp.br/PHL_IMG/ATOS/036-2011.pdf>. Acesso em: 01.08.2018.

${ }^{498}$ BRASIL. Procuradoria Geral de Justiça. Ato PGJ no 36, de 06 de maio de 2011. Cria grupo de trabalho para análise e fixação de premissas relativas à valoração de dano ambiental. Diário Oficial da República Federativa do Brasil, Brasília, 07 de maio de 2011. Seção I, p. 50. Disponível em

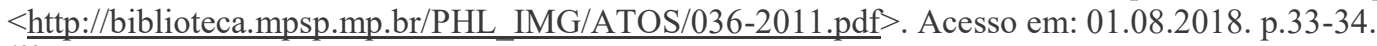

499 O Código Civil dá início a discussão sobre elementos ou parâmetros a serem considerados no valor da indenização, conforme os arts. 944, 945, 946 e ss., que serão abordados no próximo capítulo.

${ }^{500}$ PARLAMENTO EUROPEU; CONSELHO EUROPEU. Diretiva 2004/35/CE. Jornal Oficial da União Europeia. Publicado em 30.4.2004, p. 67. Conforme Anexo II: "Reparação dos Danos Ambientais 1. Reparação de danos causados à água, às espécies e habitats naturais protegidos A reparação de danos ambientais causados à água, às espécies e habitats naturais protegidos é alcançada através da restituição do ambiente ao seu estado inicial por via de reparação primária, complementar e compensatória, sendo: a) Reparação «primária», qualquer medida de reparação que restitui os recursos naturais e/ou serviços danificados ao estado inicial, ou os aproxima desse estado; b) Reparação «complementar», qualquer medida de reparação tomada em relação aos recursos naturais e/ou serviços para compensar pelo facto de a reparação primária não resultar no pleno restabelecimento dos recursos naturais e/ou serviços danificados; c) Reparação «compensatória», qualquer acção destinada a compensar perdas transitórias de recursos naturais e/ou de serviços verificadas a partir da data de ocorrência dos danos até a reparação primária ter atingido plenamente os seus efeitos; d) «Perdas transitórias»: perdas resultantes do facto de os recursos naturais e/ou serviços danificados não poderem realizar as suas funções ecológicas ou prestar serviços a outros recursos naturais ou ao público enquanto as medidas primárias ou complementares não tiverem produzido efeitos. Não consiste numa compensação financeira para os membros do público." Disponível em: $<\underline{\text { https: } / / \text { eur- }}$ lex.europa.eu/LexUriServ/LexUriServ.do?uri=OJ:L:2004:143:0056:0075:pt:PDF> Acesso em: 18.08.2018.
} 
medida de reparação ecológica, e deve sempre visar a recomposição das funções ecossistêmicas do ambiente.

Com relação a área que será reparada por medida compensatória, a escolha deve considerar alguns critérios, sendo eles: "urgência, risco, tempo, custos financeiros, chancela da comunidade atingida, possibilidade de êxito, relação geográfica com o sítio originalmente danificado e restauração de funções ecológicas perdidas no sítio originalmente degradado". ${ }^{501}$

Assim, preza-se pela proximidade ao local afetado na escolha da compensação, vez que justamente ele deverá ser beneficiado de alguma forma, mesmo que indiretamente, assim como a comunidade no entorno. Nesse sentido, defende-se aqui inclusive a possibilidade de adoção de mecanismos de compensação ambiental até mesmo para danos extrapatrimoniais difusos e coletivos, visto que, dificilmente o pagamento de indenizações será revertido à perda de qualidade de vida da população local.

Mais especificamente, a título exemplificativo, uma vez constatado dano extrapatrimonial coletivo, em decorrência de um derramamento, por perda de qualidade de vida de uma comunidade que vive na praia, ao invés do pagamento de eventual indenização ser direcionado a um fundo de direitos difusos, poderia ser determinada uma medida de compensação que melhorasse a qualidade de vida dessa população, por exemplo, com o desenvolvimento de projetos socioambientais específicos para a região. Entretanto, tais medidas ainda não são comuns em decisões judiciais, sendo menos incomuns em Termos de Ajustamento de Conduta.

Assim, em suma, sendo nos casos de danos ecológicos puros, ou até mesmo nos casos dos danos extrapatrimoniais difusos e coletivos, apenas nos casos de inviabilidade da restauração ou da compensação ambiental, deve-se optar pela a indenização pecuniária, ${ }^{502}$ conforme será melhor apresentado ao final do presente capítulo.

${ }^{501}$ PINHO, H. G.. Prevenção e reparação de danos ambientais: as medidas de reposição natural, compensatórias e preventivas e a indenização pecuniária. Rio de Janeiro: GZ Ed, 2010, p. 445.

502 GONÇALVES, C. R. Direito Civil Brasileiro: responsabilidade civil. São Paulo, Saraiva, v.4, 7 ed., 2012 , p. 359. 


\subsubsection{A compensação ambiental nos Termos de Ajustamento de Conduta}

Os Termos de Ajustamento de Condutas (TACs) são compromissos firmados entre os órgãos públicos legitimados ${ }^{503} \mathrm{e}$ os causadores do dano a um direito coletivo, com a finalidade de ajustar as condutas às exigências legais, reparando o dano causado (conforme art. $5^{\circ}, \S 6^{\circ}$, da Lei Federal $\left.n^{\circ} 7.347 / 1985\right)$. Referido instrumento é respaldado pelo art. $5^{\circ}, \S 6^{\circ}$, da Lei Federal $\mathrm{n}^{\circ} 7.347 / 1985$, a qual disciplina a ação civil pública de responsabilidade por danos causados ao meio-ambiente (por isso, também conhecida como "Lei da ação civil pública").

No que tange ao Ministério Público, a Resolução n 179/2017 de seu Conselho Nacional ${ }^{504}$ regulamenta o art. $5^{\circ}, \S 6^{\circ}$, da Lei da ação civil pública, disciplinando a tomada do compromisso de ajustamento de conduta no âmbito deste órgão. Nessa mesma Resolução, o artigo $5^{\circ}, \S 1^{\circ}$, determina que é admissível, quando não for possível a reconstituição específica do bem lesado, que os termos de ajustamento de conduta pré-determinem a destinação de recursos para: (i) projetos de prevenção ou reparação de danos de bens jurídicos da mesma natureza; (ii) apoio a entidades cuja finalidade institucional inclua a proteção aos direitos ou interesses difusos; (iii) depósito em contas judiciais; ou (iv) destinação específica que tenha a mesma finalidade dos fundos previstos em lei, ou esteja em conformidade com a natureza e a dimensão do dano. Ainda, o art. $5^{\circ}, \S 2^{\circ}$, dessa mesma Resolução determina que os valores referentes às medidas compensatórias deverão ser, preferencialmente, revertidos em proveito da região ou pessoas impactadas.

Nesse sentido, e com relação à aplicação prática dos TACs na esfera ambiental, Pinho desenvolveu pesquisa, em 2004, com 55 promotores de justiça atuantes na área. Nessa oportunidade, $73 \%$ dos entrevistados afirmaram adotar a medida de aplicação prática da compensação ambiental nos TACs celebrados. Dentre as formas de compensação adotadas nesses compromissos, a principal medida citada foi a aquisição de equipamentos destinados a órgãos de fisscalização, seguida pela aplicação em restauração de áreas degradadas.

Tais resultados levaram a autora a algumas conclusões, diante da constatação da real aplicação da compensação ambiental por promotores de justiça via TACs: ao menos nos TACs,

\footnotetext{
${ }^{503}$ Nos termos do art. $5^{\circ}$ da Lei Federal $n^{\circ} 7.347 / 1985$, que disciplina a ação civil pública de responsabilidade por danos causados ao meio-ambiente, ao consumidor, a bens e direitos de valor artístico, estético, histórico, turístico e paisagístico e dá outras providências.

${ }^{504}$ CONSELHO NACIONAL DO MINISTÉRIO PÚBLICO. Resolução $\mathbf{n}^{\mathbf{0}}$ 179, de 26 de julho de 2017. Regulamenta o $\S 6^{\circ}$ do art. $5^{\circ}$ da Lei $n^{\circ} 7.347 / 1985$, disciplinando, no âmbito do Ministério Público, a tomada do compromisso de ajustamento de conduta.
} 
diferentemente das Ações Judiciais, a adoção da compensação é considerada uma solução alternativa à restauração ecológica e eficaz. Entretanto, a autora salienta que, por meio de suas pesquisas, observou a necessidade de um maior apoio técnico para a determinação dos valores a serem aplicados nas medidas compensatórias. Ressaltou ainda a ausência de critérios comuns entre os promotores, sendo importante a construção tanto de um referencial doutrinário mais expressivo, quanto de um contexto regulatório mínimo para todo o país.

Por sua vez, a análise dos TACs firmados nos casos mais emblemáticos de derramamentos de óleo no mar do Brasil foi realizada de forma aprofundada no capítulo 3 deste trabalho. Nesse capítulo, constatou-se que diversos TACs priorizaram medidas de compensação ambiental em detrimento da indenização, de forma a beneficiar diretamente o ambiente afetado com as medidas.

A mero título exemplificativo, cita-se o TAC firmado entre Chevron, MPF, ANP e IBAMA, que fixa, entre outras obrigações, a de executar medidas compensatórias com

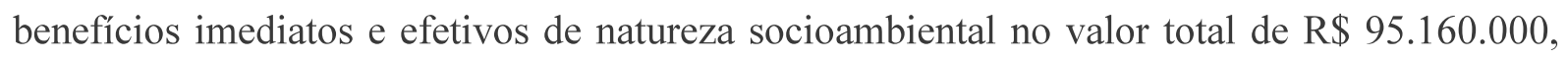
conforme projetos previamente aprovados pelo MPF, ouvidos a ANP e IBAMA.

\subsection{Indenização}

A indenização é forma alternativa válida de reparação de danos ambientais, nos termos do art. $225, \S 3^{\circ}$, da Constituição Federal: "As condutas e atividades consideradas lesivas ao meio ambiente sujeitarão os infratores, pessoas físicas ou jurídicas, a sanções penais e administrativas, independentemente da obrigação de reparar os danos causados".

A CF/1988 igualmente aborda a indenização, em seu art. $5^{\circ}, \mathrm{V}$ e X, reconhecendo sua aplicação diante de danos morais. ${ }^{505} \mathrm{~A}$ indenização pode ser entendida nos casos ora analisados, a grosso modo, como o pagamento, em pecúnia, de valor equivalente à lesão gerada ao meio ambiente, valor este que será identificado de acordo com o método de valoração do dano escolhido, conforme será explorado no capítulo 8.Os valores pecuniários arrecadados em função de indenizações de lesões ao meio ambiente ficam depositados em fundos de direitos difusos, federal ou estadual, nos termos do art. 13 da Lei Federal $n^{\circ} 7.347 / 1985$, devendo ser destinados à compensação ecológica. ${ }^{506}$

${ }^{505}$ LEMOS, P. F. I.. Meio Ambiente e responsabilidade civil do proprietário: análise do nexo causal. São Paulo: RT, 2008, p. 120.

${ }^{506}$ LEITE, J. R. M.; AYALA, P. de. Dano ambiental: do individual ao coletivo extrapatrimonial. Teoria e Prática.

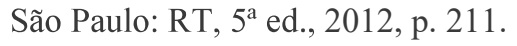


Apesar da indenização pecuniária ser abordada no capítulo 8 deste trabalho, cabe, no presente capítulo, analisar se existe prioridade entre as duas formas alternativas de reparação ambiental (ou seja, entre a compensação e a indenização), e como devem ser aplicadas na prática.

Inicialmente, cabe a ressalva de que a doutrina é pacífica acerca da priorização à reparação do meio ambiente em detrimento da mera indenização pecuniária, quando se trata de responsabilidade civil ambiental. ${ }^{507}$ Nesse sentido, Leite e Ayala indicam que a ordem das obrigações de restaurar e/ou indenizar, conforme redigidas nos arts. $4^{\circ}$, VII, e $14, \S 1^{\circ}$, ambos da Lei 6.938/1981, e no art. 225, $\S 3^{\circ}$, da Constituição Federal de 1988, tornam clara a intenção do legislador de priorizar a restauração do bem ambiental e, apenas quando inviável, partir-se para a indenização por sucedâneo ou compensação. ${ }^{508} \mathrm{Na}$ mesma linha, Milaré defende que apenas nos casos em que a restauração in natura for inviável ou insuficiente, fática ou tecnicamente, será admitida a indenização pecuniária, como forma indireta de sanar a lesão ambiental. $^{509}$

Importante ressaltar que o dano ecológico puro normalmente não é reparado integralmente através da restauração ecológica in situ, e apenas nessa hipótese é admissível adotar medidas compensatórias ${ }^{510}$ e de indenização pecuniária - sendo esta última considerada remédio subsidiário e excepcional de medidas de reposição natural e compensatórias. ${ }^{511}$ Dessa forma, e seguindo o princípio da reparação integral, é possível cumular a condenação do poluidor ao pagamento de indenização juntamente com obrigações de fazer voltadas à prevenção de danos futuros ou à medidas compensatórias. ${ }^{512}$

Melo defende ser necessária a reparação do dano ambiental de forma integral, admitindo formas de reparação cumuladas, por restauração, ou compensação do dano além da indenização pecuniária. ${ }^{513}$ Nos mesmos termos, a Súmula no 629 do STJ indica que: "Quanto ao dano

507 MACHADO, P. A. L. Direito Ambiental Brasileiro. São Paulo: Malheiros, 25 ed., 2017, p. 431-432.

${ }^{508}$ LEITE, J. R. M.; AYALA, P. de. Dano ambiental: do individual ao coletivo extrapatrimonial. Teoria e Prática.

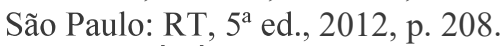

${ }^{509}$ MILARÉ, É.. Direito do ambiente. $10^{a}$ ed. São Paulo: Editora Revista dos Tribunais 201, pp. 335-336.

${ }^{510}$ PINHO, H. G.. Prevenção e reparação de danos ambientais: as medidas de reposição natural, compensatórias e preventivas e a indenização pecuniária. Rio de Janeiro: GZ Ed, 2010, p. 411.

511 PINHO, H. G.. Prevenção e reparação de danos ambientais: as medidas de reposição natural, compensatórias e preventivas e a indenização pecuniária. Rio de Janeiro: GZ Ed, 2010, p. 519.

${ }^{512}$ MAZZILLI, H. N.. A Defesa dos Interesses Difusos em Juízo, $21^{\text {a }}$ ed., São Paulo, Saraiva, 2008, p. 140.

${ }^{513}$ MELO, M. E. Restauração ambiental: do dever jurídico às técnicas. São Paulo: Livraria do Advogado, 2012. 
ambiental, é admitida a condenação do réu à obrigação de fazer ou à de não fazer cumulada com a de indenizar".

Portanto, da análise realizada, conclui-se que a indenização pecuniária é meio adequado de reparar danos patrimoniais e deve ser adotada nos casos de danos extrapatrimoniais com as ressalvas já indicadas neste mesmo capítulo. No entanto, nos casos de dano ecológico puro, a indenização pecuniária deve ser a última opção de reparação do meio ambiente.

\subsection{Conclusões parciais}

O presente capítulo trouxe as diversas possibilidades admitidas pelo Direito Civil Ambiental dentro do conceito macro de reparação ambiental. Muito embora a função principal reparatória, a ser priorizada pelo Direito, seja a restauração, o próprio aprofundamento do conhecimento acerca dos danos ecológicos leva a entender que, nos casos de derramamentos de óleo no mar, o retorno ao estado original do ambiente, na maioria das vezes, não é possível integralmente. Isso compreenderia sanar completamente a inúmera gama de danos verificada no capítulo 5.

Porém, isso não quer dizer que, na impossibilidade da restauração deve-se recorrer à indenização. Pelo contrário. Antes mesmo de se adentrar nas desvantagens ambientais da indenização, que serão apresentadas nos capítulos seguintes, foi necessária a elaboração do presente capítulo para demonstrar que, não somente a indenização deve ser a última opção, como há pelo menos três formas de reparação que devem ser adotadas antes dela, a exemplo da recuperação, da remediação, e, principalmente, da compensação ambiental. Se possível, até mesmo soluções que levem em conta as três formas, de maneira complementar, devem ser priorizadas.

A regra a ser seguida é muito simples, apesar do desafio ser complexo ao ponto de motivar a elaboração da presente tese. Deve-se buscar aquela alternativa que leve ao meio ambiente e à qualidade de vida das pessoas o retorno mais imediato. Partindo-se desse ponto, as dificuldades encontradas nas caracterizações dos danos vão conduzir a escolha da forma de reparação mais adequada.

Por meio das ações judiciais analisadas pode-se notar que cada vez mais os desfechos dos conflitos envolvendo derramamentos de óleo no mar estão sendo realizados por meio de acordos. Os Termos de Ajustamento de Conduta são instrumentos que abrangem inúmeras possibilidades de formas de reparação dos danos e, principalmente, permitem o acompanhamento e a fisscalização das medidas acordadas. Sem dúvida podem ser uma 
alternativa segura de se viabilizar o benefício direto aos ecossistemas afetados pelo óleo, promovendo uma reparação limitada na medida do possível, mas mais eficiente do que um simples pagamento de indenização. 


\section{INDENIZAÇÃO PECUNIÁRIA NA RESPONSABILIDADE CIVIL POR DERRAMAMENTOS DE ÓLEO NO MAR}

\subsection{Aplicabilidade da indenização pecuniária no Direito Civil Ambiental}

Apesar do Direito Civil Ambiental prezar pelo resgate do ambiente atingido, não se pode deixar de reconhecer que, em alguns casos, é constatada não somente a inviabilidade de restauração, mas igualmente de compensação do dano. A reparação integral passa a ser vista como possível apenas do ponto de vista jurídico, visto que, para a Ecologia, a matéria e a energia perdidas em decorrência de um dano ambiental são irrecuperáveis, tornando-o irreversível. ${ }^{514}$ Porém, tal fato não pode servir de escusa para se buscar o ressarcimento pela lesão ambiental causada. Na verdade, devem ser priorizados todos os meios que possibilitem a reparação do bem ambiental. ${ }^{515}$

A indenização seria, portanto, a última alternativa de busca pela reparação de danos ambientais, dentre as possíveis para o Direito Civil, ou pode ser admitida ainda como medida cumulativa às outras duas principais: restauração e compensação. Muito embora a indenização deva ser exceção na responsabilidade civil por danos ambientais, a partir da análise de julgados envolvendo derramamentos de óleo, desenvolvida no capítulo 3 do presente trabalho, observouse nos acórdãos selecionados a adoção da indenização como forma de reparação primordial, até mesmo em situações cujos relatos indicavam a pertinência da adoção da restauração parcial dos danos, ou da compensação ambiental.

Ocorre que, as dificuldades práticas na determinação de medidas de remediação eficientes cada vez mais induzem os tribunais brasileiros ao arbitramento de indenizações. Não se pode negar que, para a determinação de medidas de remediação efetivas, há a necessidade de uma análise complexa e interdisciplinar acerca dos ambientes afetados, que requer tempo e gastos. Ademais, nos casos práticos não são raras as divergências acerca do que seria ou não reparável. Dessa forma, os danos acabam valorados, e ao réu é imposto um valor a ser pago a título de reparação.

Entretanto, na aplicação da valoração ambiental ao direito, o cálculo da indenização deve ponderar a falta de familiaridade dos juristas com fórmulas matemáticas e dados técnicos.

\footnotetext{
${ }^{514}$ BERTÃo, S. F. Técnicas. Valoração econômica de danos ambientais. Revista Jurídica do Ministério Público do Estado de Minas Gerais, Belo Horizonte: MPMG, n.9, jul./dez. 2007, p.389.

${ }^{515}$ LEITE, J. R. M.; AYALA, P. de. Dano ambiental: do individual ao coletivo extrapatrimonial. Teoria e Prática. São Paulo: RT, $5^{\text {a }}$ ed., 2012, p. 207-208.
} 
Ademais, devem ser considerados valores protegidos pelo ordenamento jurídico ambiental, além das funções da responsabilidade civil objetiva. ${ }^{516}$

Ou seja, quando aplicadas sob o arcabouço do Direito Civil, as metodologias de valoração de danos ambientais ecológicos devem respeitar as limitações legais, a exemplo do artigo 944 do Código Civil de 2002, que determina que a indenização deve ser medida pela extensão do dano. Ou seja, não seria possível, no contexto da responsabilidade civil, a aplicação de uma metodologia de valoração que não considere as reais dimensões do dano - sendo, assim, meramente punitiva -, justamente por falta de previsão legal.

Entretanto, entende-se pela aplicabilidade apenas do caput do referido artigo 944 para os casos de dano material ambiental. Por conta do caráter objetivo da responsabilidade civil por dano ambiental, o parágrafo único, ao prever que "se houver excessiva desproporção entre a gravidade da culpa e o dano, poderá o juiz reduzir, equitativamente, a indenização", deveria ser restrito apenas aos casos de responsabilidade subjetiva, reforçando ainda mais o fato de que o arbitramento das indenizações civis ambientais deve ser restrito unicamente ao dano verificado.

Portanto, a escolha entre as diversas metodologias de valoração ambiental deve ser coerente com o contexto e funções da forma de responsabilidade avaliada. Ou seja, o cálculo de indenização, quando aplicado em casos de responsabilidade civil, deve valorar o dano ambiental propriamente dito, ou eventuais danos decorrentes dos ecológicos puros, mas a caracterização do dano deve ser sempre realizada.

Assim, deve-se atentar para a diferenciação entre responsabilidade civil ambiental e criminal ambiental, quanto à adoção da indenização.

Diferentemente da responsabilidade civil, que é objetiva e tem como elemento essência a demonstração dano, os crimes ambientais no regime jurídico brasileiro são previstos pela Lei de Crimes Ambientais, Lei $n^{\circ}$ 9.605/1998, que consagrou também a modalidade de crime de perigo, dando maior importância à prevenção e não apenas ao dano, que consumado pela efetiva

${ }^{516}$ STEIGLEDER, A. M.. Valoração de Danos Ambientais Irreversíveis. Revista MPMG Jurídico. Ed Especial de meio ambiente. DIPE. 2011, pp. 24-25. 
lesão do bem jurídico. ${ }^{517} \mathrm{~A}$ responsabilidade penal diferentemente da perspectiva cível, atinge questões de índole social, ${ }^{518}$ ao atribuir ao poluidor um estigma negativo. ${ }^{519}$

Com relação ao caráter subjetivo, os crimes ambientais podem ser punidos a título de dolo - o que é considerado a regra - ou de ou culpa - apenas nos casos expressos em legislação. A forma culposa nos crimes ambientais se tornou mais comum com a Lei $n^{\circ} 9.605 / 1998$. Com relação aos derramamentos de óleo no mar, antigamente não bastava a culpa para serem considerados crimes. Entretanto, o problema foi sanado pela Lei de 1998, ao prever a modalidade culposa para vários ilícitos penais ambientais. ${ }^{520}$

As funções da pena são diferentes daquelas protegidas pelo Direito Civil. Dentre elas, destaca-se, primeiramente, a função preventiva, quando o prejuízo à imagem de quem comete a prática delituosa gera um desestímulo à sociedade, inibindo a mesma prática por outros. ${ }^{521} \mathrm{Já}^{2}$ no âmbito da função punitiva, a Lei de Crimes Ambientais prevê, em seu art. $8^{\circ}$, IV, como uma das penas restritivas de direito à pessoa física a prestação pecuniária, caracterizada como uma obrigação de dar, e "que consiste no pagamento em dinheiro à vítima ou à entidade pública ou privada com fím social, de importância fixada pelo juiz (criminal), não inferior a um salário mínimo nem superior a trezentos e sessenta salários mínimos (art. 12)." 522

Para determinação da valoração da prestação pecuniária, deve o juiz observar os critérios previstos no artigo 59, caput, do Código Penal Brasileiro, chegando a um valor adequado tanto para a prevenção, quanto para a reprovação do delito. Para tanto, na avaliação da culpabilidade, deverá levar em conta a situação econômica do acusado, além das circunstâncias do fato. ${ }^{523}$

\footnotetext{
${ }^{517}$ FREITAS, V. P. de; FREITAS, G. P. de. Crimes contra a natureza. São Paulo: RT, 9a ed., 2012. p. 39-40. 518 "O motivo de um crime é a vantagem que se representa com ele, a eficácia da pena está na desvantagem que se espera dela. O que ocasiona a pena na essência da punição não é a sensação do sofrimento, mas a ideia de uma dor, de um desprazer, de um inconveniente - a 'pena' da ideia da pena. A punição não precisa, portanto, utilizar o corpo, mas a representação". FOUCAULT, M. Vigiar e punir: nascimento da prisão. Lígia M. Pondé Vassallo (Trad.). Petrópolis: Vozes, $13^{\mathrm{a}}$ ed., 1987, p. 85. Apud DINO NETO, N.; BELLO FILHO, N.; DINO, F. Crimes e infrações administrativas ambientais. Belo Horizonte: Del Rey Editora, $3^{\mathrm{a}}$ ed., 2011.

519 MARCHESAN, A. M. M.; CAPPELLI, S. Introdução. In: MARCHESAN, A. M. M.; STEIGLEDER, A. M.. Crimes ambientais: comentários à Lei 9.605/98. Porto Alegre: Livraria do Advogado Editora, 2013. p. 14.

${ }^{520}$ FREITAS, V. P. de; FREITAS, G. P. de. Crimes contra a natureza. São Paulo: RT, $9^{\text {a }}$ ed., 2012, p. 41.

${ }^{521}$ DINO NETO, N.; BELLO FILHO, N.; DINO, F. Crimes e infrações administrativas ambientais. Belo Horizonte: Del Rey Editora, $3^{\text {a }}$ ed., 2011, p. 69.

${ }^{522}$ FREITAS, G. P. de. Ilícito Penal Ambiental e Reparação do Dano. São Paulo: RT, 2005, p. 143.

${ }^{523}$ GOMES, L. F.. Penas e medidas alternativas à prisão. $2^{\mathrm{a}}$ edição. São Paulo: Ed. Revista dos Tribunais, 2000. Apud FREITAS, G. P. de. Ilícito Penal Ambiental e Reparação do Dano. São Paulo: Editora Revista dos Tribunais, 2005, p. 145-146.
} 
Além da pena de prestação pecuniária, que consiste em pena restritiva de direitos, há a previsão legal da pena de multa, havendo a possibilidade de ambas serem aplicadas cumulativamente. ${ }^{524} \mathrm{O}$ cálculo da pena de multa evidencia ainda mais a subjetividade, uma vez que, a Lei n 9.605/1998, em seu artigo 18, estabelece que o seu cálculo atenderá, primeiramente, aos critérios do art. 60 do Código Penal e, não sendo satisfatório o resultado, poderá o valor ser aumentado em até três vezes, a depender da vantagem econômica auferida. Ademais, poderá ser aplicado de forma cumulativa o artigo $60, \S 1^{\circ}$ do Código Penal, que prevê o aumento a depender da situação econômica do réu. ${ }^{525}$

Dessa forma, portanto, assim como ocorre com a pena de prestação pecuniária, na pena de multa, o seu valor não está, necessariamente, ligado apenas à dimensão do dano, sendo observadas também a situação econômica do infrator e a vantagem auferida no caso concreto. Esse dispositivo visa garantir não apenas a efetiva reparação do dano, mas também o caráter dissuasório da pena, tutelando da devida forma o bem jurídico protegido e desestimulando o delito por parte de toda a sociedade.

Para fins de aplicação e gradação da pena, a autoridade competente deverá observar os critérios do artigo $6^{\circ}$ da Lei de Crimes Ambientais. ${ }^{526}$ Conforme pode-se depreender desse dispositivo, a gravidade do fato, isto é, o alcance do dano, com relevância para suas consequências para a saúde pública e para o meio ambiente (inciso I), é apenas um dos critérios de fixação da pena, podendo o magistrado optar por um valor superior àquele correspondente exclusivamente ao dano.

Conclui-se, assim, que, para o Direito Penal, a quantificação do dano é apenas um dos fatores para a fixação da pena. Consequentemente, a reparação do dano não é o único objetivo a ser considerado, sendo acompanhada do caráter pedagógico e dissuasório embutidos na pena. Já no âmbito das normas do Direito Civil, as resoluções dos conflitos judiciais devem objetivar

\footnotetext{
${ }^{524}$ A pena de prestação pecuniária pode ser substituída ou convertida em pena privativa de liberdade, nos casos de descumprimento. MARTINI, D. A dosimetria da pena. Integração com a Parte Geral do Código Penal. As penas aplicáveis às pessoas físicas. (artigos $6^{\circ}$ a 13). In: MARCHESAN, A. M. M.; STEIGLEDER, A. M.. Crimes ambientais: comentários à Lei 9.605/98. Porto Alegre: Livraria do Advogado Editora, 2013. p. 93.

525 DINO NETO, N.; BELLO FILHO, N.; DINO, F. Crimes e infrações administrativas ambientais. Belo Horizonte: Del Rey Editora, $3^{\mathrm{a}}$ ed., 2011, p. 93.

526 Art. 6, Lei no 9.605 de 1998: "Art. 6 Para imposição e gradação da penalidade, a autoridade competente observará: I - a gravidade do fato, tendo em vista os motivos da infração e suas conseqüências para a saúde pública e para o meio ambiente; II - os antecedentes do infrator quanto ao cumprimento da legislação de interesse ambiental; III - a situação econômica do infrator, no caso de multa".
} 
a reparação do dano independentemente de qualquer juízo de valor ou de subjetividade em relação ao poluidor.

Diante das evidenciadas diferenças de funções entre essas duas faces do Direito ambiental, a escolha de metodologias de valoração deve considerar inicialmente a finalidade da indenização. Desde já, vale dizer, para a solução de um conflito ambiental no âmbito civil, não aparenta ser adequada a adoção de um método que não objetiva a reparação do dano.

Por isso, a busca pela efetividade da reparação do dano ambiental deve avaliar, dentre as formas de reparação possíveis, aquelas que atendam às funções da responsabilidade civil, e possibilitem a proteção dos bens ambientais materiais e imateriais. ${ }^{527}$ Desse modo, as discussões a seguir propostas irão considerar o contexto da responsabilidade civil, ao tratar da valoração de danos ambientais.

\subsection{Valoração ambiental}

A valoração ambiental surge da teoria neoclássica de locação, que "pressupõe que o capital natural pode ser substituído infinitamente pelo capital material (feito pelo homem)" ${ }^{528} \mathrm{Com}$ isso, a necessidade de valorar o meio ambiente, por meio de técnicas que estimam valores surge em resposta ao fato de que "a maioria dos bens e serviços ambientais e das funções providas ao homem pelo ambiente não é transacionada pelo mercado". ${ }^{529}$

Diante desse fato, foram desenvolvidas técnicas que procuram estimar valores ambientais em termos monetários, de modo a torná-los comparáveis a outros valores de mercado, subsidiando tomadas de decisões que envolvam recursos naturais. ${ }^{530}$ Os métodos neoclássicos de Valoração Econômica do Recurso Ambiental (VERA) consideram a seguinte equação base:

527 STEIGLEDER, A. M.. Valoração de Danos Ambientais Irreversíveis. Revista MPMG Jurídico, edição especial de Meio Ambiente, 2011, p.24.

528 MAY, Peter H. Economia ecológica e o desenvolvimento equitativo no Brasil. In: Economia Ecológica: aplicações no Brasil, Editora Campus, Rio de Janeiro, 1995, p.05.

${ }^{529}$ MARQUES, J. F.; COMUNE, A. E. A teoria neoclássica e a valoração ambiental. In: ROMEIRO, A. R., REYDON, B. P., LEONARDI, M. L. A. (Org.). Economia do meio ambiente: teoria, políticas e a gestão de espaços regionais. Editora UNICAMP, 1996, cap. 1.

${ }^{530}$ BRASIL. Procuradoria Geral de Justiça. Ato PGJ n 36, de 06 de maio de 2011. Cria grupo de trabalho para análise e fixação de premissas relativas à valoração de dano ambiental. Diário Oficial da República Federativa do Brasil, Brasília, 07 de maio de 2011. Seção I, p. 50. Disponível em

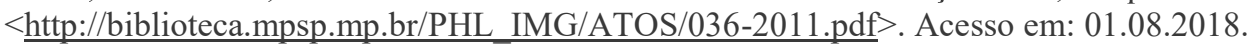




$$
\mathrm{VERA}^{531}=(\mathrm{VUD}+\mathrm{VUI}+\mathrm{VO})+\mathrm{VNU}
$$

O VERA é calculado considerando, primeiramente, valores de uso e de não uso dos recursos. Entende-se por Valor de Uso: "valor que os indivíduos atribuem a um recurso ambiental pelo seu uso presente ou pelo seu potencial de uso futuro". ${ }^{532} \mathrm{O}$ valor de uso pode ser subdividido em três categorias: valor de uso direto, valor de uso indireto, e valor de opção.

Já o Valor de não uso, ou Valor de Existência:

(...) está dissociado do uso (embora represente o consumo ambiental) e derive de uma posição moral, cultural ou ética ou altruística em relação aos direitos de existência de espécies não-humanas ou de preservação de outras riquezas naturais, mesmo que estas não representem uso atual ou futuro para o indivíduo. Um exemplo claro deste valor é a grande mobilização da opinião pública para salvamento dos ursos panda ou das baleias mesmo em regiões em que a maioria das pessoas nunca poderá estar ou fazer qualquer uso de sua existência. ${ }^{533}$

Os componentes da equação acima são explicados por Ronaldo Motta, ao apresentá-los em uma sistematização denominada: "Taxonomia do valor econômico do meio ambiente: valor econômico do recurso ambiental", cujas definições dos valores foram replicadas na elaboração do quadro abaixo:

Tabela 13 - Componentes da valoração econômica do recurso ambiental (VERA)

\begin{tabular}{|c|c|c|c|c|}
\hline $\begin{array}{c}\text { CLASSIFICAÇÃO } \\
\text { DO VALOR }\end{array}$ & \multicolumn{3}{|c|}{$\begin{array}{l}\text { VALOR DE } \\
\text { USO }\end{array}$} & $\begin{array}{l}\text { VALOR DE } \\
\text { NÃO USO }\end{array}$ \\
\hline CONCEITOS & $\begin{array}{l}\text { Valor de uso } \\
\text { direto }\end{array}$ & $\begin{array}{l}\text { Valor de uso } \\
\text { indireto }\end{array}$ & $\begin{array}{l}\text { Valor de } \\
\text { opção }\end{array}$ & $\begin{array}{l}\text { Valor de } \\
\text { existência }\end{array}$ \\
\hline
\end{tabular}

(continua)

\footnotetext{
531 "Para a determinação do VERA, é necessário identificar preliminarmente eventuais conflitos de uso do recurso ambiental e definir a situação paradigma da valoração, observadas as disposições legais aplicáveis". Cf. ABNT. NBR 14653-6: 2008, p. 06.

532 BRASIL. DEA. MME. ELETROBRAS. NUTTI, Mírian Regini (Coord.). Metodologia de valoração das externalidades ambientais da geração hidrelétrica e termelétrica com vistas à sua incorporação no planejamento de longo prazo do setor elétrico. Rio de Janeiro: Eletrobrás, 2000, p. 05.

533 BRASIL. DEA. MME. ELETROBRAS. NUTTI, Mírian Regini (Coord.). Metodologia de valoração das externalidades ambientais da geração hidrelétrica e termelétrica com vistas à sua incorporação no planejamento de longo prazo do setor elétrico. Rio de Janeiro: Eletrobrás, 2000, p. 06.
} 
(conclusão)

\begin{tabular}{|c|c|c|c|c|}
\hline CLASSIFICAÇÃO & \multicolumn{3}{|c|}{ VALOR DE USO } & VALOR DE \\
\hline DEFINIÇÕES ${ }^{534}$ & $\begin{array}{l}\text { Bens e serviços } \\
\text { ambientais } \\
\text { apropriados } \\
\text { diretamente da } \\
\text { exploração do } \\
\text { recurso e } \\
\text { consumidos } \\
\text { hoje. }\end{array}$ & $\begin{array}{l}\text { Bens e serviços } \\
\text { ambientais que } \\
\text { são gerados de } \\
\text { funções } \\
\text { ecossistêmicas } \\
\text { e apropriados } \\
\text { indiretamente } \\
\text { hoje. }\end{array}$ & $\begin{array}{l}\text { Bens } \\
\text { serviços } \\
\text { ambientais de } \\
\text { usos diretos e } \\
\text { indiretos a } \\
\text { serem } \\
\text { apropriados } \\
\text { no futuro. }\end{array}$ & $\begin{array}{l}\text { Valor não } \\
\text { associado ao uso } \\
\text { atual ou futuro e } \\
\text { que reflete } \\
\text { questões morais, } \\
\text { culturais, éticas } \\
\text { ou } \\
\text { altruísticas. }{ }^{535}\end{array}$ \\
\hline EXEMPLOS & $\begin{array}{l}\text { Peixes, } \\
\text { moluscos }\end{array}$ & $\begin{array}{l}\text { Fotossíntese } \\
\text { pelo } \\
\text { fitoplâncton }{ }^{536}\end{array}$ & Recreação & $\begin{array}{l}\text { Simbologia das } \\
\text { baleias }\end{array}$ \\
\hline
\end{tabular}

Fonte: MOTTA, R. S. da. Economia ambiental. Rio de Janeiro: Editora FGV, 2006.

A partir dos conceitos acima, são estabelecidas algumas formas de classificação dos métodos de valoração ambiental. A mais comum, apresentada na norma ABNT NBR 14653-6: 2008, os divide entre métodos diretos, e métodos indiretos. Segundo esta definição:

Métodos diretos: utilizam mercados de bens e serviços substitutos e complementares, ou mercados hipotéticos para medir as variações de bem-estar diretamente da demanda dos indivíduos pela qualidade ambiental;

Métodos indiretos: valoram os benefícios ambientais usando os custos evitados, relacionados indiretamente com as mudanças na qualidade ambiental, sem estarem

\footnotetext{
${ }^{534}$ Replicadas de "Quadro 1 - Taxonomia do valor econômico do meio ambiente: valor econômico do recurso ambiental", disponível em: MOTTA, R. S. da. Economia ambiental. Rio de Janeiro: Editora FGV, 2006, p.12. 535 "Na verdade, existem possibilidades ilimitadas para o cálculo do valor de existência. Virtualmente, qualquer objeto investido com importância simbólica tem um valor de existência. A partir desse ponto, tem início um grande debate (ainda não concluído) sobre validade, aplicabilidade e operacionalidade do conceito no mister de avaliar os bens ou serviços ambientais no sentido econômico." NOGUEIRA, J. M; MEDEIROS, M. A. A. de. Quanto vale aquilo que não tem valor? Valor de existência, economia e meio ambiente. Cadernos de Ciência \& Tecnologia. Brasília, v.16, n.3, p. 59-83, set/dez. 1999, p. 67.

${ }^{536} \mathrm{O}$ fitoplâncton é formado por organismos microscópicos que vivem dispersos na coluna d'água e possuem a capacidade de realizar o processo de fotossíntese, que consiste na transformação de matéria inorgânica (como o gás carbônico) em matéria orgânica, tornando-a disponível para os consumidores na cadeia alimentar. Para maiores informaç̃oes sobre serviços ecossistêmicos Marinhos, ver: MOORE, C. M. et al. Processes and Patterns of Oceanic Nutrient Limitation. Nature Geoscience, v.6, n.9, p. 701-710, set. 2013.
} 
diretamente relacionados com uma alteração de bem-estar, medida pela disposição a pagar ou a receber dos indivíduos. ${ }^{537}$

Os métodos de valoração ambiental ainda devem ser diferenciados entre métodos de valoração de recursos e métodos de valoração de danos, conforme será melhor exposto no próximo item.

\subsubsection{Valoração de recursos versus valoração de danos}

O estudo dos métodos de valoração ambiental ressalta a importância dos componentes ambientais nas tomadas de decisão, permitindo, quando for o caso, a escolha de formas alternativas de desenvolvimento para uma atividade. ${ }^{538}$ Ou seja, com relação ao viés preventivo, a caracterização dos bens ambientais e dos respectivos valores é essencial na avaliação prévia de possíveis impactos ambientais.

Entretanto, não se pode confundir valoração de recursos ambientais com valoração de danos ambientais. "Do ponto de vista prático, há uma tênue, mas importante diferença entre valoração de bens e serviços ambientais e valoração de danos ambientais: a primeira mensura recursos existentes e a segunda, o valor de reposição e compensação pela perda deles", como concluem dois pesquisadores no tema. ${ }^{539}$

Grande parte dos métodos de valoração econômica ambiental possuem um viés preventivo, sendo ferramentas para a formulação de políticas públicas, para melhoria de qualidade de vida, ou para conservação, a exemplo do "levantamento dos custos associados à saúde humana provocados pela poluição atmosférica, realizado pela Companhia de Tecnologia de Saneamento Ambiental (CETESB - São Paulo), para direcionar seu programa integrado de transportes urbanos". 540

Apesar das diferenças de finalidade entre a valoração de bens e a de danos, dificilmente será possível atribuir um valor ao dano ambiental, quando não se conhece o valor do bem ambiental lesado. Ou seja, se não houver a identificação e a valoração do recurso previamente à lesão, possivelmente o cálculo do dano será prejudicado.

\footnotetext{
${ }^{537}$ Cf. ABNT. NBR 14653-6: 2008, p. 06.

538 SCHAEFFER-NOVELLI, Y.; TOGNELLA DE ROSA, M. M. P. Ecossistema manguezal, o desenvolvimento sustentado e a valoração ambiental. In: Congreso Latino americano de Ciencias Del Mar, 1995, Buenos Aires, p.196.

539 SILVA, T. B. B.; CORRÊA, R. S. Comparação entre métodos de valoração de danos ambientais para fins periciais. Revista Brasileira de Criminalística, Brasília, v.4, n.3, 2015, p.9. Disponível em: $<$ http://rbc.org.br/ojs/index.php/rbc/article/view/101/pdf_39>. Acesso em: 01.08.2018.

${ }^{540}$ ORTIZ, R. A. Valoração Econômica Ambiental. In: MAY, Peter H. Economia Ecológica: aplicações no Brasil. Rio de Janeiro: Editora Campus, 1995, p.98.
} 
Em outras palavras, seria ideal que os métodos de valoração de um dano ambiental fossem precedidos de conhecimento aprofundado sobre as características dos bens e serviços de um ecossistema, o que somente seria possível com o desenvolvimento de estudos em um cenário prévio às interferências danosas. Infelizmente, conforme será demonstrado a seguir, nem sempre os métodos consideram dados sobre recursos ambientais sadios, o que torna a valoração de danos ambientais um instrumento de difícil aplicação como subsídio ao arbitramento de indenizações civis ambientais.

\subsubsection{Métodos de valoração}

A valoração de danos ambientais deve ser precedida de algumas etapas, anteriores à escolha da metodologia: (i) primeiramente, devem ser caracterizadas as fontes que geraram os impactos; (ii) em seguida, devem-se identificar os impactos ambientais já esperados; (iv) posteriormente, faz-se a identificação dos danos ambientais, derivados de impactos; e, por fim, (v) a partir da identificação de metodologias apropriadas a cada uma das externalidades ambientais, chega-se à valoração dos danos correspondentes. ${ }^{541}$

Os métodos de valoração de danos ambientais devem ser capazes de captar as distintas parcelas de valor econômico do recurso ambiental lesado. Porém, é inegável que os métodos apresentam limitações. Portanto, a "adoção de cada método dependerá do objetivo da valoração, das hipóteses assumidas, da disponibilidade de dados e conhecimento da dinâmica ecológica do objeto que está sendo valorado". 542

São inúmeras as metodologias para valoração de recursos e danos ambientais. Para o presente trabalho, foram selecionados, a partir da realização de revisão bibliográfica, métodos já aplicados para a valoração de recursos, bens e danos ambientais em ambientes marinhos. As metodologias escolhidas foram sistematizadas e sintetizadas no quadro a seguir, para que seja possível a realização de leitura comparativa entre elas.

\footnotetext{
${ }^{541}$ TOLMASQUIM, M. T. et al. Metodologias de Valoração do Meio Ambiente para o Setor Elétrico. Rio de Janeiro: Instituto Alberto Luiz oimra de Pós-Graduação e Pesquisa de Engenharia (COPPE), 2000.

${ }^{542}$ MOTTA, R. S. da. Manual de valoração econômica de recursos ambientais. Rio de Janeiro: Coordenação de Estudos do Meio Ambiente do Instituto de Pesquisa EconÔmica Aplicada (CEMA/IPEA) e Coordenação Geral de Diversidade Biológica do Ministério do Meio Ambiente, dos Recursos Hídricos e da Amazônia Legal (COBIO/MMA), 1997, p.13.
} 
Tabela 14 - Métodos de valoração ambiental aplicáveis a ambientes marinhos

\begin{tabular}{|c|c|c|}
\hline $\begin{array}{l}\text { MÉTODOS DE } \\
\text { VALORAÇÃO }\end{array}$ & DESCRIÇÃO & ANÁLISE CRÍTICA \\
\hline $\begin{array}{l}\text { Produtividade } \\
\text { Marginal }\end{array}$ & $\begin{array}{l}\text { Estabelece o "valor monetário da } \\
\text { relação entre a ação causadora e o } \\
\text { atributo ambiental, através dos efeitos } \\
\text { finais sobre o homem". Avalia a } \\
\text { "perda social por um dano marginal } \\
\text { associado a mudanças na qualidade } \\
\text { de um recurso natural". }{ }^{543} \text { Sendo } \\
\text { assim, o valor do recurso natural para } \\
\text { a produção de determinado bem é } \\
\text { medido por meio de uma fórmula. }{ }^{544} \\
\text { Ex.: a água, na qualidade de recurso } \\
\text { natural, ao ser poluída irá afetar a } \\
\text { atividade pesqueira }\end{array}$ & $\begin{array}{l}\text { Os ecossistemas, principalmente os } \\
\text { marinhos, apresentam dinâmicas } \\
\text { extremamente complexas. Dessa } \\
\text { forma, não se pode assumir que as } \\
\text { relações de causa e efeito sejam } \\
\text { precisas. }{ }^{54} \text { Pode não refletir a real } \\
\text { conexão entre o dano e o resultado } \\
\text { no recurso ambiental, } \\
\text { principalmente nos casos em que } \\
\text { há outras fontes poluidoras. Ex. } \\
\text { efeitos de óleo derramado em } \\
\text { peixes que vivem nos manguezais } \\
\text { do polo industrial de Cubatão, } \\
\text { historicamente contaminado. }\end{array}$ \\
\hline
\end{tabular}

(continua)

\footnotetext{
${ }^{543}$ SINISGALLI, P. A. de A. Valoração de danos ambientais de hidrelétricas: estudos de caso. 226f. Tese de Doutorado em Economia - Instituto de Economia, UNICAMP, Campinas, 2005, p.44.

${ }^{544}$ SINISGALLI, P. A. de A. Valoração de danos ambientais de hidrelétricas: estudos de caso. 226f. Tese de Doutorado em Economia - Instituto de Economia, UNICAMP, Campinas, 2005, p.43.

${ }^{545}$ MOTTA, R. S. da.. Economia Ambiental. Rio de Janeiro: Editora FGV, 2006.
} 
(continuação)

\begin{tabular}{|c|c|c|}
\hline $\begin{array}{l}\text { MÉTODOS DE } \\
\text { VALORAÇÃO }\end{array}$ & DESCRIÇÃO & ANÁLISE CRÍTICA \\
\hline $\begin{array}{l}\text { Preços } \\
\text { Hedônicos }\end{array}$ & $\begin{array}{l}\text { Baseado na valoração do preço de } \\
\text { mercado de um bem material, } \\
\text { normalmente imóvel, em razão dos } \\
\text { atributos ambientais relacionados. }{ }^{546} \\
\text { Assim, pode ser valorada a disposição } \\
\text { a se pagar a mais por uma } \\
\text { propriedade que conta com esses } \\
\text { serviços. Ex.: valoração de imóveis } \\
\text { pela localização em uma praia limpa, } \\
\text { ou pelo nível de ruído do local. Da } \\
\text { mesma forma, pode ser calculada a } \\
\text { desvalorização do imóvel por conta } \\
\text { de danos aos atributos ambientais. }\end{array}$ & $\begin{array}{l}\text { Não apresenta a valoração do } \\
\text { recurso ou do dano em função da } \\
\text { sua relevância ecológica, mas sim } \\
\text { em função da sua importância } \\
\text { estética. Acaba valorando a } \\
\text { influência de um bem ambiental } \\
\text { para um bem imóvel apenas. }\end{array}$ \\
\hline $\begin{array}{l}\text { Custo de } \\
\text { Viagem }\end{array}$ & $\begin{array}{l}\text { Identifica o valor do recurso natural } \\
\text { pela curva de demanda da atividade } \\
\text { de lazer proporcionada. }{ }^{547} \text { É } \\
\text { mensurada a disponibilidade que o } \\
\text { usuário tem a pagar por experiências } \\
\text { específicas de recreação. Consiste na } \\
\text { relação entre o número de visitas e os } \\
\text { custos totais de viagens. }{ }^{548}\end{array}$ & $\begin{array}{l}\text { Não apresenta caráter subjetivo de } \\
\text { valoração, mas igualmente não } \\
\text { valora o recurso ou o dano em si. } \\
\text { Limita-se a calcular o quanto o } \\
\text { consumidor gasta efetivamente } \\
\text { para desfrutar do recurso } \\
\text { ambiental. }\end{array}$ \\
\hline
\end{tabular}

(continua)

${ }^{546}$ MOTTA, R. S. da.. Economia Ambiental. Rio de Janeiro: Editora FGV, 2006.

${ }^{547}$ Cf. ABNT. NBR 14653-6: 2008.

${ }^{548}$ GRASSO, M.; TOGNELLA, MMP.; SCHAEFFER-NOVELLI, Y.; COMUNE, AE., Aplicação de técnicas de avaliação econômica ao ecossistema Manguezal. In: MAY, P. (Org.). Economia Ecológica: aplicações no Brasil. Rio de Janeiro: Editora Campus, 1995, p. 62. 
(continuação)

\begin{tabular}{|c|c|c|}
\hline $\begin{array}{l}\text { MÉTODOS DE } \\
\text { VALORAÇÃO }\end{array}$ & DESCRIÇÃO & ANÁLISE CRÍTICA \\
\hline $\begin{array}{l}\text { Valoração } \\
\text { Contingente }\end{array}$ & $\begin{array}{l}\text { Consiste em entrevistas, com uma } \\
\text { amostra de consumidores, para } \\
\text { avaliar a "Disposição a pagar" (DAP) } \\
\text { e/ou a "Disposição a aceitar } \\
\text { Compensação" (DAC) pela redução } \\
\text { do nível e da qualidade de um bem ou } \\
\text { serviço ambiental. }{ }^{549}\end{array}$ & $\begin{array}{l}\text { Gera dúvidas quanto à validade das } \\
\text { respostas dos consumidores. Em } \\
\text { alguns casos, as respostas podem } \\
\text { ser enviesadas e, portanto, não } \\
\text { representam a verdadeira } \\
\text { preferência dos indivíduos. Não } \\
\text { valora o recurso ou o dano em } \\
\text { função da sua relevância ecológica, } \\
\text { mas sim em função da sua } \\
\text { importância ao consumidor. }\end{array}$ \\
\hline $\begin{array}{l}\text { Custo } \\
\text { reposição }\end{array}$ & $\begin{array}{l}\text { Estima os gastos para "restaurar a } \\
\text { capacidade produtiva e as funções } \\
\text { ecossistêmicas de um recurso } \\
\text { ambiental degradado." Considera os } \\
\text { valores gastos para a reparação, além } \\
\text { de um valor correspondente à perda } \\
\text { econômica referente ao tempo em que } \\
\text { o recurso ambiental levou para ser } \\
\text { recuperado. }\end{array}$ & $\begin{array}{l}\text { Havendo a possibilidade de se } \\
\text { calcular os custos totais para a } \\
\text { restauração ambiental, pressupõe- } \\
\text { se que o dano é reparável. Dessa } \\
\text { forma, seria preferível a imposição } \\
\text { de medidas concretas de reparação } \\
\text { à indenização, cujo valor nem } \\
\text { sempre é revertido à reparação } \\
\text { efetiva dos bens lesados. Pode ser } \\
\text { útil para determinar o valor que } \\
\text { deve ser gasto em medidas de } \\
\text { restauração. }\end{array}$ \\
\hline
\end{tabular}

(continua)

${ }^{549}$ NOGUEIRA, J. M; MEDEIROS, M. A. A. de. Quanto vale aquilo que não tem valor? Valor de existência, economia e meio ambiente. Cadernos de Ciência \& Tecnologia. Brasília, v.16, n.3, p. 59-83, set/dez. 1999 , p.73. ${ }^{550}$ Cf. ABNT. NBR 14653-6: 2008. 
(continuação)

\begin{tabular}{|c|c|c|}
\hline $\begin{array}{l}\text { MÉTODOS DE } \\
\text { VALORAÇÃO }\end{array}$ & DESCRIÇÃO & ANÁLISE CRÍTICA \\
\hline $\begin{array}{l}\text { Custos } \\
\text { proteção } \\
\text { Evitados }\end{array}$ & $\begin{array}{l}\text { Ao se preservar um recurso } \\
\text { ambiental, são calculados os custos } \\
\text { que serão evitados por não terem sido } \\
\text { gastos para a reparação do dano. Ex.: } \\
\text { gastos evitados com remoção manual } \\
\text { de óleo na praia por não ter sido } \\
\text { atingida. Podem igualmente ser } \\
\text { calculados os ganhos ambientais pela } \\
\text { não ocorrência do dano: custo da } \\
\text { redução de emissões de carbono por } \\
\text { desmatamento evitado. }{ }^{551}\end{array}$ & $\begin{array}{l}\text { O método propõe a valoração pela } \\
\text { não ocorrência do evento danoso. } \\
\text { Devido a esse fato, trata-se de um } \\
\text { método preventivo, não sendo } \\
\text { adequado à valoração de danos que } \\
\text { já ocorreram. }\end{array}$ \\
\hline $\begin{array}{l}\text { Custos } \\
\text { controle } \\
\text { Evitados }\end{array}$ & 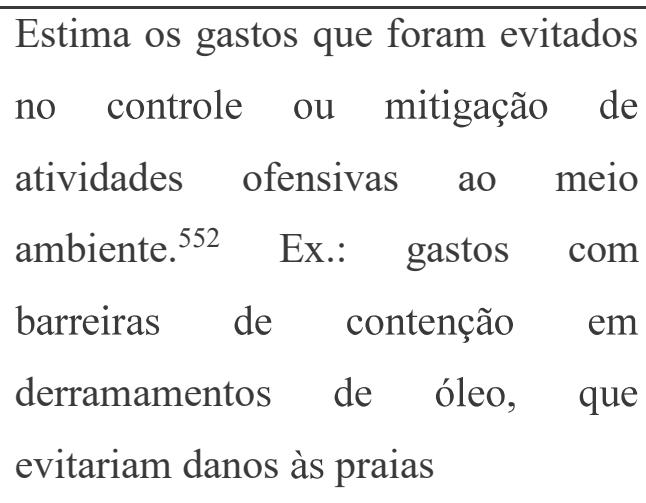 & $\begin{array}{l}\text { Método propõe a valoração de } \\
\text { medidas efetivas de mitigação e } \\
\text { não de medidas posteriores ao dano } \\
\text { para repará-lo. }\end{array}$ \\
\hline
\end{tabular}

${ }^{551}$ MOTA, J. A. et al. A Valoração da biodiversidade: conceitos e concepções metodológicas. In: MAY, P. H. (Org.). Economia do Meio Ambiente: Teoria e Prática. Rio de Janeiro: Elsevier, $2^{\mathrm{a}}$ ed., 2010. 
(continuação)

\begin{tabular}{|c|c|c|}
\hline $\begin{array}{l}\text { MÉTODOS DE } \\
\text { VALORAÇÃO }\end{array}$ & DESCRIÇÃO & ANÁLISE CRÍTICA \\
\hline $\begin{array}{l}\text { Custos de } \\
\text { Oportunidade }\end{array}$ & $\begin{array}{l}\text { Avalia o custo de oportunidade de } \\
\text { atividades econômicas restringidas } \\
\text { por conta de ações de proteção } \\
\text { ambiental. Ou seja, considera os } \\
\text { benefícios da conservação em } \\
\text { comparação ao custo do } \\
\text { desenvolvimento de uma atividade } \\
\text { econômica. }\end{array}$ & $\begin{array}{l}\text { O método não valora diretamente o } \\
\text { recurso natural, nem mesmo o dano } \\
\text { decorrente, mas sim o custo de } \\
\text { conservação. }\end{array}$ \\
\hline
\end{tabular}

(continua) 
(conclusão)

\begin{tabular}{|c|c|c|}
\hline $\begin{array}{l}\text { MÉTODOS DE } \\
\text { VALORAÇÃO }\end{array}$ & DESCRIÇÃO & ANÁLISE CRÍTICA \\
\hline $\begin{array}{l}\text { MÉTODO } \\
\text { CETESB - } \\
\text { "Critério para } \\
\text { Valoração } \\
\text { Monetária de } \\
\text { Danos Causados } \\
\text { por Derrames de } \\
\text { Petróleo ou de } \\
\text { seus Derivados } \\
\text { em Ambiente } \\
\text { Marinho" }\end{array}$ & $\begin{array}{l}\text { Propõe um critério para valoração } \\
\text { monetária de danos causados por } \\
\text { derramamentos de petróleo ou de } \\
\text { seus derivados no ambiente marinho. } \\
\text { O critério apresenta uma equação } \\
\text { matemática, cujo valor final deve ser } \\
\text { pago pela fonte poluidora a título de } \\
\text { indenização pelo dano causado. Para } \\
\text { a realização do cálculo, são } \\
\text { considerados os seguintes fatores } \\
\text { relevantes: "quantidade de produto } \\
\text { derramada, a sensibilidade das áreas } \\
\text { afetadas, a toxicidade e a persistência } \\
\text { do produto no ambiente e a } \\
\text { mortalidade de organismos". Por } \\
\text { meio de uma equação do tipo } \\
\text { exponencial, há atribuição de pesos } \\
\text { aos fatores, possibilitando que o valor } \\
\text { de indenização calculado seja } \\
\text { proporcional à gravidade dos riscos } \\
\text { ou danos verificados. } 554\end{array}$ & $\begin{array}{l}\text { Único método que propõe } \\
\text { valoração específica de danos } \\
\text { decorrentes de derramamentos de } \\
\text { óleo em ambiente marinho. Sendo } \\
\text { assim, será apresenta uma análise } \\
\text { crítica mais detalhada sobre o } \\
\text { método apartada desta tabela. }\end{array}$ \\
\hline
\end{tabular}

\subsubsection{Método CETESB de valoração}

A identificação e a mensuração dos danos ecológicos decorrentes de qualquer interferência em ambiente marinho acabam sendo tarefas complexas, pois, em raras vezes, são conhecidas as condições anteriores dos ambientes afetados, que permitam uma comparação

\footnotetext{
${ }^{554}$ MARCELINO, A. et al. Proposta de Critério para Valoração Monetária de Danos Causados por Derrames de Petróleo ou de seus Derivados no Ambiente Marinho. Congresso Brasileiro de Petróleo e CONEXPO ARPEL'94. Rio de Janeiro, 1994, p.01.
} 
com o cenário pós-acidente. Devido a esse fato, há uma grande dificuldade em se encontrar um método de valoração adequado a esses casos tão peculiares.

Em 1992, diante da carência por uma fórmula específica para valoração monetária de danos causados por derramamentos de óleo no ambiente marinho, a CETESB, a pedido do Ministério Público Federal, desenvolveu uma nova metodologia denominada "Critério para Valoração Monetária de Danos Causados por Derrames de Petróleo ou de seus Derivados em Ambiente Marinho". ${ }^{555}$ Importante ressaltar que, até hoje, trata-se do único método específico para o tema, sendo, portanto, uma tentativa pioneira no Brasil de valorar danos tão significativos e específicos.

Entretanto, diferentemente da maioria dos métodos aqui já apresentados, consiste em "uma metodologia de parametrização de diversos critérios selecionados pelos autores, relacionados ao local do derramamento e às características do óleo, para estipular valor monetário a ser pago como medida compensatória". ${ }^{556} \mathrm{Ou}$ seja, são considerados critérios ambientais efetivos que possibilitam a avaliação de bens ambientais atingidos pelo óleo.

Conforme exposto na tabela 14, a metodologia considera os seguintes fatores relevantes para o cálculo do valor de indenização: "quantidade de produto derramada, a sensibilidade das áreas afetadas, a toxicidade e a persistência do produto no ambiente, e a mortalidade de organismos", que são mensurados a partir da gravidade do derramamento. $\mathrm{Na}$ verdade, são abordados os principais aspectos de um acidente ambiental de uma forma geral, não abrangendo particularidades dos ambientes ou monitoramentos. ${ }^{557}$

Dito de outro modo, a metodologia não tem como objetivo principal a caracterização dos danos ambientais decorrentes dos derramamentos no mar, mas sim, concentra-se em ser um

\footnotetext{
${ }^{555}$ MARCELINO, A.; HADDAD, E.; AVENTURATO, H.; CAMPOS, M. V.; SERPA, R. R..Proposta de critério para valoração monetária de danos causados por derrames de petróleo ou de seus derivados no ambiente marinho. São Paulo, CETESB, 1992.

${ }_{556}$ COSTA, D. M. B. A valoração econômica como ferramenta para compensação de derramamentos de petróleo. 217f. Dissertação de Mestrado - Instituto Alberto Luiz Coimbra de Pós-Graduação e Pesquisa de Engenharia (COPPE), da Universidade Federal do Rio de Janeiro (UFRJ), Rio de Janeiro, dez. 2012, p.92. Disponível em $<$ http://www.ppe.ufrj.br/ppe/production/tesis/daniele_costa.pdf $>$. Acesso em: 01.08.2018.

${ }^{557}$ MARCELINO, A. et al. Proposta de Critério para Valoração Monetária de Danos Causados por Derrames de Petróleo ou de seus Derivados no Ambiente Marinho. Congresso Brasileiro de Petróleo e CONEXPO ARPEL'94. Rio de Janeiro, 1994, p. 02.
} 
instrumento de cálculo de indenizações em ambiente litorâneo. ${ }^{558} \mathrm{Ou}$ seja, o método não mensura fielmente os danos ambientais decorrentes do acidente. ${ }^{559}$

Muito embora a metodologia seja, sem dúvidas, a mais próxima da realidade dos derramamentos de óleo no mar, é evidente que por meio dela não se vislumbra a reparação ecológica dos danos, uma vez que tais danos não são sequer identificados caso a caso, pois não há flexibilidade na equação para adequação a variáveis que possam permear diferentes ambientes. Do mesmo modo, não avalia as interferências no bem-estar humano, pois não "considera aspectos socioeconômicos entre seus critérios". ${ }^{560}$ Ademais, não são consideradas as características da biodiversidade e as funções ecológicas do ambiente afetado pelo derramamento. Isto é, não são medidas as perdas dos serviços ambientais locais.

$\mathrm{Na}$ realidade, a metodologia apresenta um viés muito mais punitivo do que reparatório, prevendo, inclusive, a aplicação do seguinte fator agravante: "a reincidência como forma de reprimir incidentes de derramamento de petróleo ou de seus derivados originados pelas mesmas fontes". ${ }^{561}$ A função punitiva proposta pelo método, vale ressaltar, pode ser recepcionada nos casos de responsabilização Penal e Administrativa. Entretanto, nos casos de responsabilidade Civil, além de não garantir a reparação do bem ambiental, o caráter punitivo é vetado pelo caput do artigo 944 do Código Civil, conforme já discutido no presente capítulo. Ou seja, não se pode computar outros fatores além da extensão do dano ambiental para o cálculo da indenização na esfera civil.

A própria CETESB reconhece que a metodologia possui algumas inconsistências técnicas, dentre elas o fato de que "a escala máxima relativa à quantidade vazada é muito restrita, fazendo com que derrames de quantidades diferentes sejam considerados, na fórmula,

\footnotetext{
${ }^{558}$ MARCELINO, A. et al. Proposta de Critério para Valoração Monetária de Danos Causados por Derrames de Petróleo ou de seus Derivados no Ambiente Marinho. Congresso Brasileiro de Petróleo e CONEXPO ARPEL'94. Rio de Janeiro, 1994, p. 02.

559 COSTA, D. M. B. A valoração econômica como ferramenta para compensação de derramamentos de petróleo. 217f. Dissertação de Mestrado - Instituto Alberto Luiz Coimbra de Pós-Graduação e Pesquisa de Engenharia (COPPE), da Universidade Federal do Rio de Janeiro (UFRJ), Rio de Janeiro, dez. 2012 , p.92. Disponível em $<$ http://www.ppe.ufrj.br/ppe/production/tesis/daniele_costa.pdf $>$. Acesso em: 01.08.2018.

560 COSTA, D. M. B. A valoração econômica como ferramenta para compensação de derramamentos de petróleo. 217f. Dissertação de Mestrado - Instituto Alberto Luiz Coimbra de Pós-Graduação e Pesquisa de Engenharia (COPPE), da Universidade Federal do Rio de Janeiro (UFRJ), Rio de Janeiro, dez. 2012 , p.93. Disponível em $<$ http://www.ppe.ufrj.br/ppe/production/tesis/daniele costa.pdf $>$. Acesso em: 01.08.2018.

561 MPSP. Relatório final do grupo de trabalho de valoração do dano ambiental. ATO PGJ 45/2012.

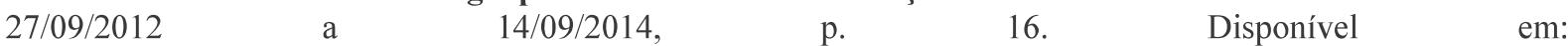
$<$ http://www.mpsp.mp.br/portal/page/portal/cao_urbanismo_e meio ambiente/relat $\% \mathrm{C} 3 \% \mathrm{~b} 3 \mathrm{rio} \% 20 \mathrm{final} \% 20$ \%20retificado_0.pdf $>$. Acesso em 19.08.2018.
} 
com pesos iguais". Além disso, conclui documento elaborado pela CETESB, "os valores finais obtidos pela aplicação da fórmula são, na maioria das vezes, muito elevados, especialmente em derrames de pequenos volumes"; e "a fórmula para o cálculo da indenização é arbitrária e exponencial". Nesse sentido, deixou de utilizar o método, retirando o relatório de seu acervo técnico em 2005. ${ }^{562}$

Entretanto, apesar da recomendação para a suspensão da utilização do método CETESB, recentes julgados referentes à casos de derramamentos de óleo no mar demonstram que a metodologia permanece sendo utilizada no arbitramento das indenizações por magistrados e promotores. Ocorre que, muito embora haja uma mudança ao longo dos anos, da frequência, localização, dimensão, quantidade de óleo derramado e características dos incidentes, observase que continuam escassos os trabalhos que busquem novas metodologias para a valoração de danos tão específicos quanto os derramamentos. ${ }^{563}$

Entretanto, há de se reconhecer que a metodologia proposta pela CETESB, mesmo não sendo mais recomendada, tem uma grande importância pelo fato de ter sido desenvolvida exclusivamente considerando certas peculiaridades dos derramamentos no mar. Não deixa de ser "um primeiro passo para que ações mais efetivas possam ser adotadas no tocante à penalização dos agentes causadores da poluição do mar", como argumenta Marcelino. ${ }^{564}$

Os tribunais consideram que a metodologia da CETESB oferece critérios objetivos para cálculo dos danos ambientais, os quais são ausentes na legislação ambiental. Assim, a metodologia da CETESB seria um caminho alternativo técnico-científico, mais objetivo que o arbitramento aleatório do valor pelo magistrado. O julgado abaixo do TRF da $3^{\mathrm{a}}$ Região ilustra com clareza este posicionamento:

- Se a lei não oferece critérios para a fixação do montante da indenização por dano ambiental, nada obsta a aplicação dos critérios estabelecidos na metodologia CETESB, atendidas, evidentemente, as particularidades do caso em exame e observados os princípios da razoabilidade e da proporcionalidade. Não obstante as

562 CETESB. Companhia Ambiental do Estado de São Paulo. Diretoria de Controle e Licenciamento Ambiental. Ofício $n^{\circ}$. 046/2011/C. Ref.: Proposta de critério para valoração monetária de danos causados por derrames de petróleo ou de seus derivados em ambiente marinho - Junho/1992. São Paulo, 30 de agosto de 2011.

${ }_{563}$ COSTA, D. M. B. A valoração econômica como ferramenta para compensação de derramamentos de petróleo. 217f. Dissertação de Mestrado - Instituto Alberto Luiz Coimbra de Pós-Graduação e Pesquisa de Engenharia (COPPE), da Universidade Federal do Rio de Janeiro (UFRJ), Rio de Janeiro, dez. 2012 , p.92. Disponível em <http://www.ppe.ufrj.br/ppe/production/tesis/daniele_costa.pdf $>$. Acesso em: 01.08.2018.

${ }^{564}$ MARCELINO, A. et al. Proposta de Critério para Valoração Monetária de Danos Causados por Derrames de Petróleo ou de seus Derivados no Ambiente Marinho. Congresso Brasileiro de Petróleo e CONEXPO ARPEL'94. Rio de Janeiro, 1994, p.09. 
críticas que a ela se fazem, não a desqualificam como um instrumento técnico adequado para estimar a quantificação monetária do valor da indenização.

- A adoção da metodologia CETESB justifica-se, ainda, por traduzir medida que evita a imposição aleatória do quantum passível de indenização, pois funciona como um padrão matemático para a valorização monetária de danos causados por derramamento de petróleo ou de seus derivados no mar, desde que precisamente observados os seus cinco aspectos relevantes (volume, vulnerabilidade da área, toxicidade do produto, persistência do produto e mortalidade de organismos), aos quais, divididos em níveis, foi atribuído peso correspondente, de acordo com a severidade do risco ou dano gerado, que varia de 0 a 0,5 , e ressalvada a necessidade de adequação do valor apurado às peculiaridades do caso e atendidos aos critérios da razoabilidade e proporcionalidade à ofensa real ao estuário. Precedentes desta corte.

- Conforme minudentemente explicitado no voto vencido, o cálculo da indenização com base na fórmula estabelecida pela CETESB representa critério técnico-científico que incorpora a razoabilidade e a proporcionalidade, de modo que dispensa e deve prevalecer sobre qualquer outra valoração." (Apelação Cível no 0006757 75.2001.4.03.6104/SP, Rel. André Nabarrete, Quarta Turma, publicado em 24/06/2015).

Importante mais uma vez ressaltar que, nos julgados analisados na presente tese, a metodologia da CETESB não foi aplicada de forma isolada, mas sim como um parâmetro objetivo para realizar o cálculo. A partir do montante calculado com base nesta metodologia, os Tribunais avaliaram outros fatores, como o comportamento de boa-fé do ofensor, medidas mitigadoras e reparatórias do dano, bem como a proporcionalidade e razoabilidade. O caso a seguir, extraído do TRF da $3^{\text {a }}$ Região, ilustra esse entendimento:

10. O 'Critério para Valoração de Danos Ambientais Causados por Derramamentos de Petróleo ou de seus derivados em Mar' adotado pela CETESB, que, no caso em tela, estimou em US\$ $354.813,00$, pode ser utilizado como parâmetro para a quantificação do dano ambiental em apreço, mas não de forma absoluta, devendo o valor indenizatório se adequar às particularidades do caso concreto, de acordo com os princípios da proporcionalidade e razoabilidade.

11. Não podendo ser ignorada a circunstância da empresa ré ter adotado, de imediato, medidas tendentes a reduzir o impacto causado ao meio ambiente pelo derramamento de óleo, a indenização deve ser reduzida para $\mathrm{R} \$ 70.000,00$ (setenta mil reais), de modo a privilegiar o comportamento pautado na boa-fé e a consciência ambiental, sem olvidar de seu caráter preventivo. (Apelação Cível $\mathrm{n}^{\circ}$ 000191338.2008.4.03.6104/SP, Rel. Antonio Cedenho, Terceira Turma, publicado em 19/02/2018).

No julgado a seguir, o Tribunal Regional Federal da $5^{\text {a }}$ Região tece longas considerações sobre a metodologia da CETESB, aprovando o critério, por considerá-lo objetivo e científico:

16. Nesta linha de raciocínio, quando a sentença determina o pagamento de uma indenização pecuniária pelos danos já causados, ou seja, pelos danos ambientais já sentidos, considera dois pressupostos: 1) que os autores cessarão com a ação predatória; e 2) o dano ambiental, pelo seu próprio conceito, por não ter reparação imediata, deve ser considerado pelo impacto ambiental causado.

17. Feitas estas considerações, tem-se que dois fatores relevantes devem ser considerados no momento de valorar a gravidade do dano para fins de se calcular o valor da indenização devida: possibilidade de recuperação do meio ambiente degradado e a efetiva recuperação; 
18. Tais fatores são adotados como pressupostos para restaurar a proporcionalidade da condenação e, assim, viabilizar o cumprimento da obrigação pecuniária em favor do Fundo de Defesa dos Direitos Difusos.

19. Propõe o MPF a utilização do método de 'Proposta de Critério para Valoração Monetária de Danos Causados por Derramamentos de Petróleo ou de seus Derivados no Ambiente Marinho' da CETESB, de autoria da Bióloga Íris Regina Fernandes Poffo, em sua dissertação de mestrado oferecida à USP.

20. Apesar de várias propostas metodológicas tencionadas a buscar solução para quantificação do dano ambiental, o fato é que não existe método preciso, perfeito ou exclusivo para fixar tais valores, cabendo ao juízo no caso concreto, sempre buscando parâmetros objetivos e contando com o bom senso do julgador.

21. Destarte, não prosperam os argumentos dos autores no sentido de que a referida metodologia restaria inaplicável ao caso, porquanto, diferentemente do que se afirma, tal proposta não está atrelada aos interesses do Ministério Público quando da propositura da ação civil pública, mas se trata de um estudo genérico direcionado à quantificação do dano ambiental de várias espécies.

22. Como proposta, o estudo apresenta soluções objetivas, partindo de uma diretriz genérica, mas que tenta abranger o maior número de situações possíveis, o que não dispensa adaptações em cada caso concreto.

23. Neste ponto vale frisar o seguinte: a utilização do valor de recuperação serve apenas para se ter um parâmetro para quantificar o dano e não significa que se está desconsiderando a recuperação ambiental e nem o fato que o autor colaborou para o êxito da recomposição do ecossistema.

(...)

27. Assim, dada a ausência de um critério objetivo para se aferir o quantum indenizatório de determinado dano ambiental e tendo como norte o Princípio da Reparação Integral, que tem como objetivo propiciar a recomposição do meio ambiente, na medida do possível, ao estado em que se encontrava antes da ocorrência do dano, parece-nos razoável a adoção do critério proposto com vistas a incutir no poluidor o caráter punitivo-pedagógico que deve possuir a reparação.

28. Múltiplos precedentes do Egrégio Tribunal Regional Federal da $3^{\text {a }}$ Região.

29. Não obstante o método da CETESB se apresente em dólares, o quantum deve ser explicitado em moeda corrente nacional, ou seja, a ser convertido em reais segundo a cotação oficial de fechamento divulgada pelo Banco Central do Brasil para a data do evento danoso, como dispõe a legislação pátria (artigo $1^{\circ}$ da Lei no 10.192/01, artigo 315 do Código Civil e artigos $1^{\circ}$ e $2^{\circ}$ do Decreto-Lei $n^{\circ} 857 / 69$ ), sendo, ao final, revertido ao Fundo para a Reconstituição de Bens Lesados (Lei 7.347/1985), e integralmente aplicado em medidas para o controle e restabelecimento do ecossistema aquático na área do estuário e adjacências. (Apelação Cível no 0801665 62.2014.4.05.8500, Rel. Manoel de Oliveira Erhardt, Primeira Turma, julgado em 20/02/2016).

Diante do exposto, é notório que o método da CETESB pode ser utilizado como base para o desenvolvimento de outros métodos, ou ainda poderá ser aprimorado, abrangendo outros critérios técnicos pertinentes aos danos causados por vazamentos de petróleo no mar. ${ }^{565} \mathrm{Ou}$ seja, o método proposto pela CETESB na década de noventa poderá ser aprimorado, ou

${ }^{565}$ MARCELINO, A. et al. Proposta de Critério para Valoração Monetária de Danos Causados por Derrames de Petróleo ou de seus Derivados no Ambiente Marinho. Congresso Brasileiro de Petróleo e CONEXPO ARPEL'94. Rio de Janeiro, 1994, p.09. 
repensado, para que, além do caráter punitivo, as futuras metodologias específicas para ambiente marinho viabilizem uma valoração mais efetiva e completa dos danos.

Nesse sentido, pode-se considerar o método como um importante primeiro passo, necessário para a valoração de danos tão complexos.

\subsubsection{Valoração de danos em ambiente marinho}

\subsubsection{Valoração de danos ambientais ecológicos e patrimoniais e extrapatrimoniais}

Inicialmente, é de extrema importância o entendimento sobre o que realmente deve ser valorado em situações de danos em ambientes marinhos. Para o cálculo de indenizações no Direito Civil, deve-se buscar a resposta para a seguinte indagação: qual bem jurídico deveria ser reparado?

Se a resposta for "a saúde", "o bem-estar", "a qualidade de vida da população", fica claro que a valoração deverá ser calculada a partir dos danos à "vida humana", que de alguma forma foi lesada, direta ou indiretamente. Entretanto, se o objetivo for a reparação ecológica do ambiente afetado, o que se busca reparar são os bens ambientais estritos e suas funções ecossistêmicas.

Para tanto, é necessário conceituar o que são bens e serviços ambientais. Quanto a isso, Grasso, Tognella, Schaeffer-Novelli e Comune asseveram que "bens englobam todos os produtos que são retirados direta ou indiretamente de um determinado ecossistema"; ao passo que "serviços são as funções ecológicas exercidas pelos mesmos, tais como reciclagem de nutrientes e manutenção de diversidade biológica". 566

Um mesmo evento pode causar danos tanto aos seres humanos, quanto aos bens e serviços ambientais. Da mesma forma, conforme já apresentado no capítulo 5 , derramamentos de óleo podem causar danos ecológicos e biológicos complexos, com desdobramentos em danos patrimoniais e extrapatrimoniais aos serem humanos. Por isso, cada bem jurídico afetado carece de reparação específica. Da mesma forma, é praticamente inviável a valoração dos diferentes tipos de danos por meio de uma única metodologia. Ou seja, uma vez identificados os tipos de

${ }^{566}$ GRASSO, M.; TOGNELLA, MMP.; SCHAEFFER-NOVELLI, Y.; COMUNE, AE., Aplicação de técnicas de avaliação econômica ao ecossistema Manguezal. In: MAY, P. (Org.). Economia Ecológica: aplicações no Brasil. Rio de Janeiro: Editora Campus, 1995, p. 57. 
danos decorrentes dos derramamentos, em seguida deverá ser avaliada qual metodologia seria mais apropriada a cada um deles.

\subsection{Valoração do dano ambiental reflexo patrimonial e extrapatrimonial}

Conforme já exposto no presente trabalho, mais precisamente no capítulo 5 , o dano ambiental pode causar efeitos reflexos em patrimônio, saúde, ou interesses individuais ou coletivos. ${ }^{567}$ Portanto, além da lesão aos bens ambientais estritos, deve ser considerado o dano injusto, que atinge aspectos patrimoniais ou morais lesados. ${ }^{568}$

O dano patrimonial se relaciona a bens e coisas materiais, e, por isso, pode ser mais facilmente quantificado e reparado. ${ }^{569}$ Uma casa atingida por óleo, por exemplo, tem o custo de reparação determinado pelo valor da limpeza e reparos. Já nos casos de danos extrapatrimoniais ambientais, a perda de qualidade de vida deve ser avaliada e, se possível, quantificada.

Nos casos de derramamentos de óleo, normalmente são identificados os seguintes danos patrimoniais: (i) atingimento de propriedades públicas e privadas, acarretando em desvalorização ou gerando prejuízos referentes à limpeza; (ii) paralização do comércio e de empresas de turismo; (iii) danos diretos ou indiretos aos consumidores; (iv) paralização e prejuízos aos mercados de peixes e alimentos; (v) despesas com limpeza da costa e com prevenção do avanço do óleo, ou com sua dispersão. ${ }^{570}$

As metodologias anteriormente apresentadas parecem mais adequadas para a valoração dos bens e serviços afetados pelos derramamentos e ligados diretamente ao indivíduo ou à coletividade, a exemplo daqueles métodos que têm como base as preferências individuais. Atividades de recreação e ecoturismo, por exemplo, são serviços cujos benefícios econômicos são melhor mensurados, podendo ser valorados pelo "Método dos Custos de Viagem" e da "Valoração Contingente". 571

${ }^{567}$ MILARÉ, E. Direito do Ambiente, $10^{a}$ ed., Editora Revista dos Tribunais, 2015, p. 325.

${ }^{568}$ LEMOS, P. F. I. Direito Ambiental: Responsabilidade civil e proteção do meio ambiente. São Paulo: RT, $2011,3^{\text {a }}$ ed., p. 125.

${ }^{569}$ LEMOS, P. F. I. Meio Ambiente e responsabilidade civil do proprietário: análise do nexo causal. São Paulo: RT,. 2008, p. 120.

570 THÉBAUD, O.; BAILLY, D.; HAY, J.; PÉREZ AGUNDEZ, J. A. The cost of oil pollution at sea: an analysis of the process of damage valuation and compensation following oil spills. In: ALBINO, P.; VÁZQUEZ, M. X. Economic, social and environmental effects of the "Prestige" oil spill. Santiago: Consello da Cultura Galega, 2003, jan. 2004, p.07. Documento disponível em: $<$ https://bit.ly/2r0fDeN>. Acesso em 05.08.2018.

571 PAIVA, R. F. P. As dimensões de valor dos recursos naturais e os métodos de valoração. Revista Iberoamericana de Economía Ecológica, v.24, 2015, p.207. 
Porém, até mesmo na valoração dos danos patrimoniais, muitas vezes, a informação necessária é fragmentada ou o custo para o levantamento de todos os agentes afetados em todas as áreas impactadas é muito elevado, além de o tempo ser fator limitante. As lacunas referentes a informações econômicas levam autores a utilizarem métodos de valorização indiretos, baseados em suposições globais sobre a estrutura econômica de uma determinada atividade. Por exemplo, no caso do acidente ocorrido "Amoco Cadiz", 572 cujos danos ecológicos foram apresentados no capítulo 5, a falta de informações detalhadas sobre o nível de atividade econômica das empresas que operavam na indústria do turismo levou os economistas a usarem indicadores como salários pagos pelas empresas ou vendas locais de farinha para avaliar o impacto global da economia, ${ }^{573}$ isto é, critérios que se afastavam muito dos possíveis danos sofridos pela população.

Mesmo nos casos em que a informação econômica está disponível no nível individual, a falta de um cenário base anterior a ocorrência do dano - ainda que, nele, prepondere a dimensão econômica -, pode prejudicar a avaliação de suas consequências. Dito de outro modo, pode ser difícil a distinção entre os reais efeitos locais relacionados ao derramamento e outros fatores de variação nos ecossistemas, por exemplo: fatores meteorológicos ou fatores hidrológicos que afetam a pesca, ou ainda flutuações nas taxas de câmbio, que afetem a indústria do turismo em nível nacional. ${ }^{574} \mathrm{O}$ próprio conhecimento detalhado da estrutura de atividades portuárias ou de fluxo de embarcações é essencial na identificação de um derramamento. Não é incomum a demora na identificação da origem das manchas, uma vez que o óleo pode se dissipar por quilômetros a partir do ponto de vazamento. ${ }^{575}$

Por outro lado, no caso dos danos extrapatrimoniais, os mais comuns derivados dos derramamentos são: a perda de amenidade, a geração de doenças psíquicas e físicas para

572 INTERNATIONAL TANKER OWNERS POLLUTION FEDERATION (IOTPF). AMOCO CADIZ, France, 1978. Disponível em: <https://www.itopf.org/in-action/case-studies/case-study/amoco-cadiz-france-1978/>. Acesso em: 10.11.2017.

573 THÉBAUD, O.; BAILLY, D.; HAY, J.; PÉREZ AGUNDEZ, J. A. The cost of oil pollution at sea: an analysis of the process of damage valuation and compensation following oil spills. In: ALBINO, P.; VÁZQUEZ, M. X. Economic, social and environmental effects of the "Prestige" oil spill. Santiago: Consello da Cultura Galega,

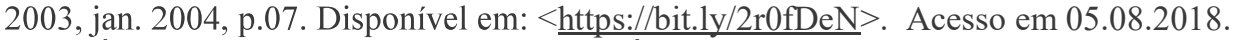

574 THÉBAUD, O.; BAILLY, D.; HAY, J.; PÉREZ AGUNDEZ, J. A. The cost of oil pollution at sea: an analysis of the process of damage valuation and compensation following oil spills. In: ALBINO, P.; VÁZQUEZ, M. X. Economic, social and environmental effects of the "Prestige" oil spill. Santiago: Consello da Cultura Galega,

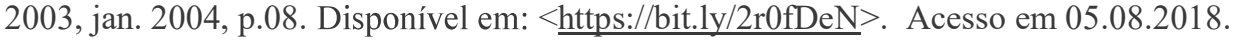

575 POFFO, I. R. F. Percepção de riscos e comportamento da comunidade diante de acidentes ambientais em áreas portuárias de santos e São Sebastião. 119f. Pós-Doutorado em Psicologia Clínica - Programa de Estudos Pós-Graduados em Psicologia Clínica, Univers, Pontifícia Universidade Católica de São Paulo (PUC/SP), São Paulo, jna. 2011, p.96. 
moradores do entorno. ${ }^{576}$ Ademais, a diminuição do conforto associado aos danos à paisagem deve ser considerada na mensuração da perda de qualidade de vida.

As mudanças individuais e de bem-estar podem ser observadas a partir de uma comparação de cenários anterior, durante e após derramamento. ${ }^{577}$ Tal constatação aponta que, mesmo nesses casos, não se pode admitir uma valoração imediata, desenvolvida logo após o ocorrido. Mas sim, a perda da qualidade de vida poderá se manifestar em cenários revelados após algum tempo do derramamento, uma vez que os efeitos do óleo no ambiente podem não ser imediatos, gerando reflexos futuros nas populações do entorno do acidente. Para tanto, o monitoramento ao longo do tempo, mais uma vez, aparece como fator essencial à identificação dos danos, mas quase nunca contemplado nas metodologias de valoração.

Para Steigleder, os valores de opção e de existência poderiam ser aplicados nas decisões judiciais, que de forma arbitrária reconhecem a dimensão extrapatrimonial do dano ambiental. Entretanto, para a valoração de funções ecossistêmicas, haveria a necessidade de metodologias interdisciplinares. ${ }^{578}$

\subsection{Valoração do dano ambiental ecológico}

A análise dos métodos apresentados no presente capítulo deixa claro que a valoração de danos ao ser humano (patrimoniais e extrapatrimoniais) parece ser mais concreta e plausível do que a valoração de danos ecológicos. Entretanto, nos casos em que realmente é impossível a reparação, ou compensação dos danos ecológicos, não se pode afastar a via da valoração. Diante deste fato, pergunta-se: como tornar a valoração dessa categoria de danos mais eficiente?

Uma das premissas necessárias à valoração econômica de danos ambientais em ambientes marinhos é o conhecimento das características do local previamente e posteriormente à ocorrência do dano, conforme já pontuado.

\footnotetext{
576 THÉBAUD, O.; BAILLY, D.; HAY, J.; PÉREZ AGUNDEZ, J. A. The cost of oil pollution at sea: an analysis of the process of damage valuation and compensation following oil spills. In: ALBINO, P.; VÁZQUEZ, M. X. Economic, social and environmental effects of the "Prestige" oil spill. Santiago: Consello da Cultura Galega,

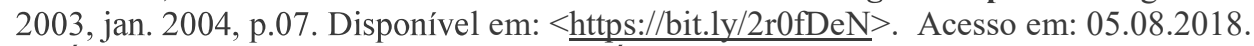

THÉBAUD, O.; BAILLY, D.; HAY, J.; PÉREZ AGUNDEZ, J. A. The cost of oil pollution at sea: an analysis of the process of damage valuation and compensation following oil spills. In: ALBINO, P.; VÁZQUEZ, M. X. Economic, social and environmental effects of the "Prestige" oil spill. Santiago: Consello da Cultura Galega, 2003, jan. 2004, p.07. Disponível em: $<$ https://bit.ly/2r0fDeN $>$. Acesso em 05.08.2018.

578 STEIGLEDER, A. M. Valoração de Danos Ambientais Irreversíveis. Revista MPMG Jurídico, edição especial de Meio Ambiente, 2011, p.27.
} 
Para que seja bem-sucedida a obtenção das informações decorrentes do evento danoso, a estratégia de ação após determinado acidente já deve ser prevista em Planos de Emergência Individuais (PEIs) e em Planos de Áreas (PAs), ${ }^{579}$ e iniciadas imediatamente. As dimensões do acidente nas esferas ambientais e humanas só podem ser efetivamente avaliadas a partir da obtenção de dados de forma rápida e adequada. ${ }^{580}$

Com relação às informações prévias à contaminação de ambientes marinhos, deve-se reconhecer que não se pode estimar as reais alterações sofridas pelo ambiente sem dados anteriores ao impacto. ${ }^{581}$ Desse modo, "o conhecimento das funções ecossistêmicas e dos valores a elas associados permite a realização de estudos de valoração mais completos e, portanto, capazes de orientar o processo de tomada de decisões que leve em conta o risco de perdas irreversíveis". 582

É inegável que, conforme apresentado, informações primárias, que apresentem uma caracterização multidisciplinar dos ambientes anteriormente à ocorrência do dano, são essenciais não somente para o planejamento da resposta imediata aos derramamentos, mas também para o cálculo de eventual indenização ou, prioritariamente, para a definição de medidas de reparação ou compensação ambiental.

O Brasil ainda não possui um modelo de utilização de fundos para o pagamento de indenização associado ao ressarcimento de custos dispendidos pela população com medidas de reparação, a exemplo do que é realizado nos Estados Unidos. ${ }^{583}$ Entretanto, conforme apresentado, o país conta com técnicas de valoração associadas a medidas de reparação e mitigação efetivamente ocorridas e evitadas.

\footnotetext{
579 “A Lei Federal n ${ }^{\circ}$ 9966/2000 trata nos seus Artigos 5, $7^{\circ}$ e $8^{\circ}$ sobre planos de contingência Individual (PEI), de Área (PA), Regional (PR) e Nacional (PNC) a incidentes de poluição por óleo nas águas brasileiras, bem como sobre a obrigatoriedade de dispor dos meios adequados para o combate à poluição." Disponível em: $<$ https://cetesb.sp.gov.br/emergencias-quimicas/tipos-de-acidentes/vazamentos-de-oleo/preparacao-pararesposta/planos-de-contingencia-para-vazamentos-de-oleo-no-mar/>. Acesso em 02.04.2018.

580 ARAUJO, R. C. Valoração econômica do dano ambiental em inquérito civil público. Brasília: Escola Superior do Ministério Público da União, 2011, p. 12. Disponível em: $<$ http://escola.mpu.mp.br/publicacoes/obras-avulsas/e-books/valoracao-do-dano-ambiental-em-inquerito-civilpublico $>$. Acesso em: 01.08.2018.

${ }^{581}$ GRASSO, M.; TOGNELLA, MMP.; SCHAEFFER-NOVELLI, Y.; COMUNE, AE., Aplicação de técnicas de avaliação econômica ao ecossistema Manguezal. In: MAY, P. (Org.). Economia Ecológica: aplicações no Brasil. Rio de Janeiro: Editora Campus, 1995, p. 51.

582 PAIVA, R. F. P. As dimensões de valor dos recursos naturais e os métodos de valoração. Revista Iberoamericana de Economía Ecológica, v. 24, 2015, p.205.
} 
As informações prévias aos derramamentos de óleo devem considerar os aspectos geomorfológicos das áreas do litoral, a fauna, flora e funções ecológicas correlatas. Dentre as fontes primárias de informações a serem consideradas destacam-se as "Cartas de Sensibilidade Ambiental a Derramamentos de Óleo" (Cartas SAO). Por meio delas, é possível mapear ambientes a serem protegidos e sacrificados, permitindo o direcionamento adequado das equipes de contenção e limpeza. ${ }^{584}$

Em relação ao conteúdo, as Cartas SAO consideram as seguintes informações principais: (i) sensibilidade ambiental do litoral; (ii) recursos biológicos sensíveis; (iii) atividades socioeconômicas que podem ser prejudicadas por derramamentos ou mesmo afetadas pelas ações de resposta; bem como (iv) diretrizes para as ações de resposta. ${ }^{585}$

Ainda no tocante à caracterização prévia dos ambientes marinhos e costeiros, destacase a importância da modelagem ecossistêmica, que apresenta como objetivo principal "a determinação da escala sustentável de uso dos recursos naturais e seus impactos sobre o estoque de capital natural existente", podendo servir de base para a avaliação das reais consequências após o dano. Assim, a realização de estudos de valoração prévia à exploração pode levar a resultados qualitativos, ao invés da determinação de valores monetários, ${ }^{586}$ sendo mais fiéis à caracterização dos danos ecológicos decorrentes dos derramamentos. Nos casos de derramamentos, resultados qualitativos que demonstrem prejuízo de funções ecossistêmicas parecem ser mais efetivos à reparação ambiental do que avaliações quantitativas e monetárias.

Entretanto, mesmo nos casos em que o ambiente afetado era suficientemente conhecido, não se pode negar que regiões marinhas e costeiras possuem uma complexidade de bens e

\footnotetext{
584 “A Lei N 9.966, de 28 de abril de 2000, atribuiu ao Ministério do Meio Ambiente responsabilidades na identificação, localização e definição dos limites das áreas ecologicamente sensíveis com relação à poluição causada por lançamento de óleo e outras substâncias nocivas ou perigosas em águas sob jurisdição nacional. Além disto, a Resolução CONAMA n 398, de 11/06/2008, insere as Cartas SAO no conteúdo mínimo dos Planos de Emergência Individuais (PEI) para determinados empreendimentos. Por sua vez, o Decreto $\mathrm{n}^{\circ} 4.871$, de 06/11/2003, estabelece que os Planos de Área para o combate à poluição por óleo em águas sob jurisdição nacional deverão conter mapas de sensibilidade ambiental, conforme as especificações e normas técnicas para elaboração das Cartas SÃO." Cf. BRASIL. Ministério do Meio Ambiente. Cartas de Sensibilidade ao Óleo. Texto disponível na página oficial do ministério em: <http://www.mma.gov.br/seguranca-quimica/cartas-de-sensibilidade-ao-

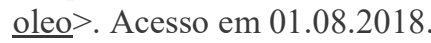

${ }^{585}$ De acordo com o Ministério do Meio Ambiente, As seguintes bacias foram mapeadas: Ceará e Potiguar (2004); Santos (2007); Espírito Santos (2010); Sul da Bahia (2013); Sergipe-Alagoas/Pernambuco-Paraíba (2013); Foz do Amazonas (2017); Pará-Maranhão/Barreirinhas (2017); Campos (2017); Pelotas (2017) Cf. BRASIL. Ministério do Meio Ambiente. Cartas de Sensibilidade ao Óleo. Texto disponível na página oficial do ministério em:

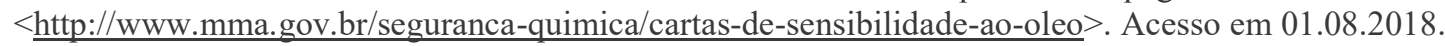

586 PAIVA, R. F. P. As dimensões de valor dos recursos naturais e os métodos de valoração. Revista Iberoamericana de Economía Ecológica, v.24, 2015, p.209.
} 
funções que dificultam qualquer tipo de valoração. Dentre os ecossistemas mais atingidos pelos derramamentos, destacam-se os manguezais. Porém, como já foi argumentado em estudo anterior, "os dados necessários para a obtenção do real valor das áreas de mangue são complexos e bastante difíceis de serem encontrados". 587

Schaeffer-Novelli e Tognella desenvolveram estudos de valoração de manguezais, envolvendo as técnicas de Custo Viagem e Disposição a Pagar para casos em Bertioga, e de Avaliação de Contingente em casos semelhantes em Cananéia e Iguape, todas a cidades pertencentes ao litoral de São Paulo. Os resultados mostraram que "apesar das falhas inerentes de cada metodologia, assim como de suas dificuldades de implementação, é possível identificar preferências sociais no que diz respeito ao ecossistema em questão". As autoras concluíram que, por meio da aplicação das técnicas, foi possível destacar a "importância dos manguezais como base da economia social". 588

Entretanto, resultados numéricos da aplicação das técnicas de valoração a esse ambiente tão essencial parecem não expressar a real importância de suas funções para a regulação do ecossistema, principalmente quando são utilizados métodos subjetivos, cuja a base é a preferência pessoal.

A aplicação do método de valoração contingente referente ao manguezal de Cananéia por Grasso et al. demonstra que "somente 17\% dos entrevistados, com uma renda média de US\$ 1.700,00 mensais se dispuseram a pagar algum valor". Os autores explicam em seu trabalho que "[e]ssa proporção relativamente baixa de usuários do recurso dispostos a pagar pela sua preservação corresponde a uma atitude comum frente a um recurso considerado de livre acesso sob domínio público". 589

Não há dúvidas de que o valor de preservação de manguezais em regiões tão relevantes ambientalmente como o litoral do Estado de São Paulo deveria ser muito além daquele expressado pela consulta à população. Porém, é inegável a utilidade prática dessas técnicas de

\footnotetext{
${ }^{587}$ GRASSO, M.; TOGNELLA, MMP.; SCHAEFFER-NOVELLI, Y.; COMUNE, AE., Aplicação de técnicas de avaliação econômica ao ecossistema Manguezal. In: MAY, P. (Org.). Economia Ecológica: aplicações no Brasil. Rio de Janeiro: Editora Campus, 1995, p. 51.

${ }^{588}$ SCHAEFFER-NOVELLI, Y.; TOGNELLA DE ROSA, M. M. P. Ecossistema manguezal, o desenvolvimento sustentado e a valoração ambiental. In: Congreso Latino americano de Ciencias Del Mar, 1995, Buenos Aires, p.196.

${ }^{589}$ GRASSO, M.; TOGNELLA, MMP.; SCHAEFFER-NOVELLI, Y.; COMUNE, AE., Aplicação de técnicas de avaliação econômica ao ecossistema Manguezal. In: MAY, P. (Org.). Economia Ecológica: aplicações no Brasil. Rio de Janeiro: Editora Campus, 1995, p. 73.
} 
valoração, principalmente para o desenvolvimento de políticas de informação que levem ao aumento da sensação de pertencimento e valorização desses ambientes pela população. Por outro lado, para funções reparatórias, as metodologias avaliadas tendem a subvalorizar os ecossistemas litorâneos e marinhos.

Deste modo, além das imprecisões decorrentes da falta de caracterização exata dos ambientes afetados antes e depois do óleo derramado, a escolha da metodologia é considerada, portanto, outro obstáculo para a valoração dos danos, principalmente quando aplicada aos danos ecológicos.

Conforme exposto, os bens que não possuem preço de mercado acabam sendo valorados por métodos que não são capazes de expressar as verdadeiras perdas ecológicas, como, por exemplo, custo de viagem, avaliação contingente ou técnicas de transferência de benefícios.

Devido a esse fato, a Assembleia Geral do Fundo IOPC, ${ }^{590}$ em sua primeira sessão extraordinária realizada em outubro de 1980, acordou que as compensações a serem pagas pelo Fundo não deveriam ser baseadas na quantificação abstrata dos danos, calculadas por metodologias teóricas. Com isso, as reclamações relacionadas a danos ecológicos passaram a ser aceitas apenas se os danos pudessem ser medidos por custos financeiros incorridos, em associação com medidas razoáveis de restabelecimento do ambiente após um derramamento.

A mesma restrição foi aplicada a outras situações em que não foi possível a mensuração direta de custos monetários, a exemplo de benefícios recreativos. No caso do Erika, ${ }^{591}$ por exemplo, o custo dos danos para pescadores recreativos foi estimado em aproximadamente 100 milhões de euros, mas não foi levado em consideração pelo "sistema internacional de responsabilidade e compensação de danos causados por derramamentos de óleo". 592

\footnotetext{
${ }^{590}$ Os Fundos IOPC (o Fundo de 1992 e o Fundo Complementar) fornecem compensação por danos resultantes de derramamentos de óleo persistente de navios-tanque. Informações podem ser obtidas em: $<$ https://www.iopcfunds.org/> . Acesso em: 01.08.2018.

${ }^{591} \mathrm{O}$ navio-tanque ERIKA transportava cerca de 31.000 toneladas de óleo pesado como carga, quando, em decorrência de uma violenta tempestade, partiu-se em dois, no Golfo da Biscaia, França, em 12 de dezembro de 1999. Cerca de 20.000 toneladas de óleo foram derramadas. Disponível em: < https://www.itopf.org/in-action/casestudies/case-study/erika-west-of-france-1999/>. Acesso em: 01.08.2018.

THÉBAUD, O.; BAILLY, D.; HAY, J.; PÉREZ AGUNDEZ, J. A. The cost of oil pollution at sea: an analysis of the process of damage valuation and compensation following oil spills. In: ALBINO, P.; VÁZQUEZ, M. X. Economic, social and environmental effects of the "Prestige" oil spill. Santiago: Consello da Cultura Galega,

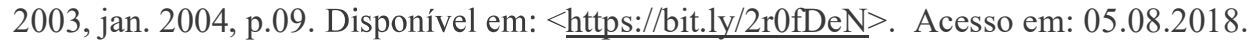


Nos casos de ecossistemas marinhos e costeiros, a aplicação dos métodos subjetivos, até mesmo para valoração preventiva, parece não traduzir a importância das funções ecossistêmicas. Com relação à valoração pós-derramamentos, métodos baseados em perdas econômicas não podem ser utilizados para valorar perdas ambientais. Mesmo os métodos que busquem a real caracterização ecológica dos danos nunca vão ser totalmente efetivos, pois tendem a ser imediatos, uma vez que subsidiam a tomada de decisão por juízes.

Schaeffer-Novelli e Varjabedian defendem que parte dos danos vai se manifestando ao longo dos anos, sendo impossível uma quantificação total imediata, mas apenas por meio de monitoramentos que podem durar décadas. Um exemplo utilizado pelos autores é o caso do rompimento do duto da Petrobrás, ocorrido em outubro de 1983, na altura do Canal de Bertioga, Litoral de São Paulo, cujas consequências puderam ser observadas décadas depois, como a presença de óleo no sedimento do manguezal do Rio Iriri. ${ }^{593}$

No mesmo sentido, Pozzi Neto defende que "[a] gravidade do impacto ocorrido, assim como a avaliação dos danos decorrentes, são funções do fator tempo. Apenas com o monitoramento da área serão obtidas as respostas quali-quantitativas necessárias às avaliações pretendidas". 594

Ocorre que, muito embora as ações judiciais sejam em sua grande maioria morosas, o rito processual não permite o acompanhamento da evolução dos monitoramentos das áreas atingidas. Normalmente, é realizada uma perícia técnica, que irá subsidiar a decisão do magistrado.

Surge, então, um impasse quanto às contribuições técnicas à decisão judicial. Se, por um lado, fica claro o fato de que danos decorrentes de derramamentos são complexos, por outro, as Ações Judiciais normalmente vão abranger apenas uma parcela desses danos, mais precisamente os agudos e visíveis logo após o incidente.

Nos casos de derramamentos de óleo, os dados necessários para uma valoração que atenda a uma reparação ecológica são muito específicos, tanto diante da grande variedade de tipos de derramamentos, quanto da diversidade de ambientes possivelmente afetados.

\footnotetext{
593 SCHAEFFER-NOVELLI, Yara; VARJABEDIAN, R. Valoração Monetária de Danos Ambientais: Experiências na Zona Costeira, Ferramentas e Comentários. Revista do Ministério Público de Minas Gerais (MPMG) jurídico, edição especial Meio Ambiente, 2011, p.51.

${ }^{594}$ POZZI NETO, D. Baixada santista, manguezal e vazamento de óleo: uma valoração econômica-ecológica. Dissertação de Mestrado - Programa de Pós-Graduação em Ciências Ambientais (PROCAM), Instituto de Energia e Ambiente (IEE), Universidade de São Paulo (USP), São Paulo, 2000, p.94.
} 
Além das difículdades inerentes aos métodos de valoração existentes e relacionadas à complexidade dos ecossistemas analisados, sua capacidade de aplicação pelo judiciário não pode ser ignorada como importante fator. A partir do momento em que os resultados vão ser utilizados pelos magistrados, devem refletir princípios basilares do Direito, como, entre outros, os princípios da proporcionalidade e da razoabilidade.

No caso do vazamento de óleo do navio "Zoe Colocotroni", que ocorreu ao final da década de 1970, no Caribe, os peritos do Governo de Porto Rico utilizaram a técnica de substituição dos recursos perdidos, por meio da qual foram adotados valores de espécies animais, vegetais e do próprio substrato impregnado pelo óleo, em substituição àqueles das áreas afetadas. Entretanto, o método não foi aceito pelos juristas do caso. ${ }^{595}$

Já no caso do desastre do Exxon Valdez, ${ }^{596}$ a valoração dos danos foi baseada na avaliação contingente das perdas da sociedade, bem como dos custos de recuperação dos ecossistemas. A imensidão das penalidades judiciais atribuídas neste caso levou a Administração Nacional Oceânica e Atmosférica dos EUA a propor uma orientação em relação a essa avaliação de danos, adotando, como regra geral, um máximo de $50 \%$ sobre os danos de valor contingente. ${ }^{597}$

Diante dos precedentes, fica claro que a valoração não só deve buscar o real valor do recurso ambiental, mas igualmente atender às limitações e expectativas do Direito, tornando possível a sua aplicação no mundo jurídico.

Para Steigleder, há a necessidade de adoção de metodologia capaz de aferir os aspectos intangíveis do ecossistema. Uma possível solução aplicável aos casos de responsabilidade civil seria o desenvolvimento de um método que considere os critérios estabelecidos pelo Decreto

\footnotetext{
${ }^{595}$ SCHAEFFER-NOVELLI, Yara; VARJABEDIAN, R. Valoração Monetária de Danos Ambientais: Experiências na Zona Costeira, Ferramentas e Comentários. Revista do Ministério Público de Minas Gerais (MPMG) jurídico, edição especial Meio Ambiente, 2011, p.51.

596 O Navio EXXON VALDEZ encalhou em Bligh Reef, em Prince William Sound, no Alasca, em 24 de março de 1989. Cerca de 37.000 toneladas de petróleo bruto vazaram. Informação disponível em: $<$ https://www.itopf.org/in-action/case-studies/case-study/exxon-valdez-alaska-united-stated-1989/>. Acesso em: 05.08.2018.

${ }^{597}$ MAY, P. H. Globalization, Economic Valuation, and Natural Resource Polices in Brasil. In: (Editor). Natural Resource Valuation and Policy in Brasil Methods and Cases. Nova Iorque: Columbia University Press, 1999, p.23.
} 
Federal $n^{\circ} 6.848 / 2009$, para delimitação do Grau de Impacto, com base no método de custos de recuperação. 598

A autora sugere que, para tanto, caberia um estudo mais apurado para avaliar a viabilidade de se utilizar os atributos adotados no art. 31-A do Decreto $n^{\circ}$ 6.848/2009 para a valoração de impactos negativos à biodiversidade na esfera da responsabilização civil, com a substituição do fator "custo de investimento" pelo fator "custo de recuperação necessários ao hipotético retorno ao status quo ante." ${ }^{, 599}$

Como parte da metodologia proposta pela autora, peritos, preferencialmente com formação interdisciplinar, deverão responder aos quesitos claros e objetivos formulados por promotores e seus assistentes técnicos, além de estimar as providências necessárias à restauração do dano, orçando os custos de restauração e o monitoramento futuro do local. ${ }^{600}$ Entretanto, entende-se que, até mesmo por meio desta metodologia, apenas a parcela mensurável dos danos ecológicos seria abrangida com a perícia. O fator da complexidade dos danos decorrentes de derramamentos parece impedir que uma única metodologia de valoração abranja tantas variáveis.

Assim, visando abranger tal complexidade de danos ambientais decorrentes dos derramamentos de óleo no mar, sugere-se no presente trabalho a adoção de mais de uma técnica de valoração para um mesmo incidente. Foi a opção defendida por Monteiro, ${ }^{601} \mathrm{em}$ sua Tese de Doutorado, que apresenta um estudo de caso do Complexo REDUC-DTSE, vazamento ocorrido na Baía de Guanabara, Rio de Janeiro, em janeiro de 2000.

Para a avaliação das Perdas sofridas pelos produtores e consumidores com o vazamento de óleo na Baía de Guanabara, a autora desenvolveu uma "árvore de impactos" e os classificou em métodos de valoração, destacando-se: (i) produção sacrificada: para a avaliação das perdas no transporte e pesca; (ii) gastos defensivos: para avaliar os impactos econômicos no turismo;

\footnotetext{
598 STEIGLEDER, A. M. Valoração de Danos Ambientais Irreversíveis. Revista MPMG Jurídico, edição especial de Meio Ambiente, 2011, p.30.

599 STEIGLEDER, A. M. Valoração de Danos Ambientais Irreversíveis. Revista MPMG Jurídico, edição especial de Meio Ambiente, 2011, p.28.

600 STEIGLEDER, A. M. Valoração de Danos Ambientais Irreversíveis. Revista MPMG Jurídico, edição especial de Meio Ambiente, 2011, p.29.

${ }^{601}$ MONTEIRO, A. Metodologia de avaliação de custos ambientais provocados por vazamento de óleo: o estudo de caso do Complexo REDUC-DTSE. 293f. Tese de Doutorado - Coordenação dos Programadas de PósGraduação de Engenharia (COPPE), Universidade Federal do Rio de Janeiro (UFRJ). Rio de Janeiro, 2003, p.180.
} 
(iii) custos de reposição: para a avaliação das perdas relacionadas aos manguezais; (iv) capital humano: para impactos à saúde, e valoração contingente: para perda de qualidade de vida. ${ }^{602}$

A adoção de várias metodologias parece ser a opção mais adequada diante da pluralidade e complexidade dos danos decorrentes. Entretanto, mesmo assim, as metodologias mais utilizadas refletem apenas uma valoração das perdas humanas e de atividades econômicas associadas, e não propriamente dos danos e suas consequências ao meio ambiente.

Nesse sentido, os danos ecológicos e biológicos causados por derramamentos de óleo no mar devem ser objeto de valoração diferenciada dos danos materiais e morais. Não foi possível identificar nenhuma metodologia que considerasse as complexidades dos danos ambientais originados pelo óleo no mar e, portanto, os métodos de valoração existentes precisam ser adaptados para atenderem a tais demandas.

\subsection{Conclusões parciais}

O presente capítulo abordou os métodos de valoração do meio ambiente que surgiram da teoria econômica neoclássica de alocação, a qual "pressupõe que o capital natural pode ser substituído infinitamente pelo capital material (feito pelo homem)". 603 Já "a economia ecológica", argumenta May, "procura uma abordagem preventiva contra as catástrofes ambientais iminentes, pregando a conservação dos recursos naturais através de uma ótica que adequadamente considere as necessidades potenciais das gerações futuras". ${ }^{604}$

Se, por um lado, os métodos neoclássicos tradicionais são limitados e incapazes de abranger a complexidade das funções ambientais e ecológicas, por outro, a economia ecológica acaba sendo mais efetiva, porém limitada à valoração de recursos pré-danos.

\footnotetext{
${ }^{602}$ Importante esclarecer que, para a autora, "perda de qualidade de vida" abrangeu no trabalho em referência: "questões do tipo: lazer, fatores estéticos (paisagem, odor, etc.), fatores psicológicos (desconforto pelo meio ambiente contaminado, etc.). Apesar deste conceito está relacionado a saúde, estes são operativamente diferentes porque seu cálculo esteve relacionado com o gasto provocado pelo atendimento devido às doenças e a falta de produtividade que esta origina". MONTEIRO, A. Metodologia de avaliação de custos ambientais provocados por vazamento de óleo: o estudo de caso do Complexo REDUC-DTSE. 293f. Tese de Doutorado - Coordenação dos Programadas de Pós-Graduação de Engenharia (COPPE), Universidade Federal do Rio de Janeiro (UFRJ). Rio de Janeiro, 2003, p.180.

${ }^{603}$ MAY, P. H.. Economia ecológica e o desenvolvimento equitativo no Brasil. In: Ecológica: aplicações no Brasil. Rio de Janeiro: Editora Campus, 1995, p.05.

604 MAY, P. H. Economia ecológica e o desenvolvimento equitativo no Brasil. In: Ecológica: aplicações no Brasil. Rio de Janeiro: Editora Campus, 1995, p.06. (Org.). Economia (Org.). Economia
} 
Conforme discutido, o valor econômico dos recursos ambientais geralmente não é observado no mercado através de suas funções ecossistêmicas. Então, como identificar este valor econômico?

Primeiro, devemos perceber que o valor econômico dos recursos ambientais é derivado de todos os seus atributos; e, segundo, que estes atributos podem estar ou não associados a um uso. Ou seja, o consumo de um recurso ambiental se realiza via uso e não-uso. ${ }^{605}$

Há metodologias que tentam valorar o dano ambiental buscando precificar o bem ambiental lesado. Há outras, como sugere Monteiro, que consideram que "para determinar a magnitude do dano econômico em consequência do vazamento, deve-se avaliar a perda na qualidade de vida das pessoas que foram afetadas pelo acidente". ${ }^{606}$

Entretanto, os exemplos práticos analisados no presente trabalho, que buscam aplicar as metodologias de valoração neoclássica aos danos ou recursos ambientais marinhos, acabam por valorar o bem ambiental em decorrência da sua relação direta ou indireta com o ser humano. Dito de outro modo, as metodologias não são capazes de avaliar a relação de valor intrínseco de qualquer bem danificado com o ecossistema em que está inserido, sendo apenas eficientes para a valoração de danos ambientais reflexos, ou patrimoniais.

As técnicas tradicionais de valoração de danos ambientais dificilmente vão abranger danos que perduram por um tempo, ou que se revelam em tempo futuro, que podem ser classificados como crônicos, cujos reflexos ao meio ambiente podem ser tão ou mais significativos do que os causados pelos danos agudos.

Verifica-se que as metodologias neoclássicas se baseiam em subestimativas e não são capazes de compreender toda a complexidade e a importância dos conceitos da ecologia (abordagem da economia ecológica). ${ }^{607}$ Em outras palavras, as funções ecológicas e

\footnotetext{
${ }^{605}$ MOTTA, R. S. da. Manual de valoração econômica de recursos ambientais. Rio de Janeiro: Coordenação de Estudos do Meio Ambiente do Instituto de Pesquisa EconÔmica Aplicada (CEMA/IPEA) e Coordenação Geral de Diversidade Biológica do Ministério do Meio Ambiente, dos Recursos Hídricos e da Amazônia Legal (COBIO/MMA), 1997, p.11.

${ }^{606}$ MONTEIRO, A. Metodologia de avaliação de custos ambientais provocados por vazamento de óleo: o estudo de caso do Complexo REDUC-DTSE. 293f. Tese de Doutorado - Coordenação dos Programadas de PósGraduação de Engenharia (COPPE), Universidade Federal do Rio de Janeiro (UFRJ). Rio de Janeiro, 2003, p.179. 607 SCHAEFFER-NOVELLI, Yara; VARJABEDIAN, R. Valoração Monetária de Danos Ambientais: Experiências na Zona Costeira, Ferramentas e Comentários. Revista do Ministério Público de Minas Gerais (MPMG) jurídico, edição especial Meio Ambiente, 2011, p.53.
} 
ecossistêmicas dos bens e recursos ambientais parecem estar longe de serem efetivamente mensuradas pelas técnicas aqui analisadas.

Nesse sentido, o grande problema da valoração econômica neoclássica consiste na busca por “estimativas plausíveis a partir de situações reais onde não existem 'mercados aparentes' ou existem "mercados muito imperfeitos"”. Como argumentam Nogueira e Medeiros, "sendo possível obter tais valores, eles estarão captando pelo menos parte do que deve ser chamado de valor intrínseco, considerando o ambiente como uma entidade em si mesma". ${ }^{608}$

Schaeffer-Novelli e Varjabedian defendem a necessidade de se "efetuar uma análise crítica de situações fáticas em que diferentes metodologias de valoração monetária de danos ambientais vêm sendo aplicadas na instrução de demandas judiciais". Com isso, seria possível o "aprofundamento e discussão de aspectos conceituais e metodológicos correlatos, bem como o resgate de questões de ordem prática", buscando, assim, "a desmistificação de várias teses recorrentes geradoras de equívocos, conflitos, questionamentos e contradições em demandas judiciais". 609

É notório que a escolha da metodologia de valoração deve levar em conta elementos do caso específico, como, por exemplo, a existência ou não de dados pretéritos ao vazamento óleo. Entretanto, a pluralidade de metodologias parece não garantir segurança jurídica, nem ecológica na efetividade da reparação dos danos.

Diante desse fato, pergunta-se se o mecanismo de indenização por meio de técnicas de valoração do dano pode ser considerado uma espécie de reparação ambiental necessária à justa responsabilização na esfera do direito Civil Ambiental.

Ocorre que, o Judiciário tende a solucionar um conflito arbitrando indenizações, a fim de reparar o dano causado. O Poder Judiciário brasileiro em sua atuação diária não possui instrumentos econômicos que avaliem a verdadeira perda ambiental. Geralmente, magistrados estipulam valores de multas considerando limites legalmente determinados, ou encaminham as partes acordos e Termos de Ajustamento de Conduta. ${ }^{610}$

${ }^{608}$ NOGUEIRA, J. M; MEDEIROS, M. A. A. de. Quanto vale aquilo que não tem valor? Valor de existência, economia e meio ambiente. Cadernos de Ciência \& Tecnologia. Brasília, v.16, n.3, p. 59-83, set/dez. 1999 , p.64. 609 SCHAEFFER-NOVELLI, Yara; VARJABEDIAN, R. Valoração Monetária de Danos Ambientais: Experiências na Zona Costeira, Ferramentas e Comentários. Revista do Ministério Público de Minas Gerais (MPMG) jurídico, edição especial Meio Ambiente, 2011, p.54.

${ }^{610}$ ARAUJO, R. C. Valoração econômica do dano ambiental em inquérito civil público. Brasília: Escola Superior do Ministério Público da União, 2011, p. 12. Disponível em: 
Entretanto, nos casos de responsabilidade civil ambiental, o judiciário não pode se afastar da real função pretendida, qual seja, a reparação do dano. A indenização somente deve ser aceita nos casos de total impossibilidade de se reparar ou compensar o dano.

O ponto crucial nos casos de derramamentos é que diferentemente de outros sistemas de responsabilização, nos quais os danos podem ser resolvidos exclusivamente por pagamento de indenizações; na responsabilidade civil ambiental, a restauração ou remediação do ambiente afetado devem ser priorizadas. Nesse sentido, a opção de pagar pelos danos existirá apenas nos casos em que a restauração seja totalmente ou parcialmente impossível. Para tanto, o órgão ambiental deve ser consultado sobre a viabilidade. ${ }^{611}$

Além de a medida de indenização acabar se tornando regra a danos irreparáveis -, e não a exceção, como deveria ser -, devido ao curto espaço de tempo disponível para a realização de perícia, o valor do dano acaba sendo subestimado. ${ }^{612}$ Como bem pontua Antônio Herman V. Benjamin, nas hipóteses em que não há possibilidade de reconstituição do bem lesado, e em que, portanto, acaba sendo determinada a indenização, "a responsabilidade civil obriga, em última análise, a agregar-se um frio valor monetário à natureza, comercializando-a como tal. ${ }^{613}$

Por fim, o valor da indenização é direcionado para fundos de interesses difusos e deveria ser revertido ao ambiente afetado. Porém, não é o que se observa na prática, conforme será demonstrado a seguir.

\footnotetext{
$<$ http://escola.mpu.mp.br/publicacoes/obras-avulsas/e-books/valoracao-do-dano-ambiental-em-inquerito-civilpublico >. Acesso em: 01.08.2018. Acesso em: 01.08.2018.

611 GABARDO, I. et al. Lessons Learned On Oil Spill Environment Impact Assessment: 10 Years of Petrobras Experience Review. International Oil Spill Conference Proceedings, mar. 2011.

${ }^{612}$ GRASSO, M.; TOGNELLA, MMP.; SCHAEFFER-NOVELLI, Y.; COMUNE, AE., Aplicação de técnicas de avaliação econômica ao ecossistema Manguezal. In: MAY, P. (Org.). Economia Ecológica: aplicações no Brasil. Rio de Janeiro: Editora Campus, 1995, p. 50.

${ }^{613}$ BENJAMIM, A. H. V. Responsabilidade civil pelo dano ambiental. In: NERY JUNIOR, N.; NERY, R. M. de A. (Org.). Doutrinas Essenciais. Responsabilidade Civil. Volume VII. RT, São Paulo 2010, p. 457.
} 


\section{FUNDOS COMO SUBSÍDIO PARA A REPARAÇÃO DE DANOS POR DERRAMAMENTOS DE ÓLEO NO MAR}

\subsection{Contexto Mundial}

Os fundos específicos para reparação de danos são relativamente comuns em países da Europa e América do Norte, mas se baseiam em modelos de responsabilidades diferentes das adotadas no Brasil, principalmente no que diz respeito à Responsabilidade Civil em decorrência de danos ambientais. Ademais, ao contrário do Brasil - cujos fundos são todos públicos -, em outros países são encontrados fundos privados, muitas vezes vinculados as seguradoras, que se constituem por meio de contribuições e não por indenizações, provenientes de empresas de um mesmo ramo de atividades.

No presente capítulo serão apresentados, primeiramente, os principais fundos internacionais para reparação de danos originados de derramamentos de óleo. Em seguida, será realizada uma avaliação crítica dos fundos existentes no Brasil sob o aspecto da reparação dos danos ambientais provenientes de derramamentos de óleo.

\subsubsection{International Oil Pollution Compensation Fund}

Conforme já apresentado no capítulo 4, o International Oil Pollution Compensation Fund ${ }^{614}$ (IOPC), ou Fundo Internacional para Compensação de Poluição por Óleo, foi criado com base no regime de responsabilidade trazido pelo Protocolo de 1992, referente à Convenção sobre Responsabilidade Civil de $1969 .{ }^{615}$

A referida Convenção trata da responsabilidade dos proprietários de embarcações por danos decorrentes de derramamento de óleo, com base no princípio da responsabilidade restrita aos proprietários, e criou um sistema de seguro obrigatório de responsabilidade civil, que será tratado no próximo capítulo.

Já o Protocolo de 1992 criou um Fundo suplementar à Convenção de 1969, estabelecendo um regime para compensação das vítimas. Nesse sentido, arca com a indenização

\footnotetext{
614 INTERNATIONAL OIL POLLUTION COMPENSATION FUNDS. Liability and compensation for oil pollution damage: Texts of the 1992 Civil Liability Convention, the 1992 Fund Convention and the Supplementary Fund Protocol. London: International Oil Pollution Compensation Funds, 2018. Disponível em: $<$ https://www.iopcfunds.org/uploads/tx iopcpublications/Text_of_Conventions_e 01.pdf $>$. Acesso em: 09.08.2018.

${ }^{615}$ Até 09 de julho de 2018, 137 Estados tinham ratificado a Convenção de Responsabilidade Civil e 115 tinha ratificado ou aderido ao Fundo de 1992. Fonte: <https://www.iopcfunds.org/about-us/membership/map/\#>. Acesso em: 09.08.2018.
} 
dos afetados pelos danos de poluição em um Estado Membro que não foram contemplados pelas regras da Convenção de Responsabilidade, por um dos seguintes motivos: (i) o proprietário do navio é isento de responsabilidade, em razão de um dos motivos previstos na Convenção; (ii) o proprietário é incapaz financeiramente de arcar com suas obrigações e sua seguradora é insuficiente para satisfazer os requerimentos de compensação por poluição; ou (iii) o dano excede a responsabilidade do proprietário.

Importante ressaltar que, ficou estabelecido que o Fundo não arca com indenizações se o dano ocorrer em um Estado que não é membro da Convenção, se o dano for decorrente de um ato de guerra ou causado por um navio de guerra, ou ainda se o requerente não puder provar que o dano foi resultado de um acidente envolvendo um ou mais navios, conforme definidos na Convenção.

O Fundo de 1992 é financiado por contribuições arrecadadas de qualquer ente que tenha recebido, em um ano-calendário, mais de 150.000 toneladas de óleo bruto e óleo combustível pesado, recebidos em um porto ou terminal instalado em um Estado-membro, após o transporte marítimo. ${ }^{616}$ Além disso, contribuições anuais também são cobradas, para atender aos pagamentos antecipados de compensação e despesas administrativas durante o próximo ano.

Em março de 2005, foi criada uma complementação ao Fundo de 1992, inaugurando-se o Fundo Suplementar, ${ }^{617}$ ratificado por 32 Estados. Ele provê valores de compensação adicionais, possibilitando um aumento no valor disponível para compensação de danos por poluição, para incidentes ocorridos depois do Protocolo adotado em 2003.

O Brasil não participa como Estado-membro do IOPC e realmente não haveria como participar por conta do modelo da responsabilidade civil objetiva, sem admissão de excludentes, nos termos da posição consagrada pelo Superior tribunal de Justiça, conforme explicado no capítulo 6. Devido a esse fato, pelo ordenamento jurídico brasileiro, dificilmente o proprietário de um navio que foi envolvido em um derramamento seria isento de responsabilidade. Ademais, de acordo com o art. 944 do Código Civil de 2002, a responsabilidade mede-se pela extensão do dano. Nesses termos, no país, não se admite igualmente a limitação de responsabilidade por dano ambiental.

\footnotetext{
616 Informação disponível em: <https://www.iopcfunds.org/about-us/what-we-do/oil-reporting-andcontributions/>. Acesso em: 09.08.2018.

${ }^{617}$ Informação disponível em: < https://www.iopcfunds.org/about-us/legal-framework/1992-fund-convention-andsupplementary-fund-protocol/>.Acesso em: 09.08.2018.
} 
Outra crítica possível ao fundo é que ele não se volta a reparação de danos ambientais, mas sim, às vítimas, o que não resolveria a deficiência encontrada no Brasil. Entretanto, vale dizer que seu sistema de constituição e arrecadação pode servir de base para a criação de um possível fundo brasileiro.

\subsubsection{Finnish Oil Pollution Compensation Fund (Finlândia)}

A Finlândia conta com um cenário muito particular para resposta à derramamentos. De acordo com a Seção 10, do Act n ${ }^{\circ} 1673 / 2009$ (Acton Oil Pollution Response), ${ }^{618}$ as autoridades governamentais possuem responsabilidade diante dos acidentes. Sendo assim, o Ministério do Meio Ambiente do País é o principal responsável pelas ações de resposta, além da Agência de Segurança e Transporte, Forças de Defesa, Guarda Costeira e Municipalidades.

Os custos das ações de resposta, entretanto, não saem dos cofres públicos, e sim de um Fundo específico de Compensação por Poluição por Óleo, cuja arrecadação é realizada, basicamente por: (i) taxa de proteção do óleo, recolhida para o óleo que é importado para a Finlândia ou transportado pela Finlândia (sendo que a taxa é duplicada para embarcações que não possuam casco duplo); e (ii) parte do imposto cobrado sobre resíduos petrolíferos. As compensações pagas anualmente totalizam cerca de 10 milhões de euros. ${ }^{619}$

O Fundo é administrado pelo Ministério do Meio Ambiente da Finlândia e utilizado para reembolsar os custos de remediação e resposta a derramamentos de óleo em terra e no mar, quando a parte que causou o acidente não é conhecida ou não tem condições de pagar os custos. ${ }^{620}$ Ou seja, trata-se de uma fonte secundária de remediação por derramamento de óleo, não eximindo de sua responsabilidade aquele que causou o derramamento. Inclusive, há a previsão de que os responsáveis reembolsem o Fundo, caso haja utilização de seus recursos. ${ }^{621}$

${ }^{618}$ FINLÂNDIA. Ministério do Ambiente. Act $\mathbf{n}^{\mathbf{0}}$ 1673/2009. Act on Oil Pollution Response. Helsinki, 2009. Disponível em: <https://www.finlex.fi/fi/laki/kaannokset/2009/en20091673.pdf> . Acesso em: 09.01.2018.

619 Informação disponível em: <http://www.ym.fi/en-US/The environment/Finnish_Oil_Pollution_Fund $>$. Acesso em 08.09.2018.

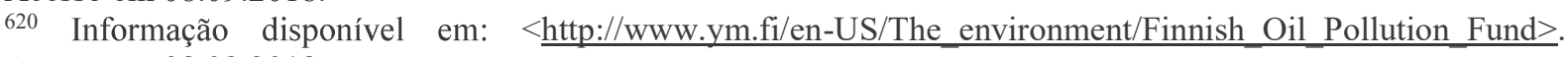
Acesso em 08.09.2018.

621 Informação disponível em: <http://www.ym.fi/en-US/The environment/Finnish_Oil_Pollution_Fund $>$. Acesso em 08.09.2018. 
Tanto as medidas de prevenção, quanto as de resposta podem ser realizadas com verbas provenientes do Fundo. Os beneficiados são, em regra, os órgãos governamentais federais que atuam diretamente, bem como os municípios e serviços regionais de resgate. ${ }^{622}$

Nesse sentido, o Fundo finlandês, sem dúvidas, é um exemplo interessante a ser considerado com vistas ao caso brasileiro. Primeiramente, por permitir que a concentração das ações de resposta em agências governamentais conte com as verbas necessárias, sem que, no entanto, tais recursos tenham que sair de cofres públicos.

Hoje em dia, agências brasileiras, a exemplo da CETESB, já trabalham automaticamente em ações de resposta à derramamentos. Entretanto, o trabalho acaba sendo bem limitado, por conta de não haver subsídio financeiro. Os funcionários públicos (pagos, vale frisar, com dinheiro público), em um contingente bem reduzido, são deslocados de suas funções para orientarem empresas privadas na condução das medidas de remediação.

Entretanto, nem sempre as empresas privadas agem adequadamente. A ideia de concentração de ações de respostas em alguns órgãos governamentais federais e locais, munidos de equipamentos adequados e com um contingente suficiente de técnicos treinados, soa utópica nas condições financeiras em que o Brasil se encontra. Nesse sentido, nada seria mais justo do que as próprias atividades de extração, refino, transporte de óleo fossem as fomentadoras de um fundo adequado ao caso, a exemplo do que ocorre na Finlândia.

Certamente, haveria não somente maior segurança ambiental na remediação rápida e adequada, mas também maior previsibilidade jurídica, eliminando em parte ações judiciais que acabam não viabilizando a reparação dos danos decorrentes de derramamentos.

\subsubsection{Ship-Source Oil Pollution Fund (Canadá)}

No Canadá, o proprietário do navio é sempre responsável pela remediação em decorrência de derramamento de óleo, de forma limitada. Isso inclui perdas e danos de terceiros, além de danos em águas costeiras, interiores e em meio terrestre. Além da responsabilidade do causador, este país conta ainda com os Fundos Internacionais de Compensação por Poluição

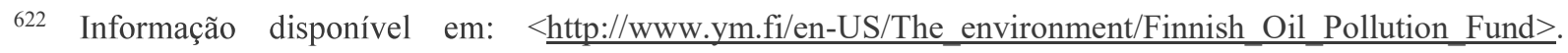
Acesso em 08.09.2018. 
por Óleo - que são fruto de convenções das quais é signatário -, e o Fundo próprio, Ship-Source Oil Pollution Fund, traduzido por Fundo de Poluição por Óleo de Navio. ${ }^{623}$

As verbas do fundo canadense podem ser utilizadas para a compensação de todas as medidas razoáveis que tiverem sido tomadas para recuperar o dano causado. ${ }^{624} \mathrm{O}$ fator inovador do fundo é que ele é mais abrangente do que os previstos em Convenções Internacionais e outros países, que se limitam geralmente a derramamentos de óleo persistente de petroleiros. Diferentemente, o Fundo canadense é único que abrange não apenas os navios de alto mar, mas destina-se também a pagar sinistros relativos a derramamentos de petróleo de todas as classes de navios, tais como navios de carga geral, navios de cruzeiro, balsas e outros não-petroleiros, além de abranger derramamentos de óleos persistentes e não persistentes. Há inclusive a previsão de cobertura para os casos em que a identidade do navio que causou a descarga não é identificada. ${ }^{625}$

A Seção 101 da Lei de Responsabilidade Marítima do Canadá ${ }^{626}$ esclarece as hipóteses em que o Fundo pode ser acionado, sendo mais comuns os casos em que os pedidos de compensação excedem o limite de responsabilidade do navio causador do derramamento ou se este for financeiramente incapaz de cumprir suas obrigações, além das hipóteses de desconhecimento do causador. ${ }^{627}$

Conforme previsto na legislação Canadense, qualquer cidadão ou pessoa jurídica incluindo empresas privadas, a exemplo de empresas do setor pesqueiro, e também órgãos governamentais - podem reivindicar a perda de receita causada por um derramamento de óleo de um navio. Para tanto, o procedimento consiste no registro de reclamação junto ao Administrador do Fundo, relatando perdas, danos, custos e despesas resultantes da poluição proveniente de navios. ${ }^{628}$ Depois que o Administrador indeniza o pleiteante, ele tem o dever de

\footnotetext{
623 Informação disponível em: <http://www.tc.gc.ca/eng/marinesafety/liability-compensation-ship-source-oilspills-4512.html>. Acesso em: 01.09.2018.

${ }^{624}$ As verbas máximas possíveis de serem pagas por cada acidente são anualmente revistas. Para o ano de 2018 foram determinadas em \$174,611,294. Fonte: $<$ http://sopf.gc.ca/?page id=256> . Acesso em: 01.09.2018.

625 Informação obtida no Q\&A do site Ship-Source Oil Pollution Fund, disponível em:

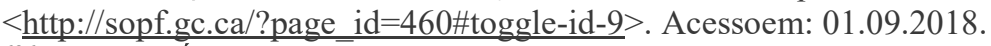

${ }^{626}$ CANADÁ. Ministério da Justiça. Marine Liability Act.An act respecting marine liability, and to validate certain by-laws and regulations. S.C. 2001, c.6. Ottawa, 2001. Disponível em: <http://lawslois.justice.gc.ca/PDF/M-0.7.pdf> Acesso em: 09.08.2018.

627 Informação obtida no Q\&A do site Ship-SourceOilPollutionFund, disponível em:

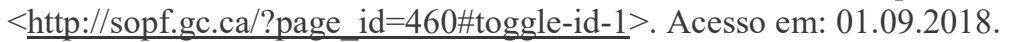

${ }^{628}$ Seção 103 do Marine Liability Act. CANADÁ. Ministério da Justiça. Marine Liability Act. An act respecting marine liability, and to validate certain by-laws and regulations. S.C. 2001, c.6. Ottawa, 2001. Disponível em:

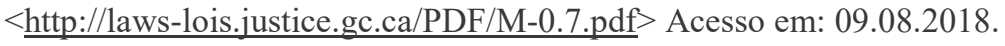


cobrar do proprietário do navio, ou de qualquer outra fonte pertinente, o ressarcimento dos valores pagos (quando se enquadrar nos casos previstos em lei). ${ }^{629}$

Um ponto interessante do sistema canadense é que as contribuições ao fundo deveriam ser realizadas pelos transportadores e receptores de óleo do Canadá, de forma semelhante ao previsto na Finlândia. Entretanto, as contribuições não são pagas desde 1976, pois o Fundo é totalmente capitalizado. ${ }^{630}$

\subsection{Contexto brasileiro}

O Brasil não conta com fundos específicos para reparação de danos ambientais provenientes de derramamentos de óleo no mar, muito embora tenha havido uma tentativa, por meio de Projeto de Lei que terminou rejeitado e arquivado.

O Projeto de Lei (PL) da Câmara dos Deputados n ${ }^{\circ} 623 / 2003,{ }^{631}$ buscou criar o "Fundo para Reparação de Danos Ambientais Causados por Poluição por Hidrocarbonetos", que teria como fonte primária parte dos recursos da Contribuição de Intervenção no Domínio Econômico (CIDE). Para isso, acrescentava à Lei n ${ }^{\circ}$ 10.636/2002, que dispõe sobre a aplicação dos recursos originários da CIDE, um novo artigo que criava o Fundo, vinculava-o ao Ministério do Meio Ambiente e o destinava à implementação de ações urgentes para a recuperação de danos ambientais causados por poluição por hidrocarbonetos.

O PL foi apresentado ao Plenário da Câmara dos Deputados no dia 02 de abril de 2003 e tinha como justificativa, dentre outros argumentos, a imensurabilidade dos impactos ambientais causados por catástrofes de derramamentos de óleo. Em sua justificativa, o autor do projeto, Maurício Quintella Lessa (PSB/AL), alegou que:

Na maioria dos acidentes a reparação dos danos ambientais requer ações urgentes, que não podem esperar a apuração das responsabilidades dos agentes causadores da poluição, e, também, com frequência, o responsável não tem condições financeiras para arcar com tais custos.

${ }^{629}$ CANADÁ. Ministério da Justiça. Marine Liability Act. An act respecting marine liability, and to validate certain by-laws and regulations. S.C. 2001, c.6. Ottawa, 2001. Disponível em: <http://lawslois.justice.gc.ca/PDF/M-0.7.pdf> Acesso em: 09.08.2018.

${ }^{630}$ Os contribuintes que sejam receptores de óleo devem, no entanto, arquivar um retorno de informação até 28 de fevereiro, se o volume de carga contribuinte do ano anterior exceder 150.000 toneladas métricas de óleo persistente ou 17.000 toneladas métricas de óleo não persistente. CANADÁ. Ministério da Justiça. Marine Liability and Information Return Regulations - $\quad$ SOR/2016-307.Disponível em: $<\underline{\text { http: } / / \text { laws- }}$ lois.justice.gc.ca/eng/regulations/SOR-2016-307/page-1.html>. Acesso em: 09.08.2018.

${ }^{631}$ BRASIL. Câmara dos Deputados. Projeto de Lei $\mathbf{n}^{\mathbf{0}} \mathbf{6 2 3}$, de 2003, proposto por Maurício Quintella Lessa. Disponível em: <http://www.camara.gov.br/proposicoesWeb/prop_mostrarintegra;jsessionid=57043BCEADD76C46FE802EA0 FA8F1F69.proposicoesWebExterno2? codteor=450876\&filename=PL+623/2003 > . Acesso em: 09.08.2018. 
Ao PL n ${ }^{\circ}$ 623/2003 foram apensados, ainda, os PLs n $n^{\circ} 1.434 / 2003$ e $n^{\circ} 6.120 / 2009$. O primeiro criava o Fundo Nacional de Prevenção de Desastre Ambiental, enquanto o segundo criava o Fundo dos Custos de Prevenção, Precaução, Correção e Reparação de Danos Ambientais.

Por parte da Comissão de Meio Ambiente e Desenvolvimento Sustentável, sobrevieram diversos pareceres favoráveis ao PL, como o de relatoria do Deputado Oliveira Filho (PL/PR), apresentado em 25 de outubro de 2005, ${ }^{632}$ que defendia a aprovação do PL n ${ }^{\circ} 623 / 2003$, mas a rejeição dos PLs apensos a ele.

Em 2010, a Comissão de Meio Ambiente e Desenvolvimento Sustentável voltou a se posicionar a favor do PL de 2003, agora sob relatoria do Deputado Arnaldo Jardim (PPS/SP). Em ambos os pareceres, os relatores deixavam explícito que os recursos da CIDE, caso aprovado o PL n ${ }^{\circ}$ 623/2003, não poderiam ser aplicados em projetos e ações definidos como de responsabilidade dos concessionários nos respectivos contratos de concessão, firmados com a ANP. Da mesma forma, votaram contra os outros dois PLs apensados, pois defendiam que os recursos da CIDE só poderiam ser aplicados no financiamento de projetos ligados à indústria do petróleo. Além disso, argumentavam que as situações de emergência e calamidade pública estão afetos à atuação do Poder Público, por meio da Defesa Civil.

Porém, em 2010, a Comissão de Meio Ambiente e Desenvolvimento Sustentável, apresentou substitutivo aos Projetos de Lei $n^{\circ} 623 / 2003$ e n ${ }^{\circ} 6.120 / 2009$, alterando a redação para criar o Fundo de Financiamento a Projetos Ambientais Relacionados à Indústria de Petróleo e seus Derivados e do Gás e seus Derivados (FUPAP). ${ }^{633}$

Apesar de todos os pareceres da Comissão de Meio Ambiente e Desenvolvimento Sustentável, o entendimento da Comissão de Finanças e Tributação caminhou no sentido oposto. ${ }^{634}$ Esta Comissão apresentou parecer em 07 de dezembro de 2011, concluindo, de forma unânime, pela incompatibilidade e inadequação financeira e orçamentária dos PLs $\mathrm{n}^{\circ} 623$ $\mathrm{A} / 2003, \mathrm{n}^{\circ} 1.434 / 2003$ e $\mathrm{n}^{\circ} 6.120 / 2009$. Como fundamento, alegaram o disposto no artigo $6^{\circ}$,

${ }^{632}$ BRASIL. Câmara dos Deputados. Projeto de Lei no 623, de 2003, proposto por Maurício Quintella Lessa. Disponível

$<$ http://www.camara.gov.br/proposicoesWeb/prop mostrarintegra? codteor=350526\&filename $=$ PRL $+1+$ CMADS $+\% 3 \mathrm{D} \% 3 \mathrm{E}+\mathrm{PL}+623 / 2003>$. Acesso em 12.11.2018.

${ }^{633}$ Como recursos do FUPAP, cumpre destacar que $12 \%$ dos recursos são originários da CIDE.

${ }^{634}$ BRASIL. Câmara dos Deputados. Comissão de Finanças e Tributação. Parecer sobre o projeto de lei n ${ }^{\circ}$ 623-

B, de 2003.Disponível em: <http://www.camara.leg.br/internet/ordemdodia/integras/975274.htm>. Acesso em: 12.11.2018. 
inciso II, ${ }^{635}$ da Norma Interna da Comissão de Finanças e Tributação, defendendo que as ações previstas pelo PL n ${ }^{\circ}$ 623/2003 (e apensos) são cotidianamente executadas por órgãos da administração pública federal e que o projeto não continha regras precisas sobre a gestão, funcionamento e controle do Fundo. Assim, O PL n ${ }^{\circ}$ 623/2003, juntamente com todos seus apensos, foi, enfim, arquivado definitivamente no Diário da Câmara dos Deputados de 18 de maio de 2012.

Nesse sentido, o que resta ao Brasil são fundos mais generalistas, que recebem verbas, principalmente provenientes de condenações judiciais por danos ambientais e multas por infrações ambientais, além de parte de compensações por exploração de petróleo denominadas royalties.

Defende-se aqui que o ideal seria a realização de uma avaliação sobre o destino que é dado às verbas especificas de indenizações e multas por derramamento de óleo após integrarem os fundos. Entretanto, mesmo após consulta aos sites oficiais dos fundos aqui estudados e, após solicitações formais por informações complementares, não foi possível a obtenção de dados tão detalhados.

Foi possível, em parte, a realização de uma análise preliminar acerca dos projetos contemplados pelas verbas dos fundos, cujas observações seguem abaixo.

\subsubsection{Fundos Federais}

\subsubsection{Fundo de Defesa de Direitos Difusos - FDD}

No Brasil, a Lei Federal $n^{0}$ 7.347/1985 disciplina a "ação civil pública de responsabilidade por danos causados ao meio-ambiente, ao consumidor, a bens e direitos de valor artístico, estético, histórico, turístico e paisagístico". Em seu artigo 13, determina que a indenização pelo dano causado deve ser revertida a um fundo, gerido por um Conselho

635 Artigo $6^{\circ}$, da Norma Interna da Comissão de Finanças e Tributação: "É inadequada orçamentária e financeiramente a proposição que cria ou prevê a criação de fundos com recursos da União. Parágrafo único. Ressalvam-se do disposto no "caput" deste artigo, observadas as demais disposições desta Norma Interna e desde que a proposição contenha regras precisas sobre a gestão, funcionamento e controle do fundo, os casos em que:[...]II - as atribuições previstas para o fundo não puderem ser realizadas pela estrutura departamental da Administração pública". 
Federal $^{636}$ ou por Conselhos Estaduais, ${ }^{637}$ de que participarão necessariamente o Ministério Público e representantes da comunidade. O mesmo artigo deixa claro que os recursos devem obrigatoriamente ser destinados à reconstituição dos bens lesados.

Já o Decreto $n^{\circ} 1.306 / 1994$ regulamenta o Fundo de Defesa de Direitos Difusos (FDD) ${ }^{638}$ Em seu primeiro artigo, apresenta a finalidade do FDD, qual seja: a reparação dos danos causados ao meio ambiente e a outros interesses difusos e coletivos. O Decreto vai além, ao deixar claro que os recursos arrecadados ${ }^{639}$ deverão ser prioritariamente aplicados na reparação específica do dano que os deu causa (nos termos do parágrafo único, do artigo $7^{\circ}$, do Decreto), sempre que tal fato for possível.

O parágrafo único, do artigo $8^{\circ}$, do Decreto, por sua vez, determina que a importância recolhida ao FDD terá sua destinação sustada, enquanto estiverem pendentes de recursos as ações de indenização pelos danos individuais. De certa forma, o artigo $8^{\circ}$ acaba prejudicando a utilização dos recursos para as reparações em caráter emergencial. Porém, conforme será exposto, o próprio mecanismo de destinação dos recursos dificulta sua aplicação a qualquer

\footnotetext{
${ }^{636}$ As indenizações oriundas de Ações Civis Públicas perante a Justiça Federal serão geridas pelo Conselho Federal Gestor do Fundo de Defesa de Direitos Difusos, criado no âmbito da estrutura organizacional do Ministério da Justiça, por meio da Lei ${ }^{\circ} 9.008 / 1995$. A composição do Conselho é hibrida, abrigando representantes de Ministérios (Justiça - presidente do conselho, Meio Ambiente, Recursos Hídricos e da Amazônia Legal, Cultura, Saúde e Fazenda), além representantes do Conselho Administrativo de Defesa Econômica (CADE); Ministério Público Federal; e três representantes de entidades civis que atendam aos pressupostos dos incisos I e II do art. $5^{\circ}$ da Lei n ${ }^{\circ}$ 7.347, de 1985. Já as indenizações provenientes de Ações Judiciais Estaduais serão geridas por Conselhos Estaduais.

${ }^{637}$ No âmbito estadual, o fundo mais conhecido é o Fundo de Defesa dos Interesses Difusos de São Paulo, criado nos termos da Lei n ${ }^{\circ} 6.536 / 1989$ e mantido por ações civis públicas. Seus recursos são destinados ao ressarcimento, à coletividade, dos danos causados ao meio ambiente, ao consumidor, a bens e direitos de valor artístico, estético, histórico, turístico e paisagístico. Os recursos do FID podem apoiar projetos apresentados por órgãos da administração pública direta ou indireta, de âmbito federal, estadual e municipal, ONGs, organizações sociais, organizações da sociedade civil de interesse público e entidades civis sem fins lucrativos.

${ }^{638}$ Importante enfatizar a diferença do FDD e do Fundo Nacional do Meio Ambiente (FNMA), cuja finalidade é o financiamento de medidas que visem a implementação da Política Nacional do Meio Ambiente, não recebendo receitas fruto de indenizações.

${ }^{639}$ Art. $2^{\circ}$, do Decreto 1.306/1994 especifica a origem das receitas do Fundo: "Constituem recursos do FDD, o produto da arrecadação: I - das condenações judiciais de que tratam os arts. 11 e 13, da Lei n ${ }^{\circ} 7.347$, de 24 de julho de 1985; II - das multas e indenizações decorrentes da aplicação da Lei nº 7.853, de 24 de outubro de 1989, desde que não destinadas à reparação de danos a interesses individuais; III - dos valores destinados à União em virtude da aplicação da multa prevista no art. 57 e seu parágrafo único e do produto de indenização prevista no art. 100, parágrafo único, da Lei ${ }^{\circ} 8.078$, de 11 de setembro de 1990;IV - das condenações judiciais de que trata o parágrafo $2^{\circ}$, do art. $2^{\circ}$, da Lei $n^{\circ} 7.913$, de 7 de dezembro de 1989; V - das multas referidas no art. 84, da Lei no 8.884 , de 11 de junho de 1994; VI - dos rendimentos auferidos com a aplicação dos recursos do Fundo; VII - de outras receitas que vierem a ser destinada ao Fundo; VIII - de doações de pessoas físicas ou jurídicas, nacionais ou estrangeiras.". Importante destacar que artigo semelhante consta na Lei 9.008/1995, entretanto a redação que constava no inciso II, do $\S 2^{\circ}$, do Art. $1^{\circ}$, idêntica ao inc. II do Art. $2^{\circ}$ Decreto $1.306 / 1994$, foi revogada pela Lei $13.146 / 2015$.
} 
medida de reparação ecológica que tenha relação direta com o dano cuja indenização tenha sida revertida ao fundo.

Os recursos arrecadados pelo FDD devem ser distribuídos para efetivação de medidas relacionadas aos objetivos da Lei $n^{\circ} 7.347 / 1985$, e, no campo ambiental, a destinação deveria se limitar à reparação dos danos apurados pelas Ações Judiciais. Entretanto, de acordo com o § $3^{\circ}$, do art. $1^{\circ}$, da Lei 9.008/1995, os recursos arrecadados pelo FDD igualmente poderão ser aplicados na promoção de eventos educativos, científicos e na edição de material informativo especificamente relacionados com a natureza da infração ou do dano causado, bem como na modernização administrativa dos órgãos públicos.

No tocante às medidas de educação, apesar de não guardarem relação com a reparação dos danos, podem até ser aceitáveis, desde que se destinem à prevenção de danos futuros. Salles ${ }^{640}$ e Dellore ${ }^{641}$ entendem que o fundo apresenta função de compensação e não de efetiva reparação do dano. Para Salles, os bens ambientais lesados devem ser compreendidos de forma genérica, a título de "meio ambiente" como um todo. ${ }^{642}$ Partindo desse entendimento, Dellore considera que as medidas educativas podem ser vistas como compensatórias e positivas ao meio ambiente. ${ }^{643}$ Dessa forma, não precisariam guardar relação com danos ambientais específicos.

Diante das constatações dos autores, cabem algumas observações. Primeiramente, defende-se no presente trabalho que o judiciário, ao arbitrar o pagamento indenizações busca uma reparação jurídica do dano, que muitas vezes poderia ser pelo menos em parte reparado tecnicamente. Portanto, não há discordância dos autores acerca do caráter compensatório do fundo. $\mathrm{Na}$ verdade, entende-se que ele assume esse papel apenas para aqueles danos que não podem de forma alguma ser reparados.

Ainda com relação às medidas de compensação, conforme será melhor apresentado no próximo capítulo 7 , devem ser aceitas à luz das finalidades protegidas pelo conceito de “compensação ecológica" e não de "compensação jurídica". Para Sendim, a compensação

${ }^{640}$ SALLES, C. A. de. Execução Judicial em matéria ambiental. São Paulo: RT, 1998, p.315

${ }^{641}$ DELLORE, L. G. P. Fundo Federal de Reparação de Direitos Difusos (FDD): aspectos atuais e análise comparativa com instrumentos norte-americanos. Revista de Direito Ambiental. São Paulo, n.38, p. 124-139, abr./jun. 2005.

${ }^{642}$ SALLES, C. A. de. Execução Judicial em matéria ambiental. São Paulo: RT, 1998, p.315

${ }^{643}$ DELLORE, L. G. P. Fundo Federal de Reparação de Direitos Difusos (FDD): aspectos atuais e análise comparativa com instrumentos norte-americanos. Revista de Direito Ambiental. São Paulo, n.38, p. 124-139, abr./jun. 2005. 
ecológica deve ocorrer no local original do dano, visando o reestabelecimento das funções ecológicas perdidas. ${ }^{644}$

Nesse sentido, defende-se aqui a possibilidade da adoção de medidas compensatórias, a exemplo de ações de educação ambiental, apenas nos casos em que o dano não é reparável tecnicamente ou na parcela em que não é possível a sua reparação. Ademais, formas de compensação somente devem ser admitidas se proporcionarem ganho ambiental às áreas afetadas pelo dano.

Com relação à destinação de verbas para a modernização da estrutura administrativa, não parece cumprir com funções preventivas tampouco reparatórias e, nesse sentido, afasta-se do real objetivo para o qual o fundo foi criado. Levando-se em conta a função reparatória dos danos, inerente à responsabilidade civil, Paulo Affonso Leme Machado critica o financiamento de eventos e de obras públicas por meio do FDD. Defende que as obras não poderiam anteporse à reparação de bens ambientais lesados, uma vez que, para essas finalidades, há inclusive o Fundo Nacional do Meio Ambiente. ${ }^{645}$

As regras que regem o FDD determinam, na prática, que o local do dano só será beneficiado com o recurso oriundo de indenização pecuniária no caso de um projeto específico para aquela área, proposto por organização civil não governamental ou por instituições governamentais locais, ser aprovado após passar por uma concorrência com outros tantos projetos de temáticas diversas. ${ }^{646}$

Entretanto, na prática, a aplicação das verbas do FDD acaba contemplando em grande parte projetos e obras, sem ligação nenhuma com a origem dos valores arrecadados. A arrecadação anual do FDD é realmente muito expressiva. Em anos anteriores, foi de: R\$ 563.326.342,06 (2015), 775.034.487,75 (2016), e 591.748.123,54 (2017). ${ }^{647}$ Importante destacar que os relatórios que detalham as origens das arrecadações apontam valores muito baixos, em comparação ao total, especificados como "condenações judiciais -Meio Ambiente", sendo: R\$ 192.407,34 (2015), 2.732.991,28 (2016), e R\$ 4.313,766,06 (2017). Ocorre que grande parte dos recursos restantes, que compõe os valores totais anuais, é declarada como:

\footnotetext{
${ }^{644}$ SENDIM, J.. De Souza Cunhal. Responsabilidade Civil por danos ecológicos: da reparação do dano através da restauração natural. Coimbra: Coimbra Editora, 1998, p. 196.

${ }^{645}$ MACHADO, P. A. L. Direito Ambiental Brasileiro. São Paulo: Malheiros, 25 ed., 2017, p. 452.

${ }^{646}$ PINHO, H.G.. Prevenção e Reparação de Danos Ambientais. As medidas de Reposição Natural, Compensatórias e Preventivas e a Indenização Pecuniária. GZ verde. Rio de Janeiro. 2010, p. 535.

647 Informação disponível em: <http://www.justica.gov.br/seus-direitos/consumidor/direitosdifusos/anexos/valores-arrecadados-receitas-do-fdd-lei-9008 95-1.pdf/view>. Acesso em: 01.09.2018.
} 
"doações", "devoluções de exercícios anteriores", ou "qualquer outro interesse difuso ou coletivo". 648

Muito embora a arrecadação seja alta, os relatórios anuais de prestação de contas demonstram que há uma grande dificuldade na escolha e no repasse dos valores para projetos em geral. A última chamada para aplicação das receitas do Fundo de Defesa de Direitos Difusos, realizada em 2017, revelou que, de um total de 1.691 propostas recebidas pela Secretaria-Executiva do CFDD, 895 foram habilitadas, cujo valor total dos projetos variava do mínimo permitido em edital -R \$ 100.000,00 - ao máximo - R \$350.000,00. ${ }^{649}$ Porém, apenas 18 projetos foram selecionados como prioritários, sendo que, desses, apenas dois propunham medidas de reparação de danos ambientais. Foram eles: (i) Restauração de 15 hectares de APPs degradadas em Alta Floresta/MT, através do uso Sistemas Agroflorestais (SAFs), visando a formação de corredores ecológicos; e (ii) Revitalização da Microbacia do Ribeirão Estiva no Município de Luz, em Minas Gerais. ${ }^{650}$

Os dados referentes ao chamamento anterior são ainda mais preocupantes. Em 2015, o Conselho do FDD recebeu 897 propostas para seleção dos projetos para 2016, sendo 470 da área meio ambiente - praticamente a metade. Entretanto, dos 897 projetos, 26 foram selecionados como prioritários, e apenas 8 efetivamente conveniados. Ainda, em 2016, ano de expressiva arrecadação pelo fundo, não houve chamamento público para seleção de propostas de trabalho, sob a justificativa de terem ocorrido mudanças políticas no Poder Executivo. ${ }^{651}$

Os números apresentados sugerem que, o pagamento de indenizações por danos ambientais e a consequente destinação ao FDD não parecem garantir, sequer em parte, formas efetivas de reparação dos bens ambientais lesados que fomentaram o fundo. O que se verifica é que, em alguns poucos casos, danos diversos dos objetos das indenizações são contemplados

${ }^{648}$ Informações obtidas no site do Ministério da Justiça. Disponível em: < http://www.justica.gov.br/seusdireitos/consumidor/direitos-difusos/arrecadacao>. Acesso em: 02.09.2018.

649 Informações retiradas de: $\quad$ http://www.justica.gov.br/seus-direitos/consumidor/direitosdifusos/anexos/selecao-de-projetos-2017-2018>. Acesso em Acesso em: 02.09.2018.

${ }^{650}$ BRASIL. Ministério da Justiça e Segurança Pública. Secretaria Nacional do Consumidor. Portaria no 9, de 11 de outubro de 2017. Divulga o resultado final de projetos prioritários e cadastro de reserva, aprovado pelo Conselho Federal Gestor do Fundo de Defesa de Direitos Difusos, conforme Editais de Chamamento Público CFDD $n^{\circ}$ 01/2017 e $\mathrm{n}^{\circ}$ 02/2017. Disponível em: <http://www.justica.gov.br/seus-direitos/consumidor/direitosdifusos/anexos/portaria-09-resultado-final.pdf>. Acesso em 02.09.2018.

${ }^{651}$ BRASIL. Ministério da Justiça e Segurança Pública. Secretaria Nacional do Consumidor. Relatório de Gestão do Exercício de 2016. Unidade Prestadora Consolidadora: Secretaria Nacional do Consumidor. Unidade Prestadora Consolidada: Fundo de Defesa de Direitos Difusos. Brasília, Maio 2017, pp. 33 - 38. Disponível em: $<\underline{\text { http://www.justica.gov.br/seus-direitos/consumidor/direitos-difusos/anexos/relatorio-de-gestao-do-exercicio- }}$ de-2016.pdf $>$. Acesso em 02.09.2018. 
por recursos. Diante desse fato, Morato Leite e Dantas defendem que os recursos devam ser aplicados no mesmo local em que ocorreu o dano, não se admitindo, portanto, o desvio do fundo para reparação de bens diversos. ${ }^{652}$

Traduzindo a constatação para o cenário de derramamentos de óleos, a situação aparenta ser ainda mais preocupante. As ações civis públicas federais que apuram os derramamentos resultam, em grande maioria, na celebração de TACs, ou no pagamento de indenizações ao FDD. Na última hipótese, não somente se tem o problema da valoração dos danos, discutido no capítulo 8, mas também a evidência de que os valores que chegam ao fundo dificilmente vão ser empregados na reparação de ecossistemas marinhos e costeiros atingidos pelos derramamentos de óleo, por exemplo.

Nesse sentido, fica evidente que não se pode contar com recursos de pagamentos de indenizações para a realização de reparação de danos ambientais. Os dados acima apresentados mostram claramente que o mecanismo de repasse das verbas do FDD não é adequado à resposta necessária aos danos decorrentes de derramamentos, pois as indenizações arrecadadas raramente são revertidas aos ambientes lesados.

Se, por um lado, os danos por derramamentos em ambientes marinhos são considerados irreparáveis e, portanto, quantificados por meio de indenizações; por outro, os recursos arrecadados sequer são empregados em medidas de compensação, nem mesmo para melhoria da qualidade de vida da população afetada.

O Brasil conta com outros fundos federais e municipais. Importante pontuar que para o desenvolvimento do presente capítulo foram também estudados os seguintes fundos: Fundo de Compensação Ambiental, vinculado ao Sistema Nacional de Unidades de Conservação (Lei ${ }^{\circ}$ 9.985/2000); Fundo Estadual de Prevenção e Controle da Poluição - SP (Lei Estadual n ${ }^{\circ}$ 11.160/02); Fundo Estadual de Recursos Hídricos RJ (FUNDRHI) (Lei Estadual no 3239/99); e Fundo Especial de Despesa para a Preservação da Biodiversidade e dos Recursos Naturais (FPBRN - SMA/SP) (Decreto Estadual n 27.143/87).

${ }^{652}$ LEITE, J. R. M.; DANTAS, M. B. Algumas considerações acerca do fundo para reconstituição dos bens lesados. Revista dos Tribunais. São Paulo, v.85, n.726, abr. 1996, p.82. 
Esses fundos não foram, contudo, contemplados na análise realizada no presente capítulo, pois possuem natureza distinta do tema aqui estudado, não trazendo relação com a possibilidade de reparação de danos em ambiente marinho.

\subsubsection{Fundos Estaduais}

Serão apresentados a seguir os fundos que que possuem potencial aplicação de seus recursos na reparação de danos em ambientes marinhos.

\subsubsection{Fundo Estadual de Defesa dos Interesses Difusos (FID) - SP}

O Fundo Estadual de Defesa dos Interesses Difusos (FID) foi criado pela Lei Estadual $n^{\circ} 6.536 / 1989$ (alterada pela Lei Estadual $n^{\circ} 13.555 / 2009$ ), e está vinculado à Secretaria da Justiça e da Defesa da Cidadania. O FID tem por objetivo gerir os recursos destinados à reparação dos danos a interesses difusos ou coletivos de forma ampla, incluindo danos ao meio ambiente, e aos bens de valor turístico, paisagístico e urbanístico (art. $2^{\circ}$ da Lei Estadual $n^{\circ}$ $6.536 / 1989)$.

De acordo com o artigo $3^{\circ}$ da Lei Estadual $n^{\circ} 6.536 / 1989$, as receitas do FID são constituídas pelas indenizações decorrentes de condenações por danos causados aos bens difusos ou coletivos, e pelas multas provenientes do descumprimento dessas condenações. Constituem ainda receitas do FID rendimentos, contribuições, doações e produtos de incentivos fiscais instituídos a favor desses bens.

O FID é gerido por um Conselho Gestor que, dentre outras atribuições, é responsável por examinar e aprovar projetos relativos à reconstituição e reparação dos bens descritos no artigo $2^{\circ}$ da Lei. Conforme artigo $8^{\circ}$, podem solicitar apoio do FID os órgãos da Administração Pública, Organizações não governamentais, Organizações da Sociedade Civil de Interesse Público e Entidades Civis sem fins lucrativos, sempre através da abertura de edital.

No resultado do edital de chamamento público $\mathrm{n}^{\circ} 01$ SJDC/FID/2017 ${ }^{653}$ foram selecionados 149 projetos, dentre 238 aprovados. Cerca de 20 projetos propunham ações para

\footnotetext{
${ }^{653}$ Há poucos editais e resultados disponíveis, tendo sido analisados os seguintes documentos: GOVERNO DO ESTADO DE SÃO PAULO. Secretaria da Justiça e da Defesa da Cidadania. Resultado da Pré-seleção das cartas consulta etapa 1 do edital de chamamento público no 01 SJDC/FID/2017; e BRASIL. Ministério da Justiça. Secretaria da Justiça e da Defesa da Cidadania. Resultado da Análise da etapa 2 do edital de chamamento público $\quad \mathbf{n}^{\circ} \quad \mathbf{0 1} \quad$ SJDC/FID/2017. Ambos estão disponíveis em: $<$ http://www.justica.sp.gov.br/portal/site/SJDC/menuitem.950ae5e425a1881721d46c70390f8ca0/?vgnextoid=02 0ce86057880410VgnVCM10000093f0c80aRCRD\&vgnextchannel=020ce86057880410VgnVCM10000093f0c8

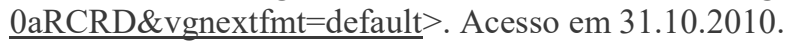


a reparação de danos ambientais. ${ }^{654}$ Entre os 149 , entretanto, não foi possível identificar nenhum projeto cujo escopo abrangesse recuperação de danos em área marinha.

\subsubsection{Fundo Estadual de Recursos Hídricos (FEHIDRO) - SP}

A Lei Estadual n 7.663/1991 estabeleceu normas de orientação à Política Estadual de Recursos Hídricos bem como ao Sistema Integrado de Gerenciamento de Recursos Hídricos. Para isso, criou o Fundo Estadual de Recursos Hídricos (FEHIDRO), em seu capítulo III, artigo 35 e seguintes, regulamentado pelo Decreto Estadual no 48.896/2004.

O artigo 36 da Lei prevê os recursos que constituem o Fundo. Dentre eles, merece destaque o inciso IV, que indica, como fonte, parte da compensação financeira que o Estado receber pela exploração de petróleo gás natural e recursos minerais em seu território (a título de royalties). ${ }^{655}$ Entretanto, quando a Lei trata da aplicação das verbas do Fundo, em seu artigo 37, não consta nenhuma previsão para reparação de danos ambientais de forma direta, nem mesmo para restauração de recursos hídricos ou áreas de entorno eventualmente degradadas.

Nas informações constantes do endereço eletrônico da Secretaria de Saneamento e Recursos Hídricos de São Paulo, ${ }^{656}$ desde sua criação foram investidos R $\$ 1,272$ bilhões em recursos do FEHIDRO e R \$386,3 milhões, em contrapartidas, em 9 tipos de empreendimentos: (i) drenagem urbana; (ii) educação ambiental; (iii) controle de perdas e uso racional; (iv) canalizações; (v) afastamento e tratamento de esgotos; (vi) controle de erosões; (vii) estudos e projetos; (viii) planejamento; e (ix) outros. Ou seja, aparentemente, nem mesmo a parcela da verba derivada de compensações por exploração de petróleo foi empregada na recuperação de danos e ambientes diretamente afetados.

\footnotetext{
${ }^{654} \mathrm{~A}$ exemplo do projeto da Prefeitura Municipal de Nova Granada, projeto ${ }^{\circ} 1318293$, para a "Recuperação de áreas degradadas (voçoroca)"; projeto da Prefeitura Municipal de Novais, projeto n 1331729 , para a "Recuperação de áreas degradadas de erosões e construção de dissipadores"; projeto da Prefeitura Municipal de Hortolândia, projeto $\mathrm{n}^{\circ}$ 1324676, para a "Recuperação da Nascente do Ribeirão Jacuba e seu entorno", o projeto do Grupo Dispersores, "De olho os olhos - Proteção e Recuperação de Áreas de Preservação Permanentes, e criação de RPPNs" (projeto no 1329669); e o projeto da Prefeitura Municipal de Pirajuí, "Revitalização de Área Degradada e Construção de Ecoparque" (projeto $n^{\circ}$ 1326765). Não foi localizado nenhum projeto aprovado na área de derramamento de óleo.

${ }^{655}$ Artigo 36, da Lei no .663/1991: "Constituirão recursos do FEHIDRO: [...] IV - parte da compensação financeira que o Estado receber pela exploração de petróleo, gás natural e recursos minerais em seu território, definida pelo Conselho Estadual de Geologia e Recursos Minerais - COGEMIN, pela aplicação exclusiva em levantamentos, estudos e programas de interesse para o gerenciamento dos recursos hídricos subterrâneos".

${ }^{656}$ Informação disponível em: <http://www.saneamento.sp.gov.br/informacoes fehidro.html $>$. Acesso em: 01.11.2018.
} 


\subsubsection{Fundo Estadual de Conservação Ambiental e Desenvolvimento Urbano (FECAM)} $-\mathbf{R J}$

O Fundo Estadual de Conservação Ambiental e Desenvolvimento Urbano (FECAM) do Rio de Janeiro foi criado pela Lei $n^{\circ}$ 1.060/1986, para apoio da Política Estadual de Controle Ambiental (Decreto-Lei $n^{\circ}$ 134/1975). De acordo com parágrafo único do artigo $2^{\circ}$ da Lei, os recursos do FECAM podem ser utilizados em programas e projetos ambientais de órgãos públicos estaduais, prefeituras municipais, universidades públicas e organizações nãogovernamentais, sem fins lucrativos.

Os recursos do FECAM, nos termos do artigo $3^{\circ}$ da Lei 1.060/1986, são em grande parte provenientes dos royalties do petróleo recebidos pelo Estado do Rio de Janeiro, além de multas e indenizações arrecadadas pelo estado em decorrência de infrações à legislação de proteção ambiental federal (art. $3^{\circ}$, alínea b, da referida Lei), bem como arrecadação de taxas ou contribuições em virtude da utilização de recursos ambientais, dotações, créditos adicionais e transferências de diversas naturezas.

O Relatório Anual mais atualizado e disponível retratando a aplicação das verbas do fundo corresponde a 2016. ${ }^{657}$ Apesar da principal receita do fundo ser proveniente dos royalties do petróleo, dentre os projetos que receberam recursos do fundo, aqueles que possuíam alguma relação com ambiente marinho tratavam de esgotamento sanitário, coleta de "lixo flutuante" na Baia de Guanabara e conservação do boto cinza - e mesmo assim receberam quantias inexpressivas perto das arrecadadas.

\subsubsection{Conclusões parciais}

Os fundos brasileiros para proteção de interesses difusos, principalmente o FDD, instituído pela Lei de Ação Civil Pública, conforme observado na prática, não garantem a reparação ou a compensação ecológica dos danos que originam suas receitas.

Por outro lado, fundos de compensação autônomos são vistos como uma alternativa mais célere de garantia tanto da reparação de danos ambientais, quanto da indenização de indivíduos lesados. Normalmente, são financiados pelos potenciais causadores dos danos por

${ }^{657}$ GOVERNO DO ESTADO DO RIO DE JANEIRO. Secretaria de estado do ambiente. Fundo Estadual de Conservação Ambiental e Desenvolvimento Urbano (FECAM). Relatório Anual 2016. Disponível em:

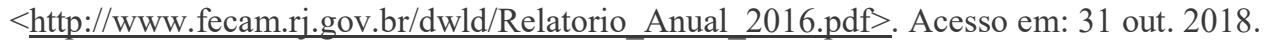


meio do pagamento de quotas, ${ }^{658}$ que podem ser calculadas, por exemplo, pelo volume de óleo transportado ou vendido.

O país ainda não possui fundos de arrecadação prévia, de natureza preventiva para poluição por óleo no mar. Fundos dessa natureza são um importante instrumento de viabilização financeira de respostas rápidas aos derramamentos, o que é essencial para a obtenção do sucesso na contenção e reparação de danos. Possibilitam que haja, inclusive, o engajamento de organizações governamentais, ou privadas e da população nas ações em campo. O mecanismo é inverso ao verificado no Brasil, uma vez que, os fundos cobrem parte, ou totalmente os custos de reparação por meio de reembolsos, ressarcindo as despesas comprovadas por aqueles que se engajaram na reparação.

Para a realidade brasileira, na qual a frequência de derramamentos é alta, porém concentrada nos pequenos volumes de óleo e, em muitas vezes, por fontes não detectadas, um fundo garantiria o financiamento das devidas medidas de reparação de danos, até mesmo nos casos de manchas órfãs.

Apesar dos órgãos ambientais não serem responsáveis diretos pela reparação de danos, a exemplo da Finlândia, não se pode negar que cabe ao Estado agir principalmente nos casos em que não é identificado o responsável legal pela poluição. Ademais, órgãos estaduais e federais, como a Cetesb (SP) e o IBAMA, por exemplo, constantemente são acionados para atuarem nas ações de resposta aos derramamentos de óleo no mar; por vezes, apenas instruindo o setor privado, mas, por outras, atuando diretamente nas ações de contenção e remediação, inclusive com a utilização de recursos e equipamentos públicos.

Para esses casos, os fundos poderiam não somente reembolsar o Estado pela remediação dos danos, mas inclusive fomentar a compra de equipamentos, o custo de treinamentos - para os órgãos públicos, mas também para equipes a serem alocadas nas principais áreas de risco e ocorrências. O financiamento das medidas preventivas, além das reparatórias, por parte daqueles setores vistos como potenciais causadores do dano refletem a aplicação do princípio do "poluidor pagador", na prática. ${ }^{659}$

${ }^{658}$ LEITE, J. R. M.; AYALA, P. de. Dano ambiental: do individual ao coletivo extrapatrimonial. Teoria e Prática.

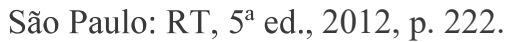

${ }^{659}$ COMISSÃO EUROPEIA. Livro Verde sobre a reparação dos danos causados no ambiente. Comunicação da Comissão de, 14 de maio de 1993 [COM (93) 47 final], ao Parlamento Europeu e ao Comitê Econômico e Social. Bruxelas: Serviço das Publicações Oficiais das Comunidades Europeias, 14 mai.1993, p.20. 
Entretanto, o sistema dos fundos não pode ser visto como forma de exclusão de responsabilidade ao real causador do dano. Para tanto, o mecanismo de regresso deve ser garantido. Da mesma forma, pelo fato do fundo receber a contribuição de diversos agentes, não se pode admitir a inclusão de todos como responsáveis solidários pelo dano constatado. O nexo causal deve ser estabelecido em relação a quem deu origem ou contribuiu para o evento danoso e não a quem reparou, sob o risco de se gerar uma situação de grande insegurança jurídica. Da mesma forma, aqueles que contribuem com as medidas de reparação, sendo eles entes públicos ou privados, ao pleitearem o reembolso pelo fundo das despesas gastas não podem ser enquadrados como responsáveis solidários.

Quanto à origem das receitas a comporem os fundos, entende-se que o melhor modelo seria por meio da contribuição individual das empresas potenciais causadoras do dano diretamente ao fundo. O projeto de Lei relatado no presente capítulo, que previa a criação de um "Fundo para Reparação de Danos Ambientais Causados por Poluição por Hidrocarbonetos", apesar de se inovador e de grande relevância para a proteção de ambientes costeiros e marinhos, propunha que a arrecadação fosse realizada por meio de recursos da Contribuição de Intervenção no Domínio Econômico (CIDE). Ou seja, seria uma fonte de natureza tributária e decorrente de intervenção da União no domínio econômico, afastando do fundo o caráter autônomo e transformando-o em mais um fundo de gestão pública para o País.

Entende-se que um eventual fundo de reparação de derramamentos de óleo no Brasil não deveria ser constituído com parte dos royalties ${ }^{660}$ arrecadados. Primeiramente, cumpre ressaltar que o direito que a União, os Estados e os Municípios exercem ao receberem essa recompensa financeira ocorre em virtude da extração do Petróleo, ou seja, se assemelha a uma participação e não se trata de uma compensação por possíveis impactos ao ambiente. Ademais, as regras atuais que regem a distribuição desses recursos são estabelecidas pela Lei Federal $n^{\circ}$ 12.858/2013, e enfatizam muito mais um caráter de desenvolvimento social do que ambiental. $^{661}$

\footnotetext{
${ }^{660}$ Conforme consta do site da ANP: "O royalty é uma compensação financeira devida à União pelas empresas que produzem petróleo e gás natural no território brasileiro: uma remuneração à sociedade pela exploração desses recursos não renováveis. Os royalties incidem sobre o valor da produção do campo e são recolhidos mensalmente pelas empresas concessionárias por meio de pagamentos efetuados à Secretaria do Tesouro Nacional (STN) até o último dia do mês seguinte àquele em que ocorreu a produção. A STN repassa os royalties aos beneficiários com base nos cálculos efetuados pela ANP". Disponível em: $<$ http://www.anp.gov.br/royalties-e-outrasparticipacoes/royalties>. Acesso em: 01.09.2018.

${ }^{661}$ Conforme o art. $2^{\circ}$, inciso II da Lei Federal $n^{\circ} 12.858 / 2013$, deverão ser destinados exclusivamente para a educação pública, com prioridade para a educação básica, e para a saúde os recursos obtidos pelos Estados, Distrito
} 
Mesmo no período anterior à Lei Federal $n^{\circ}$ 12.351/2010, quando parte dos royalties era destinada ao Ministério da ciência e Tecnologia, possuindo dentre seus objetivos, o emprego em atividades de fiscalização e proteção das áreas de produção, fomento de programas de amparo à pesquisa científica, e de programas de prevenção e recuperação de danos causados ao meio ambiente pelas indústrias do petróleo, a aplicação das quantias era realizada exclusivamente pelo poder público.

Ademais, a origem dos royalties é proveniente apenas das atividades de exploração e produção, excluindo as demais atividades envolvidas na cadeia do óleo, a exemplo do transporte - maior causador de acidentes que geram derramamentos, e das atividades portuárias em si. Decerto, conciliar arrecadação de todos os setores envolvidos em um único fundo não parece ser a melhor das alternativas, pois, se assim fosse, tanto as convenções, quanto os fundos internacionais e até mesmo os seguros não se destinariam a tratar das atividades de extração e transporte de óleo de forma apartada.

Entretanto, um ponto é unânime nos casos analisados: as contribuições para fundos de prevenção e reparação por derramamentos de óleo devem ser recolhidas para essa finalidade exclusiva, ao invés de serem desviadas a esses fundos parte de contribuições historicamente recolhidas por outros motivos.

Uma forma semelhante aos fundos de reparação de danos, que inova ao ser gerenciada por particulares, está vinculada a um tipo de seguro que será melhor abordado no próximo capítulo: o Seguro de Proteção e Indenização (P\&I), de natureza mutualística e que prevê a reparação de danos ambientais decorrentes de derramamentos de óleo por meio da utilização de verbas de um fundo comum.

Federal e Municípios provenientes dos royalties e da participação especial, relativas a contratos celebrados a partir de 3 de dezembro de 2012, sob os regimes de concessão, de cessão onerosa e de partilha de produção, de que tratam respectivamente as Leis $n^{\circ} 9.478$, de 6 de agosto de 1997, $n^{\circ} 12.276$, de 30 de junho de 2010, e $n^{\circ} 12.351$, de 22 de dezembro de 2010, quando a lavra ocorrer na plataforma continental, no mar territorial ou na zona econômica exclusiva. Já segundo o Art. $3^{\circ}$, quando os recursos de royalties forem originários de campos de produção localizados no pré-sal, sua destinação deverá ser integralmente realizada para o Fundo Social previsto no art. 47 da Lei ${ }^{\circ} 12.351$, de 22 de dezembro de 2010. 


\section{SEGUROS COMO GARANTIA PARA REPARAÇÃO DE DERRAMAMENTOS DE ÓLEO}

\subsection{Seguros ambientais}

\subsubsection{Risco nos seguros ambientais}

A Constituição Federal brasileira, de 1988, aborda os riscos ambientais em seu artigo 225 , incisos V e VII, do parágrafo $1^{\circ}$, definindo que, cabe ao Poder Público controlar a produção e a comercialização de substâncias que tragam riscos à vida, à qualidade de vida e ao meio ambiente; bem como proteger a fauna e a flora, sendo vedadas as atividades que coloquem em risco sua função ecológica.

Apesar do controle do risco ser atribuído ao Poder Público pela própria Constituição Federal, de forma tradicionalmente preventiva, não se pode negar que a identificação e mensuração de tal fator é de difícil precisão, sendo necessários outros instrumentos de controle.

O contrato de seguro é abordado pelos artigos 757 a 802 da Lei $n^{\circ} 10.406 / 2002$, que institui o Código Civil brasileiro. O artigo $757^{662}$ traz os elementos essenciais desse tipo de contrato, quais sejam: a garantia do interesse do segurado, a partir de um pagamento de um prêmio, que será limitado pelo risco predeterminado conhecido como sinistro. O artigo 759, por sua vez, reforça a necessidade de o risco ser declarado previamente à emissão da apólice.

Destaca-se que a análise do risco é fator de extrema importância para a padronização das apólices e elaboração dos clausulados. ${ }^{663} \mathrm{O}$ agrupamento de riscos em um mesmo contrato confere aos seguros o caráter mutualístico, de dimensões coletivas, já que as contrapartidas financeiras pagas pelos segurados são administradas pelas Seguradoras "para solver o conjunto de negócios e não apenas um segurado individualmente". 664

Quando falamos em riscos ambientais abarcados pelos seguros, devemos reconhecer que tais instrumentos devem contar com uma estimativa de riscos que abranja tanto os danos imediatos, quanto os danos futuros e incertos. ${ }^{665}$ Normalmente, a estimativa dos riscos ambientais é realizada considerando dois possíveis contextos: o da responsabilidade civil

\footnotetext{
662 Art. 757 do Código Civil, de 2002: “Art. 757: Pelo contrato de seguro, o segurador se obriga, mediante o pagamento do prêmio, a garantir interesse legítimo do segurado, relativo a pessoa ou a coisa, contra riscos predeterminados".

${ }^{663}$ TZIRULNIK, E.; CAVALCANTI, F. de Q. B.; PIMENTEL, A. O Contrato de Seguro de acordo com o novo código civil brasileiro.São Paulo: RT, $2^{\mathrm{a}}$ ed, 2003, p.30.

${ }^{664}$ POLIDO, W. A. Contrato de Seguro: a efetividade do seguro ambiental na composição de danos. Revista de Direito Ambiental, São Paulo, n.45, jan./mar. 2007, p.06.

${ }^{665}$ DINIZ, M. H. Tratado Teórico e Prático dos Contratos. São Paulo: Saraiva, $3^{\text {a }}$ ed., 1999, p. 321.
} 
ambiental e o dos desastres ambientais. Vale dizer que a legislação local e a incerteza acerca das consequências dos danos são grandes limitadores do desenvolvimento dos seguros ambientais, ${ }^{666}$ situação que se torna mais complexa ao se considerar o cenário de derramamentos de óleos no mar.

Assim, o universo dos seguros atua exatamente em função dos riscos das atividades, tanto no sentido preventivo, quanto mais frequentemente reparatório. No sentido preventivo, destacam-se as próprias apólices dos Seguros de Riscos Ambientais. Para que o segurado possa aderir, deve comprovar que atende à padrões, técnicas e legislação em busca da prevenção de danos. O seguro ambiental é, inclusive, considerado efetivo instrumento de gestão ambiental para o "Plano Nacional de Prevenção, Preparação e Resposta Rápida a Emergências Ambientais com Produtos Químicos Perigosos" (P2R2), ${ }^{667}$ uma vez que, na ocorrência de acidentes, há garantia de remediação dos danos ambientais. Além disso, as empresas acabam sendo fiscalizadas pelas seguradoras e buscam se adequar diminuindo a ocorrência de emergências. ${ }^{668}$

No mesmo sentido, nos seguros de Proteção e Indenização, conhecidos internacionalmente como Protection \& Indemnity (P\&I), que serão apresentados mais adiante, os responsáveis pelos navios devem adotar as diligências necessárias para evitar danos às embarcações e a terceiros. Caso seja comprovada a negligência, os danos podem não ser cobertos pelas apólices. ${ }^{669}$

A partir da avaliação dos riscos ambientais, vale retomar o conceito de danos futuros abordado no capítulo 5 do presente trabalho. Devido às próprias características do dano ambiental, seu prejuízo pode ou se estender por um período, ou se manifestar em um momento futuro e incerto. 670

\footnotetext{
${ }^{666}$ MONTI, A. Environmental Risks and Insurance. A comparative analysis of the role of insurance in the management of environment-related risks. In: Organization for Economic Cooperation and Development (OECD). OECD Report: Environmental Risks and Insurance. Paris: OECD, jun. 2002, p.06.

667 O Plano Nacional de Prevenção, Preparação e Resposta Rápida a Emergências Ambientais com Produtos Químicos Perigosos (P2R2) foi criado pelo Decreto n 5.098 de 2004, e tem como principal objetivo prevenir a ocorrência de acidentes com produtos químicos perigosos e aprimorar o sistema de preparação e resposta a emergências químicas no País, por meio de ações, atividades e projetos a serem formulados e executados de forma participativa e integrada pelos governos federal, distrital, estaduais e municipais e pela sociedade civil.

${ }^{668}$ BRASIL. MMA. Plano Nacional de Prevenção, preparação e resposta rápida a emergências ambientais com produtos químicos perigosos - P2R2. Brasília: Ministério do Meio Ambiente, 2007, p. 31. Disponível em: <http://www.mma.gov.br/estruturas/sqa_p2r2_1/arquivos/livro_2007_106.pdf $>$. Acesso em: 01.08.2018.

${ }^{669}$ GARD. Rules 2018. Denmark: Rosendahls, 2018, p. 66-73. Disponível em:

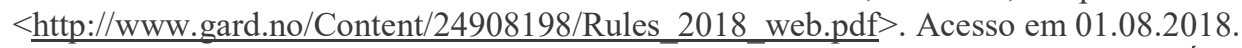

${ }^{670}$ LUCARELLI, F. D. Responsabilidade Civil por Dano Ambiental. In: MILARÉ, E; MACHADO, P. A. L. (Orgs.). Doutrinas Essenciais: Direito Ambiental. São Paulo: RT, v.5, 2011, p. 254.
} 
Os seguros relacionados a riscos ambientais são diferenciados, pois devem abranger os direitos difusos, além dos individuais, e, por consequência, os bens e os danos aos recursos naturais. Com relação aos danos, conforme pontuado, além das incertezas técnicas, as incertezas temporais são observadas, uma vez que as consequências de um fato danoso podem ser observadas apenas no futuro. ${ }^{671}$

Os próprios danos ambientais futuros podem surgir em razão de fatores cumulativos, a partir de um risco, conduta, ou de danos presentes. ${ }^{672}$ Assim, diante da possibilidade de danos futuros, os seguros não podem se basear apenas no risco imediato, devendo igualmente ser considerado o risco futuro, aquele que se protrai no tempo.

No campo dos derramamentos de óleo, já se mostrou aqui que os danos podem se perpetuar no tempo ou emergirem em momentos posteriores ao incidente, como no caso dos efeitos do óleo em manguezais, cujos exemplares arbóreos apresentam mortalidade tardia. Nesse sentido, os seguros aplicáveis à atividade de exploração e transporte de óleo, específicos para riscos e danos ambientais, não podem se limitar a danos imediatos. É inegável que os danos decorrentes de derramamentos de óleo no mar são de reparação custosa, principalmente nos casos em que a quantidade vazada é expressiva.

As empresas responsáveis nem sempre contam com capital suficiente para arcar com todas as despesas de reparação ambiental e de danos reflexos, que atinjam seres humanos. Deste modo, a sociedade como um todo acaba arcando em parte com as externalidades. De acordo com Ashford, para todo $\$ 1$ de custo direto associado com um acidente há $\$ 4$ a $\$ 10$ custos sociais individuais causados pela empresa. ${ }^{673}$ Nesse sentido, destacam-se os seguros como mecanismos garantidores não só da reparação ambiental, mas igualmente de proteção social.

O presente capítulo abordará as modalidades de seguros aplicáveis ao derramamento de óleo no mar e o seu cenário no Brasil. Porém, antes de adentrarmos aos detalhes sobre cada tipo de seguro, a seguinte pergunta deve ser respondida: os seguros ambientais são obrigatórios no Brasil?

${ }^{671}$ POLIDO, W. A. Programa de Seguros de Riscos Ambientais no Brasil: Estágio de desenvolvimento atual. Rio de Janeiro: Escola Nacional de Seguros (Funseg), 3ª ed., 2015, p.100.

${ }^{672}$ CARVALHO, D. W. de. Dano ambiental futuro: a responsabilização civil pelo risco ambiental. Porto Alegre: Livraria do Advogado, $2^{\mathrm{a}}$ ed., 2013. p.194.

${ }^{673}$ ASHFORD, N. A. et al.. The Encouragement of Technological Change for Preventing Chemical Accidents: Moving Firms from Secondary Prevention and Mitigation to Primary Prevention. A Report to the U. S. Environmental Protection Agency, Center for Technology, Policy and Industrial Development at MIT, Cambridge,

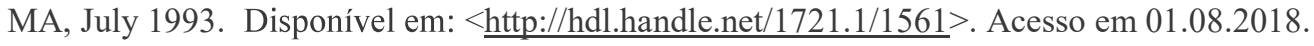




\subsubsection{Seguros ambientais são obrigatórios?}

Os programas de seguros ambientais passaram a ser comercializados no Brasil apenas em 2004. Anteriormente, a temática era abordada apenas como uma cobertura adicional aos seguros de Responsabilidade Civil. A inovação garante a cobertura em uma mesma apólice de vários riscos ambientais originados de uma mesma atividade, a exemplo dos: riscos industriais, comerciais, de transportes de mercadorias. Entretanto, o foco principal desse tipo de seguro se dá nos riscos catastróficos, ou seja, pontuais e mais expressivos. ${ }^{674}$

Com relação à obrigatoriedade de seguros ou garantias para embarcações, de uma forma mais abrangente, devem ser relembradas algumas das convenções internacionais abordadas no cap. 4, que trazem a obrigatoriedade de forma expressa. Dentre elas destacam-se: (i) Convenção Internacional sobre a Responsabilidade Civil pelos Prejuízos devidos à Poluição por Hidrocarbonetos, de 1969, e seu Protocolo 1992, que buscam assegurar a indenização pessoal em decorrência de acidentes marítimos envolvendo navios que transportam petróleo; (ii) Bunker 2001, que defende que a indenização adequada e célere seja paga aos que sofrem danos causados por derramamentos de petróleo combustível de navios; e (iii) Convenção Internacional de Nairobi para a Remoção de Destroços, de 2007, que define a responsabilidade do proprietário pelos custos da remoção de navios e destroços.

Em alguns países europeus, determinados seguros ou garantias na área de responsabilidade civil são obrigatórios e permitem a socialização dos prejuízos com base no princípio da necessidade social. ${ }^{675}$

No tocante ao tema "transferência de resíduos", a instituição de um sistema de garantias financeiras ou de um seguro que lhes seja equivalente é prevista no Regulamento CEE $\mathrm{n}^{\circ}$ 259/93, do Conselho das Comunidades Europeias ${ }^{676}$ e no Regulamento CE n ${ }^{\circ} 1.013 / 06,{ }^{677}$ do Parlamento Europeu e do Conselho, que, em seu artigo $6^{\circ}$, apresenta o conteúdo mínimo a ser

\footnotetext{
${ }^{674}$ POLIDO, W. A. Programa de Seguros de Riscos Ambientais no Brasil: Estágio de desenvolvimento atual. Rio de Janeiro: Escola Nacional de Seguros (Funseg), $3^{\text {a }}$ ed., 2015, p. 59-63.

${ }^{675}$ POLIDO, W. A. Contrato de Seguro: a efetividade do seguro ambiental na composição de danos. Revista de Direito Ambiental, São Paulo, n.45, jan./mar. 2007, p.10.

${ }^{676}$ CONSELHO DAS COMUNIDADES EUROPEIAS. Regulamento CEE $\mathbf{n}^{\mathbf{0}} \mathbf{2 5 9 / 9 3}$ do Conselho, de 01 de fevereiro de 1993, relativo à fiscalização e ao controle das transferências de resíduos no interior, à entrada e à saída da Comunidade. Jornal Oficial das Comunidades Europeias, $\mathrm{n}^{\circ} \mathrm{L}$ 30/1, 1993. Disponível em: < $\underline{\text { https://eur- }}$ lex.europa.eu/legal-content/PT/TXT/PDF/?uri=CELEX:31993R0259\&from=en>. Acesso em: 05.10.2018.

677 PARLAMENTO EUROPEU; CONSELHO DA UNIÃO EUROPEIA. Regulamento CE $\mathbf{n}^{\mathbf{0}} \mathbf{1 0 1 3 / 2 0 0 6}$ do Parlamento Europeu e do Conselho, de 14 de junho de 2006, relativo a transferências de resíduos. Jornal Oficial da União Europeia, $\mathrm{n}^{\circ}$ L 190/1, 2006. Disponível em: <https://eur-lex.europa.eu/legalcontent/PT/TXT/PDF/?uri=CELEX:32006R1013\&from=en>. Acesso em: 05.10.2018.
} 
abrangido, que se restringe aos custos de transporte, valorização ou eliminação e de armazenagem, não havendo menção expressa a custos por danos ambientais.

Já a Dinamarca, por meio do seu Acton Contaminated Soil, ${ }^{678}$ determina que os proprietários de grandes tanques de óleo (tanques com um conteúdo de óleo maior do que 6000L para aquecimento doméstico), devem possuir seguro que cubra as despesas exigidas pelas autoridades ambientais nos casos de contaminações, que compreendam a cobertura de investigações, limpeza, remoção, restauração e medidas corretivas.

Importante ressaltar que a grande maioria dos seguros existentes na Europa e nos Estados Unidos não cobre os custos de reparação de danos ambientais quando comprovada a negligência, imprudência ou imperícia. Ou seja, tais apólices consideram a responsabilidade subjetiva nesses casos, diferentemente do que preceitua a responsabilidade civil por danos ambientais. No caso da Dinamarca, por exemplo, os custos da poluição não são cobertos pela seguradora quando é reconhecido que o proprietário deu causa ao acidente ou se os danos foram originados de instalação de navio-tanque em desconformidade com regras e padrões.

Na Alemanha, por sua vez, o Ato de 1990 sobre Responsabilidade Civil Ambiental prevê, em sua seção 19, um mecanismo de seguridade financeira aplicável à "indústria perigosa". Os seguros devem garantir, nos termos desta norma, a compensação de danos ambientais que causem a morte de pessoas, danos ao corpo, à saúde ou à propriedade. Caso uma Indústria não contrate um seguro dessa natureza, a autoridade competente pode proibir sua operação de forma completa ou parcial. ${ }^{679}$

Já em Portugal, há a obrigatoriedade para vários tipos de seguros de responsabilidade civil aplicáveis ao transporte marítimo, por conta da adesão a convenções internacionais acima relembradas. Ademais, o Decreto-Lei n 50/2012, ao internalizar a Diretiva n ${ }^{\circ}$ 2009/20/CE para a jurisdição nacional, aborda a obrigatoriedade para os proprietários de navios de aderirem a um seguro para créditos marítimos, devendo haver cobertura de proteção e indenização, conhecido internacionalmente por Protection \& Indemnity (P\&I), para os navios de arqueação bruta igual ou superior a 300. Por meio desta Diretiva, os navios estrangeiros que não possuírem

\footnotetext{
${ }^{678}$ DINAMARCA. Acton Contaminated Soil, $\mathbf{n}^{\mathbf{0}}$ 1427, de 4 de dezembro de 2009. Copenhague: 2009. Disponível em: $<$ https://www.retsinformation.dk/Forms/R0710.aspx?id=128733 > . Acesso em: 05.10.2018.

${ }^{679}$ ALEMANHA. Environmental Liability Act, de 10 de dezembro de 1990. Umwelthaftungsgesetz. Tradução de EileenFlügel. Munchen, 1990. Disponível em: < internet.de/englisch umwelthg/englisch umwelthg.pdf>. Acesso em: 05.10.2010.
} 
o seguro ou que em determinado tempo não contratem um são expulsos dos portos da União Europeia. ${ }^{680}$

A Convenção sobre Responsabilidade Civil por danos resultantes de atividades perigosas para o meio ambiente prevê, em seu artigo 12, um regime de garantia financeira obrigatória para operadores que exerçam alguma das atividades perigosas definidas no artigo $2^{\circ}$. Dentre elas, destacam-se a produção, a manipulação, o armazenamento ou qualquer outro tipo de operação envolvendo substâncias perigosas. ${ }^{681}$

Por fim, o Livro Branco sobre Responsabilidade Ambiental da Comunidade Europeia reconhece a importância dos seguros para assegurar a responsabilidade ambiental das empresas, além de ser considerado um mecanismo de prevenção, uma vez que geralmente as empresas passam por auditorias realizadas pelas seguradoras. ${ }^{62} \mathrm{O}$ livro vai além, ao considerar a importância do "desenvolvimento de critérios qualitativos e quantitativos fiáveis para o reconhecimento e a medição dos danos ambientais" como fator de segurança financeira, e reconhecer o fato de que os riscos ambientais ainda não serão facilmente identificados e calculados.

Com isso, declara o seguro como opcional aos Estados da Comunidade, conforme verifica-se:

Além disso, o regime comunitário não deverá impor a obrigação de ter uma segurança financeira, a fim de permitir a flexibilidade necessária enquanto ainda for necessário acumular experiência com o novo regime. A oferta de segurança financeira por parte dos sectores de seguros e bancário para os riscos resultantes do regime deverá ocorrer voluntariamente. ${ }^{683}$

O Anexo 2 do Livro Branco expõe as preocupações das seguradoras com relação aos seguros ambientais:

${ }^{680}$ SARDINHA, A. M. Seguros no Transporte Marítimo. 44f. Dissertação de Mestrado em Direito e Economia do mar - Faculdade de Direito, Universidade Nova de Lisboa, Lisboa, dez. 2017, p.36-39. Disponível em: $<$ https://transportemaritimoglobal.files.wordpress.com/2018/02/00-alvaro-sardinha-seguros-no-transportemarc3adtimo-tmg-mar-doc1.pdf $>$. Acesso em: 05.10.2010.

${ }^{681}$ CONSELHO EUROPEU. Convention on Civil Liability for Damage Resulting from Activities Dangerous to the Environment. European Treaty Series, $\mathrm{n}^{\circ}$ 150. Lugano, 1993. Disponível em:

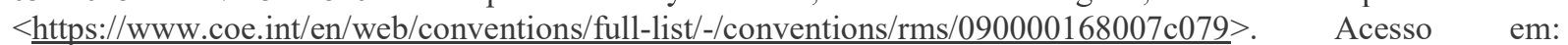
05.10 .2018 .

${ }^{682}$ COMISSÃO EUROPEIA. Livro Branco sobre Responsabilidade Ambiental. Luxemburgo: Serviço das Publicações Oficiais das Comunidades Europeias, 2000, p. 25. Disponível em:

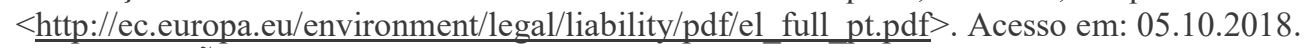

${ }^{683}$ COMISSÃO EUROPEIA. Livro Branco sobre Responsabilidade Ambiental. Luxemburgo: Serviço das Publicações Oficiais das Comunidades Europeias, 2000, p. 26. Disponível em:

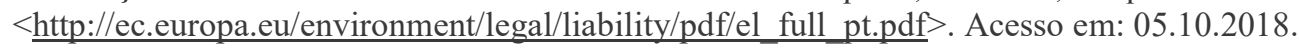


As companhias de seguros manifestaram duas preocupações distintas em relação aos sistemas de responsabilidade ambiental. Uma é a maior vulnerabilidade das companhias de seguros devido ao peso sobre as apólices de riscos antigos, decorrentes da poluição histórica, em especial no âmbito de um sistema de responsabilidade retroactiva. A outra é a necessidade de mudar as apólices de seguros a fim de fazer face a uma responsabilidade ambiental mais rigorosa.

No Brasil, as dificuldades enfretadas pelas seguradoras para a implementação de apólices no ramo de petróleo são significativas, visto que o seguro ambiental foi de fato implementado no país recentemente, não havendo demanda expressiva. Ademais, por conta da regra de responsabilidade civil objetiva por danos ambientais, o dispositivo que estabelece excludente de cobertura por culpa parece ir contra o ordenamento jurídico do país. Com isso, as apólices devem prever uma cobertura mais ampla do que se verifica em outros países.

No caso do Brasil, muito embora a obrigatoriedade de seguros ambientais apareça em algumas normas, a exigibilidade na prática não ocorre, principalmente por questões de mercado. Ainda que de forma não obrigatória ou não exigida na prática, os seguros ambientais estão cada vez mais presentes na legislação brasileira, a exemplo das leis: Lei ${ }^{\circ} 6.938$, de 1981, que institui a política nacional do meio ambiente e traz como um de seus instrumentos o seguro ambiental; ${ }^{684}$ Lei $n^{\circ} 11.284$, de 2006, que trata da gestão de florestas públicas para a produção sustentável e cria o Fundo Nacional de Desenvolvimento Florestal (FNDF), trazendo a previsão da exigência de seguros e garantias para os editais de concessões florestais; ${ }^{685}$ e Lei $\mathrm{n}^{\circ} 12.305$, de 02 de agosto de 2010 (que institui a Política Nacional de Resíduos Sólidos, que dispõe sobre a possibilidade do Sistema Nacional do Meio Ambiente (Sisnama), ao exigir a contratação de seguro de responsabilidade civil por danos causados ao meio ambiente nos licenciamentos ambientais. $^{686}$

Atualmente, tramitam no Congresso Nacional dois Projetos de Lei (PL) versando sobre a obrigatoriedade de adesão a seguros relacionados a questões ambientais no país: PL $\mathrm{n}^{\circ}$ 2.313/2003 e PL n ${ }^{\circ} 10.494 / 2018$, estando, atualmente, o primeiro apensado ao segundo. ${ }^{687}$

${ }^{684}$ Disponível em: $<$ http://www.planalto.gov.br/ccivil 03/Leis/L6938.htm>. Acesso em: 05.10.2018.

${ }^{685}$ Disponível em: <http://www.planalto.gov.br/ccivil_03/_Ato2004-2006/2006/Lei/L11284.htm>. Acesso em: 05.10.2018.

686 Disponível em: <http://www.planalto.gov.br/ccivil_03/_ato2007-2010/2010/lei/112305.htm>. Acesso em: 05.10.2018.

687 Informação obtida no site da Câmara dos Deputados:

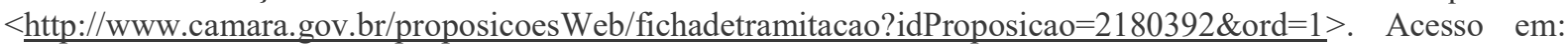
23.09.2018. 
O PL n ${ }^{\circ} 2.313$, de 2003, ${ }^{688}$ propõe a alteração do art. 20 do Decreto-Lei $n^{\circ} 73$, de 21 de novembro de 1966, que "dispõe sobre o Sistema Nacional de Seguros Privados e regula as operações de seguros e resseguros e dá outras providências", acrescentando à lista de seguros obrigatórios o seguro de "responsabilidade civil do poluidor, pessoa física ou jurídica que exerça atividades econômicas potencialmente causadoras de degradação ambiental, por danos a pessoas e ao meio ambiente em zonas urbanas ou rurais". Através da proposta, o seguro obrigatório deveria cobrir indenizações decorrentes de danos a pessoas ou a recursos naturais, em decorrência de atividades de exploração depredatória ou de acidentes.

Muito embora o Projeto de Lei busque a obrigatoriedade do seguro aplicável especificamente à danos ambientais, não foi contemplada no texto a possibilidade de a cobertura abranger custos com reparação ambiental, mas tão somente os pagamentos de indenizações, seguindo a mesma linha da maioria dos seguros praticados no país.

Já o recente PL no 10.494, de 2018, ${ }^{689}$ busca a alteração da Lei ${ }^{\circ} 6.938$, de 31 de agosto de 1981, Lei da Política Nacional do Meio Ambiente, ao impor a exigência de seguro ambiental quando for necessária a elaboração de Estudo de Impacto Ambiental (EIA) e de Relatório de Impacto Ambiental (Rima). A comprovação do seguro passaria a ser uma condição para a obtenção da Licença Ambiental.

No mesmo sentido, em fevereiro de 2017, foi publicada a Decisão de Diretoria (DD) $\mathrm{n}^{\circ}$ 038/2017 da Cetesb, ${ }^{690}$ relacionada ao gerenciamento de áreas contaminadas, que reforçou a exigência contida no artigo 45 do Decreto n 59.263/2013, que obriga o Responsável Legal da área a apresentar garantia bancária ou seguro ambiental, no valor de $125 \%$ do custo estimado projeto de remediação.

${ }^{688}$ BRASIL. Câmara dos Deputados. Projeto de Lei no 2313, de 2003. Altera dispositivos do Decreto-Lei $n^{\circ} 73$, de 21 de novembro de 1966, e dá outras providências. Disponível em: $<\underline{\text { http://www.camara.gov.br/proposicoesWeb/prop_mostrarintegra? codteor }=172770 \& \text { filename }=\mathrm{PL}+2313 / 2003}>$. Acesso em: 05.10.2018.

${ }^{689}$ BRASIL. Câmara dos Deputados. Projeto de Lei $\mathbf{n}^{\circ} \mathbf{1 0 . 4 9 4}$, de 2018. Altera a Lei ${ }^{\circ} 6.938$, de 31 de agosto de 1981 (Lei da Política Nacional do Meio Ambiente), para permitir a exigência de seguro ambiental quando for necessária a elaboração de Estudo de Impacto Ambiental (EIA) e de Relatório de Impacto Ambiental (Rima). Disponível em: $<$ http://www.camara.gov.br/proposicoesWeb/prop mostrarintegra;jsessionid=4ABC7DCE8B4D3FD160C8FBB C760A134D.proposicoesWebExterno1?codteor $=1676141 \&$ filename $=$ Avulso+-PL+10494/2018 $>$. Acesso em: 05.10.2018.

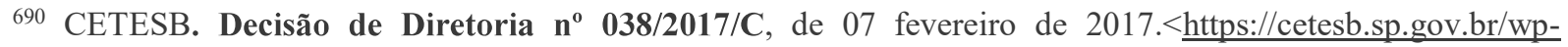
content/uploads/2014/12/DD-038-2017-C.pdf $>$. Acesso em: 01.10.2018. 
A, então, deputada e relatora do PL n ${ }^{\circ} 2.313 / 2003$, Ann Pontes, apresentou parecer ${ }^{691}$ favorável, porém com ressalvas em relação à obrigatoriedade dos seguros de responsabilidade civil aos agentes poluidores. Defendeu a relatora que os seguros ambientais, além de viabilizarem a reparação dos danos, acabam funcionando como desincentivo ao cometimento de novos danos ambientais, uma vez que as seguradoras adotam medidas de vigilância das atividades.

Sendo assim, de acordo com sua opinião, os seguros seriam um mecanismo efetivo de imposição de responsabilidade civil. Apresentou ainda, expondo suas ressalvas, que a partir da aprovação deste PL, normas disciplinares do seguro deveriam ser publicadas prevendo que: $58 \%$ do prêmio arrecadado ficaria a cargo das sociedades seguradoras responsáveis pelo pagamento das indenizações, outros $30 \%$ seriam destinados, proporcionalmente às suas arrecadações, à União, aos Estados e aos Municípios, e os 12\% restantes deveriam compor a verba do Fundo Nacional de Meio Ambiente. Ou seja, para a relatora, a imposição do Seguro seria uma alternativa de aplicação da lei, visto que, em suas palavras: "a aplicação desses dispositivos legais sobre a responsabilidade civil em matéria ambiental nem sempre é simples".692

Não se pode negar que as decisões judiciais, principalmente analisadas no presente trabalho, não proporcionam, em sua grande maioria, a reparação efetiva dos danos ambientais, principalmente por poluição por petróleo. Entretanto, o que se pretende defender aqui não é a substituição da função do judiciário e da legislação, mas sim a garantia de que as medidas de reparação impostas através do devido processo legal sejam efetivas, possam ser cumpridas e, o que é crucial nesse tema, sejam céleres.

Apesar de os projetos de lei analisados objetivarem uma segurança ambiental através da obrigatoriedade dos seguros, não se pode desvirtuar as reais funções desses mecanismos. É questionável, por exemplo, que parte de prêmios seja desviada para fundos e para compor a

${ }^{691}$ BRASIL. Comissão de Legislação Participativa da Câmara dos Deputados. Relator Ann Pontes. Parecer ao PL $\mathbf{n}^{\circ}$ 2.313/2003. Brasília: Câmara dos Deputados. Disponível em: <http://www.camara.gov.br/proposicoesWeb/prop_mostrarintegra;jsessionid=988252A0949D21A68904734A19 E2A4AA.proposicoesWebExterno2? codteor $=192076 \&$ filename=Tramitacao-PL+2313/2003 $>$. Acesso em 19.04.2018.

${ }^{692}$ BRASIL. Comissão de Legislação Participativa da Câmara dos Deputados. Relator Ann Pontes. Parecer ao PL $\mathbf{n}^{\circ}$ 2.313/2003. Brasília: Câmara dos Deputados. Disponível em: $<$ http://www.camara.gov.br/proposicoesWeb/prop_mostrarintegra;jsessionid=988252A0949D21A68904734A19 E2A4AA.proposicoesWebExterno2?codteor=192076\&filename=Tramitacao-PL+2313/2003>. Acesso em 19.04.2018. 
receita de Estados e Municípios, sem a efetiva aplicação dos recursos na recuperação dos ambientes degradados. Os próprios valores das apólices são calculados para a cobertura total dos riscos de danos mapeados, tornando sem sentido o direcionamento das verbas para outros fins.

Walter Polido acrescenta que a maioria dos seguros de responsabilidade civil obrigatórios acaba adotando características de fundos de reparação, distorcendo as "bases teóricas e jurídicas comuns ao contrato de seguro típico de responsabilidade civill". ${ }^{693}$ Para o Brasil, tal possibilidade é alarmante, pois, conforme já apresentado, nem mesmo os próprios fundos cumprem com seu papel de direcionamento dos montantes à reparação dos danos que originaram as indenizações. Se os seguros adotarem tais características, os ambientes naturais, mais precisamente os ecossistemas marinhos, ficarão cada vez mais descobertos.

Com relação especificamente à obrigatoriedade do seguro ambiental, Walter Polido apresenta em suas obras ${ }^{694}$ algumas premissas esclarecedoras, que vão contra a tendência da legislação brasileira. $\mathrm{O}$ autor elenca algumas justificativas desfavoráveis à obrigatoriedade dos seguros, ao concluir, por exemplo, que: (i) a obrigatoriedade limita o desenvolvimento de produtos por cada Seguradora; (ii) o fato de o seguro ser obrigatório não garante a adesão integral de seguradoras dispostas a aceitarem os riscos das atividades; (iii) a mensuração dos riscos deve ser realizada por cada seguradora e não imposta; (iv) o cumprimento das normas referentes à prevenção e reparação de danos por acidentes deve ser feito pelo poder público e não imposto às seguradoras; (v) seguros possuem natureza distinta de licenças ambientais, não podendo exercer tal papel; e (vi) a compulsoriedade do seguro pode inviabilizar atividades, principalmente quando exercidas por empresas de menor porte.

\subsection{Os seguros marítimos}

Os seguros surgiram em decorrência da relação do homem com o mar, mais precisamente, devido à necessidade de se realizar o transporte de mercadorias por embarcações.

Os registros indicam que de 1500 a.C. a 300 a.C. havia atividades de trocas de mercadorias no mar Mediterrâneo. Diante dos riscos de naufrágios e ataques piratas, os fenícios

\footnotetext{
${ }^{693}$ POLIDO, W. A. Contrato de Seguro: a efetividade do seguro ambiental na composição de danos. Revista de Direito Ambiental, São Paulo, n.45, jan./mar. 2007, p.11.

${ }^{694}$ POLIDO, W. A. Programa de Seguros de Riscos Ambientais no Brasil: Estágio de desenvolvimento atual. Rio de Janeiro: Escola Nacional de Seguros (Funseg), 3ª ed., 2015, p. 219-220; e POLIDO, W. A. Contrato de Seguro: a efetividade do seguro ambiental na composição de danos. Revista de Direito Ambiental, São Paulo, n.45, jan./mar. 2007, p.22.
} 
reservavam parte dos lucros em um tipo de fundo comum, para compensar eventuais perdas em viagens que corressem mal. Já a primeira apólice escrita que se tem registro foi elaborada em Pisa, no ano 1343, e tratava do transporte de dez fardos de lã, para a Sicília. ${ }^{695}$

Apesar de serem tão antigos, no Brasil a oferta de seguros no ramo se restringe principalmente à proteção de cargas e embarcações. As preocupações relativas aos danos ambientais em decorrência da atividade em mar são recentes e vêm sendo aos poucos incorporadas em modalidades específicas de seguros.

\subsubsection{Seguros para embarcações, mercadorias, plataformas e operadores portuários}

Muito embora o Brasil conte com um grande fluxo de embarcações, possua uma costa extremamente expressiva de tamanho e biodiversidade e seja potencial e real receptor de poluição marinha de várias formas, o país não conta com um mercado nacional de seguros ligados a atividades onshore e offshore tão desenvolvido quanto no exterior.

Especificamente para embarcações, as seguradoras mundiais apresentam as seguintes opções de seguros: responsabilidade civil, riscos ambientais e de petróleo; transportes; cascos marítimos; operadores portuários; e seguro de proteção e indenização, Protection \& Indemnity (P\&I). Essas modalidades serão apresentadas a seguir.

\subsubsection{Seguros de Responsabilidade Civil}

O Seguro de Responsabilidade Civil encontra-se previsto na Seção II, do Código Civil, denominada "Seguros de Danos", sendo que o artigo 787 do mesmo diploma deixa claro que o objeto principal deste tipo de seguro é o "pagamento de perdas e danos". Conforme se observa em sua redação: "No seguro de responsabilidade civil, o segurador garante o pagamento de perdas e danos devidos pelo segurado a terceiro". Apesar desse tipo de seguro se destinar apenas os danos acidentais, em regra, não são cobertos os danos causados por poluição, contaminação e vazamento. ${ }^{696}$

\footnotetext{
${ }^{695}$ SARDINHA, A. M. Seguros no Transporte Marítimo. 44f. Dissertação de Mestrado em Direito e Economia do mar - Faculdade de Direito, Universidade Nova de Lisboa, Lisboa, dez. 2017, p.17-19. Disponível em: $<$ https://ransportemaritimoglobal.files.wordpress.com/2018/02/00-alvaro-sardinha-seguros-no-transportemarc3adtimo-tmg-mar-doc1.pdf > . Acesso em 01.08.2018.

${ }^{696}$ Ainda, conforme nos explica Walter A. Polido, os termos "contaminação" e "poluição" não deveriam ser utilizados com a mesma conotação. Nos clausulados brasileiros, o termo "poluição" se destina as possíveis contaminações de solo, pessoas ou outros bens alheios ao segurado, enquanto o termo "contaminação" é utilizado para se referir à contaminação do próprio produto segurado. Por isso, o autor sugere que a exclusão da cobertura de contaminação seja clausulada de forma explícita, uma vez que não faria sentido para uma apólice de seguro ambiental. POLIDO, W. A. Seguros de Responsabilidade civil: manual prático e teórico. Curitiba: Juruá, 2013, p.482.
} 
Ao tratar dos Seguros de Responsabilidade Civil, Walter Polido defende que os riscos ambientais não podem ser abrangidos por essa cobertura clássica, pois são muito mais específicos. ${ }^{697}$ Ou seja, deve haver um seguro ambiental específico, que leve em conta riscos ao meio ambiente e garanta a cobertura aos danos sofridos por bens naturais:

\begin{abstract}
Para evidenciar e caracterizar um contrato de seguro específico de riscos ambientais, também os bens naturais devem estar obrigatoriamente garantidos pelas coberturas da apólice. Do contrário, não poderá ser classificado como sendo um seguro de riscos ambientais efetivamente e deve dispor, inclusive, de outra nomenclatura e de modo mesmo a não induzir os eventuais interessados por produtos mais consistentes a erro. ${ }^{698}$
\end{abstract}

\title{
10.2.1.2. Seguro de Riscos Ambientais
}

Antes de 2004, o mercado brasileiro, diferentemente dos Estados Unidos, ${ }^{699}$ contava praticamente com apólices de Responsabilidade Civil tradicional. A partir desse ano, os seguros ambientais se destinavam apenas aos riscos de poluição ambiental acidental e súbita. Com o passar dos anos, mas de forma muito incipiente, começaram a ser aprimoradas as coberturas para poluição gradual. ${ }^{700}$ Os contratos de risco de natureza súbita e acidental referem-se aos danos de natureza inesperada, ocorridos durante a vigência da apólice. Já as coberturas de poluição gradual abrangem os danos que se manifestam em momento posterior ao incidente ou que se prolatam no tempo. ${ }^{701}$

A amplitude de cobertura para danos graduais e para efeitos futuros dos acidentes é não somente pertinente, mas de extrema importância para a remediação de danos decorrentes de derramamentos de óleo no mar. Entretanto, há diversos problemas encontrados nas apólices de poluição gradual, dentre eles, destacam-se: os efeitos da contaminação pré-existente e de outras possíveis fontes de contaminação; os atos dolosos de terceiros; os danos provocados por eventos climáticos; e a própria delimitação temporal de cobertura prevista na apólice. ${ }^{702}$ Ademais, não se pode deixar de ressaltar que a própria ausência de caracterização prévia dos ambientes

${ }^{697}$ POLIDO, W. A. Seguros de Responsabilidade civil: manual prático e teórico. Curitiba: Juruá, 2013, p.1102. ${ }^{698}$ POLIDO, W. A. Seguros de Responsabilidade civil: manual prático e teórico. Curitiba: Juruá, 2013, p. 1102.

${ }^{699}$ Nos Estados Unidos, os seguros de riscos ambientais são comercializados individualmente pelas Seguradoras, com o respaldo dos seus Resseguradores. São previstos, inclusive, clausulados de coberturas de seguros abrangendo os danos ecológicos puros. POLIDO, W. A. Contrato de Seguro: a efetividade do seguro ambiental na composição de danos. Revista de Direito Ambiental, São Paulo, n.45, jan./mar. 2007, p. 13.

${ }^{700}$ POLIDO, W. A. Seguros de Responsabilidade civil: manual prático e teórico. Curitiba: Juruá, 2013, p. 11181122.

${ }^{701}$ POLIDO, W. A. Contrato de Seguro: a efetividade do seguro ambiental na composição de danos. Revista de Direito Ambiental, São Paulo, n.45, jan./mar. 2007, p.14.

POLIDO, W. A. Contrato de Seguro: a efetividade do seguro ambiental na composição de danos. Revista de Direito Ambiental, São Paulo, n.45, jan./mar. 2007, p.15. 
atingidos e a dificuldade de caracterização dos danos gerados são fatores que prejudicam a identificação dos reais riscos que possam ser abrangidos por uma cobertura para danos graduais.

As apólices para riscos ambientais, normalmente, cobrem: poluição súbita; poluição gradual; honorários advocatícios e custas judiciais para a defesa do segurado. ${ }^{703}$ Além dessas coberturas, o seguro ambiental passa a contribuir inclusive para a contenção de danos, etapa tão importante nos derramamentos de óleo, graças à previsão do artigo $779^{704}$ do Código Civil, que incluiu as despesas de contenção de sinistros nos prejuízos a serem indenizados pelo contrato de seguro. Assim, pode-se entender que a Seguradora, nos casos de acidentes com óleo no Brasil, deveria participar, inclusive, das medidas emergenciais, não se limitando aos posteriores custos de reparação.

\subsubsection{Seguro de Riscos de Petróleo}

No Brasil, as coberturas oferecidas nos planos de Riscos de Petróleo buscam garantir as indenizações aos danos causados por equipamentos e instalações que exerçam atividades de produção, prospecção e perfuração de óleo e gás, incluindo:

I - unidades de perfuração e unidades de produção; II - unidades de armazenamento no campo de produção em terra (onshore) e marítimas (offshore) e dutos offshore; III - manutenção, conservação e construção de unidades dos tipos UE (unidades de exploração), UP (unidades de produção), UA (unidades de armazenamento) e outras estruturas submarinas, incluindo dutos offshore, ligadas à produção ou exploração de óleo ou gás; IV - óleo e/ou gás armazenado na unidade de produção e/ou unidade offshore de armazenamento. ${ }^{705}$

Conforme se depreende da leitura da Circular SUSEP n ${ }^{\circ} 470$, de 28 de junho de $2013^{706}$ - que "dispõe sobre as regras e os critérios para operação das coberturas oferecidas em plano de seguro de Riscos de Petróleo, e dá outras providências"-, o escopo das apólices abrange apenas as coberturas de responsabilidade civil, para o pagamento de indenizações resultantes de ocorrências, reclamação ou perdas financeiras relacionadas ao equipamentos e instalações

\footnotetext{
${ }^{703}$ POLIDO, W. A. Contrato de Seguro: a efetividade do seguro ambiental na composição de danos. Revista de Direito Ambiental, São Paulo, n.45, jan./mar. 2007, p.14.

704 Art. 779 do Código Civil de 2002: "O risco do seguro compreenderá todos os prejuízos resultantes ou conseqüentes, como sejam os estragos ocasionados para evitar o sinistro, minorar o dano, ou salvar a coisa."

${ }^{705}$ SUSEP. Circular $\mathbf{n}^{\mathbf{0}} \mathbf{4 7 0}$, de 28 de junho de 2013. Dispõe sobre as regras e os critérios para operação das coberturas oferecidas em plano de seguro de Riscos de Petróleo, e dá outras providências. Disponível em: $<$ http://www2.susep.gov.br/bibliotecaweb/docOriginal.aspx?tipo=1\&codigo=31124 > . Acesso em: 01.08.2018.

${ }^{706}$ SUSEP. Circular $\mathbf{n}^{0} \mathbf{4 7 0}$, de 28 de junho de 2013. Dispõe sobre as regras e os critérios para operação das coberturas oferecidas em plano de seguro de Riscos de Petróleo, e dá outras providências. Disponível em:

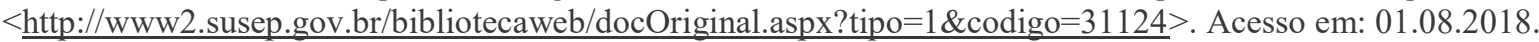


acima especificados. Em outras palavras, não estão automaticamente contemplados pelos planos de seguro de riscos de petróleo os riscos ambientais decorrentes de acidentes.

\subsubsection{Seguros de Transportes}

O seguro de transportes garantirá ao dono da carga indenização pelos prejuízos sofridos pelos bens segurados durante o seu transporte em viagens aquaviárias, terrestres e aéreas, em percursos nacionais e internacionais, podendo ser a cobertura estendida durante a permanência das mercadorias em armazéns. Trata-se de modalidade de contratação obrigatória para pessoas jurídicas privadas. $^{707}$

Já o seguro de responsabilidade civil do transportador, diferentemente, é contratado pelo proprietário do veículo de transporte e se limita a cobrir prejuízos inerentes a ele, a exemplo de "colisão, capotagem, abalroamento, incêndio ou explosão". 708

Conforme é possível concluir, tanto o seguro de transporte, como do transportador se restringem às indenizações por perdas financeiras, sejam com relação à carga ou ao veículo. Sendo assim, no caso de navios, não cobrem custos de reparação por danos ambientais, mesmo se a carga perdida for óleo.

\subsubsection{Cascos Marítimos}

No Brasil, os seguros de cascos marítimos são aplicáveis à "embarcações de longo curso, de cabotagem, fluviais, de apoio às plataformas ou embarcações pertencentes a empresas brasileiras de navegação registradas no Registro Especial Brasileiro - REB", ${ }^{709}$ e destinam-se, como o próprio nome sugere, à indenização em decorrência de perdas e danos associados às estruturas das embarcações que por ventura sejam danificadas. ${ }^{710}$

707 Informações disponíveis em: <http://www.susep.gov.br/menu/informacoes-ao-publico/planos-eprodutos/seguros/seguro-de-transportes $>$. Acesso em: 01.08.2018.

708 Informações disponíveis em: <http://www.susep.gov.br/menu/informacoes-ao-publico/planos-eprodutos/seguros/seguro-de-transportes $>$. Acesso em: 01.08.2018.

709 SUSEP. Circular $\mathbf{n}^{\mathbf{0}}$ 392, de 16 de outubro de 2009.Disponível em:

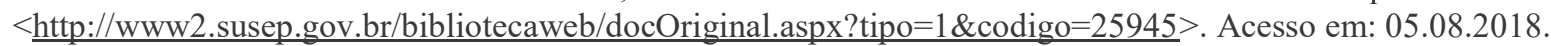

${ }^{710}$ Cumpre ao seguros de cascos marítimos "indenizar os prejuízos sofridos pelo Segurado e/ou Benefíciário designado nesta apólice, por perdas ou danos que atinjam a embarcação objeto do presente seguro - seu casco, suas máquinas e todos os seus aparelhos, motores, instalações, equipamentos, peças, provisões, suprimentos e demais pertences ou parte dos mesmos e/ou a outro interesse em risco abrangido por este seguro, em viagem ou não, em quaisquer serviços e tráfegos no mar ou em rios, canais ou outra via navegável, em portos ou ancoradouros, ou em diques, estaleiros, carreiras ou rampas - pela ocorrência de riscos inerentes à fortuna do mar, de incêndio, raio, terremoto, intempérie, ou por alijamento, ou por barataria ou rebeldia do capitão e/ou de tripulantes (...)". SUSEP, Circular $\mathbf{n}^{\mathbf{0}}$ 001, de 07 de janeiro de 1985. Disponível em:

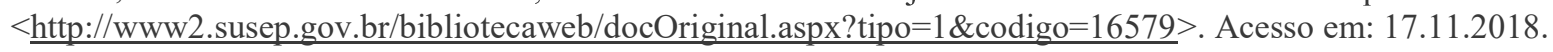


Antes do século XIX, os seguros marítimos se restringiam a seguros de caso e máquinas, principalmente de veleiros. Devido ao maior fluxo de navios a vapor e ao aumento do risco de colisões, as seguradoras introduziram uma cláusula de limitação de responsabilidade, que persiste ainda hoje, denominada CollisionClause ou Running Down Clause, que limita o pagamento a três quartos do valor envolvido em colisões. ${ }^{711}$

Muito embora nesta modalidade de seguro não sejam abrangidos os custos de reparação por derramamentos, de acordo com Walter Polido, no Brasil, há ainda a possibilidade de contratação de vários tipos de seguros, que garantem parcelas de riscos de poluição ambiental, em uma espécie de "pulverização do risco ambiental em ramos". Dentre eles, o autor cita dois ramos: (i) Riscos de Petróleo onshore e offshore; e (ii) Cascos (embarcações), para os riscos de derramamento de petróleo e/ou derivados por navios, com coberturas acessórias de responsabilidade civil e poluição. Tais coberturas abarcam:

a) Responsabilidade Civil por perdas, danos ou contaminação causados pelo derramamento ou emanação de qualquer substância, não apenas óleo, mas também gases, produtos químicos, esgotos e lixos;

b) Despesas com limpeza de áreas poluídas ou contaminadas;

c) Custos com medidas impostas por normas governamentais a fim de conter ou minimizar uma ocorrência ou a poluição, respectivamente;

d) Responsabilidade Civil sob contrato de salvamento, ou seja, medidas tomadas por empresas de salvatagem com a finalidade de conter a ocorrência de poluição. ${ }^{712}$

Nesse sentido, não é incomum que os riscos ambientais sejam coberturas acessórias de apólices de casco marítimo, apesar de não ser o cenário ideal.

\subsubsection{Operadores Portuários}

Inicialmente, cumpre definir quem são os operadores portuários. De acordo com Processo SUSEP n 15414.003688/2003-46, "Seguro Compreensivo Padronizado para Operadores Portuários", entende-se por operador portuário a pessoa jurídica que seja "a) préqualificada para a execução de operações portuárias, em área de porto organizado"; ou, então,

"b) que movimenta e/ou armazena mercadorias destinadas e/ou provenientes de transporte

${ }^{711}$ SARDINHA, A. M. Seguros no Transporte Marítimo. 44f. Dissertação de Mestrado em Direito e Economia do mar - Faculdade de Direito, Universidade Nova de Lisboa, Lisboa, dez. 2017, p. 28.

712 POLIDO, W. A. Seguros de Responsabilidade civil: manual prático e teórico. Curitiba: Juruá, 2013, p. 11231124. 
aquaviário, em instalações portuárias de uso privativo, situadas dentro ou fora de área de porto organizado". 713

Normalmente, os seguros de operadores portuários cobrem os riscos das operações desenvolvidas em áreas de porto organizado, em instalações privadas, restringindo-se à movimentação e ao armazenamento das mercadorias transportadas. Podem ainda cobrir danos materiais, corporais, perdas e danos causados a terceiros, além de prejuízos decorrentes de paralisações. $^{714}$

Não são cobertos os custos de poluição, contaminação, limpeza e contenção que eventualmente sejam causados por acidentes com derramamento de substâncias químicas. É considerada exceção à vedação da cobertura a poluição acidental, sem cunho intencional, causada por risco coberto pela apólice, dentro de sua vigência, descoberta em até 72 horas após o início, com envio de comunicação à seguradora. Entretanto, nesse caso, não são contempladas pela apólice "multas, punições de qualquer espécie, indenizações por danos morais e quaisquer outras indenizações que representem ampliação das compensações". 715

\subsubsection{O Seguro de Proteção e Indenização, Protection \& Indemnity (P\&I)}

Em complemento aos seguros que apresentam natureza de responsabilidade civil e que visam proteger navios e cargas, foram criados os seguros de Proteção e Indenização (P\&I). ${ }^{716}$ O termo Protection traduz a proteção com relação à danos a pessoas e patrimônio. Já Indemnity refere-se aos prejuízos que podem afetar a carga. Os seguros de P\&I aglutinam em uma só apólice diferentes coberturas para navios que antes eram adquiridas isoladamente. Ademais, trazem a possibilidade de coberturas acessórias que podem (ou não) ser adquiridas por armadores, a exemplo das coberturas para despesas judiciais para defesa contra reclamações. 717

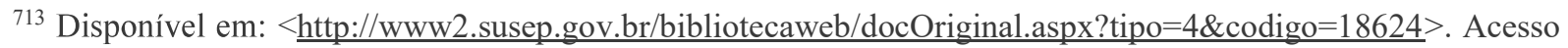
em: 01.10.2018.

${ }^{714}$ SUSEP. Processo $\mathbf{n}^{0}$ 15414.003688/2003-46. Seguro Compreensivo Padronizado para Operadores Portuários.

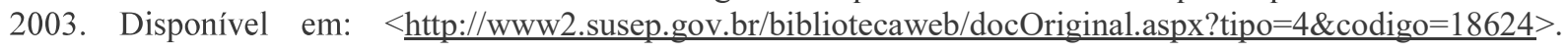
Acesso em: 01.10.2018.

${ }^{715}$ SUSEP. Processo $\mathbf{n}^{\mathbf{0}} \mathbf{1 5 4 1 4 . 0 0 3 6 8 8} / \mathbf{2 0 0 3 - 4 6}$. Seguro Compreensivo Padronizado para Operadores Portuários.

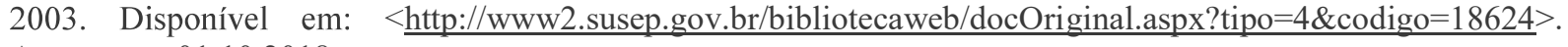
Acesso em: 01.10.2018.

716 PORTUGAL. ASF. Glossário de seguros. Informação disponível em: $<$ https://www.asf.com.pt/ISP/Gloss\%C3\%A1rio>. Acesso em: 01.10.2018.

717 SARDINHA, A. M. Seguros no Transporte Marítimo. 44f. Dissertação de Mestrado em Direito e Economia do mar - Faculdade de Direito, Universidade Nova de Lisboa, Lisboa, dez. 2017, p.28
} 
Devido à natureza dos danos cobertos por essa modalidade de seguro que podem chegar a valores exorbitantes e com uma cobertura muito ampla, os seguros de P\&I não são gerenciados por seguradoras isoladas (o que não seria viável em termos financeiros), mas sim por Clubes de Proteção e Indenização. Atualmente, existem aproximadamente 26 clubes concentrados entre Estados Unidos e Europa. ${ }^{718}$

As diferenças com relação aos demais seguros marítimos vão além dessas. Não há, por exemplo, adesão a apólices, mas, sim, a aceitação das regras que regem o clube - Club's Rulebook. Os valores são arrecadados por meio de calls, que são convocações ilimitadas para que os armadores paguem certas quantias calculadas com base em alguns fatores, como, por exemplo, tonelagem do navio, quantidade de sinistros ou percursos percorridos. As quantias são armazenadas e utilizadas como reembolso de sinistros futuros.

O sistema se assemelha a um fundo privado, mas para receber as quantias o armador deve primeiramente arcar com suas despesas perante terceiros. O sistema é conhecido como pay to be paid ou pagar para ser reembolsado. ${ }^{719}$ A garantia do reembolso pode ocorrer em três níveis: a primeira, conforme exposto, pelo pagamento efetuado por meio do próprio clube. A segunda e a terceira são verificadas para treze clubes que se uniram em um grupo maior, denominado International Group of Protection \& Indemnity Clubs (IGP\&I). ${ }^{720}$ O objetivo principal do grupo é o aumento da garantia securitária, tanto pelo contrato de pooling, quanto pela previsão de resseguro acionado principalmente para as perdas catastróficas, a exemplo dos derramamentos de óleo de grandes dimensões. Inclusive, dentre as possibilidades de cobertura por resseguros há expressa menção pelo grupo aos casos de poluição por óleo, com cobertura de até um bilhão de dólares. ${ }^{721}$

Os principais riscos cobertos são passivos, despesas e custos relacionados a: perda de vida, ferimentos e doenças da tripulação, passageiros e outras pessoas; perda de carga, escassez ou dano; colisão; danos a docas, boias e outros objetos fixos e flutuantes, mesmo que pertencentes a terceiros; remoção de destroços; multas e penalidades; motim e má conduta por parte da tripulação; repatriação e substituição de tripulações; danos à propriedade a bordo do

\footnotetext{
718 PORTUGAL. ASF. Glossário de seguros. Informação disponível em: $<$ https://www.asf.com.pt/ISP/Gloss\%C3\%A1rio >. Acesso em: 01.10.2018.

${ }^{719}$ SARDINHA, A. M. Seguros no Transporte Marítimo. 44f. Dissertação de Mestrado em Direito e Economia do mar - Faculdade de Direito, Universidade Nova de Lisboa, Lisboa, dez. 2017, p.29-30.

${ }^{720}$ Disponível em: $<$ https://www.igpandi.org/about $>$. Acesso em: 01.10.2018.

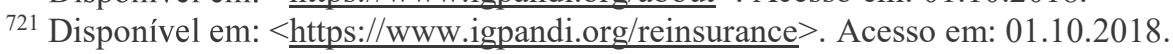


navio segurado, a exemplo de máquinas e containers; bem como despesas de desvio de embarcações. ${ }^{722}$

Além de todas as coberturas acima elencadas, os seguros de P\&I trazem a previsão de cobertura para Poluição, fator inovador e importante ao presente trabalho. No segmento de poluição, há a previsão de cobertura para as ações judiciais, custos e despesas, a exemplo de multas e para defesa em inquéritos e ações decorrentes de derramamentos de óleo no mar. ${ }^{723}$ São ainda cobertas as medidas de remediação de danos, incluindo limpeza, além de custos para adoção de medidas mitigadoras determinadas por órgãos governamentais. ${ }^{724}$

\subsection{Conclusões parciais}

Conforme apresentado, os seguros ambientais são recentes no Brasil, ainda carecem de aprimoramento e aceitação de mercado e nem sempre são obrigatórios para algumas atividades. Entretanto, o que se vê é que o cenário internacional de transporte marítimo e exploração de óleo conta com convenções que obrigam as embarcações a aderirem a seguros capazes de cobrir danos ambientais. Mesmo que o país não seja signatário de algumas convenções e protocolos, cada vez mais as pressões de mercado externas vão exigir da frota brasileira esse tipo de adesão.

O fato é que o risco de derramamentos apresenta tratamento no mundo todo, sendo que as embarcações acabam se associando aos clubes de Protection \& Indemnity (P\&I) ao invés de contratarem seguros privados tradicionais. Entretanto, o Brasil não conta com clubes de P\&I, obrigando os armadores de bandeira brasileira a se filiarem a clubes estrangeiros. Essa única opção apresenta, contudo, alguns problemas de cunho prático.

Primeiramente, com relação à legislação nacional, conforme já abordado, a forma de responsabilidade civil por danos ambientais no Brasil não admite excludentes baseadas em culpa. Por outro lado, as apólices são praticamente contratos de adesão que não podem ser adaptados. Nesse sentido, a embarcação brasileira corre o risco de aderir a uma apólice inaplicável ao ordenamento jurídico pátrio.

722 THE AMERICAN CLUB By-Laws, Rules, List of Correspondents: 2018-2019. New York: THE AMERICAN CLUB, p. 48-65, 2018. Disponível em: <https://www.americanclub.com/files/files/1819.pdf\#page=32>. Acesso em: 01.10.2018.

723 GARD. Gard Guidance to the Rules 2018. Rule 38: Pollution. Disponível em: $<\underline{\text { http://www.gard.no/web/publications/document/chapter?p_subdoc_id=20748000\&p document_id=20747880. }}$. Acesso em: 01.10.2018.

724 THE AMERICAN CLUB. By-Laws, Rules, List of Correspondents: 2018-2019. New York: THE AMERICAN CLUB, p. 48-65, 2018. Disponível em: <https://www.americanclub.com/files/files/1819.pdf\#page=32>. Acesso em: 01.10.2018. 
Outros dois problemas comuns são: a língua, já que os contratos normalmente são redigidos em inglês, o que pode gerar ruídos de interpretação no momento da tradução; e o pagamento das indenizações decorrentes do sinistro, uma vez que, conforme salientado, os clubes contam com um fundo comum e indenizam os prejuízos sofridos pelo armador. Porém, os fundos não estão alocados no Brasil, o que acarreta, ademais, em demora e impostos exorbitantes para o repasse dos recursos.

Devido aos fatores apresentados, deve-se destacar a emergente necessidade de o Brasil criar incentivos e regulamentação para a criação de pools de seguradoras no país. A partir da análise desenvolvida no presente capítulo, conclui-se que faltam mecanismos internos que impulsionem armadores e concessionárias que desenvolvem exploração de óleo a buscarem os seguros que abranjam riscos de derramamentos de óleo e suas consequências.

Por outro lado, as seguradoras que já oferecem produtos no país são desestimuladas não somente pela alta exposição ao risco, mas também pela necessidade de investimentos na área de subscrição, com a aquisição de equipamentos e contratação de pessoal para inspecionar, monitorar e avaliar os riscos dos possíveis contratantes. ${ }^{725}$ É certo que o próprio serviço de intermédio de venda de seguros de P\&I de clubes estrangeiros requer a infraestrutura de avaliação local. Sendo assim, a criação de um clube local seria uma realização importante.

Com relação especificamente às atividades de prospecção e perfuração, apesar das apólices tradicionais de Seguros para Riscos de Petróleo não se destinarem aos riscos de poluição e danos ambientais, o próprio governo entende que tal cobertura é necessária. É possível extrair essa conclusão da leitura da última "Minuta de Contrato de Concessão para Exploração e Produção de Petróleo e Gás Natural", referente à $15^{\circ}$ rodada de licitação em blocos, que em sua Cláusula $22^{\circ}$, ao tratar do tema seguros, determina que o Concessionário deverá contratar seguro que possua cobertura para, dentre outros: (i) limpeza decorrente de acidente; (ii) descontaminação decorrente de acidente; (iii) responsabilidade civil para danos ao meio ambiente e ao patrimônio da União. ${ }^{726}$

725 POLIDO, W. A. Contrato de Seguro: a efetividade do seguro ambiental na composição de danos. Revista de Direito Ambiental, São Paulo, n.45, jan./mar. 2007, p.23.

${ }^{726}$ Importante ressaltar que o Edital de Licitação publicado em conjunto com a minuta contratual citada não faz menção à contratação de seguros específicos para danos ambientais, conforme pode-se verificar no documento: ANP. Edital de Licitações. 15 $^{\text {a }}$ rodada de licitações - Mar. Blocos Exploratórios. Outorga dos contratos de concessão para atividades de exploração e produção de petróleo e gás natural. Rio de Janeiro, 26 de janeiro de 2018. Disponível em: <http://rodadas.anp.gov.br/pt/15-rodada-de-licitacao-de-blocos/edital-e-modelo-docontrato-de-concessao $>$. Acesso em: 01.10.2018. 
Não se pode deixar de frisar que o papel do Judiciário é fundamental para o desenvolvimento dos seguros no Brasil. ${ }^{727}$ Isso porque a forma em que as empresas são responsabilizadas por danos ambientais decorrentes de derramamentos vai refletir diretamente no aumento pela adesão aos seguros.

Há, portanto, a necessidade de que os próprios planos de gestão de risco considerem todos os tipos de respostas viáveis, dentre elas, as que requeiram recursos financeiros. Os seguros não deixam de ser mecanismos de promoção de respostas adequadas e até mesmo de prevenção de danos. Não se pode negar que a interação de atividades que envolvam petróleo e meio ambiente apresentam grande potencial catastrófico. Por isso, as políticas públicas de prevenção e resposta não somente devem considerar os diferentes ramos, mas contar com a contribuição de todos dentro de suas áreas, incluindo atores econômicos, públicos e organizações. ${ }^{728}$

${ }^{727}$ POLIDO, W. A. Contrato de Seguro: a efetividade do seguro ambiental na composição de danos. Revista de Direito Ambiental, São Paulo, n.45, jan./mar. 2007, p.17-19.

MONTI, A. Environmental Risks and Insurance. A comparative analysis of the role of insurance in the management of environment-related risks. In: Organization for Economic Cooperation and Development (OECD). OECD Report: Environmental Risks and Insurance. Paris: OECD, jun. 2002, p.2. 


\section{CONCLUSÃO}

O desenvolvimento do presente trabalho foi impulsionado por uma percepção inicial acerca da falta de comunicação entre as diferentes ciências aplicáveis aos derramamentos de óleo no mar. Conforme brevemente apresentado na introdução, por meio das primeiras pesquisas, realizadas ainda em 2005, no âmbito do curso de Gerenciamento Costeiro da Unesp de São Vicente, sobre técnicas de remediação, foi possível perceber que, naquela época, a legislação vigente não refletia as alternativas técnicas existentes.

Ademais, foi possível ainda notar que, nem mesmo as formas de prevenção eram plenamente claras na legislação. Após mais de dez anos das primeiras impressões sobre o assunto, foram verificados significativos avanços referentes à legislação, o que, inclusive, corroborou para a diminuição da quantidade dos derramamentos mais expressivos, bem como para o aprimoramento das respostas a eles.

Por outro lado, por meio da recente análise aprofundada tanto da legislação nacional, quanto dos tratados e convenções internacionais recepcionados pelo Brasil, como parte do desenvolvimento desta tese, foi possível notar que algumas falhas e incongruências permanecem. No âmbito da legislação nacional, muito embora tenha sido muito aprimorada na última década, verificou-se que houve aumento das obrigações aos potenciais causadores de derramamentos, mas não foram desenvolvidas políticas públicas nacionais efetivas de resposta aos incidentes. Os planos de resposta de uma forma geral são de obrigação dos particulares, e não poderia ser diferente disso, por conta das regras de responsabilidade aqui vistas, porém, não há uma articulação nacional governamental instituída para o tema.

Tal fator pode ser verificado na prática. Nos casos de grandes derramamentos, órgãos ambientais estaduais se articulam voluntariamente, em conjunto com os nacionais, para prestarem auxílio e para realizarem levantamentos técnicos de causas e consequências, porém sem nenhum respaldo oficial financeiro, ou formal de políticas públicas instituídas. Literalmente, as cooperações ocorrem por conta da boa vontade.

Não é à toa que, principalmente no Estado de São Paulo, conforme verificado por meio da análise jurisprudencial, a CETESB é constantemente ouvida nas ações judiciais para que promotores e juízes possam ter maiores subsídios técnicos para compreenderem os casos práticos. Entretanto, as demandas não são acompanhadas do correto aparelhamento e fomento dos órgãos ambientais. 
Ainda com relação à legislação nacional, foi observada uma incongruência na atribuição de responsabilidade por manchas órfãs, consideradas uma das maiores causas de danos por óleo em ambientes marinhos e costeiros na atualidade. Conforme apresentado nos capítulos 4 e 6, a legislação aloca a responsabilidade pela reparação de tais manchas àqueles que não deram causa as mesmas, contrariando inclusive as regras de responsabilidade que regem de forma clara o Direito Civil Ambiental.

Com relação à legislação internacional, além do difícil acesso e compreensão sobre quais convenções foram internalizadas, e sob quais condições específicas, uma vez que, em alguns casos não foram recepcionados pelo Brasil protocolos, anexos, ou ainda as ratificações foram realizadas com ressalvas, o maior problema verificado foi a previsão de excludentes de responsabilidade em tais normas.

Conforme amplamente demonstrado, os tribunais superiores brasileiros reconhecem, de forma quase unânime, a aplicação da teoria do risco integral aos derramamentos de óleo no mar. Assim, não são admitidas as excludentes de responsabilidade nesses casos, sendo que todos aqueles que contribuem para a geração dos danos ambientais devem responder de forma solidária.

Porém, de forma contraditória ao ordenamento pátrio, não somente por meio de tratados e convenções há a previsão de tais excludentes, estas estão previstas também em apólices de seguros ambientais, muitas vezes contratadas em países estrangeiros, ou elaboradas internamente com base em clausulados desenvolvidos por clubes de P\&Is, sendo encontradas possibilidades de excludentes de responsabilidade, gerando patente insegurança jurídica aos envolvidos.

Contudo, mesmo não sendo o objeto principal do presente trabalho, entendeu-se por necessária a realização de um levantamento crítico da legislação aplicável aos derramamentos de óleo no mar, como forma de contribuição para posteriores trabalhos que se dediquem ao seu aprimoramento, ou a quem sabe, elaboração de políticas públicas nacionais sobre o tema.

Retornando ao real objetivo desta tese, qual seja: a análise da responsabilidade pelos derramamentos de óleo no mar, o capítulo que tratou dos danos ambientais demonstrou a imensidão de tipos de danos e de bens jurídicos e ambientais afetados sob duas óticas: a jurídica e a ecológica. Foi possível verificar que o judiciário ainda não exige um levantamento extensivo e aprofundado dos danos ambientais nos casos de derramamentos. Entretanto, a compreensão 
acerca da complexidade dos danos mostra que muitos deles não são abrangidos nas formas de reparação adotadas.

O que se pretende demonstrar aqui é a indiscutível necessidade de que o tema seja abordado por meio de uma avaliação interdisciplinar, por mais que o Direito ainda relute muitas vezes em não recepcionar contribuições de outras ciências. Se os próprios operadores do direito, sendo promotores de justiça, ou magistrados não passarem a considerar e a exigir caracterizações aprofundadas de danos e de ambientes afetados por óleo, cada vez mais os trabalhos científicos aqui consultados perderão em parte suas funções e serão constantemente desestimulados.

As formas de reparação atribuídas pelo judiciário devem ser repensadas. A compreensão acerca do que o termo "reparação" representa para a ecologia é essencial para o seu aprimoramento. Ademais, a ideia de uma medida pontual dar fim ao problema deve ser abandonada. Uma reparação efetiva de ambientes contaminados por óleo exige predominantemente um monitoramento. Uma única forma de reparação, na maioria dos casos não atenderá a todos os danos verificados, dados às suas complexidades.

O tratamento dado aos danos ambientais patrimoniais e extrapatrimoniais não deve ser o mesmo dado aos danos ecológicos. Desse modo, o pagamento de indenizações nem sempre será a medida adequada a todos eles.

As críticas aqui desenvolvidas contra a indenização como forma de reparação de danos não se limitam ao fato de que, em muitos casos, não são atendidas as necessidades emergenciais dos ambientes atingidos pelo óleo. A questão é muito mais complexa. Além das incertezas trazidas pelos métodos de valoração desses montantes, e das dúvidas apresentadas questionando a efíciência dos cálculos para danos puramente ecológicos, o principal fator de preocupação acerca dessa forma de reparação está na destinação do valor pago a título de indenização. Os fundos brasileiros que atendem a interesses difusos apresentam um sistema de utilização dos valores que, na grande maioria dos casos acaba por não contemplar os ambientes atingidos pelos danos ambientais. Ou seja, as indenizações pagas aos fundos não são revertidas aos locais atingidos. Essa é a maior prova de que as funções da reparação claramente estipuladas pelo Direito Civil Ambiental não são respeitadas na prática.

Após essas reflexões, o presente trabalho deixa como legado duas propostas para o aprimoramento da efetividade da reparação de danos mesmo com a condenação por pagamento de indenizações: 
A primeira delas consiste em uma revisão das regras que regem os fundos de interesses difusos. A forma com que a seleção de projetos a serem contemplados com os valores arrecadados é realizada, não prioriza na prática a destinação à recuperação dos ambientes cujos danos sofridos originaram aqueles valores. Não somente as regras devem ser alteradas, como inclusive a divulgação sobre os editais, e o consequente incentivo à participação por parte de organizações que realmente representem os interesses da população e locais afetados.

A segunda proposta consiste em um maior incentivo e união de esforços para que, principalmente em casos mais complexos de derramamentos de óleo no mar Termos de Ajustamento de Conduta sejam firmados, tanto como desfecho de ações judiciais, quanto de forma a evitar tais vias. Os TACs analisados na presente tese surpreenderam tanto no detalhamento das medidas de reparação, quanto de prevenção. Muitos deles apresentaram previsões de monitoramentos de ambientes afetados e medidas alternativas de melhoria de qualidade de vida da população afetada, por meio, por exemplo, de desenvolvimento de projetos sociais.

Se por um lado, os TACs ainda não abrangem todos os danos ambientais decorrentes de derramamentos, por outro lado demonstram uma efetividade, não somente do ponto de vista de recuperação de ecossistemas, quanto jurídica, muito maior do que os pagamentos de meras indenizações. Ainda, não se pode esquecer que, se firmados previamente, de forma a se evitar a judicialização dos conflitos, a eficiência ambiental das medidas reparatórias torna-se ainda maior, uma vez que serão aplicadas com mais celeridade.

As ações judiciais, mesmo com concessão de pedidos liminares, que em parte aceleram a adoção de medidas reparatórias, são muito morosas. Os derramamentos de óleo no mar apresentam danos agudos significativos, que não podem esperar para serem remediados. Não se pode esquecer que cabe também aos responsáveis a realização de um diagnóstico dos danos para que sejam escolhidas as formas de reparação mais adequadas. É inviável que isso seja determinado em uma fase de perícia meses, ou anos após o ocorrido.

Muito embora o trabalho tenha sido desenvolvido com foco principal na reparação dos danos, não deixou de abordar sugestões para aprimoramentos da prevenção, que, inclusive, deve igualmente ser vista como uma forma de mitigação de danos. Sabe-se que acidentes podem ocorrer independentemente dos cuidados adotados. Porém, a organização prévia das respostas a eles não deixa de ser um método de prevenção, assim como a garantia de que não faltarão recursos para que todas as medidas sejam adotadas. 
Por esse motivo, foi dada especial atenção tanto aos fundos de arrecadação prévia, referentes às atividades envolvendo petróleo, quanto aos seguros ambientais. Mesmo que ainda não muito expressivos no Brasil, são importantes ferramentas tanto no auxílio à rápida resposta nos casos de derramamentos, quanto na prevenção dos mesmos, pois as empresas vinculadas são fiscalizadas e a elas são exigidas adequações. Não deixam de ser uma maneira de autorregulação do setor para melhoria ambiental, de certa forma desonerando o Estado.

Porém, a própria dificuldade em encontrar bibliografia nacional abordando ambos os assuntos demonstram que estes ainda são incipientes no Brasil. Assim, não se pode deixar aqui de registrar a necessidade de maiores incentivos, inclusive por meio de políticas públicas, para que sejam desenvolvidos. Os próprios setores de seguros ainda encontram resistência ao desenvolvimento de seguros ambientais no país por insegurança jurídica e técnica e ainda por desestimulo de mercado.

Por fïm, cumpre esclarecer que não se teve a pretensão no presente trabalho de solucionar os problemas verificados nas formas de reparação adotadas em virtude de derramamentos de óleo no mar, mas sim, de melhor desenvolver os elementos que compõe o tema, como contribuição para posteriores trabalhos, ou mesmo para a aplicação em novos casos práticos que venham a surgir.

A partir das reflexões aqui apresentadas, foi possível concluir que não há uma solução única, que compreenda a forma de reparação ideal para danos ambientais gerados pelos derramamentos de óleo no mar. Justamente ao contrário. A abordagem interdisciplinar adotada mostra que os danos decorrentes dos derramamentos são tão complexos que cada caso específico vai requerer uma forma de reparação mais adequada, sendo, a princípio, inaplicáveis tanto fórmulas matemáticas pré-moldadas, quanto aplicação de julgados emblemáticos para casos aparentemente semelhantes, mas com danos tão peculiares, que agridam ambientes e bens de diferentes tipos.

Reforça-se aqui que a solução aos derramamentos de óleo no mar não pode visar atender apenas ao que o Direito prega como justiça. A relevância dos ecossistemas afetados inclusive é elemento essencial à sadia qualidade de vida humana. Assim, os casos práticos carecem de uma maior intersecção de abordagens, de uma maior abertura para a contribuição de outras ciências e visões. Somente assim, além da justiça humana, será possível se chegar à justiça ecológica. 


\section{REFERÊNCIAS}

AB'SÁBER, Aziz Nacib. Litoral do Brasil. São Paulo: Metalivros, 2001.

ADZIGBLI, L.; YUEWEN D. Assessing the Impact of Oil Spills on Marine Organisms. Journal of Oceanography and Marine Research, v.6, n. 1, p. 1-7, 2018. Disponível em $<$ https://www.omicsonline.org/open-access/assessing-the-impact-of-oil-spills-on-marineorganisms-257t2-3103-1000179.pdf > . Acesso em: 10 jan. 2019.

AGÊNCIA NACIONAL DO PETRÓLEO, GÁS NATURAL E BIOCOMBUSTÍVEIS (ANP). Análise do Acidente com a Plataforma P-36 - Relatório da Comissão de Investigação ANP/DPC: Relatório Técnico. Rio de Janeiro: ANP, jul. 2001. 24p. Disponível em: $<\mathrm{http}$ //www.anp.gov.br/images/EXPLORACAO_E_PRODUCAO_DE_OLEO_E_GAS/Segu ranca_Operacional/Relat_incidentes/Relatorio_P-36.pdf $>$. Acesso em: 10 jan. $201 \overline{9}$.

AGUILERA, F. et al. Review on the effects of exposure to spilled oils on human health. Journal of Applied Toxicology, v. 30, p. 291-301, May 2010.

AICHINGER DIAS, L. et al. Exposure of cetaceans to petroleum products following the Deepwater Horizon oil spill in the Gulf of Mexico. Endangered Species Research, v. 33, p. 119-125, 2017. Disponível em: <https://doi.org/10.3354/esr00770>. Acesso em: 10 jan. 2019.

ALBARELlO, Lilian Cristiane. O Vazamento do Oleoduto Olapa (Morretes, Paraná): Avaliação Ambiental e Reconstituição do Comportamento do Óleo, da Serra do Mar ao Complexo Estuarino de Paranaguá. 188 p. Dissertação de Mestrado - Instituto de Geociências, Universidade Federal do Rio Grande do Sul (UFRGS), Porto Alegre, 2012.

AMARAL, Antônia Cecília Z.; JABLONSKI, Sílvio. Conservação da biodiversidade marinha e costeira no Brasil. Megadiversidade, v. 1, n. 1, p. 43-51, Julho 2005.

AMERICAN STEAMSHIP OWNERS MUTUAL PROTECTION AND INDEMNITY ASSOCIATION, INC. (THE AMERICAN CLUB). By-Laws, Rules, List of Correspondents: 2018-2019. New York: THE AMERICAN CLUB, 2018. Disponível em: $<$ https://www.american-club.com/files/files/1819.pdf\#page=32>. Acesso em: 10 jan. 2019.

ARAUJO, Romana Coêlho de. Valoração econômica do dano ambiental em inquérito civil público. Brasília: Escola Superior do Ministério Público da União, 2011. Disponível em: $<$ http://escola.mpu.mp.br/publicacoes/obras-avulsas/e-books/valoracao-do-dano-ambientalem-inquerito-civil-publico>. Acesso em: 10 jan. 2019.

ARAÚJO, Vanessa Donato de. Generalidade sobre o dano. In: ARAÚJO, Vanessa Donato. (Coord.); HIRONAKA, Giselda Maria Fernandes (Orient.). Direito Civil: Responsabilidade Civil, São Paulo: Editora Revista dos Tribunais, v. 5, 2008.

ARCHER, Antônio Barreto. Direito do Ambiente e Responsabilidade Civil. Coimbra: Almedina, 2009.

ASHFORD, N. A. et al. The Encouragement of Technological Change for Preventing Chemical Accidents: Moving Firms from Secondary Prevention and Mitigation to Primary Prevention. A Report to the U. S. Environmental Protection Agency, Center for Technology, 
Policy, and Industrial Development at MIT. Cambridge: Center for Technology, Policy and Industrial Development at Massachusetts Institute of Technology (MIT), July 1993. Disponível em: <http://hdl.handle.net/1721.1/1561>. Acesso em: 10 jan. 2019.

ASSOCIAÇÃO BRASILEIRA DOS CONSTRUTORES DE BARCOS E SEUS IMPLEMENTOS (ACOBAR) et. al. Indústria náutica brasileira: fatos e números 2012. Rio de Janeiro, [2012?].

AYALA, P. de A.; RODRIGUES, E. de M. W.; SILVEIRA, P. G. Cumulação de Obrigação de Fazer, Não Fazer e de Indenizar: Comentários da Doutrina ao REsp 1.198.727-MG (Rel. Min. Herman Benjamin). Revista do Superior Tribunal de Justiça, Brasília: Superior Tribunal de Justiça, v. 239, tomo 1, p. 41-50, jul/ago/set 2015.

AZEVEDO, Álvaro Villaça. Responsabilidade civil em sede de poluição. Culpa do Poder Público. Ausência de nexo causal, na atividade das poluidoras, e de solidariedade entre elas. In: NERY JUNIOR, Nelson; NERY, Rosa Maria de Andrade. Doutrinas Essenciais: Responsabilidade Civil. São Paulo: Editora Revista dos Tribunais, v. 7, 2010.

AZEVEDO, Antônio Junqueira de. Por uma nova categoria de dano na responsabilidade civil: o dano social. In: . Novos estudos e pareceres de direito privado. São Paulo: Saraiva, 2009.

BENJAMIM, Antônio Herman de Vasconcelos. Responsabilidade civil pelo dano ambiental. In: NERY JUNIOR, N.; NERY, R. M. de A. (Org.). Doutrinas Essenciais: Responsabilidade Civil. São Paulo: Editora Revista dos Tribunais, v. 7, 2010.

. O princípio poluidor-pagador e a reparação do dano ambiental. In: (Coord.). Dano ambiental: prevenção, reparação e repressão. São Paulo: Editora Revista dos Tribunais, 1993.

Paisagem, natureza e direito: uma homenagem a Alexandre Kiss. In: (Org). Paisagem, natureza e direito. São Paulo: Instituto O Direito por um Planeta Verde, v. 2 , 2005.

. Responsabilidade civil pelo dano ambiental. In: MILARÉ, Édis; MACHADO, Paulo Affonso Leme. (Org.). Doutrinas Essenciais: Direito Ambiental. Responsabilidade em matéria ambiental. São Paulo: Editora Revista dos Tribunais, v. 5, 2011.

. Responsabilidade civil pelo dano ambiental. Revista de Direito Ambiental, São Paulo: Editora Revista dos Tribunais, n. 9, jan./mar. 1998.

. Responsabilidade civil pelo dano ambiental. In: NERY JUNIOR, Nelson; NERY, Rosa Maria de Andrade (Org.). Direito ambiental. São Paulo: Editora Revista dos Tribunais, 2010.

BERRY, Thomas. O Sonho da Terra. Tradução Ephraim Ferreira Alves. Petrópolis: Editora Vozes, 1991. 
BERTÃO, Shirley Fenzi. Técnicas. Valoração econômica de danos ambientais. Revista Jurídica do Ministério Público do Estado de Minas Gerais, Belo Horizonte: Ministério Público de Minas Gerais, n. 9, p. 286-393, jul./dez. 2007.

BERTOLI, Ana Lúcia; RIBEIRO, Maisa de Souza. Passivo ambiental: estudo de caso da Petróleo Brasileiro S.A. - Petrobrás. A repercussão ambiental nas demonstrações contábeis, em consequência dos acidentes ocorridos. Revista de Administração Contemporânea. Curitiba, v.10, n.2, p. 117-136, abr.jun. 2006. Disponível em: $<$ http://www.scielo.br/scielo.php?script=sci_arttext\&pid=S1415-65552006000200007>.

Acesso em: 10 jan. 2019.

BRASIL. Agência Nacional de Transportes Aquaviários (ANTAQ). Estatístico Aquaviário. Disponível em: <http://web.antaq.gov.br/Anuario/>. Acesso em: 10 jan. 2019.

. Comissão de Legislação Participativa da Câmara dos Deputados. Relator Ann Pontes. Parecer ao PL $\mathbf{n}^{\mathbf{0}}$ 2.313/2003. Brasília: Câmara dos Deputados. Disponível em: $<$ http://www.camara.gov.br/proposicoesWeb/prop_mostrarintegra;jsessionid=988252A0949D 21A68904734A19E2A4AA.proposicoesWebExterno2? codteor $=192076 \&$ filename $=$ Tramitaca o-PL+2313/2003>. Acesso em: 10 jan. 2019.

Departamento de Energia e Meio Ambiente (DEA) do Ministério de Minas e Energia (MME). Centrais Elétricas Brasileiras S.A. (ELETROBRAS). NUTTI, Mírian Regini (Coord.) Metodologia de valoração das externalidades ambientais da geração hidrelétrica e termelétrica com vistas à sua incorporação no planejamento de longo prazo do setor elétrico. Rio de Janeiro: Eletrobrás, 2000.

. Ministério do Meio Ambiente (MMA). Cartas de Sensibilidade ao Óleo. Disponível em: $<$ http://www.mma.gov.br/seguranca-quimica/cartas-de-sensibilidade-ao-oleo $>$. Acesso em 10 jan. 2019.

. Ministério do Meio Ambiente (MMA). Macrodiagnóstico da Zona Costeira e Marinha do Brasil. 2 ${ }^{\circ}$ Macrodiagnóstico da ZC - Óleo e Gás. Disponível em: $<$ http://www.mma.gov.br/images/arquivo/80033/Macrodiagnosticocapitulos/xpre7.SPMacrod iagZonaEconmicaExclusiva_p173-187.pdf.> Acesso em: 10 jan. 2019.

Ministério do Meio Ambiente (MMA). Plano Nacional de Prevenção, Preparação e Resposta Rápida a Emergências Ambientais com Produtos Químicos Perigosos - P2R2. Brasília: Ministério do Meio Ambiente, 2007. Disponível em: $<$ http://www.mma.gov.br/estruturas/sqa_p2r2_1/_arquivos/livro_2007_106.pdf $>$. Acesso em 10 jan. 2019.

Ministério do Meio Ambiente (MMA). Zona Costeira e Marinha. Disponível em: <www.mma.gov.br/biodiversidade/biodiversidade-aquatica/zona-costeira-e-marinha.html $>$. Acesso em: 10 jan. 2019.

. Ministério do Meio Ambiente. Especificações e normas técnicas para elaboração de cartas de sensibilidade ambiental para derramamentos de óleo. Brasília, 2004.

Ministério Público Federal (MPF). Termo de Compromisso de Ajustamento de Conduta (TAC) entre MPF, Chevron Brasil Upstream Frade Ltda, Chevron Latin America 
Marketing LLC e TRANSOCEAN BRASIL LTDA, assinado em 13 de setembro de 2013. Disponível em: <http://www.anp.gov.br/noticias/1533-anp-mpf-ibama-chevron-e-transoceanassinam-termo-de-ajustamento-de-conduta>. Acesso em: 10 jan. 2019.

. Portal Brasileiro de Dados Abertos. Marinha do Brasil - Embarcações. Dado criado em 30 jul. 2018, com última atualização em 21 nov. 2018. Disponível em: $<$ http://dados.gov.br/dataset/embarcacoes $>$. Acesso em: 10 jan. 2019.

CANADÁ. Liability and compensation for ship-source oil spills. Disponível em: $<$ http://www.tc.gc.ca/eng/marinesafety/liability-compensation-ship-source-oil-spills4512.html>. Acesso em: 10 jan. 2019.

CARVALHO RAMOS, André de. A ação civil pública e o dano moral coletivo. Revista de Direito do Consumidor. São Paulo: Editora Revista dos Tribunais, v. 25, 1998.

CARVALHO, Délton Winter de. Dano ambiental futuro: a responsabilização civil pelo risco ambiental. Porto Alegre: Livraria do Advogado, $2^{\mathrm{a}}$ ed., 2013.

O dano ambiental futuro: da assimilação dos riscos ecológicos pelo direito à formação de vínculos jurídicos intergeracionais. 2006. 255 f. Tese de Doutorado em Direito Programa de Pós-Graduação em Direito da Universidade Vale do Rio dos Sinos, Rio Grande do Sul, 2006.

CATALÁ, Lucía Gomes. Responsabilidad por Daños al Medio Ambiente. Madrid: Arazandi Editorial, 1998.

CENTRAIS ELÉTRICAS BRASILEIRAS S.A., DEA. Metodologia de valoração das externalidades ambientais da geração hidrelétrica e termelétrica com vistas à sua incorporação no planejamento de longo prazo do setor elétrico. Coordenado por Mírian Regini Nutti. - Rio de Janeiro: Eletrobrás, 2000, p. 05.

CENTRO DE EXCELENCIA PARA O MAR BRASILEIRO (CEMBRA). FERNANDES, Luiz Phillipe da Costa (Coord.). O Brasil e o mar no século XXI: Relatório aos tomadores de decisão do País. Niterói: BHMN, 2a ed., 2012.

CERRI NETO, Mauro. Impacto ambiental, degradação ambiental, poluição, contaminação e dano ambiental: comparação entre conceitos legal e técnico. 2008. 127 f. Dissertação de Mestrado - Instituto de Geociências e Ciências Exatas da Universidade Estadual Paulista, Rio Claro, 2008. Disponível em: <http://hdl.handle.net/11449/92757>. Acesso em: 10 jan. 2019.

CHANG, Stephanie E. et. al. Consequences of oil spills: a review and framework for informing planning, Ecology and Society, v. 2, n. 19, article 26, 2014. Disponível em $<$ https://www.ecologyandsociety.org/vol19/iss2/art26/ >. Acesso em: 10 jan. 2019.

COMISSÃO EUROPEIA. Direção-geral do Ambiente. Livro Branco sobre Responsabilidade Ambiental. Luxemburgo: Serviço das Publicações Oficiais das Comunidades $\quad 2000.20$ Disponível $<$ http://ec.europa.eu/environment/legal/liability/pdf/el_full_pt.pdf $>$. Acesso em: 10 jan. 2019. 
Livro Verde sobre a reparação dos danos causados no ambiente. Comunicação da Comissão [COM (93) 47 final] ao Parlamento Europeu e ao Comitê Econômico e Social. Bruxelas: Serviço das Publicações Oficiais das Comunidades Europeias, 14 mai. 1993.

COMPANHIA AMBIENTAL DO ESTADO DE SÃO PAUlO (CETESB). Diretoria de Controle e Licenciamento Ambiental. Ofício n⿳0 046/2011/C - Ref.: Proposta de critério para valoração monetária de danos causados por derrames de petróleo ou de seus derivados em ambiente marinho. São Paulo: CETESB, jun. 1992.

Operação Smyrni: Relatório Técnico. São Paulo: CETESB, 1998. 112p.

. Operação Tebar VI - Emissão Submarino: Relatório Técnico. São Paulo: CETESB, 1999. 18p + anexos. Disponível em: < https://cetesb.sp.gov.br/emergencias-quimicas/wpcontent/uploads/sites/22/2013/12/00.pdf $>$. Acesso em: 10 jan. 2019.

CONFERÊNCIA DAS NAÇÕES UNIDAS SOBRE COMÉRCIO E DESENVOLVIMENTO (UNCTAD). Review of Maritime Transport: 2018. New York: United Nations, 2018. Disponível em: <https://unctad.org/en/PublicationsLibrary/rmt2018_en.pdf > Acesso em: 10 jan. 2019.

CONSELHO DE JUSTIÇA FEDERAL. Centro de Estudos Judiciários. Min. Ruy Rosado de Aguiar Júnior (Coord.). Jornadas de Direito Civil I, III, IV e V: enunciados aprovados. Brasília, DF: Centro de Estudos Judiciários, 2012. Disponível em: $<$ https://www.cjf.jus.br/cjf/corregedoria-da-justica-federal/centro-de-estudos-judiciarios1/publicacoes-1/jornadas-cej/EnunciadosAprovados-Jornadas-1345.pdf/view $>$. Acesso em: 10 jan. 2019.

COSTA SUL E SUDESTE BRASILEIRA: SÍNTESE DE CONHECIMENTOS, 2., 1990, São Paulo. Anais Academia de Ciências do Estado de São Paulo (ACIESP). São Paulo: Academia de Ciências do Estado, 1990. p. 375-399.

COSTA, Daniele Mesquita Bordalo da. A valoração econômica como ferramenta para compensação de derramamentos de petróleo. 2012. 217f. Dissertação de Mestrado Instituto Alberto Luiz Coimbra de Pós-Graduação e Pesquisa de Engenharia (COPPE), da Universidade Federal do Rio de Janeiro (UFRJ), Rio de Janeiro, dez. 2012. Disponível em: $<$ http://www.ppe.ufrj.br/index.php/pt/publicacoes/dissertacoes/2012/549-a-valoracaoeconomica-como-ferramenta-para-compensacao-de-derramamentos-de-petroleo $>$. Acesso em: 10 jan. 2019.

CRUZ, Gisela Sampaio da. O problema do nexo causal na responsabilidade civil. Rio de Janeiro: Renovar, 2005.

D'ANDREA, Mark A.; REDDY, Kessava. The Development of Long-Term Adverse Health Effects in Oil Spill Cleanup Workers of the Deepwater Horizon Offshore Drilling Rig Disaster. Front Public Health. V.6, n.117. Disponível em: $<10.3389 /$ fpubh.2018.00117 >. Acesso em: 10 jan. 2019.

DELLORE, Luiz Guilherme Pennacchi. Fundo Federal de Reparação de Direitos Difusos (FDD): aspectos atuais e análise comparativa com instrumentos norte-americanos. São Paulo: Revista de Direito Ambiental, n. 38, p. 124-139, abr./jun. 2005. 
DERANI, Cristiane. Direito ambiental e econômico. São Paulo: Editora Max Limonad, 1997.

DICKS, Brian. The environmental impact of marine oil spills: Effects, recovery and compensation. International seminar on tanker safety, pollution prevention, spill response and compensation, Rio de Janeiro, Brasil, 6 nov. 1998. Disponível em < https://www.itopf.org/knowledge-resources/documents-guides/document/the-environmentalimpact-of-marine-oil-spills-effects-recovery-and-compensation-1998/>. Acesso em: 10 jan. 2019.

DINAMARCA. Act on Contaminated Soil, $\mathbf{n}^{\mathbf{0}}$ 1427. Copenhague: 2009.

DINIZ, Maria Helena. Tratado Teórico e Prático dos Contratos. São Paulo: Editora Saraiva,

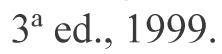

DINO NETO, Nicolao; BELLO FILHO, Ney; DINO, Fábio. Crimes e infrações administrativas ambientais. Belo Horizonte: Del Rey Editora, $3^{\mathrm{a}}$ ed, 2011.

DUX, James P., STALZER, Robert F. Managing Safety in the Chemical Laboratory. New York: Van Nostrand Reinhold, 1988.

ESPÍRITO SANTO. Instituto Estadual de Meio Ambiente e Recursos Hídricos (IEMA). Transpetro é multada em mais de R \$ 6 milhões por acidente ambiental no Espírito Santo. Disponível em: $<$ https://iema.es.gov.br/transpetro-e-multada-em-mais-de-r-6-milhoes-p $>$. Acesso em: 10 jan. 2019.

FARIAS, Cristiano Chaves de; BRAGA NETTO, Felipe Peixoto; ROSENVALD, Nelson. Novo tratado de responsabilidade civil. São Paulo: Atlas, 2015.

FINLÂNDIA. Ministério do Meio Ambiente. Act $\mathbf{n}^{\mathbf{0}}$ 1673/2009. Act on Oil Pollution Response. Helsinki: 2009. Disponível em: $<$ https://www.finlex.fi/fi/laki/kaannokset/2009/en20091673.pdf $>$. Acesso em: 10 jan. 2019.

. Ministério do Meio Ambiente. Finnish Oil Pollution Compensation Fund. Disponível em: <http://www.ym.fi/en-US/The_environment/Finnish_Oil_Pollution_Fund $>$. Acesso em: 10 jan. 2019.

FOUCAULT, Michel Vigiar e punir: nascimento da prisão. Tradução Lígia M. Pondé Vassallo. Petrópolis: Vozes, $13^{\mathrm{a}}$ ed., 1987.

FREITAS, Gilberto Passos de. Ilícito Penal Ambiental e Reparação do Dano. São Paulo: Editora Revista dos Tribunais, 2005.

FREITAS, Vladimir Passos de; FREITAS, Gilberto Passos de. Crimes contra a natureza. São Paulo: Editora Revista dos Tribunais, $9^{\mathrm{a}}$ ed., 2012.

GABARDO, Irene et al. Lessons Learned On Oil Spill Environment Impact Assessment: 10 Years of Petrobras Experience Review. International Oil Spill Conference Proceedings. V. 2011, n. 1, abs426, mar. 2011. Disponível em: <https://doi.org/10.7901/2169-3358-2011-1426>. Acesso em: 10 jan. 2019. 
GAGLIANO, Pablo Stolze; PAMPlONA FILHO, Rodolfo. Novo curso de Direito Civil: Responsabilidade Civil. São Paulo: Saraiva, v. 3, 9a ed., 2011.

GARD. Gard Guidance to the Rules 2018. Rule 38: Pollution. Disponível em: $<$ http://www.gard.no/web/publications/document/chapter?p_subdoc_id=20748000\&p_docum ent_id=20747880>. Acesso em: 10 jan. 2019.

Rules 2018. Denmark: Rosendahls, 2018. Disponível em: $<$ http://www.gard.no/Content/24908198/Rules_2018_web.pdf $>$. Acesso em 10 jan. 2019.

GOLDENBERG, Isidoro H. CAFFERATTA, Néstor A. Dañ̃ ambiental: problemática de la determinación causal. Buenos Aires: Abeldo-Perrot, 2001.

GOMES, Carla Amado. De que falamos quando falamos de dano ambiental: direito, mentiras

e críticas. Actualidad Jurídica Ambiental. 15 mar. 2010. Disponível em: $<$ http://www.actualidadjuridicaambiental.com/wp-

content/uploads/2010/03/AMADOGOMES150320102.pdf >. Acesso em: 10 jan. 2019.

GONÇALVES, Carlos Roberto. Direito Civil Brasileiro: responsabilidade civil. São Paulo: Editora Saraiva, v. 4, $7^{\mathrm{a}}$ ed., 2012. 1995.

Responsabilidade civil: doutrina, jurisprudência. São Paulo: Editora Saraiva, $6^{\text {a }}$ ed.,

GRANZIERA, Maria Luiza Machado. Direito Ambiental. São Paulo: Editora Atlas, 4ª ed., 2015.

GRASSO, Mônica; TOGNELLA, Mônica Maria Pereira; SCHAEFFER-NOVELLI, Yara; COMUNE, Antônio Evaldo. Aplicação de técnicas de avaliação econômica ao ecossistema Manguezal. In: MAY, Peter Herman (Org.). Economia Ecológica: aplicações no Brasil. Rio de Janeiro: Editora Campus, 1995.

GURGEL, Aline do Monte; MEDEIROS, Ana Catarina Leite Veras; ALVES, Paloma Corrêa; SILVA, José Marcos da; GURGEL, Idê Gomes Dantas; AUGUSTO, Lia Giraldo da Silva. Framework dos cenários de riscos no contexto da implantação de uma refinaria de petróleo em Pernambuco. Ciência \& Saúde Coletiva. Rio de Janeiro, v. 14, n. 6, p. 2027-2038, 2009. Disponível em: $\quad<$ http://www.scielo.br/scielo.php?pid=S1413$81232009000600010 \&$ script $=$ sci_abstract\&tlng=pt $>$. Acesso em: 10 jan. 2019.

HA, Mina.; CHEONG, Hae-Kwan. Oil spill clean-up: a trade-off between human health and ecological restoration? The Lancet Public Health, v.2, n.12, p. e534-e535, dez. 2017.

HIRONAKA, Giselda Maria Fernandes Novaes. Responsabilidade Pressuposta. São Paulo: Editora Del Rey, 2005.

INSTITUTO BRASILEIRO DE AVALIAÇÕES E PERÍCIAS DE ENGENHARIA DE SÃO PAULO (IBAPE/SP). Sistema de identificação do dano ambiental decorrente de vazamento de 
petróleo: uma proposta de modelo de avaliação. XV Congresso Brasileiro de Engenharia de Avaliações e Perícia, Trabalho de Perícia, 2009. Disponível em: <http://ibapenacional.com.br/biblioteca/wp-content/uploads/2012/09/MEDALHA-CLAUDIOBOCK_AMBIENTAL.pdf>. Acesso em: 10 jan. 2019.

INSTITUTO BRASILEIRO DO MEIO AMBIENTE E DOS RECURSOS NATURAIS RENOVÁVEIS (IBAMA). INSTITUTO AMBIENTAL DO PARANÁ (IAP). Laudo técnico do acidente do navio Vicunã, ocorrido em Paranaguá no dia 15 de novembro de 2004: Relatório Técnico. Paranaguá: IBAMA/IAP, mai. 2004. 67p + anexos.

INSTITUTO ESTADUAL DO MEIO AMBIENTE (INEA). Relatório de Atendimento de emergências n. ${ }^{\circ}$ 300014/2015: Relatório Técnico. [Rio de Janeiro?]: INEA, abr. 2015. 12p + anexos.

INTERNATIONAL MARITIME ORGANIZATION (IMO). Convention on the Prevention of Marine Pollution by Dumping of Wastes and Other Matter. Disponível em: $<$ http://www.imo.org/en/About/Conventions/ListOfConventions/Pages/Convention-on-thePrevention-of-Marine-Pollution-by-Dumping-of-Wastes-and-Other-Matter.aspx $>$. Acesso em: 10 jan. 2019.

$\begin{array}{cccc}\text { International Convention Relating to Intervention on the High Seas in Cases of } \\ \text { Oil } & \text { Collution } & \text { Casualties, } & \text { 1969. }\end{array}$ $<$ http://www.imo.org/en/About/Conventions/ListOfConventions/Pages/InternationalConvention-Relating-to-Intervention-on-the-High-Seas-in-Cases-of-Oil-PollutionCasualties.aspx>. Acesso em: 10 jan. 2019.

. International Convention for the Safety of Life at Sea (SOLAS). Disponível em:

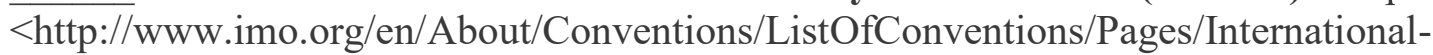
Convention-for-the-Safety-of-Life-at-Sea-(SOLAS),-1974.aspx>. Acesso em: 10 jan. 2019.

. International Convention for the Prevention of Pollution of the Sea by Oil. Disponível em: <http://sedac.ciesin.org/entri/texts/pollution.of.sea.by.oil.1954.html> Acesso em 10 jan. 2019.

. International Convention on Civil Liability for Oil Pollution Damage (CLC). Texto original de 29 de novembro de 1969. Disponível em: $<$ http://www.imo.org/en/About/Conventions/ListOfConventions/Pages/InternationalConvention-on-Civil-Liability-for-Oil-Pollution-Damage-(CLC).aspx $>$ Acesso em: 10 jan. 2019.

(BUNKER).

International Convention on Civil Liability for Bunker Oil Pollution Damage $<$ http://www.imo.org/en/About/Conventions/ListOfConventions/Pages/InternationalConvention-on-Civil-Liability-for-Bunker-Oil-Pollution-Damage-(BUNKER).aspx $>$ Acesso em: 10 jan. 2019.

- Manual on Chemical Pollution - Section 1: Problem Assessment and Response Arrangements. London: International Maritime Organization, 1987. 
INTERNATIONAL OIL POLLUTION COMPENSATION FUNDS (IOPC Funds). Liability and compensation for oil pollution damage: Texts of the 1992 Civil Liability Convention, the 1992 Fund Convention and the Supplementary Fund Protocol. London: International Oil Pollution Compensation Funds, 2018. Disponível em: $<$ https://www.iopcfunds.org/uploads/tx_iopcpublications/Text_of_Conventions_e_01.pdf $>$. Acesso em: 10 jan. 2019.

INTERNATIONAL PETROLEUM INDUSTRY ENVIRONMENTAL CONSERVATION ASSOCIATION (IPIECA). IPIECA report series - Biological impacts of oil pollution: coral reefs. London: IPIECA, v.3, $2^{\mathrm{a}}$ ed., 2004. Disponível em: $<$ https://www.amn.pt/DCPM/Documents/Corals.pdf >. Acesso em: 10 jan. 2019.

IPIECA report series - Biological impacts of oil pollution: Mangrooves. London:

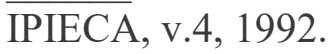

IPIECA report series - Biological impacts of oil pollution: rocky shores. London:

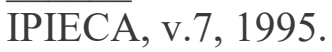

. INTERNATIONAL ASSOCIATION OF OIL \& GAS PRODUCERS (IOGP). Good Practice Guide Series: Good practice guidelines for incident management and emergency response personnel - Impacts of oil spills on shorelines. London: IPIECA-IOGP, 2a ed., 2016.

INTERNATIONAL TANKER OWNERS POLLUTION FEDERATION (ITOPF). AMOCO CADIZ, France, 1978. Disponível em: <https://www.itopf.org/in-action/case-studies/casestudy/amoco-cadiz-france-1978/>. Acesso em: 10 jan. 2019.

Technical Information Paper 13 (TIP 13): Effects of Oil Pollution on the Marine Environment. London: International Tanker Owners Pollution Federation, v. 13, 2014. Disponível em: $<$ https://www.itopf.org/knowledge-resources/documents-guides/document/tip13-effects-of-oil-pollution-on-the-marine-environment/>. Acesso em: 10 jan. 2019.

JOHANSSON, Sif; LARSSON, Ulf; BOEHM, Paul. The Tsesis oil spill impact on the pelagic ecosystem. Marine Pollution Bulletin. V.11, n.10, p. 284-293, out. 1980.

JURAS, Ilídia da A. G. Martins. Estudo - Dezembro/2002: Medidas de Prevenção de Acidentes com Navios Petroleiros. Brasília: Câmara dos Deputados, Consultoria Legislativa, dez. 2002.

KINGSTON, Paul F. Long-term environmental impact of oil spills. Spill Science \& Technology Bulletin. V.7, n. 1-2, p.53-61, jun. 2002.

KWOK, Richard K. et. al. Mental health indicators associated with oil spill response and cleanup: cross-sectional analysis of the GuLF STUDY cohort. The Lancet Public Health. V.2, n.12, p. e560-e567, dez. 2017. Disponível em: <10.1016/S2468-2667(17)30194-9 >. Acesso em: 10 jan. 2019.

LAMPARELLI Claudia; RODRIGUES, Fabíola de Oliveira; MOURA, Débora Orgler de. Long-term assessment of an oil-spill in a mangrove forest in Sao Paulo, Brazil. In: KJERFVE, B.; LACERDA L. D.; DIOP, E. H. S. Mangrove ecosystem studies in Latin America and Africa. Paris: UNESCO, 1997. 
LANGANGEN, Ø. et. al. The effects of oil spills on marine fish: Implications of spatial variation in natural mortality. Marine pollution bulletin. V.119, n.1, p. 102-109, jun. 2017. Disponível em: <https://doi.org/10.1016/j.marpolbul.2017.03.037>. Acesso em: 10 jan. 2019.

LEAO, Zelinda M. A. N.; DOMINGUEZ, José M. L. Tropical Coast of Brazil. Marine Pollution Bulletin. V.41, n. 1-6, p 112-122, jun. 2000. Disponível em: $<$ https://doi.org/10.1016/S0025-326X(00)00105-3>. Acesso em: 10 jan. 2019.

LEITE, José Rubens Morato; AYALA, Patryck de Araújo de. Dano ambiental: do individual ao coletivo extrapatrimonial. Teoria e Prática. São Paulo: Editora Revista dos Tribunais, $5^{\text {a }}$ ed., 2012.

LEITE, José Rubens Morato; DANTAS, Marcelo Buzaglo. Algumas considerações acerca do fundo para reconstituição dos bens lesados. Revista dos Tribunais. São Paulo, v.85, n. 726, p. 71-82, abr. 1996.

LEMOS, Patrícia Faga Iglecias. Direito Ambiental: Responsabilidade civil e proteção do meio ambiente. São Paulo: Editora Revista dos Tribunais, $3^{\mathrm{a}}$ ed., 2011.

- Meio ambiente e responsabilidade civil do proprietário: responsabilidade civil e proteção ao meio ambiente. São Paulo: Editora Revista dos Tribunais, 2a ed., 2012.

LOPES, Carlos Ferreira; MILANELLI, João Carlos Carvalho; KADEKARU, N.; JOHNSCHER-FORNASARO, G. Efeitos ecológicos do derrame de óleo "Penélope" e da limpeza por jateamento a baixa-pressão nos costões rochosos da praia do Viana: Relatório Técnico. São Paulo: CETESB, 1992. 14p + anexos.

LOPES, Carlos Ferreira; MILANELLI, João Carlos Carvalho; POFFO, Íris Regina Fernandes. Ambientes costeiros contaminados por óleo: procedimentos de limpeza. Manual de Orientação. São Paulo: Secretaria de Estado do Meio Ambiente, 2007.

LOPEZ, Teresa Ancona. O dano estético: responsabilidade civil. São Paulo: Editora Revista dos Tribunais, 1999.

LUCARELLI, Fábio Dutra. Responsabilidade Civil por Dano Ambiental. In: Milaré, Édis; MACHADO, Paulo Affonso Leme. (Organizadores). Doutrinas Essenciais: Direito Ambiental. São Paulo: Editora Revista dos Tribunais, v.5, 2011.

MACHADO, A. R.; SALEME, E. R. Tratamento jurídico dado ao vazamento de petróleo no Campo de Frade. Estudo de caso: responsabilidade civil e assinatura do termo de ajustamento de conduta. In: III Encontro de Internacionalização do CONPEDI - Madrid, Publicações, v.1, n.12, p. 335-357, 2015.

MACHADO, Paulo Affonso Leme. Direito Ambiental Brasileiro. São Paulo: Editora Malheiros, $25^{\mathrm{a}}$ ed., 2017.

MACIEL-SOUZA, Maria do Carmo et al. Chemical and microbiological characterization of mangrove sediments after a large oil-spill in Guanabara Bay - RJ - Brazil. Brazilian Journal Microbiology. São Paulo, v.37, n. 3., p. 262-266, set. 2006. 
MAIDA, M.; FERREIRA, B. Coral Reefs of Brazil. In: Proceedings of the 8th International Coral Reef Symposium. V.1, p. 263-274, 1997.

MARCELINO, Adalberto et al. Proposta de Critério para Valoração Monetária de Danos Causados por Derrames de Petróleo ou de seus Derivados no Ambiente Marinho. In: Congresso Brasileiro de Petróleo e CONEXPO ARPEL'94. Rio de Janeiro, 1994.

MARCHESAN, Ana Maria Moreira; CAPPELLI, Sívia. Introdução. In: MARCHESAN, Ana Maria Moreira; STEIGLEDER, Annelise Monteiro. Crimes ambientais: comentários à Lei 9.605/98. Porto Alegre: Livraria do Advogado Editora, 2013.

MARQUES, João Fernando; COMUNE, Antônio Evaldo. A teoria neoclássica e a valoração ambiental. In: ROMEIRO, Ademar Romeiro; REYDON, Bastiaan; LEONARDI, Maria Lucia Azevedo (Organizadores). Economia do meio ambiente: teoria, políticas e a gestão de espaços regionais. Editora UNICAMP, 1996.

MARTINI, Daniel. A dosimetria da pena. Integração com a Parte Geral do Código Penal. As penas aplicáveis às pessoas físicas. (artigos $6^{\circ}$ a 13). In: MARCHESAN, Ana Maria Moreira; STEIGLEDER, Annelise Monteiro. Crimes ambientais: comentários à Lei 9.605/98. Porto Alegre: Livraria do Advogado Editora, 2013.

MAY, Peter Herman. Economia ecológica e o desenvolvimento equitativo no Brasil. In:

(Organizador). Economia Ecológica: aplicações no Brasil. Rio de Janeiro: Editora Campus, 1995.

Globalization, Economic Valuation, and Natural Resource Polices in Brasil. In: (Editor). Natural Resource Valuation and Policy in Brasil Methods and Cases. Nova Iorque: Columbia University Press, 1999.

MAZZILLI, Hugo Nigro. A Defesa dos Interesses Difusos em Juízo. São Paulo: Editora Saraiva, $21^{\mathrm{a}}$ ed., 2008.

MCCANN, M. et al. Key taxa in food web responses to stressors: The Deepwater Horizon oil spill. Frontiers in Ecology and the Environment. V.15, n. 3, p. 142-149, 2017. Disponível em: $<$ https://doi.org/10.1002/fee.1474>. Acesso em: 10 jan. 2019.

MELO, Melissa Ely. Restauração ambiental: do dever jurídico às técnicas. São Paulo: Livraria do Advogado, 2012.

MELO, Nehemis Domingos de. Responsabilidade civil por erro médico: doutrina e jurisprudência. São Paulo: Atlas, 2008.

MICHEL, Jacqueline; RUTHERFORD, Nicolle. Oil spills in marshes: Planning, responses and considerations. Washington: National Oceanic and Atmospheric Administration (NOAA) and American Petroleum Institute (API), 2013. Disponível em: $<$ https://response.restoration.noaa.gov/sites/default/files/Oil_Spills_in_Marshes.pdf $>$. Acesso em: 10 jan. 2019. 
MILANELLI, J. C. C. et. al. Biomonitoramento de costões rochosos - instrumento para avaliação de impactos gerados por vazamentos de óleo na região do Canal de São Sebastião - São Paulo. 2003. 293f. Tese de Doutorado - Instituto de Oceanografia, Universidade de São Paulo, São Paulo, 2003.

MILARÉ, Édis. Direito do ambiente. São Paulo: Editora Revista dos Tribunais, 10ª ed., 2015.

MINISTÉRIO PÚBLICO DO ESTADO DE SÃO PAULO (MPSP). Relatório final do grupo de trabalho de valoração do dano ambiental: A to PGJ n ${ }^{\circ}$ 45/2012 - Relatório final do Grupo de trabalho de valoração do dano ambiental. [São Paulo?]: MPSP, set. 2014, 125p + anexos. Disponível em: $<$ http://www.mpsp.mp.br/portal/page/portal/cao_urbanismo_e_meio_ambiente/relat $\%$ C3\%b3r io\%20final\%20-\%20retificado_0.pdf $>$. Acesso em: 10 jan. $\overline{20} \overline{1} 9$.

MIRAGEM, Bruno. Direito Civil: responsabilidade civil. São Paulo: Saraiva, 5a ed., 2015.

MIRANDA, Pontes de. Direito das obrigações: consequências do inadimplemento; exceções de contrato não adimplido, ou adimplido insatisfatoriamente, e de inseguridade; enriquecimento injustificado; estipulação a favor de terceiro; eficácia protectiva de terceiro; mudanças de circunstâncias; compromisso. Atualização Ruy Rosado de Aguiar Júnior e Nelson Néry Jr. São Paulo: Editora Revista dos Tribunais, tomo 26, 2012.

. Direito das obrigações: direito das obrigações, fatos ilícitos absolutos, atos-fatos

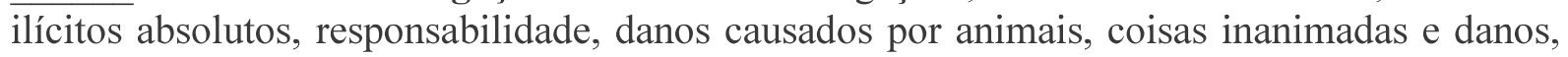
estado e servidores, profissionais. Atualização Rui Stoco. São Paulo: Editora Revista dos Tribunais, 2012.

MIRRA, Álvaro Luiz Valery. Ação civil pública e a reparação do dano ao meio ambiente. São Paulo: Editora Juarez de Oliveira, 2002.

MITCHELMORE, C. L.; BISHOP, C. A.; COLLIER, T. K. Toxicological estimation of mortality of oceanic sea turtles oiled during the Deepwater Horizon oil spill. Endangered Species Research. V.33, p. 39-50, jan. 2017. Disponível em: $<$ https://doi.org/10.3354/esr00758>. Acesso em: 10 jan. 2019.

MONTEIRO, Aline Guimarães. Metodologia de avaliação de custos ambientais provocados por vazamento de óleo: o estudo de caso do Complexo REDUC-DTSE. 2003. 293f. Tese de Doutorado - Coordenação dos Programadas de Pós-Graduação de Engenharia (COPPE), da Universidade Federal do Rio de Janeiro (UFRJ). Rio de Janeiro, 2003.

MONTI, A. Environmental Risks and Insurance: A comparative analysis of the role of insurance in the management of environment-related risks. In: Organization for Economic Cooperation and Development (OECD). OECD Report: Environmental Risks and Insurance. Paris: OECD, jun. 2002.

MOORE, C. M. et al. Processes and Patterns of Oceanic Nutrient Limitation. Nature Geoscience. V.6, n.9, p. 701-710, set. 2013. 
MOTA, J. A. et al. A Valoração da biodiversidade: conceitos e concepções metodológicas. In: MAY, Peter H. (Org.). Economia do Meio Ambiente: Teoria e Prática. Rio de Janeiro: Editora Elsevier, $2^{\mathrm{a}}$ ed., 2010.

MOTTA, Ronaldo Seroa da. Economia ambiental. Rio de Janeiro: Editora FGV, 2006.

Manual de valoração econômica de recursos ambientais. Rio de Janeiro: Coordenação de Estudos do Meio Ambiente do Instituto de Pesquisa Econômica Aplicada (CEMA/IPEA) e Coordenação Geral de Diversidade Biológica do Ministério do Meio Ambiente, dos Recursos Hídricos e da Amazônia Legal (COBIO/MMA), 1997.

NOGUEIRA, Jorge Madeira; MEDEIROS, Marcelino Antônio Asano de. Quanto vale aquilo que não tem valor? Valor de existência, economia e meio ambiente. Cadernos de Ciência \& Tecnologia. Brasília, v.16, n. 3, p. 59-83, set./dez. 1999.

O'HARA, Patrick D.; MORANDIN, Lara A. Effects of sheens associated with offshore oil and gas development on the feather microstructure of pelagic seabirds. Marine Pollution Bulletin. NÃO ACHEI CIDADE, v.60, n.5, p.672-678, mai. 2010. Disponível em https://www.researchgate.net/publication/40897886_Effects_of_sheens_associated_with_offs hore_oil_and_gas_development_on_the_feather_microstructure_of_pelagic_seabirds. Acesso em: 10 jan. 2019.

ODUM, Eugene P. Ecologia. Rio de Janeiro: Guanabara, 1983.

ORTIZ, Ramon Arigoni. Valoração Econômica Ambiental. In: MAY, Peter Herman. Economia Ecológica: aplicações no Brasil. Rio de Janeiro: Editora Campos, 1995.

OST, François. A natureza à margem da lei: A ecologia à prova do direito. Lisboa: Instituto Piaget, 1995.

PAIVA, R. F. P. As dimensões de valor dos recursos naturais e os métodos de valoração.

Revista Iberoamericana de Economía Ecológica. V. 24, p. 203-219. 2015.

PEREIRA, Caio Mário da Silva. Instituições de direito civil: Contratos. Rio de Janeiro: Editora Forense, v. 3, 2012.

PETERSON Charles H. et al. Long-term ecosystem response to the Exxon Valdez oil spill. Science. V.302, n. 5653, p. 2082-2086, dez. 2003.

PETRÓlEO BRASILEIRO S.A. (Petrobrás). Pré-Sal. Disponível em: $<$ http://www.petrobras.com.br/pt/nossas-atividades/areas-de-atuacao/exploracao-e-producaode-petroleo-e-gas/pre-sal/>. Acesso em: 10 jan. 2019.

PIZZATTO, Luciano; PIZZATTO, Raquel. Dicionário Socioambiental brasileiro. São Paulo: Editora Ambiente Brasil, 2009.

POFFO, Íris Regina Fernandes. Gerenciamento de riscos socioambientais no complexo portuário de Santos na ótica ecossistêmica. 2007. 172f. Tese de doutorado - Programa de 
Ciência Ambiental (PROCAM), do Instituto de Energia e Ambiente (IEE), da Universidade de São Paulo (USP), São Paulo, set. 2007.

- Percepção de riscos e comportamento da comunidade diante de acidentes ambientais em áreas portuárias de santos e São Sebastião. 2011. 119f. Pós-Doutorado Programa de Estudos Pós-Graduados em Psicologia Clínica, da Pontifícia Universidade Católica de São Paulo (PUC-SP), São Paulo, jan. 2011.

. Vazamento de óleo no Litoral Norte do Estado de São Paulo: análise histórico (1974 a 1999). 2000. Dissertação de Mestrado - Programa de Ciência Ambiental (PROCAM), do Instituto de Energia e Ambiente (IEE), da Universidade de São Paulo (USP), São Paulo, dez. 2000. Disponível em: $<$ https://cetesb.sp.gov.br/emergencias-quimicas/wpcontent/uploads/sites/22/2018/02/mestrado_IrisPoffo-1.pdf>. Acesso em: 10 jan. 2019.

. Vazamentos de Óleo no Litoral Norte do Estado de São Paulo: análise histórica (1974 a 1999). In: ABRAMOVAY, Ricardo (Org.). Construindo a Ciência Ambiental. São Paulo: Annablume, 2002.

POLIDO, Walter A. Contrato de Seguro: a efetividade do seguro ambiental na composição de danos. Revista de Direito Ambiental. São Paulo, n. 45, jan./mar. 2007.

. Programa de Seguros de Riscos Ambientais no Brasil: Estágio de desenvolvimento atual. Rio de Janeiro: Escola Nacional de Seguros (Funenseg), 3ª ed., 2015.

2013.

. Seguros de Responsabilidade civil: manual prático e teórico. Curitiba: Editora Juruá,

PORTUGAL. Autoridade de Supervisão de Seguros e Fundos de Pensões de Portugal (ASF). Glossário de seguros. Disponível em: <https://www.asf.com.pt/ISP/Gloss\%C3\%A1rio>. Acesso em: 10 jan. 2019.

POZZI NETO, Dante. Baixada santista, manguezal e vazamento de óleo: uma valoração econômica-ecológica. 2000. Dissertação de Mestrado - Programa de Pós-Graduação em Ciências Ambientais (PROCAM), do Instituto de Energia e Ambiente (IEE) da Universidade de São Paulo (USP), São Paulo, 2000.

REAKA-KUDLA, Marjorie L. The global biodiversity of coral reefs: a comparison with rain forests. In: REAKA-KUDLA, Marjorie L.; WILSON, Don E.; WILSON, Edward O. (Ed.). Biodiversity II: understanding and protecting our biological resources. Washington: J. H. Press, 1997.

RIO DE JANEIRO (Estado). Instituto Estadual do Meio Ambiente (INEA). Termo de Compromisso de Ajustamento de Conduta (TAC) $\mathrm{n}^{\circ}$ 02/2016 entre INEA e Petrobras Transporte S/A, assinado em 08 de abril de 2016. Disponível em: $<$ http://www.inea.rj.gov.br/cs/groups/public/documents/document/zwew/mtcx/ edisp/inea017 1374.pdf>. Acesso em: 10 jan. 2019.

Procuradoria Geral do Estado do Rio de Janeiro. Termo de Compromisso de Ajustamento de Conduta (TAC) entre o Estado do Rio de Janeiro e a empresa Transhipping Agenciamento Marítimo Ltda., assinado em 23 de agosto de 2017. Disponível em: 
$<$ http://www.rj.gov.br/c/document_library/get_file?uuid=aef08454-a8d1-41ae-b8520e212f2bf152\&groupId=132946>. Acesso em: 10 jan. 2019.

ROLIM, Maria Helena Fonseca de Souza. Poluição Marítima por Óleo. Justitia. São Paulo, v.115, n. 43, p. 120-142, out./dez. 1981.

ROSENVALD, Nelson. As funções da responsabilidade civil: a reparação e a pena civil. São Paulo: Editora Atlas, $2^{\mathrm{a}}$ ed., 2014.

SALLES, Carlos Alberto de. Execução judicial em matéria ambiental. Boletim Informativo da Escola Superior do Ministério Público de São Paulo. São Paulo, 15/8-12, out. 1998.

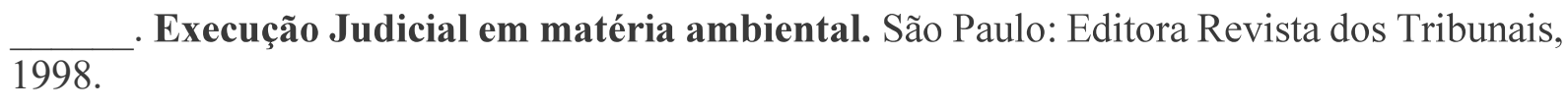

SÁNCHEZ, Luis Enrique. Avaliação de impacto ambiental: conceitos e métodos. São Paulo: Editora Oficina de Textos, $2^{\mathrm{a}}$ ed., 2013.

SANTOS, Luciana Cavalcanti Maia et al. Long-term effects of oil pollution in mangrove forests (Baixada Santista, Southeast Brazil) detected using a GIS-based multitemporal analysis of aerial photographs. Brazilian Journal of Oceanography. São Paulo, v.60, n.2, p. 159-170, jun. 2012. Disponível em: <http://dx.doi.org/10.1590/S1679-87592012000200006>. Acesso em: 10 jan. 2019.

SANTOS, Romualdo Baptista dos. Teoria Geral da Responsabilidade Civil. In: ARAÚJO, Vanessa Donato de. (coord.); HIRONAKA, Giselda Maria Fernandes. (Orient.) Direito Civil: Responsabilidade Civil, vol. 5, São Paulo: Editora Revista dos Tribunais, 2008.

SÃO PAUlO (Estado). Companhia Ambiental do Estado de São Paulo (CETESB). Emergências Químicas: Sistema de Informações sobre Emergências Químicas da CETESB (SIEQ). Disponível em: <http://sistemasinter.cetesb.sp.gov.br/emergencia/relatorio.php>. Acesso em: 10 jan. 2019.

. Companhia Ambiental do Estado de São Paulo (CETESB). Manchas Órfãs. Disponível em: $\quad<$ https://cetesb.sp.gov.br/emergencias-quimicas/tipos-de-acidentes/vazamentos-deoleo/manchas-orfas/>. Acesso em: 10 jan. 2019.

Companhia Ambiental do Estado de São Paulo (CETESB). Principais acidentes. Disponível em: $\quad<$ https://cetesb.sp.gov.br/emergencias-quimicas/tipos-deacidentes/dutos/principais-acidentes/>. Acesso em: 10 jan. 2019.

SARDINHA, Álvaro Máximo. Seguros no Transporte Marítimo. 2017. 44f. Dissertação de Mestrado em Direito e Economia no Mar: a governação do mar - Faculdade de Direito da Universidade Nova de Lisboa, Lisboa, dez. 2017. Disponível em: $<$ https://transportemaritimoglobal.files.wordpress.com/2018/02/00-alvaro-sardinha-segurosno-transporte-marc3adtimo-tmg-mar-doc1.pdf>. Acesso em: 10 jan. 2019.

SAVI, Sérgio. Responsabilidade civil por perda de uma chance, São Paulo: Atlas, 2006. 
SCHAEFFER-NOVELLI, Yara. Manguezal: Ecossistema entre a Terra e o Mar. São Paulo: Caribbean Ecological Research. 1995.

SCHAEFFER-NOVELLI, Yara. Vulnerabilidade do litoral norte do Estado de São Paulo a vazamentos de petróleo e derivados. In: SIMPÓSIO SOBRE ECOSSISTEMAS DA

SCHAEFFER-NOVELLI, Yara; TOGNELLA DE ROSA, M. M. P. Ecossistema manguezal, o desenvolvimento sustentado e a valoração ambiental. In: CONGRESO LATINOAMERICANO DE CIENCIAS, 1995, Buenos Aires.

SCHAEFFER-NOVELLI, Yara; VARJABEDIAN, R. Valoração Monetária de Danos Ambientais: Experiências na Zona Costeira, Ferramentas e Comentários. Revista do Ministério Público de Minas Gerais (MPMG) jurídico. Edição especial Meio Ambiente, p. 50-55, 2011.

SCHMIDT, A. J.; BEMVENUTI, C. E.; DIELE, K. Sobre a definição da Zona de Apicum e sua importância ecológica para populações de Caranguejo-Uçá Ucides cordatus (LINNAEUS, 1763). Boletim Técnico Científico. Centro Nacional de Pesquisa e Conservação da Biodiversidade Marinha do Nordeste (CEPENE), Tamandaré, v. 19, n.1, p. 9-25, 2013.

SCHREIBER, Anderson. Novos paradigmas da responsabilidade civil. São Paulo: Atlas, $6^{\text {a }}$ ed., 2015.

SENDIM, José de Souza Cunha. Responsabilidade civil por danos ecológicos. Coimbra: Almedina, 2002.

SHORT, M. K. J. Guanabara Bay Oil Spill 2000, Brazil - Cetacean Response. International Oil Spill Conference, Vancouver, v.2003, n.1, p. 1035-1037, abr. 2003. Disponível em: $<$ https://doi.org/10.7901/2169-3358-2003-1-1035>. Acesso em 10 jan. 2019.

SILVA FILHO, Artur Marques da. A responsabilidade civil e o dano estético. In: NERY JÚNIOR, Nelson; NERY, Rosa Maria de Andrade. (Org.) Responsabilidade Civil: Teoria Geral. São Paulo: Editora Revista dos Tribunais, v.1, 2010.

SILVA, T. B. B.; CORRÊA, R. S. Comparação entre métodos de valoração de danos ambientais para fins periciais. Revista Brasileira de Criminalística. Brasília, v.4, n.3, p. 7-14, 2015. Disponível em: <http://rbc.org.br/ojs/index.php/rbc/article/view/101/pdf_39>. Acesso em: 10 jan. 2019.

SINISGALLI, Paulo Antônio de Almeida. Valoração de danos ambientais de hidrelétricas: estudos de caso. 2005. 213f. Tese de Doutorado - Instituto de Economia da Universidade Estadual de Campinas, Campinas, jul. 2005.

STEIGLEDER, Annelise Monteiro. Responsabilidade civil ambiental: as dimensões do dano ambiental no direito brasileiro. Porto Alegre: Livraria do Advogado, $2^{\mathrm{a}}$ ed., 2011.

- Valoração de Danos Ambientais Irreversíveis. Revista do Ministério Público de Minas Gerais (MPMG) jurídico. Edição Especial de Meio Ambiente. 2011. 
STIEGLITZ, J. D. Effects of the Deepwater Horizon Oil Spill on Pelagic Fish Species of the Gulf of Mexico. 2014. 117f. PhD dissertation - Marine Biology and Fisheries (Marine), University of Miami, Miami, sep. 2014. Disponível em: https://scholarlyrepository.miami.edu/oa_dissertations/1317>. Acesso em: 10 jan. 2019.

STOCO, Rui. Tratado de Responsabilidade Civil: Doutrina e jurisprudência. São Paulo: Revista dos Tribunais, $7^{\text {a }}$ ed., 2007.

TAN, Alan Khee-Jin. Vessel-Source Marine Pollution: The Law and Politics of International Regulation. New York: Cambridge University Press, 2006.

TARTUCE, Flávio. Direito Civil: Direito das obrigações e responsabilidade civil. Rio de Janeiro: Forense, v.2, 12 ${ }^{\mathrm{a}}$ ed., 2012.

Manual de direito civil. São Paulo: Método, $3^{\mathrm{a}}$. ed., 2013.

THE INTERNATIONAL TANKER OWNERS POLLUTION FEDERATION LIMITED (ITOPF). Effects of oil pollution on social and economic activities. Technical Information Paper (TIP). London, v.12, 2011. Disponível em: <http://www.itopf.com/knowledgeresources/documents-guides/document/tip-12-effects-of-oil-pollution-on-social-andeconomic-activities/>. Acesso em: 10 jan. 2019.

THÉBAUD, O.; BAILLY, D.; HAY, J.; AGÚNDEZ, J. A. P. The cost of oil pollution at sea: an analysis of the process of damage valuation and compensation following oil spills. In: ALBINO, P.; VÁZQUEZ, M. X. Economic, social and environmental effects of the "Prestige" oil spill. Santiago: Consello da Cultura Galega, 2003. Disponível em: $<$ https://bit.ly/2r0fDeN>. Acesso em: 10 jan. 2019.

TOLMASQUIM, M. T. et al., Metodologias de Valoração do Meio Ambiente para o Setor Elétrico. Rio de Janeiro: Instituto Alberto Luiz Coimbra de Pós-Graduação e Pesquisa de Engenharia (COPPE), 2000.

TZIRULNIK, E.; CAVAlCANTI, F. de Q. B.; PIMENTEL, A. O Contrato de Seguro de acordo com o novo código civil brasileiro. São Paulo: Editora Revista dos Tribunais, $2^{\mathrm{a}}$ ed., 2003.

UNITED NATIONS (ONU). Report of the United Nations Conference on Environment and Development. A/CONF.151/26. Rio de Janeiro: ONU, 1992. Disponível em: $<$ http://www.un.org/documents/ga/conf151/aconf15126-1annex1.htm>. Acesso em: 10 jan. 2019.

. Oceans \& Law of the Sea. The United Nations Convention on the Law of the Sea: A historical perspective. Disponível em: $<$ http://www.un.org/depts/los/convention_agreements/convention_historical_perspective.htm $>$ Acesso em: 10 jan. 2019.

VAUGHAN, Adam. Torrey Canyon disaster: the UK's worst-ever oil spill 50 years on. The Guardian, London, march 18, 2017. Disponível em: $<$ https://www.theguardian.com/environment/2017/mar/18/torrey-canyon-disaster-uk-worstever-oil-spill-50tha-anniversary>. Acesso em: 10 jan. 2019. 
VEIGA, J. E. da; ZATZ, L. Desenvolvimento sustentável, que bicho é esse? Campinas: Autores Associados, 2008.

WALLACE, B. P. et al. Estimating sea turtle exposures to Deepwater Horizon oil. Endangered Species Research. V.33, p. 51-67, 2017. Disponível em: <https://doi.org/10.3354/esr00728>. Acesso em 10 jan. 2019

ZANIN, R. B. O direito do mar e a legislação brasileira. Revista Brasileira de Direito Constitucional (RBDC). São Paulo, n.16, p. 83-97, 2010.

ZICCARDI, Michael H. et al. Pinniped and Cetacean Oil Spill Response Guidelines. NOAA Technical Memorandum NMFS (OPR-52). Washington: U.S. Department of Commerce, v. 52, 2015. Disponível em: <https://repository.library.noaa.gov/view/noaa/10479>. Acesso em: 10 jan. 2019

ZOCK, J. P. Some clues for studying long-term health effects of oil spills. Occupational and Environmental Medicine (BJM Journals). London, v.75, 2018.

\section{- Decisões judiciais consultadas}

\section{a) Supremo Tribunal Federal (STF):}

STF. Ação Cível Originária: ACO nº 1676/RJ. Rel. Min. Ricardo Lewandowski. Decisão monocrática. Julgado em 03/12/2016.

. Agravo Regimental no Recurso Extraordinário: ArRg no RE nº 898.716/PR. Rel. Min. Rosa Weber. Primeira Turma. Julgado em 29/07/2015.

b) Superior Tribunal de Justiça (STJ):

STJ. Agravo em Recurso Especial: AREsp n 995.868-RJ. Ministra Laurita Vaz. Decisão Monocrática. Julgado em 20/10/2016.

Agravo Interno no Recurso Especial: AREsp no 1.399.305/SP. Rel. Min. Assusete Magalhães. Segunda Turma. Julgado em 20/09/2018.

Agravo Interno nos Embargos de Declaração no Conflito de Competência: Ag nos EDcl no CC nº 132.505/RJ. Rel. Min. Antônio Carlos Ferreira. Segunda Seção. Julgado em $23 / 11 / 2016$

. Agravo Interno nos Embargos de Declaração no Conflito de Competência: Ag nos EDcl no CC nº 143.516/RJ. Rel. Luis Felipe Salomão. Segunda Seção. Julgado em 23/11/2016.

. Agravo Regimental no Agravo ao Recurso Especial: AgRg no AREsp nº 62.584/RJ. Rel. Ministro Sérgio Kukina. Primeira Turma. DJe: 07/10/2015.

. Agravo Regimental no Agravo de Instrumento: AgRg no Ag n 1.370.562/PR. Rel. Min. Massami Yueda. Terceira Turma. Julgado em 07/04/2011. 
. Agravo Regimental no Agravo de Instrumento: AgRg no Ag n 113.103/PR. Rel. Min. Sidnei Beneti. Terceira Turma. Julgado em 26/06/2012.

Agravo Regimental no Agravo de Instrumento: AgRg no Ag n ${ }^{\circ} 222.483 / S P$. Rel. Min. Benedito Gonçalves. Primeira Turma. Julgado em 18/11/2014.

. Agravo Regimental no Agravo em Recurso Especial: AgRg no AREsp n 71.324/PR. Rel. Min. Antonio Carlos Ferreira. Quarta Turma. Julgado em 26/02/2013.

Agravo Regimental no Agravo em Recurso Especial: AgRg no AREsp n 249.208/PR. Rel. Min. Marco Buzzi. Quarta Turma. Julgado em 18/12/2012.

Agravo Regimental no Agravo em Recurso Especial: AgRg no AREsp n ${ }^{\circ} 778.589 / \mathrm{SP}$. Rel. Min. Mauro Campbell Marques. Segunda Turma. Julgado em 03/12/2015.

. Agravo Regimental no Agravo em Recurso Especial: AgRg no AREsp nº 254.149/PR. Rel. Min. Sidnei Beneti. Terceira Turma. Julgado em 19/02/2013.

. Agravo Regimental no Agravo em Recurso Especial: AgRg no AREsp n ${ }^{\circ} 430.850 / \mathrm{SP}$. Rel. Min. Herman Benjamin. Segunda Turma. Julgado em 11/02/2014.

Agravo Regimental no Agravo em Recurso Especial: AgRg no AREsp n 201.350/PR. Rel. Min. Marco Buzzi. Quarta Turma. Julgado em 01/10/2013.

Agravo Regimental no Agravo em Recurso Especial: AgRg no AREsp nº 249.208/PR. Rel. Min. Marco Buzzi. Quarta Turma. Julgado em 18/12/2012.

Agravo Regimental no Recurso Especial: AgRg no REsp n ${ }^{\circ} 1.133 .842 / P R$. Rel. Min. Sidnei Beneti. Terceira Turma. Julgado em 15/12/2009.

Agravo Regimental no Agravo em Recurso Especial: AgRg no AREsp 62.584/RJ, Rel. Ministro Sérgio Kukina. Primeira Turma. DJe: 07/10/2015.

Conflito de Competência: CC n 143.204/RJ. Rel. Min. Ricardo Villas Bôas Cueva. Segunda Seção. Julgado em 13/04/2016.

. Conflito de Competência: CC n ${ }^{\circ} 16.863 /$ SP. Rel. Min. Demócrito Reinaldo. Primeira Seção. Julgado em 26/06/1996.

Conflito de Competência: CC no 2.473-0/SP. Rel. Min. Antônio de Pádua Ribeiro. Primeira Seção. Julgado em 26/05/1992.

. Conflito de Competência: CC n ${ }^{\circ}$ 10.445-9/SP. Rel. Min. Demócrito Reinaldo. Primeira Seção. Julgado em 13/09/1994.

. Embargos de Declaração no Conflito de Competência: EDcl no CC nº 2.374-0/SP. Rel. Min. Antônio de Pádua Ribeiro. Primeira Seção. Julgado em 20/04/1993.

Embargos de Declaração no Recurso Especial: EDcl no REsp n ${ }^{\circ} 1.346 .430 / P R$. Rel. Min. Luis Felipe Salomão. Quarta Turma. Julgado em 05/02/2013. 
. Recurso Especial: REsp n ${ }^{\circ}$ 1.079.293/PR. Rel. Carlos Fernando Mathias (juiz federal convocado do TRF $1^{\text {a }}$ Região). Quarta Turma. Julgado em 07/10/2008.

. Recurso Especial: REsp n ${ }^{\circ}$ 1.100.698/PR. Rel. Min. Francisco Falcão. Primeira Turma.

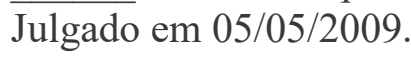

. Recurso Especial: REsp $n^{\circ}$ 1.114.398. Rel. Min. Sidnei Beneti. Segunda Seção.

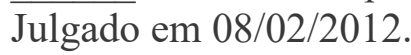

. Recurso Especial: REsp n ${ }^{\circ}$ 1.346.430/PR. Rel. Min. Luis Felipe Salomão. Quarta Turma. Julgado em 18/10/2012.

. Recurso Especial: REsp n 1.596.081/PR. Rel. Min. Ricardo Villas Bôas Cueva. Segunda Seção. Julgado em 25/10/2017.

. Recurso Especial: REsp n ${ }^{\circ}$ 1.602.106/PR. Rel. Ministro Ricardo Villas Bôas Cueva. Segunda Seção. Julgado em 25/10/2017.

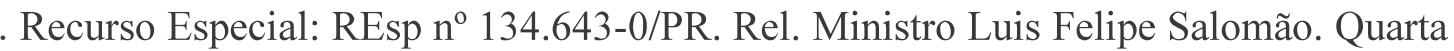
Turma. DJe: 21/11/2012.

. Recurso Especial: REsp no 46.728-4/SP. Rel. Demócrito Reinaldo. Primeira Turma.

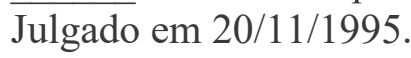

. Recurso Especial: REsp n ${ }^{\circ}$ 945.593/SP. Rel. Min. Nancy Andrighi. Terceira Turma.

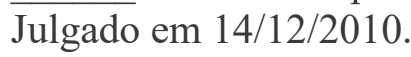
em 6/5/2014.

. Recurso Especial: REsp 1.373.788-SP, Rel. Min. Paulo de Tarso Sanseverino, julgado

. Recurso Especial: REsp nº 1.114.398 - PR, Rel. Min. Sidnei Beneti, Segunda Seção, DJe 16/02/2012.

. Recurso Especial: REsp n ${ }^{\circ}$ 1.602.106/PR. Rel. Ministro Ricardo Villas Bôas Cueva, Segunda Seção, julgado em 25/10/2017.

. Recurso Especial: REsp n ${ }^{\circ}$ 134.643-0/PR, Rel. Ministro Luis Felipe Salomão, Quarta Turma, DJe 21/11/2012.

. Agravo em Recurso Especial: AREsp n 149.660/PR. Rel. Min. Massami Uyeda. Terceira Turma. Julgado em 20/11/2012.

. Agravo em Recurso Especial: AREsp nº 232.494/PR. Rel. Min. Marco Buzzi. Quarta Turma. Julgado em 20/10/2015.

Agravo em Recurso Especial: AREsp n 258.263/ PR. Rel. Min. Antonio Carlos Ferreira. Quarta Turma. Julgado em 12/03/2013. 
Agravo Regimental no Agravo em Recurso Especial: AgRg no AREsp n 92.652/ PR.

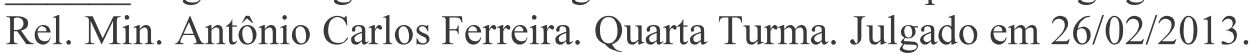

. Recurso Especial: REsp no $1.057 .878 /$ RS. Rel. Min. Herman Benjamin. Segunda Turma. Julgado em 26/05/2009.

. Recurso Especial: REsp no 1.666.017/RJ. Rel. Min. Herman Benjamin. Segunda Turma. Julgado em 27/06/2017.

\section{c) Tribunais Regionais Federais (TRF):}

TRF1. Apelação Cível: ACi nº 0203724-40.1994.4.03.6104/SP. Rel. Marli Ferreira. Quarta Turma.

DJe:

$09 / 11 / 2010$.

. Apelação Cível: ACi no 1998.37.00.006939-1/MA. Rel. João Batista Moreira. Sexta Turma. Julgado em 06/08/2018.

. Apelação Cível: ACi nº 2002.01.00.001805-9/BA. Rel. Marcio Barbosa Maia. Quarta Turma. Julgado em 18/09/2012.

. Apelação Cível: ACi nº 2004.37.00.001610-3/MA. Rel. Jirair Aram Meguerian. Sexta Turma. Julgado em 15.05.2017.

. Apelação Cível: ACi no 2004.37.00.001610-3/MA. Rel. Jirair Aram Meguerian. Sexta Turma. Julgado em $15 / 05 / 2017$

TRF2. Agravo de Instrumento: Ag no 2012.02.01.004075-2. Rel. Guilherme Diefenthaeler. Quinta Turma Especializada. Julgado em 31/07/2012.

. Apelação Cível: ACi n ${ }^{\circ}$ 462813. Rel. Marcelo Pereira (juiz federal convocado). Oitava Turma Especializada. Julgado em 27/04/2010.

Apelação Cível: ACi nº 0006782-42.2011.4.03.6103/SP. Rel. Johonsom Di Salvo. Sexta Turma. DJ: 23/11/2015.

Apelação Cível: ACi no 0007231-60.2012.4.03.6104/SP. Rel. Mônica Nobre. Quarta Turma. DJ: 17/12/2015.

. Apelação Cível: ACi n ${ }^{\circ}$ 2005.50.01.003084-5. Rel. Reis Friede. Sétima Turma Especializada. Julgado em 27/04/2011.

Apelação Cível: ACi no 2005.51.02.0063310. Rel. Luiz Paulo da Silva Araújo Filho. $7^{\text {a }}$ Turma Especializada. DJe 12/02/2014.

Apelação Cível: ACi no 2005.51.02.0063310. Rel. Luiz Paulo da Silva Araújo Filho. Sétima Turma Especializada. Julgado em 18/12/2013.

. Remessa Ex Officio n ${ }^{\circ}$ 0114234-10.2015.4.02.5001. Rel. Aluísio Gonçalves de Castro Mendes. Quinta Turma Especializada. Julgado em 07/08/2018. 
. Agravo de Instrumento: $\mathrm{Ag} \mathrm{n}^{\circ}$ 2007.02.01.004310-1. Rel. Reis Friede. Sétima Turma Especializada. Julgado em 03/10/2007.

TRF3. Ação Civil Pública: ACP nº 0004703-58.2009.4.03.6104. DJ: 11/05/2009.

. Agravo de Instrumento: Ag n ${ }^{\circ}$ 0017917-90.2012.4.03.0000/SP, Rel. Hélio Nogueira, Primeira Turma, julgado em 25/10/2016.

Agravo de Instrumento: Ag $\mathrm{n}^{\circ}$ 10763/SP. Rel. Manoel Álvares (juiz federal convocado). Quarta Turma. Julgado em 31/05/2000.

$\overline{\operatorname{em} 27 / 1} 1 / 1996$.

. Agravo de Instrumento: Ag n 25116. Rel. Lucia Figueiredo. Quarta Turma. Julgado

. Agravo de Instrumento: Ag n ${ }^{\circ}$ 6057/SP. Rel. Manoel Álvares (juiz federal convocado). Quarta Turma. Julgado em 31/05/2000.

. Agravo de Instrumento: Ag n 96.03.010258-0/SP. Rel. Souza Pires. Quarta Turma.

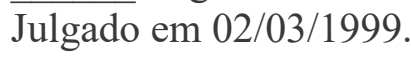

. Agravo de Instrumento: Ag n 97.03.006336-5/SP. Rel. Souza Pires. Quarta Turma.

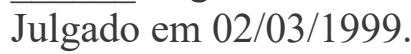

. Agravo de Instrumento: Ag n 98.03.105622-0. Rel. Cecília Hamati. Terceira Turma.

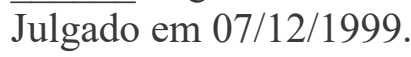

. Agravo de Instrumento: AI no 0017917-90.2012.4.03.0000/SP. Rel. Hélio Nogueira, Primeira Turma. Julgado em 25/10/2016.

. Agravo em Apelação Cível: Ag em AC no 0002183-09.2001.4.03.6104/SP. Rel. Nery Junior. Terceira Turma. DJ: 15/04/2013.

. Agravo em Apelação Cível: Ag em AC nº 0011207-85.2006.4.03.6104/SP. Rel. Nery Junior. Terceira Turma. DJ: 17/02/2014.

. Apelação Cível: ACi nº 0000024-93.2001.4.03.6104/SP. Rel. Márcio Moraes. Terceira Turma. DJ: 31/01/2011.

. Apelação Cível: ACi no 0000922-33.2006.4.03.6104/SP. Rel. Nelton dos Santos.

Terceira Turma. Julgado em 18/08/2016.

. Apelação Cível: ACi nº 0001635-81.2001.4.03.6104/SP. Rel. Cecilia Marcondes.

Terceira Turma. DJ: 26/10/2010.

. Apelação Cível: ACi nº 0001897-31.2001.4.03.6104/SP. Rel. Monica Nobre. Quarta Turma. DJ: 17/12/2015.

$\overline{19 / 02 / 2018}$

. Apelação Cível: ACi nº 0001913-38.2008.4.03.6104 - SP Rel. Antônio Cedenho, DJe 
. Apelação Cível: ACi no 0001913-38.2008.4.03.6104/SP. Rel. Antonio Cedenho. Terceira Turma. Julgado em 07/02/2018.

. Apelação Cível: ACi no 0002051-49.2001.4.03.6104/SP. Rel. Johonsom Di Salvo. Sexta Turma. DJ: 19/05/2014.

. Apelação Cível: ACi n ${ }^{\circ}$ 0002456-80.2004.4.03.6104/SP. Rel. André Nabarrete. Quarta Turma. DJ: 07/10/2015.

Apelação Cível: ACi nº 0002549-96.2011.4.03.6104/SP. Rel. Marli Ferreira. Quarta Turma. DJ: 17/07/2018.

. Apelação Cível: ACi nº 0003577-46.2004.4.03.6104/SP, Rel. Johonsom Di Salvo, Sexta Turma, julgado em 13/03/2014.

Apelação Cível: ACi nº 0003577-46.2004.4.03.6104/SP. Rel. Johonsom Di Salvo. Sexta Turma. Julgado em 13/03/2014.

Apelação Cível: ACi no 0003659-43.2005.4.03.6104/SP. Rel. Cecília Marcondes.

Terceira Turma. DJ: 01/10/2012.

Apelação Cível: ACi n ${ }^{\circ}$ 0004742-21.2010.4.03.6104/SP. Rel. Marcelo Saraiva. Quarta Turma. DJ: 09/02/2018.

. Apelação Cível: ACi n ${ }^{\circ}$ 0004797-79.2004.4.03.6104/SP. Rel. André Nabarrete. Quarta Turma. DJ: 10/09/2012.

Apelação Cível: ACi n ${ }^{\circ}$ 0006384-15.1999.4.03.6104/SP. Rel. Salette Nascimento. Quarta Turma. DJ: 05/04/2011.

. Apelação Cível: ACi n ${ }^{\circ}$ 0006567-68.2008.4.03.6104/SP. Rel. Nelton dos Santos.

Terceira Turma. DJ: 07/12/2015.

. Apelação Cível: ACi nº 0006757-75.2001.4.03.6104. Rel. André Nabarrete. Quarta Turma. DJ: 24/06/2015.

. Apelação Cível: ACi nº 0006782-42.2011.4.03.6103. Rel. Johonsom Di Salvo. Sexta Turma. DJe 19/11/2015.

Apelação Cível: ACi nº 0006782-42.2011.4.03.6103/SP. Rel. Johonsom Di Salvo. Sexta Turma. DJ: 23/11/2015.

. Apelação Cível: ACi nº 0007231-60.2012.4.03.6104/SP. Rel. Mônica Nobre. Quarta Turma. DJ: 17/12/2015.

. Apelação Cível: ACi nº 0007233-30.2012.4.03.6104. Rel. Mônica Nobre. Quarta Turma. DJe 14/09/2016.

. Apelação Cível: ACi nº 0007251-22.2010.4.03.6104/SP. Rel. Mônica Nobre. Quarta Turma. DJ: 17/12/2015. 
. Apelação Cível: ACi nº 0008377-78.2008.4.03.6104/SP. Rel. Mônica Nobre. Quarta Turma. DJ: 03/03/2016.

. Apelação Cível: ACi n ${ }^{\circ}$ 0008783-02.2008.4.03.6104/SP. Rel. Antonio Cedenho. Terceira Turma. DJ: 26/04/2018.

. Apelação Cível: ACi no 0008838-65.1999.4.03.6104/SP. Rel. Alda Basto. Quarta Turma. DJ: 19/12/2012.

. Apelação Cível: ACi n ${ }^{\circ}$ 0009399-11.2007.4.03.6104/SP. Rel. Márcio Moraes. Terceira Turma. DJ: 31/03/2014.

. Apelação Cível: ACi no 0009548-94.2013.4.03.6104/SP. Rel. Carlos Muta. Terceira Turma. DJ: 14/09/2017.

- Apelação Cível: ACi n ${ }^{\circ}$ 0010607-88.2011.4.03.6104/SP. Rel. Roberto Jeuken. Terceira Turma. DJ: 12/11/2014.

Apelação Cível: ACi nº 0013488-09.2009.4.03.6104/SP. Rel. Johonsom Di Salvo. Sexta Turma. DJ: 07/10/2013.

. Apelação Cível: ACi nº 0200639-41.1997.4.03.6104/SP. Rel. Consuelo Yoshida. Sexta Turma. DJ: 11/11/2011.

. Apelação Cível: ACi no 0200640-26.1997.4.03.6104/SP. Rel. Consuelo Yoshida. Sexta Turma. DJ: 11/11/2011.

. Apelação Cível: ACi no 0201611-79.1995.4.03.6104/SP. Rel. Silva Neto. Turma "C" do Projeto Mutirão Judiciário. DJ: 27/01/2011.

Apelação Cível: ACi nº 0201612-64.1995.4.03.6104/SP. Rel. Consuelo Yoshida. Sexta Turma. DJ: 25/11/2011.

. Apelação Cível: ACi nº 0202534-81.1990.4.03.6104/SP. Rel. Johonsom Di Salvo.

Sexta Turma. DJ: 09/12/2014.

. Apelação Cível: ACi n ${ }^{\circ}$ 0203549-46.1994.4.03.6104/SP. Rel. Regina Costa. Sexta Turma. DJ: 09/12/2011.

. Apelação Cível: ACi n no203550-31.1994.4.03.6104/SP. Rel. Márico Moraes. Terceira Turma. DJ: 14/07/2014.

. Apelação Cível: ACi n ${ }^{0}$ 0203553-25.1990.4.03.6104/SP. Rel. Consuelo Yoshida. Sexta Turma. DJ: 17/11/2010.

$\overline{\text { DJe } 03 / 11 / 2010 .}$

Apelação Cível: ACi nº 0203607-49.1994.4.03.6104 - SP. Rel. Consuelo Yoshida. 
. Apelação Cível: ACi n ${ }^{0}$ 0203607-49.1994.4.03.6104/SP. Rel. Consuelo Yoshida. Sexta Turma. DJ: 03/11/2010.

. Apelação Cível: ACi no 0203725-25.1994.4.03.6104/SP. Rel. Alda Basto. Quarta Turma. DJ: 06/08/2010.

. Apelação Cível: ACi nº 0204313-37.1991.4.03.6104/SP. Rel. Marli Ferreira. Quarta Turma. DJ: 22/12/2010.

Apelação Cível: ACi no 0204317-74.1991.4.03.6104/SP. Rel. Leonel Ferreira (juiz federal convocado). Turma "D". DJ: 02/05/2011.

. Apelação Cível: ACi nº 0204723-32.1990.4.03.6104/SP. Rel. Paulo Conrado. Turma "A". DJ: 07/10/2011.

Apelação Cível: ACi no 0205088-76.1996.4.03.6104/SP. Rel. Salette Nascimento. Sexta Turma. Julgado em 18/10/2010.

. Apelação Cível: ACi no 0205123-65.1998.4.03.6104/SP. Rel. Silva Neto. Turma "C" do Projeto Mutirão Judiciário. DJ: 21/01/2011.

. Apelação Cível: ACi n ${ }^{\circ}$ 0205453-77.1989.4.03.6104/SP. Rel. André Nabarrete. Quarta Turma. DJ: 10/09/2012.

Apelação Cível: ACi no 0205472-68.1998.4.03.6104/SP. Rel. Consuelo Yoshida. Sexta Turma. DJ: 27/04/2012.

Apelação Cível: ACi no 0206469-90.1994.4.03.6104/SP. Rel. Consuelo Yoshida. Sexta Turma. DJ: 11/11/2011.

Apelação Cível: ACi nº 0206470-75.1994.4.03.6104/SP. Rel. Consuelo Yoshida. Sexta Turma. DJ: 03/11/2010.

. Apelação Cível: ACi nº 0208505-42.1993.4.03.6104/SP. Rel. Paulo Conrado. Turma A. DJ: 02/09/2011.

Apelação Cível: ACi nº 0401857-02.1992.4.03.6103 - SP. Rel. Cotrim Guimarães. $\overline{\text { DJe } 19 / 10 / 2012 .}$

Apelação Cível: ACi nº 0401857-02.1992.4.03.6103/SP. Rel. Cotrim Guimarães.

Segunda Turma. DJ: 19/10/2012.

. Apelação Cível: ACi no 1999.03.99.009734-6/SP. Rel. Silva Neto (juiz federal convocado). Turma Suplementar da Segunda Seção. Julgado em 03/05/2007.

. Apelação Cível: ACi n 1999.03.99.016662-9/SP. Rel. Lazarano Neto. Sexta Turma. DJ: $16 / 03 / 2010$.

Apelação Cível: ACi n 2002.03.99.013233-5788365/SP. Rel. Cecília Marcondes.

Terceira Turma. Julgado em 18/12/2002. 
. Apelação Cível: ACi no 2002.03.99.016725-8. Rel. Cecília Marcondes. Terceira Turma. Julgado em 13/12/2004.

. Apelação Cível: ACi nº 304592/SP. Rel. Marli Ferreira. Sexta Turma. DJ: 26/01/2005. $\overline{17 / 08 / 2005}$

Apelação Cível: ACi nº 322074. Rel. Salette Nascimento. Quarta Turma. DJ: . Apelação Cível: ACi n 330505. Rel. Salette Nascimento. Quarta Turma. Julgado em $11 / 05 / 2005$.

. Apelação Cível: ACi no 401518/SP. Rel. Salette Nascimento. Sexta Turma. Julgado em 23/05/2001. $\overline{11 / 02 / 2004}$

. Apelação Cível: ACi n 421143. Rel. Salette Nascimento. Quarta Turma. Julgado em $18 / 05 / 2005$

Apelação Cível: ACi nº 430646. Rel. Salette Nascimento. Quarta Turma. Julgado em $18 / 12 / 2002$

. Apelação Cível: ACi nº 432487. Rel. Cecília Marcondes. Terceira Turma. Julgado em . Apelação Cível: ACi n ${ }^{\circ}$ 795909. Rel. Cecília Marcondes. Terceira Turma. Julgado em $\overline{13 / 12 / 2004}$ $\overline{05 / 02 / 199 .}$

Apelação Cível: ACi n 89.03.004240-9. Rel. Oliveira Lima. Quarta Turma. DJ:

. Apelação Cível: ACi n 96.03.014267-0 304590. Rel. Rubens Calixto (juiz federal convocado). Terceira Turma. Julgado em 01/08/2007.

. Apelação Cível: ACi nº 96.03.044818-4 322073. Rel. André Nabarrete. Quinta Turma.

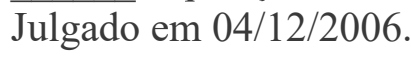
$\overline{26 / 05 / 2010}$

Apelação Cível: ACi no 97.03.064646-8/SP. Rel. Fabio Prieto. Quarta Turma. DJ:

. Apelação Cível: ACi nº 98.03.067546-0 432487. Rel. Cecília Marcondes. Terceira Turma. Julgado em 18/12/2002.

. Embargos de Declaração em Apelação Cível: EDcl em ACi no 000357746.2004.4.03.6104/SP, Rel. Johonsom Di Salvo, Sexta Turma, julgado em 03/07/2014.

- Embargos de Declaração em Apelação Cível: EDcl em ACi no 000092233.2006.4.03.6104/SP. Rel. Nelton dos Santos. Terceira Turma. Publicado em 04/05/2017.

. Embargos de Declaração em Apelação Cível: EDcl em ACi no 000357746.2004.4.03.6104/SP. Rel. Johonsom Di Salvo. Sexta Turma. Julgado em 03/07/2014. 
. Embargos de Declaração: EDcl no 2002.03.99.013233-5788365. Rel. Cecilia Marcondes. Terceira Turma. Julgado em 18/03/2003.

. Embargos Infringentes: EI $n^{\circ}$ 0203549-46.1994.4.03.6104/SP. Rel. Marli Ferreira. Segunda Seção. DJ: 28/03/2014.

Apelação Cível: ACi no 0004643-95.2003.4.03.6104/SP. Rel. Cecília Marcondes. Terceira Turma. DJ: 25/11/2013.

. Apelação Cível: ACi n 96.03.067409-5 335080. Rel. Salette Nascimento. Sexta Turma. Julgado em 15/05/2002.

Apelação Cível: ACi nº 0006757-75.2001.4.03.6104/SP. Rel. Andre Nabarrete. Quarta Turma. DJ: 24/06/2015.

TRF4. Agravo de Instrumento: Ag n ${ }^{\circ}$ 0001227-27.2010.404.0000/SC. Rel. Marga Inge Barth Tessler. Quarta Turma. DJ: 30/03/2010

. Agravo de Instrumento: $\mathrm{Ag} \mathrm{n}^{\circ}$ 0001229-94.2010.404.0000/SC. Rel. Marga Inge Barth Tessler. Quarta Turma. DJ: 27/04/2010

. Agravo de Instrumento: Ag n ${ }^{\circ}$ 0001264-54.2010.404.0000/SC. Rel. Marga Inge Barth Tessler. Quarta Turma. DJ: 27/04/2010

Agravo de Instrumento: $\mathrm{Ag} \mathrm{n}^{\circ}$ 0008714-48.2010.404.0000/SC. Rel. Marga Inge Barth Tessler. Quarta Turma. DJ: 15/06/2010.

. Agravo de Instrumento: $\mathrm{Ag} \mathrm{n}^{\circ}$ 0008734-39.2010.404.0000/SC. Rel. Marga Inge Barth Tessler. Quarta Turma. DJ: 15/06/2010.

Agravo de Instrumento: $\mathrm{Ag} \mathrm{n}^{\circ}$ 0008748-23.2010.404.0000/SC. Rel. Marga Inge Barth Tessler. Quarta Turma. DJ: 15/06/2010.

. Agravo de Instrumento: Ag nº 0008828-84.2010.404.0000/SC. Rel. Marga Inge Barth Tessler. Quarta Turma. DJ: 15/06/2010.

. Agravo de Instrumento: $\mathrm{Ag} \mathrm{n}^{\circ}$ 0008887-72.2010.404.0000/SC. Rel. Marga Inge Barth Tessler. Quarta Turma. DJ: 15/06/2010.

Agravo de Instrumento: Ag n ${ }^{\circ}$ 0008894-64.2010.404.0000/SC. Rel. Marga Inge Barth Tessler., Quarta Turma. DJ: 15/06/2010.

Agravo de Instrumento: $\mathrm{Ag} \mathrm{n}^{\circ}$ 0008912-85.2010.404.0000/SC. Rel. Marga Inge Barth Tessler. Quarta Turma. DJ: 15/06/2010.

. Agravo de Instrumento: $\mathrm{Ag} \mathrm{n}^{\circ}$ 0008913-70.2010.404.0000/SC. Rel. Marga Inge Barth Tessler. Quarta Turma. DJ: 15/06/2010. 
. Agravo de Instrumento: Ag no 0008994-19.2010.404.0000/SC. Rel. Marga Inge Barth

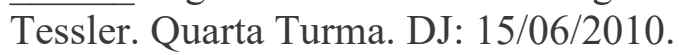

. Agravo de Instrumento: Ag no 0009001-11.2010.404.0000/SC. Rel. Marga Inge Barth Tessler. Quarta Turma. DJ: 15/06/2010.

. Agravo de Instrumento: Ag $\mathrm{n}^{\circ}$ 0009050-52.2010.404.0000/SC. Rel. Marga Inge Barth Tessler. Quarta Turma. DJ: 15/06/2010.

. Agravo de Instrumento: Ag n ${ }^{\circ}$ 0009053-07.2010.404.0000/SC. Rel. Marga Inge Barth Tessler. Quarta Turma. DJ: 15/06/2010.

. Agravo de Instrumento: $\mathrm{Ag} \mathrm{n}^{\circ}$ 0009055-74.2010.404.0000/SC. Rel. Marga Inge Barth Tessler. Quarta Turma. DJ: 15/06/2010.

. Agravo de Instrumento: Ag n ${ }^{\circ}$ 0009061-81.2010.404.0000/SC. Rel. Marga Inge Barth Tessler. Quarta Turma. DJ: 15/06/2010.

. Agravo de Instrumento: Ag n ${ }^{\circ}$ 0011413-12.2010.404.0000/SC. Rel. Marga Inge Barth Tessler. Quarta Turma. DJ: 15/06/2010.

. Agravo de Instrumento: Ag $n^{\circ}$ 0011417-49.2010.404.0000/SC. Rel. Marga Inge Barth Tessler. Quarta Turma. DJ: 13/07/2010.

. Agravo de Instrumento: Ag n ${ }^{\circ}$ 0011435-70.2010.404.0000/SC. Rel. Marga Inge Barth Tessler. Quarta Turma. DJ: 15/06/2010.

. Agravo de Instrumento: Ag n ${ }^{\circ}$ 0011527-48.2010.404.0000/SC. Rel. Marga Inge Barth Tessler. Quarta Turma. DJ: 15/06/2010.

- Agravo de Instrumento: Ag $\mathrm{n}^{\circ}$ 2005.04.01.041559-0/RS. Rel. Marga Inge Barth Tessler. Quarta Turma. DJ: 11/12/2007.

. Agravo de Instrumento: Ag no 2009.04.00.041788-1/SC. Rel. Hermes da Conceição (juiz federal convocado). Quarta Turma. DJ: 30/03/2010.

. Agravo de Instrumento: Ag nº 2009.04.00.041810-1/SC. Rel. Maria Lúcia Luz Leiria. Terceira Turma. DJ: 25/03/2010.

. Agravo de Instrumento: Ag n ${ }^{\circ}$ 2009.04.00.041870-8/SC. Rel. Hermes da Conceição (juiz federal convocado). Quarta Turma. DJ: 30/03/2010.

. Agravo de Instrumento: Ag $n^{\circ}$ 2009.04.00.041873-3/SC. Rel. Marga Inge Barth Tessler. Quarta Turma. DJ: 23/03/2010.

Agravo de Instrumento: Ag $\mathrm{n}^{\circ}$ 2009.04.00.041922-1/SC. Rel. Marga Inge Barth Tessler. Quarta Turma. DJ: 23/03/2010.

. Agravo de Instrumento: Ag $\mathrm{n}^{\circ}$ 2009.04.00.041971-3/SC. Rel. Marga Inge Barth Tessler. Quarta Turma. DJ: 30/03/2010. 
. Agravo de Instrumento: Ag no 2009.04.00.041974-9/SC. Rel. Hermes da Conceição (juiz federal convocado). Quarta Turma. DJ: 30/03/2010.

. Agravo de Instrumento: $\mathrm{Ag} \mathrm{n}^{\circ}$ 2009.04.00.042226-8/SC. Rel. Hermes da Conceição (juiz federal convocado). Quarta Turma. DJ: 30/03/2010.

Agravo de Instrumento: $A g \mathrm{n}^{\circ}$ 2009.04.00.042234-7/SC. Rel. Marga Inge Barth Tessler. Quarta Turma. DJ: 23/03/2010.

. Agravo de Instrumento: Ag no 2009.04.00.042249-9/SC. Rel. Hermes da Conceição (juiz federal convocado). Quarta Turma. DJ: 30/03/2010.

. Agravo de Instrumento: Ag no 2009.04.00.042264-5/SC. Rel. Hermes da Conceição (juiz federal convocado). Quarta Turma. DJ: 30/03/2010.

. Agravo de Instrumento: Ag nº 2009.04.00.042303-0/SC. Rel. Hermes da Conceição (juiz federal convocado). Quarta Turma. DJ: 30/03/2010.

Agravo de Instrumento: $A g \mathrm{n}^{\circ}$ 2009.04.00.042356-0/SC. Rel. Marga Inge Barth Tessler. Quarta Turma. DJ: 02/03/2010.

- Agravo de Instrumento: $A g \mathrm{n}^{\circ}$ 2009.04.00.042363-7/SC. Rel. Marga Inge Barth Tessler. Quarta Turma. DJ: 30/03/2010.

. Agravo de Instrumento: Ag n 2009.04.00.042367-4/SC. Rel. Hermes da Conceição (juiz federal convocado). Quarta Turma. DJ: 30/03/2010.

Agravo de Instrumento: Ag $\mathrm{n}^{\circ}$ 2009.04.00.043873-2/SC. Rel. Marga Inge Barth Tessler. Quarta Turma. DJ: 23/03/2010.

. Agravo de Instrumento: $A g \mathrm{n}^{\circ}$ 2009.04.00.043874-4/SC. Rel. Marga Inge Barth Tessler. Quarta Turma. DJ: 23/03/2010.

. Agravo de Instrumento: Ag $\mathrm{n}^{\circ}$ 2009.04.00.043962-1/SC. Rel. Marga Inge Barth Tessler. Quarta Turma. DJ: 23/03/2010.

Agravo de Instrumento: Ag $n^{\circ}$ 2009.04.00.043969-4/SC. Rel. Marga Inge Barth Tessler. Quarta Turma. DJ: 23/03/2010.

Agravo de Instrumento: Ag $\mathrm{n}^{\circ}$ 2009.04.00.043972-4/SC. Rel. Marga Inge Barth Tessler. Quarta Turma. DJ: 23/03/2010.

. Agravo de Instrumento: $A g \mathrm{n}^{\circ}$ 2009.04.00.044136-6/SC. Rel. Marga Inge Barth Tessler. Quarta Turma. DJ: 23/03/2010.

Agravo de Instrumento: Ag $\mathrm{n}^{\mathrm{0}}$ 2009.04.00.044148-2/SC. Rel. Marga Inge Barth Tessler. Quarta Turma. DJ: 27/04/2010. 
. Agravo de Instrumento: $A g \mathrm{n}^{\circ}$ 2009.04.00.044150-0/SC. Rel. Marga Inge Barth Tessler. Quarta Turma. DJ: 23/03/2010.

- Apelação Cível: AC no 0004155-95.2004.404.7101/RS. Rel. Carlos Eduardo Thompson Flores Lens. Terceira Turma. Publicado em 27/09/2010.

. Apelação Cível: ACi n ${ }^{\circ}$ 2005.71.01.001046-6/RS. Rel. Carlos Eduardo. Terceira Turma. DJ: 19/11/2007.

. Apelação Cível: ACi n 5001112-21.2011.404.7101/RS. Rel. Vivian Josete Pantaleão Caminha. Quarta Turma. Julgado em 05/08/2014.

. Apelação Cível: ACi nº 5006075-38.2012.4.04.7101/RS. Rel. Vivian Josete Pantaleão

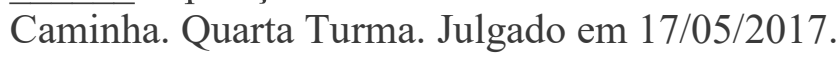

. Apelação Cível: ACi n ${ }^{\circ}$ 5013215-58.2014.4.04.7100/RS. Rel. Fernando Quadros da Silva. Terceira Turma. Julgado em 27/09/2016.

TRF4: Agravo de Instrumento: Ag nº 2009.04.00.041771-6/SC. Rel. Maria Lúcia Luz Leiria. Terceira Turma. DJ: 08/04/2010.

TRF5. Apelação Cível: ACi nº 0801665-62.2014.4.05.8500. Rel. Manoel de Oliveira Erhardt. Primeira Turma. Julgado em 20/02/2016.

. Apelação Cível: ACi n ${ }^{\circ}$ 0805878-43.2016.4.05.8500. Rel. Rubens de Mendonça Canuto Neto. Quarta Turma. Julgado em 25/05/2018.

. Apelação Cível: ACi nº 572679. Rel. Paulo Machado Cordeiro. Terceira Turma. Julgado em 14/01/2016.

d) Tribunais de Justiça Estaduais (TJ):

TJES. Apelação Cível: ACi nº 0025537-17.2010.8.08, Rel. Samuel Meira Brasil Junior, $3^{\text {a }}$ Câmara Cível, publicado em 16/12/2016.

. Apelação Cível: ACi no 0025537-17.2010.8.08. Rel. Samuel Meira Brasil Junior. $3^{\mathrm{a}}$ Câmara Cível.DJ: 16/12/2016.

. Embargos de Declaração na Apelação Cível: EDcl em ACi nº 0025537-17.2010.8.08. Rel. Samuel Meira Brasil Junior. 3ª Câmara Cível. DJ:27/03/2018.

. Embargos de Declaração nos Embargos de Declaração na Apelação Cível: EDcl nos EDcl em ACi n ${ }^{\circ}$ 0025537-17.2010.8.08. Rel. Samuel Meira Brasil Junior. $3^{\text {a }}$ Câmara Cível. DJ: 03/07/2018.

TJPR. Ação Rescisória: AR n 5000455-97.2016.8.16.0000, Rel. Francisco Luiz Macedo Junior, 9ª Câmara Cível, julgado em 17/11/2016. 
. Ação Rescisória: AR n ${ }^{0}$ 5001164-35.2016.8.16.0000, Rel. Francisco Luiz Macedo Junior, $9^{a}$ Câmara Cível, julgado em 17/11/2016.

Apelação Cível: ACi n ${ }^{\circ}$ 821.671-5. Rel. Francisco Luiz Macedo Junior. $1^{\text {a }}$ Vara Cível da Comarca de Paranaguá. Julgado em 20/10/2011.

. Apelação Cível: ACi nº 0005698-94.2005.8.16.0129. Rel. Albino Jacomel Guérios. 9a Câmara Cível. Julgado em 05/07/2018.

Apelação Cível: ACi nº 0006035-20.2004.8.16.0129. Rel. Luiz Lopes. 10ª Câmara Cível. Julgado em 22/11/2018.

Apelação Cível: ACi n ${ }^{\circ}$ 0008838-39.2005.8.16.0129. Rel. Ângela Khury. 10ª Câmara Cível. Julgado em 26/07/2018.

. Apelação Cível: ACi no 0010185-10.2005.8.16.0129. Rel. Luis Sérgio Swiech. $8^{\mathrm{a}}$ Câmara Cível. Julgado em 22/11/2018.

Apelação Cível: ACi no 0010767-10.2005.8.16.0129. Rel. Coimbra de Moura. 9a Câmara Cível. Julgado em 23/08/2018.

. Apelação Cível: ACi nº 0011003-98.2001.8.16.0129. Rel. Vicente Del Prete Misurelli. 8a Câmara Cível. Julgado em 21/07/2018.

- Apelação Cível: ACi no 0014849-21.2004.8.16.0129. Rel. Rafael Vieira de Vasconcellos Pedroso. $1^{a}$ Vara Cível da Comarca de Paranaguá. Julgado em 16/08/2018.

. Apelação Cível: ACi no 011887-25.2004.8.16.0129. Rel. Alexandre Barbosa Fabiani. $8^{a}$ Vara Cível. Julgado em 29/11/2018.

. Apelação Cível: ACi n ${ }^{1048863.2001 .8 .16 .0129 . ~ R e l . ~ L u i z ~ L o p e s . ~} 10^{\mathrm{a}}$ Câmara Cível. Julgado em 12/07/2018.

. Apelação Cível: ACi n 14096-64.2004.8.16.0129 Rel. Alexandre Barbosa Fabiani

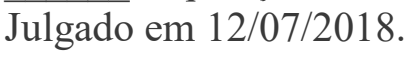

Apelação Cível: ACi nº 446.118-1. Rel. Sergio Luiz Pantitucci. 9ª Câmara Cível.

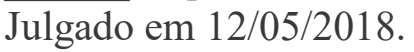

Apelação Cível: ACi nº 689.918-9. Rel. D’Artagnan Serpa Sá. 9ª Câmara Cível. Julgado em 18/11/2010.

. Apelação Cível: ACi n 691.230-1. Rel. D’Artagnan Serpa Sá. $1^{a}$ Vara Cível. Julgado em 18/11/2010.

. Apelação Cível: ACi n 694.173-3. Rel. D’Artagnan Serpa Sá. 1ª Vara Cível. Julgado em 23/09/2010.

Apelação Cível: ACi n ${ }^{\circ}$ 966.702-2. Rel. D’Artagnan Serpa Sá. $1^{a}$ Vara Cível. Julgado em 23/09/2010. 
. Apelação Cível: ACi n ${ }^{\circ}$ 713.463-6. Rel. Arquelau Araújo Ribas. $1^{\text {a }}$ Vara Cível da

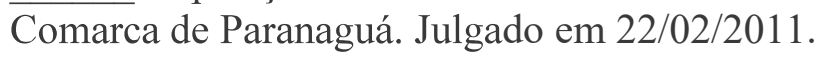

- Apelação Cível: ACi n 714.534-4, Rel. D’Artagnan Serpa Sá, 9a Câmara Cível, julgado em 18/11/2010.

. Apelação Cível: ACi n ${ }^{\circ} 780.440-2$, Rel. Arquelau Araújo Ribas. $1^{\text {a }}$ Vara Cível da Comarca de Paranaguá. Julgado em 22/02/2011.

em 17/11/2011.

. Apelação Cível: ACi nº 821.625-3. Rel. D’Artagnan Serpa Sá. 1ª Vara Cível. Julgado

- Apelação Cível: ACi n ${ }^{\circ}$ 877.639-6. Rel. Arquelau Araújo Ribas. $1^{a}$ Vara Cível da

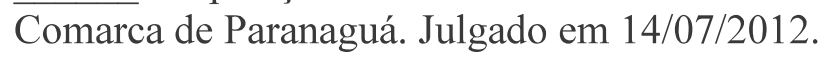

. Apelação Cível: ACi no 943.169-6. Rel. D’Artagnan Serpa Sá. 9ª Câmara Cível. Julgado em 23/08/2012.

. Apelação Cível: ACi n 956.355-7. Rel. D’Artagnan Serpa Sá. 1ª Vara Cível. Julgado em 18/10/2012.

. Apelação Cível: ACi nº 0005698-94.2005.8.16.0129. Rel. Albino Jacomel Guérios. 9a Câmara Cível. Julgado em 05/07/2018.

. Apelação Cível: ACi no 0006035-20.2004.8.16.0129. Rel. Luiz Lopes. 10ª Câmara Cível. Julgado em 22/11/2018.

. Apelação Cível: ACi no 0008838-39.2005.8.16.0129. Rel. Ângela Khury. 10ª Câmara Cível. Julgado em 26/07/2018.

. Apelação Cível: ACi no 0010185-10.2005.8.16.0129. Rel. Luis Sérgio Swiech. $8^{\mathrm{a}}$ Câmara Cível. Julgado em 22/11/2018.

. Apelação Cível: ACi n ${ }^{\circ}$ 0011003-98.2001.8.16.0129. Rel. Vicente Del Prete Misurelli. $8^{a}$ Câmara Cível. Julgado em 21/07/2018.

Apelação Cível: ACi no 0014849-21.2004.8.16.0129. Rel. Rafael Vieira de Vasconcellos Pedroso. 1ª Vara Cível da Comarca de Paranaguá. Julgado em 16/08/2018.

. Apelação Cível: ACi nº 011887-25.2004.8.16.0129. Rel. Alexandre Barbosa Fabiani. $8^{a}$ Vara Cível. Julgado em 29/11/2018.

. Apelação Cível: ACi no 14096-64.2004.8.16.0129. Rel. Alexandre Barbosa Fabiani.

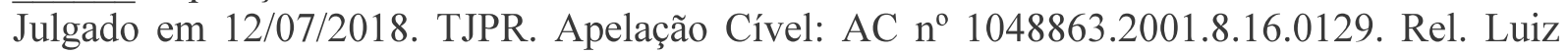
Lopes. $10^{a}$ Câmara Cível. Julgado em 12/07/2018.

. Apelação Cível: ACi n ${ }^{\circ}$ 446.118-1. Rel. Sergio Luiz Pantitucci. 9ª Câmara Cível.

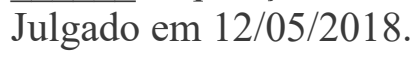


Apelação Cível: ACi nº 689.918-9. Rel. D’Artagnan Serpa Sá. 9a Câmara Cível.

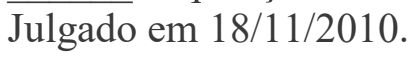

. Apelação Cível: ACi no 0010767-10.2005.8.16.0129. Rel. Coimbra de Moura. 9a Câmara Cível. Julgado em 23/08/2018.

. Apelação Cível: ACi n 691.230-1. Rel. D’Artagnan Serpa Sá. $1^{a}$ Vara Cível. Julgado em 18/11/2010.

. Apelação Cível: ACi n ${ }^{\circ}$ 694.173-3. Rel. D’Artagnan Serpa Sá. $1^{a}$ Vara Cível. Julgado em 23/09/2010.

. Apelação Cível: ACi nº 696.702-2. Rel. D’Artagnan Serpa Sá. $1^{\text {a }}$ Vara Cível. Julgado em 23/09/2010.

. Apelação Cível: ACi n ${ }^{\circ} 713.463-6$. Rel. Arquelau Araújo Ribas. $1^{\text {a }}$ Vara Cível da Comarca de Paranaguá. Julgado em 22/02/2011.

Apelação Cível: ACi nº 714.534-4. Rel. D’Artagnan Serpa Sá. 9ª Câmara Cível. Julgado em 18/11/2010.

Apelação Cível: ACi nº 943.169-6. Rel. D’Artagnan Serpa Sá. 9ª Câmara Cível.

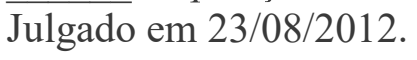

Apelação Cível: ACi n ${ }^{\circ} 780.440-2$. Rel. Arquelau Araújo Ribas. $1^{\text {a }}$ Vara Cível da Comarca de Paranaguá. Julgado em 22/02/2011.

. Apelação Cível: ACi nº 821.625-3. Rel. D’Artagnan Serpa Sá. $1^{a}$ Vara Cível. Julgado em 17/11/2011. em 18/10/2012.

Apelação Cível: ACi n 956.355-7. Rel. D’Artagnan Serpa Sá. $1^{a}$ Vara Cível. Julgado Apelação Cível: ACi n ${ }^{\circ}$ 821.671-5. Rel. Francisco Luiz Macedo Junior. $1^{\text {a }}$ Vara Cível da Comarca de Paranaguá. Julgado em 20/10/2011.

. Apelação Cível: ACi nº 877.639-6. Rel. Arquelau Araújo Ribas. $1^{\text {a }}$ Vara Cível da Comarca de Paranaguá. Julgado em 14/07/2012.

Embargos de Declaração: EDcl n 475.312-4, Rel. Carvílio da Silveira Filho, 2a Vara Cível da Comarca de Paranaguá, julgado em 07/02/2013.

. Embargos de Declaração: EDcl n ${ }^{0}$ 5000742-26.2017.8.16.0000. Rel. Coimbra de Moura. $9^{a}$ Câmara Cível. Julgado em 10/08/2017.

. Embargos de Declaração: EDcl no 5000605-44.2017.8.16.0000. Rel. Coimbra de Moura. $9^{a}$ Câmara Cível. Julgado em 10/08/2017.

Embargos de Declaração: EDcl no 5000865-24.2017.8.16.0000. Rel. Coimbra de Moura. $9^{a}$ Câmara Cível. Julgado em 10/08/2017. 
. Embargos de Declaração: EDcl n ${ }^{\circ}$ 5000743-11.2017.8.16.0000. Rel. Coimbra de Moura. $9^{a}$ Câmara Cível. Julgado em 10/08/2017.

. Embargos de Declaração: EDcl no 5001464-60.2017.8.16.0000. Rel. Coimbra de Moura. 9a Câmara Cível. Julgado em 10/08/2017.

TJPR. Embargos de Declaração: EDcl n 5001463-75.2017.8.16.0000. Rel. Coimbra de Moura. $9^{a}$ Câmara Cível. Julgado em 10/08/2017.

. Embargos de Declaração n ${ }^{0}$ 5001468-97.2017.8.16.0000, Rel. Coimbra de Moura, $9^{\mathrm{a}}$ Câmara Cível, julgado em 10/08/2017; TJPR. Embargos de Declaração n ${ }^{\circ}$ 500146545.2017.8.16.0000, Rel. Coimbra de Moura, $9^{a}$ Câmara Cível, julgado em 10/08/2017;

. Embargos de Declaração n ${ }^{\circ}$ 5001470-67.2017.8.16.0000, Rel. Coimbra de Moura, $9^{\mathrm{a}}$ Câmara Cível, julgado em 10/08/2017; TJPR. Embargos de Declaração no ${ }^{\circ}$ 500146982.2017.8.16.0000, Rel. Coimbra de Moura, 9a Câmara Cível, julgado em 10/08/2017;

. Embargos de Declaração: EDcl n 475.312-4. Rel. Carvílio da Silveira Filho. 2a Vara Cível da Comarca de Paranaguá. Julgado em 07/02/2013.

. Embargos de Declaração: EDcl n ${ }^{\circ}$ 5000605-44.2017.8.16.0000. Rel. Coimbra de Moura. $9^{a}$ Câmara Cível. Julgado em 10/08/2017.

. Embargos de Declaração: EDcl n ${ }^{\circ}$ 5000742-26.2017.8.16.0000. Rel. Coimbra de Moura. $9^{a}$ Câmara Cível. Julgado em 10/08/2017.

. Embargos de Declaração: EDcl n ${ }^{\circ}$ 5000743-11.2017.8.16.0000. Rel. Coimbra de Moura. $9^{a}$ Câmara Cível. Julgado em 10/08/2017.

. Embargos de Declaração: EDcl no 5000865-24.2017.8.16.0000. Rel. Coimbra de Moura. $9^{a}$ Câmara Cível. Julgado em 10/08/2017.

. Embargos de Declaração: EDcl no 5001463-75.2017.8.16.0000. Rel. Coimbra de Moura. $9^{a}$ Câmara Cível. Julgado em 10/08/2017.

. Embargos de Declaração: EDcl no 5001464-60.2017.8.16.0000. Rel. Coimbra de Moura. $9^{a}$ Câmara Cível. Julgado em 10/08/2017.

. Embargos de Declaração: EDcl no 5001465-45.2017.8.16.0000. Rel. Coimbra de Moura. 9a Câmara Cível. Julgado em 10/08/2017.

. Embargos de Declaração: EDcl no 5001468-97.2017.8.16.0000. Rel. Coimbra de Moura. $9^{a}$ Câmara Cível. Julgado em 10/08/2017.

. Embargos de Declaração: EDcl n ${ }^{\circ}$ 5001469-82.2017.8.16.0000. Rel. Coimbra de Moura. $9^{a}$ Câmara Cível. Julgado em 10/08/2017.

. Embargos de Declaração: EDcl n ${ }^{\circ}$ 5001470-67.2017.8.16.0000. Rel. Coimbra de Moura. $9^{a}$ Câmara Cível. Julgado em 10/08/2017. 
TJRJ. Agravo de Instrumento n ${ }^{\circ}$ 0009120-09.2016.8.19.0000, Rel. Ferdinaldo Nascimento, $19^{\mathrm{a}}$ Vara Cível, julgado em 14/06/2014.

. Agravo de Instrumento $\mathrm{n}^{\mathrm{o}}$ 0039335-07.2012.8.19.000, Rel. Valéria Dacheux, $13^{\mathrm{a}}$ Câmara Cível, julgado em 02/05/2016

- Agravo de Instrumento: Ag $\mathrm{n}^{0}$ 0009120-09.2016.8.19.0000. Rel. Ferdinaldo Nascimento. 19ª Vara Cível. Julgado em 14/06/2014.

. Agravo de Instrumento: Ag n ${ }^{\circ}$ 0039335-07.2012.8.19.000. Rel. Valéria Dacheux. 13a Câmara Cível. Julgado em 02/05/2016.

TJRS. Apelação Cível: ACi n ${ }^{\circ}$ 70066439845. Rel. Jorge Luiz Lopes do Canto. $5^{\text {a }}$ Câmara Cível. DJ 04/02/2016.

Julgado Apelação Cível: ACi nº 70071641260. Rel. Eugênio Facchini Neto. 9ª Câmara Cível. em $14 / 12 / 2016$.

TJSC. Apelação Cível: ACi no 2012.003881-7. Rel. Saul Steil. $3^{\text {a }}$ Câmara de Direito Civil. Julgado em 13/08/2013.

. Apelação Cível: ACi nº 2012.005251-8. Rel. Saul Steil. 3ª Câmara de Direito Civil.

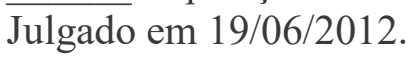

Apelação Cível: ACi no 2012.006972-6. Rel. Ronei Danielli. 6ª Câmara de Direito Civil. Julgado em 18/07/2013.

Apelação Cível: ACi n 2012.007064-0. Rel. João Batista Góes Ulysséa. 2aa Câmara Cível. Julgado em 20/08/2013.

Apelação Cível: ACi nº 2012.007073-6. Rel. Saul Steil. $3^{\mathrm{a}}$ Câmara de Direito Civil.

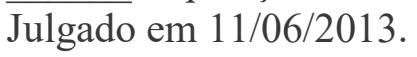

Apelação Cível: ACi no 2012.007073-6. Rel. Victor Ferreira. 4ª Câmara de Direito Civil. Julgado em 08/04/2013.

. Apelação Cível: ACi nº 2012.007126-4. Rel. Saul Steil. $3^{\text {a }}$ Câmara de Direito Civil. Julgado em 06/08/2013.

Apelação Cível: ACi nº 2012.008077-5. Rel. Ronei Danielli. 6a Câmara de Direito Civil. Julgado em 18/07/2013.

. Apelação Cível: ACi nº 2012.008131-3. Rel. Jorge Luis Costa Beber. 4ª Câmara de Direito Civil. Julgado em 13/08/2012.

Apelação Cível: ACi nº 2012.008131-3. Rel. Saul Steil. $3^{\mathrm{a}}$ Câmara de Direito Civil.

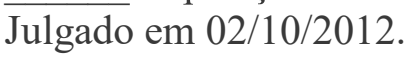


. Apelação Cível: ACi nº 2012.008306-3. Rel. Saul Steil. $3^{\mathrm{a}}$ Câmara de Direito Civil.

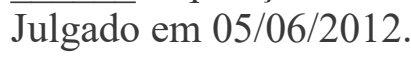

. Apelação Cível: ACi no 2012.008311-1. Rel. Saul Steil. $3^{\mathrm{a}}$ Câmara de Direito Civil.

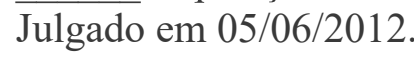

. Apelação Cível: ACi nº 2012.009360-0. Rel. João Batista Góes Ulysséa. 2ª Câmara Cível. Julgado em 20/08/2013.

. Apelação Cível: ACi n ${ }^{\circ}$ 2012.012397-2. Rel. Saul Steil. $3^{\mathrm{a}}$ Câmara de Direito Civil. Julgado em 05/02/2013.

- Apelação Cível: ACi no 2012.015604-3. Rel. Jorge Luis Costa Beber. $4^{\mathrm{a}}$ Câmara de Direito Civil. Julgado em 13/08/2012.

. Apelação Cível: ACi nº 2012.016330-9. Rel. Saul Steil. $3^{\text {a }}$ Câmara de Direito Civil.

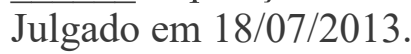

. Apelação Cível: ACi n 2012.016460-0. Rel. Saul Steil. $3^{\mathrm{a}}$ Câmara de Direito Civil. Julgado em 26/06/2012.

. Apelação Cível: ACi n 2012.016537-2. Rel. Saul Steil. $3^{\mathrm{a}}$ Câmara de Direito Civil.

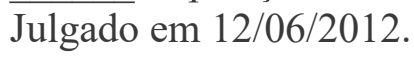

. Apelação Cível: ACi nº 2012.016605-1. Rel. Saul Steil. $3^{\mathrm{a}}$ Câmara de Direito Civil.

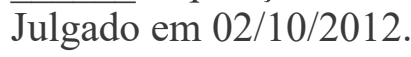

. Apelação Cível: ACi n 2012.016763-7. Rel. João Batista Góes Ulysséa. 2a Câmara Cível. Julgado em 20/08/2013.

. Apelação Cível: ACi n 2012.026480-7. Rel. Saul Steil. $3^{\text {a }}$ Câmara de Direito Civil. Julgado em 24/09/2013.

. Apelação Cível: ACi nº 2012.056621-3. Rel. Saul Steil. $3^{\mathrm{a}}$ Câmara de Direito Civil.

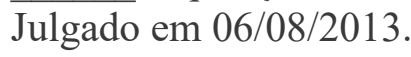

. Apelação Cível: ACi no 2012.063458-5. Rel. Saul Steil. $3^{\mathrm{a}}$ Câmara de Direito Civil. Julgado em 30/10/2012.

. Apelação Cível: ACi n 2012.089148-4. Rel. Saul Steil. $3^{\mathrm{a}}$ Câmara de Direito Civil. Julgado em 18/06/2013.

. Apelação Cível: ACi n ${ }^{\circ}$ 2013.002279-0. Rel. Saul Steil. $3^{\mathrm{a}}$ Câmara de Direito Civil.

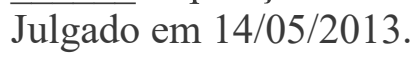

. Apelação Cível: ACi n ${ }^{\circ}$ 2013.012858-0. Rel. Saul Steil. $3^{\mathrm{a}}$ Câmara de Direito Civil.

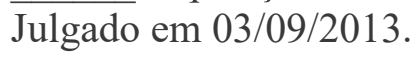

. Apelação Cível: ACi n 2013.020769-7. Rel. Ronei Danielli. 6 Câmara de Direito Civil. Julgado em 18/07/2013. 
. Apelação Cível: ACi no 2013.021367-6. Rel. João Batista Góes Ulysséa. 2ª Câmara Cível. Julgado em 20/08/2013.

. Apelação Cível: ACi no 2013.029909-2. Rel. Gilberto Gomes de Oliveira. 2a Câmara de Direito Civil. Julgado em 11/07/2013.

. Apelação Cível: ACi nº 2013.029910-2. Rel. Saul Steil. $3^{\mathrm{a}}$ Câmara de Direito Civil. Julgado em 18/06/2013.

Apelação Cível: ACi nº 2013.032911-3. Rel. Ronei Danielli. 6a Câmara de Direito Civil. Julgado em 18/07/2013.

Apelação Cível: ACi n 2013.032971-1. Rel. Saul Steil. $3^{\mathrm{a}}$ Câmara de Direito Civil. Julgado em 27/08/2013.

. Apelação Cível: ACi nº 2013.034898-6. Rel. Saul Steil. $3^{\mathrm{a}}$ Câmara de Direito Civil. Julgado em 03/09/2013.

Apelação Cível: ACi n 2013.035004-6. Rel. João Batista Góes Ulysséa. 2a Câmara Cível. Julgado em 20/08/2013.

Apelação Cível: ACi no 2013.037744-4. Rel. Ronei Danielli. 6a Câmara de Direito Civil. Julgado em 18/07/2013.

. Apelação Cível: ACi nº 2013.038064-7. Rel. Saul Steil. $3^{\mathrm{a}}$ Câmara de Direito Civil.

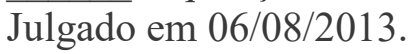

. Apelação Cível: ACi no 2013.039462-2. Rel. Gilberto Gomes de Oliveira. 2a Câmara de Direito Civil. Julgado em 25/07/2013.

Apelação Cível: ACi nº 2013.039507-1. Rel. Saul Steil. $3^{\text {a }}$ Câmara de Direito Civil.

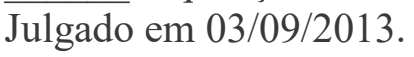

Apelação Cível: ACi n ${ }^{\circ}$ 2013.041385-0. Rel. Saul Steil. $3^{\text {a }}$ Câmara de Direito Civil.

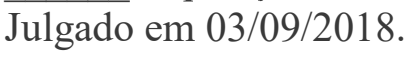

. Apelação Cível: ACi n ${ }^{\circ}$ 2013.041498-6. Rel. Ronei Danielli. 6a Câmara de Direito Civil. Julgado em 15/08/2013.

Apelação Cível: ACi n ${ }^{0}$ 2013.045499-7. Rel. Saul Steil. 3ª Câmara de Direito Civil. Julgado em 27/08/2013.

Apelação Cível: ACi no 2013.046349-1. Rel. Ronei Danielli. 6a Câmara de Direito Civil. Julgado em 10/12/2013.

. Apelação Cível: ACi nº 2012.003881-7. Rel. Saul Steil. $3^{\mathrm{a}}$ Câmara de Direito Civil.

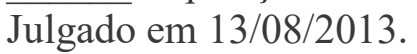


. Apelação Cível: ACi nº 2012.005251-8. Rel. Saul Steil. $3^{\mathrm{a}}$ Câmara de Direito Civil.

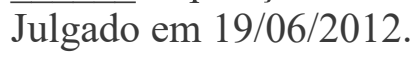

. Apelação Cível: ACi nº 2012.006972-6. Rel. Ronei Danielli. 6a Câmara de Direito Civil. Julgado em 18/07/2013.

. Apelação Cível: ACi nº 2012.007064-0. Rel. João Batista Góes Ulysséa. 2a Câmara Cível. Julgado em 20/08/2013.

. Apelação Cível: ACi nº 2012.007073-6. Rel. Saul Steil. $3^{\mathrm{a}}$ Câmara de Direito Civil. Julgado em 11/06/2013.

. Apelação Cível: ACi nº 2012.007126-4. Rel. Saul Steil. $3^{\mathrm{a}}$ Câmara de Direito Civil.

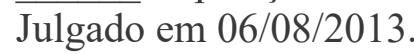

. Apelação Cível: ACi nº 2012.008077-5. Rel. Ronei Danielli. 6a Câmara de Direito

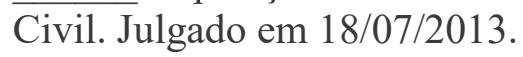

. Apelação Cível: ACi nº 2012.008131-3. Rel. Jorge Luis Costa Beber. 4ª Câmara de Direito Civil. Julgado em 13/08/2012.

. Apelação Cível: ACi nº 2012.008131-3. Rel. Saul Steil. $3^{\mathrm{a}}$ Câmara de Direito Civil.

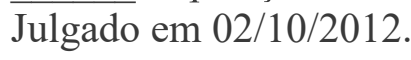

. Apelação Cível: ACi n ${ }^{\circ}$ 2012.008306-3. Rel. Saul Steil. $3^{\mathrm{a}}$ Câmara de Direito Civil.

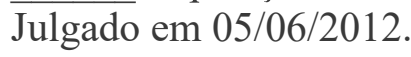

. Apelação Cível: ACi nº 2012.008311-1. Rel. Saul Steil. $3^{\mathrm{a}}$ Câmara de Direito Civil.

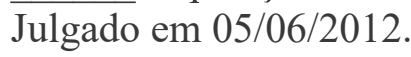

. Apelação Cível: ACi nº 2012.009360-0. Rel. João Batista Góes Ulysséa. 2a Câmara Cível. Julgado em 20/08/2013.

. Apelação Cível: ACi no 2012.012397-2. Rel. Saul Steil. $3^{\text {a }}$ Câmara de Direito Civil.

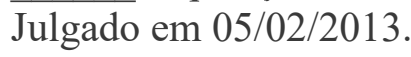

. Apelação Cível: ACi n ${ }^{\circ}$ 2012.015604-3. Rel. Jorge Luis Costa Beber. $4^{\mathrm{a}}$ Câmara de Direito Civil. Julgado em 13/08/2012.

. Apelação Cível: ACi n ${ }^{\circ}$ 2012.016330-9. Rel. Saul Steil. $3^{\mathrm{a}}$ Câmara de Direito Civil. Julgado em 18/07/2013.

. Apelação Cível: ACi nº 2012.016460-0. Rel. Saul Steil. $3^{\mathrm{a}}$ Câmara de Direito Civil.

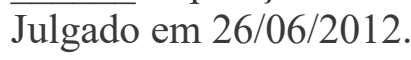

. Apelação Cível: ACi n ${ }^{\circ}$ 2012.016537-2. Rel. Saul Steil. $3^{\mathrm{a}}$ Câmara de Direito Civil.

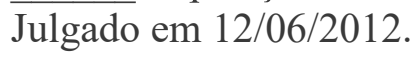

. Apelação Cível: ACi nº 2012.016605-1. Rel. Saul Steil. $3^{\mathrm{a}}$ Câmara de Direito Civil.

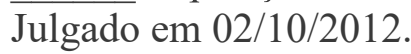


. Apelação Cível: ACi no 2012.016763-7. Rel. João Batista Góes Ulysséa. 2a Câmara Cível. Julgado em 20/08/2013.

. Apelação Cível: ACi nº 2012.026480-7. Rel. Saul Steil. $3^{\text {a }}$ Câmara de Direito Civil.

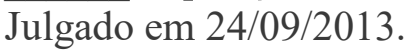

. Apelação Cível: ACi nº 2012.056621-3. Rel. Saul Steil. $3^{\text {a }}$ Câmara de Direito Civil. Julgado em 06/08/2013.

Apelação Cível: ACi n ${ }^{0}$ 2012.063458-5. Rel. Saul Steil. $3^{\mathrm{a}}$ Câmara de Direito Civil.

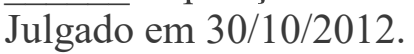

Apelação Cível: ACi nº 2012.089148-4. Rel. Saul Steil. $3^{\mathrm{a}}$ Câmara de Direito Civil. Julgado em 18/06/2013.

Apelação Cível: ACi n 2013.002279-0. Rel. Saul Steil. $3^{\mathrm{a}}$ Câmara de Direito Civil.

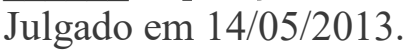

Apelação Cível: ACi n 2013.012858-0. Rel. Saul Steil. $3^{\text {a }}$ Câmara de Direito Civil. Julgado em 03/09/2013.

Apelação Cível: ACi no 2013.020769-7. Rel. Ronei Danielli. 6a Câmara de Direito Civil. Julgado em 18/07/2013.

Apelação Cível: ACi nº 2013.021367-6. Rel. João Batista Góes Ulysséa. 2a Câmara Cível. Julgado em 20/08/2013.

. Apelação Cível: ACi no 2013.029909-2. Rel. Gilberto Gomes de Oliveira. 2a Câmara de Direito Civil. Julgado em 11/07/2013.

. Apelação Cível: ACi nº 2013.029910-2, Rel. Saul Steil, $3^{\text {a }}$ Câmara de Direito Civil. Julgado em 18/06/2013.

Apelação Cível: ACi no 2013.032911-3. Rel. Ronei Danielli. 6a Câmara de Direito Civil. Julgado em 18/07/2013.

. Apelação Cível: ACi nº 2013.032971-1. Rel. Saul Steil. $3^{\text {a }}$ Câmara de Direito Civil. Julgado em 27/08/2013.

Apelação Cível: ACi nº 2013.034898-6. Rel. Saul Steil. $3^{\text {a }}$ Câmara de Direito Civil. Julgado em 03/09/2013.

Apelação Cível: ACi n 2013.035004-6. Rel. João Batista Góes Ulysséa. 2a Câmara Cível. Julgado em 20/08/2013.

Apelação Cível: ACi nº 2013.037744-4. Rel. Ronei Danielli. 6a Câmara de Direito Civil. Julgado em 18/07/2013.

Apelação Cível: ACi nº 2013.038064-7. Rel. Saul Steil. $3^{\text {a }}$ Câmara de Direito Civil. 
Julgado em 06/08/2013.

. Apelação Cível: ACi nº 2013.039462-2. Rel. Gilberto Gomes de Oliveira. 2ª Câmara de Direito Civil. Julgado em 25/07/2013.

. Apelação Cível: ACi nº 2013.039507-1. Rel. Saul Steil. $3^{\mathrm{a}}$ Câmara de Direito Civil.

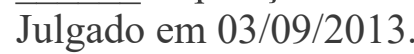

. Apelação Cível: ACi nº 2013.041385-0. Rel. Saul Steil. $3^{a}$ Câmara de Direito Civil. Julgado em 03/09/2018.

. Apelação Cível: ACi no 2013.041498-6. Rel. Ronei Danielli. 6a Câmara de Direito Civil. Julgado em 15/08/2013.

. Apelação Cível: ACi n ${ }^{\circ}$ 2013.045499-7. Rel. Saul Steil. $3^{\mathrm{a}}$ Câmara de Direito Civil.

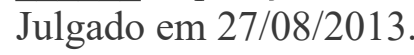

. Apelação Cível: ACi nº 2013.046349-1. Rel. Ronei Danielli. 6a Câmara de Direito

TJSP. Apelação Cível: ACi n ${ }^{\circ}$ 1001703-71.2014.8.26.0126. Rel. José Joaquim dos Santos. 2 ${ }^{\mathrm{a}}$ Câmara de Direito Privado. DJe 03/08/2016.

. Apelação Cível: ACi no 0012083-10.2013.8.26.0126. Rel. Elcio Trujillo. 10ª Câmara de Direito Privado. DJe 01/09/2016.

. Apelação Cível: ACi nº 0002294-59.2013.8.26.0587. Rel. Teixeira Leite. 28ª Câmara Extraordinária de Direito Privado. DJe 04/10/2017.

\section{- Legislação e acordos consultados}

ALEMANHA. Environmental Liability Act, december 10, 1990. Tradução Eileen Flügel. Munchen. Disponível em: <http://www.gesetze-iminternet.de/englisch_umwelthg/englisch_umwelthg.pdf>. Acesso em: 10 jan. 2019.

BRASIL. Câmara dos Deputados. Projeto de Lei no 10.494, de 2018. Altera a Lei $n^{\circ} 6.938$, de 31 de agosto de 1981 (Lei da Política Nacional do Meio Ambiente), para permitir a exigência de seguro ambiental quando for necessária a elaboração de Estudo de Impacto Ambiental (EIA) e de Relatório de Impacto Ambiental (Rima). Disponível em: $<$ http://www.camara.gov.br/proposicoesWeb/prop_mostrarintegra;jsessionid=4ABC7DCE8B 4D3FD160C8FBBC760A134D.proposicoesWebExterno1 codteor $=1676141 \&$ filename $=$ Avul so+-PL+10494/2018>. Acesso em: 10 jan. 2019.

. Câmara dos Deputados. Projeto de Lei no 10.494/2018. Altera a Lei n ${ }^{\circ} 6.838$, de 31 de agosto de 1981 (Política Nacional do Meio Ambiente), para permitir a exigência de seguro ambiental quando for necessária a elaboração de Estudo de Impacto Ambiental (EIA) e de Relatório de Impacto Ambiental (RIMA). Disponível em: $<$ http://www.camara.gov.br/proposicoesWeb/fichadetramitacao?idProposicao=2180392\&ord $=1>$. Acesso em: 10 jan. 2019. 
Câmara dos Deputados. Projeto de Lei $n^{\circ} 2.313$, de 2003. Altera dispositivos do Decreto-Lei $\mathrm{n}^{\circ} 73$, de 21 de novembro de 1966, e dá outras providências. Disponível em: $<$ http://www.camara.gov.br/proposicoesWeb/prop_mostrarintegra?codteor $=172770 \&$ filename $=$ PL $+2313 / 2003>$. Acesso em: 10 jan. 2019.

. Câmara dos Deputados. Projeto de Lei $n^{\circ}$ 623, de 2003. Acrescenta artigo à Lei ${ }^{0}$ 10.636, de 30 de dezembro de 2002, que dispõe sobre a aplicação dos recursos originários da Contribuição de Intervenção do Domínio Econômico - Cide. Disponível em: $<$ http://www.camara.gov.br/proposicoesWeb/prop_mostrarintegra;jsessionid=57043BCEAD D76C46FE802EA0FA8F1F69.proposicoesWebExterno2? codteor $=450876 \&$ filename $=$ PL +62 3/2003>. Acesso em: 09 jan. 2019.

Conselho Nacional do Meio Ambiente (CONAMA). Resolução CONAMA nº 482, de 03 de outubro de 2017. Trata da queima controlada emergencial como ação de resposta a incidentes de poluição por óleo no mar. Disponível em: $<$ http://www2.mma.gov.br/port/conama/legiabre.cfm?codlegi=729>. Acesso: 10 jan. 2019.

Conselho Nacional do Meio Ambiente (CONAMA). Resolução CONAMA n ${ }^{\circ}$, de 23 de janeiro de 1986. Dispõe sobre os critérios básicos e diretrizes gerais para a avaliação de impacto ambiental. Disponível em: $<$ http://www2.mma.gov.br/port/conama/legislacao/CONAMA_RES_CONS_1986_001.pdf > Acesso em: 10 jan. 2019.

Conselho Nacional do Ministério Público (CNMP). Resolução CNMP n 179, de 26 de julho de 2017. Regulamenta o $\S 6^{\circ}$ do art. $5^{\circ}$ da Lei $n^{\circ} 7.347 / 1985$, disciplinando, no âmbito do Ministério Público, a tomada do compromisso de ajustamento de conduta. Disponível em: $<$ http://www.cnmp.mp.br/portal/images/Resolucoes/Resolu\%C3\%A7\%C3\%A3o-179.pdf $>$. Acesso em: 10 jan. 2019.

. Constituição (1988). Constituição da República Federativa do Brasil de 1988, de 5 de outubro de $1988 . \quad$ Disponível em: $<$ http://www.planalto.gov.br/ccivil_03/Constituicao/Constituicao.htm>. Acesso em: 10 jan. 2019.

Decreto Federal n. ${ }^{\circ}$ 6.478, de 10 de junho de 2008. Promulga o texto da Convenção Internacional relativa à intervenção em alto-mar em casos de acidentes com poluição por óleo, feita em bruxelas, em 29 de novembro de 1969, e o protocolo relativo à intervenção em altomar em casos de poluição por substâncias outras que não óleo, feito em Londres, em 2 de novembro de 1973. Disponível em: <https://www.planalto.gov.br/ccivil_03/_ato20072010/2008/decreto/d6478.htm>. Acesso em: 10 jan. 2019.

Decreto Federal n. ${ }^{\circ}$ 79.437, de 28 de março de 1977. Promulga o texto da Convenção Internacional sobre Responsabilidade Civil em Danos Causados por Poluição por óleo, 1969. Disponível em: <http://www.planalto.gov.br/ccivil_03/decreto/1970-1979/D79437.htm>. Acesso em: 10 jan. 2019.

Decreto Federal no 1.306, de 9 de novembro de 1994. Regulamenta o Fundo de Defesa de Direitos Difusos, de que tratam os arts. 13 e 20 da Lei no 7.347, de 24 de julho de 1985, seu conselho gestor e dá outras providências. Disponível em: 
$<$ http://www.planalto.gov.br/ccivil_03/decreto/1990-1994/D1306.htm>. Acesso em: 10 jan. 2019.

Decreto Federal $\mathrm{n}^{\circ}$ 1.530, de 22 de junho de 1995. Declara a entrada em vigor da Convenção das Nações Unidas sobre o Direito do Mar, concluída em Montego Bay, Jamaica, em 10 de dezembro de 1982. Disponível em: $<$ http://www.planalto.gov.br/ccivil_03/decreto/1995/D1530.htm>. Acesso em: 10 jan. 2019.

Decreto Federal no 2.508, de 04 de março de 1998. Promulga o Convenção Internacional para a Prevenção da Poluição Causada por Navios, concluída em Londres, em 2 de novembro de 1973, seu Protocolo, concluído em Londres, em 17 de fevereiro de 1978, suas Emendas de 1984 e seus Anexos Opcionais III, IV e V. Acesso em: < http://www.planalto.gov.br/ccivil_03/decreto/D2508.htm>. Acesso em: 10 jan. 2019.

. Decreto Federal n $\mathrm{n}^{\circ}$.742, de 20 de agosto de 1998. Promulga o Protocolo ao Tratado da Antártida sobre Proteção ao Meio Ambiente, assinado em Madri, em 4 de outubro de 1991. Disponível em: <http://www.planalto.gov.br/ccivil_03/decreto/D2742.htm>. Acesso em: 10 jan. 2019.

Decreto Federal $\mathrm{n}^{\circ}$ 2.870, de 10 de dezembro de 1998. Promulga a Convenção Internacional sobre Preparo, Resposta e Cooperação em Caso de Poluição por Óleo, assinada em Londres, em 30 de novembro de 1990. Disponível em: $<$ http://www.planalto.gov.br/ccivil_03/decreto/D2870.htm>. Acesso em: 10 jan. 2019.

. Decreto Federal $n^{\circ} 4.581$, de 27 de janeiro de 2003. Promulga a emenda ao Anexo I e adoção dos Anexos VIII e IX à Convenção de Basileia sobre o Controle do Movimento Transfronteiriço de Resíduos Perigosos e seu Depósito. Disponível em: <http://www.planalto.gov.br/ccivil_03/decreto/2003/d4581.htm>. Acesso em: 10 jan. 2019.

Decreto Federal no 6.511, de 13 de março de 2008. Promulga o Acordo de Cooperação Mútua entre o Governo da República Federativa do Brasil e o Governo da República Oriental do Uruguai para Combater o Tráfego de Aeronaves Envolvidas com Atividades Ilícitas Transnacionais, celebrado em Montevidéu, em 14 de setembro de 2004. Disponível em: <http://www.planalto.gov.br/ccivil_03/_Ato20072010/2008/Decreto/D6398.htm>. Acesso em: 10 jan. 2019.

Decreto Federal $n^{\circ}$ 87.186, de 18 de maio de 1982. Promulga a Convenção Internacional para Salvaguarda da Vida Humana no Mar, 1974. Disponível em: $<$ http://www.planalto.gov.br/ccivil_03/decreto/1980-1989/1980-1984/D87186.htm>. Acesso em: 10 jan. 2019.

. Decreto Federal no 87.566, de 16 de setembro de 1982. Promulga o texto da convenção sobre Prevenção da Poluição Marinha por Alijamento de Resíduos e Outras Matérias, concluída em Londres, a 29 de dezembro de 1972. Disponível em: $<$ http://www.planalto.gov.br/ccivil_03/decreto/1980-1989/1980-1984/D87566.htm>. Acesso em: 10 jan. 2019.

. Decreto Federal n 92.610, de 02 de maio de 1986. Promulga o Protocolo de 1978 relativo à Convenção Internacional para a Salvaguarda da Vida Humana no Mar de 1974. Disponível em: <http://www2.camara.leg.br/legin/fed/decret/1980-1987/decreto-92610-2maio-1986-442634-publicacaooriginal-1-pe.html>. Acesso em: 10 jan. 2019. 
Decreto $n^{\circ} 4.871$, de 06 de novembro de 2003. Dispõe sobre a instituição dos Planos de Áreas para o combate à poluição por óleo em águas sob jurisdição nacional e dá outras providências. Disponível em: <http://www.planalto.gov.br/ccivil_03/decreto/2003/D4871.htm>. Acesso em: 10 jan. 2019.

Decreto $n^{\circ} 5.098$, de 3 de junho de 2004. Dispõe sobre a criação do Plano Nacional de Prevenção, Preparação e Resposta Rápida a Emergência Ambientais com Produtos Químicos Perigosos - P2R2, e dá outras providências. Disponível em: $<$ http://www.planalto.gov.br/ccivil_03/_Ato2004-2006/2004/Decreto/D5098.htm>. Acesso em: 10 jan. 2019.

Instituto Brasileiro do Meio Ambiente e dos Recursos Naturais Renováveis (IBAMA). Instrução Normativa IBAMA n ${ }^{\circ} 07$, de 09 de julho de 2001. Altera a IN IBAMA n ${ }^{\circ} 1 / 2000$, a qual estabelece critérios para concessão do registro de dispersantes químicos empregados nas ações de combate a derrames de petróleo e seus derivados no mar.

Lei Federal $\mathrm{n}^{\circ} 10.406$, de 10 de janeiro de 2002. Institui o Código Civil. Disponível em <http://www.planalto.gov.br/ccivil_03/leis/2002/110406.htm>. Acesso em: 10 jan. 2019.

Lei Federal $n^{\circ} 12.858$, de 9 de setembro de 2013. Dispõe sobre a destinação para as áreas de educação e saúde de parcela da participação no resultado ou da compensação financeira pela exportação de petróleo e gás natural, com a finalidade de cumprimento da meta prevista no inciso VI do caput do art. 214 e no art. 196 da Constituição; altera a Lei n 7.990, de 28 de dezembro de 1980, e dá outras providências. Disponível em: $<$ http://www.planalto.gov.br/ccivil_03/_Ato2011-2014/2013/Lei/L12858.htm>. Acesso em: 10 jan. 2019.

Lei Federal $n^{\circ}$ 6.938, de 31 de agosto de 1981. Dispõe sobre a Política Nacional do Meio Ambiente, seus fins e mecanismos de formulação e aplicação, e dá outras providências. Disponível em: <http://www.planalto.gov.br/ccivil_03/Leis/L6938.htm>. Acesso em: 10 jan. 2019.

Lei Federal no 7.347, de 24 de julho de 1985. Disciplina a ação civil pública de responsabilidade por danos causados ao meio-ambiente, ao consumidor, a bens e direitos de valor artístico, estético, histórico, turístico e paisagístico (VETADO) e dá outras providências. Disponível em: <http://www.planalto.gov.br/ccivil_03/Leis/L7347orig.htm>. Acesso em: 10 jan. 2019.

. Lei Federal n 8.078, de 11 de setembro de 1990 (Código de Defesa do Consumidor CDC). Dispõe sobre a proteção do consumidor e dá outras providências. Disponível em: $<$ http://www.planalto.gov.br/ccivil_03/Leis/L8078.htm>. Acesso em: 10 jan. 2019.

Lei Federal $n^{\circ}$ 9.605, de 12 de fevereiro de 1998. Dispõe sobre as sanções penais e administrativas derivadas de condutas e atividades lesivas ao meio ambiente, e dá outras providências. Disponível em: <http://www.planalto.gov.br/ccivil_03/LEIS/L9605.htm>. Acesso em: 10 jan. 2019.

Lei $\mathrm{n}^{\circ} 11.284$, de 2 de março de 2006. Dispõe sobre a gestão de florestars públicas para a produção sustentável; institui, na estrutura do Ministério do Meio Ambiente, o Serviço 
Florestal Brasileiro (SFB); cria o Fundo Nacional de Desenvolvimento Florestal (FNDF); altera as Leis $n^{\circ} 10.683 / 2003, n^{\circ} 5.868 / 1972, n^{\circ} 9.605 / 1998, n^{\circ} 4.771 / 1965, n^{\circ} 6.938 / 1981$ e $n^{\circ}$ 6.015/1973, e dá outras providências. Disponível em: $<$ http://www.planalto.gov.br/ccivil_03/_Ato2004-2006/2006/Lei/L11284.htm>. Acesso em: 10 jan. 2019.

. Lei $\mathrm{n}^{\circ} 12.305$, de 2 de agosto de 2010. Institui a Política Nacional de Resíduos Sólidos, altera a Lei $\mathrm{n}^{\circ}$ 9.605, de 12 de fevereiro de 1998, e dá outras providências. Disponível em: $<$ http://www.planalto.gov.br/ccivil_03/_ato2007-2010/2010/1ei/112305.htm>. Acesso em: 10 jan. 2019.

. Lei $n^{\circ}$ 6.938, de 31 de agosto de 1981. Dispõe sobre a Política Nacional de Meio Ambiente, seus fins e mecanismos de formulação e aplicação, e dá outras providências. Disponível em: $<$ http://www.planalto.gov.br/ccivil_03/Leis/L6938.htm>. Acesso em: 10 jan. 2019.

Ministério da Justiça e Segurança Pública. Secretaria Nacional do Consumidor. Portaria $\mathrm{n}^{\circ}$ 9, de 11 de outubro de 2017. Divulga o resultado final de projetos prioritários e cadastro de reserva, aprovado pelo Conselho Federal Gestor do Fundo de Defesa de Direitos Difusos, conforme Editais de Chamamento Público CFDD n ${ }^{\circ}$ 01/2017 e nº 02/2017. Disponível em: <http://www.justica.gov.br/seus-direitos/consumidor/direitos-difusos/anexos/portaria-09resultado-final.pdf $>$. Acesso em: 10 jan. 2019.

. Ministério do Interior. Portaria MINTER nº 124, de 20 de agosto de 1980. Disponível em:

$<$ http:/www.legislacaoambiental.com.br/system/files/lglLegislacao/2010/01/13/543D7C9CD8E2-4871-BB5F-83624DA6E575.pdf>. Acesso em: 10 jan. 2019.

. Ministério do Meio Ambiente (MMA). Comissão Interministerial para os Recursos do Mar (CIRM). Resolução $n^{\circ}$ 5, de 03 de dezembro de 1997. Aprova o Plano Nacional de Gerenciamento Costeiro (PNGC II).

. Ministério do Meio Ambiente (MMA). Conselho Nacional do Meio Ambiente (CONAMA). Resolução CONAMA n 398, de 12 de junho de 2008. Dispõe sobre o conteúdo mínimo do Plano de Emergência Individual para incidentes de poluição por óleo em águas sob jurisdição nacional, originadas em portos organizados, instalações portuárias, terminais, dutos, sondas terrestres, plataformas e suas instalações de apoio, refinarias, estaleiros, marinas, clubes náuticos e instalações similares, e orienta a sua elaboração. Disponível em: $<$ http://www2.mma.gov.br/port/conama/legiabre.cfm? codlegi=575>. Acesso em: 10 jan. 2019.

. Ministério do Meio Ambiente (MMA). Portaria MMA n 9, de 23 de janeiro de 2007. Reconhece áreas prioritárias para a conservação, utilização sustentável e repartição de benefícios da biodiversidade brasileira. Disponível em: $<$ http://www.icmbio.gov.br/portal/images/stories/portaria_mma_092007.pdf $>$. Acesso em: 10 jan. 2019.

CANADÁ. Justice Ministry. Marine Liability Act. An act respecting marine liability, and to validate certain by-laws and regulations. S.C. 2001, c.6. Ottawa, 2001. Disponível em: $<$ http://laws-lois.justice.gc.ca/PDF/M-0.7.pdf> Acesso em: 10 jan. 2019. 
. Justice Ministry. Marine Liability Act. An act respecting marine liability, and to validate certain by-laws and regulations. Disponível em: $<$ http://laws-lois.justice.gc.ca/PDF/M0.7.pdf>. Acesso em: 10 jan. 2019.

Justice Ministry. Marine Liability and Information Return Regulations SOR/2016-307. Disponível em: <http://laws-lois.justice.gc.ca/eng/regulations/SOR-2016307/page-1.html>. Acesso em: 10 jan. 2019.

CETESB. Decisão de Diretoria $n^{\circ}$ 038/2017/C, de 07 fevereiro de 2017. Dispõe sobre a aprovação do "Procedimento para a Proteção da Qualidade do Solo e das Águas Subterrâneas", da revisão do "Procedimento para o Gerenciamento de Áreas Contaminadas" e estabelece "Diretrizes para Gerenciamento de Áreas Contaminadas no Âmbito do Licenciamento Ambiental", em função da publicação da Lei Estadual n 13.577/2009 e seu Regulamento, aprovado por meio do Decreto $\mathrm{n}^{0} 59.263 / 2013$, e dá outras providências. Disponível em: $<$ https://cetesb.sp.gov.br/wp-content/uploads/2014/12/DD-038-2017-C.pdf $>$. Acesso em: 10 jan. 2019.

COMISSÃO COORDENADORA DOS ASSUNTOS DA INTERNATIONAL MARITIME ORGANIZATION. Convenção Internacional para a Prevenção da Poluição por Navios. Brasília, versão traduzida para o português, 1973.

CONSELHO DAS COMUNIDADES EUROPEIAS. Regulamento CEE $n^{\circ}$ 259/93 do Conselho, de 01 de fevereiro de 1993. Relativo à fiscalização e ao controle das transferências de resíduos no interior, à entrada e à saída da Comunidade. Disponível em: $<$ https://eurlex.europa.eu/legal-content/PT/TXT/PDF/?uri=CELEX:31993R0259\&from=en $>$. Acesso em: 10 jan. 2019.

CONSELHO EUROPEU. Convention on Civil Liability for Damage Resulting from Activities Dangerous to the Environment. European Treaty Series, $n^{\circ} 150$. Lugano, 1993. Disponível em: $<$ https://www.coe.int/en/web/conventions/full-list/-/conventions/rms/090000168007c079>.

Acesso em: 10 jan. 2019.

FINLÂNDIA. Environmental Ministry. Act $n^{\circ} 1673 / 2009$. Act on Oil Pollution Response. Disponível em: < https://www.finlex.fi/fi/laki/kaannokset/2009/en20091673.pdf>. Acesso em: 10 jan. 2019.

PARLAMENTO EUROPEU. Conselho da União Europeia. Regulamento CE nº 1013/2006 do Parlamento Europeu e do Conselho, de 14 de junho de 2006, relativo a transferências de resíduos. Disponível em: <https:/eur-lex.europa.eu/legalcontent/PT/TXT/PDF/?uri=CELEX:32006R1013\&from=en>. Acesso em: 10 jan. 2019.

SÃO PAULO (Estado). Procuradoria Geral de Justiça (PGJ). Ato PGJ nº 36, de 06 de maio de 2011. Cria grupo de trabalho para análise e fixação de premissas relativas à valoração de dano ambiental. 